\title{
Aquatic Monocotyledons of North America
}

\author{
Ecology, Life History, and Systematics
}

Donald H. Les

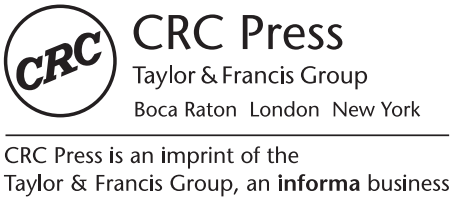


CRC Press

Taylor \& Francis Group

6000 Broken Sound Parkway NW, Suite 300

Boca Raton, FL 33487-2742

@ 2020 by Taylor \& Francis Group, LLC <change as necessary>

CRC Press is an imprint of Taylor \& Francis Group, an Informa business

No claim to original U.S. Government works

Printed on acid-free paper

International Standard Book Number-13: 978-1-1380-5493-6 (Hardback)

This book contains information obtained from authentic and highly regarded sources. Reasonable efforts have been made to publish reliable data and information, but the author and publisher cannot assume responsibility for the validity of all materials or the consequences of their use. The authors and publishers have attempted to trace the copyright holders of all material reproduced in this publication and apologize to copyright holders if permission to publish in this form has not been obtained. If any copyright material has not been acknowledged please write and let us know so we may rectify in any future reprint.

Except as permitted under U.S. Copyright Law, no part of this book may be reprinted, reproduced, transmitted, or utilized in any form by any electronic, mechanical, or other means, now known or hereafter invented, including photocopying, microfilming, and recording, or in any information storage or retrieval system, without written permission from the publishers.

For permission to photocopy or use material electronically from this work, please access www.copyright.com (http://www.copyright.com/) or contact the Copyright Clearance Center, Inc. (CCC), 222 Rosewood Drive, Danvers, MA 01923, 978-750-8400. CCC is a not-for-profit organization that provides licenses and registration for a variety of users. For organizations that have been granted a photocopy license by the CCC, a separate system of payment has been arranged.

Trademark Notice: Product or corporate names may be trademarks or registered trademarks, and are used only for identification and explanation without intent to infringe.

Visit the Taylor \& Francis Web site at

http://www.taylorandfrancis.com

and the CRC Press Web site at

http://www.crcpress.com 
This book is dedicated to Elias Landolt (1926-2013), whose incredible contributions to the study of the world's smallest monocotyledons (duckweeds) represent some of the most remarkable taxonomic insights of the past century. 
$\because$ Taylor \& Francis

Taylor \& Francis Group

http://taylorandfrancis.com 


\section{Contents}

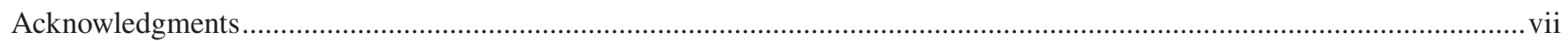

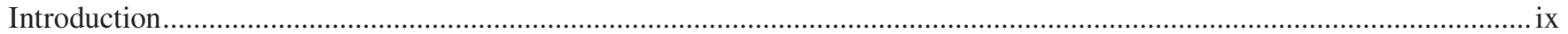

\section{The Monocotyledons}

Chapter 1 Monocotyledons I: Early Diverging Monocotyledons ……......................................................................

A group of uncertain phylogenetic position (Acorales) …............................................................................... 3

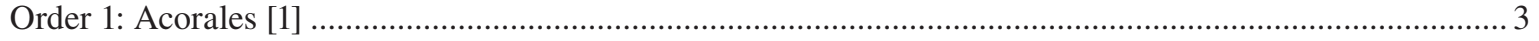

Family 1.1. Acoraceae $[1]$............................................................................................................ 3

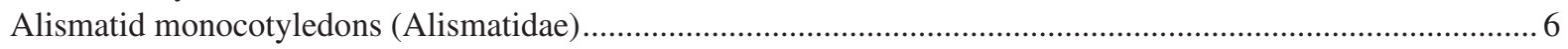

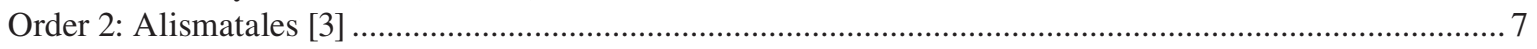

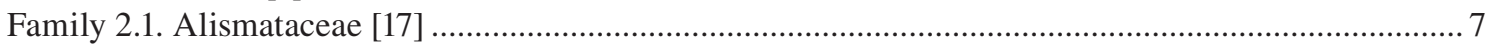

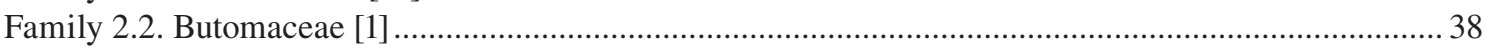

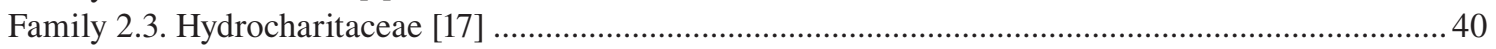

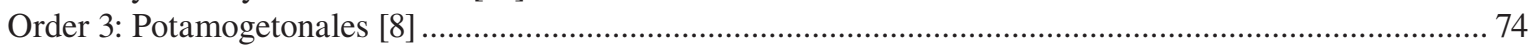

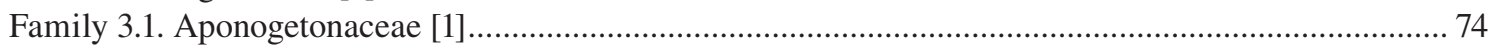

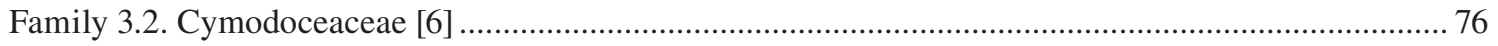

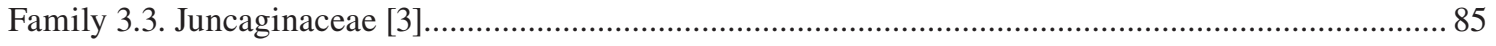

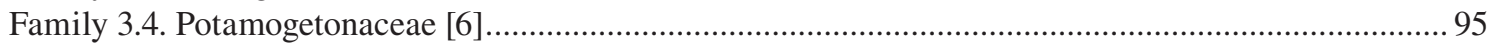

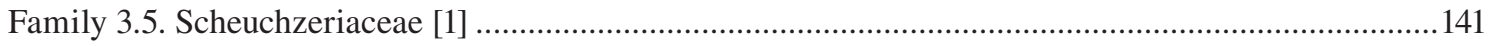

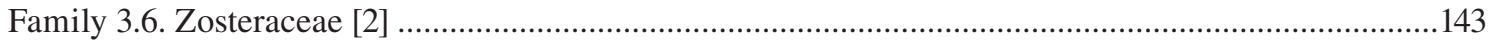

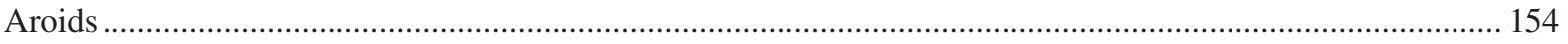

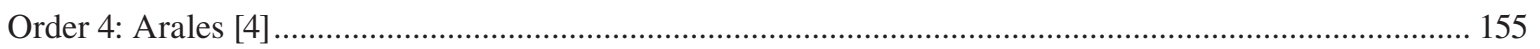

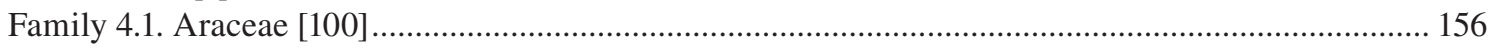

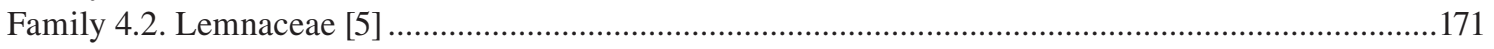

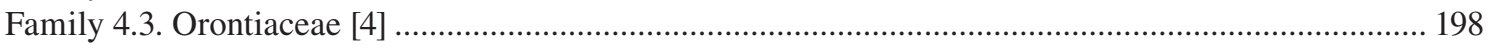

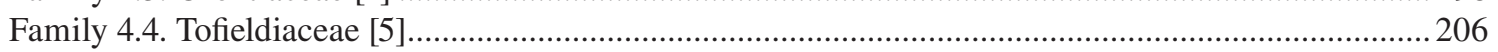

Chapter 2 Monocotyledons II: Lilioid Monocotyledons ("Liliidae”) .......................................................................... 215

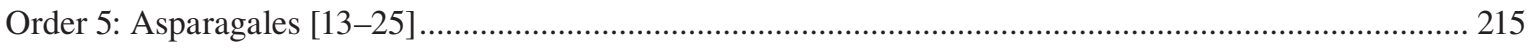

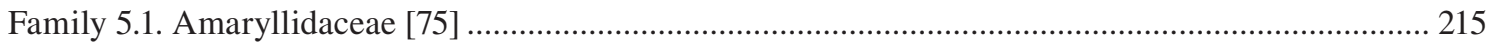

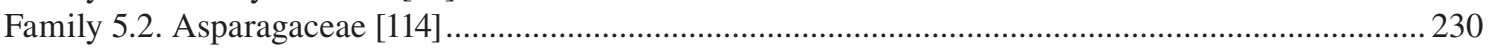

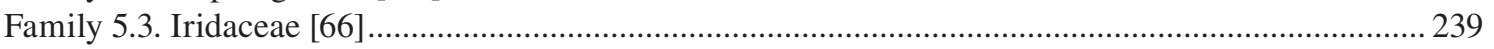

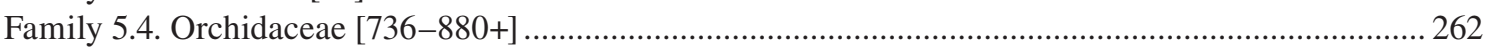

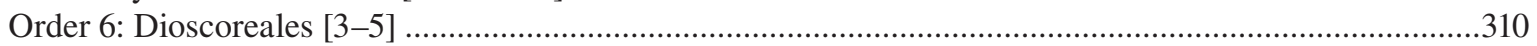

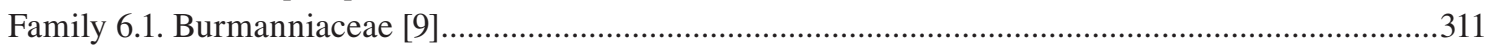

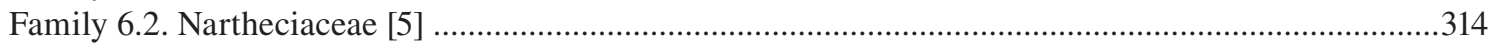

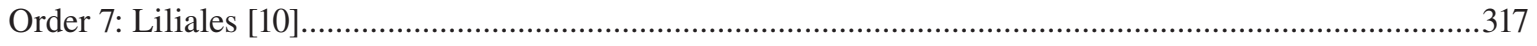

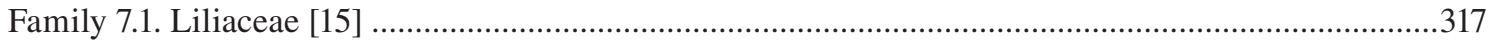

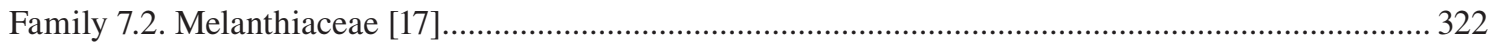

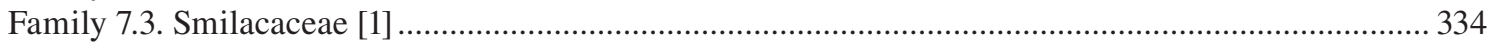

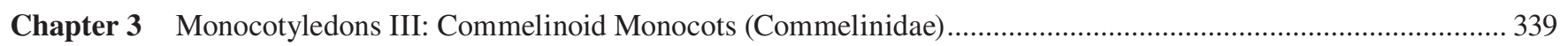

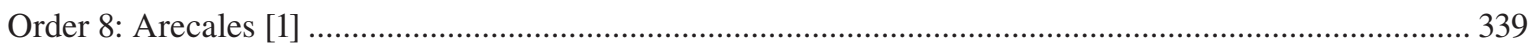

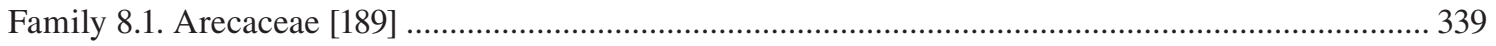

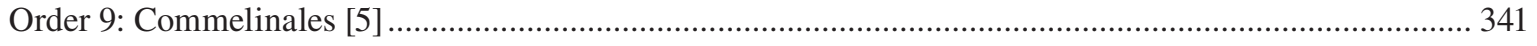

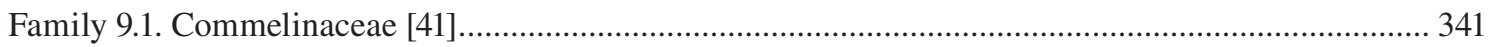

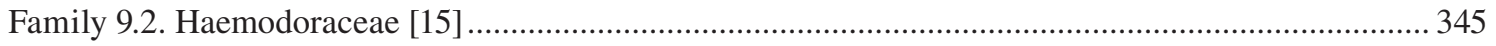

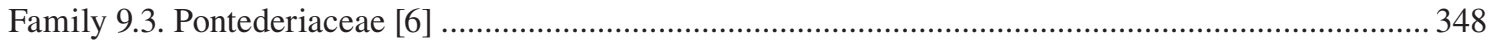




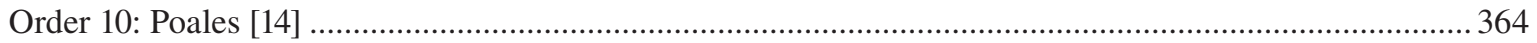

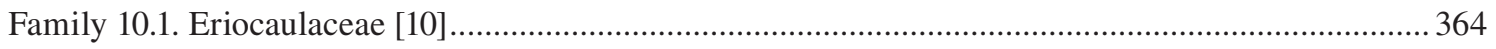

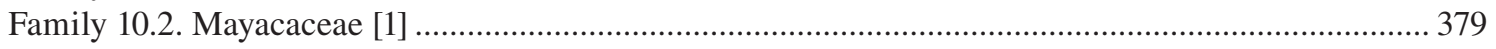

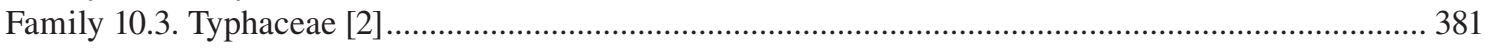

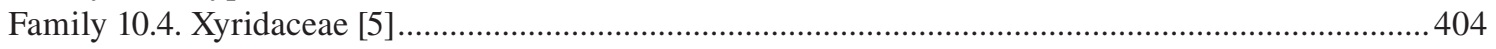

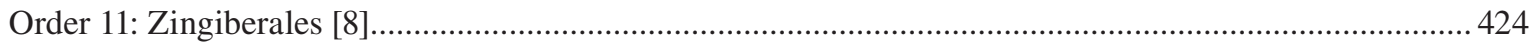

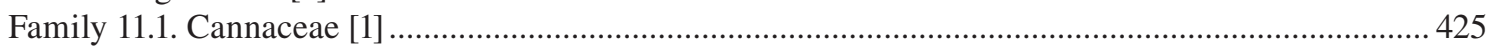

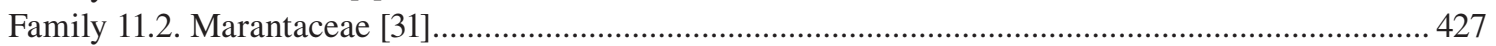

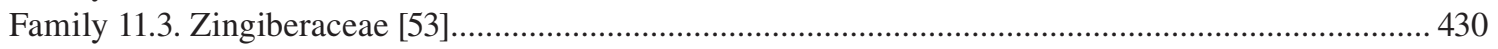

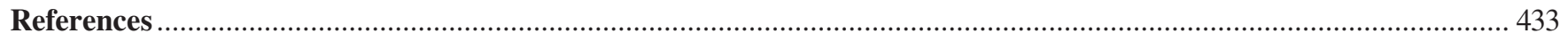

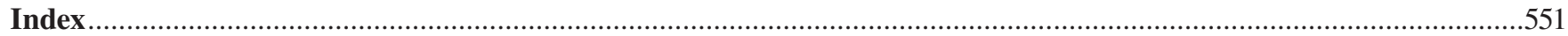




\section{Acknowledgments}

My sincere thanks go out to all of the people who have influenced my study of aquatic plants. I especially recognize R.O. Belcher, E.G. Voss, J. Hiltunen, R.L. Stuckey, R.P. Wunderlin, and D.J. Crawford, who provided inestimable encouragement, inspiration, and mentorship during the earliest stages of my career. So many others, including numerous colleagues and graduate students, contributed invaluable expertise and camaraderie during the years leading to the completion of this manuscript. Finally, I thank my wife Jane, who has faithfully endured my monomaniacal pursuit of this book's completion. 


\section{$\Longrightarrow$ Taylor \& Francis Taylor \& Francis Group \\ http://taylorandfrancis.com}




\section{Introduction}

This book is intended to serve as a companion volume to Aquatic Dicotyledons of North America (Les, 2017) and follows a similar format by providing a comprehensive overview of the life history, ecology, and systematics of those monocotyledon species designated as obligate wetland indicators (abbreviated throughout the text as OBL) in North America. Following the previous treatment (Les, 2017), aquatic plants are defined as: "indicative taxa capable of perpetuating their life cycles and continuing their existence in still or flowing standing water or upon inundated or non-inundated hydric soils." Additional clarification should be sought in the more detailed discussion provided in the previous volume (Les, 2017).

The primary focus of this book is to provide information on the indicative taxa, which include those flowering plant species most readily recognized as being adapted to aquatic habitats. As in the companion volume, the species selected for inclusion here meet the criterion of "indicative" by their recognition as OBL wetland indicators in at least some portion of their North American range (Lichvar et al., 2016; USACE, 2016). Consequently, only those species most likely to occur in aquatic and wetland habitats are included. It is important to emphasize that the OBL category can include species that require water to complete an essential part of their life history, even though they might often appear to be growing on dryland following the subsidence of the water table.

This volume follows version 3.3 of the National wetland plant list (http://rsgisias.crrel.usace.army.mil/NWPL/), which designates more than 800 monocotyledon species as OBL North American indicators. Of these, 305 species in 97 genera, 34 families, and 11 orders have been included here in exclusion of species belonging to three graminoid families: Cyperaceae, Juncaceae, and Poaceae (see explanation below). Previous versions of the wetland plant list defined the indicator categories quantitatively, using numerical percentages of occurrence in wetlands as delimiters. However, subsequent versions of the list have abandoned that practice in favor of a qualitative assessment, which delimits the various indicator categories as follows:

1. Obligate (OBL): almost always occur in wetlands

2. Facultative wetland (FACW): usually occur in wetlands, but may occur in non-wetlands

3. Facultative (FAC): occur in wetlands and non-wetlands

4. Facultative upland (FACU): usually occur in nonwetlands, but may occur in wetlands

5. Upland (UPL): almost never occur in wetlands

The life history information summarized here for these OBL taxa is intended to facilitate their evaluation as wetland indicators with respect to the categories defined above.

Although this book focuses strictly on aquatic monocotyledonous flowering plants, it is not a taxonomic guide for aquatic plant species identification but should be regarded as a source of information on their life history, ecology, and systematics. Necessarily, one must first identify a species in order to apply this information effectively, using one of the several available manuals to facilitate species identifications (e.g., those referenced in Les, 2017). The geographical coverage of this book is restricted to North America, which is defined here as comprising the lower 48 United States, Alaska, and Canada. Because many North American aquatics also are found throughout the world, this reference also should be useful elsewhere. Except for the taxonomic outline, the following remarks essentially reiterate those of the companion volume (Les, 2017), but are repeated here for convenience.

The entries in this book are first organized as follows:

\section{Monocotyledons}

Monocotyledons I: Early diverging monocotyledons A group of uncertain phylogenetic position (Acorales) Alismatid monocotyledons (Alismatidae) Aroids

Monocotyledons II: Lilioid monocotyledons ("Liliidae")
Monocotyledons III: Commelinoid monocots
(Commelinidae)

The entries then are grouped secondarily by their respective orders (arranged alphabetically), which except for Alismatales and Arales, closely follow the APG IV classification (APG, 2016). A bracketed number follows each ordinal name to indicate the total number of families recognized. A systematic overview (with text citations) follows each order and indicates specifically those families that contain OBL indicator taxa. An overview of each family containing OBL taxa follows sequentially in alphabetical order. Family names are followed by a bracketed estimate of the total number of genera contained. An overview of each family follows (again with cited references) to summarize information on the systematics and economic importance. Each family treatment ends with an alphabetical list of genera that contain OBL species, listing the taxonomic authority for each genus.

Phylogenetic trees describing ordinal and familial relationships are included whenever available. However, it is important to emphasize that the putative relationships indicated by the organization of this book or by the phylogenetic trees included, all represent hypotheses rather than fact and that no assurance can be given regarding their accuracy beyond the conclusions advocated by the relevant studies cited.

The main part of the text focuses on genera and species. Each genus name is arranged alphabetically within a family and is followed (in parentheses) by a common name or names in English and French (when available), with the latter separated by a semicolon. Generic treatments follow the same format, listing first the etymology of the name, major synonyms, 
and the global and North American distribution and species numbers. Compilation of synonyms was facilitated by consulting The Plant List (2013) (www.theplantlist.org/). "In part" is used for synonyms that do not apply exclusively to the taxon. Asterisks designate nonindigenous distributional regions. Next is a list of any species designated as OBL along with any alternative regional rankings (i.e., FACW, FAC, FACU, or UPL) applied to these species. Generic and species names primarily are those accepted by ITIS (www.itis.gov/); otherwise, nomenclatural deviations are explained in the relevant "Systematics" section.

Following that listing is a description of habitat, which indicates salinity (freshwater to marine) and general community type. The latter includes four categories: lacustrine, palustrine, riverine, and oceanic. Lacustrine refers to those species found primarily in the deeper waters of lakes, riverine to those species preferentially occupying watercourses, and palustrine to "wetland" communities, often including those that occur along the shorelines of rivers and lakes. The $\mathrm{pH}$ value given next represents the complete range of values (or a qualitative assessment) reported among the individual species or is listed as "unknown" if reports were not found. The entry for "depth" also summarizes the full range of water depth associated with all the OBL species in the genus.

Life-forms are summarized for all the OBL species discussed. Herbs are herbaceous species where the leaves are scattered along an elongate stem (vittate) or extend from a common basal point (rosulate). For herbs, "emergent" refers to those species where substantial vegetative growth (shoot and leaf production) occurs above the water surface; "submersed" plants grow with their shoots and leaves underwater (excluding flowering portions in some cases); "suspended" plants are those whose shoots and leaves remain buoyant just beneath the water surface without any attachment to the substrate; "floating-leaved" plants produce leaves on the surface of water bodies and are rooted in the substrate; all structures of "free-floating" plants float on the water surface and do not attach to the substrate unless stranded in very shallow water or along shorelines. Woody plants grow only as emergents and include trees (strong ascending trunks exceeding $6 \mathrm{~m}$ in height) and shrubs (multiply branched, usually less than $6 \mathrm{~m}$ in height).

The section on "key morphology" is somewhat nontraditional in that it describes the genus with respect to the salient characteristics summarized only for the OBL species. Consequently, a measurement such as "to $50 \mathrm{~cm}$ " indicates that at least one OBL species in the genus is characterized by this value, even though others might be substantially smaller in stature; or potentially, some of the non-OBL members could be larger. Where several discrete ranges occur among the OBL species, they are separated by a comma, e.g. "to 5-10, 50-60 mm." The values provided indicate the longest axis of a structure, which is not necessarily its length. For monotypic genera or where a single OBL species exists, the description provided is of that species.

The life history section summarizes information for all OBL species in the genus. For duration, the relevant structure is indicated in parentheses; for fruits, an indication of frequency is indicated parenthetically as well as the presumed vectors associated with the structures involved in local and long-distance dispersal (additional details are provided within the included species treatments).

The imperilment status is summarized for each species using the data reported by NatureServe (www.natureserve. org/). The global [G] rank and regional ranks (where applicable) are listed for each OBL species using standard abbreviations for the US states and Canadian provinces; the latter are underlined for distinction. Taxa that are secure globally will include only the global [G] ranking. Because infraspecific designations are merged with a species name, the same state or province may appear in different categories when subspecies or varieties are given a different imperilment status. The NatureServe website should be consulted to clarify such discrepancies. It is important to realize that the rankings listed reflect the status when each treatment was prepared and always should be verified because they are updated continually to incorporate various taxonomic and ranking changes.

A general ecological overview of each genus is provided, which indicates the frequency of OBL taxa, and summarizes basic common features such as reproductive modes, pollinators, and seed ecology. When a genus is monotypic, information is excluded from this section and is simply summarized under the species treatment.

Each OBL species within the genus is treated successively in alphabetical order. Species names are highlighted in bold and include the names of taxonomic authorities. Habitat types reported in literature accounts or from specimen label descriptions are listed alphabetically. Some designations (e.g., "dunes") might appear unusual for aquatic plants, but refer to wet areas (pools, swales, etc.) occurring within these landforms. For additional clarification, adjectives for many of the habitat designations are provided in parentheses. For example, an entry of "prairies (mesic, wet)" would indicate that some records simply have described the habitat as "prairies," whereas others more specifically have cited "mesic prairies" or "wet prairies." Elevation data have been determined from literature reports or from specimen databases and represent the highest reliably documented values. Thus, a value of "to 3489 m" does not mean that the plants cannot occur above this specific elevation, but only that the designation represents the highest credible value found in the literature and database searches. Evidently anomalous values (due apparently to conversion errors, etc.) have been excluded at the discretion of the author. All available life history information that could be reasonably extracted from literature accounts and specimen database records is summarized. A conscientious effort has been made to locate information pertaining to reproductive ecology, pollination biology, seed germination, dispersal, and other important life history information for each species. When such information is incomplete or essentially absent for a species, a comment usually is made regarding the need for additional research, hopefully as an inspiration to others.

Where specific organisms are mentioned by their common name (e.g., "honeybees" as pollinators), additional taxonomic 
information (e.g., "Insecta: Hymenoptera: Apidae: Apis) is provided parenthetically to enable the reader to more specifically identify the intended taxon. Although it might seem obvious and/or redundant to constantly repeat groups like Aves (birds) and Insecta (insects), this convention has been followed for two reasons. First, a designation simply of "insects (Insecta)" indicates that no additional taxonomic information (e.g., order, family, etc.) was available for that particular entry at the time of consultation. Second, the use of this book by non-English speaking readers hopefully will be facilitated by including the scientific names along with the English common names, with which they might be unfamiliar.

To conserve space, none of the information summarized in the species treatments contains any literature citations; however, any literature from which information has been obtained is compiled at the end of each generic treatment under "References." Admittedly, although more space efficient, this convention does make it somewhat difficult to track down the original source of a specific entry, especially where lengthy reference lists occur.

Comprehensive lists of "Reported associates" are provided for each species, relative to the information available. The names presented here are those accepted in ITIS (www.itis. gov), except for a relatively few instances of disagreement at the author's discretion. These lists reflect the reported ecological association of any plant genus or species (including nonangiosperms) with the subject species in a variety of resources including published books and papers as well as various data repositories (see Les, 2017 for additional clarification).

Because these lists summarize data throughout the range of a species, they may or may not provide an accurate account of the likely or possible associations at a particular locality, especially for widespread species. Also, there are many factors that influence the inclusion of species in these lists. Records of imperiled taxa often exclude associated species, even when reported on database records, if those records have been "masked" to ensure site confidentiality (which is a widespread convention). Herbarium records for very weedy species often do not mention many associated species because such plants frequently grow in dense monocultures where associated species may not be evident to a collector. Sometimes the associated reports reflect a broader community that includes the habitat of a species, and it often is difficult to distinguish such reports from those where species might be growing closely together in one portion of a habitat. Consequently, these lists should be viewed as identifying those plants most likely to be found in habitats similar to that of the subject species. At the discretion of the author, highly improbable associations have been omitted, but these occurrences represented relatively few of the records evaluated. Unlike the preceding volume, the genus names of associates have not been abbreviated where multiple species occur. Although less space efficient, this convention made it easier to alphabetize the lists and more readily accommodate any necessary nomenclatural changes during the preparation of the text. Listing the full binomial also makes it easier for users of electronic text versions to search for a particular species.
Because infraspecific taxa are not reported, the accuracy of species identities depends entirely on the source from which the data were obtained. In some cases there will be inaccuracies. For instance, if a source cited only "Xyris caroliniana" as an associated species, it is impossible to tell whether the author of the record was referring to Xyris caroliniana Walter, rather than to an infraspecific taxon such as $X$. caroliniana var. olneyi Alph. Wood, which in this case would represent an entirely different species (i.e., X. smalliana Nash). Such errors are unavoidable but hopefully represent only a small fraction of those records reported.

A key rationale for including the listing of ecological associates is to provide an alternative means for evaluating the overall wetland indicator status of a particular species. By enumerating and comparing the wetland designations of all the associated species, one can potentially obtain a more accurate perspective of the typical wetland affinity of a single target species. If the associates of a particular OBL species also are typically designated as OBL, then that species itself would serve as a reliable wetland indicator; however, if the associates commonly include species ranked as facultative or upland, then that species would be a poor wetland indicator overall and a re-evaluation of its OBL status might be warranted.

Following the species accounts is a section on their use by wildlife. The species are discussed alphabetically as consistently as possible. Scientific names (at various ranks determined to provide adequate categorization) are provided for all associated organisms mentioned. In addition to published literature accounts, this information also relied on several websites, which are enumerated in the companion volume (Les, 2017).

The economic importance of species in each genus was summarized primarily from literature accounts and information provided by the Native American Ethnobotany website (http://naeb.brit.org/). CAUTION: The information regarding food and medicinal uses of plant species provided in this book does not represent an endorsement of their edibility, medical efficacy, or toxicity; but simply reports information that exists in the literature. Consequently, no wild plant ever should be used for food or medicinal purposes based solely on the information reported here.

The RHS horticultural database (http://apps.rhs.org.uk/ horticulturaldatabase/) served as a primary source for information on species that are maintained regularly under cultivation. To provide additional information on weeds, the database on herbicide resistant weeds (www.weedscience.org/ summary/home.aspx) was consulted.

The systematics section was compiled with the objective of evaluating recent literature on each included genus to provide reasonable syntheses of appropriate classifications, overviews of phylogenetic relationships, cytological information, hybridization, and other systematically pertinent topics. Although infraspecific taxa are not included in the individual OBL species accounts, they are discussed in this section whenever deemed relevant. Phylogenetic trees have been included whenever available and are provided to convey 
current (or at least recent) hypotheses regarding evolutionary relationships among the pertinent groups shown. These trees have been simplified without any indication of branch lengths, internal branch support, or other statistics, which usually can be found in the original source that is referenced in the figure caption. Because the simplified trees depicted here may differ in some respects from those presented in the original citation, the original source always should be consulted for a definitive interpretation.

A convention followed throughout the book is to indicate any taxon (at any rank) that contains at least one OBL species to be set in bold type when appearing on a tree diagram. Non-OBL taxa appearing on diagrams typically appear in lighter-shaded (50\% gray) type and also display their wetland indicator status where applicable. In many cases, this representation provides a fair estimate of how many independent origins of the OBL habit have occurred in the group shown (depending on the accuracy of the given phylogenetic tree, of course). It also is important to realize that taxa occurring only outside of North America never will be designated as OBL (because they have not been ranked), even though they may very well represent true aquatic plants.

The "Distribution" section primarily summarizes the geographical distributions of each species in North America and elsewhere, occasionally adding additional important information not covered in other sections.

Lastly, each genus treatment ends with a list of the primary references from which any specific information conveyed in the preceding account was obtained. A number of "general" references (e.g., Sculthorpe, 1967) were consulted throughout the book and are not listed repetitively in each reference section. 


\section{The Monocotyledons}

The term "monocotyledons" (or "monocots") refers anatomically to those flowering plants (angiosperms) having a shoot apex that is lateral to a single embryonic seed leaf, which otherwise is known as the cotyledon (Fahn, 1982). The primary root is short-lived in most of the species, resulting in a proliferation of adventitious roots, which often take on a highly fibrous appearance. All of the species lack secondary growth from a vascular cambium, but some (e.g., Smilax laurifolia) possess shoots that appear to be "woody" due to a cork cambium and its associated secondary tissues. Most of the species are small herbs, but some (e.g., Acoelorraphe wrightii) can reach arborescent stature by means of diffuse secondary growth or a secondary thickening meristem (Esau, 1977; Fahn, 1982). The shoot vasculature of monocots varies, but is organized commonly as a series of scattered bundles, which also occur in some early diverging dicotyledon groups.

A trimerous floral perianth was once thought to reliably distinguish between monocots and dicots; however, many dicot families (e.g., Annonaceae, Aristolochiaceae, Berberidaceae, Cabombaceae, Elatinaceae, Haloragaceae, Lauraceae, Lythraceae, Magnoliaceae, Myristicaceae, Papaveraceae, and Polygonaceae) also possess trimerous flowers. Monocots uniformly possess monosulcate pollen, which occurs also in some dicotyledons.

Monocotyledon leaf venation usually is described as "parallel" because of its superficial appearance as prominent, parallel vascular strands. Technically the veins all connect ultimately through smaller lateral veins, rather than ending blindly within the mesophyll as in dicot leaves (Fahn, 1982). Sheathed leaves are common in the group. Although toothed leaf margins are generally uncommon in monocots, a number of aquatic species (e.g., many Hydrocharitaceae) do possess serrate foliage. Compound leaves occur rarely (except for the families Araceae and Arecaceae), and are found in only one OBL monocot (Arecaceae: Acoelorraphe wrightii). Many monocots possess linear or elongate "grass-like" leaves, which are described as "graminoid" (see below).
Monocotyledons have long been regarded as a monophyletic group and numerous phylogenetic analyses have substantiated that conclusion (Judd et al., 2016). However, their conceptual systematic relationship to dicotyledons has changed considerably over the past decades as a consequence of those same analyses. The long-standing concept of monocots and dicots representing two distinct sister clades was first seriously questioned as the result of a phylogenetic analysis of plastid $(r b c L)$ gene sequence data, which resolved the clade as embedded within the monosulcate dicotyledons (Chase et al., 1993). Although most molecular studies have shown similar results, they have relied on highly divergent sequences (e.g., gymnosperms or Amborella) as outgroups, the consequences of which are not fully understood.

One problem is that despite its association with various monosulcate dicot families, the monocot clade resolves in different positions among them. In many cases, the topology of the angiosperm clade is such that simply moving the root actually can resolve the monocots and dicots as sister clades. These factors stress a precarious reliance on divergent outgroup sequences to place the angiosperm root properly in phylogenetic analyses. In other cases, the topology rendered obviously is problematic. Notable examples include profile alignments of $18 s+26 s$ rDNA data, which resolve the anomalous dicotyledon family Ceratophyllaceae within the monocots as the sister group of Tofieldiaceae (Maia et al., 2014), and PHYC data or cpDNA genome sequences, which place Acoraceae among the dicotyledons (Goremykin et al., 2005; Hertweck et al., 2015). As yet, it seems best to accept the monocots as a clade, but one for which a precise phylogenetic placement within the angiosperms remains equivocal.

Plants with grass-like foliage are found throughout the monocots but occur predominately in three families (Cyperaceae, Juncaceae, and Poaceae), which are denoted here as the "graminoid monocots." Although these families are rich in wetland species (comprising about $65 \%$ of all OBL monocots), more than half of their OBL species belong to just 
four genera (Carex, Eleocharis, Juncus, and Rhynchospora), making it difficult to treat them while avoiding excessively redundant information. Moreover, because of their highly modified structure, the species in these families are notoriously difficult to identify, and therefore, less useful as wetland indicators to those who are not taxonomic specialists in these groups. Because their inclusion in a book of this nature (which relies on the prior identification of a species) would be of questionable utility, the three graminoid families have been excluded. 


\section{Monocotyledons I Early Diverging Monocotyledons}

\section{A GROUP OF UNCERTAIN PHYLOGENETIC POSITION (ACORALES)}

\section{Order 1: Acorales [1]}

\subsection{Acoraceae Martinov}

\section{Family 1.1. Acoraceae [1]}

Because the Acorales contain only the single extant family Acoraceae, the two groups are discussed here simultaneously, with the characteristics of the order being those of the family. Acorales/Acoraceae (as Acorus) had been assigned formerly to the family Araceae (Arales). However, morphological and molecular evidence (e.g., Grayum, 1987; Duvall, 1993a) convincingly indicated that Acorus should be assigned to its own family (i.e., Acoraceae), a conclusion that later was substantiated by several phylogenetic analyses, which allied the group with other early diverging monocots but in various topological positions (Figure 1.1). Although many authors accept without reservation that Acorales represent the sister group of all monocotyledons, the fundamentally different placement of this clade in different phylogenetic analyses (e.g., Petersen et al., 2016) indicates that the question of its relationship to other monocots is still far from being settled.

Acoraceae contain fewer than six species, all within the genus Acorus. The family is distinctive and undeniably monophyletic, although no more than three of the presumed taxa (Ryuk et al., 2014) have yet been analyzed simultaneously in comparative genetic studies. All of the species are aromatic, rhizomatous perennial herbs with equitant, elongate, gladiate leaves. The leaf apex is acute and bent asymmetrically as in the genus Iris (Iridaceae), with which it can be confused when found in vegetative condition. The flowers of all species are bisexual, trimerous (six tepals), and arranged densely in a cylindrical spadix, which is associated with a sympodial, spathe-like leaf. The flowers are pollinated either by insects (Insecta) or by wind. The berrylike fruits have thin but leathery pericarps, which are dispersed abiotically by water.

The family is distributed widely throughout the temperate Northern Hemisphere and extends into the higher elevations of tropical Asia; some species have been introduced to the Southern Hemisphere (Thompson, 2000a).

Acorus plants have been used in traditional medicinal practices throughout many parts of the world. Numerous cultivars exist, which are planted as marginal water garden ornamentals.

The OBL North American indicators occur within one genus:

\subsubsection{Acorus L.}

\subsubsection{Acorus}

Ratroot, sweetflag; acore, belle-angélique

Etymology: from the Latin ăcor, meaning "sour taste"

Synonyms: Calamus Garsault [nom. illeg.]

Distribution: global: Africa; Asia; North America; North America: widespread

Diversity: global: 3-6 species; North America: 2 species Indicators (USA): obligate wetland (OBL): Acorus americanus, A. calamus

Habitat: freshwater; palustrine; pH: 5.5-8.6; depth: $<1 \mathrm{~m}$; life-form(s): emergent herb

Key morphology: rhizomes (to $25 \mathrm{~cm}$ ) branched, aromatic, pinkish, thick; leaves basal, aromatic, equitant, sessile, the blades (to $175 \mathrm{~cm}$ ) gladiate, flattened medially, the apex acute, bent asymmetrically; inflorescence a dense, cylindrical spadix (to $9 \mathrm{~cm}$ ), projecting laterally from a sympodial, leaflike bract (to $184 \mathrm{~cm}$ ); flowers (to $4 \mathrm{~mm}$ ) numerous (to 652), radial; tepals (to $4 \mathrm{~mm}$ ) 6; stamens 6; ovary 1, 3-locular; berries (to $6 \mathrm{~mm}$ ) obpyramidal, the pericarp thin, leathery; seeds (to 4 $\mathrm{mm}) 1-14$, apical, embedded in mucilage

Life history: duration: perennial (rhizomes); asexual reproduction: rhizomes; pollination: insect or wind (uncertain); sexual condition: hermaphroditic; fruit: leathery berries (absent or common); local dispersal: water (rhizome fragments, seeds); long-distance dispersal: water (seeds)

Imperilment: 1. Acorus americanus [G5]; SH (DE, MT); S1

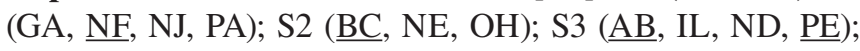
2. A. calamus [G4]; S1 (CO, MS); S2 (NC); S3 (IA)

Ecology: general: All Acorus species are obligate wetland plants, which occur only where high substrate moisture levels are maintained. They grow in open meadow-like exposures along with a variety of other graminoid wetland plants. The pollination biology of Acorus is uncertain but is assumed to be mediated by insects or wind. Although the triploid taxa are sterile, fairly high fertility can occur in diploids or tetraploids. The spadices of some diploid species emit a large volume of volatile floral substances (e.g., tetrahydrofurans), which are believed to attract insects. In fertile plants, the seeds are morphophysiologically dormant and require a period of cold stratification to induce germination. They are dispersed by water and will lose viability if stored dry for extended periods. The plants reproduce vegetatively by the extension of thick rhizomes, which can fragment; the fragments also are dispersed by water, particularly along watercourses. Due to taxonomic confusion between the following two species (see Systematics), it is possible that some of the subsequent 


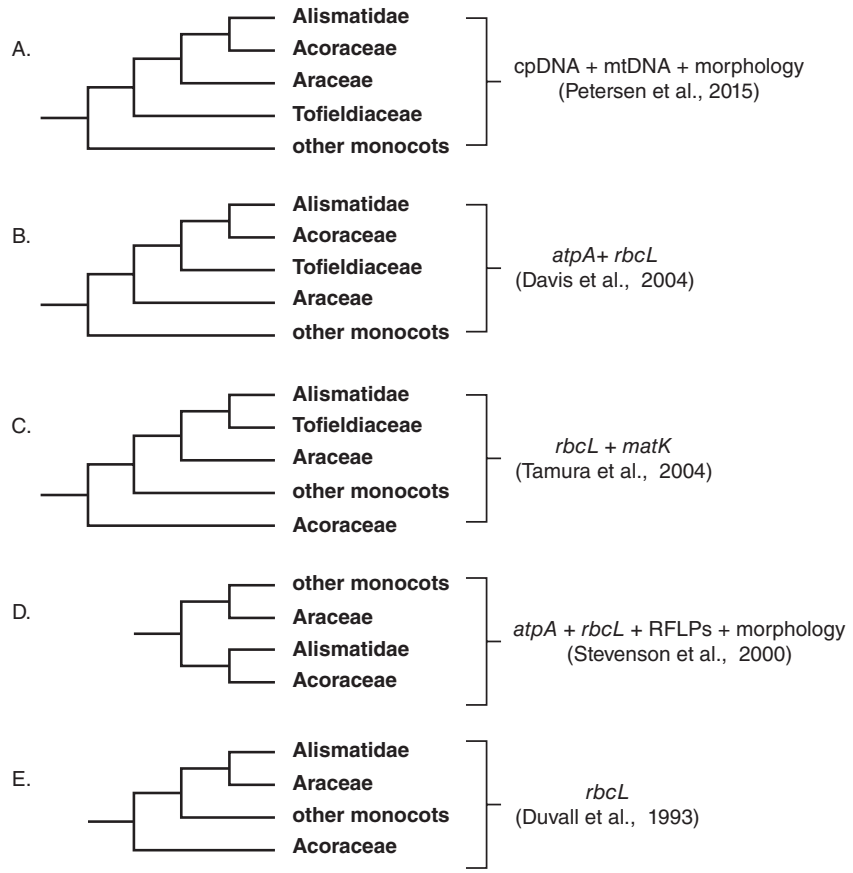

FIGURE 1.1 The groups of early diverging monocotyledons (i.e., Acoraceae, Alismatidae, Araceae, Tofieldiaceae) represent distinct clades; however, their interrelationships remain tenuous as indicated by the varied results obtained in different phylogenetic analyses (A-E). Although many authors have redefined the order "Alismatales" to include Alismatidae, Araceae, and Tofieldiaceae, such a disposition is inconsistent with several of these analyses (e.g., A, B, D). In contrast, the present treatment recognizes Alismatales as one of the two major clades resolved consistently within the alismatid monocots (Alismatidae).

information was assigned incorrectly in the literature consulted; however, care was taken to minimize that possibility. 1.1.1.1. Acorus americanus (Raf.) Raf. inhabits bogs, bottomlands, coves, depressions, ditches, fens, floodplains, levees, marshes, meadows, mudflats, prairies, seeps, swales, swamps (in openings), and the margins of lakes, ponds, reservoirs, rivers, streams, and swamps at elevations to $915 \mathrm{~m}$. The plants can tolerate shallow standing water and grow primarily in exposures that receive full sunlight. The best growth occurs in freshwaters, with declining growth rates observed at $25-100 \mathrm{mM} \mathrm{NaCl}$ concentrations. Conductivity levels are low to moderate $\left(10-240 \mu \mathrm{mhos} \mathrm{cm}^{-1}\right)$ with low alkalinity (5-115 $\mathrm{mg} \mathrm{l}^{-1} \mathrm{CaCO}_{3}$ ). Reported substrates span a range of acidity ( $\mathrm{pH}$ : 5.5-8.6) and include clay, loam, muck, and mud. Experimentally, the plants grow optimally at $\mathrm{pH} 7.0$ but decline substantially at $\mathrm{pH}$ levels $>8$. Flowering occurs from May to September, with fruiting extending into October. Although the precise pollination mechanism is unknown, each spadix can produce from 492 to 652 berries yielding a total of 1,700-2,700 seeds. The seeds are dispersed by water. They can be stored in water (at $1^{\circ} \mathrm{C}-3^{\circ} \mathrm{C}$ ) in which viability will be retained for at least 7 months. The seeds are dormant and require a period of cold stratification and light in order to germinate. Satisfactory germination has been reported for seeds dried at $20^{\circ} \mathrm{C}-25^{\circ} \mathrm{C}$, then stratified at $2^{\circ} \mathrm{C}-4^{\circ} \mathrm{C}$ for 4 weeks, and then incubated under a $25^{\circ} \mathrm{C} / 15^{\circ} \mathrm{C}$ day/night temperature regime. Under those conditions, the seedlings emerge after 10-30 days. The plants also can be cultivated readily using rhizome cuttings. The plants lack drought tolerance adaptations, but develop drought avoidance characteristics such as fewer stomata having smaller pores, and produce less biomass when growing under water-deprived conditions. Reported associates: Acer saccharinum, Agalinis purpurea, Alisma, Alopecurus aequalis, Amorpha fruticosa, Apocynum cannabinum, Arnoglossum plantagineum, Asclepias incarnata, Betula nigra, Bidens laevis, Boehmeria cylindrica, Bolboschoenus fluviatilis, Calamagrostis canadensis, Calla palustris, Carex aquatilis, Carex cristatella, Carex haydenii, Carex hystericina, Carex lacustris, Carex pellita, Carex stricta, Carex utriculata, Carex vesicaria, Carex vulpinoidea, Cephalanthus occidentalis, Chelone glabra, Cicuta bulbifera, Clinopodium glabrum, Comarum palustre, Cornus amomum, Cornus racemosa, Crataegus, Cyperus strigosus, Dasiphora floribunda, Deschampsia cespitosa, Dulichium arundinaceum, Echinochloa crus-galli, Eleocharis palustris, Equisetum fluviatile, Eupatorium perfoliatum, Eutrochium maculatum, Filipendula rubra, Galium obtusum, Galium triflorum, Gentiana andrewsii, Glyceria grandis, Glyceria striata, Gratiola aurea, Helenium autumnale, Helianthus grosseserratus, Hippuris vulgaris, Howellia aquatilis, Hypericum kalmianum, Hypericum sphaerocarpum, Impatiens capensis, Iris pseudacorus, Iris virginica, Juncus dudleyi, Juncus nodosus, Juncus torreyi, Leersia oryzoides, Liparis loeselii, Lobelia spicata, Lycopus americanus, Lycopus uniflorus, Lysimachia ciliata, Lysimachia quadriflora, Lysimachia thyrsiflora, Lythrum alatum, Lythrum salicaria, Mimulus ringens, Muhlenbergia mexicana, Myosotis scorpioides, Osmunda regalis, Parnassia glauca, Pedicularis lanceolata, Peltandra virginica, Persicaria amphibia, Persicaria coccinea, Persicaria hydropiperoides, Persicaria maculosa, Persicaria pensylvanica, Persicaria punctata, Phalaris arundinacea, Phleum, Phlox glaberrima, Physostegia virginiana, Platanthera flava, Platanthera leucophaea, Populus deltoides, Prenanthes racemosa, Pycnanthemum virginianum, Rumex britannica, Sagittaria cuneata, Sagittaria latifolia, Salix exigua, Salix interior, Salix nigra, Schoenoplectus acutus, Schoenoplectus tabernaemontani, Scolochloa festucacea, Scutellaria galericulata, Sium suave, Solidago gigantea, Solidago ohioensis, Solidago riddellii, Sparganium emersum, Sparganium eurycarpum, Spartina pectinata, Sphagnum, Stachys pilosa, Stellaria longifolia, Symphyotrichum ericoides, Symphyotrichum firmum, Symphyotrichum laeve, Symphyotrichum novae-angliae, Thelypteris palustris, Triadenum virginicum, Typha angustifolia, Typha latifolia, Verbena hastata, Veronicastrum virginicum, Viburnum lentago, Zizania aquatica.

1.1.1.2. Acorus calamus L. is a nonindigenous species, which grows in bogs, brooks, canals, depressions, ditches, floodplains, marshes, meadows, pools, prairies, rivulets, roadsides, seeps, sloughs, springs, swales, swamps (openings), and along the margins of lakes, ponds, reservoirs, rivers, and streams at elevations to $1060 \mathrm{~m}$. The plants will tolerate shallow standing water $(5-45 \mathrm{~cm}$ deep) and primarily occupy exposures of full sunlight. The substrates, 
primarily silt ( $49 \%)$ and sand ( $37 \%)$, tend to be acidic (pH: $<6)$ but can span a broader range (pH: 5.6-7.2). The nitrogen content of sediments tends to be low (e.g., $3.2 \mu \mathrm{g} \mathrm{l}^{-1}$ ), but the organic matter (1-2\%) and clay (e.g., 14\%) content are relatively high. The substrates are described as alluvium, clay, gravel, humus, loam, muck, mud, and sand. Flowering occurs from May to October (fruiting is not observed in North America). Although sexually sterile, the plants can disperse effectively by vegetative propagules derived from rhizome fragments. These propagules are dispersed by water, wherein they can remain buoyant for at least 6 months and retain an adequate capacity (e.g., 58\%) to resprout. Rhizome length has been found to correlate positively with aluminum, calcium, and magnesium levels in the sediment. The rhizomes are tolerant of flooding or drawdown conditions, light or moderate shade, and nitrogen limitation. Reported associates (North America): Acer saccharinum, Alisma subcordatum, Amphicarpa bracteata, Angelica atropurpurea, Asclepias incarnata, Asparagus, Boehmeria cylindrica, Calamagrostis canadensis, Caltha palustris, Carex conjuncta, Carex crus-corvi, Carex frankii, Carex grayi, Carex jamesii, Carex leavenworthii, Carex lupulina, Carex muskingumensis, Carex typhina, Celtis occidentalis, Cephalanthus occidentalis, Chasmanthium latifolium, Cladium mariscoides, Convolvulus sepium, Cyperus, Dulichium arundinaceum, Equisetum arvense, Festuca subverticillata, Fraxinus pennsylvanica, Fraxinus profunda, Glyceria striata, Gratiola aurea, Hypericum mutilum, Hypericum prolificum, Impatiens capensis, Iodanthus pinnatifidus, Iris pseudacorus, Juglans, Laportea canadensis, Leersia oryzoides, Leersia virginica, Lemna minor, Lolium perenne, Lycopus virginicus, Lysimachia ciliata, Lysimachia thyrsiflora, Mentha, Parthenocissus, Pastinaca sativa, Persicaria amphibia, Persicaria punctata, Phalaris arundinacea, Phalaris arundinacea, Phleum pratense, Pilea pumila, Poa nemoralis, Prunella vulgaris, Rhus, Robinia pseudoacacia, Rosa, Rubus occidentalis, Rumex, Sagittaria latifolia, Salix interior, Salix nigra, Sambucus, Sanicula canadensis, Scirpus, Scutellaria lateriflora, Solidago, Sparganium eurycarpum, Spiraea, Symphyotrichum lanceolatum, Symphyotrichum lateriflorum, Symphyotrichum ontarionis, Symplocarpus foetidus, Toxicodendron radicans, Typha latifolia, Ulmus americana, Utricularia macrorhiza, Verbena hastata, Viola sororia, Vitis cinerea, Vitis riparia.

Use by wildlife: Acorus americanus and A. calamus rhizomes are eaten by muskrats (Mammalia: Cricetidae: Ondatra zibethicus) and other mammals. Neither species is particularly valued as a waterfowl food but the seeds of A. calamus are eaten by redhead ducks (Aves: Anatidae: Aythya americana). The foliage is used as cover by waterfowl. The plants are rated as highly resistant to grazing by deer (Mammalia: Cervidae: Odocoileus). The leaves of A. americanus are oviposition sites for damselflies (Insecta: Odonata: Aeshnidae: Aeshna constricta). Acorus calamus is a host to several Fungi (Ascomycota: Glomerellaceae: Colletotrichum; Dermateaceae: Cylindrosporium acori; Mycosphaerellaceae: Ramularia aromatica, Septocylindrium, Sphaerulina acori;
Phaeosphaeriaceae: Phaeosphaeria acori; Basidiomycota: Ceratobasidiaceae: Rhizoctonia solani; Doassansiaceae: Nannfeldtiomyces sparganii; Pucciniaceae: Nigredo pyriformis, Uromyces pyriformis; U. sparganii; Oomycota: Pythiaceae: Pythium).

Economic importance: food: Consumption of Acorus can be dangerous given its potentially toxic properties, and its use as food is not recommended. Deleterious effects can include constipation, diarrhea, digestive disorders, gastroenteritis, and internal bleeding. Some constituents (e.g., $\beta$-asarone) are known to induce tumors in laboratory animals. However, the young flower stems and leaf stalks, which emerge in early spring, reportedly are edible in raw form and the candied rhizomes have been made into a confection. Because A. americanus lacks the carcinogenic $\beta$-asarone and its phenylpropane derivatives, presumably it would be less dangerous to consume; medicinal: The medicinal and pharmacological literature on Acorus is voluminous. The essential oil of Acorus contains over 240 volatile components, including $\beta$-asarone, $\beta$-farnesene, cis-methylisoeugenol, epishyobunone, geranylacetate, isoshyobunone, methyleugenol, and shyobunone. Concentrations of these substances can differ widely among the taxa; e.g., $\beta$-asarone, which occurs at low levels (5\%) in A. calamus but is absent in A. americanus. The plants have been used for centuries to treat numerous ailments worldwide. The rhizomes of $A$. americanus contain $\alpha$-asarone (similar chemically to the alkaloid mescaline), which is a stimulant at low concentrations but hallucinogenic if ingested in "higher" amounts; $\beta$-asarone also is hallucinogenic. Both the essential oil and the asarones are smooth muscle relaxants, having effects similar to those of papaverine (a constituent of opium). The oils also have a wide range of antibacterial and fungicidal properties. Acorus species produce lectins, which are mitogenic to human lymphocytes and inhibitory to some cancer cell lines. Many indigenous North American tribes regarded Acorus as a medicinal panacea. The plants were particularly important medicinally to the Aboriginal inhabitants of Alberta, Canada. The Chippewa, Hocak, Ojibwa, and Potawatomi people used small amounts of the plants to treat colds. The Meskwaki treated burns and sores from boiled rhizome extracts. In other parts of North America the plants have been used as a stimulant and also to treat diabetes, diarrhea, fever, flatulence, heartburn, hyperlipidity, indigestion, liver disorders, pain, rheumatism, stomach upset, and many other disorders; cultivation: Acorus was first cultivated in Europe during the 16th century and is grown today as an ornamental marginal plant for water gardens. Cultivars of A. calamus include 'Argenteostriatus', 'Purpureus', and 'Variegatus'; misc. products: Acorus has long been used for various ceremonial purposes, with remains of the plants recovered from the tomb of King Tutankhamen (dating to the 14th century BC). In modern times, A. americanus extracts have been sprayed around camping tents to repel spiders (Arthropoda: Arachnida: Araneae) and snakes (Reptilia: Squamata: Serpentes). Essential oils from the rhizome of A. calamus have been used as a household deodorant, as a flavoring for alcoholic beverages (e.g., beer, bitters, gin, vermouth, and wine), as a perfume essence, as a pest repellant, 
Aquatic Monocotyledons of North America

for ritual oils, and to tan leather. The matted foliage was once used as a floor covering. Exposure to the volatile oils of $A$. calamus causes sterility in male domestic house flies (Insecta: Diptera: Muscidae: Musca domestica); weeds: Acorus calamus can compete with more useful wildlife plants; nonindigenous species: The introduction of Acorus calamus to North America probably occurred during the mid-18th century.

Systematics: Although the systematic position of Acorus remains uncertain, even after the phylogenetic evaluation of a large amount of molecular data (e.g., Figure 1.1), the genus clearly is monophyletic. However, the taxonomy of the genus itself is problematic, with no consensus on the number of species that should be recognized. Molecular phylogenetic analyses have distinguished at least three distinct taxa: A. calamus, A. gramineus (much smaller in stature), and A. angustatus (= A. tatarinowii, etc.). The latter possibly is conspecific with A. americanus (not included in simultaneous phylogenetic analyses), but this issue has not yet been resolved. The chloroplast genome sequences of A. americanus and A. calamus in GenBank are virtually identical (>99.9\% sequence identity), which indicates that the triploid (or hexaploid) A. calamus likely is derived from an ancestor similar to the diploid (or tetraploid) A. americanus (or A. angustatus if conspecific with the latter). Some of the taxonomic problems are associated with inconsistent cytological observations. The basic chromosome number of Acorus has been difficult to determine due to numerous conflicting accounts. It is widely regarded as $x=12$, with the fertile $A$. americanus $(2 n=24)$ interpreted as diploid and the sterile $A$. calamus $(2 n=36)$ as a triploid. Tetraploid $(2 n=48)$ and hexaploid $(2 n=72)$ races of $A$. calamus also have been reported outside of North America. However, other researchers have found $x=7$ (and an aneuploid derivative $x=9$ ) as the base numbers in numerous Asian accessions. Several other "anomalous" counts reported (e.g., $2 n=54,66,72$ ) could be explained readily by a base number of $x=6$ (rather than 12), which also would accommodate the more widely accepted counts. In that case, A. americanus would represent a tetraploid and $A$. calamus a hexaploid. A more definitive cytological assessment of Acorus seems necessary in order to reconcile these inconsistencies.

Distribution: Acorus americanus is distributed across northern North America; A. calamus is widespread throughout the eastern United States and occurs sporadically in the western United States and eastern Canada.

References: Angier, 1974; Azuma \& Toyota, 2012; Bains et al., 2005; Baskin \& Baskin, 1998; Beal, 1977; Bogner \& Mayo, 1998; Calvo-Polanco et al., 2014; Cottam, 1939; Crothers, 2012; Davis et al., 2004; Dolan, 2014; Dozier, 1945; Duvall et al., 1993a; Elmore et al., 2016; Fernald \& Kinsey, 1943; Geiger \& Banker, 2012; Haines, 2000a; Kindscher \& Hurlburt, 1998; Kumar \& Singh, 2015; Les \& Mehrhoff, 1999; Marles, 2001; Mathur \& Saxena, 1975; Morgan, 1980; Morton, 1963; Motley, 1994; Muenscher, 1936a; Nichols, 1999; Packer \& Ringius, 1984; Pai \& McCarthy, 2005; 2010; Perdomo et al., 2004; Petersen et al., 2016; Romanello et al., 2008; Rudgley, 1999; Sarneel, 2013; Smreciu et al., 2014; 2015; Stevenson et al., 2000; Strong, 2000; Tamura et al., 2004;
Thompson, 2000a; Wang et al., 2001; Wein, 1939; 1940a; 1940b; Wieffering, 1972.

\section{ALISMATID MONOCOTYLEDONS (ALISMATIDAE)}

The alismatid monocotyledons consist entirely of aquatic and wetland species, which represent the greatest hydrophyte radiation within the angiosperms. All of the North American members are designated as OBL indicators throughout their ranges. The 11-12 "core" families (a distinction between Cymodoceaceae and Ruppiaceae remains unsettled) comprise a distinct, monophyletic group, which has been recognized at various taxonomic levels (Les \& Tippery, 2013; Ross et al., 2016). Although once included in the group, the families Petrosaviaceae and Triuridaceae now are regarded as unrelated (Les \& Tippery, 2013).

A long-standing tradition has been to treat this aquatic clade as a subclass (Alismatidae) containing two to four orders (e.g., Takhtajan, 1969; Cronquist, 1981). Older literature refers to the same taxon by the illegitimate ordinal name Helobiae. However, many recent authors (e.g., APG, 2016) have adopted a broader classification circumscribing one large order (Alismatales sensu lato), which contains the alismatid clade along with the former members of Arales (Araceae, Lemnaceae), and Tofieldiaceae. Although the broader concept of Alismatales has been widely followed, several phylogenetic studies (e.g., Figure 1.1A, B, D) do not support that assemblage as monophyletic. Until more consistent and compelling phylogenetic information is available, it seems prudent to restrict the circumscription of alismatids to include only the core families while excluding Araceae, Lemnaceae, and Tofieldiaceae (Les \& Tippery, 2013). Full plastid genome sequence analyses (Ross et al., 2016) also indicate that the core alismatids are quite distinct genetically from both Arales and Tofieldiaceae, which also would argue for the distinction of these groups as smaller, ordinal subdivisions. Consequently, the treatment followed here is to recognize the alismatids as a subclass (Alismatidae) containing the twelve core aquatic families (Figure 1.2).

The Alismatidae can be subdivided effectively into two orders. Various molecular phylogenetic analyses (e.g., Les et al., 1993; 1997c; Les \& Haynes, 1995; Les \& Tippery, 2013; Ross et al., 2016) consistently have resolved two major clades within the group. These clades correspond with distinct (i.e., petaloid vs. tepaloid) floral morphologies (Posluszny et al., 2000) and have been recognized respectively as the orders Alismatales (sensu stricto) and Potamogetonales (Les \& Tippery, 2013), which is the convention followed here (Figure 1.2). In this interpretation, the Alismatidae contain 12 families, 57 genera, and about 480 species.

Alismatids are highly diverse, making it difficult to identify consistent synapomorphic traits. Although the group is regarded as representing unspecialized or "primitive" monocots by its inclusion of plants having a combination of polypetalous, hermaphroditic flowers with radial symmetry, apocarpous gynoecia, and numerous stamens and carpels, it also contains many species having derived traits such as 


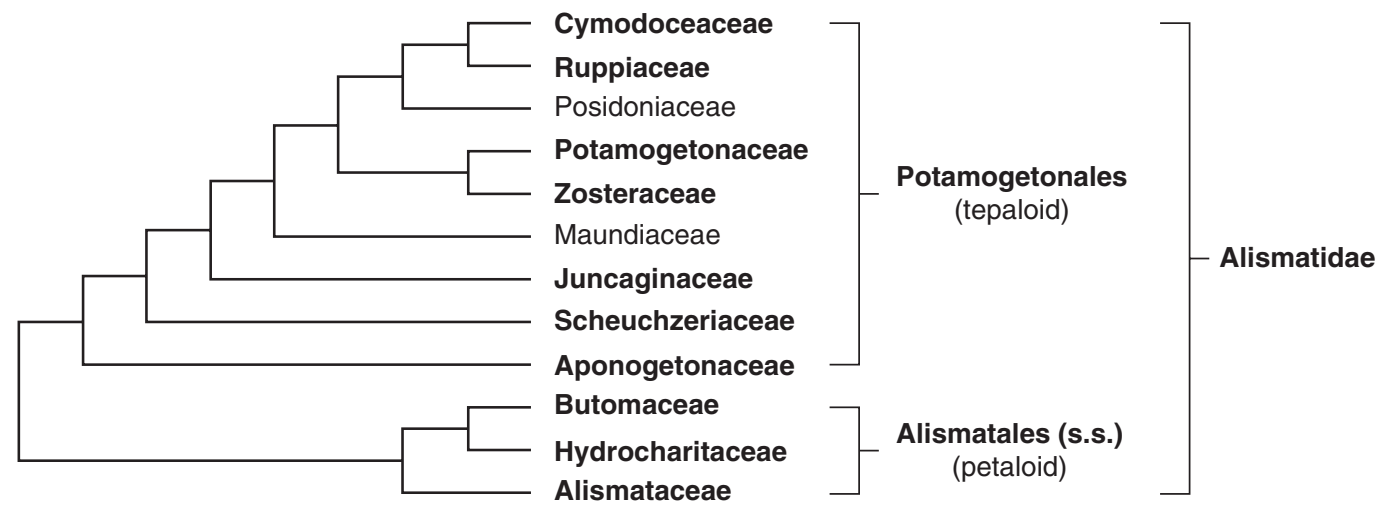

FIGURE 1.2 Phylogenetic relationships of alismatid families as indicated by a likelihood analysis of 83 plastid gene sequences (adapted from Ross et al., 2016). The North American families containing OBL indicators are highlighted in bold (Ruppiaceae are merged with Cymodoceaceae in the present treatment).

unisexuality, syncarpy, epigyny, and the only known flowering plants adapted to life in marine habitats. The subclass also exhibits a broad spectrum of pollination mechanisms incorporating biotic (Insecta) and abiotic (water, wind) vectors as well as self-pollination (Les, 1988; Les et al., 1997a). Representatives of the subclass are found throughout the world.

\section{Order 2: Alismatales [3]}

In molecular phylogenetic analyses, Alismatales consistently comprise a well-defined clade which is sister to the Potamogetonales (Figure 1.2). Referred to commonly as the "petaloid clade," these species are distinguished from other Alismatidae by having well-differentiated perianths consisting of both a calyx and corolla (Posluszny \& Charlton, 1993; Posluszny et al., 2000). Most of the flowers are relatively showy and entomophilous. In some species they are unisexual and arranged in dioecious or monoecious sexual conditions. Until recently, the order segregated Butomopsis, Hydrocleys, and Limnocharis as a fourth family, Limnocharitaceae. Although these three genera associate as a clade, phylogenetic analyses resolve them as being nested in Alismataceae, within which they have been subsumed (Les \& Tippery, 2013; Ross et al., 2016).

Alismatales are cosmopolitan in distribution. The order contains three families, all having OBL North American representatives:

\subsection{Alismataceae Ventenat \\ 2.2. Butomaceae Mirbel \\ 2.3. Hydrocharitaceae Jussieu}

\section{Family 2.1. Alismataceae [17]}

The water-plantains (Alismataceae) are herbaceous annuals (rarely) or rhizomatous perennials, which grow in standing water or in wetlands. Their foliage commonly contains laticifers (except Sagittaria) and abundant airspace lacunae. The leaves typically are basal and are differentiated into blade and petiole, except when growing under submersed conditions when they can assume an elongate, graminoid shape (Sculthorpe, 1967; Cronquist, 1981; Judd et al., 2016). The hypogynous flowers are perfect or unisexual, often in whorls, and consist of a well-differentiated perianth of three sepals and three white, pink, or yellowish petals, six-numerous stamens, and an apocarpous gynoecium of three-numerous pistils; the fruits are aggregates of achenes or follicles (Cronquist, 1981; Haynes \& Holm-Nielsen, 1994; Haynes et al., 1998a; Judd et al., 2016). Pollination of the nectariferous flowers is facilitated by insects (Insecta: Diptera; Hymenoptera). The fruits are dispersed by water or transported endozoically by waterfowl (Aves: Anatidae).

The family includes three genera (Butomopsis, Hydrocleys, Limnocharis), which formerly were assigned to Butomaceae or were segregated as the family Limnocharitaceae. However, most molecular phylogenetic analyses (e.g., Figure 1.3) resolve these genera as embedded within the clade containing the traditional genera of Alismataceae, where they have been included here. However, conflicting phylogenetic results have been obtained by analyses incorporating morphological characters, which resolve the "Limnocharit" genera as a basal grade of Alismataceae (Lehtonen, 2009).

Members of some genera (e.g., Echinodorus, Hydrocleys, Limnocharis, Sagittaria) are grown as ornamental water garden specimens. The underground organs of some species have been used as a source of food or medicine.

Alismataceae have a nearly cosmopolitan distribution. OBL indicators occur in six North American genera:

\subsubsection{Alisma L.}

2.1.2. Damasonium Mill.

2.1.3. Echinodorus Rich. \& Engelm. ex A. Gray

2.1.4. Helanthium (Benth. \& Hook.f.) Engelm. ex J.G.Sm.

2.1.5. Hydrocleys Rich.

2.1.6. Sagittaria L.

\subsubsection{Alisma}

Water plantain; plantain d'eau 


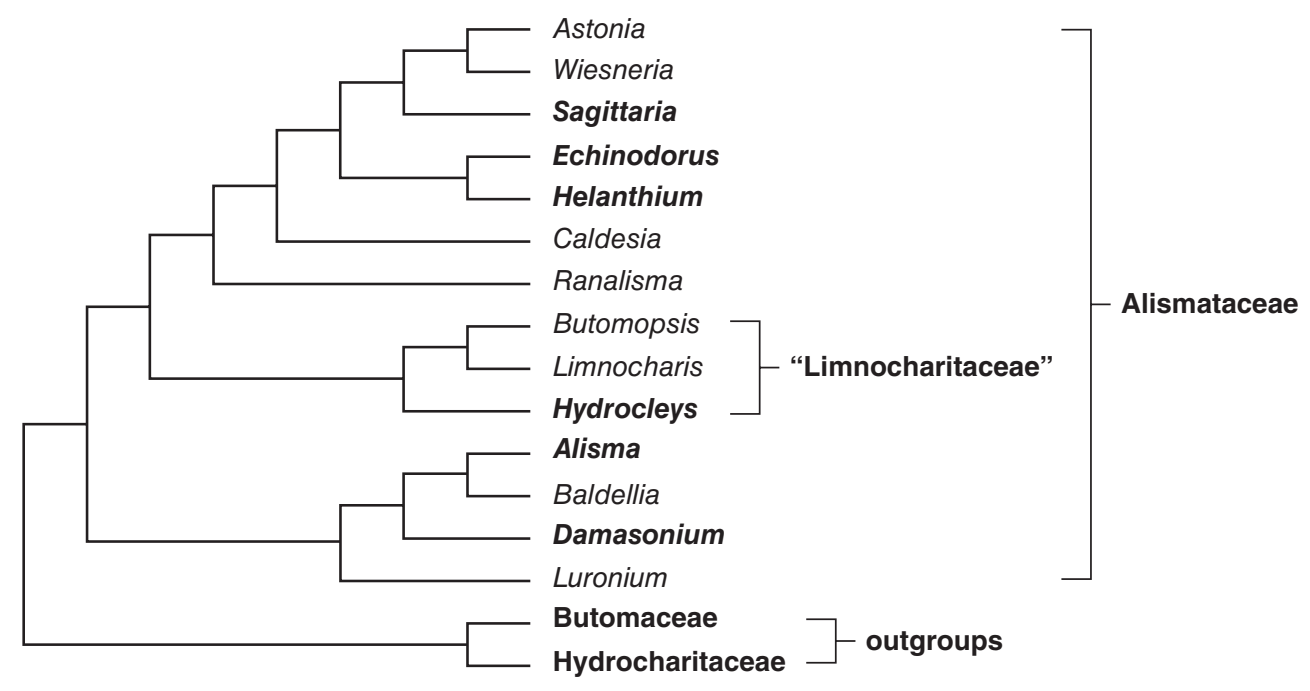

FIGURE 1.3 Intergeneric relationships in Alismataceae as indicated by a likelihood analysis of 83 plastid gene sequences (adapted from Ross et al., 2016). The North American groups containing OBL indicators are highlighted in bold.

Etymology: an ancient name of unknown meaning but possibly derived from alcea, another Greek name for these plants Synonyms: none

Distribution: global: nearly cosmopolitan; North America: widespread

Diversity: global: 9 species; North America: 4 species

Indicators (USA): obligate wetland (OBL): Alisma gramineum, A. lanceolatum, $A$. subcordatum, A. triviale

Habitat: brackish to freshwater; lacustrine, palustrine, riverine; pH: 4.5-9.6; depth: $<1 \mathrm{~m}$; life-form(s): emergent herb, floating-leaved, submersed (rosulate)

Key morphology: plants (to $1 \mathrm{~m}$ ) arising from a corm-like rhizome (to $3.5 \mathrm{~cm}$ ) with non-septate roots; leaves basal, the blades (to $35 \mathrm{~cm}$ ) linear-lanceolate to elliptic or ovate and petiolate (to $55 \mathrm{~cm}$ ) when emersed or floating, linear (to 100 $\mathrm{cm}$ ) and sessile when submersed, the margins entire; panicles (to $1 \mathrm{~m}$ ) spreading, with whorls (to 10) of verticillate cymes containing pedicellate (to $47 \mathrm{~mm}$ ) flowers; flowers bisexual, radial, cleistogamous (submersed) or chasmogamous (emergent); perianth 3-merous, differentiated into calyx and corolla, petals (to $6.5 \mathrm{~mm}$ ) pink, purplish, or white; stamens 6-8; gynoecium apocarpous, the pistils (to 28) arranged in a flat ring (to $8 \mathrm{~mm}$ ); achenes (to $3.1 \mathrm{~mm}$ ) compressed laterally Life history: duration: perennial (rhizomes); asexual reproduction: rhizomes (lateral); pollination: insect, self; sexual condition: dioecious, hermaphroditic, monoecious; fruit: aggregates of achenes or follicles (common); local dispersal: seeds (water); long-distance dispersal: seeds (birds)

Imperilment: 1. Alisma gramineum [G5]; S1 (CA, MB); S2 (NY, WY); S3 ( $\underline{\mathrm{AB}}, \underline{\mathrm{BC}}, \underline{\mathrm{QC}}, \underline{\mathrm{SK}}) ; 2$. A. lanceolatum [G4]; 3. A. subcordatum [G5]; S1 (MS, $\underline{\mathrm{NB}}, \mathrm{WY}) ; \mathrm{S} 3$ (NC, $\underline{\mathrm{QC}}) ; 4$. A. triviale [G5]; S1 (F, NJ, PA, YT); S2 (IL); S3 (OH, WY) Ecology: general: Alisma is entirely aquatic and all of the North American species are designated as OBL indicators throughout their ranges. The genus is perennial, with some species behaving on occasion as annuals. The flowers contain septal nectaries and are produced in profusion, numbering up to 1,000 in some plants. They are self-compatible and lack dichogamy, but can be self-pollinating or outcrossed by small insects such as flies (e.g., Insecta: Diptera: Syrphidae) and also by the wind. Submersed, self-pollinating, cleistogamous flowers are produced in some species. The average seed set typically is high, in the range of $88-96 \%$. The seeds are buoyant, dispersed by water, and can remain afloat for extended periods of up to several months. Some seeds reportedly can germinate without treatment but nearly all become physiologically dormant and require a period of cold stratification (e.g., 30-210 days at $2^{\circ} \mathrm{C}$ ) for optimal germination (at $20^{\circ} \mathrm{C}$ or $25^{\circ} \mathrm{C} / 15^{\circ} \mathrm{C}$ ). Germination rates typically are low, usually only $5-10 \%$. Slightly higher rates (to $15 \%$ ) occur under maximum moisture conditions. The seeds of some species are known to remain viable for more than 10 years and seed banks can develop. Vegetative reproduction can occur by means of lateral offshoots arising from the bulbous rhizome and is more prevalent in plants growing under shaded conditions.

Because of historical taxonomic misunderstandings (see Systematics), information can be difficult to associate unambiguously with occurrences of Alisma subcordatum and A. triviale, which at one time were recognized in North America as subspecies or varieties of A. plantago-aquatica (i.e., A. plantago-aquatica var. parviflorum and A. plantago-aquatica var. americanum, respectively). It is now quite evident that both $A$. subcordatum and A. triviale are distinct from $A$. plantago-aquatica (see Systematics) and that the latter does not actually occur in the New World, despite numerous conflicting reports. Consequently, although designated as an OBL North American indicator, A. plantago-aquatica has been excluded here.

2.1.1.1. Alisma gramineum Lej. grows in shallow to moderately deep (to $1.6 \mathrm{~m}$ ), fresh to brackish, still to flowing waters of backwashes, beaches, bottoms, canals (dry), channels, depressions, ditches, flats, floodplains, marshes (tidal), mudflats, pools, puddles, roadsides, shores, slopes (to 1\%), sloughs, springs, streams, vernal pools, washes, and along the margins 
of canals, channels, lakes, playas, ponds, reservoirs, and rivers at elevations to $3180 \mathrm{~m}$. The plants can grow completely submersed (then with ribbon-like foliage and cleistogamous flowers) but also occur often on drying or exposed substrates where ephemeral waters have receded. Their optimal depth has been reported as $50-70 \mathrm{~cm}$. Exposures typically receive full sunlight. The substrates are described as alkaline (e.g., pH: 7.5-9.6; total alkalinity: 48-108 ppm) and include clay, clay loam, clay muck, clay mud, clay silt, gravel, limestone, muck, mucky clay, mud, muddy clay, rock, sand, sandstone, sandy gravel, sandy muck, sandy silt, shales, silty clay, and stones. The flowers of emergent plants are chasmogamous and normally insect pollinated, whereas those of submersed plants are cleistogamous and self-pollinated. Flowering and fruiting occur from June to September. The flowers remain open from 6:30 am to 10:00 pm. Seed set in open-pollinated plants has been estimated at $88 \%$. The achenes are buoyant and dispersed by water, but under continuous agitation, they sink within 128 h. A persistent seed bank develops. Dried seeds (at $15 \%$ relative humidity) that are frozen (at $-20^{\circ} \mathrm{C}$ ) have remained viable for at least a year. Scarification of the pericarp or stratification is necessary to promote germination. A $60 \%$ germination rate has been reported for dried, stored seeds that have been re-exposed to high humidity for 1 day at $21^{\circ} \mathrm{C}$, then physically scarified and incubated at $26^{\circ} \mathrm{C}$ under a 12/12-h photoperiod. High germination rates (56\%) have been obtained for seeds that have been cold stratified (e.g., 10 months at $6^{\circ} \mathrm{C}$ ) and then incubated in shallow water under constant $\left(25^{\circ} \mathrm{C}\right)$ or fluctuating $\left(25^{\circ} \mathrm{C} / 10^{\circ} \mathrm{C}\right)$ temperatures. Germination rates are reduced nearly by half if the seeds are stratified for a comparable time at $20^{\circ} \mathrm{C}$. The best germination rates $(94-100 \%)$ have been obtained for cold, wet-stored seeds that are pre-treated with bleach and then incubated at $20^{\circ} \mathrm{C}-30^{\circ} \mathrm{C}$. The seedlings have a relatively high vulnerability to winter conditions, and do not fare well unless they initially establish soundly on exposed substrates during the late summer and fall. Because new seedlings are killed by high water conditions, much of the annual reproduction occurs by seed. In subsequent years, the plants must overwinter under water to avoid being killed by frost. Overall, the plants are poorly adapted to changing habitat conditions, although they tolerate constant submergence well. Established stands are known to reduce wave energies, resulting in higher local sedimentation rates. Denser stands can produce $85 \mathrm{culms} \mathrm{m}^{-2}$ and achieve a mean biomass of $125 \mathrm{~g}$ ash-free dry mass $[\mathrm{DM}] \mathrm{m}^{-2}$. Reported associates: Acorus calamus, Alisma triviale, Allium geyeri, Alopecurus aequalis, Alopecurus saccatus, Artemisia nova, Aulosira, Bacopa monnieri, Beckmannia syzigachne, Bidens beckii, Bidens laevis, Bidens polylepis, Bolboschoenus fluviatilis, Bolboschoenus maritimus, Butomus umbellatus, Carex praegracilis, Ceratophyllum demersum, Chara vulgaris, Chenopodium glaucum, Chenopodium rubrum, Deschampsia danthonioides, Distichlis spicata, Downingia elegans, Elaeagnus angustifolia, Elatine, Eleocharis acicularis, Eleocharis macrostachya, Eleocharis palustris, Elodea canadensis, Elymus, Epilobium, Eryngium petiolatum, Glyceria leptostachya, Gnaphalium palustre,
Gratiola ebracteata, Grindelia squarrosa, Heliotropium, Heteranthera dubia, Hippuris, Hippuris vulgaris, Honckenya peploides, Hordeum jubatum, Hydrocharis morsus-ranae, Isoetes howellii, Iva axillaris, Juncus articulatus, Juncus balticus, Juncus effusus, Juncus tenuis, Lemna minor, Lemna trisulca, Leptochloa fusca, Limosella aquatica, Myosotis laxa, Myosurus minimus, Myriophyllum sibiricum, Najas flexilis, Navarretia intertexta, Navarretia squarrosa, Nuphar, Oryza sativa, Oscillatoria, Panicum capillare, Paspalum distichum, Persicaria amphibia, Persicaria coccinea, Persicaria lapathifolia, Persicaria punctata, Phalaris arundinacea, Plagiobothrys leptocladus, Plantago maritima, Pluchea odorata, Polygonum ramosissimum, Polypogon monspeliensis, Potamogeton amplifolius, Potamogeton berchtoldii, Potamogeton friesii, Potamogeton pusillus, Potamogeton richardsonii, Potamogeton zosteriformis, Potentilla anserina, Puccinellia nuttalliana, Ranunculus aquatilis, Ranunculus subrigidus, Rorippa curvisiliqua, Rorippa sinuata, Rorippa teres, Rumex maritimus, Rumex stenophyllus, Rumex triangulivalvis, Ruppia maritima, Sagittaria cuneata, Salicornia depressa, Salix caroliniana, Salix exigua, Sarcobatus vermiculatus, Schoenoplectus acutus, Schoenoplectus pungens, Schoenoplectus tabernaemontani, Sium suave, Sparganium eurycarpum, Spergularia, Spirodela, Stuckenia filiformis, Stuckenia pectinata, Stuckenia vaginata, Triglochin scilloides, Typha angustifolia, Typha latifolia, Vallisneria americana, Zannichellia palustris.

2.1.1.2. Alisma lanceolatum With. is a nonindigenous species, which grows in shallow standing waters or on exposed substrates in channels (bottoms), depressions, ditches, floodplains, gravel pits, marshes, meadows, mudflats, pools, seeps, streams (intermittent), swamps (drying), washes, and along the margins of lakes, ponds, rivers, and streams at elevations to $1267 \mathrm{~m}$. The plants originate from regions having relatively warmer climate conditions. Exposures range from open sunlight to partial shade. The substrates are circumneutral (pH: 6.5-8.5), tend to be nutrient-rich, and include clay, gravel, mud, sand, and silt. Flowering and fruiting occur from April to August in North America. Fluctuating water conditions appear to promote the flowering response. The flowers remain open from 7:30 am to 7:00 $\mathrm{pm}$ and are pollinated by insects (Insecta). Typical seed set in open-pollinated plants has been estimated at $89 \%$. The flat achenes are buoyant and are dispersed by water; however, under continuous agitation, they sink within $96 \mathrm{~h}$. They also are known to be spread by attachment to agricultural machinery. The seeds are dormant when shed and require a period of cold stratification to induce germination. Germination rates often are above $30 \%$. Optimal germination rates (62-75\%) have been obtained for seeds that have been cold stratified (e.g., $3-10$ months at $6^{\circ} \mathrm{C}$ ) and then incubated in shallow water under constant $\left(15^{\circ} \mathrm{C}\right.$, $\left.25^{\circ} \mathrm{C}\right)$ or fluctuating $\left(25^{\circ} \mathrm{C} / 10^{\circ} \mathrm{C}\right)$ temperatures. Stratification at higher temperatures (e.g., $20^{\circ} \mathrm{C}$ ) greatly decreases their germination rates. The plants adapt only moderately to changing habitat conditions. However, when conditions are favorable, seed germination is rapid and synchronous, which facilitates colonization and establishment. Seedlings establish more 
successfully when they remain emergent or develop under fluctuating water conditions. Higher seedling survival rates occur when growing under submersed conditions (e.g., 40-80 cm depth). The plants have been described both as mycorrhizal (arbuscular) and non-mycorrhizal. Reported associates (North America): Adiantum, Alopecurus aequalis, Artemisia douglasiana, Athyrium, Bidens, Convolvulus arvensis, Cotula coronopifolia, Downingia, Festuca perennis, Gratiola, Isolepis carinata, Lemna, Melilotus indicus, Oryza sativa, Rubus, Rubus ulmifolius, Rumex, Rumex conglomeratus, Salix, Salix laevigata, Tribulus terrestris, Typha latifolia, Urtica dioica, Veronica.

2.1.1.3. Alisma subcordatum Raf. is found in shallow (e.g., $10-30 \mathrm{~cm}$ ) standing water or on exposed substrates in alluvial fans, beaches, bogs, bottomlands, bottoms (stream), canals, channels (river), depressions, ditches, flats, floodplains, gravel bars, marshes (ephemeral), meadows, mudflats, oxbows, ponds (intermittent), pools (artificial; ephemeral), prairies (mesic; remnant), puddles, right-of-ways (powerline; railroad), roadsides (springy), sandbars, seeps, shores (marshy), sloughs, springs (outflow), streams (shallow), swamps, thickets (seepy), swales, woodlands, and along the margins of lagoons, lakes, ponds, reservoirs, rivers, streams, swamps, and woodlands at elevations to $1448 \mathrm{~m}$. The plants are heterophyllous, producing floating leaves when grown in standing water (e.g., $25 \mathrm{~cm}$ deep) and emergent foliage when growing under shallow conditions (e.g., $2 \mathrm{~cm}$ water). Exposures range from fully open conditions to partial shade. The substrates are circumneutral (pH: 6.2-8.4; total alkalinity: 11-290 mg $1^{-1}$ ) and are described as alluvium, clay loam muck, cobble, gravel, Hepler silt loam, loamy clay, loamy muck, muck, mud, peat, peaty muck, sand, sandy clay, sandy loam, sandy muck (organic), shale, and silt. Flowering and fruiting occur from May to September. Warming global temperatures have been implicated in a 2 month earlier flowering initiation of some populations during the past two decades. The flowers are selfcompatible, but remain open from 11:30 am to 7:30 pm, which enables cross-pollination by insects (see Use by Wildlife). Typical seed set in open-pollinated plants has been estimated to approach $90 \%$. Each flower produces from 6 to 18 fruits. The achenes float and are dispersed locally by water, but will sink within $128 \mathrm{hr}$ if the surface is agitated periodically. The seeds are physiologically dormant and require a period of cold stratification (e.g., 210 days at $2^{\circ} \mathrm{C}-5^{\circ} \mathrm{C}$ ) to induce germination (under a $25^{\circ} \mathrm{C} / 15^{\circ} \mathrm{C}$ day/night temperature regime). Successful germination also has been reported for seeds stratified at $5^{\circ} \mathrm{C}$ for 60 days, and then placed on sand under water. Reported germination rates vary from $0.4 \%$ to $35 \%$. The seeds germinate optimally under flooded conditions (up to 62\%) but remain dormant under unflooded conditions or when buried. A persistent seed bank can develop and refrigerated achenes have retained $50 \%$ viability after 9 years of storage. Adult plants more typically occur in non-flooded sites. Exposed substrates are necessary for the effective establishment of seedlings. The roots reportedly have weak arbuscular mycorrhizal development. Reported associates: Acalypha rhomboidea, Acer negundo, Acer saccharinum, Acorus calamus,
Agrimonia parviflora, Agrostis gigantea, Agrostis hyemalis, Agrostis perennans, Agrostis stolonifera, Alisma triviale, Ambrosia artemisiifolia, Ammannia coccinea, Ammannia robusta, Amorpha fruticosa, Apios americana, Asclepias incarnata, Asclepias syriaca, Bacopa rotundifolia, Betula nigra, Bidens cernuus, Bidens connatus, Bidens polylepis, Bidens tripartitus, Boehmeria cylindrica, Bolboschoenus fluviatilis, Boltonia asteroides, Calamagrostis canadensis, Campsis radicans, Cardamine bulbosa, Carex caroliniana, Carex conjuncta, Carex corrugata, Carex cristatella, Carex frankii, Carex granularis, Carex grayi, Carex haydenii, Carex hyalinolepis, Carex lacustris, Carex lupulina, Carex lurida, Carex muskingumensis, Carex shortiana, Carex stipata, Carex stricta, Carex tribuloides, Carex typhina, Cephalanthus occidentalis, Chelone glabra, Chelone obliqua, Chenopodium simplex, Cicuta maculata, Cladium jamaicense, Coleataenia longifolia, Conoclinium coelestinum, Cornus amomum, Cuscuta gronovii, Cyperus acuminatus, Cyperus bipartitus, Cyperus esculentus, Cyperus odoratus, Cyperus strigosus, Dichanthelium clandestinum, Dipsacus fullonum, Echinochloa crus-galli, Echinodorus berteroi, Eclipta prostrata, Eleocharis acicularis, Eleocharis engelmannii, Eleocharis erythropoda, Eleocharis macrostachya, Eleocharis obtusa, Eleocharis ovata, Eleocharis palustris, Eleocharis quadrangulata, Epilobium coloratum, Equisetum arvense, Equisetum fluviatile, Erechtites hieraciifolius, Eupatorium perfoliatum, Eupatorium serotinum, Eutrochium maculatum, Fallopia scandens, Fimbristylis autumnalis, Fraxinus pennsylvanica, Fraxinus profunda, Galium obtusum, Galium tinctorium, Gentiana andrewsii, Geum laciniatum, Glyceria striata, Gratiola aurea, Gratiola neglecta, Helenium autumnale, Helianthus grosseserratus, Helianthus mollis, Hibiscus moscheutos, Holcus lanatus, Humbertacalia, Hypericum canadense, Impatiens capensis, Ipomoea lacunosa, Iris virginica, Juncus acuminatus, Juncus effusus, Juncus marginatus, Juncus tenuis, Juncus torreyi, Laportea canadensis, Leersia lenticularis, Leersia oryzoides, Leersia virginica, Lemna minor, Leucospora multifida, Lindernia dubia, Lobelia siphilitica, Ludwigia alternifolia, Ludwigia palustris, Ludwigia polycarpa, Lycopus americanus, Lycopus virginicus, Lysimachia ciliata, Lysimachia nummularia, Lysimachia quadriflora, Lysimachia terrestris, Lythrum alatum, Lythrum salicaria, Mentha arvensis, Mentha $\times$ piperita, Mimulus ringens, Myriophyllum aquaticum, Nymphoides peltata, Nyssa sylvatica, Oenothera pilosella, Onoclea sensibilis, Panicum dichotomiflorum, Panicum virgatum, Panicum virgatum, Parthenocissus quinquefolia, Pedicularis lanceolata, Peltandra virginica, Penthorum sedoides, Persicaria amphibia, Persicaria careyi, Persicaria hydropiperoides, Persicaria lapathifolia, Persicaria pensylvanica, Persicaria punctata, Persicaria setacea, Phalaris arundinacea, Phragmites australis, Phyla lanceolata, Pilea pumila, Platanthera peramoena, Platanus occidentalis, Poa nemoralis, Polygonum ramosissimum, Pontederia cordata, Populus deltoides, Potamogeton nodosus, Proserpinaca, Prunella vulgaris, Pycnanthemum virginianum, Quercus bicolor, Quercus macrocarpa, Quercus 
palustris, Ranunculus hispidus, Ranunculus pensylvanicus, Rhamnus frangula, Rhynchospora capitellata, Rosa multiflora, Rubus setosus, Rudbeckia subtomentosa, Rumex obtusifolius, Rumex verticillatus, Sabatia angularis, Saccharum, Sagittaria australis, Sagittaria latifolia, Sagittaria montevidensis, Salix discolor, Salix interior, Salix myricoides, Salix nigra, Samolus valerandi, Saururus cernuus, Schoenoplectus hallii, Schoenoplectus mucronatus, Schoenoplectus pungens, Schoenoplectus tabernaemontani, Scirpus atrovirens, Scirpus cyperinus, Scutellaria galericulata, Scutellaria lateriflora, Sium suave, Smilax, Solanum dulcamara, Solidago riddellii, Sparganium americanum, Sparganium androcladum, Sparganium emersum, Sparganium eurycarpum, Spartina pectinata, Sphagnum, Spiraea tomentosa, Spirodela polyrhiza, Stachys palustris, Stellaria longifolia, Symphyotrichum lanceolatum, Symphyotrichum novi-belgii, Symphyotrichum ontarionis, Symphyotrichum praealtum, Teucrium canadense, Thalictrum clavatum, Thelypteris palustris, Toxicodendron radicans, Tridens flavus, Typha angustifolia, Typha latifolia, Verbena hastata, Vernonia fasciculata, Veronicastrum virginicum, Viola sororia, Vitis cinerea, Vitis riparia, Xanthium strumarium.

2.1.1.4. Alisma triviale Pursh occurs in shallow (0.05-1.0 m) fresh to somewhat saline standing waters, or on exposed substrates in backwaters, bays (shallow), bogs, canals, channels (intermittent), ditches (irrigation; roadside), flats (river), floodplains, glades, impoundments, lakes, marshes, meadows, mudflats, oxbows (swampy), ponds (beaver; intermittent; stock), pools (dry; seasonal; vernal), potholes, prairies, puddles, reservoirs (dry), rice fields, roadsides, shores, slopes (to $6 \%$ ), sloughs, springs, stream beds, swales (drying), swamps, tanks, and along the margins of lagoons, lakes, ponds, pools, reservoirs, rivers (estuaries), and streams at elevations to 2830 m. In experimental manipulations, the optimal water depth ranged from 15 to $20 \mathrm{~cm}$. Exposures can vary from full to partial sunlight. The substrates have been described as acidic or alkaline (pH: 4.5-8.0; total alkalinity: 13.5-47.5 $\mathrm{mg} \mathrm{l}^{-1}$ ) and include adobe, bentonite, clay (Gumbo; Pierre), gravel, loam, loamy clay, logs (decayed), muck (organic), mud, peat, peaty mud, sand, sandy clay loam, sandy loam, silt, silty mud, and stones. Flowering and fruiting extend from June to November. The flowers remain open from 8:00 am to 6:30 pm. Average seed set in open-pollinated plants has been estimated at $91 \%$. The achenes are dispersed by water, and under intermittent agitation, will sink within $96 \mathrm{~h}$. Specific conditions for germination have not been reported, but germination rates have been observed to increase proportionally with water depth. The mean density of germinating seeds can reach 128.2 seeds $\mathrm{m}^{-2}$. The greatest seedling growth occurs at water depths from 2 to $7 \mathrm{~cm}$. The roots reportedly are colonized by arbuscular mycorrhizae. The plants are known to occur commonly along hedgerows that are adjacent to agricultural fields. Reported associates: Acer glabrum, Acer negundo, Acer saccharinum, Achillea millefolium, Acmispon wrightii, Acorus calamus, Agrostis exarata, Agrostis scabra, Agrostis stolonifera, Alisma gramineum, Alisma subcordatum, Alnus, Alopecurus aequalis, Alopecurus geniculatus, Amaranthus powellii, Amaranthus tuberculatus, Ambrosia tomentosa, Ammannia, Amorpha fruticosa, Apocynum cannabinum, Arctium minus, Aristida oligantha, Asclepias incarnata, Astragalus humistratus, Azolla cristata, Baccharis douglasii, Baccharis salicifolia, Beckmannia syzigachne, Bidens aristosus, Bidens beckii, Bidens cernuus, Bidens connatus, Bidens frondosus, Bidens trichospermus, Bistorta bistortoides, Bolboschoenus fluviatilis, Bolboschoenus maritimus, Bolboschoenus robustus, Boltonia asteroides, Bouteloua curtipendula, Brassica, Brickellia californica, Bromus inermis, Bromus tectorum, Calamagrostis canadensis, Callitriche heterophylla, Callitriche palustris, Capsella bursa-pastoris, Carex annectens, Carex aquatilis, Carex athrostachya, Carex bebbii, Carex brevior, Carex buxbaumii, Carex canescens, Carex comosa, Carex cristatella, Carex densa, Carex frankii, Carex lasiocarpa, Carex leptalea, Carex lupuliformis, Carex lyngbyei, Carex meadii, Carex muskingumensis, Carex normalis, Carex occidentalis, Carex pellita, Carex praegracilis, Carex retrorsa, Carex scoparia, Carex siccata, Carex simulata, Carex stipata, Carex utriculata, Carex vesicaria, Carex $\times$ cayouettei, Castilleja angustifolia, Ceanothus fendleri, Ceratophyllum demersum, Chara, Chelone glabra, Chenopodium, Cicuta bulbifera, Cicuta maculata, Cirsium arvense, Cirsium undulatum, Cirsium vulgare, Cirsium wheeleri, Clintonia, Conium maculatum, Convolvulus, Coreopsis, Cornus amomum, Cornus drummondii, Cornus sericea, Crypsis vaginiflora, Cuscuta glomerata, Cyperus difformis, Cyperus eragrostis, Cyperus strigosus, Damasonium californicum, Decodon verticillatus, Deschampsia elongata, Dichanthelium oligosanthes, Distichlis spicata, Downingia laeta, Dracocephalum parviflorum, Echinochloa crus-galli, Echinodorus berteroi, Echinodorus cordifolius, Eclipta prostrata, Elatine californica, Elatine chilensis, Elatine rubella, Eleocharis acicularis, Eleocharis engelmannii, Eleocharis erythropoda, Eleocharis macrostachya, Eleocharis montana, Eleocharis ovata, Eleocharis palustris, Eleocharis parishii, Eleocharis rostellata, Eleocharis tenuis, Eleocharis wolfii, Elodea canadensis, Elymus elymoides, Epilobium campestre, Epilobium ciliatum, Epilobium torreyi, Equisetum arvense, Equisetum fluviatile, Equisetum laevigatum, Eragrostis pectinacea, Erigeron divergens, Erigeron speciosus, Erigeron strigosus, Eriogonum racemosum, Eryngium articulatum, Eupatorium perfoliatum, Euphorbia marginata, Eustoma exaltatum, Euthamia occidentalis, Eutrochium maculatum, Fallopia convolvulus, Fallugia paradoxa, Festuca arizonica, Fimbristylis spadicea, Flaveria campestris, Forestiera pubescens, Fraxinus pennsylvanica, Galium aparine, Galium trifidum, Geranium caespitosum, Geranium richardsonii, Geum laciniatum, Geum macrophyllum, Glyceria borealis, Glyceria elata, Glyceria grandis, Glyceria septentrionalis, Glyceria striata, Glycyrrhiza lepidota, Gnaphalium exilifolium, Gnaphalium uliginosum, Gratiola neglecta, Grindelia squarrosa, Hackelia floribunda, Helianthus annuus, Helianthus grosseserratus, Helianthus maximiliani, Heteranthera, Hippuris vulgaris, Hordeum jubatum, Hymenoxys hoopesii, Hymenoxys subintegra, Hypericum 
anagalloides, Impatiens capensis, Impatiens pallida, Iris missouriensis, Isoetes, Juncus acuminatus, Juncus articulatus, Juncus balticus, Juncus bufonius, Juncus effusus, Juncus ensifolius, Juncus interior, Juncus oxymeris, Juncus patens, Juncus torreyi, Juncus xiphioides, Juniperus monosperma, Juniperus osteosperma, Juniperus scopulorum, Lactuca serriola, Landoltia punctata, Lappula occidentalis, Leersia lenticularis, Leersia oryzoides, Leersia virginica, Lemna minor, Liatris lancifolia, Lilaeopsis, Limosella acaulis, Lindernia dubia, Lobelia cardinalis, Lobelia siphilitica, Ludwigia palustris, Ludwigia peploides, Lupinus argenteus, Lupinus kingii, Lycopus americanus, Lycopus asper, Lycopus uniflorus, Lysimachia terrestris, Lythrum alatum, Lythrum hyssopifolia, Lythrum salicaria, Madia, Marsilea mollis, Marsilea vestita, Medicago lupulina, Medicago sativa, Melilotus albus, Melilotus officinalis, Mentha arvensis, Mentha ×piperita, Mikania scandens, Mimulus guttatus, Mimulus ringens, Muhlenbergia frondosa, Muhlenbergia wrightii, Myosotis laxa, Myosurus, Myriophyllum pinnatum, Myriophyllum sibiricum, Najas flexilis, Nasturtium, Navarretia intertexta, Nuphar polysepala, Oenothera rhombipetala, Onoclea sensibilis, Orthocarpus luteus, Ottelia alismoides, Panicum virgatum, Parthenocissus quinquefolia, Pascopyrum smithii, Paspalum distichum, Peltandra virginica, Pennisetum glaucum, Penstemon barbatus, Penstemon linarioides, Penthorum sedoides, Persicaria amphibia, Persicaria coccinea, Persicaria coccinea, Persicaria hydropiper, Persicaria hydropiperoides, Persicaria lapathifolia, Persicaria maculosa, Persicaria pensylvanica, Persicaria punctata, Phalaris arundinacea, Phleum pratense, Phragmites australis, Phyla lanceolata, Phyla nodiflora, Picea mariana, Pinus ponderosa, Plagiobothrys, Plantago, Platanus occidentalis, Poa arida, Poa nemoralis, Poa pratensis, Polygonum aviculare, Polygonum douglasii, Polypogon monspeliensis, Pontederia cordata, Populus angustifolia, Populus deltoides, Populus tremuloides, Porterella carnosula, Portulaca oleracea, Potamogeton amplifolius, Potamogeton berchtoldii, Potamogeton diversifolius, Potamogeton foliosus, Potamogeton gramineus, Potamogeton natans, Potamogeton nodosus, Potamogeton pusillus, Potamogeton richardsonii, Potamogeton zosteriformis, Potentilla crinita, Potentilla gracilis, Potentilla hippiana, Potentilla norvegica, Prunella, Prunus virginiana, Pseudocymopterus montanus, Pseudognaphalium luteoalbum, Quercus bicolor, Quercus gambelii, Quercus grisea, Ranunculus aquatilis, Ranunculus cymbalaria, Ranunculus trichophyllus, Rhus aromatica, Ribes cereum, Robinia neomexicana, Rorippa curvipes, Rorippa islandica, Rorippa sphaerocarpa, Rosa arkansana, Rosa woodsii, Rotala, Rumex crispus, Rumex maritimus, Rumex salicifolius, Rumex triangulivalvis, Sagittaria cuneata, Sagittaria latifolia, Sagittaria montevidensis, Salix amygdaloides, Salix exigua, Salix gooddingii, Salix nigra, Salix interior, Sambucus nigra, Schizachyrium scoparium, Schoenoplectus acutus, Schoenoplectus pungens, Schoenoplectus tabernaemontani, Schoenoplectus triqueter, Scirpus atrovirens, Scirpus cyperinus, Scirpus lineatus, Scirpus microcarpus, Scrophularia parviflora, Scutellaria lateriflora, Senecio spartioides, Senecio wootonii, Setaria parviflora, Setaria viridis, Sidalcea, Sisyrinchium angustifolium, Sium suave, Solanum dulcamara, Solidago missouriensis, Sparganium angustifolium, Sparganium emersum, Spartina pectinata, Sphenoclea zeylanica, Sphenopholis obtusata, Spiraea, Spiranthes cernua, Spiranthes diluvialis, Spirodela polyrhiza, Sporobolus compositus, Stachys palustris, Stachys pilosa, Stuckenia pectinata, Suaeda calceoliformis, Symphoricarpos, Symphyotrichum ericoides, Symphyotrichum lanceolatum, Symphyotrichum lateriflorum, Symphyotrichum subulatum, Taraxacum officinale, Thalictrum fendleri, Thermopsis, Torreyochloa pallida, Toxicodendron radicans, Tragopogon, Triglochin scilloides, Typha angustifolia, Typha latifolia, Urtica dioica, Utricularia, Verbascum thapsus, Verbena bracteata, Verbena hastata, Verbena urticifolia, Vernonia fasciculata, Veronica anagallis-aquatica, Veronica peregrina, Veronica serpyllifolia, Vicia cracca, Viola sororia, Vitis riparia, Wolffia brasiliensis, Wolffia columbiana, Xanthium strumarium, Zannichellia palustris.

Use by wildlife: The achenes of Alisma gramineum are eaten by various ducks (Aves: Anatidae: Anas), including baldpates (A. americana), blue-winged teal (A. discors), gadwells ( $A$. strepera), and shovelers (A. clypeata). Alisma subcordatum is grazed by Canada geese (Aves: Anatidae: Branta canadensis) and European ambersnails (Gastropoda: Succineidae: Succinea putris). Its flowers are visited (and likely pollinated) by flies (Insecta: Diptera) and occasionally by skippers (Insecta: Lepidoptera: Hesperiidae: Ancyloxypha numitor). Alisma triviale is a host to moth larvae (Lepidoptera: Noctuidae: Hypena madefactalis) and spittlebugs (Insecta: Hemiptera: Cercopidae). The roots are host to slime molds (Fungi: Myxomycota: Plasmodiophoraceae: Ligniera junci). The plants serve as an oviposition substrate for aster leafhoppers (Insecta: Hemiptera: Cicadellidae: Macrosteles fascifrons). The achenes are eaten by blue-winged teal (Aves: Anatidae: Anas discors) and mallard ducks (Anas platyrhynchos). In North America, Alisma plants (species uncertain) are host to several Fungi (Ascomycota: Mycosphaerellaceae: Cercospora alismatis, C. callae; Basidiomycota: Doassansiaceae: Doassansia alismatis; Blastocladiomycota: Cladochytrium alismatis).

Economic importance: food: After washing and drying, the bulblike leaf bases of Alisma plants were eaten by the Calmucks; however, some sources suggest that the foliage (especially when bruised) can be poisonous or cause skin irritation; medicinal: Some Alisma species contain protostane triterpenoids, which exhibit antiplasmodial activity against Plasmodium falciparum, a causative agent of malaria. Alisma gramineum has been used to treat gastrointestinal disorders, skin diseases, and to treat abrasions and cuts in parts of Asia. Alisma subcordatum was used by the Cherokee to treat gastrointestinal disorders and skin ailments. The Iroquois used A. triviale to treat kidney ailments and tuberculosis; cultivation: Various Alisma species are planted occasionally as ornamental plants in water gardens or along river gardens; misc. products: Alisma gramineum has been used as a natural 
insect repellant. Seeds of A. subcordatum have been included in mixes used for wetland restoration programs. Alisma triviale has been planted in free water surface constructed wetlands; weeds: Alisma lanceolatum and A. triviale have been reported as rice field weeds in western North America. Strains resistant to bensulfuron-methyl herbicides have been reported in A. lanceolatum; nonindigenous species: Alisma lanceolatum likely was introduced to California and Oregon from Eurasia by means of contaminated rice stock. Alisma plantago-aquatica has been characterized as nonindigenous to North America; however, no verifiable records of this species are known to occur in the region.

Systematics: Various analyses of DNA sequence data (e.g., Figures 1.3 and 1.4) confirm that Alisma is monophyletic and indicate that it is related most closely to Baldellia. Analysis of nrITS sequence data (Figure 1.4) effectively distinguishes $A$. gramineum and A. lanceolatum from the majority of species but fails to resolve relationships among A.plantago-aquatica, A. subcordatum, and A. triviale, which indicates their relatively recent divergence. However, all three taxa are clearly separable using RAPDs markers. Although North American specimens of $A$. subcordatum and A. triviale were long treated taxonomically as variants of the Old World diploid species A. plantago-aquatica, many morphological, chromosomal, and genetic isolating distinctions eventually became evident. Even though these taxa are similar morphologically, no crosses have succeeded despite numerous reciprocal attempts involving A. plantago-aquatica $\times$ A. subcordatum, A. plantago-aquatica or A. subcordatum $\times A$. triviale, which indicates that all three species are well isolated genetically. In contrast, some successful crosses (i.e., those resulting in seed set) have been obtained involving either A. lanceolatum or $A$. gramineum $\times A$. plantago-aquatica, and A. lanceolatum $\times$ A. gramineum, which exhibit more distant interrelationships. The basic chromosome number of Alisma is $x=7$. Alisma

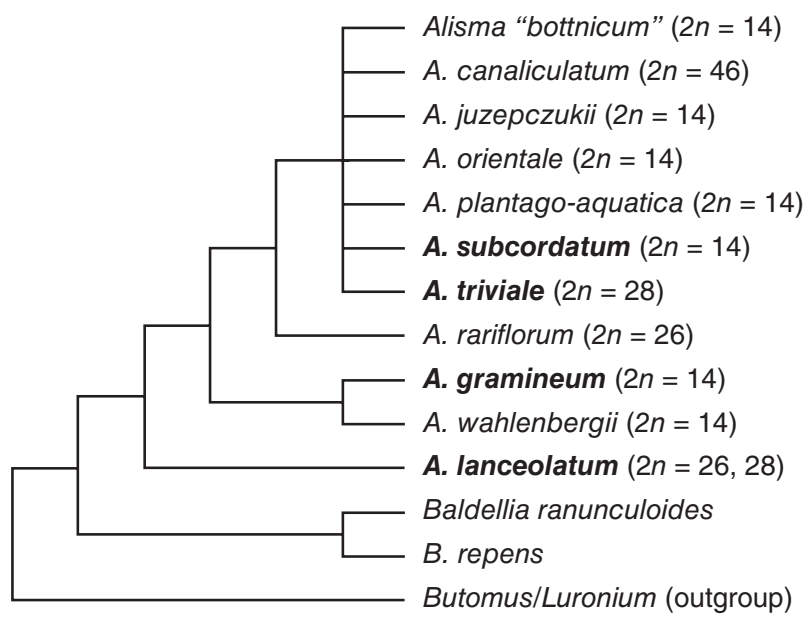

FIGURE 1.4 Phylogenetic relationships of Alisma derived from analysis of nrITS sequence data (adapted from Jacobson \& Hedrén, 2007). The North American species categorized as OBL indicators are highlighted in bold. Confirmed ploidy levels for the Alisma species are shown in parentheses. gramineum and A. subcordatum $(2 n=14)$ are diploids; A. lanceolatum $(2 n=26,28)$ and $A$. triviale $(2 n=28)$ are tetraploids. The two cytotypes of A. lanceolatum are well isolated genetically. No spontaneous interspecific Alisma hybrids have been reported in North America. There have been no successful intergeneric hybrids resulting from crossing attempts involving Alisma, Baldellia, and Luronium.

Distribution: Alisma gramineum and A. triviale occur throughout central North America and A. subcordatum is widespread in the eastern United States. The nonindigenous A. lanceolatum is restricted to California and Oregon.

References: Adams et al., 2011; Andersson et al., 2000; Baldwin, Jr. \& Speese, 1955; Barrett \& Seaman, 1980; Baskin \& Baskin, 1998; Beas et al., 2013; Bergeron \& Pellerin, 2014; Björkqvist, 1967; 1968; Boutin et al., 2002; Burgess, 1970; Calha et al., 1998; Conover \& Pelikan, 2010; Countryman, 1968; Duke, 2000; Fernald, 1946; Fernald \& Kinsey, 1943; Grau \& Leonard, 1978; Haynes \& HolmNielsen, 1994; Haynes \& Hellquist, 2000a; Haynes et al., 1998a; Hellquist \& Crow, 1981; Hendricks, 1957; Hopkins, 1969; Hroudová et al., 2004; Hudon, 1997; Johnson, 1999; Kaul, 1978; 1985; Keith, 1961; Kellogg et al., 2003; Knight, 1965; Kratzer, 2014; Les \& Tippery, 2013; Lieneman, 1929; Lovell, 1899; McIntyre \& Newnham, 1988; Mollik et al., 2010; Moravcová et al., 2001; Parker et al., 1969; Pogan, 1963; Putman, 1953; Ransom \& Oelke, 1983; Rhoades, 1962; Rogers, 1983; Ryser et al., 2011; Scott, 2014; Seabloom et al., 1998; Smith, 1953; Swanson \& Bartonek, 1970; Todorova et al., 2013; Tucker et al., 2015; Ungar, 1964; Vermaat et al., 2000; Vymaza, 2013; Wagner \& Oplinger, 2017; Wang \& Qiu, 2006; Way, 1982; Weiher et al., 2003; Yatskievych \& Raveill, 2001; Zákravsky \& Hroudová, 1998.

\subsubsection{Damasonium}

Fringed water plantain

Etymology: an ancient name of unknown derivation, but possibly commemorating Damasos, a Trojan soldier of the Iliad Synonyms: Actinocarpus; Machaerocarpus

Distribution: global: Australia; Europe; North America; North America: western

Diversity: global: 5 species; North America: 1 species Indicators (USA): obligate wetland (OBL): Damasonium californicum

Habitat: freshwater; lacustrine, palustrine, riverine; $\mathbf{p H}$ : alkaline; depth: $<1 \mathrm{~m}$; life-form(s): emergent or floatingleaved herb

Key morphology: foliage arising from a corm; the leaves erect, blades undeveloped or lanceolate to ovate (to $9 \mathrm{~cm}$ ), the margins entire, petioles (to $15 \mathrm{~cm}$ ) triangular in section; inflorescence an erect raceme (rarely a panicle), the flowers (to $22 \mathrm{~mm}$ ) bisexual, trimerous, apocarpous, pedicellate (to 65 $\mathrm{mm}$ ), in whorls (to 9); sepals (to $5 \mathrm{~mm}$ ) persistent, somewhat hoodlike; petals (to $10 \mathrm{~mm}$ ) white with basal yellow spot, rarely pink, their apex erose; stamens 6; pistils (to 15) in a ring, spreading or radiating in a star-like pattern; follicles (to $5.5 \mathrm{~mm}$ ) laterally compressed, beaked (to $6 \mathrm{~mm}$ ), dehiscing basally, sometimes indehiscent and achene-like 
Aquatic Monocotyledons of North America

Life history: duration: annual (seeds) or perennial (corms); asexual reproduction: corm buds; pollination: insect or self; sexual condition: hermaphroditic; fruit: aggregates (follicles) (common); local dispersal: mud, water; long-distance dispersal: mud, water

Imperilment: 1. Damasonium californicum [G4]; S1 (WA); S2 (ID)

Ecology: general: All Damasonium species occur in wetlands. The plants are perennial or annual, but all North American representatives are perennial. All of the species are self-compatible, with most being highly autogamous or even cleistogamous. The North American plants are outcrossing, which is associated with protandry, higher pollen quantities (i.e., greater pollen:ovule ratios), and fewer but heavier seeds than the inbreeding Australian or European species, which are homogamous, produce less pollen, and have lighter seeds. The seeds are dispersed in mud or by water. Vegetative reproduction occurs in two species by the production of corm buds. 2.1.2.1. Damasonium californicum Torr. occurs in shallow waters (e.g., 15-61 cm deep) or on exposed substrates associated with bottoms (pool; stream), canals (drying), depressions, ditches (roadside), flats, floodplains, marshes, meadows, mudflats (drying), playas, ponds, pools, prairies, rice fields, roadsides, seeps, shores, sloughs (roadside; vernal), streams (flowing), swales, vernal pools, and along the margins of lakes, ponds, reservoirs, and streams (intermittent) at elevations to $2057 \mathrm{~m}$. Although typically emergent, the plants will develop floating leaves when growing in deeper water. The habitats occur in open exposures that receive full sunlight. The substrates are alkaline and include adobe, alluvium, clay, loamy clay, muck, mud, rock (basaltic), sand, sandy silt, serpentine, silty clay, silty mud, stony Tuscan loam, and Tuscan mudflow. Flowering and fruiting occur from May to September, often after standing waters recede. Plants grown in cultivation have flowered from April to June. The variance in flower production is substantial, but averages about 47 flowers/plant. The flowers are strongly protandrous, have the highest pollen:ovule ratios $(1,000-1,200: 1)$ in the genus, and are assumed to be highly outcrossed, presumably by insects (Insecta). The male phase occurs from 9 to $14 \mathrm{hr}$ after the onset of flowering, with pollen often accumulating near the base of the petals. The female phase initiates on the second day (27-32 hr after the onset of flowering), as the styles spread radially to expose the stigmas. The petals remain open throughout anthesis. Although the flowers are highly self-compatible, their protandry prevents spontaneous self-pollination. The seeds (averaging 1.42 $\mathrm{mg}$ ) are dispersed by water or in mud that becomes attached to animal vectors. Reported associates: Alisma, Allium, Arnica chamissonis, Artemisia cana, Artemisia tridentata, Arthrocnemum subterminale, Callitriche hermaphroditica, Carex praegracilis, Comarum palustre, Crypsis schoenoides, Cynodon dactylon, Distichlis spicata, Downingia bacigalupii, Downingia concolor, Downingia insignis, Downingia ornatissima, Downingia yina, Eleocharis macrostachya, Eleocharis palustris, Epilobium campestre, Epilobium cleistogamum, Eryngium alismifolium, Eryngium aristulatum, Eryngium castrense, Frankenia salina, Hippuris vulgaris,
Hydrocotyle ranunculoides, Isoetes howellii, Juncus arcticus, Juncus balticus, Juncus nevadensis, Lasthenia conjugens, Lasthenia glaberrima, Limosella, Lythrum hyssopifolia, Marsilea vestita, Muhlenbergia richardsonis, Myriophyllum sibiricum, Navarretia leucocephala, Nuphar polysepala, Orcuttia tenuis, Pascopyrum smithii, Phyla, Plagiobothrys leptocladus, Plagiobothrys mollis, Plagiobothrys scouleri, Plagiobothrys stipitatus, Plantago elongata, Pleuropogon, Porterella carnosula, Potamogeton amplifolius, Potamogeton gramineus, Psilocarphus brevissimus, Ranunculus aquatilis, Rosa, Rumex, Sagittaria cuneata, Sparganium, Triglochin scilloides, Typha latifolia, Utricularia macrorhiza, Xanthium strumarium, Zannichellia palustris.

Use by wildlife: The seeds of Damasonium californicum are eaten by waterfowl (Aves: Anatidae). The plants are a host of nematodes (Nematoda: Hoplolaimidae: Pratylenchus morettoi).

Economic importance: food: no reported uses; medicinal: no reported uses; cultivation: not in cultivation; misc. products: none; weeds: none; nonindigenous species: none.

Systematics: In molecular phylogenetic analyses (e.g., Figure 1.3), Damasonium resolves as the sister group to a clade containing Alisma and Baldellia. Although the genus appears to be monophyletic, a comprehensive phylogenetic survey has yet to be conducted for the group. The basic chromosome number of Damasonium is $x=7$. Counts are unavailable for D. californicum.

Distribution: Damasonium californicum occurs in the western United States.

References: Cook, 1996; Haynes \& Hellquist, 2000a; Kaul, 1976; Les \& Tippery, 2013; Martin \& Uhler, 1951; Michel et al., 1986; Ramaley, 1919; Ross et al., 2016; Turner et al., 2012; Vuille, 1987.

\subsubsection{Echinodorus}

Burhead, swordplant; plante-épée

Etymology: from the Greek echinos doro ("spiny spear") in reference to the spiny fruiting heads and sword-like leaves

Synonyms: Alisma (in part); Sagittaria (in part)

Distribution: global: New World; North America: southern Diversity: global: 28 species; North America: 3 species Indicators (USA): obligate wetland (OBL): Echinodorus berteroi, E. cordifolius, E. grandiflorus

Habitat: freshwater; lacustrine, palustrine, riverine; $\mathbf{p H}$ : 4.8-7.4; depth: 0-2 m; life-form(s): emergent herb, floatingleaved, submersed (rosulate)

Key morphology: shoots herbaceous, rosulate, rhizomatous; leaves all basal, the blades (to $32 \mathrm{~cm}$ ) emersed or submersed, lanceolate, ovate, or elliptic, and marked by translucent lines or dots, the base attenuate, cordate, or truncate, the margins entire, often undulating, the petioles (to $115 \mathrm{~cm}$ ) triangular (rarely roundish) or ridged; inflorescence (to $131 \mathrm{~cm}$ ) an erect or decumbent (then arching and proliferating) raceme or erect panicle, the flowers $(1.1-4 \mathrm{~cm})$ in 1-9 whorls, bisexual, pedicellate (to $7.5 \mathrm{~cm}$ ), trimerous; sepals (to 21 -veined) erect, recurved, or spreading; petals (to $15 \mathrm{~mm}$ ) white, clawed or sessile; stamens numerous (to 22), the anthers versatile; pistils 
numerous (to 250), arranged spirally in a head; achenes (to $2.5 \mathrm{~mm}$ ) oblanceolate, 3-5-ribbed, beaked (to $1.3 \mathrm{~mm}$ ), sometimes flattened

Life history: duration: annual (fruits/seeds); perennial (rhizomes); asexual reproduction: rhizomes; pollination: insect, self; sexual condition: hermaphroditic; fruit: aggregates (achenes) (common); local dispersal: rhizomes, achenes (water, wind); long-distance dispersal: achenes (waterfowl)

Imperilment: 1. Echinodorus berteroi [G5]; SX (IN); S1 (AZ, TN, UT); S2 (AR, KY, OH); 2. E. cordifolius [G5]; SX (DC); S1 (IN, MD); S2 (KS); S3 (IL, NC, VA); 3. E. grandiflorus [GNR]

Ecology: general: All Echinodorus species characteristically are aquatic, growing either in standing waters or on moist substrates at sites where the waters have receded. The three North American species are designated as OBL indicators throughout their distributional ranges. Although fairly showy, the flowers of most species appear to be strongly self-compatible, which allows for self-pollination to occur. Otherwise they are believed to be pollinated by insects (Insecta). The plants most often are perennial but reportedly can behave as annuals in more temperate areas. The seeds generally germinate well at high temperatures $\left(25^{\circ} \mathrm{C}-30^{\circ} \mathrm{C}\right)$ and any dormancy usually can be broken by incubating them in a $50^{\circ} \mathrm{C}$ water bath for $10 \mathrm{~min}$, followed by warm incubation at $30^{\circ} \mathrm{C}-35^{\circ} \mathrm{C}$ until germination occurs. They are buoyant and are dispersed locally by water or wind, or to greater distances via epizoic transport by waterfowl (Aves: Anatidae) or other animal vectors. Most of the species are rhizomatous. When submersed, some taxa develop proliferous inflorescences, which produce vegetative propagules (bulbils) or adventitious plantlets. Because of their popularity as aquarium specimens, many of the species present a risk of becoming nonindigenous introductions via their escape from cultivation.

2.1.3.1. Echinodorus berteroi (Spreng.) Fassett is an amphibious annual or perennial, which grows in standing waters (e.g., 7-180 cm deep) or on exposed substrates of beaches, canals, depressions, dikes, ditches (roadside), flats, floodplains, lake beds (dried), marshes, meadows, mudflats, playas, ponds (stock), pools, rice fields, river bottoms, riverbeds (drying), roadsides, sandbars, seeps, shores (drying), silt bars, sloughs (vernal), stream beds (dry), swamps, tire ruts, washes, and along the margins of borrow pits, gravel pits, lakes (drying), ponds, reservoirs, and streams at elevations to $2080 \mathrm{~m}$. The plants occur typically in small, temporary water bodies. In deeper waters (and under short photoperiods) the plants remain sterile and produce elongate, ribbon-like leaves. Water temperatures from $18^{\circ} \mathrm{C}$ to $27^{\circ} \mathrm{C}$ are considered optimal. Habitat exposures range from full sun to partial shade. The substrates are characterized as alkaline or saline and include alluvium, clay, clay loam, gravel, humus, loamy clay, muck, mud, Riverwash, sand (coarse), sandstone, sandy gravel, sandy loam, sandy muck, silt, silty clay, and stones. Flowering and fruiting extend from April to October. The flowers are selfcompatible and have high seed set, presumably as a consequence of self-pollination. The achenes often remain attached to the receptacle when mature, even after the inflorescences senesce. When shed, they float for prolonged periods and also can be dispersed by their attachment to fur, feathers, or in mud that clings to a potential animal vector. The achenes require no pretreatment and germinate readily at $25^{\circ} \mathrm{C}-30^{\circ} \mathrm{C}$. In North America, the plants usually perennate and disperse locally by means of rhizomes; however, they reportedly behave as annuals when growing at more temperate latitudes. Reported associates: Acer negundo, Acer saccharinum, Alisma subcordatum, Alisma triviale, Amaranthus tuberculatus, Ambrosia psilostachya, Ammannia coccinea, Ammannia robusta, Artemisia californica, Atriplex serenana, Azolla filiculoides, Baccharis salicifolia, Baccharis sarothroides, Baccharis sergiloides, Bassia hyssopifolia, Bergia texana, Bidens connatus, Bidens frondosus, Bidens tripartitus, Bolboschoenus fluviatilis, Brassica nigra, Brickellia californica, Celtis laevigata, Cenchrus setaceus, Cephalanthus occidentalis, Ceratophyllum demersum, Chaenactis glabriuscula, Chara, Cirsium vulgare, Coleataenia longifolia, Conoclinium coelestinum, Conyza canadensis, Cressa truxillensis, Crypsis schoenoides, Crypsis vaginiflora, Cylindropuntia prolifera, Cynodon dactylon, Cyperus acuminatus, Cyperus eragrostis, Cyperus erythrorhizos, Cyperus esculentus, Cyperus squarrosus, Cyperus strigosus, Datura wrightii, Digitaria sanguinalis, Echinochloa crus-galli, Echinochloa muricata, Eclipta prostrata, Eleocharis acicularis, Eleocharis macrostachya, Eleocharis obtusa, Eleocharis palustris, Epilobium ciliatum, Epilobium densiflorum, Epilobium torreyi, Eragrostis hypnoides, Eriogonum fasciculatum, Ferocactus viridescens, Frankenia salina, Fraxinus, Gratiola neglecta, Helianthus annuus, Heliotropium, Heteranthera limosa, Hordeum murinum, Ibicella lutea, Iva axillaris, Juglans, Lasthenia glaberrima, Leersia oryzoides, Lemna gibba, Leptochloa fusca, Lindernia dubia, Ludwigia palustris, Ludwigia peploides, Ludwigia polycarpa, Lythrum hyssopifolia, Malvella leprosa, Marsilea vestita, Mimulus cardinalis, Najas, Nasturtium officinale, Navarretia fossalis, Oryza sativa, Panicum capillare, Panicum dichotomiflorum, Paspalum dilatatum, Paspalum distichum, Paspalum pubiflorum, Penthorum sedoides, Persicaria coccinea, Persicaria lapathifolia, Phalaris arundinacea, Phyla lanceolata, Phyla nodiflora, Plagiobothrys leptocladus, Plagiobothrys undulatus, Plantago major, Platanus racemosa, Pluchea odorata, Polypogon monspeliensis, Pontederia cordata, Populus fremontii, Potamogeton nodosus, Pseudognaphalium luteoalbum, Quercus berberidifolia, Raphanus sativus, Rotala ramosior, Rumex persicarioides, Rumex pulcher, Sagittaria graminea, Sagittaria latifolia, Sagittaria montevidensis, Salix gooddingii, Salix laevigata, Schinus molle, Schoenoplectus acutus, Schoenoplectus californicus, Schoenoplectus hallii, Schoenoplectus mucronatus, Schoenoplectus tabernaemontani, Sphenoclea zeylanica, Stuckenia pectinata, Tamarisk, Trichocoronis wrightii, Typha angustifolia, Typha domingensis, Typha latifolia, Veronica anagallis-aquatica, Veronica peregrina, Xanthium strumarium, Zannichellia palustris.

2.1.3.2. Echinodorus cordifolius (L.) Griseb. is a perennial, which grows in shallow (e.g., 1-20 cm depth), tidal or non-tidal waters or on exposed substrates of backwaters, 
Aquatic Monocotyledons of North America

bayous, bottomlands, depressions, ditches (roadside), floodplains, marshes, meadows, mudflats, oxbows, ponds (depression), pools, prairies, rice fields (abandoned), roadsides, shores (seepy), sloughs, springs, streams, swales, swamps, and along the margins of canals, Carolina bays, channels, lakes, ponds, reservoirs, and rivers at elevations to $500 \mathrm{~m}$. The plants frequently occur as emergents in drawdown areas but will develop submersed leaves when growing under photoperiods of less than $12 \mathrm{~h}$. All the leaves will die back when temperatures fall below $10^{\circ} \mathrm{C}$. Site exposures range from full sunlight to partial shade. The substrates ( $\mathrm{pH}$ : 5.8-7.4) are described as calcareous and include alluvium (clayey), clay, clay mud, humus, loam, muck, mucky Dowling clay, mud, sand, sandy loam (Cecil), sandy silt, silt, silty loam, and silty sand. Flowering occurs under long-day conditions from May to October; fruiting has been observed from July to October. Low seed set typically has been reported, which might indicate a greater requirement for pollinator visitation (and increased outcrossing). A seed bank can develop with recovery densities of germinating seeds ranging from 0.7 (nonflooded sites) to 1.4 (flooded sites) seeds $\mathrm{m}^{-2}$. The arching inflorescences proliferate by producing adventitious plantlets, which can function as vegetative propagules. Vegetative reproduction also occurs by means of rhizomes. The plants have been micropropagated successfully (from rhizomes) using a combination of $24.6 \mu \mathrm{M} \mathrm{N}$-isopentenyladenine and $2.68 \mu \mathrm{M}$ naphthalene acetic acid. Reported associates: Acer saccharinum, Ammannia coccinea, Ampelopsis arborea, Asclepias perennis, Bacopa, Bergia texana, Boehmeria cylindrica, Bolboschoenus fluviatalis, Campsis radicans, Carex comosa, Carex crus-corvi, Carex longii, Carex lupulina, Carpinus caroliniana, Celtis laevigata, Cephalanthus occidentalis, Chamaecrista fasciculata, Chasmanthium latifolium, Cornus foemina, Cynosciadium digitatum, Cyperus pseudovegetus, Cyperus squarrosus, Diospyros virginiana, Echinochloa colona, Elaeagnus umbellata, Elatine californica, Eragrostis hypnoides, Eupatorium, Forestiera acuminata, Hibiscus, Hydrolea uniflora, Ipomoea hederacea, Iris tridentata, Juncus effusus, Leersia oryzoides, Lemna, Leptochloa fusca, Leptochloa panicoides, Leucospora, Lindernia dubia, Liquidambar styraciflua, Lobelia cardinalis, Ludwigia alternifolia, Ludwigia peploides, Ludwigia repens, Marsilea vestita, Micranthemum umbrosum, Mimulus alatus, Najas flexilis, Nelumbo lutea, Nuphar, Nyssa biflora, Persicaria hydropiperoides, Phyla lanceolata, Phyla nodiflora, Pilea, Pinus taeda, Planera aquatica, Pluchea camphorata, Populus heterophylla, Quercus lyrata, Quercus nigra, Quercus palustris, Quercus shumardii, Rhynchospora corniculata, Rotala ramosior, Sabal minor, Sabatia calycina, Sagittaria latifolia, Sagittaria platyphylla, Salix caroliniana, Salix nigra, Sarracenia flava, Saururus cernuus, Schoenoplectus tabernaemontani, Scirpus cyperinus, Scleria, Senna marilandica, Sium, Sparganium americanum, Taxodium distichum, Torilis, Toxicodendron radicans, Triadica sebifera, Tridens flavus, Typha latifolia, Ulmus alata, Ulmus rubra, Utricularia gibba, Vitis, Xanthium strumarium, Zannichellia palustris.

\subsubsection{Echinodorus grandiflorus (Cham. \& Schltdl.)}

Micheli is a nonindigenous perennial, which occurs in swamps at elevations to $10 \mathrm{~m}$. The plants can tolerate a fairly wide range of acidity ( $\mathrm{pH}: 4.8-7.4)$ and in North America, occur on sand substrates. Flowering (North America) occurs from summer through the fall. In its native range, flowering occurs in the mornings of the rainy season and lasts about $8 \mathrm{hr}$ in duration. The plants are self-compatible but attract various pollinating bees (Insecta: Hymenoptera: Andrenidae; Anthophoridae; Apidae; Colletidae; Halictidae). Seed set can range from $0.2 \%$ to $73 \%$ but typically is low; it is substantially higher in open-pollinated plants than in selfed individuals. The unscarified seeds germinate moderately (18-35\%) when incubated under continuous illumination at $25^{\circ} \mathrm{C}-30^{\circ} \mathrm{C}$, but not under continuous darkness. Scarified seeds (the seed coat slit near the site of embryo emergence) germinate well (98-99\%) under constant illumination or in darkness. The inflorescences are proliferous and produce numerous vegetative plantlets. Vegetative reproduction also occurs by means of rhizomes. Reported associates (North America): Acer rubrum, Colocasia esculenta, Juncus effusus, Magnolia virginiana, Mikania scandens, Myrica cerifera, Nyssa biflora, Osmunda regalis, Osmundastrum cinnamomeum, Persea palustris, Persicaria punctata, Pinus elliottii, Rhynchospora miliacea, Sabal minor, Saururus cernuus, Smilax walteri, Taxodium distichum, Thelypteris palustris, Woodwardia areolata.

Use by wildlife: The achenes of several Echinodorus species are eaten occasionally by waterfowl (e.g., Aves: Anatidae: Anas platyrhynchos), which have been suggested as potential long-distance dispersal agents. The achenes of E. berteroi are eaten by cinnamon teal (Aves: Anatidae: Anas cyanoptera). Echinodorus berteroi is used frequently as a nesting site of coots (Aves: Rallidae: Fulica americana, F. caribaea). Echinodorus berteroi and E. cordifolius are the hosts of sac Fungi (Ascomycota: Mycosphaerellaceae: Cercospora echinodori). Echinodorus cordifolius is a larval host plant of moths (Insecta: Lepidoptera: Crambidae: Synclita occidentalis); it also is fed upon by weevils (Insecta: Coleoptera: Curculionidae: Listronotus echinodori).

Economic importance: food: Echinodorus cordifolius plants can contain up to $81.6 \%$ digestible dry matter and $17.2 \%$ protein; however, they have not been used as a human food; medicinal: Root decoctions of $E$. berteroi have been used as a folk remedy for epilepsy and have been found to exhibit neuroleptic and antiepileptic activity. Aqueous extracts of E. grandiflorus have been shown to exhibit potent vasodilator activity and also may be a potential therapeutic agent for asthma; ethanolic extracts from the plants are antihypertensive. Foliar alcoholic extracts of E. grandiflorus are rich in diterpenes and flavonoids, which have been linked to their effectiveness in treating inflammatory conditions; cultivation: Several Echinodorus species are cultivated widely as ornamental aquarium plants, including E. berteroi, E. cordifolius, and E. grandiflorus. Cultivars of E. cordifolius include 'Marble Queen', 'Oriental', and 'Ozelot Green'; misc. products: Echinodorus cordifolius has been recommended as a 
potentially effective phytoremedial agent for the removal of azo dyes, ethylene glycol, and phosphorous from contaminated wastewater; weeds: Echinodorus berteroi is a weed of California rice fields; nonindigenous species: Echinodorus grandiflorus was introduced to Florida as an escape from cultivation, sometime before 1981.

Systematics: Echinodorus resolves as a clade after the removal of species assigned previously to subgenus Helanthium, which have been transferred to the genera Albidella and Helanthium. Its sister group is not certain, but has included combinations of various genera (Alisma, Astonia, Baldellia, Helanthium, Sagittaria, and Wiesneria) depending on the analysis and data sets analyzed. Originally named as a distinct species, E. floridanus does not appear to differ from E. grandiflorus (Figure 1.5), and it has been treated here as a synonym of the latter (along with the transfer of its OBL indicator status to $E$. grandiflorus). Phylogenetic analyses have indicated that the formerly proposed sectional divisions of Echinodorus are not entirely monophyletic. However, the assignment of E. cordifolius and E. grandiflorus to the same section (sect. Cordifolii) and E. berteroi to a different section (sect. Berteroii) is consistent with the results of phylogenetic analyses, which resolve $E$. berteroi as a distinct group and unite E. cordifolius and E. grandiflorus within the same clade (Figure 1.5). The basic chromosome number of Echinodorus is $x=11$. All counted species in the genus, including E. berteroi, E. cordifolius, and E. grandiflorus, are uniformly diploid $(2 n=22)$. Hybridization is known to occur commonly among species in cultivation; however, no accounts of natural hybridization involving Echinodorus have been reported in North America. Putative intergeneric hybrids involving Alisma and Echinodorus have been called $\times$ Alismodorus H.R.Wehrh.

Distribution: Echinodorus berteroi occurs across southern North America, with E. cordifolius restricted to the southeastern United States; both species extend into South America. The nonindigenous $E$. grandiflorus currently occurs only in Florida, but is native to South America.

References: Beal, 1977; Boyd \& McGinty, 1981; Braun et al., 2014; Brugiolo et al., 2011; Buznego \& Pérez-Saad, 2006; Cook, 1996; Correll \& Correll, 1975; de Faria Garcia et al., 2010; Dissanayake et al., 2007; DiTomaso \& Healy, 2003; Fassett, 1955; 1957; Gordón, 1997; Harms \& Grodowitz, 2009; Haynes \& Burkhalter, 1998; Haynes \& Hellquist, 2000a; Haynes \& Holm-Nielsen, 1994; Hohman \& Ankney, 1994; Kasselmann, 2001; Knobloch, 1972; Lehtonen, 2009a; Lehtonen \& Myllys, 2008; Lessa et al., 2008; McAtee, 1918; McNair \& Cramer-Burke, 2006; Middleton, 2009; Mühlberg, 1982; Munz \& Johnston, 1922; Noonpui \& Thiravetyan, 2011; Rataj, 1975; 2004; Reese \& Lubinski, 1983; Teamkao \& Thiravetyan, 2010; Tibiriçá et al., 2007; Torit et al., 2012; Tucker et al., 2015; Usinger, 1956; Vieira \& de Souza Lima, 1997.

\subsubsection{Helanthium}

Marsh flower, mudbabies

Etymology: from the Greek helos anthos ("marsh flower") in reference to the habitat
Synonyms: Alisma (in part); Echinodorus (in part); Helianthium

Distribution: global: New World; North America: eastern United States

Diversity: global: 3 species; North America: 1 species Indicators (USA): obligate wetland (OBL): Helanthium tenellum

Habitat: freshwater; freshwater (tidal); palustrine; pH: 6.17.6; depth: $<1 \mathrm{~m}$; life-form(s): emergent or submersed (rosulate) herbs

Key morphology: foliage (to $6 \mathrm{~cm}$ ) arising from rosettes, connected by fine pseudostolons; submersed leaves (to 10 $\mathrm{cm}$ ) sessile and linear, emersed leaves with ridged petioles (to $9.5 \mathrm{~cm}$ ), the blades (to $7.4 \mathrm{~cm}$ ) narrowly lanceolate to ovate; umbels or racemes (to $8 \mathrm{~cm}$ ) pedunculate (to $4 \mathrm{~cm}$ ), with 1-2 whorls of 4-16 flowers; flowers (to $10 \mathrm{~mm}$ ) pedicellate (to 3 $\mathrm{cm}$ ), trimerous, radial; petals (to $4 \mathrm{~mm}$ ) clawed, white; stamens 9; gynoecium apocarpous (to 20 pistils); fruit a headlike aggregate of flattened achenes (to $1.5 \mathrm{~mm}$ ) with lateral beaks (to $0.2 \mathrm{~mm}$ )

Life history: duration: annual (fruits/seeds); asexual reproduction: pseudostolons; pollination: unknown; sexual condition: hermaphroditic; fruit: aggregates (achenes) (common); local dispersal: achenes (water?), pseudostolons; longdistance dispersal: achenes (animals)

Imperilment: 1. Helanthium tenellum [G5]; SX (DE, NY); SH (LA, MA, NC); S1 (CT, IL, KS, MI, MS, VA); S2 (SC)

Ecology: general: All Helanthium species occur in wetlands and are amphibious plants capable of growing under emersed or submersed conditions. Their reproductive biology and seed ecology have not been described in any detail and require further study.

2.1.4.1. Helanthium tenellum Britt. is an annual, which inhabits shallow waters (up to at least $50 \mathrm{~cm}$ depth) or colonizes exposed substrates in borrow pits, canals, depressions, ditches, flats, meadows, pools (gum; swamp), prairies, sinkholes, swales, and along the margins of small lakes (depression), ponds (depression; drying; limesink depression; sink hole; temporary; swale), rivers, and streams at elevations to $591 \mathrm{~m}$. Although most often found on wet, exposed substrates, the plants also grow well when fully submersed. Exposures typically receive full sunlight, but also include partially shaded conditions. Occurrences span a $\mathrm{pH}$ range from 6.1 to 7.6 , but the plants thrive in weakly acidic waters of soft to medium hardness at temperatures from $18^{\circ} \mathrm{C}$ to $28^{\circ} \mathrm{C}$ (but up to $33^{\circ} \mathrm{C}$ ). The substrates typically are acidic and include clay, Cowarts (typic hapludults), loam, muck (organic), mud (exposed), peat, peaty sand, Plummer (grossarenic paleaquults), Rutlege (typic humaquepts), sand, sandy peat, and silty loam. Flowering occurs only when the inflorescences are emersed. Flowering and fruiting extend from March to September. The pollination biology of this species has not been described, but seed set tends to be high as in most annuals. In its South American range, this species can dominate the seed bank, comprising more than $24 \%$ of the total germinating propagules. The mechanism of seed dispersal also has not been elucidated but likely involves water over short distances 


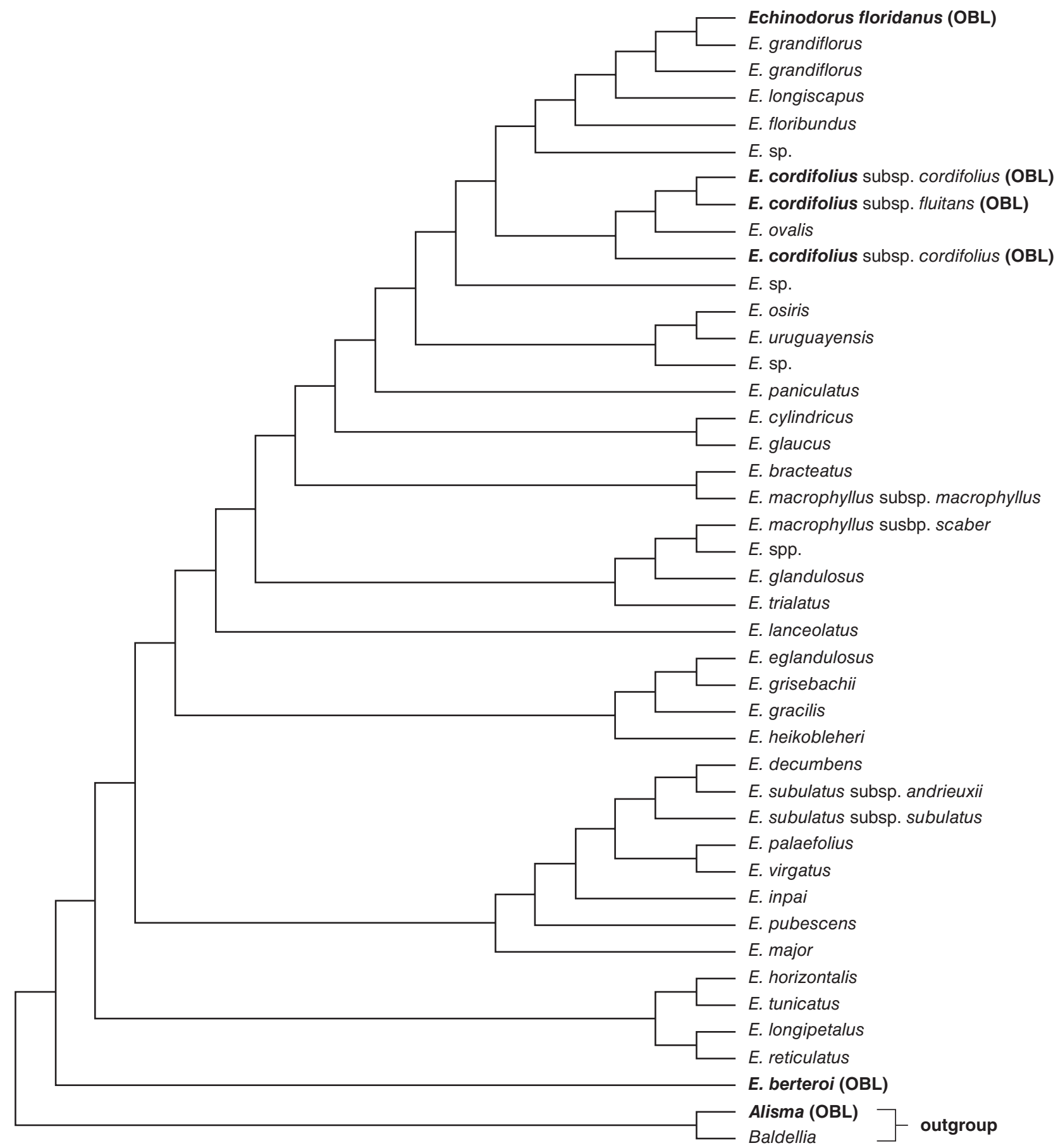

FIGURE 1.5 Interspecific relationships in Echinodorus as indicated by phylogenetic analysis of combined morphological and DNA sequence data (adapted from Lehtonen \& Myllys, 2008). The OBL North American wetland indicators (in bold) represent diverse origins in the genus. These results do not distinguish E. floridanus and E. grandiflorus (the latter name has been retained in the present treatment); the currently defined subspecific divisions of E. cordifolius also are untenable.

and attachment to various animal vectors over greater distances. The plants can be connected by delicate "pseudostolons," i.e., sterilized inflorescences from which vegetative buds can develop. Although unusual for an annual species, this means of vegetative reproduction can quickly result in the development of large, dense "cushions" of plants during the growing season. Reported associates: Alisma triviale, Bidens cernuus, Bidens connatus, Bidens frondosus, Bidens vulgatus, Boehmeria cylindrica, Bolboschoenus fluviatilis, Callitriche heterophylla, Cardamine pensylvanica, Carex barrattii, Carex lasiocarpa, Carex lurida, Cephalanthus occidentalis, Chelone glabra, Coleataenia longifolia, Cyperus dentatus, Cyperus diandrus, Cyperus esculentus, Cyperus haspan, Cyperus strigosus, Echinochloa crus-galli, Eleocharis acicularis, Eleocharis melanocarpa, Eleocharis obtusa, Eleocharis ovata, Eleocharis palustris, Fimbristylis 
vahlii, Gratiola aurea, Helenium virginicum, Heteranthera limosa, Hypericum mutilum, Hyptis alata, Isoetes virginica, Juncus acuminatus, Leersia oryzoides, Lindernia dubia, Lipocarpha maculata, Lipocarpha micrantha, Ludwigia palustris, Lycopus uniflorus, Lysimachia terrestris, Lythrum salicaria, Mayaca fluviatilis, Mentha arvensis, Nelumbo lutea, Nuphar variegata, Nymphaea odorata, Oldenlandia boscii, Oldenlandia uniflora, Panicum hemitomon, Panicum verrucosum, Penthorum sedoides, Persicaria hydropiperoides, Persicaria lapathifolia, Persicaria longiseta, Persicaria maculosa, Persicaria pensylvanica, Phalaris arundinacea, Physostegia leptophylla, Pilea pumila, Polypremum procumbens, Pontederia cordata, Proserpinaca palustris, Rhexia virginica, Rorippa palustris, Rotala ramosior, Rotala ramosior, Sagittaria graminea, Sagittaria latifolia, Schoenoplectus erectus, Schoenoplectus hallii, Schoenoplectus smithii, Scirpus cyperinus, Scutellaria lateriflora, Serenoa repens, Solanum dulcamara, Sparganium americanum, Sphagnum, Stachys hyssopifolia, Symphyotrichum lateriflorum, Taxodium, Typha latifolia, Xanthium strumarium, Xyris jupicai.

Use by wildlife: none reported.

Economic importance: food: not reported as edible; medicinal: Helanthium tenellum has been used in South America in preparing treatments for headaches, rheumatism, and syphilis; cultivation: Helanthium tenellum is grown as an aquarium plant; misc. products: none; weeds: none; nonindigenous species: none.

Systematics: Once treated as a section or subgenus of Echinodorus, Helanthium has more recently been recognized as a distinct genus in accordance with results of phylogenetic analyses. The species assigned to Helanthium group consistently as a clade, which resolves as the sister group of Echinodorus in several studies, including analyses of complete cpDNA gene sequences (Figure 1.3); however, other studies indicate Ranalisma as a possible sister group (Figure 1.6). Phylogenetic analyses of the three consistently recognized species using combined molecular and morphological data resolve $H$. tenellum as the sister to the remainder of the genus (Figure 1.6). Some authors have recognized as many as 10 species in the genus, indicating that a more comprehensive taxonomic evaluation is necessary. The base

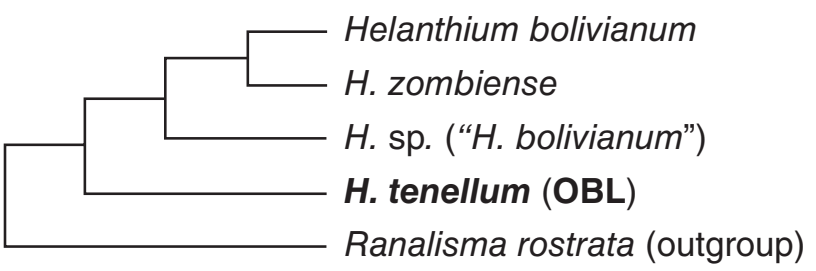

FIGURE 1.6 Phylogenetic relationships in Helanthium as indicated by analysis of combined molecular and morphological data (adapted from Lehtonen \& Myllys, 2008). These results resolve the OBL H. tenellum (in bold) as the sister to the remainder of the genus. They also indicate the possibility of a fourth species, which had been identified provisionally as $H$. bolivianum, but does not associate with that species. chromosome number of Helanthium is $x=11$. Helanthium tenellum has diploid and triploid cytotypes $(2 n=22,33)$. The triploids have meiotic abnormalities and reduced pollen stainability $(\sim 50 \%)$ with respect to the diploids (normal meiosis and $100 \%$ pollen stainability). Chromosomal (C-banding) analyses indicate that the triploids are of autopolyploid origin. Distribution: Helanthium tenellum occurs sporadically throughout the eastern United States.

References: Bercu, 2015; Brooks \& Wardrop, 2013; Charlton, 1979; Chester \& Palmer-Ball, 2011; Chester \& Souza, 1984; Costa, 2004; Haynes \& Hellquist, 2000a; Haynes \& HolmNielsen, 1994; Kasselmann, 2003; Lehtonen, 2007; 2009; Lehtonen \& Myllys, 2008; Les \& Tippery, 2013; Pagotto et al., 2011; Rataj, 2004.

\subsubsection{Hydrocleys}

\section{Waterpoppy}

Etymology: probably from the Greek hydro keleuthos ("leaving a water path"), in reference to the stepping-stone-like pattern displayed on the water by the floating leaves

Synonyms: Hydrocleis; Ostenia; Vespuccia

Distribution: global: New World; North America: southern United States

Diversity: global: 5 species; North America: 1 species

Indicators (USA): obligate wetland (OBL): Hydrocleys nymphoides

Habitat: freshwater; lacustrine, palustrine; pH: 5.5-6.0; depth: 0-2 m; life-form(s): floating-leaved

Key morphology: plants (to $50 \mathrm{~cm}$ ) stoloniferous (to $45 \mathrm{~cm}$ ); leaves submersed (sessile and phyllodial) or floating, then the petioles long (to $40 \mathrm{~cm}$ ), septate, sheathing (to $8.5 \mathrm{~cm}$ ), the blades (to $11.9 \mathrm{~cm}$ ) ovate to orbiculate, the base rounded or cordate; inflorescence (to 6 flowers) umbellate, proliferous, the peduncle (to $30 \mathrm{~cm}$ ) septate; flowers (to $6.5 \mathrm{~cm}$ ) pedicellate (to $17.5 \mathrm{~cm}$ ); petals (to $4.1 \mathrm{~cm}$ ) spreading, yellow to white, yellow at base; stamens (to 25) and outer staminodes (to 20+) numerous; gynoecium apocarpous, pistils $(5-8$; to $10 \mathrm{~mm})$ attenuate to an inwardly curved style; follicles (to $14.5 \mathrm{~mm}$ ) beaked (to $5.5 \mathrm{~mm}$ ), dehiscing adaxially; seeds (to 50+) small $(\sim 1 \mathrm{~mm})$, with glandular trichomes (to $0.15 \mathrm{~mm}$ )

Life history: duration: perennial (stolons); asexual reproduction: stolons; pollination: insect; sexual condition: hermaphroditic; fruit: aggregates of follicles (common); local dispersal: seeds (water), stolons, vegetative plantlets (water); long-distance dispersal: seeds (water, waterfowl?)

Imperilment: 1. Hydrocleys nymphoides [G5]

Ecology: general: All Hydrocleys species are floatingleaved hydrophytes (also producing submersed foliage), which occupy relatively shallow lentic or standing waters. Although normally rooted in the muddy substrate, the plants can dislodge and assume a free-floating habit. They produce floating inflorescences with showy flowers that are pollinated primarily by bees (Insecta: Hymenoptera: Apidae; Colletidae) or flies (Insecta: Diptera), which are attracted to their bright perianths by volatile methoxylated aromatics (e.g., $\rho$-methylanisole). Unlike many monocots, the perianth is not shed, but becomes extremely soft when water-soaked, 
eventually withering. Flowering can extend year-round in the native South American range. The sterility of some nonindigenous populations indicates the possibility of self-compatibility in the genus, but that prospect has not been investigated. The seeds are dispersed by water and possibly to greater distances by attachment to the plumage of waterfowl (Aves: Anatidae). There are no known specific germination requirements. The inflorescences of some species proliferate and produce vegetative buds, which produce adventitious roots and can develop into new plantlets as the peduncles arch over and contact the substrate.

2.1.5.1. Hydrocleys nymphoides (Humb. \& Bonpl. ex Willd.) Buch. is a nonindigenous perennial, which grows in ditches, pools (shallow), and along the margins of lakes at elevations to $70 \mathrm{~m}$. It can tolerate depths to $2 \mathrm{~m}$, but thrives in shallower waters from 20 to $45 \mathrm{~cm}$. Exposures can range from fully open to strongly shaded sites. Waters in the native South American habitats are acidic ( $\mathrm{pH}: 5.5-6.0$ ), soft, and can range from $6^{\circ} \mathrm{C}$ to $24^{\circ} \mathrm{C}$; the native substrates include loam and sandy gravel. Flowering (North America) has been observed in July, but the pollination biology has not been studied in this nonindigenous region. In their native South American range, the flowers are visited by flies (Insecta: Diptera) and bees (Insecta: Hymenoptera: Apidae: Geotrigona argentina) and the pollen is found in various honey samples, which indicates that the plants normally are entomophilous. Plants introduced to Australia completely fail to set seed. The inflorescence often proliferates into leaves or stolons, which are capable of vegetative reproduction (the primary reproductive mode at least in nonindigenous populations). Detached, floating vegetative plantlets can facilitate late seasonal dispersal. Unlike many indigenous species, the photosynthetic surface area (and biomass accumulation) increases proportionally with nutrient levels, which facilitates their invasion into new territories. The plants are non-mycorrhizal. Reported associates (North America): Acmella repens, Alternanthera philoxeroides, Cyperus flavicomus, Diodia virginiana, Eleocharis obtusa, Hydrocotyle verticillata, Kyllinga brevifolia, Sagittaria platyphylla.

Use by wildlife: In the Pantanal of Brazil, Hydrocleys nymphoides is consumed frequently by marsh deer (Mammalia: Cervidae: Blastocerus dichotomus). The plants are known hosts of powdery mildew (Fungi: Ascomaycota: Erysiphaceae: Erysiphe).

Economic importance: food: Hydrocleys nymphoides supposedly is edible, but no specific uses have been reported; medicinal: Extracts of Hydrocleys nymphoides have exhibited antimicrobial activity against pathogenic bovine mastitis microbes; cultivation: Hydrocleys nymphoides is a popular ornamental plant for aquariums and garden ponds; misc. products: none; weeds: Hydrocleys nymphoides is a "vigorously controlled" weed in New Zealand; nonindigenous species: Hydrocleys nymphoides is nonindigenous to North America, having escaped from cultivation sometime during the 20th century. The plants were introduced to Hawaii before 1938. They also have become naturalized in Australia, Japan, Korea, New Zealand, and Taiwan.
Systematics: Hydrocleys formerly was placed in the Butomaceae or Limnocharitaceae until several phylogenetic analyses consistently indicated that the group was nested within Alismataceae. However, the sister group of Hydrocleys remains somewhat uncertain, with either Butomopsis or Butomopsis + Limnocharis resolving in that position depending on the specific data set analyzed. A closer relationship between Butomopsis and Hydrocleys is indicated by their highly similar chromosome morphology and symmetry; chromosomally, they are both interpreted as relatively primitive elements compared to Limnocharis. Interspecific relationships in Hydrocleys have been investigated to some degree using morphological phylogenetic analyses, which indicate that the group is monophyletic. However, those analyses are incongruent with respect to the relationships depicted when using different outgroups (i.e., Butomopsis vs. Limnocharis), which is problematic given the uncertain sister-group relationships (see above). Hydrocleys nymphoides resolves either as the sister species of $H$. martii or $H$. mattogrossensis in the morphological cladograms. A phylogenetic evaluation of the genus using molecular data potentially would be helpful in resolving the interspecific relationships and also might help to clarify the sister group of Hydrocleys. The chromosomal base number is $x=7$ or $x=8$. Hydrocleys nymphoides $(2 n=16 ; x=8)$ is a diploid, with a triploid cytotype $(2 n=24)$ also reported. The diploid $H$. modesta $(2 n=14 ; x=7)$ differs by having a pair of telocentric chromosomes and a pair of acrocentric chromosomes replaced by a pair of metacentric chromosomes as a result of Robertsonian fission or fusion. No natural hybrids involving $H$. nymphoides have been reported.

Distribution: The nonindigenous Hydrocleys nymphoides reportedly is naturalized in Florida, Louisiana, and Texas.

References: Aston \& Jacobs, 1980; Boxell, 2014; Carvalho et al., 2014; Clayton, 1996; Cook et al., 1997; Edgerton, 2014; Fagúndez \& Caccavari, 2006; Forni-Martins \& Calligaris, 2002; Haynes, 2004; Haynes \& Holm-Nielsen, 1992; Haynes et al., 1998b; Kadono, 2004; Kasselmann, 2003; Kenton, 1981; Les \& Tippery, 2013; MacRoberts \& MacRoberts, 2010; McKenzie \& Lovell, 1992; Nesom, 2009; Ross et al., 2016; Rossi et al., 2011; Shin et al., 2012; Tomas \& Salis, 2000; Vossler et al., 2010; Wang \& Qiu, 2006; Wester, 1992; Wu et al., 2010.

\subsubsection{Sagittaria}

Arrowhead, wapato; flèche d'eau, sagittaire

Etymology: derived from the Latin sagitta ("arrow"), in reference to the arrow-like leaves of some species

Synonyms: Alisma (in part); Echinodorus (in part); Lophiocarpus (later homonym); Lophotocarpus

Distribution: global: Eurasia; Western hemisphere; North America: widespread

Diversity: global: 40 species; North America: 26 species

Indicators (USA): obligate wetland (OBL): Sagittaria ambigua, S. australis, S. brevirostra, S. calycina, S. cristata, $S$. cuneata, $S$. demersa, S. engelmanniana, S. fasciculata, $S$. filiformis, S. graminea, S. guayanensis, S. isoetiformis, S. kurziana, S. lancifolia, S. latifolia, S. longiloba, S. macrocarpa, 
S. montevidensis, S. papillosa, S. platyphylla, S. rigida, S. sanfordii, S. secundifolia, S. subulata, S. teres

Habitat: brackish, freshwater; freshwater (tidal); lacustrine, palustrine, riverine; pH: 4.4-9.2; depth: 0-2 m; life-form(s): emergent, floating-leaved, or submersed (rosulate) herbs

Key morphology: rosettes emersed, floating-leaved, or submersed, with stolons or rhizomes (sometimes producing tubers), the roots septate; leaves (when submersed) phyllodial (to 7-70 $\mathrm{cm}$; to $250 \mathrm{~cm}$ in some species), leaves (when emersed or floating) with blades cordate, elliptic, hastate, lance-elliptic, lanceolate, linear, linear-lanceolate, linear-oblanceolate, linear-ovate, ovate, sagittate, spatulate (to $2.5-35 \mathrm{~cm}$ ), margins entire, petioles (to $4-100 \mathrm{~cm}$ ) circular or triangular; inflorescences (to 4-72 cm) erect, floating, or emergent racemes or panicles, the flowers (to $0.8-4.0 \mathrm{~cm}$ ) sessile (rarely) or stalked (to $1.0-6.5 \mathrm{~cm}$ ), in whorls (to 4-17); flowers bisexual (rarely) or unisexual and in andromonoecious (rarely; normally pistillate flowers with a ring of stamens), dioecious (rarely), or monoecious (distally male) arrangements, perianth trimerous; sepals recurved or erect; petals white (rarely with a purplish spot); stamens numerous (to 30 ); gynoecium apocarpous, pistils numerous (to 1,500+), spirally arranged; fruit an aggregate head (to $0.5-3.0 \mathrm{~cm}$ ) of achenes (to $1.5-4.0 \mathrm{~mm}$ ); achenes compressed, abaxial keel and/or abaxial/lateral wings absent or present, with an erect or lateral beak (to $0.2-2.1 \mathrm{~mm}$; to $17 \mathrm{~mm}$ in one species)

Life history: duration: annual (fruits/seeds); perennial (corms, rhizomes, stolons); asexual reproduction: rhizomes, stolons, tubers; pollination: insect; sexual condition: dioecious, monoecious; fruit: aggregates (achenes) (common); local dispersal: fish, water (achenes); long-distance dispersal: birds (achenes)

Imperilment: 1. Sagittaria ambigua [G2]; S1 (AR, MO); S2 (KS); 2. S. australis [G5]; S1 (DC, IL, NJ); S2 (IN); 3. S. brevirostra [G5]; SH (MN, VA); S1 (TN); S2 (CO); S3 (IL); 4. S. calycina [G5]; SH (DC, NH); S1 (CO, DE, MA, NC, PA, QC, VA, WI, WV); S2 (MD, NB, NJ, NY, OR, WV); S3 (CT, DE, IL, ME, NJ); 5. S. cristata [G4]; S3 (ON); 6. S. cuneata [G5]; S1 (CT, NH, NJ, OH, OK, PA); S2 (MA, YT); S3 (IA, WY); 7. S. demersa [G2/G4]; 8. S. engelmanniana [G5]; SH (VA); S1 (WV); S2 (DE, MD, NC); 9. S. fasciculata [G2]; S2 (NC, SC); 10. S. filiformis [G4/G5]; SX (PA); $\mathrm{SH}$ (NC, NJ); $\mathrm{S} 2$ (ME); 11. S. graminea [G5]; S1 (AZ, CO, KY, NC, OH, PE, SC, TN); S2 (DE, KS, NC, NE, RI); S3 (GA, IA, IL, NC, NF, VA); 12. S. guayanensis [G5]; 13. S. isoetiformis [G4]; S1 (MS); S2 (AL, NC); S3 (SC); 14. S. kurziana [G4]; S1 (MS); 15. S. lancifolia [G5]; S1 (DE); S3 (NC); 16. S. latifolia [G5]; S1 (AZ, NF, WY); S2 (AB, NC); S3 (DE, OH); 17. S. longiloba [G5]; S1 (AZ, NE); 18. S. macrocarpa [G5T2]; S2 (NC); 19. S. montevidensis [G5]; 20. S. papillosa [G5]; 21. S. platyphylla [G5]; S1 (GA, KS, KY, MO, NC, OH, WV); S2 (TN); 22. S. rigida [G5]; SX (DC); SH (AR, DE, NH, PE); S1 (ID, KS, KY, MD, VA, TN); S2 (ME, MB, MA, OH); S3 (NE, QC, VT); 23. S. sanfordii [G3]; S3 (CA); 24. S. secundifolia [G1]; S1 (AL, GA); 25. S. subulata [G4]; SH (RI); S1 (MA); S2 (DE, NC, NJ); S3 (CT, NY, PA, VA); 26. S. teres [G3]; S1 (NH, NJ, NY, $\mathrm{RI}) ; \mathrm{S} 3$ (MA)
Ecology: general: Sagittaria is entirely aquatic, with all 26 North American species designated as OBL indicators throughout their ranges. Although not recognized in the National list, S. calycina and S. macrocarpa have been reinstated here as distinct species and are included as OBL indicators (see Systematics). Three species (S. chapmanii, S. spathulata, $S$. weatherbiana) retain OBL rankings on the National Wetland list, but are excluded here on taxonomic grounds (see Systematics). Information attributed to these taxa has been included with the species to which they currently are assigned. Most of the species are perennials (from coarser rhizomes or finer stolons) but a few behave as annuals. The stolons often are terminated by tubers, which some refer to as corms. The plants grow as submersed, floating-leaved, and emergent life-forms, with the various species producing leaves that range from narrow, submersed phyllodes to emergent broad-bladed structures. The flowers almost always are unisexual (sometimes the pistillate appearing to be bisexual by the presence of sterile stamens), rarely perfect, and are arranged in andromonoecious (having some perfect flowers), dioecious, or monoecious sexual conditions; sexual conditions sometimes are mixed within a species. Monoecious individuals have the staminate flowers situated above the pistillate flowers. They are self-compatible (i.e., capable of geitonogamy) but most of the flowers produce nectar and display a showy corolla of prominent white petals, which serves to attract various bees, beetles, butterflies, flies, and wasps (Insecta: Coleoptera; Diptera; Hymenoptera; Lepidoptera) as potential pollinators. Seed production generally tends to be high in both monoecious and dioecious populations. Seed germination requirements are poorly understood for many species and can be complex. Varied reports indicate germination in water without any pretreatment, germination following a five- to seven-month cold treatment, germination requiring warm stratification, and germination under constant or fluctuating incubation temperatures. Physical scarification (by puncture of the integument) is known to increase germination rates in some species. Seeds originating from dioecious plants can produce germination inhibitors, which require stratification and/or scarification to overcome. Usually, the seeds are consumed only occasionally by waterfowl (Aves: Anatidae); however, locally they can be important components of their meals, with several hundred achenes being consumed during a feeding period. The mature achenes will float (for up to 2 months) and are dispersed by water. In some species they are eaten by fish (e.g., Osteichthyes: Teleostei: Cyprinus carpio) and are excreted in viable state, which facilitates their transport within water bodies. They also are transported over longer distances by their external attachment to or consumption and subsequent egestion by birds (e.g., Aves: Anatidae; Charadriidae). Vegetative reproduction can occur in most species by the proliferation of stolons (the thicker structures categorized as rhizomes) and associated tubers. This is a taxonomically difficult group and a good number of literature accounts (even those authored by experts) often involve misidentifications or improper species assignments. 
2.1.6.1. Sagittaria ambigua J.G. Sm. is a perennial, which inhabits shallow waters or wet exposed sites in depressions, ditches, gravel pits, mudflats, ponds (shallow), pools, prairies, roadsides, sloughs, swamps, and along the margins or shores of lakes, ponds, and streams at elevations to $230 \mathrm{~m}$. The plants are common along shores where water levels fluctuate and have been characterized as pioneer species of shallow pond bottoms. The substrates often are described as mud. Flowering occurs from April to September. There is no information on the reproductive biology or seed ecology of this species. Seed dispersal likely occurs primarily by water. Reported associates: Alisma subcordatum, Ammannia auriculata, Callitriche heterophylla, Cephalanthus occidentalis, Echinochloa crusgalli, Eclipta prostrata, Eleocharis engelmannii, Eleocharis macrostachya, Eleocharis obtusa, Fimbristylis autumnalis, Gratiola virginiana, Helenium flexuosum, Hydrolea ovata, Juncus brachycarpus, Juncus torreyi, Ludwigia alternifolia, Ludwigia glandulosa, Ludwigia palustris, Nelumbo lutea, Persicaria pensylvanica, Rhexia mariana, Rotala ramosior, Sagittaria brevirostra, Sagittaria calycina, Sagittaria latifolia, Samolus ebracteatus, Schoenoplectus pungens, Schoenoplectus tabernaemontani, Typha latifolia, Verbena hastata.

2.1.6.2. Sagittaria australis (J.G. Sm.) Small is a perennial, inhabits exposed sediments or shallow waters (e.g., 15 cm depth) within bottomlands (alluvial; dry; creek), channels (river), depressions, ditches (banks), floating mats, floodplains, marshes, meadows (alluvial), oxbows, ponds (spring-fed; vernal), slopes (to 40\%), sloughs, streams (lentic), swales, swamps, and along the margins of lakes, ponds, reservoirs, streams, and swamps at elevations to $488 \mathrm{~m}$. The plants can tolerate exposures ranging from fully open to shaded conditions. The substrates are consistently circumneutral (pH: 6.07.6) and include Cecil clay loam, Cecil sandy loam, Congaree silt loam, dredge material, gravel, mud, and sand. Flowering and fruiting in this monoecious species extend from July to October. The flowers are pollinated by generalist bees (see Use by wildlife). Seeds collected from late August through early October, and stored moist or in water, have germinated well on saturated media (23\% to 52\%) within $10-11$ weeks after planting. The breeding system is not well correlated with subsequent seed germination, with higher, lower, and equal rates reported for inbred vs. outcrossed seeds. Reported associates: Acer floridanum, Acer negundo, Acer rubrum, Acorus calamus, Alisma subcordatum, Arundinaria tecta, Bacopa, Betula nigra, Bidens frondosus, Bidens tripartitus, Boltonia, Calamagrostis canadensis, Carex alata, Carex lurida, Carex vulpinoidea, Cicuta maculata, Commelina virginica, Conoclinium coelestinum, Cyperus flavescens, Cyperus squarrosus, Cyperus strigosus, Eleocharis ovata, Epilobium coloratum, Fraxinus pennsylvanica, Geum canadense, Glyceria striata, Hydrocotyle verticillata, Hypericum mutilum, Ipomoea lacunosa, Isoetes engelmannii, Juncus effusus, Kosteletzkya, Leersia oryzoides, Leersia virginica, Leptochloa, Liquidambar styraciflua, Liriodendron tulipifera, Lobelia, Ludwigia alternifolia, Lycopus virginicus, Microstegium vimineum, Mimulus alatus, Murdannia keisak,
Nitella, Nuphar advena, Nymphaea odorata, Nyssa, Oxypolis rigidior, Panicum, Peltandra virginica, Persicaria amphibia, Persicaria longiseta, Persicaria setacea, Potamogeton, Ptilimnium costatum, Quercus, Rhexia virginica, Rosa palustris, Rumex conglomeratus, Sagittaria calycina, Sagittaria latifolia, Sagittaria platyphylla, Salix caroliniana, Salix nigra, Samolus valerandi, Saururus cernuus, Scirpus cyperinus, Sesbania, Sparganium americanum, Sphenoclea zeylanica, Taxodium distichum, Typha latifolia.

2.1.6.3. Sagittaria brevirostra Mackenzie \& Bush is a perennial, which occurs on exposed substrates or in shallow waters (to $60 \mathrm{~cm}$ deep) of alluvial fans, bottomlands, canals, channels (ravine), ditches (dredged; roadside), floodplains, gravel pits, lakebeds, marshes, meadows, mud bars, mudflats, oxbows, ponds (dessicated; sand), prairies, ravines (dried), seeps, shores, slopes (to 5\%), sloughs, springs, swamps (dried), and along the margins of lakes, ponds, rivers, streams, and swamps at elevations to $1539 \mathrm{~m}$. Exposures from open sunlight to shade are tolerated. The substrates are described as clay loam, clay mud, loamy clay, loam muck, mud, rock, sand, sandy loam (Bolivar), and silt. The plants exhibit a highly plastic morphology. Smaller leaves develop when growing in dry and deepwater conditions than those when growing in shallow water. In deep waters, the leaves are quite narrow. These monoecious plants flower and fruit from June to October. Plants growing in deep waters are sterile. The individuals are self-compatible, allowing for either geitonogamous or xenogamous pollination to occur. The pollinators consist of numerous types of small insects (Insecta). Inflorescence size varies but does not influence seed set, which typically is high in all female flowers. Inflorescences are larger and produce more flowers under wet vs. dry conditions. Male flowers outnumber females in either dry or wet conditions, but sex ratios are more highly male biased in plants growing under dry conditions. Details on seed germination are unavailable. The achenes are dispersed by water. Reported associates: Acalypha rhomboidea, Acer negundo, Acer saccharinum, Agalinis purpurea, Alisma subcordatum, Ambrosia, Ammannia coccinea, Ammannia robusta, Asclepias incarnata, Azolla, Bacopa rotundifolia, Betula nigra, Boehmeria cylindrica, Bolboschoenus fluviatilis, Calamagrostis canadensis, Callitriche heterophylla, Campanula americana, Campanula aparinoides, Campsis radicans, Carex caroliniana, Carex cristatella, Carex frankii, Carex grayi, Carex muskingumensis, Carex stipata, Carex stricta, Carex tribuloides, Carex typhina, Carex vesicaria, Carya laciniosa, Cephalanthus occidentalis, Cicuta, Coleataenia longifolia, Cornus amomum, Cornus drummondii, Cornus racemosa, Doellingeria umbellata, Echinochloa crus-galli, Eleocharis erythropoda, Eleocharis macrostachya, Eleocharis obtusa, Eleocharis ovata, Epilobium leptophyllum, Equisetum, Eupatorium perfoliatum, Fraxinus pennsylvanica, Galium tinctorium, Gleditsia aquatica, Glyceria septentrionalis, Gratiola virginiana, Helenium autumnale, Helianthus hirsutus, Heteranthera limosa, Heteranthera rotundifolia, Hibiscus laevis, Hypericum mutilum, Ilex decidua, Ilex vomitoria, Impatiens capensis, Ipomoea lacunosa, Iris virginica, Juncus canadensis, 
Juncus dudleyi, Juncus effusus, Juncus torreyi, Justicia americana, Laportea canadensis, Leersia oryzoides, Lemna minor, Lindernia dubia, Lobelia cardinalis, Ludwigia alternifolia, Ludwigia palustris, Ludwigia peploides, Ludwigia polycarpa, Lycopus americanus, Lycopus rubellus, Lycopus virginicus, Lysimachia ciliata, Lysimachia quadriflora, Lythrum, Marsilea vestita, Mentha arvensis, Mimulus ringens, Myrica cerifera, Nymphaea odorata, Onoclea sensibilis, Panicum virgatum, Peltandra virginica, Penthorum sedoides, Persicaria amphibia, Persicaria bicornis, Persicaria coccinea, Persicaria hydropiperoides, Persicaria pensylvanica, Persicaria punctata, Phalaris arundinacea, Phragmites australis, Phyla, Pinus taeda, Platanus occidentalis, Polygonum ramosissimum, Populus deltoides, Potamogeton nodosus, Potamogeton pusillus, Proserpinaca pectinata, Pycnanthemum virginianum, Quercus macrocarpa, Quercus palustris, Ranunculus flabellaris, Rhynchospora, Rorippa aquatica, Rorippa palustris, Rumex altissimus, Rumex crispus, Rumex stenophyllus, Sagittaria ambigua, Sagittaria calycina, Sagittaria graminea, Sagittaria latifolia, Sagittaria rigida, Salix amygdaloides, Salix exigua, Salix interior, Salix myricoides, Salix nigra, Schoenoplectus heterochaetus, Scirpus atrovirens, Scirpus cyperinus, Scutellaria lateriflora, Sium suave, Solidago nemoralis, Solidago ulmifolia, Spiraea tomentosa, Stachys palustris, Symphyotrichum ontarionis, Symphyotrichum patens, Teucrium canadense, Thelypteris palustris, Triadenum fraseri, Tridens flavus, Typha latifolia, Verbena hastata, Vitis cinerea, Wolffia brasiliensis.

2.1.6.4. Sagittaria calycina Engelm. is an annual, which inhabits shallow $(<100 \mathrm{~cm})$, tidal or non-tidal, brackish to freshwater sites including canals, depressions, ditches (irrigation), estuaries, floodplains, gravel bars, marshes, meadows, mudflats (lake; river), ponds (artificial; catchment; sand), pools, ravines (dried), rice fields, roadsides, saltmarshes, sandbars, seeps, shores, sinkholes, sloughs, swales, swamps, and the margins of lakes (artificial; small), ponds, reservoirs, rivers, and stock tanks at elevations to $1829 \mathrm{~m}$. Although the plants can grow either emersed or submersed, they regularly appear as emergents on mudflats and at other sites with open exposures where standing waters have receded. The substrates are described as alkaline (e.g., pH: 8.5) or calcareous, and include alluvium, ballast (railroad), clay, clay loam (over limestone), loam, muck, mud, sand, sandy gravel, silt, silty loam (Humphrey's Cherty), and silty sand. Flowering occurs from June to October, with developing fruits observed by late June. Individuals are described as being andromonoecious, i.e., bearing perfect and staminate flowers. However, the perfect flowers are described as possessing either functional stamens or staminodes, depending on the source consulted. Whether these flowers retain any capacity for autogamy should be clarified, especially given the annual habit of the plants. The pollination biology of this species has not been described in any detail; however, the fruits are known to mature within a few weeks following anthesis. Mature plants can reach densities of 20-30 plants $\mathrm{m}^{-2}$ and are known to produce up to 2,000 achenes per inflorescence with up to 32 inflorescences per plant, yielding an average of 20,000 achenes per plant. Other estimates indicate achene yields of 73 cubic $\mathrm{cm} \mathrm{m}^{-2}$, or by mass, an average of $400 \mathrm{~kg} \mathrm{ha}^{-1}$. As the fruiting peduncles become prostrate along the substrate, the pedicels recurve to push the fruiting heads into the mud. Consequently, many seeds are planted near the maternal plant. However, the achenes also are buoyant and can remain afloat for up to 2 weeks. They can be dispersed locally by water, and potentially are transported over greater distances by waterfowl (Aves: Anatidae). The achenes remain viable in the seed bank where they retain $54 \%$ viability after 1 year and $45 \%$ viability after 3 years. The seeds will germinate at temperatures below $10^{\circ} \mathrm{C}$, but much higher rates are observed above $11^{\circ} \mathrm{C}$ (optimal germination occurs at $\left.12^{\circ} \mathrm{C}-24^{\circ} \mathrm{C}\right)$. Reported associates: Abutilon theophrasti, Acalypha gracilens, Acalypha rhomboidea, Acer negundo, Acer saccharinum, Agrimonia parviflora, Alisma subcordatum, Amaranthus, Ammannia coccinea, Andropogon virginicus, Apocynum cannabinum, Bergia texana, Betula nigra, Bidens aristosus, Bidens bidentoides, Bidens connatus, Bidens frondosus, Bidens tripartitus, Boehmeria cylindrica, Bolboschoenus novae-angliae, Carex hyalinolepis, Celtis, Cephalanthus occidentalis, Chamaecrista fasciculata, Chasmanthium latifolium, Coleataenia longifolia, Conoclinium coelestinum, Conyza canadensis, Cyperus acuminatus, Cyperus bipartitus, Cyperus erythrorhizos, Cyperus esculentus, Cyperus flavescens, Cyperus odoratus, Cyperus squarrosus, Cyperus strigosus, Dichanthelium clandestinum, Dichanthelium dichotomum, Digitaria ischaemum, Diodella teres, Diodia virginiana, Dioscorea, Dysphania ambrosioides, Echinochloa muricata, Echinodorus berteroi, Eclipta prostrata, Eleocharis acicularis, Eleocharis ambigens, Eleocharis diandra, Eleocharis erythropoda, Eleocharis macrostachya, Eleocharis obtusa, Eleocharis ovata, Eleocharis parvula, Eleusine indica, Eragrostis hypnoides, Eragrostis pectinacea, Erigeron annuus, Erigeron philadelphicus, Erigeron strigosus, Eriocaulon parkeri, Eupatorium perfoliatum, Eupatorium serotinum, Euphorbia maculata, Euphorbia nutans, Fimbristylis autumnalis, Fragaria virginiana, Galium triflorum, Gamochaeta purpurea, Hedeoma hispida, Helenium flexuosum, Heteranthera limosa, Heteranthera reniformis, Hypericum mutilum, Hypericum punctatum, Impatiens capensis, Isoetes riparia, Juncus acuminatus, Juncus diffusissimus, Juncus effusus, Juncus tenuis, Justicia americana, Kummerowia stipulacea, Kummerowia striata, Kyllinga brevifolia, Kyllinga pumila, Leersia oryzoides, Leersia virginica, Leptochloa fusca, Lespedeza procumbens, Lespedeza thunbergii, Leucanthemum vulgare, Lilaeopsis chinensis, Lindernia dubia, Lobelia cardinalis, Lobelia inflata, Lobelia siphilitica, Ludwigia palustris, Ludwigia peploides, Lycopus americanus, Lycopus rubellus, Microstegium vimineum, Mimulus alatus, Mimulus ringens, Mollugo verticillata, Nuphar advena, Panicum dichotomiflorum, Panicum philadelphicum, Paronychia fastigiata, Paspalum, Peltandra virginica, Penthorum sedoides, Persicaria hydropiper, Persicaria hydropiperoides, Persicaria lapathifolia, Persicaria maculosa, Persicaria pensylvanica, Persicaria posumbu, Persicaria punctata, Persicaria sagittata, Persicaria virginiana, Phlox bifida, 
Phytolacca americana, Plantago lanceolata, Plantago rugelii, Pluchea camphorata, Pluchea odorata, Pontederia cordata, Potentilla norvegica, Potentilla simplex, Prunella vulgaris, Ptelea, Quercus bicolor, Ranunculus, Rhexia mariana, Rorippa palustris, Rorippa sylvestris, Rotala ramosior, Rumex crispus, Rumex obtusifolius, Sagittaria ambigua, Sagittaria australis, Sagittaria brevirostra, Sagittaria graminea, Sagittaria latifolia, Sagittaria longiloba, Sagittaria platyphylla, Sagittaria subulata, Salix, Samolus valerandi, Schoenoplectus hallii, Schoenoplectus pungens, Schoenoplectus smithii, Scirpus polyphyllus, Scutellaria lateriflora, Senna marilandica, Setaria viridis, Sida spinosa, Solanum carolinense, Solidago canadensis, Sonchus asper, Sparganium americanum, Spartina alterniflora, Spartina cynosuroides, Symphyotrichum lanceolatum, Symphyotrichum ontarionis, Symphyotrichum pilosum, Symphyotrichum racemosum, Tradescantia bracteata, Trifolium repens, Tussilago farfara, Typha angustifolia, Typha latifolia, Urochloa platyphylla, Verbascum thapsus, Verbena hastata, Verbena urticifolia, Verbesina alternifolia, Vernonia gigantea, Vitis, Xanthium strumarium, Zizania aquatica.

2.1.6.5. Sagittaria cristata Engelm. is an annual or a perennial, which inhabits shallow to moderately deep waters (to 2 $\mathrm{m})$ in lakes, rivers, sloughs, and along the margins of lakes, ponds, and swamps at elevations to $1000 \mathrm{~m}$. The habitats are categorized as hard water ( $\mathrm{pH}$ : 7.0-8.6; total alkalinity $>40$ ppm; e.g., $54.0 \mathrm{mg} \mathrm{l}^{-1}$; sulfates $<50 \mathrm{ppm}$ ). The sediments (means: organic matter: 1.5\%; $\mathrm{pH}$ : 5.5 ; Ca: $10 / 50 \mu \mathrm{g} \mathrm{g}^{-1}$; K: 5/7.3 $\left.\mu \mathrm{g} \mathrm{g}^{-1} ; \mathrm{Mg}: 5 / 14.8 \mu \mathrm{g} \mathrm{g}^{-1} ; \mathrm{P}: 5 / 8.4 \mu \mathrm{g} \mathrm{g}^{-1}\right)$ are described as muck and sand. This is one of the more aquatic species in the genus, found normally in deeper standing water and less often on exposed shorelines. The foliage has relative low ratios of C:P (400), C:N (16), and N:P (20). The plants are monoecious, with flowering and fruiting observed from July to September. Additional details on the reproductive biology or seed ecology of this species are lacking. Reported associates: Bidens beckii, Brasenia schreberi, Ceratophyllum demersum, Chara, Drepanocladus, Dulichium arundinaceum, Elatine minima, Eleocharis acicularis, Elodea canadensis, Eriocaulon aquaticum, Heteranthera dubia, Isoetes echinospora, Juncus pelocarpus, Lemna minor, Lemna trisulca, Lobelia dortmanna, Myriophyllum sibiricum, Myriophyllum tenellum, Najas flexilis, Najas guadalupensis, Nitella, Nuphar advena, Nuphar variegata, Nymphaea odorata, Persicaria amphibia, Potamogeton amplifolius, Potamogeton foliosus, Potamogeton gramineus, Potamogeton illinoensis, Potamogeton natans, Potamogeton praelongus, Potamogeton pusillus, Potamogeton richardsonii, Potamogeton robbinsii, Potamogeton strictifolius, Potamogeton zosteriformis, Ranunculus flammula, Ruppia maritima, Schoenoplectus acutus, Schoenoplectus subterminalis, Sparganium americanum, Sparganium angustifolium, Sparganium eurycarpum, Sparganium fluctuans, Stuckenia filiformis, Stuckenia pectinata, Utricularia cornuta, Utricularia macrorhiza, Utricularia minor, Utricularia resupinata, Vallisneria americana.
2.1.6.6. Sagittaria cuneata Sheldon is a perennial, which inhabits still or slow-moving standing waters (to $1.2 \mathrm{~m}$ deep) or exposed substrates within backwaters, beaches, bogs, borrow pits, canals (irrigation), depressions, ditches (roadside), draws, fens, flats, lake beds (dry), marshes, meadows, mudflats, ponds (intermittent; montane; retention; spring-fed; stock), pools (culvert; dried; roadside), potholes, riverbeds, rivers, roadsides (disturbed; gravelly), slopes (to 6\%), sloughs, streambeds, swales, swamps, and along the margins or receding shores of channels, lakes, ponds, potholes, reservoirs, rivers, and streams at elevations to $3048 \mathrm{~m}$. The plants are highly polymorphic, producing linear or sagittate emergent foliage when growing in shallow sites but developing phyllodial submersed or cordate/sagittate floating leaves in deeper water. Exposures can range from full sun to shade. The surrounding waters can vary widely in terms of alkalinity (from 5 to $628 \mathrm{mg} \mathrm{l}^{-1} \mathrm{CaCO}_{3}$ ) but tend to be moderately alkaline to calcareous (e.g., $\mathrm{pH}: 6.8-8.9 ; \bar{x}=7.4$; total hardness: $184 \mathrm{mg}$

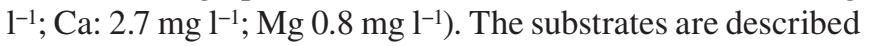
as acidic (e.g., pH: 5.5-7.0) or brackish and include alluvium, clay (black; Pierre), clay loam (Shingle-Samday; Worthenton), clay silt, gravel, gravelly sand, gumbo, loam (black; organic), muck (alkaline; black), mud (alluvial; desiccated), peat, rock, sand, sandy clay, sandy loam, sandy ooze, Shingle-Haverdad series, silt, silty clay, silty loam, silty muck, silty sand, and Worfka-Shingle-Samday series. Flowering occurs from April to September, with fruiting extending into October. Individuals are monoecious but self-compatible, theoretically enabling geitonogamous pollination to occur; however, the reproductive ecology of this species has not been characterized in any detail. Outcrossing presumably is carried out by bees (Insecta: Hymenoptera) and flies (Insecta: Diptera). A plant typically produces six flowers, which can yield about 5,150 seeds, each weighing about $0.235 \mathrm{mg}$. A seed bank develops. The highest experimental germination rates occurred for seeds buried at less than $1 \mathrm{~cm}$ (3-week stratification at $10^{\circ} \mathrm{C}$; they were then placed under ambient greenhouse conditions: $15^{\circ} \mathrm{C}-30^{\circ} \mathrm{C} ; 14-16 \mathrm{hr}$ light). The seeds are dispersed by water and perhaps to greater distances by their adherence to various animals. Reported associates: Acer negundo, Acer saccharinum, Agrostis gigantea, Alisma subcordatum, Alisma triviale, Alopecurus aequalis, Amaranthus, Anagallis minima, Angelica atropurpurea, Arnica chamissonis, Artemisia frigida, Artemisia nova, Artemisia tridentata, Asclepias incarnata, Bacopa rotundifolia, Beckmannia syzigachne, Berula erecta, Bidens cernuus, Boehmeria cylindrica, Bouteloua gracilis, Calla, Callitriche hermaphroditica, Callitriche palustris, Carex aquatilis, Carex arcta, Carex athrostachya, Carex comosa, Carex cristatella, Carex emoryi, Carex lasiocarpa, Carex molesta, Carex nebrascensis, Carex rostrata, Carex stipata, Carex utriculata, Carex utriculata, Carex vesicaria, Carex vulpinoidea, Cephalanthus occidentalis, Ceratophyllum demersum, Ceratophyllum echinatum, Chara, Chenopodium glaucum, Cicuta bulbifera, Comarum palustre, Convolvulus arvensis, Cornus amomum, Cyperus bipartitus, Cyperus odoratus, Damasonium californicum, Deschampsia cespitosa, Downingia bella, Downingia 
yina, Dulichium arundinaceum, Echinochloa crus-galli, Elaeagnus angustifolia, Elatine heterandra, Eleocharis acicularis, Eleocharis erythropoda, Eleocharis macrostachya, Eleocharis palustris, Eleocharis quinqueflora, Elodea canadensis, Equisetum fluviatile, Eupatorium perfoliatum, Fimbristylis autumnalis, Glyceria borealis, Glyceria grandis, Glyceria septentrionalis, Glyceria striata, Gnaphalium palustre, Gratiola heterosepala, Gratiola neglecta, Gutierrezia sarothrae, Helenium, Hippuris vulgaris, Hordeum jubatum, Iris virginica, Isoetes bolanderi, Juncus alpinoarticulatus, Juncus balticus, Juncus effusus, Juncus nodosus, Juncus torreyi, Leersia oryzoides, Lemna minor, Lepidium virginicum, Limosella, Lindernia dubia, Ludwigia palustris, Lycopus americanus, Lycopus asper, Lycopus uniflorus, Lysimachia nummularia, Lythrum salicaria, Madia glomerata, Marsilea vestita, Melilotus officinalis, Mentha arvensis, Mimulus primuloides, Mimulus ringens, Myriophyllum sibiricum, Myriophyllum spicatum, Najas flexilis, Najas marina, Nuphar polysepala, Nuphar variegata, Peltandra virginica, Persicaria amphibia, Persicaria coccinea, Persicaria hydropiper, Persicaria hydropiperoides, Persicaria maculosa, Persicaria punctata, Phalaris arundinacea, Phleum pratense, Phragmites australis, Physostegia virginiana, Pilea pumila, Poa nemoralis, Poa pratensis, Polypogon monspeliensis, Populus angustifolia, Populus balsamifera, Populus deltoides, Porterella carnosula, Potamogeton berchtoldii, Potamogeton diversifolius, Potamogeton epihydrus, Potamogeton foliosus, Potamogeton gramineus, Potamogeton illinoensis, Potamogeton natans, Potamogeton pusillus, Potamogeton richardsonii, Potamogeton zosteriformis, Potentilla gracilis, Ranunculus aquatilis, Ranunculus pensylvanicus, Ranunculus sceleratus, Rhamnus cathartica, Rhaponticum repens, Rorippa islandica, Rorippa palustris, Rosa multiflora, Rosa setigera, Rotala ramosior, Rudbeckia laciniata, Rumex altissimus, Rumex salicifolius, Rumex verticillatus, Sagittaria latifolia, Salix amygdaloides, Salix exigua, Salix interior, Salix lasiandra, Salix nigra, Sambucus nigra, Schedonorus arundinaceus, Schoenoplectus acutus, Schoenoplectus pungens, Schoenoplectus tabernaemontani, Scirpus atrovirens, Scutellaria lateriflora, Sium suave, Solanum dulcamara, Solidago altissima, Solidago gigantea, Sparganium angustifolium, Sparganium emersum, Sparganium eurycarpum, Spartina pectinata, Sphagnum, Spirodela polyrhiza, Stuckenia filiformis, Stuckenia pectinata, Tamarix ramosissima, Thalictrum dasycarpum, Trifolium, Triglochin scilloides, Typha angustifolia, Typha latifolia, Typha ×glauca, Ulmus americana, Urtica dioica, Vallisneria americana, Verbesina alternifolia, Vitis riparia, Zannichellia palustris.

2.1.6.7. Sagittaria demersa J.G. Sm. is an annual, which occurs in standing waters $(0.2-1.2 \mathrm{~m})$, or (more rarely) is stranded on the exposed substrates of lakes, pools, and streams at elevations from 1500 to $2082 \mathrm{~m}$. The plants produce phyllodial leaves, which are submersed or are floating. In Mexico, this species occurs in montane, clean, medium-hard to soft waters ( $\mathrm{pH}$ : $6.0-7.2 ; \mathrm{CaCO}_{3}: 48.0-88.0 \mathrm{mg} \mathrm{l}^{-1}$ ). The sediments contain average levels of nitrogen, total phosphorus, and organic matter, and are described as clay, clayey sand, and sandy sandstone. Further life history information is unavailable for this species, particularly for the few North American occurrences. The plants apparently are intolerant of pollution and readily succumb to eutrophication and other human disturbances. Reported associates: none.

2.1.6.8. Sagittaria engelmanniana J.G. Sm. is a perennial, which inhabits shallow waters (e.g., $30 \mathrm{~cm}$ deep) of alluvial fans, backwaters, beaches, bogs (peat), bottoms (exposed; stream), Carolina bays, channels (drainage), depressions, ditches, fens, floodplains, lakes, marshes, oxbows, pocosins (streamside), ponds (dried), reservoirs, shores, sloughs, swales, swamps, woodlands, and the margins of lakes, ponds, rivers, and streams at elevations to $127 \mathrm{~m}$. The sites typically occur in open exposures with waters that characteristically are acidic ( $\mathrm{pH}$ : 5.6-6.3). The substrates are described as muck, mucky peat, mud, peat, sand, and silty sand. The plants are monoecious and are in flower from June to September with fruiting extending into October. Individuals are self-compatible, which allows for geitonogamous pollination to occur (but to what extent has not been determined). The usual pollinators presumably are insects (Insecta). Other life history details are lacking for this species. Reported associates: Acer rubrum, Agrostis hyemalis, Alnus maritima, Alnus serrulata, Andropogon glomeratus, Andropogon virginicus, Apios americana, Aronia arbutifolia, Bartonia paniculata, Bartonia virginica, Bidens frondosus, Bidens mitis, Bidens trichospermus, Burmannia capitata, Calamagrostis canadensis, Callitriche heterophylla, Carex albolutescens, Carex atlantica, Carex bullata, Carex canescens, Carex exilis, Carex exilis, Carex lasiocarpa, Carex striata, Cephalanthus occidentalis, Chamaecyparis thyoides, Chamaedaphne calyculata, Cladium mariscoides, Clethra alnifolia, Coleataenia longifolia, Cuscuta, Cyperus dentatus, Cyperus squarrosus, Cyrilla racemiflora, Dichanthelium acuminatum, Dichanthelium dichotomum, Dichanthelium ensifolium, Dichanthelium scabriusculum, Drosera intermedia, Drosera rotundifolia, Dulichium arundinaceum, Eleocharis acicularis, Eleocharis equisetoides, Eleocharis flavescens, Eleocharis robbinsii, Eleocharis tenuis, Eleocharis tuberculosa, Eriocaulon aquaticum, Eriocaulon compressum, Eriocaulon decangulare, Eriophorum virginicum, Eubotrys racemosa, Eupatorium perfoliatum, Eupatorium pilosum, Eupatorium resinosum, Eupatorium $\times$ pinnatifidum, Euthamia graminifolia, Eutrochium dubium, Fuirena squarrosa, Galium tinctorium, Gaylussacia dumosa, Glyceria obtusa, Gratiola aurea, Hydrocotyle verticillata, Hypericum canadense, Hypericum densiflorum, Hypericum denticulatum, Hypericum mutilum, Ilex glabra, Iris versicolor, Itea virginica, Juncus canadensis, Juncus effusus, Juncus militaris, Juncus pelocarpus, Juncus trigonocarpus, Kalmia angustifolia, Kalmia buxifolia, Lachnanthes caroliniana, Leersia oryzoides, Lindernia dubia, Lobelia canbyi, Lobelia elongata, Lobelia nuttallii, Ludwigia palustris, Ludwigia sphaerocarpa, Lycopus amplectens, Lycopus uniflorus, Lycopus virginicus, Lyonia ligustrina, Lyonia mariana, Lysimachia terrestris, Magnolia virginiana, Micranthemum 
umbrosum, Microstegium vimineum, Mikania scandens, Muhlenbergia uniflora, Murdannia keisak, Nuphar variegata, Nymphaea odorata, Nymphoides aquatica, Nyssa sylvatica, Oclemena nemoralis, Orontium aquaticum, Osmunda regalis, Osmundastrum cinnamomeum, Oxypolis rigidior, Panicum hemitomon, Panicum verrucosum, Panicum virgatum, Peltandra virginica, Persicaria hydropiperoides, Pinus rigida, Pogonia ophioglossoides, Polygala cruciata, Polygala ramosa, Pontederia cordata, Potamogeton confervoides, Potamogeton oakesianus, Rhexia mariana, Rhexia nashii, Rhexia virginica, Rhododendron viscosum, Rhynchospora alba, Rhynchospora capitellata, Rhynchospora chalarocephala, Rhynchospora fusca, Rhynchospora microcephala, Rubus hispidus, Sabatia difformis, Sagittaria latifolia, Sagittaria macrocarpa, Sarracenia purpurea, Sassafras albidum, Schizachyrium scoparium, Schoenoplectus subterminalis, Scirpus cyperinus, Smilax glauca, Smilax herbacea, Smilax laurifolia, Smilax rotundifolia, Smilax walteri, Sparganium americanum, Sphagnum, Spiraea tomentosa, Spiranthes cernua, Symphyotrichum dumosum, Symphyotrichum novi-belgii, Taxodium, Toxicodendron radicans, Triadenum virginicum, Triadenum walteri, Utricularia cornuta, Utricularia gibba, Utricularia juncea, Utricularia striata, Vaccinium corymbosum, Vaccinium macrocarpon, Viburnum nudum, Viola lanceolata, Woodwardia areolata, Woodwardia virginica, Xyris difformis, Xyris fimbriata, Zizania aquatica.

2.1.6.9. Sagittaria fasciculata E.O. Beal is a short-lived perennial (usually $<2$ years), which grows in shallow $(<5 \mathrm{~cm}$ deep), freshwater alluvial floodplains, seeps, or streams, at elevations to $1000 \mathrm{~m}$. The plants require cool, clean waters with continuous flow, moderate levels of dissolved oxygen (3-7 $\mathrm{mg} \mathrm{l}^{-1}$ ), and low conductivities $(20-50 \mu \mathrm{S})$. They are intolerant of droughts, floods, and other hydrological fluctuations. The exposures become well shaded by late summer. The substrates are acidic (e.g., pH: 4.8-6.8) and have been described as hydrated muck-sand suspension, sandbars, or sandy mucks with a high organic matter content (6.5-10\%) and high $\mathrm{Mg}$ content $\left(108.6 \mu \mathrm{g} \mathrm{g}^{-1}\right)$. Ecological details for this rare species are difficult to compile, due in part to the redaction of information from electronic database records. Flowering occurs from May to July, with fruiting extending into August. The reproductive ecology of this species has not been elucidated. Genetic analyses using ISSR markers have indicated some genetic differentiation among watersheds but little differentiation within watersheds. The plants reproduce vegetatively by stolons (also referred to as rhizomes), which are produced in greater prevalence when flow rates or shading conditions are altered. The plants are of conservation concern, with their status interpreted as "declining." Their threats include alterations of hydrological conditions, shading by competitive vegetation, and trampling. Reported associates: Carex, Decumaria barbara, Glyceria striata, Gratiola virginiana, Murdannia keisak.

2.1.6.10. Sagittaria filiformis J.G. Sm. is a perennial, which inhabits still or flowing, shallow (0.01-1.8 m deep), tidal or non-tidal waters in canals (drainage), depressions, ditches, lakes, marshes, pits (borrow; phosphate), ponds (artificial; karst; seasonal), pools, sloughs, streams (blackwater), swamps, and the shores of lakes at elevations to $100 \mathrm{~m}$. The shoots are heterophyllous, developing linear submersed leaves and ovate floating leaves. Exposures range from open to shaded conditions. The plants supposedly inhabit more lotic sites in the north of their distribution and more lentic waters in the southern portion of their range. The waters are somewhat alkaline (e.g., pH: 7.1; alkalinity: $35.0 \mathrm{mg} \mathrm{l}^{-1}$ ). The sediments have been described as muck, mud, and sand. Flowering and fruiting occur from January to October. Some of the lower scape verticels are proliferous, capable of producing roots, phyllodial leaves, and flowering pedicels from the bract axils. The pollination biology is unknown. The seed germination requirements also have not been determined; however, a persistent seed bank does develop. Vegetative reproduction occurs by the expansion of stolons (also referred to as rhizomes). Reported associates: Acer rubrum, Alternanthera philoxeroides, Ampelopsis arborea, Azolla filiculoides, Bacopa caroliniana, Bidens discoideus, Boltonia diffusa, Brasenia schreberi, Carya cordiformis, Cephalanthus occidentalis, Ceratophyllum muricatum, Clethra alnifolia, Crotalaria spectabilis, Cynodon dactylon, Cyperus erythrorhizos, Echinodorus, Eclipta prostrata, Eleocharis baldwinii, Eubotrys racemosa, Eupatorium capillifolium, Fimbristylis autumnalis, Fraxinus, Hibiscus moscheutos, Hydrilla verticillata, Hydrocotyle ranunculoides, Hydrocotyle verticillata, Ilex myrtifolia, Juncus diffusissimus, Juncus effusus, Landoltia punctata, Leersia hexandra, Lemna valdiviana, Limnobium spongia, Lindernia dubia, Liquidambar styraciflua, Ludwigia, Lycopus, Lyonia lucida, Myrica cerifera, Myriophyllum aquaticum, Myriophyllum pinnatum, Nelumbo lutea, Nitella translucens, Nymphaea odorata, Nymphoides cordata, Nyssa biflora, Nyssa sylvatica, Panicum dichotomiflorum, Panicum hemitomon, Paspalum urvillei, Peltandra virginica, Persea palustris, Persicaria hydropiperoides, Persicaria punctata, Pinus taeda, Pistia stratiotes, Pontederia cordata, Proserpinaca palustris, Quercus phellos, Rhynchospora glomerata, Rhynchospora macrostachya, Rhynchospora microcephala, Rotala ramosior, Rumex verticillatus, Saccharum, Sagittaria graminea, Sagittaria latifolia, Saururus cernuus, Scirpus cyperinus, Smilax rotundifolia, Spirodela, Taxodium distichum, Thalia, Typha domingensis, Typha latifolia, Utricularia gibba, Utricularia purpurea.

2.1.6.11. Sagittaria graminea Michx. is a perennial, which grows in shallow to moderately deep waters $(30-180 \mathrm{~cm}$; average: $60 \mathrm{~cm}$ depth) in bogs, borrow pits, Carolina bays, cypress domes, depressions, ditches (drainage), flats, flatwoods, floodplains, gravel pits, hammocks, lakebeds, marshes, meadows, mudflats, pinelands, pocosins, pools (savannah), ponds (railroad; roadside; sand; sinkhole; stock), prairies, rice fields, roadsides, seeps, sloughs (dried), swales, swamps (blackwater; dried; river), and along the margins or shores of canals, lakes, ponds, rivers, and streams at elevations to $789 \mathrm{~m}$. The waters are broadly circumneutral $(\mathrm{pH}$ : 5.7-8.4; $\bar{x}=7.0)$ with low conductivity $\left(<200 \mu \mathrm{mhos} \mathrm{cm}^{-1}\right)$ and low total alkalinity $\left(<112 \mathrm{mg} \mathrm{l}^{-1} \mathrm{CaCO}_{3} ; \bar{x}=18.7 \mathrm{mg} \mathrm{l}^{-1}\right)$. 
The substrates are more acidic (pH: 4.4-7.7). Exposures can range from open (full sunlight) to deep shade. The substrates have been characterized as clay, clay loam, gravelly alluvium, loam, loamy sand (Ocilla), muck, mucky loam, mud (over dolomite), peat, peaty mud, Placid (typic humaquepts), psammaquents (Basinger; St. Johns), sand (organic), sandy clay loam, sandy muck, sandy peat, silt, silty loam, silty muck, and silty sandy loam. The leaf morphology varies substantially from phyllodial to broad-bladed; however, experimental transplant studies indicate only minor plasticity due to water level variation, and that plants having different leaf types are genetically distinct and adapted differentially to the specific habitats in which they are found. Flowering and fruiting occur from March to December. Submersed plants remain sterile (unless under very high irradiance and shallow conditions), with flowering generally requiring the emergence of nonphyllodial leaves from the water. Flowering (usually initiating from 5:00 to 6:00 am) can occur under daily photoperiods ranging from 7 to $15 \mathrm{hr}$ of light. The plants are monoecious. A greater proportion of male flowers is produced under high phosphorus and low nitrogen conditions; under opposite conditions (low phosphorus, high nitrogen), more female flowers, and subsequently more seeds, are produced. All flowers (and seeds) increase in number when both nutrients are elevated. Individuals are self-compatible (but protogynous within an inflorescence) and require insects (Insecta) in order to achieve successful pollination and fruit set. Female and male floral phases overlap less in smaller populations than in larger populations. Once deposited, pollen must remain undisturbed for a period of $3 \mathrm{hr}$ in order to achieve fertilization. Seed set is highly reduced (by nearly 90\%) in plants subjected to tidal activity, which is attributed to inviability or washing away of the pollen when exposed to water. Higher fruit set occurs in populations with male-biased floral sex ratios. The fruits ripen and disperse within 50 days. Seeds have germinated following 5 days of cold stratification, when subjected to a $30^{\circ} \mathrm{C} / 15^{\circ} \mathrm{C}$ day/night temperature regime. Isozyme analyses (13 loci) of the typical subspecies indicated that a single multilocus genotype characterized $97 \%$ of the accessions surveyed, which indicates extremely low levels of genetic variation in the species (see Systematics). Vegetative reproduction is well developed. High phosphorous levels yield larger corms, whereas high nitrogen levels yield smaller corms but more numerous and longer stolons (also characterized as coarse rhizomes), which produce tubers. In late fall, tuber biomass of mudflat plants $\left(124 \mathrm{~g} \mathrm{~m}^{-2}\right)$ can greatly exceed that of pond dwelling plants $\left(44 \mathrm{~g} \mathrm{~m}^{-2}\right)$. Dispersal occurs by means of the achenes or tubers, which typically are transported by water, especially during flood conditions. Reported associates: Acer rubrum, Acer saccharinum, Aletris lutea, Alisma subcordatum, Alternanthera philoxeroides, Amaranthus, Amsonia rigida, Andropogon, Asclepias incarnata, Asclepias perennis, Azolla cristata, Bacopa rotundifolia, Bidens cernuus, Bidens frondosus, Boehmeria cylindrica, Bolboschoenus fluviatilis, Brasenia schreberi, Calamagrostis canadensis, Callitriche heterophylla, Carex gigantea, Carex haydenii, Carex scoparia, Carex striata, Carex tribuloides,
Carex vesicaria, Carex vulpinoidea, Centella asiatica, Cephalanthus occidentalis, Ceratophyllum demersum, Chara, Cladium jamaicense, Commelina, Cuscuta gronovii, Cyperus haspan, Cyperus squarrosus, Cyrilla racemiflora, Didiplis diandra, Digitaria serotina, Diodella teres, Diospyros virginiana, Drosera capillaris, Dulichium arundinaceum, Elatine minima, Eleocharis acicularis, Eleocharis baldwinii, Eleocharis equisetoides, Eleocharis microcarpa, Eleocharis palustris, Eleocharis quadrangulata, Elodea canadensis, Equisetum fluviatile, Eriocaulon compressum, Eupatorium perfoliatum, Eupatorium serotinum, Fimbristylis autumnalis, Fraxinus caroliniana, Fraxinus profunda, Fuirena, Glossostigma cleistanthum, Glyceria septentrionalis, Glyceria striata, Gratiola aurea, Gratiola brevifolia, Gratiola virginiana, Helanthium tenellum, Helenium flexиosum, Helenium pinnatifidum, Heteranthera limosa, Heteranthera reniformis, Heteranthera rotundifolia, Hordeum jubatum, Hydrocotyle, Hymenocallis crassifolia, Hypericum fasciculatum, Hypericum mutilum, Ilex, Iris virginica, Isoetes lacustris, Juncus acuminatus, Juncus effusus, Juncus megacephalus, Juncus repens, Lachnanthes caroliniana, Larix laricina, Lemna minor, Lindernia grandiflora, Lindernia monticola, Liquidambar styraciflua, Ludwigia lanceolata, Ludwigia polycarpa, Lycopodiella appressa, Lysimachia nummularia, Magnolia grandiflora, Marsilea vestita, Mayaca fluviatilis, Myrica cerifera, Myriophyllum pinnatum, Myriophyllum spicatum, Myriophyllum tenellum, Najas flexilis, Najas guadalupensis, Nitella, Nuphar microphylla, Nuphar polysepala, Nuphar variegata, Nymphaea odorata, Nyssa aquatica, Nyssa biflora, Nyssa ogeche, Osmunda regalis, Panicum hemitomon, Paspalum praecox, Persea borbonia, Persicaria amphibia, Persicaria bicornis, Persicaria coccinea, Persicaria hirsuta, Persicaria hydropiperoides, Persicaria lapathifolia, Persicaria pensylvanica, Persicaria punctata, Phalaris arundinacea, Phyla lanceolata, Picea mariana, Pinus echinata, Pinus elliottii, Pinus palustris, Pinus taeda, Pluchea baccharis, Pluchea foetida, Polygala lutea, Polypremum procumbens, Pontederia cordata, Potamogeton amplifolius, Potamogeton foliosus, Potamogeton gramineus, Potamogeton nodosus, Potamogeton pusillus, Potamogeton richardsonii, Potamogeton robbinsii, Potamogeton zosteriformis, Proserpinaca pectinata, Quercus laurifolia, Quercus nigra, Quercus virginiana, Ranunculus flabellaris, Ranunculus laxicaulis, Ranunculus longirostris, Rhexia aristosa, Rhexia nashii, Rhynchospora chalarocephala, Rhynchospora inundata, Rhynchospora macra, Rhynchospora macrostachya, Rhynchospora tracyi, Rorippa aquatica, Rorippa palustris, Rubus, Rumex altissimus, Rumex crispus, Rumex stenophyllus, Sabal minor, Sabal palmetto, Sabatia, Sagittaria brevirostra, Sagittaria calycina, Sagittaria filiformis, Sagittaria lancifolia, Sagittaria latifolia, Sagittaria papillosa, Sagittaria rigida, Sagittaria subulata, Sagittaria teres, Salix amygdaloides, Salix nigra, Samolus valerandi, Saururus cernuus, Schoenoplectus acutus, Schoenoplectus heterochaetus, Schoenoplectus pungens, Schoenoplectus tabernaemontani, Scirpus cyperinus, Scirpus pendulus, Scutellaria lateriflora, Serenoa reprens, Sium 
suave, Smilax, Solanum carolinense, Solidago gigantea, Sparganium eurycarpum, Spartina cynosuroides, Sphagnum, Spirodela polyrhiza, Symphyotrichum novae-angliae, Taxodium distichum, Thalia geniculata, Tridens ambiguus, Tridens strictus, Typha angustifolia, Typha domingensis, Typha latifolia, Ulmus americana, Utricularia gibba, Utricularia macrorhiza, Vaccinium elliottii, Vallisneria americana, Verbena hastata, Viola, Wisteria frutescens, Wolffia brasiliensis, Woodwardia virginica, Xanthium strumarium, Xyris difformis.

2.1.6.12. Sagittaria guayanensis Kunth is a nonindigenous annual, which grows in ditches, pools (ephemeral), rice fields, and streams at elevations to $100 \mathrm{~m}$. The plants typically produce broad floating leaves, which superficially resemble lily pads; only the inflorescence extends above the water surface. The substrates are described as mud. Flowering occurs from summer to fall. Unlike most of their congeners, these plants are andromonoecious, with individuals bearing staminate and perfect flowers. Here, the condition is believed to have been derived secondarily from a monoecious ancestry in order to facilitate self-pollination. The flowers are preanthesis cleistogamous. Consequently, they typically attract few pollinator visits, rarely outcross, and primarily are self-pollinating. In its native range, the seeds are well represented in the seed bank (up to 37 seeds $\mathrm{m}^{-2}$ ) and germinate well under ambient greenhouse temperatures. The plants have no well-developed means of asexual reproduction. Reported associates (North America): Chara, Bacopa repens, Ammannia auriculata, Dopatrium junceum, Eriocaulon cinereum, Heteranthera limosa, Rotala ramosior, Sphenoclea zeylanica.

2.1.6.13. Sagittaria isoetiformis J.G. Sm. is a perennial, which grows in shallow waters $(2-70 \mathrm{~cm}$; typically $20-40$ $\mathrm{cm}$ ) in bottoms (pond), clay pits, depressions, ditches, ponds (karst; sinkhole), pools, and along the shores of lakes, limesinks, ponds (drying), and rivers at elevations to $73 \mathrm{~m}$. Exposures tend to receive full sunlight. The substrates are acidic (e.g., pH: 5.4) and are described as Basinger (spodic psammaquents), loamy fine sand (Albany), loamy sand, muck, mucky sand, peat, peaty sand, sand, sandy muck, sandy peat, and Troup (grossarenic paleudults). They contain relatively low levels of $\mathrm{Ca}, \mathrm{K}$, and $\mathrm{Mg}$. Flowering and fruiting have been observed from June to October. These monoecious plants are highly sexual, with most female flowers producing numerous (up to 200) achenes. Although individuals are self-compatible, they primarily are outcrossed (the male and female flowers rarely open simultaneously) by insects (Insecta). Populations maintain relatively high levels of genetic variation (94\% polymorphic loci; $\left.H_{\mathrm{ES}}=0.399\right)$; however, they are fairly differentiated $\left(G_{\mathrm{ST}}=0.399\right)$. Although possible, geitonogamous pollen transfer probably occurs rarely, being limited by the temporally exclusive sex expression and by the close proximity of different phase genets, which simultaneously offer flowers of both sexes to potential pollinators. Though capable of clonal growth, the populations are not structured genetically as being highly clonal, but exhibit patterns of diverse genetic variation, which has been attributed to the recruitment of sexual propagules from the seed bank. The seeds can germinate in wet soil or in several centimeters of water. Seed dispersal (primarily by water) likely occurs over small distances due to the lack of any obvious adaptations for long-distance dispersal. Vegetative reproduction occurs by stolons (also referred to as rhizomes), which produce small corms (yielding as many as 20 ramets annually). The corms persist for only a few weeks. Stolon connections do not persist between ramets. The plants differ from most of their congeners by their ability to implement a CAM photosynthetic pathway. Reported associates: Andropogon glomeratus, Andropogon gyrans, Brasenia schreberi, Cabomba, Carex striata, Centella asiatica, Cephalanthus occidentalis, Coleataenia tenera, Cyperus, Dichanthelium acuminatum, Drosera, Echinodorus, Eleocharis melanocarpa, Eleocharis obtusa, Eleocharis robbinsii, Eriocaulon compressum, Eubotrys racemosa, Eupatorium leptophyllum, Eupatorium leucolepis, Eupatorium mohrii, Fimbristylis perpusilla, Fuirena, Gratiola ramosa, Helanthium tenellum, Hydrocotyle umbellata, Hypericum denticulatum, Juncus repens, Lachnanthes caroliniana, Lachnocaulon anceps, Lechea, Leersia hexandra, Lobelia boykinii, Ludwigia linearis, Ludwigia spathulata, Lysimachia loomisii, Nymphaea odorata, Nymphoides cordata, Nyssa biflora, Panicum hemitomon, Panicum verrucosum, Panicum virgatum, Polygala cymosa, Pontederia, Proserpinaca palustris, Rhynchospora perplexa, Rhynchospora pusilla, Riccia, Scleria reticularis, Sclerolepis uniflora, Serenoa repens, Smilax walteri, Spartina, Syngonanthus flavidulus, Taxodium distichum, Typha, Utricularia cornuta, Utricularia gibba, Utricularia resupinata, Verbena, Viola lanceolata, Xyris.

2.1.6.14. Sagittaria kurziana Glück is a perennial, which grows in tidal or non-tidal canals, ditches (flowing), rivers (spring-fed), springs, and streams at elevations below $100 \mathrm{~m}$. It inhabits cool, clear waters that are fresh to brackish (specific conductance: $36-878 \mu \mathrm{S} \mathrm{cm}^{-1}$; chloride: 4-236 $\mathrm{mg} \mathrm{l}^{-1}$ ), clear, fast flowing (e.g., $300 \mathrm{~cm} \mathrm{~s}^{-1}$ ), and moderately deep (to $1.8 \mathrm{~m})$. They are circumneutral ( $\mathrm{pH}: 4.4-8.7 ; \bar{x}: 6.9)$; and usually hard ( $\bar{x}$ total $\mathrm{CaCO}_{3}$ alkalinity: $\left.36.2 \mathrm{mg} \mathrm{l}^{-1}\right)$ with a high total nitrogen $\left(\bar{x}: 860 \mu \mathrm{g} \mathrm{l}^{-1}\right)$ and sulfur content $(\bar{x}$ sulfate: $\left.21.8 \mathrm{mg}^{-1}\right)$. The substrates are alkaline ( $\left.\bar{x}: \mathrm{pH}: 8.3\right)$, low in organic matter, and high in $\mathrm{Ca}\left(\bar{x}: 1830 \mu \mathrm{g} \mathrm{g} \mathrm{g}^{-1}\right)$ and are described as limestone-shell sand or sandy. Unlike most of its congeners, this is an entirely submersed species, which is restricted to lotic riverine habitats, where it can grow densely to become the dominant component (by biomass). Transplant studies have failed to induce floating or emergent leaves on the plants. Flowering occurs from March to May. The flowers emerge from the otherwise inundated inflorescence during anthesis but sometimes open while underwater. The plants are monoecious, with the lower inflorescence whorl bearing three female flowers (occasionally two females and one male), and the next whorl is entirely male (rarely with one male and two female flowers or two male and one female flower); the remaining flowers are male. Further studies are needed on the pollination biology and seed ecology of this species. The plants reproduce vegetatively by the production of coarse rhizomes. Reported associates: Cabomba caroliniana, Ceratophyllum demersum, Chara, Cladophora, 
Cryptocoryne beckettii, Egeria densa, Eichhornia crassipes, Hydrilla verticillata, Hymenocallis rotata, Lemna, Lobelia cardinalis, Myriophyllum aquaticum, Myriophyllum heterophyllum, Myriophyllum laxum, Myriophyllum spicatum, Najas guadalupensis, Nuphar, Pistia stratiotes, Pontederia cordata, Potamogeton, Vallisneria americana, Zizania aquatica.

2.1.6.15. Sagittaria lancifolia $\mathbf{L}$. is a perennial, which grows in shallow (to $1.2 \mathrm{~m}$ ), sluggish to still, tidal or non-tidal, brackish (oligohaline) to freshwaters on beaches or in baygalls, bogs, borrow pits, canals (drainage), depressions, ditches, dunes, flats, flatwoods, floodplains, lakebeds (dry), marshes (depression; floating; freshwater; salt), meadows, ponds (spring-fed), pools, rice fields, roadsides, savannahs, scrub, sinkholes, slopes (to 5\%), sloughs, swales, swamps (dome; strand), and along the margins of bayous, lagoons, lakes, ponds, rivers, and streams (estuarine) at elevations to $31 \mathrm{~m}$. The plants consistently occur in open exposures, where they receive full sunlight, and less often in partial shade. They can tolerate some brackish conditions but are killed at salinity levels of $15 \%$ (especially if grazed by herbivores). The leaves elongate proportionally with increased water depth. The waters are circumneutral (pH: 5.3-8.7; $\bar{x}: 7.2)$, alkaline ( $\bar{x}$ total alkalinity: $32.9 \mathrm{mg} \mathrm{l}^{-1} ; \bar{x}$ Ca: $23.9 \mathrm{mg} \mathrm{l}^{-1} ; \bar{x}$ chloride: $\left.30.8 \mathrm{mg} \mathrm{l}^{-1}\right)$, and high in nitrogen $\left(\bar{x}\right.$ total $\left.\mathrm{N}: 1020 \mu \mathrm{g} \mathrm{l^{-1 }}\right)$. The substrates often are brackish, but somewhat acidic $(\bar{x}=\mathrm{pH}$ : 6.1), and have been characterized as clay (Schriever), clayey alluvium, dredge spoil, gravel, Lafitte-Clovelly association, loamy sand, marl, muck (Allemands; Kenner), Newhan-Corolla, peat, peaty muck, rock, sand (Duckston; Leon; Waveland), sandy loam (fine; Harleston), silt, silty clay loam (Cancienne), and silty loam. Although described as monoecious, the plants actually are subandrodioecious (mixtures of male and cosexual plants). The flowers are pollinated by insects (Insecta). Flowering and fruiting have been observed throughout the year (from January to December). The achenes float and are dispersed by water; however, the presence of resinous glands confers adhesiveness, which is believed to facilitate their attachment to animal vectors for epizoochorous dispersal. A seed bank (having up to 167 seeds $\mathrm{m}^{-2}$ ) develops; however, many of the seeds are not intact and are inviable. The achenes require light for germination, which occurs readily $(100 \%)$ at $25^{\circ} \mathrm{C}$. Warm stratification can promote germination. Germination rates are highest under inundated conditions and are reduced under anaerobic conditions; higher rates $(67 \%)$ occur in saturated sites than in flooded sites (33\%). Seed germination is inhibited completely at salinities of $2 \%$ or higher. Seedling densities of $20 \mathrm{~m}^{-2}$ have been observed at several sites. The adult plants contain a milky latex sap and reproduce vegetatively by means of a thick rhizome. Genetic analyses (using allozymes) indicate that populations are characterized by only low levels of clonality. The leaves and inflorescences are larger on plants growing under high phosphorous conditions, but more biomass is allocated to roots and rhizomes under low phosphorous conditions. The plants can attain mean plot biomass values of $254 \mathrm{~g} \mathrm{DM} \mathrm{m}^{-2}$. The roots are colonized by arbuscular mycorrhizae and dark septate endophytic Fungi. Reported associates: Acer rubrum, Acmella repens, Aeschynomene, Alternanthera philoxeroides, Ambrosia artemisiifolia, Ambrosia trifida, Ammannia latifolia, Ampelaster carolinianus, Ampelopsis arborea, Amphicarpum, Aristida palustris, Asclepias perennis, Asclepias rubra, Baccharis halimifolia, Bacopa monnieri, Berchemia scandens, Boehmeria cylindrica, Bolboschoenus robustus, Calopogon tuberosus, Celtis laevigata, Cephalanthus occidentalis, Cicuta maculata, Cirsium horridulum, Cirsium nuttallii, Cladium jamaicense, Cyperus articulatus, Cyperus odoratus, Cyperus strigosus, Cyperus virens, Decodon verticillatus, Desmanthus illinoensis, Diospyros virginiana, Echinochloa walteri, Eichhornia crassipes, Eleocharis cellulosa, Eleocharis fallax, Eleocharis montevidensis, Elephantopus carolinianus, Eragrostis elliottii, Eryngium aquaticum, Eupatorium, Fimbristylis spadicea, Fraxinus, Fuirena scirpoidea, Galium tinctorium, Gonolobus, Hibiscus laevis, Hydrocotyle verticillata, Hydrolea corymbosa, Hymenocallis rotata, Hypericum cistifolium, Hypericum fasciculatum, Ilex cassine, Ilex glabra, Ilex opaca, Ilex vomitoria, Ipomoea sagittata, Iris hexagona, Itea virginica, Iva annua, Juncus acuminatus, Juncus effusus, Juncus roemerianus, Juniperus virginiana, Lachnanthes caroliniana, Leersia hexandra, Leersia oryzoides, Leptochloa fusca, Liquidambar styraciflua, Ludwigia glandulosa, Ludwigia octovalvis, Ludwigia peploides, Ludwigia peruviana, Lythrum alatum, Lythrum lineare, Mikania scandens, Morus rubra, Myrica cerifera, Myriophyllum aquaticum, Nymphaea odorata, Nymphoides aquatica, Nyssa aquatica, Orontium aquaticum, Osmunda regalis, Packera glabella, Panicum amarum, Panicum dichotomiflorum, Panicum hemitomon, Panicum repens, Panicum virgatum, Parthenocissus, Paspalum distichum, Paspalum urvillei, Peltandra virginica, Persea, Persicaria glabra, Persicaria hydropiperoides, Persicaria punctata, Phragmites australis, Phyla lanceolata, Phyla nodiflora, Physostegia leptophylla, Pinus elliottii, Platanthera nivea, Polygala rugelii, Pontederia cordata, Ptilimnium capillaceum, Quercus, Ranunculus sardous, Rhapidophyllum hystrix, Rhynchospora caduca, Rhynchospora elliottii, Rhynchospora fascicularis, Rhynchospora inundata, Rubus argutus, Rumex conglomeratus, Rumex crispus, Rumex obovatus, Sabal minor, Sabal palmetto, Sabatia calycina, Sacciolepis striata, Sagittaria graminea, Sagittaria latifolia, Sagittaria platyphylla, Salix caroliniana, Salix nigra, Sambucus, Samolus valerandi, Saururus cernuus, Schoenoplectus californicus, Schoenoplectus tabernaemontani, Scleria lacustris, Serenoa, Smilax smallii, Spartina alterniflora, Spartina bakeri, Spartina cynosuroides, Spartina patens, Sphagnum, Symphyotrichum elliotii, Symphyotrichum novi-belgii, Symphyotrichum subulatum, Taxodium distichum, Thelypteris palustris, Tillandsia, Toxicodendron radicans, Triadica sebifera, Typha domingensis, Typha latifolia, Utricularia purpurea, Vigna luteola, Vitis, Woodwardia areolata, Xyris difformis, Zizania aquatica, Zizaniopsis miliacea.

2.1.6.16. Sagittaria latifolia Willd. is a perennial, which inhabits shallow (average depth of $10 \mathrm{~cm}$, but up to $1.2 \mathrm{~m}$ ), intertidal, non-tidal, or tidal freshwaters of backwaters, 
baygalls, beaches, bogs (quaking; sandy), bottomlands, canals (drainage), channels, depressions, dikes, ditches (roadside; verbal), fens (calcareous; poor; prairie; rich), flats (sand), floodplains, gravel pits, lagoons (dessicated), lakes (playa), marshes, meadows, mud flats, oxbows, pans (dune), ponds (sand), pools (ephermeral; roadside), prairies, rice fields, roadsides, seeps, shores, silt bars, slopes (to 1\%), sloughs, springs, streams (intermittent), swales, swamps, vernal pools, woodlands, and the margins of lagoons, lakes, ponds, potholes, reservoirs, rivers, sloughs, and streams at elevations to $2625 \mathrm{~m}$. The waters span a broad range of conditions ( $\mathrm{pH}: 4.7-9.2 ; \bar{x}$ : 6.9-7.3; conductivity: $20-510 \mu \mathrm{mhos} \mathrm{cm}^{-1}$; total alkalinity: $1.5-290 \mathrm{mg} \mathrm{l}^{-1} \mathrm{CaCO}_{3} ; \bar{x}=26.4 \mathrm{mg} \mathrm{l}^{-1}$; total $\mathrm{N}$ : 380-2470 $\mu \mathrm{gl}^{-1}$ ). Exposures range from open sites in full sunlight to areas of partial shade. The substrates include alluvium, clay (heavy), clayey sand, granite, gravel, loam, muck, mucky sand, mud (organic; soft), peaty muck, peaty mud, rocky serpentine, sand, sandy mud, sandy silty alluvium, silt (river bottom), silty clay, silty gravel, and silty sand. Flowering occurs from May to November, with fruiting observed from June to October. The flowers are pollinated by generalist insects (Insecta), including bees and wasps (Hymenoptera) or flies (Diptera). Individuals can be monoecious or dioecious. Sex expression is controlled by two Mendelian loci (male and female sterility), where dioecious males are heterozygous at both loci, and monoecious individuals are homozygous for alleles dominant to male sterility in females and recessive to female sterility in males. Allozyme data indicate that individuals of each type remain genetically distinct and that both suffer substantially from inbreeding depression. Dioecious populations contain only a subset of the haplotype diversity found in monoecious populations, indicating the derivation of the former from the latter. Reproduction primarily is sexual in monoecious populations but vegetative in dioecious populations. Selfing rates are higher in monoecious populations. In dioecious individuals, the males have larger flowers but smaller floral displays than the female flowers, which remain open for a shorter time period than the males. The larger male flowers experience higher pollinator visitation rates, but larger male floral displays result in lower pollination success. Sexual expression is highly plastic in monoecious populations with higher numbers of female flowers produced at higher nutrient levels. In monoecious individuals, the female flowers increase proportionally with plant size, while the males do not. The flat seeds are dispersed by water. A persistent seed bank develops. Germination requires light and flooded conditions. Seeds from monoecious plants germinate freely, whereas those of dioecious plants require a period of stratification. The seeds can be recalcitrant but have been stored successfully in water at $3^{\circ} \mathrm{C}$. They have germinated following 150 days of cold stratification under a $21^{\circ} \mathrm{C} / 16^{\circ} \mathrm{C}$ day/night temperature regime. Vastly higher germination rates have been obtained for seeds whose seed coats are first "nipped" using scissors. Densities of up to 20 seedlings $\mathrm{m}^{-2}$ have been observed at field sites. Vegetative propagation occurs by the formation of rhizomes, which produce large tubers. The rhizomes normally extend from 4 to $6 \mathrm{~cm}$ below the surface, but can occur as deep as
$10 \mathrm{~cm}$. An essentially 1:1 trade-off exists between sexual reproduction (primarily the production of female flowers) and the extent of vegetative reproduction. The roots can harbor large colonies of methanotrophic bacteria. The plants can tolerate short-term intrusions of salinity but suffer from decreased seed germination, and seedling emergence, survival, and growth rates when exposed to saline conditions. Reported associates: Abutilon theophrasti, Acalypha, Acer negundo, Acer rubrum, Acer saccharinum, Acmella, Agalinis, Agrostis gigantea, Agrostis stolonifera, Alisma subcordatum, Alisma triviale, Alnus serrulata, Alternanthera philoxeroides, Amaranthus tuberculatus, Ambrosia artemisiifolia, Ammannia coccinea, Ammannia robusta, Amorpha fruticosa, Andropogon glomeratus, Anemone canadensis, Angelica atropurpurea, Apios americana, Apocynum cannabinum, Aristida purpurascens, Asclepias incarnata, Asclepias syriaca, Azolla, Baccharis halimifolia, Baccharis salicifolia, Betula, Bidens aristosus, Bidens beckii, Bidens cernuus, Bidens frondosus, Bidens laevis, Bistorta bistortoides, Boehmeria cylindrica, Bolboschoenus fluviatilis, Boltonia asteroides, Brasenia schreberi, Butomus umbellatus, Calamagrostis canadensis, Calla palustris, Caltha palustris, Campanula aparinoides, Carex bebbii, Carex comosa, Carex cristatella, Carex exilis, Carex haydenii, Carex hystericina, Carex lasiocarpa, Carex limosa, Carex livida, Carex lupuliformis, Carex lurida, Carex molesta, Carex muskingumensis, Carex pellita, Carex praegracilis, Carex rostrata, Carex stipata, Carex stricta, Carex utriculata, Carex vesicaria, Carex vulpinoidea, Cephalanthus occidentalis, Ceratophyllum demersum, Chamaedaphne calyculata, Chara, Chelone glabra, Cicuta bulbifera, Comarum palustre, Conium maculatum, Conoclinium, Coreopsis gladiata, Cornus amomum, Cornus sericea, Crataegus douglasii, Cyperus erythrorhizos, Cyperus esculentus, Cyperus odoratus, Cyperus squarrosus, Cyperus strigosus, Decodon verticillatus, Distichlis spicata, Doellingeria umbellata, Drosera anglica, Dryopteris, Dulichium arundinaceum, Echinochloa crus-galli, Echinochloa walteri, Eclipta prostrata, Egeria densa, Elaeagnus angustifolia, Eleocharis acicularis, Eleocharis bella, Eleocharis erythropoda, Eleocharis obtusa, Eleocharis ovata, Eleocharis palustris, Eleocharis parishii, Eleocharis quadrangulata, Eleocharis robbinsii, Elodea canadensis, Elymus canadensis, Equisetum arvense, Equisetum fluviatile, Eragrostis hypnoides, Eriocaulon aquaticum, Eupatorium perfoliatum, Eutrochium maculatum, Fallopia scandens, Festuca, Fimbristylis vahlii, Forestiera acuminata, Fraxinus nigra, Fraxinus pennsylvanica, Galium obtusum, Galium trifidum, Galium triflorum, Gentiana andrewsii, Glyceria borealis, Glyceria grandis, Glyceria striata, Gnaphalium palustre, Hedeoma hispida, Helenium autumnale, Helianthus tuberosus, Heliopsis helianthoides, Hippuris vulgaris, Hordeum jubatum, Humulus lupulus, Hydrocotyle verticillata, Hypericum canadense, Hypericum sphaerocarpum, Ilex cassine, Impatiens capensis, Iris pseudacorus, Iris virginica, Isoetes lacustris, Juncus acuminatus, Juncus effusus, Juncus nodosus, Laportea canadensis, Lathyrus palustris, Leersia oryzoides, Lemna minor, Lemna trisulca, Lepidium 
latifolium, Leptochloa panicea, Lilaeopsis, Lilium michiganense, Lindernia dubia, Lipocarpha micrantha, Ludwigia palustris, Ludwigia peploides, Ludwigia polycarpa, Lycopus americanus, Lycopus rubellus, Lycopus uniflorus, Lycopus virginicus, Lysimachia ciliata, Lysimachia nummularia, Lysimachia vulgaris, Lythrum salicaria, Mazus pumilus, Melilotus albus, Mentha arvensis, Menyanthes trifoliata, Mimulus ringens, Murdannia, Myriophyllum sibiricum, Navarretia, Nuphar polysepala, Nuphar variegata, Nymphaea odorata, Nyssa biflora, Oenothera biennis, Panicum dichotomiflorum, Panicum hemitomon, Panicum virgatum, Paspalum dilatatum, Peltandra virginica, Penthorum sedoides, Persicaria amphibia, Persicaria arifolia, Persicaria coccinea, Persicaria hydropiperoides, Persicaria lapathifolia, Persicaria pensylvanica, Persicaria punctata, Persicaria sagittata, Phalaris arundinacea, Phanopyrum gymnocarpon, Phragmites australis, Phyla lanceolata, Physostegia virginiana, Poa nemoralis, Poa pratensis, Polytrichum, Pontederia cordata, Populus angustifolia, Potamogeton amplifolius, Potamogeton berchtoldii, Potamogeton crispus, Potamogeton foliosus, Potamogeton gramineus, Potamogeton illinoensis, Potamogeton natans, Potamogeton natans, Potamogeton pusillus, Potamogeton richardsonii, Potamogeton zosteriformis, Potentilla norvegica, Proserpinaca palustris, Prunus virginiana, Puccinellia, Pycnanthemum virginianum, Ranunculus aquatilis, Ranunculus flammula, Ranunculus pensylvanicus, Ranunculus recurvatus, Rhexia mariana, Rhododendron canescens, Rhus glabra, Rhynchospora inundata, Ribes americanum, Rorippa islandica, Rorippa palustris, Rosa setigera, Rubus argutus, Rudbeckia laciniata, Rumex altissimus, Rumex verticillatus, Sagittaria ambigua, Sagittaria australis, Sagittaria calycina, Sagittaria cuneata, Sagittaria engelmanniana, Sagittaria filiformis, Sagittaria graminea, Sagittaria lancifolia, Sagittaria montevidensis, Sagittaria platyphylla, Sagittaria rigida, Sagittaria sanfordii, Sagittaria teres, Salix amygdaloides, Salix exigua, Salix gooddingii, Salix interior, Salix lasiandra, Salix nigra, Sambucus nigra, Saururus cernuus, Scheuchzeria palustris, Schoenoplectus acutus, Schoenoplectus americanus, Schoenoplectus hallii, Schoenoplectus lacustris, Schoenoplectus tabernaemontani, Schoenoplectus triqueter, Scirpus atrovirens, Scirpus cyperinus, Scutellaria lateriflora, Sesbania drummondii, Sicyos angulatus, Silene nivea, Silphium perfoliatum, Sium suave, Solidago gigantea, Sonchus arvensis, Sparganium androcladum, Sparganium emersum, Sparganium eurycarpum, Sparganium natans, Sphagnum angustifolium, Sphagnum centrale, Sphagnum teres, Spiraea douglasii, Spirodela polyrhiza, Stuckenia pectinata, Stuckenia vaginata, Stylisma aquatica, Symphyotrichum lanceolatum, Symphyotrichum pilosum, Symphyotrichum puniceum, Symphyotrichum subulatum, Symplocarpus foetidus, Taxodium distichum, Thalia geniculata, Thalictrum dasycarpum, Toxicodendron radicans, Toxicodendron vernix, Tradescantia virginiana, Triadenum virginicum, Typha angustifolia, Typha domingensis, Typha latifolia, Urtica dioica, Utricularia macrorhiza, Utricularia purpurea, Vallisneria americana, Verbascum thapsus, Verbena bonariensis, Verbena hastata, Vernonia fasciculata, Veronica anagallis-aquatica, Veronica catenata, Veronica peregrina, Viburnum lentago, Viola lanceolata, Vitis riparia, Wolffia brasiliensis, Wolffia columbiana, Xanthium strumarium, Zannichellia palustris, Zizania palustris.

2.1.6.17. Sagittaria longiloba Engelm. ex J.G. Sm. is a perennial, which grows in shallow waters (to $45 \mathrm{~cm}$ ) in canals (irrigation), cienegas, ditches (drainage; roadside), marshes, mudflats, playas, ponds, pools (alkaline; ephemeral), rice fields, and along the margins of lakes, ponds, rivers, and streams at elevations to $1676 \mathrm{~m}$. This is a common species of playa lakes and similar habitats. The exposures typically are open and receive full sunlight. The substrates are described as alkaline and include clay, clay loam, mud, and sand. Flowering occurs from May to October, with fruiting observed from July to October. The plants are monoecious and probably are pollinated by insects (Insecta). Viable achenes are known to be passed through the digestive tracts of birds (Aves: Anatidae: Anas platyrhynchos; Charadriidae: Charadrius vociferus) after retention times ranging from 8 to $16 \mathrm{~h}$, which implicates birds as agents of their long-distance dispersal. The achenes germinate in a few centimeters of water under ambient greenhouse conditions. The seedlings typically establish in sites that have been shallowly flooded for more than 2 weeks. In appropriately flooded sites, germination is continuous throughout the growing season. Seedling densities from 25 to $75 \mathrm{~m}^{-2}$ have been observed in the field. Vegetative reproduction occurs by the production of tubers. Reported associates: Agropyron, Alisma triviale, Ambrosia grayi, Ammannia coccinea, Bacopa rotundifolia, Callitriche heterophylla, Chara, Cyperus digitatus, Digitaria sanguinalis, Echinochloa crus-galli, Echinodorus berteroi, Eleocharis macrostachya, Eleocharis palustris, Helianthus ciliaris, Heteranthera dubia, Heteranthera limosa, Heteranthera mexicana, Juncus, Juniperus, Lemna, Leptochloa fusca, Limosella aquatica, Ludwigia glandulosa, Ludwigia palustris, Marsilea vestita, Myriophyllum pinnatum, Paspalum distichum, Persicaria bicornis, Persicaria glabra, Persicaria hydropiperoides, Persicaria lapathifolia, Pontederia cordata, Populus fremontii, Potamogeton natans, Potamogeton nodosus, Rumex chrysocarpus, Rumex crispus, Sagittaria calycina, Sagittaria latifolia, Schoenoplectus californicus, Spirodela polyrhiza, Stuckenia pectinata, Symphyotrichum subulatum, Typha domingensis, Xanthium.

2.1.6.18. Sagittaria macrocarpa J.G. Sm. is a perennial (or sometimes annual?), which is narrowly distributed and endemic to the inner coastal plain Sandhills Region of the southeastern United States. The plants occur in very shallow waters of ponds (artificial; beaver), pools, seepage bogs, streamheads (blackwater), and lakeshores at low elevations. The waters are acidic, darkly stained (blackwaters), and low in nutrients. The substrates have been described as clay, clayey sand, mud, peaty sand, and sand. The plants are monoecious and flower during summer (their specific flowering period has not been clarified). The plants reproduce vegetatively by the production of slender stolons. Much life history information is needed for 
this species, which until recently had been regarded as a synonym of S. graminea (see Systematics). Reported associates: Dichanthelium, Eleocharis flavescens, Eleocharis robbinsii, Juncus debilis, Lachnanthes caroliniana, Mayaca fluviatilis, Nymphaea odorata, Nymphoides, Nyssa biflora, Panicum hemitomon, Potamogeton diversifolius, Sagittaria engelmanniana, Sagittaria graminea, Schoenoplectus etuberculatus, Sparganium americanum, Sphagnum.

2.1.6.19. Sagittaria montevidensis Cham. \& Schlecht. is a perennial, which colonizes shallow waters or exposed substrates in ditches (landscaped), mudflats (riverine), sloughs (roadside), and along the margins of swamps (roadside) at elevations to $10 \mathrm{~m}$. The substrates are described as muddy clay. The plants are monoecious, with the female flowers lacking the ring of stamens found in S. calycina. The petals possess a bright crimson spot, which presumably serves as an attractant to potential pollinators. Flowering occurs from July to October. Aside from these few details, most of the North American information for this taxon has been attributed incorrectly and refers instead to $S$. calycina, a distinct, native species (see Systematics). Reliable information pertaining correctly to the North American occurrences of this nonindigenous species is scarce and should be compiled. Reported associates (North America): Nymphaea capensis, Sagittaria latifolia, Sagittaria platyphylla.

2.1.6.20. Sagittaria papillosa Buch. is a perennial, which grows in shallow (e.g., 6.5-20 cm depth), brackish to freshwaters of bogs, borrow pits, ditches (roadside), flats, flatwoods (pine), marshes, meadows, pools (roadside), prairies (coastal; saline), savannahs, swamps, terraces (river), wastelands, woodlands (sparse), and along the margins of lakes and ponds at elevations to $67 \mathrm{~m}$. Exposures are described as open. The substrates are acidic (mean values: $\mathrm{pH}$ : 4.9-5.2; organic matter: <1-3.5\%; Ca (as CaO): 118-308 ppm; $\mathrm{K}$ (as $\mathrm{K}_{2} \mathrm{O}$ ): 34-78 ppm; $\mathrm{Mg}$ (as $\mathrm{MgO}$ ): 30-104 ppm; $\mathrm{P}$ (as $\mathrm{P}_{2} \mathrm{O}_{5}$ ): 7-39.5 ppm). Flowering and fruiting occur from April to September. The plants normally are racemose and monoecious, but occasionally produce branched inflorescences (panicles) having staminate and bisexual flowers on the lowest branches (i.e., they are andromonoecious); the stamens of the bisexual flowers are functional. Individuals are self-compatible, which allows for self-pollination to occur. The natural pollinators of openpollinated plants have not been enumerated, but likely are insects (Insecta). Only racemose, monoecious plants have been observed to develop under greenhouse conditions (and from $\mathrm{F}_{2}$ crosses), indicating that the anomalous floral features are environmentally plastic and not strictly determined genetically. Additional information on the pollination biology or seed ecology of this species is unavailable. The plants reproduce vegetatively by the production of coarse rhizomes, from which new vegetative plantlets develop. The connections with the maternal plant sever by the onset of anthesis, which yields clonal ramets in near proximity. Reported associates: Acer negundo, Baccharis halimifolia, Bacopa caroliniana, Boehmeria cylindrica, Carex amphibola, Carex arkansana, Celtis laevigata, Centella asiatica, Cephalanthus occidentalis, Cornus foemina, Crataegus mollis, Crataegus viridis,
Cyrilla racemiflora, Eleocharis macrostachya, Eleocharis quadrangulata, Eleocharis wolfi, Eupatorium rotundifolium, Euthamia leptocephala, Helenium flexuosum, Hydrolea ovata, Hymenocallis liriosme, Ilex, Iris brevicaulis, Iris hexagona, Isoetes melanopoda, Juncus acuminatus, Juncus brachycarpus, Juncus dichotomus, Juncus effusus, Juncus marginatus, Juncus nodatus, Limnosciadium pinnatum, Ludwigia, Ludwigia palustris, Mikania scandens, Myrica, Oplismenus hirtellus, Panicum hemitomon, Paspalidium geminatum, Paspalum wrightii, Persicaria hydropiperoides, Pinus palustris, Pluchea, Pontederia cordata, Proserpinaca palustris, Quercus, Ranunculus hispidus, Rhynchospora corniculata, Sabal minor, Sagittaria graminea, Salix nigra, Sambucus nigra, Samolus valerandi, Sarracenia, Schoenolirion croceum, Scutellaria integrifolia, Sesbania drummondii, Steinchisma hians, Thalia dealbata, Tridens strictus, Typha latifolia.

2.1.6.21. Sagittaria platyphylla (Engelm.) J.G. Sm. is a perennial, which grows in shallow (e.g., 8-50 cm deep), tidal or non-tidal, brackish or freshwaters of bayous, bogs (hillside), bottoms (lake), canals (drainage), cobble bars, ditches (drainage; roadside), flats, flatwoods, gravel pits, lagoons, levees (wooded), mudflats, lakes, marshes, mudflats, ponds (farm; retention; seasonal), pools, rice fields, roadsides, sand pits, spillways, streams, swales, swamps (roadside), woodlands, and along the margins or shores of lakes, ponds, pools, and reservoirs at elevations to $316 \mathrm{~m}$. Although the plants occur occasionally in brackish sites, their biomass declines at salinities of 3 ppt; salinity levels of $6 \%$ are lethal. In cultivation, the plants thrive in water temperatures from $20^{\circ} \mathrm{C}$ to $24^{\circ} \mathrm{C}$. Exposures typically are open sites with full sunlight, and uncommonly are characterized by shade. The substrates are acidic (mean pH: 5.8), high in organic matter (mean: $23.8 \%$ ), and include clay, clayey alluvium, gravel, muck (tidal), mud, sand (fine; Mascotte), sandy clay, sandy silt, silt, silty clay, and silty clay loam (Schriever). Flowering and fruiting extend from April to December. The plants are monoecious and likely pollinated by insects (Insecta). The fruits are buoyant and dispersed by water currents. Although no persistent seed banks have been reported, the seeds are known to remain viable for several years when stored in uncontaminated water. In one study, all $S$. platyphylla accessions surveyed genetically possessed a single multilocus isozyme genotype (13 loci), indicating extremely low levels of genetic variation in the species. Those results contrast with a study of invasive populations in Australia, where each surveyed individual possessed a unique (AFLP) genotype, which indicated that seeds are the primary propagules involved in dispersal. Vegetative reproduction occurs by means of rhizomes, from which large tubers are produced. Detached tubers sink initially, then float to the surface once the shoots develop, but eventually sink again when the roots develop. They also are dispersed by water. Compared to other aquatic species, S. platyphylla has a relative slow exponential leaf decay rate $(0.053$ day $\left.^{-1}\right)$. Reported associates: Acmella repens, Alternanthera philoxeroides, Ammannia coccinea, Ampelopsis arborea, Asclepias, Azolla filiculoides, Bacopa monnieri, Briza minor, 
Bromus catharticus, Caperonia, Cephalanthus occidentalis, Ceratophyllum demersum, Colocasia esculenta, Commelina diffusa, Corchorus, Cyperus difformis, Cyperus flavicomus, Cyperus haspan, Cyperus pseudovegetus, Cyperus strigosus, Cyperus virens, Dichanthelium, Diodia virginiana, Diospyros virginiana, Echinochloa crus-galli, Echinodorus berteroi, Echinodorus cordifolius, Egeria densa, Eleocharis ambigens, Eleocharis baldwinii, Eleocharis montana, Eleocharis obtusa, Elymus virginicus, Eupatorium capillifolium, Euphorbia, Fagus grandifolia, Fimbristylis dichotoma, Gleditsia aquatica, Hydrilla verticillata, Hydrocleys nymphoides, Hydrocotyle umbellata, Hydrocotyle verticillata, Hydrolea ovata, Hydrolea uniflora, Ilex glabra, Juncus effusus, Juncus megacephalus, Juncus repens, Justicia ovata, Kyllinga brevifolia, Leersia oryzoides, Lepidium virginicum, Leptochloa, Liquidambar styraciflua, Lobelia, Lonicera japonica, Ludwigia alternifolia, Ludwigia octovalvis, Ludwigia palustris, Ludwigia peploides, Ludwigia repens, Marsilea vestita, Micranthemum umbrosum, Mikania scandens, Myrica cerifera, Najas guadalupensis, Najas minor, Nyssa biflora, Paspalum urvillei, Persicaria punctata, Phyla nodiflora, Pinus taeda, Plantago patagonica, Potamogeton crispus, Potamogeton diversifolius, Potamogeton illinoensis, Potamogeton nodosus, Quercus nigra, Rhynchospora colorata, Rhynchospora corniculata, Rotala ramosior, Rubus trivialis, Rumex conglomeratus, Rumex crispus, Sabal palmetto, Sagittaria australis, Sagittaria calycina, Sagittaria lancifolia, Sagittaria latifolia, Sagittaria montevidensis, Salix, Schoenoplectus americanus, Sesbania, Solidago altissima, Sphenoclea zeylanica, Taxodium distichum, Triadica sebifera, Typha domingensis, Typha latifolia, Vallisneria americana, Verbena brasiliensis, Zizania texana.

2.1.6.22. Sagittaria rigida Pursh is a perennial, which grows in shallow to deep (e.g., $0.2-1.8 \mathrm{~m}$ ), still or flowing, brackish to fresh, tidal or non-tidal waters of bays, bogs, canals, channels, depressions, ditches, meadows, mudflats, oxbows, ponds (artificial; dried; farm; natural; shallow; small; stock; upland), sinkholes (depression), swales, thickets (swamp), and along the margins or shores (receding) of lakes, ponds, reservoirs, rivers, streams, and swamps at elevations to $1385 \mathrm{~m}$. The plants are tolerant of turbidity and fairly eutrophic conditions. In standing waters, they often occur at greater depths $(>1.0$ $\mathrm{m})$. Exposures typically receive full sunlight. The waters $(\mathrm{pH}$ : 5.4-8.9; $\bar{x}=7.4$; specific conductance: $319-340 \mu \mathrm{S} \mathrm{cm}^{-1}$; total alkalinity as $\mathrm{CaCO}_{3}: 10-140 \mathrm{mg} \mathrm{l}^{-1}$ ) have been characterized as brackish, calcareous, or hard. The substrates (pH: 5.9; $2.7 \%$ organic matter) include muck (marly), mucky sand, mud (alluvial), rock, sand, and sandy muck. Flowering and fruiting extend from May to September. The plants are monoecious. The pollination system has not been described but probably is mediated by small insects (Insecta). A persistent seed bank develops, with a mean density of up to 119 seeds $\mathrm{m}^{-2}$ reported from shallowly flooded sites. Seeds that are freshly collected in the spring have germinated well following several days of cold $\left(4^{\circ} \mathrm{C}\right)$, wet storage. Seedling establishment occurs optimally during drawdown conditions. The plants reproduce vegetatively by rhizomes, from which tubers can develop.
Reported associates: Alisma triviale, Bacopa rotundifolia, Bolboschoenus fluviatilis, Brasenia schreberi, Butomus umbellatus, Carex gynandra, Carex interior, Carex lupulina, Cephalanthus occidentalis, Ceratophyllum demersum, Ceratophyllum echinatum, Cyperus bipartitus, Dulichium arundinaceum, Eleocharis erythropoda, Eleocharis obtusa, Eleocharis palustris, Elodea canadensis, Eriophorum angustifolium, Heteranthera limosa, Heteranthera multiflora, Heteranthera reniformis, Heteranthera rotundifolia, Hibiscus, Hypericum mutilum, Iris pseudacorus, Isoetes riparia, Juncus acuminatus, Justicia americana, Kyllinga gracillima, Leersia oryzoides, Lemna minor, Lindernia dubia, Ludwigia palustris, Lythrum salicaria, Marsilea vestita, Menyanthes trifoliata, Myriophyllum sibiricum, Nelumbo lutea, Nuphar polysepala, Nymphaea odorata, Orontium aquaticum, Peltandra virginica, Persicaria amphibia, Persicaria bicornis, Persicaria coccinea, Persicaria hydropiperoides, Persicaria punctata, Phalaris arundinacea, Phragmites australis, Phyla lanceolata, Pontederia cordata, Potamogeton foliosus, Potamogeton nodosus, Potamogeton richardsonii, Potamogeton vaseyi, Ranunculus ambigens, Rumex altissimus, Rumex crispus, Rumex stenophyllus, Sagittaria brevirostra, Sagittaria graminea, Sagittaria latifolia, Sagittaria sanfordii, Saururus cernuus, Schoenoplectus acutus, Schoenoplectus heterochaetus, Schoenoplectus pungens, Schoenoplectus smithii, Schoenoplectus tabernaemontani, Scirpus cyperinus, Sparganium americanum, Sparganium emersum, Sphagnum magellanicum, Sphagnum palustre, Sphagnum subsecundum, Thelypteris palustris, Typha angustifolia, Typha latifolia, Utricularia macrorhiza, Wolffia columbiana, Zizania aquatica, Zizania palustris.

2.1.6.23. Sagittaria sanfordii Greene is a perennial, which inhabits waters (to $1 \mathrm{~m}$ deep) in canals, ditches, floodplains, lakes (vernal), marshes, mudflats, pools (alkaline; vernal), rice fields, river bottoms (drying), sloughs, streams and the margins of canals, lakes, ponds (beaver; stock), rivers, and streams at elevations to $609 \mathrm{~m}$. The habitats are categorized as alkaline, with substrates described as alluvium (rocky), clay, loam (gummy), mud (drying), and Tuscan mudflow. Flowering occurs from May to October. The plants are monoecious, but occasionally produce perfect (but normally pistillate) flowers with functional stamens. The plants reproduce vegetatively by rhizomes, which produce spherical tubers. Little additional information exists on the reproductive or seed ecology. This is a relatively rare species, which has become extirpated in many areas due to habitat loss. Its life history deserves a comprehensive evaluation. Reported associates: Alisma, Artemisia douglasiana, Callitriche, Carex, Cyperus eragrostis, Eleocharis macrostachya, Eleocharis quadrangulata, Iris pseudacorus, Isoetes, Juncus effusus, Legenere valdiviana, Ludwigia peploides, Marsilea, Polygonum, Potamogeton, Ranunculus, Sagittaria calycina, Sagittaria latifolia, Sagittaria rigida, Schoenoplectus acutus, Typha.

2.1.6.24. Sagittaria secundifolia $\mathbf{K r a l}$ is a perennial, which inhabits clear, slow to swift, riverine waters associated with pools (shallow), rapids, riffles (shallow), and shoals at elevations to $466 \mathrm{~m}$. The plants can grow in exposed shallows or 
at depths of up to $75 \mathrm{~cm}$. They are intolerant of pollution and epiphytic growths of filamentous algae. Exposures typically receive full sunlight, with populations declining where a wooded overstory is present. The substrates are characterized as boulders (small), cobble, rocky (sandstone) crevices, sand, and slabs (flat; jointed; sandstone). The plants do not occur in highly turbulent water, deep pools, or on substrates consisting of large boulders. Plants growing in swift, shallow water are short in stature, sterile, and reproduce vegetatively by thick, elongate rhizomes (to $10 \mathrm{~cm}$ ), which anchor amidst the cracks and fissures in the rocky substrate. In quieter waters, the plants produce longer leaves, shorter rhizomes, and are fertile. Flowering occurs from May to August, with fruiting from July to September. The flowers (which appear to float on the water surface) develop only under full sunlight and on plants growing near the water surface, which are conditions associated with low water flow periods. Most of the plants are devoid of flowers and reproduce asexually; however, preliminary studies indicate that populations retain a fair level of genetic variability. The perianth is essentially absent on pistillate flowers, but of normal proportions in the staminate flowers. Pollination presumably is facilitated by bees (Insecta: Hymenoptera), but the reproductive biology and seed ecology of this species remain virtually unknown. Reported associates: Justicia americana, Lindernia, Ludwigia, Myriophyllum, Persicaria, Potamogeton, Najas, Podostemum ceratophyllum.

2.1.6.25. Sagittaria subulata (L.) Buch. is a perennial, which inhabits shallow (to $61 \mathrm{~cm}$ ), coastal, brackish (salinity: 0.5-18 ppt), tidal or non-tidal waters in bays, canals, depressions, hammocks, marshes (tidal), mudflats, streams, and along the margins of ponds and rivers at elevations $<100 \mathrm{~m}$. The plants occur commonly in areas that become exposed at low tide. The waters are circumneutral ( $\mathrm{pH}: 4.8-8.3 ; \bar{x}: 6.6-6.7)$, low in total alkalinity $\left(0.4-56.4 \mathrm{mg} \mathrm{l}^{-1} ; \bar{x}: 18.5-20.3 \mathrm{mg} \mathrm{l}^{-1}\right)$, with a relatively low total nitrogen content $\left(\bar{x}: 700 \mu \mathrm{g}^{-1}\right)$. In cultivation, the plants thrive in water temperatures from $18^{\circ} \mathrm{C}$ to $28^{\circ} \mathrm{C}$. The substrates include mud, muddy peat, sand, sandy gravel, silty clay, and silty mud. Flowering can extend from March to November. The individuals are monoecious, with the flowers pollinated by small flies (Insecta: Diptera). In deeper waters, the upper (male) flowers open only partially, with the lower (pistillate) flowers rarely becoming emersed above the water surface. Few seeds are produced and nothing is known regarding their germination requirements. The plants primarily reproduce vegetatively by the production of stolons, from which tubers can develop. The leaves lack Krantz anatomy but exhibit CAM-like concentrations of malate, which indicates a similar but modified $\mathrm{C}_{4}$ photosynthetic pathway. Reported associates: Acer, Alternanthera philoxeroides, Azolla filiculoides, Bacopa rotundifolia, Bidens bidentoides, Bidens eatonii, Bidens hyperboreus, Callitriche heterophylla, Cardamine longii, Carex glaucescens, Carya cordiformis, Ceratophyllum demersum, Cornus foemina, Crassula aquatica, Crotalaria spectabilis, Cyperus virens, Echinodorus berteroi, Egeria densa, Eichhornia crassipes, Eleocharis acicularis, Eleocharis diandra, Eleocharis engelmannii, Eleocharis flavescens, Eleocharis obtusa, Eleocharis parvula, Eriocaulon parkeri, Festuca filiformis, Fimbristylis autumnalis, Fraxinus, Heteranthera multiflora, Heteranthera reniformis, Hydrilla verticillata, Hydrocotyle umbellata, Hydrolea quadrivalvis, Isoetes mattaponi, Lemna valdiviana, Lilaeopsis chinensis, Limosella australis, Lindernia dubia, Ludwigia palustris, Luziola fluitans, Micranthemum micranthemoides, Najas guadalupensis, Nuphar advena, Nymphaea, Nyssa biflora, Orontium aquaticum, Persicaria arifolia, Persicaria hydropiperoides, Persicaria punctata, Pistia stratiotes, Planera aquatica, Pontederia cordata, Potamogeton diversifolius, Potamogeton illinoensis, Potamogeton pusillus, Proserpinaca palustris, Ptilimnium capillaceum, Rhynchospora glomerata, Rhynchospora microcephala, Ruppia maritima, Sagittaria calycina, Sagittaria graminea, Salvinia, Schoenoplectus smithii, Spergularia salina, Taxodium distichum, Typha domingensis, Utricularia gibba, Utricularia inflata, Vallisneria americana, Zannichellia palustris.

2.1.6.26. Sagittaria teres S. Wats. is a perennial, which grows in shallow (to $100 \mathrm{~cm}$ ) waters of borrow pits, swamps, and along the margins or shores of lakes and ponds at elevations to $64 \mathrm{~m}$. Exposures are open and receive full sunlight. The waters are acidic ( $\mathrm{pH}: 4.5-6.7 ; \bar{x}=5.2)$ and very soft (total alkalinity $4-7 \mathrm{mg} \mathrm{l}^{-1} ; \bar{x}=5.5 \mathrm{mg} \mathrm{l}^{-1}$ ). The substrates can include cobble, gravel, or sand (mucky; pure; silty; white). Flowering and fruiting extend from July to September. The plants are monoecious. The fruits normally develop and ripen underwater and can differ morphologically if ripened above water. Only scarce information exists on the reproductive biology and seed ecology. Allozyme analyses indicate high levels of genetic variation in populations, which implicates recruitment from the seed bank as a principal means of population persistence (although seed bank data are not available). Vegetative reproduction occurs by the production of stolons, from which minute tubers can develop. However, genetic analyses also indicate that populations are not highly clonally structured, despite their capacity for asexual reproduction. Reported associates: Carex longii, Coreopsis rosea, Cyperus squarrosus, Drosera filiformis, Drosera intermedia, Drosera rotundifolia, Dulichium arundinaceum, Eleocharis robbinsii, Eleocharis tricostata, Eleocharis tuberculosa, Eriocaulon aquaticum, Eupatorium leucolepis, Eupatorium perfoliatum, Fimbristylis autumnalis, Fuirena pumila, Gratiola aurea, Hypericum adpressum, Hypericum mutilum, Isoetes echinospora, Juncus militaris, Juncus pelocarpus, Lipocarpha micrantha, Lobelia dortmanna, Najas flexilis, Nymphaea odorata, Nymphoides cordata, Panicum verrucosum, Pontederia cordata, Potamogeton illinoensis, Potamogeton perfoliatus, Proserpinaca pectinata, Rhexia virginica, Rhynchospora inundata, Rhynchospora macrostachya, Rhynchospora scirpoides, Rotala ramosior, Sabatia kennedyana, Sagittaria graminea, Sagittaria latifolia, Schoenoplectus etuberculatus, Scleria reticularis, Sparganium angustifolium, Utricularia cornuta, Utricularia geminiscapa, Utricularia gibba, Utricularia resupinata, Vallisneria americana, Viola lanceolata, Xyris difformis, Xyris smalliana. 
Use by wildlife: The starchy tubers of various Sagittaria species are eaten by beavers (Mammalia: Castoridae: Castor canadensis), muskrats (Mammalia: Cricetidae: Ondatra zibethicus), and waterfowl (Aves: Anatidae). The plants (species unspecified) host many insects (Insecta), including beetles and weevils (Coleoptera: Chrysomelidae: Donacia caerulea, Galerucella nymphaea, Plateumaris rufa; Curculionidae: Brachybamus electus, Listronotus turbatus, Onychylis angustus, O. nigrirostris), flies (Diptera: Ephydridae Hydrellia deceptor, $H$. griseola), and larval moths (Lepidoptera: Noctuidae: Acronicta oblinita, Argyrogramma verruca, Bellura obliqua, Homophoberia cristata). The seeds of Sagittaria ambigua reportedly are eaten by birds (Aves). The flowers of S. australis are visited (and pollinated) primarily by generalist bees (Insecta: Hymenoptera: Apidae: Ceratina; Halictidae: Augochlora, Lasioglossum). The tubers are eaten by weevils (Insecta: Coleoptera: Curculionidae: Listronotus caudatus, L. echinodori); the flowers are attacked by L. appendiculatus. The plants provide cover and shade for small fish. The nutlets of S. calycina are eaten by canvasbacks (Aves: Anatidae: Aythya valisineria) and by other ducks (Aves: Anatidae: Anas) in low to locally high quantities. Sagittaria cristata is colonized by various freshwater sponges (Bryozoa: Cristatellidae: Cristatella mucedo; Fredericellidae: Fredericella sultana; Paludicellidae: Paludicella articulata; Pectinatellidae: Pectinatella magnifica; Plumatellidae: Hyalinella punctata, Plumatella emarginata, P. repens). It is a minor food item for ducks (Aves: Anatidae). The foliage of S. cuneata contains $21.8 \%$ crude protein, $17.3 \%$ crude fiber and is high in $\mathrm{K}, \mathrm{Fe}$, and Mo. The plants are grazed by muskrats (Mammalia: Cricetidae: Ondatra zibethicus) and domestic livestock (Mammalia: Bovidae) including cattle (Bos taurus) and sheep (Ovis aries). The achenes and tubers are eaten by various waterfowl (Aves: Anatidae) including Canada geese (Branta canadensis), mallards (Anas platyrhynchos), and wood ducks (Aix sponsa). The plants also are host to weevils (Insecta: Coleoptera: Curculionidae: Listronotus rubtzoffi). They have been found to harbor more than 39 million nitrifying bacteria. The flower heads, leaves, and roots of $S$. engelmanniana are fed upon by weevils (Insecta: Coleoptera: Curculionidae: Listronotus appendiculatus, L. neocallosus, L. sordidus). Various weevils (Insecta: Coleoptera: Curculionidae) also are hosted by S. graminea (Listronotus neocallosus), S. filiformis (L. neocallosus) and S. lancifolia (Listronotus cryptops). The foliage of $S$. graminea is eaten by grass carp (Vertebrata: Osteichthyes: Cyprinidae: Ctenopharyngodon idella) and nutria (Mammalia: Myocastoridae: Myocastor coypus); its tubers (15.9\% crude protein; $16.1 \%$ crude fiber) are consumed by canvasbacks (Aves: Anatidae: Aythya valisineria) and wood ducks (Aves: Anatidae: Aix sponsa) during winter months. The plants are categorized overall as a good food for ducks (Aves: Anatidae). In Asia, S. guayanensis is fed to pigs (Mammalia: Suidae: Sus scrofa) as fodder. The leaves of S. kurziana support large populations of larval flies (Insecta: Diptera: Chironomidae) and provide habitat for the Ichetucknee siltsnail (Mollusca: Gastropoda: Hydrobiidae: Floridobia mica). Sagittaria lancifolia is a host of smut (Fungi: Basidiomycota: Doassansiaceae: Doassansia sagittariae; Doassansiopsis deformans). The foliage is used for oviposition by Florida applesnails (Mollusca: Gastropoda: Ampullariidae: Pomacea paludosa), and is eaten by grasshoppers (Insecta: Orthoptera: Romaleidae: Romalea microptera) and white-tailed deer (Mammalia: Cervidae: Odocoileus virginianus seminolus); the flower buds (primarily the males) are eaten by weevils (Insecta: Coleoptera: Curculionidae: Listronotus appendiculatus). Sagittaria latifolia is eaten by moose (Mammalia: Cervidae: Alces americanus) and white-tailed deer (Mammalia: Cervidae: Odocoileus virginianus); its tubers are consumed by pintail ducks (Aves: Anatidae: Aythya valisineria) and other waterfowl. The seeds and foliage are eaten by American wigeons (Aves: Anatidae: Anas americana) and occasionally by bullfrogs (Amphibia: Ranidae: Rana catesbeiana). The plants host numerous insects (Insecta), including aphids (Homoptera: Aphididae: Rhopalosiphum nymphaeae), beetles and weevils (Coleoptera: Chrysomelidae: Donacia caerulea, D. subtilis; Coccinellidae: Coleomegilla maculata; Curculionidae: Hyperodes solutus, Listronotus appendiculatus, L. delumbis, L. echinodori, L. squamiger, Lixellus lutulentus), caddis flies (Trichoptera:Lemnephilidae: Pycnopsyche; Leptoceridae: Leptocerus americanus, Nectopsyche, Triaenodes abus, T. ignitus, T. injustus, T. marginatus; Polycentropodidae: Neureclipsis crepuscularis, Polycentropus), flies (Diptera: Itonididae), grasshoppers (Orthoptera: Acrididae: Paroxya atlantica, P. clavuliger, Romalea microptera), leafhoppers (Homoptera: Cicadellidae: Draeculacephala), moths (Lepidoptera: Crambidae: Munroessa icciusalis, Paraponyx obscuralis; Noctuidae: Cryptocala acadiensis), and stink bugs (Hemiptera: Pentatomidae: Amaurochrous cinctipes). The flowers are visited by a variety of potentially pollinating insects (Insecta), including bees (Hymenoptera: Apidae: Apis mellifera, Bombus, Ceratina; Halictidae: Augochlora, Halictus, Lasioglossum), beetles (Coleoptera: Cantharidae: Chauliognathus pennsylvanicus; Chrysomelidae: Diabrotica undecimpunctata; Coccinellidae: Coleomegilla maculata), butterflies (Lepidoptera: Hesperiidae: Ancyloxypha numitor), flies (Diptera: Syrphidae: Allograpta, Criorhina, Eristalis, Heliophilus; Tachinidae: Linnaemya), and wasps (Hymenoptera: Vespidae: Euodynerus). The foliage is colonized by freshwater sponges (Paludicellidae: Paludicella articulata; Plumatellidae: Plumatella repens). Sagittaria longiloba is eaten by sandhill cranes (Aves: Gruidae: Grus canadensis) and waterfowl (Aves: Anatidae). The seeds are eaten by ducks (Aves: Anatidae: Anas platyrhynchos) and killdeer (Charadriidae: Charadrius vociferus). The plants are fed on by weevils (Insecta: Coleoptera: Curculionidae: Listronotus manifestus, L. scapularis). Sagittaria platyphylla is eaten by feral swine (Mammalia: Suidae: Sus scrofa), nutria (Mammalia: Myocastoridae: Myocastor coypus), and whitetailed deer (Mammalia: Cervidae: Odocoileus virginianus). The leaf axils provide refuge for larval dragonflies (Insecta: Odonata: Libellulidae: Pachydiplax longipennis), and emergent portions of the plant are used as mating sites by adult 
dragonflies (Insecta: Odonata: Coenagrionidae Telebasis salva). The foliage provides an oviposition site for fountain darters (Osteichthyes: Percidae: Etheostoma fonticola), cover and habitat for fish (Osteichthyes: Cyprinidae: Notropis chalybaeus), and serves as an attachment substrate for ciliophorans (Protozoa: Peritrichida: Operculariidae: Opercularia wallgreni). The large (e.g., $2.5 \mathrm{~cm})$ tubers $(19.9 \%$ crude protein; $56.1 \%$ total digestible nutrients) provide an important food for turtles (Reptilia: Emydidae: Pseudemys texana) and various waterfowl (Aves: Antidae), including canvasbacks (Aythya valisineria), gadwalls (Anas strepera), mallards (Anas platyrhynchos), pintails (Anas acuta), and ring-necked ducks (Aythya collaris). The foliage of S. rigida ( $14.78 \%$ crude protein; $23.69 \%$ crude fiber; Fe: 2083 ppm) is eaten by muskrats (Mammalia: Cricetidae: Ondatra zibethicus). The plants are inhabited by beetles (Insecta: Coleoptera: Chrysomelidae: Donacia caerulea). The tubers (11.6\% crude protein; $2.0 \%$ crude fiber; $0.6 \%$ crude fat) are consumed by canvasback ducks (Aves: Anatidae: Aythya valisineria) and tundra swans (Aves: Anatidae: Cygnus columbianus). The seeds and tubers of $S$. subulata are consumed occasionally by waterfowl (Aves: Anatidae). Sagittaria teres is eaten by pintail ducks (Aves: Anatidae: Anas acuta).

Economic importance: food: The tubers of Sagittaria species are rich in starch and were eaten by Native Americans and European settlers, who boiled them to temper the bitter taste imparted by their milky sap. Tubers of $S$. cuneata were eaten by the Klamath and Menominee, Montana, Ojibwa, and Paiute tribes. Sagittaria guayanensis is eaten as a rainy season vegetable in Laos. Sagittaria latifolia contains $13.7 \%$ crude protein. Its tubers were eaten by the Chippewa, Cocopa, Dakota, Klamath, Lakota, Meskwaki, Omaha, Pawnee, Pomo, Potawatomi, Thompson, and Winnebago tribes, who often stored them as a winter food; medicinal: The Cheyenne and Chippewa administered S. cuneata medicinally for various ailments. The plants were regarded as an analgesic by the Navajo, and the corms were eaten by the Ojibway to treat indigestion. Decoctions prepared from Sagittaria guayanensis are used in parts of Asia as a body wash ('Banarbhega') to control fever; the plant juices (mixed with honey) are drunk to facilitate recovery following childbirth. Sagittaria lancifolia was used by the Florida Seminoles to treat alligator bites. Extracts from the plant have been found to inhibit several Bacteria (Pseudomonadaceae: Pseudomonas aeruginosa; Staphylococcaceae: Staphylococcus aureus). Infusions of $S$. latifolia were used by the Cherokee to treat fevers (leaves) and by the Chippewa as a remedy for gastrointestinal disorders (roots). The Iroquois used infusions from the plant for treating rheumatism and fabricated various compound decoctions as remedies for boils, constipation, and itching. The species also was used medicinally by the Lakota and the Potawatomi, the latter applying a poultice from the corms to heal wounds; cultivation: Several Sagittaria species are grown as ornamental water garden plants. 'Benni' is a patented cultivar of S. australis (US PP12,198 P2); 'Crushed Ice' is a cultivar of S. graminea. Sagittaria lancifolia and S. montevidensis are used as water garden ornamentals. Sagittaria platyphylla is distributed occasionally as an aquarium plant, whereas $S$. subulata is a popular decorative aquarium species; misc. products: Sagittaria lancifolia and S. latifolia have been used in wetland restoration projects. The Iroquois used a root decoction of $S$. latifolia as a medicine to improve corn yields; weeds: Sagittaria guayanensis is a rice-field weed in Louisiana and also in Brazil and Peru. It has developed resistance to ALS inhibitor herbicides (bensulfuronmethyl) in Malaysia; bensulfuron-methyl resistant strains of S. montevidensis occur in California. Sagittaria latifolia has been reported as a rice-field weed in California; S. longiloba is a common rice-field weed in the western United States. Sagittaria montevidensis is a nuisance rice-field weed in South America; herbicide resistant strains have evolved (various ALS inhibitors) in Australia, Brazil, China, and the United States (California). Sagittaria sanfordii is regarded as a rice-field weed in California; nonindigenous species: Sagittaria graminea has been introduced to Washington state. It is invasive in China and has been introduced to Australia and France, where it also is problematic. Sagittaria guayanensis was introduced to Louisiana from tropical America. Sagittaria latifolia has been introduced widely throughout Europe. It is possible that S. longiloba was introduced to California, where nearly all of the records are associated with rice fields. Sagittaria montevidensis has been introduced to Australia, China, and the southeastern United States, where it has been distributed commercially as an ornamental; it also has been introduced to California, reportedly as an inadvertent consequence of disposed shipping ballast. Sagittaria platyphylla is nonindigenous to Australia and European Russia. Sagittaria rigida has been introduced to California, Idaho, and Washington in the United States, and to Ireland and the United Kingdom in Europe. Sagittaria subulata has been introduced to the British Isles.

Systematics: Sagittaria remains in need of taxonomic revision, with even basic species boundaries yet to be determined reliably. There is still some debate whether to subdivide the genus by excluding Lophotocarpus, which contains those annual species having perfect flowers with hypogynous stamens. Because the Lophotocarpus group resolves phylogenetically as the sister clade to the remainder of Sagittaria (Figure 1.7), either taxonomic disposition could be reconciled. In either case, Sagittaria appears to be monophyletic, with Astonia, Limnophyton, and Wiesneria among its most closely related genera (e.g., Figures 1.3 and 1.7). Several species (which retain OBL designations) are now regarded as various synonyms. Sagittaria chapmanii and S. weatherbiana are treated as subspecies of $S$. graminea. Although each taxon appears to be distinct phylogenetically (Figure 1.7), the nuclear data used to construct that tree do not exclude the possibility that $S$. chapmanii and $S$. weatherbiana could be of hybrid origin, with both having $S$. graminea as one parent. This hypothesis is consistent with results from crossing studies, which have shown $S$. graminea to be highly interfertile with $S$. isoetiformis (with which $S$. chapmanii resolves), and at least partially interfertile with $S$. fasciculata (with which $S$. weatherbiana resolves; Figure 1.7). Although S. chapmanii 


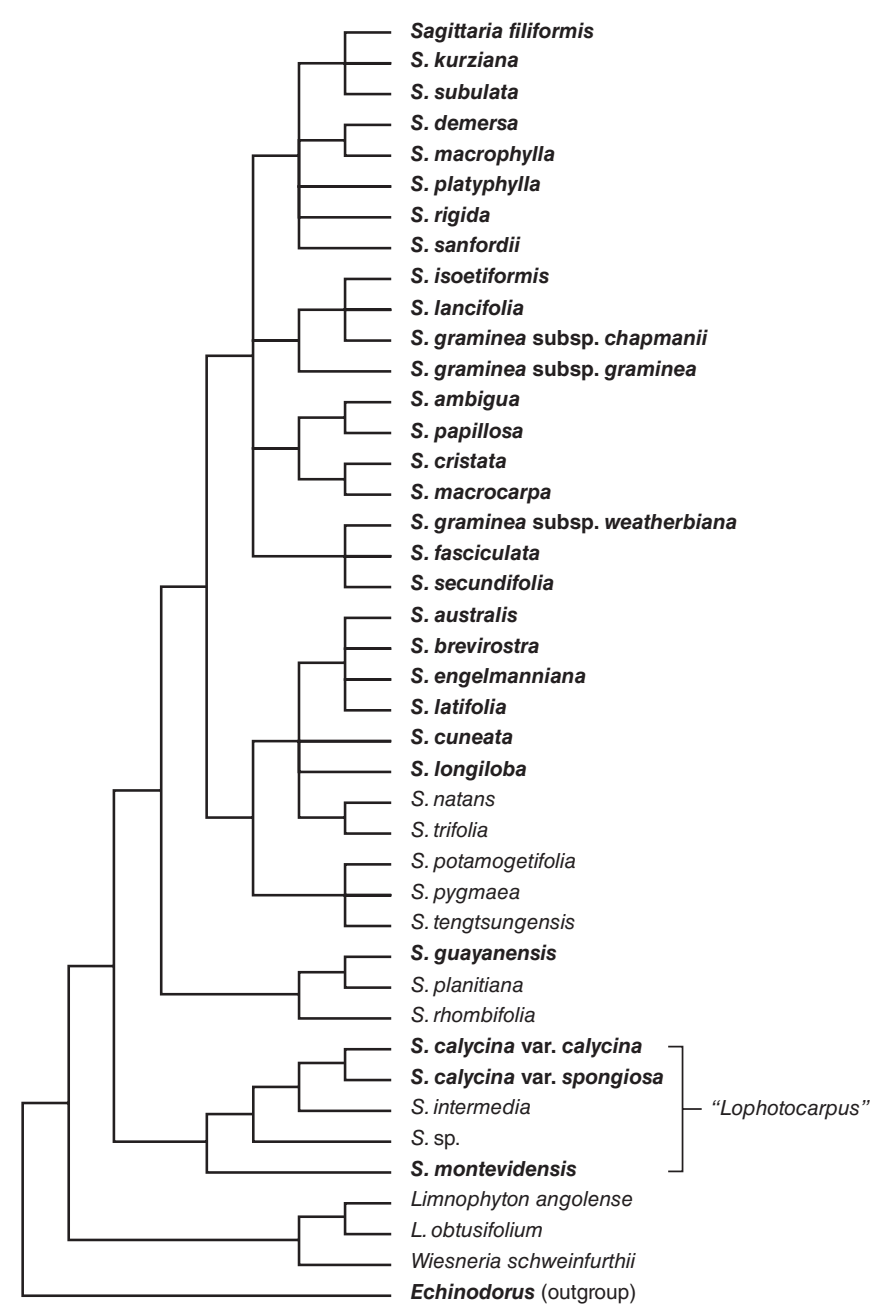

FIGURE 1.7 Interspecific relationships in Sagittaria as indicated by analysis of 5S-NTS data (modified from Keener, 2005). North American taxa designated as OBL indicators are highlighted in bold. The species recognized by some authors within the segregate genus Lophotocarpus resolve within a clade as indicated. The disjunct placement of $S$. graminea subspecies possibly reflects their hybrid origin (see text).

(= S. graminea subsp. chapmanii) is interfertile with $S$. graminea, the allozymically determined genetic identity of these two taxa is remarkably low (0.473). Also, in contrast with the typical subspecies, S. graminea subsp. chapmanii is quite variable genetically. Both factors could be a consequence of hybridization involving more distant species. Sagittaria graminea is well isolated reproductively from $S$. cristata and S. teres. Sagittaria spathulata is treated as a synonym of $S$. calycina. Although regarded by some authors as a synonym of S. montevidensis, $S$. calycina is retained here as a distinct species in accordance with its unique morphological features and genetic distinctness from the former (e.g., Figure 1.7). It seems clear that $S$. montevidensis and $S$. calycina should not be treated as synonyms. However, $S$. calycina includes a variety (S. calycina var. spongiosa), which some authors have distinguished as $S$. spathulata. In any case, both are closely related sister taxa (Figure 1.7). Sagittaria macrocarpa has been recognized as a synonym of S. fasciculata; however, morphological and genetic evidence (e.g., Figure 1.7) indicate its status as a distinct species, which has been accepted here (but does not preclude the possibility that $S$. fasciculata might be of hybrid origin). DNA sequence data resolve $S$. macrocarpa as the sister species of $S$. cristata (Figure 1.7). Though $S$. cuneata and $S$. latifolia bear a superficial morphological similarity, they are distinct genetically (e.g., by both isozyme and DNA markers). Furthermore, crossing studies have demonstrated that strong infertility barriers exist among $S$. australis, S. brevirostra, S. cuneata, S. engelmanniana, and S. latifolia, which all are well isolated reproductively. Allozyme data indicate that $S$. isoetiformis and $S$.teres are a closely related progenitor-derivative species pair. Specimens of S. filiformis, S. kurziana, and S. subulata often show a history of confused identifications, which has been attributed to extensive phenotypic plasticity relating to water depth. Observations of extensive variation in leaf morphology have raised doubts regarding the distinctness of these three taxa, which are separated by relatively minor fruit features and share a close phylogenetic interrelationship (Figure 1.7). Furthermore, because artificial hybridizations between $S$. filiformis and S. kurziana (Figure 1.7) have produced fertile $F_{1}$ offspring, the recognition of these three taxa at the species level should be re-evaluated by additional genetic studies.

Distribution: Sagittaria cuneata is widespread throughout northern North America; S. graminea occurs in eastern North America and is disjunct in Washington State; S. latifolia is widespread in eastern North America and sporadic in the west. Sagittaria australis, S. brevirostra, S. calycina, and $S$. platyphylla occur primarily in the eastern United States; S. rigida occurs in the eastern United States and southeastern Canada, with nonindigenous stations in Idaho and Washington; S. cristata occurs throughout the upper Great Lakes region. Sagittaria engelmanniana, S. filiformis, $S$. isoetiformis, and S. lancifolia occur along the southeastern Coastal Plain of the United States. Sagittaria subulata occurs along the eastern and southeastern coastal areas of the United States; $S$. teres is restricted to the coastal plain of the northeastern United States. Sagittaria longiloba occurs in the southwestern United States, and extends into Mexico and Central America. Species with more restricted distributions include S. ambigua (Illinois, Indiana, Kansas, and Missouri), $S$. demersa (New Mexico and elsewhere restricted to a small region of central Mexico), S. fasciculata (North and South Carolina), S. kurziana (Florida), S. papillosa (Arkansas, Louisiana, Oklahoma, and Texas), S. macrocarpa (endemic to the Sandhills Region of the Carolinas), S. sanfordii (endemic to California), and S. secundifolia (Alabama and Georgia). Sagittaria guayanensis has been introduced to Louisiana from the New World tropics; S. montevidensis was introduced to the southeastern United States and to California.

References: Abbitt \& Scott, 2001; Adair et al., 2012; Adams \& Godfrey, 1961; Ainsworth, 2006; Alves Pagotto et al., 2011; Atwood, 1950; Badzinski et al., 2006; Baldwin \& Mendelssohn, 1998; Baskin \& Baskin, 1998; 2015; Baxter, 2007; Beal, 1977; 
Beal et al., 1982; Bowes et al., 2002; Bowker, 1991; Bowyer et al., 2005; Boyd \& McGinty, 1981; Broadhurst \& Chong, 2011; Brewis, 1975; Brown, 1942; Bushnell, Jr., 1966; Calhoun \& King, 1998; Chafin, 2007; Colle et al., 1978; Collon \& Velasquez, 1989; Cooperrider, 1955; Coulter, 1955; Craven \& Hunt, 1984; Crocker, 1907; Crow, 1969; Cruden, 1988; Das et al., 2006; Davis, 1993; Delesalle \& Blum, 1994; De Oliveira et al., 2015; DeVlaming \& Proctor, 1968; Diamond, 2016; Dirrigl, Jr. \& Mohlenbrock, 2012; DiTomaso \& Healy, 2003; Dorken \& Barrett, 2003; 2004a; 2004b; 2004c; Dorken et al., 2002; Edwards \& Sharitz, 2000; 2003; Emerson, 1921; Enser \& Caljouw, 1989; Everitt et al., 1999; Fassett, 1957; Ferren, Jr., 1973; Ferren, Jr. \& Schuyler, 1980; Fields et al., 2003; Fraser et al., 1980; Frost \& Hicks, 2012; Glaettli \& Barrett, 2008; Gleason et al., 2003; Gluck, 1927; Godfrey \& Adams, 1964; Gonzalez et al., 1983; Grabowski, 2001; Grace \& Ford, 1996; Graves, 1984; Grier, 1916; Hamel \& Parsons, 2001; Harms \& Grodowitz, 2009; Harrison \& Knapp, 2010; Harvey \& Haines, 2003; Hauber \& Lege, 1999; Haukos \& Smith, 1997; 2001; Haynes \& Hellquist, 2000a; Haynes \& Holm-Nielsen, 1994; Haynes \& Les, 2004; Heilman \& Carlton, 2001; Hellquist \& Crow, 1981; Hendricks \& Goodwin, Jr., 1952; Hestand \& Carter, 1974; Hoagland \& Buthod, 2007; Hoagland et al., 2001; Hohman et al., 1990; Hooper, 1951; Howard \& Mendelssohn, 1995; Hoyer et al., 1996; Huang, 2003; Huang et al., 2000; Hussner, 2012; Jacono, 2001; 2002; Johnson \& Rohwer, 2000; Kandalepas et al., 2010; Kasselmann, 2003; Kaul, 1976; 1979; 1991; Kenow \& Lyon, 2009; Kissoon et al., 2013; 2015; Knapton \& Pauls, 1994; Koch, 1970; Korschgen \& Moyle, 1955; Kral, 1982; Labisky et al., 2003; Lagueux et al., 1995; Laidig \& Zampella, 1996; Landers et al., 1977; Lavoie et al., 2003; Leck \& Graveline, 1979; Lehman et al., 2009; Lehtonen, 2009; Les \& Tippery, 2013; Linn et al., 1975; Little, Jr., 1938; Lot et al., 2002; Low \& Bellrose, Jr., 1944; Luken \& Thieret, 2001; MacGillivray, 1903; MacRoberts \& MacRoberts, 2010; Manandhar, 1985; Mancera et al., 2005; Manolis, 2016; Marburger, 1993; Martin \& Shaffer, 2005; Mason, 1957; Mattson et al., 1995; Matulewich \& Finstein, 1978; McAtee, 1939; McGaha, 1952; McKee \& Mendelssohn, 1989; McPherson \& Paskewitz, 1984; Middleton, 1989; Mitchell, 1926; Mohr, 1901; Morrone, 2013; Moyle, 1945; Muenchow, 1998; Muenchow \& Delesalle, 1992; 1994; Mulhouse, 2004; Nakamura \& Nelson, 2001; Newberry, 1991; Norquist, 1990; O'Brien, 1997; Padgett et al., 2004; Pates \& Madsen, 1955; Perkin et al., 2012; Perry \& Dorken, 2011; Pezeshki et al., 2000; Phillips, 1911; Phillips et al., 2011; Pollux, 2011; Power, 1996; Profous \& Loeb, 1984; Quinlan et al., 2008; Reid et al., 2010; Rhodes, 1978; Richards \& Ivey, 2004; Robinson \& Frye, 1986; Rosen, 2007; Rubtsov, 1975; Sarkissian et al., 2001; Sasser et al., 1995a; Sawyer et al., 2005; Schlickeisen et al., 2003; Schuyler \& Gordon, 2002; Shaffer et al., 1992; Schaffner, 1924; Self et al., 1975; Sharitz et al., 2010; Skinner \& Telfer, 1974; Sletten \& Larson, 1984; Smith, 1895; 1900; Smith \& Capinera, 2005; Sneddon \& Lamont, 2010; Snyder, 1988; Sorrie et al., 2006; 2007; Stevens, 1957; Strong \& Kelloff, 1994; Sugden \& Driver, 1980; Sullivan, 1981; Takos, 1947; Terrell et al., 1978; Thieret, 1969; 1970; Thompson \&
McKinney, 2006; Tom \& Karr, 2013; Turner, 1996; Turner et al., 2012; USFWS, 1983; 2014; Vamosi et al., 2006; Van der Valk \& Rosburg, 1997; Van der Valk et al., 2009; Van Drunen \& Dorken, 2012; Vidal, 1960; Wallis, 2007; Wang et al., 2006; Wang et al., 2012a; Wellborn \& Robinson, 1987; Weller, 1988; Wells \& Alexander, 2014; West, 1945; Whetstone et al., 1987; Whyte \& Cain, 1981; Wilson, 1937; Wooten, 1970; 1971; 1973a; 1973b; 1978; 1986; Wooten \& Brown, 1983; Yanovsky, 1936; Yatskievych \& Jenkins, 1981; Zaremba \& Lamont, 1993; Zebryk, 2004; Zhang et al., 2010a; 2013a; Zhang et al., 2014a.

\section{Family 2.2. Butomaceae [1]}

Although once recognized as a somewhat broader taxon that included members of the former Limnocharitaceae (now merged with Alismataceae), Butomaceae currently are circumscribed as a monotypic family comprising only Butomus and the single species B. umbellatus (Cronquist, 1981). Phylogenetic analysis of sequence data from the $r b c L$ gene provided supportive evidence that Butomaceae were not only distinct from Limnocharitaceae but resolved as the sister group to Hydrocharitaceae rather than Alismataceae, where the limnocharit genera were included (Les et al., 1997a). The same sister-group association of Butomaceae and Hydrocharitaceae has been recovered in many subsequent analyses (see Les \& Tippery, 2013), including those incorporating sequence data from complete cpDNA genomes (Ross et al., 2016; Figure 1.2).

This is a fairly distinctive group of aquatics bearing linear, distichous, sheathing leaves that arise from an elongate rhizome, and perfect, hypogynous, trimerous flowers with an apocarpous gynoecium of nectariferous, basally connate, distally unsealed carpels, which mature into follicles; placentation is laminar (Cronquist, 1981). The flowers are arranged in large, showy, determinate umbels, which terminate an elongate, naked scape. Other aspects of the life history, economic uses, etc. are discussed below under the generic treatment.

Butomaceae are indigenous to temperate Eurasia and North Africa, but introduced to North America. One North American genus contains OBL indicators:

\subsubsection{Butomus L.}

\subsubsection{Butomus}

Flowering rush; butome à ombelle

Etymology: after the Greek bous tomos ("ox cutting") in reference to the unsuitability of the plant for fodder

Synonyms: none

Distribution: global: Africa (northern); Eurasia; North America; North America: north central

Diversity: global: 1 species; North America: 1 species Indicators (USA): obligate wetland (OBL): Butomus umbellatus

Habitat: freshwater; lacustrine, palustrine, riverine; $\mathbf{p H :} 7.3-$ 7.6; depth: 0-2.5 m; life-form(s): emergent, floating-leaved, or submersed (rosulate) herb

Key morphology: plants stemless, rhizomatous (to $40 \mathrm{~cm}$ ), emersed, floating-leaved, or submersed; leaves (to $2.7 \mathrm{~m}$ ) 
basal, sessile, sheathed, linear, triangular in section, flattened distally; inflorescence an erect, scapose, umbel (to 25-flowered), the scape (to $150 \mathrm{~cm}$ ) naked, triangular in section; flowers (to $2.5 \mathrm{~cm}$ ) bisexual, pedicellate (to $10 \mathrm{~cm}$ ), hypogynous, trimerous; tepals (to $11.5 \mathrm{~mm}$ ) six, pinkish purple, the veins darker; stamens (to $5.5 \mathrm{~mm}$ ) nine, in two cycles; gynoecium apocarpous (but coherent basally), pistils six, placentation laminar, ovules 50; follicles (to $1 \mathrm{~cm}$ ) leathery, beaked

Life history: duration: perennial (bulbils, rhizomes); asexual reproduction: bulbils, rhizomes; pollination: self; insect; sexual condition: hermaphroditic; fruit: follicles (infrequent); local dispersal: bulbils (water), rhizome fragments (water), seeds (gravity, wind); long-distance dispersal: bulbils (water), seeds (birds, water)

Imperilment: 1. Butomus umbellatus [G5]

Ecology: general: Monotypic (see next).

2.2.1.1 Butomus umbellatus L. is a nonindigenous perennial, which inhabits exposed substrates to relatively deeper waters (typically $0.9-1.3 \mathrm{~m}$ but up to $4.5 \mathrm{~m}$ ) in backwaters (diked), bays, bogs (floating), channels (dried), ditches, flats (river), floodplains, gravel pits, lakes, marshes, meadows, mudflats, ponds (retention), rivers, sand/mud bars, shoals, shores (receding), sloughs, streams, swales, and along the margins of canals, lakes, ponds, reservoirs, rivers, and streams at elevations to $1372 \mathrm{~m}$. Site exposures are open and receive full sunlight. The sites typically are alkaline (e.g., pH: 7.3-7.6; total alkalinity: 55-153 $\mathrm{mg} \mathrm{l}^{-1}$ ). The plants grow as emergent, floating-leaved, or completely submersed life-forms and occur often in swift currents. The biomass peaks at $1.3 \mathrm{~m}$ depth and decreases in deeper water. The plants have a strong affinity for coarse substrates but occur on clay, clayey sand, gravel, muck, mucky cobble, mud, rock, sand, and silt. Flowering occurs from June to October with fruiting extending from July to October. The flowers of diploids are self-compatible (the triploids being sterile). However, they are protandrous (with a short, initial male phase) and require pollinators to achieve seed set. At the umbel level, the plants are synchronously dichogamous, with nearly three quarters of the female flowers being receptive while the male phase is absent. Pollen is shed sequentially from 3 to $11 \mathrm{hr}$ after anthesis and is completely removed from the flowers by $12 \mathrm{hr}$; the stigmas sequentially become receptive at about $15 \mathrm{hr}$ from the onset of anthesis, continuing until about $21 \mathrm{hr}$ after the initial floral opening. Pollen retains high viability for $7 \mathrm{hr}$, but becomes inviable after $24 \mathrm{hr}$; wet pollen rapidly loses viability. During the male phase, the dehiscence of anthers is "reversible"; i.e., being able to reclose in wet conditions and reopen subsequently (within 13-20 min) under dryer conditions. The insect (Insecta) pollinators include bees (Hymenoptera: Apidae) and flies (Diptera: Syrphidae). The highest floral visitation rates occur on sunny days when the flowers are dry. Polymorphic gynoecium color (pink or white) has been observed in China, where pink morphs (the common type) produce more pollen and ovules (and exhibit correspondingly higher seed production) than the white morphs. A single plant can produce 35,000 small $(0.16 \mathrm{mg})$ seeds on average, with larger plants yielding an estimated 500 fruits and 258,000 seeds. Typically, the seeds fall directly on the ground beneath the maternal plant or are dispersed locally by wind; however, they are buoyant and can remain afloat for several days, which facilitates longer distance dispersal by water. The seeds also are believed to be dispersed by becoming entangled within the feathers of birds (Aves). The seeds reportedly germinate adequately (20-50\%) after being cold stratified for several months in water and then subjected to an $8 / 16$-hr light/dark regime at $25^{\circ} \mathrm{C} / 10^{\circ} \mathrm{C}$. They require light for germination, which also has been achieved successfully for stratified seeds incubated at $20^{\circ} \mathrm{C}-30^{\circ} \mathrm{C}$ under long-day conditions. The seeds are known to retain up to $68 \%$ viability after 5 years of storage in cold water. The seedlings grow well in cultivation under a $14 / 10 \mathrm{hr}, 30^{\circ} \mathrm{C} / 20^{\circ} \mathrm{C}$, light/temperature regime (70\% relative humidity). The seedlings grow slowly, are capable of floatation, and require at least 2 months of unshaded conditions in order to establish. Vegetative bulbils can replace flowers in the inflorescence and also develop from the rhizomes; either can function as asexual propagules. There are somewhat conflicting reports regarding the production of vegetative structures relative to different cytotypes. In native European populations, triploid plants reproduce primarily by vegetative reproduction involving prolific, detachable, rhizome buds and the development of inflorescence bulbils, which both are capable of water dispersal; the diploids produce fewer rhizome buds and lack floral bulbils. Individual plants consistently can produce upward of 200 vegetative bulbils annually. However, in the introduced North American plants, diploid plants were found to invest highly in sexual structures as well as in clonal bulbils, whereas the triploids were sterile and did not produce vegetative bulbils. Plants in introduced regions also produce a greater number of sexual inflorescences and asexual bulbils and invest more biomass in each reproductive mode than those in native populations, which may account for their successful invasion ability. The bulbils appear in midAugust when water temperatures approach $22.5^{\circ} \mathrm{C}$ and can be produced by plants less than $25 \mathrm{~cm}$ in length. They reach their highest density (averaging 200-300 buds $\mathrm{m}^{-2}$ ) at depths from 0.3 to $1.6 \mathrm{~m}$. The plants spread rapidly during periods of low water, which results in more substrate for colonization by sexual and vegetative propagules. The average ramet density can approach $100 \mathrm{~m}^{-2}$. Genetic studies have confirmed that reduced variability and fewer genets characterize the introduced North American populations, which presumably underwent a severe bottleneck at their time of introduction. North American plants emerge from May to June and reach peak DM biomass by late July, which can exceed $108 \mathrm{~g} \mathrm{~m}^{-2}$. Reported associates (North America): Alisma subcordatum, Asclepias incarnata, Bidens cernuus, Bidens trichospermus, Bolboschoenus fluviatilis, Carex cristatella, Ceratophyllum demersum, Chara, Drepanocladus, Echinochloa crusgalli, Eleocharis erythropoda, Eleocharis obtusa, Elodea canadensis, Glyceria grandis, Glyceria striata, Heteranthera dubia, Hippuris vulgaris, Hydrocharis morsus-ranae, Iris pseudacorus, Iris virginica, Leersia oryzoides, Lemna minor, Lindernia dubia, Ludwigia palustris, Ludwigia polycarpa, Lycopus virginicus, Lythrum salicaria, Mentha arvensis, Myriophyllum hippuroides, Myriophyllum sibiricum, 
Myriophyllum spicatum, Najas flexilis, Nitella, Nuphar advena, Nuphar variegata, Nymphaea odorata, Nymphoides peltata, Peltandra virginica, Persicaria amphibia, Persicaria lapathifolia, Phalaris arundinacea, Phragmites australis, Poa palustris, Pontederia cordata, Populus angustifolia, Populus deltoides, Potamogeton amplifolius, Potamogeton crispus, Potamogeton foliosus, Potamogeton gramineus, Potamogeton illinoensis, Potamogeton nodosus, Potamogeton praelongus, Potamogeton pusillus, Potamogeton richardsonii, Potamogeton robbinsii, Potamogeton zosteriformis, Potentilla anserina, Ranunculus aquatilis, Ranunculus flabellaris, Ricciocarpus, Rorippa aquatica, Rosa woodsii, Rumex altissimus, Rumex crispus, Rumex verticillatus, Sagittaria cuneata, Sagittaria latifolia, Salix exigua, Schoenoplectus acutus, Schoenoplectus pungens, Schoenoplectus tabernaemontani, Scirpus atrovirens, Sparganium androcladum, Sparganium eurycarpum, Stuckenia pectinata, Trapa natans, Typha angustifolia, Typha latifolia, Utricularia macrorhiza, Vallisneria americana, Xanthium strumarium, Zannichellia palustris, Zizania aquatica.

Use by wildlife: The leaves of Butomus umbellatus are eaten by muskrats (Mammalia: Cricetidae: Ondatra zibethicus), and the bulbils are consumed by blue-winged teal (Aves: Anatidae: Anas discors). North American plants also are host to chytrids (Fungi: Blastocladiomycota: Physodermataceae: Physoderma butomi), Fungi (Ascomycota: Nectriaceae: Fusarium oxysporum; Pestalotiopsidaceae: Pestalotiopsis guepinii; Xylariaceae: Dicyma ovalispora, Virgaria nigra; Basidiomycota: Agaricaceae: Phoma), larval caddisflies (Insecta: Trichoptera: Leptoceridae: Ylodes; Ceraclea, Oecetis, Triaenodes), larval flies (Insecta: Diptera: Chironomidae: Chironomus, Rheotanytarsus), and snails (Mollusca: Gastropoda: Lymnaeidae: Lymnaea stagnalis; Physidae: Physa).

Economic importance: food: The rhizomes and bulbils of Butomus umbellatus are high in starch and have been eaten (when dried or roasted) or ground into flour for bread making; medicinal: Acetone extracts of Butomus umbellatus are inhibitory to some microbes (Bacteria: Bacillaceae: Bacillus subtilis); cultivation: Butomus umbellatus is grown as an ornamental water garden plant and has been distributed under the cultivar names 'Rosenrot' and 'Schneeweisschen'; misc. products: The Iroquois made a decoction using whole plants of Butomus, which they added to livestock feed as a treatment for parasitic worms; weeds: Butomus umbellatus is a weed of North American wetlands, where it has been described as being more invasive than purple loosestrife (Lythraceae: Lythrum salicaria); nonindigenous species: Butomus umbellatus is nonindigenous to the New World, introduced to North America sometime prior to 1897. Morphological and genetic data indicate that there have been several separate introductions of the species from different regions of Eurasia. The first introductions presumably resulted from the seed-contaminated ballast and packing materials disposed by ships along the St. Lawrence River. Introductions have continued, primarily via the escape of horticultural specimens.
Systematics: Molecular phylogenetic analyses consistently resolve the monotypic Butomus as the sister group of Hydrocharitaceae (e.g., Figures 1.2 and 1.3). Being monotypic, the genus also is monophyletic. Although two species have been proposed by some researchers, most evidence (including transplant studies) indicates that there is a single but cytotypically variable species. The base chromosome number of Butomus is $x=13$. Butomus umbellatus has diploid $(2 n=26)$ and triploid $(2 n=39)$ cytotypes, which both occur in New World populations. Triploid populations are believed to have multiple origins. All coding regions for the chloroplast and mitochondrial genomes of $B$. umbellatus have been sequenced, providing ample data for phylogenetic studies. Butomus is not known to hybridize.

Comments: Butomus umbellatus occurs throughout central North America, north of the glacial maxima.

References: Anderson et al., 1974; Barrett et al., 2008; Bhardwaj \& Eckert, 2001; Brown \& Eckert, 2005; Core, 1941; Countryman, 1970; Cuenca et al., 2013; Delisle et al., 2003; Eckert et al., 2000; Fernald \& Kinsey, 1943; Fernando \& Cass, 1996; Gunderson et al., 2016; Harms \& Shearer, 2015; Haynes, 2000a; Hroudová \& Zákravský, 1993; 2003; Hroudová et al., 2004; Huang \& Tang, 2008; Les \& Mehrhoff, 1999; Les \& Tippery, 2013; Li et al., 2012; Lohammar, 1954; Lui et al., 2005; Madsen et al., 2016; Maki \& Galatowitsch, 2004; Muenscher, 1936; Özbay \& Alim, 2009; Ross et al., 2016; Salisbury, 1976; Sparrow, 1974; Stuckey, 1968; Turnage et al., 2012.

\section{Family 2.3. Hydrocharitaceae [17]}

With approximately 127 entirely aquatic species, Hydrocharitaceae are among the most diverse hydrophyte families. Every member of the group is designated as an OBL indicator throughout North America. Although not large in terms of species, the family contains an impressive assortment of growth forms (emergent, floating-leaved, free-floating, submersed), habits (annual, perennial, rosulate, vitatte), and pollination systems (anemophily, entomophily, epihydrophily, hypohydrophily, self-pollination). It is the only known angiosperm family to contain an unusual water-mediated pollination system, which involves detached, free-floating, male flowers. Moreover, it is one of only three angiosperm families to contain "seagrasses" (i.e., angiosperms adapted marine habitats) as well as freshwater species. Leaf and floral morphology are equally diverse.

Various phylogenetic studies (e.g., Les \& Haynes, 1995; Les \& Tippery, 2013; Les et al., 1993; 1997c; 2006a; Petersen et al., 2006; Ross et al., 2016; Shaffer-Fehre, 1991) have clarified the circumscription of the family to include the former Najadaceae, whose highly reduced morphology has made it difficult to place among other alismatid monocots. All of these studies, which encompass morphological as well as DNA sequence data (from mitochondrial, nuclear, and plastid genomes), have consistently supported the merger of Najadaceae and Hydrocharitaceae as a single clade. Similar lines of evidence (e.g., Figures 1.2 and 1.3) support Butomaceae as the sister group. 
Economically, the family is important as a source of ornamental water garden and aquarium plants, which are represented by a large number of genera. For decades, introductory botany courses have used Egeria densa as a "classic example" for illustrating the phenomenon of cytoplasmic streaming. Many species provide food and cover for a variety of wildlife. The three marine genera (Enhalus, Halophila, and Thalassia) are of particular importance to the ecology of coastal marine habitats. However, a number of genera (e.g., Egeria, Hydrilla, Hydrocharis, Lagarosiphon, Najas) also include noxious, weedy species, which have seriously disrupted the ecology of many freshwater systems. In North America, all such cases represent nonindigenous introductions. Some of the resulting infestations have had significant economic consequences and are responsible for millions of dollars in annual expenditures directed at their control.

Eleven genera occur in North America and all contain OBL indicators:

2.3.1. Blyxa Noronha ex Thouars

2.3.2. Egeria Planch.

2.3.3. Elodea Michx.

2.3.4. Halophila Thouars

2.3.5. Hydrilla Rich.

2.3.6. Hydrocharis L.

2.3.7. Limnobium Rich.

2.3.8. Najas L.

2.3.9. Ottelia Pers.

2.3.10. Thalassia Banks \& Sol. ex K.D. Koenig

2.3.11. Vallisneria L.

\subsubsection{Blyxa}

Bamboo plant, blyxa

Etymology: thought to be derived from the Greek blyzo ("to flow"), in reference to the habitat

Synonyms: Diplosiphon; Enhydrias; Hydrilla (in part); Hydrolirion; Hydrotrophus; Saivala; Vallisneria (in part)

Distribution: global: Africa; Asia; Australia; North America*; North America: southern United States

Diversity: global: 12 species; North America: 1 species

Indicators (USA): obligate wetland (OBL): Blyxa aubertii

Habitat: brackish, freshwater; lacustrine; pH: 6.0-7.4; depth: $<1 \mathrm{~m}$; life-form(s): submersed (rosulate)

Key morphology: stems (to $3 \mathrm{~cm}$ ) cormose; leaves (to $60 \mathrm{~cm}$ ) basal, submersed, linear, sessile, the margins finely serrate; inflorescence solitary, peduncled (to $50 \mathrm{~cm}$ ) or sessile (rarely), with flattened spathe; flowers (to $15 \mathrm{~cm}$ ) bisexual, trimerous, emersed (then chasmogamous) or submersed (then cleistogamous); sepals (to $10 \mathrm{~mm}$ ) green; petals (to $17 \mathrm{~mm}$ ) linear, white or reddish; stamens (to $5.8 \mathrm{~mm}$ ) 3; capsules (to $80 \mathrm{~mm}$ ) terete, cylindrical, 1-locular, style single, stigmas (to $15 \mathrm{~mm}$ ) linear; seeds (to $1.8 \mathrm{~mm}$ ) numerous, the surface smooth or with up to 12 warty ridges

Life history: duration: annual (fruits/seeds); asexual reproduction: none; pollination: autogamy; sexual condition: hermaphroditic; fruit: capsules (common); local dispersal: seeds (water); long-distance dispersal: seeds (birds)
Imperilment: 1. Blyxa aubertii [GNR]

Ecology: general: All Blyxa species are submersed, obligately aquatic plants, with only their flowers emerging from the water during sexual reproduction. The species include rosulate or vittate annuals and perennials, with the latter developing stolons. The flowers can be bisexual or unisexual (then arranged dioeciously). The bisexual flowers are either emergent and chasmogamous or submersed and cleistogamous (when growing in deeper water), with both types being highly autogamous. The unisexual flowers are emergent and are pollinated by insects (Insecta: Diptera; Odonata). The seeds are smooth or spiny (sometimes variable within a species), with the latter capable of tangling together and then being dispersed as a larger unit. Local dispersal occurs by water and probably over greater distances by animal vectors (presumably by seeds attached in adhering mud). The seeds are known to be eaten by birds (Aves), but it has not determined whether they remain viable after passage through their digestive tract. Large seed banks can develop in some species. The highest seed germination occurs on the sediment surface. 2.3.1.1. Blyxa aubertii Rich. is an annual which grows in borrow pits, lakes (artificial), pools, and rice fields at elevations to $70 \mathrm{~m}$. In North America, the plants occur primarily in turbid waters (to $91 \mathrm{~cm}$ depth), which are associated with anthropogenically disturbed habitats. In portions of the native range, the waters are circumneutral (pH: 6.0-7.4) and often are characterized by iron precipitation. The plants have been cultivated successfully in subalkaline waters of medium hardness at $20^{\circ} \mathrm{C}-28^{\circ} \mathrm{C}$. In North America, the substrates are nutrient poor and have been described as clay, clay mud, and mud. Flowering in North America has been observed from July to December. The plants can allocate up to $38.1 \%$ of their DM biomass to sexual reproduction. The flowers are bisexual, self-compatible, and chasmogamous when emersed but cleistogamous when submersed (which occurs when excessive water depth precludes floral emergence). Because the anthers dehisce before the perianth and the stigmas expand beyond the calyx (pollen is collected as their expansion ensues), both types are highly autogamous and have comparable levels of seed set. During anthesis (lasting just 2 days), little pollen is exposed to potential pollinators, and no biotic pollinators have been observed. Studies of populations in Japan found there to be from 10 to 71 flowers/plant, 45.3 seeds/fruit, and $92.9 \%$ seed set on average. Individual plants are capable of producing from 340 to 4224 seeds, with larger plants producing higher seed numbers. Mechanisms of seed dispersal in this species are uncertain, but presumably include water (locally) and adherence to mud on the feet of migrating waterfowl (Aves: Anatidae) over greater distances. Seeds also have been dispersed inadvertently by transport within contaminated rice (Poaceae: Oryza) seed. Reported associates (North America): Ceratophyllum demersum, Egeria densa, Juncus repens, Limnophila indica, Limnophila $\times$ ludoviciana, Najas minor, Nymphaea odorata, Potamogeton diversifolius, Sagittaria platyphylla.

Use by wildlife: Blyxa seeds are eaten by black-winged stilts (Recurvirostridae: Himantopus himantopus). The foliage is eaten by snails (Mollusca: Gastropoda). 
Economic importance: food: Blyxa aubertii is eaten as a green leaf vegetable in Vietnam; medicinal: Blyxa is mentioned in Ayurveda medical texts as a universal remedy; cultivation: Due to its fragile leaves (and annual habit), Blyxa aubertii is cultivated only occasionally as an aquarium plant; misc. products: none; weeds: Blyxa aubertii is a rice-field weed in Asia and North America. Korean populations of $B$. aubertii have become resistant to ALS inhibitor type herbicides; nonindigenous species: Blyxa aubertii was introduced to Louisiana rice fields around the 1960s.

Systematics: Molecular phylogenetic analyses consistently resolve Blyxa and Ottelia as sister genera; however, further taxon sampling will be necessary in order to determine whether Ottelia is monophyletic and distinct from Blyxa (e.g., Figure 1.8). Blyxa aubertii possesses a seed amino acid profile similar to that of $B$. echinosperma, which some authors treat as a variety of the former. The two taxa undoubtedly are closely related if not conspecific. The basic chromosome number of Blyxa probably is $x=6$. Several anomalous counts $(2 n=16,24$, and 40$)$ have been reported for B. aubertii and the cytology of this species requires further clarification. No Blyxa hybrids have been reported.

Distribution: In North America, Blyxa aubertii currently is known only from Louisiana and Mississippi.

References: Bhunia \& Mondal, 2014; Cook, 1996a; 1996b; Cook \& Lïönd, 1983; Feitoza et al., 2009; Haynes, 2000b; Jiang \& Kadono, 2001; Kasselmann, 2003; McNair \& Alford, 2014; Ogle et al., 2001; Quattrocchi, 2012; Sullivan, 1981; Thieret et al., 1969.

\subsubsection{Egeria}

Brazilian elodea, Brazilian waterweed, South American waterweed

Etymology: after the Latin Aegeria, a legendary Roman nymph of springs

Synonyms: Anacharis (in part); Elodea (in part); Philotria (in part); Udora (in part)

Distribution: global: New World; North America: United States, British Columbia (Canada)

Diversity: global: 3 species; North America: 2 species

Indicators (USA): obligate wetland (OBL): Egeria densa, E. naias

Habitat: brackish (coastal), freshwater; lacustrine, riverine; pH: 5.2-8.9; depth: to $3 \mathrm{~m}$; life-form(s): submersed (vittate) Key morphology: stems (to $3 \mathrm{~m}+$ ) completely submersed or floating, single or branched, rooted in the substrate (or water); leaves cauline, in whorls (of 4-5+), dense (internodes to $2.4 \mathrm{~cm}$ ), sessile, the blades (to $40 \mathrm{~mm}$ ) linear, flat or recurved, the margins finely to strongly serrate, the apex tipped by a single spine; flowers unisexual (plants dioecious); inflorescence (ठ) 2-5-flowered, enclosed in a sessile spathe (to $12 \mathrm{~mm}$ ), the flowers raised above the surface by an elongate peduncle (to $80 \mathrm{~mm}$ ); sepals 3, green (to $4.4 \mathrm{~mm}$ ); petals (to $10.5 \mathrm{~mm}$ ) 3, white, shiny; stamens 9, the filaments (to $4.5 \mathrm{~mm}$ ) clavate, papillose, yellow, contracted below anthers (to $1.8 \mathrm{~mm}$ ); pistillate flowers (o) either absent or smaller than the male flowers; when present, the spathes (to $8 \mathrm{~mm}$ ) 1-2-flowered, the flowers

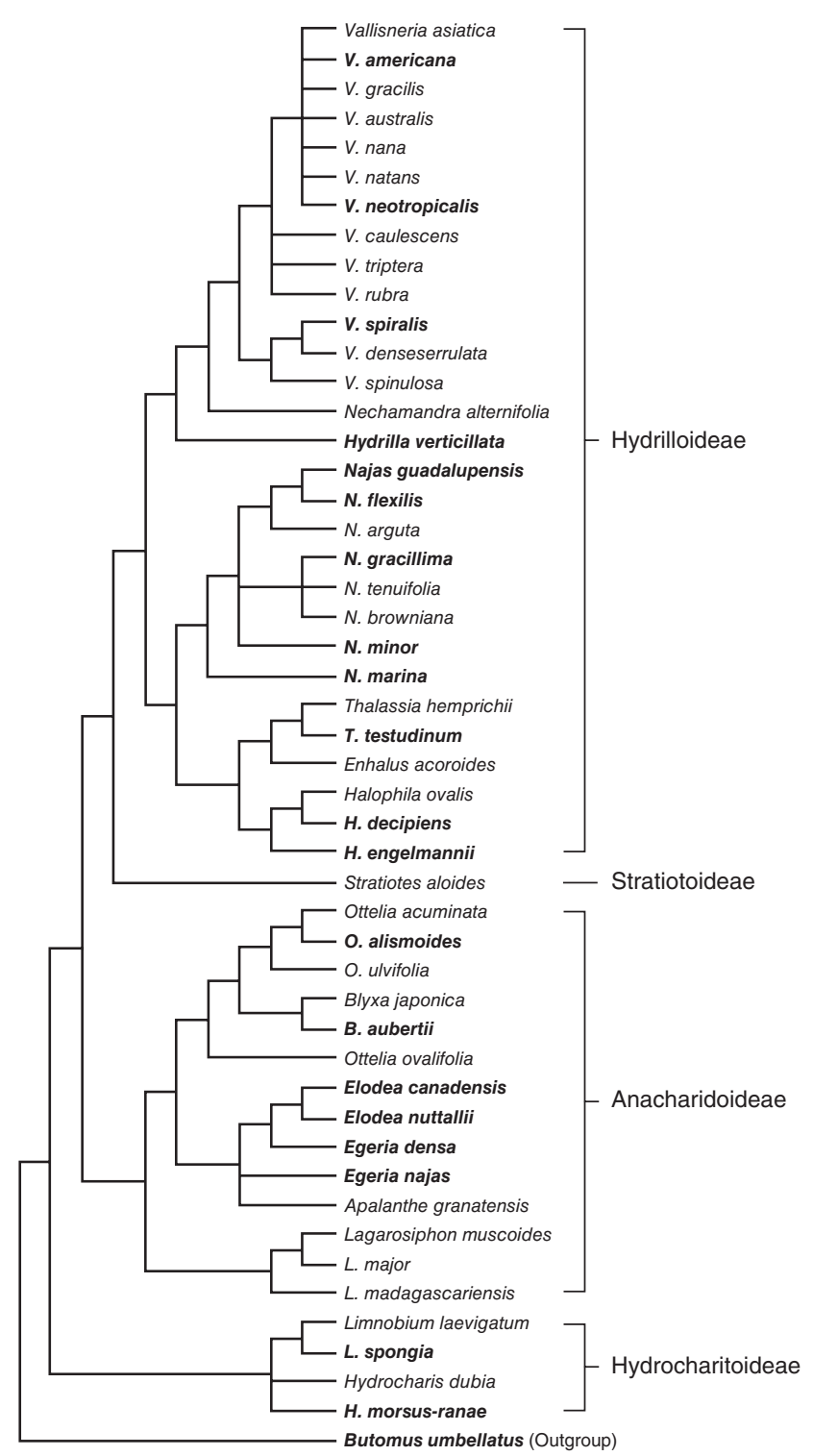

FIGURE 1.8 Phylogenetic relationships in Hydrocharitaceae as indicated by a 167-taxon analysis of $r b c L$ sequence data (adapted from Les \& Tippery, 2013). The result is similar to an analysis of full cpDNA data (Ross et al., 2016) by resolving four distinct clades corresponding to subfamilies Anacharidoideae, Hydrilloideae, Hydrocharitoideae, and Stratiotoideae; however, the interrelationships among these clades are resolved somewhat differently in the two studies. Although the entire family is aquatic, the OBL North American taxa (highlighted in bold) are scattered throughout the phylogeny.

raised above the water surface by their elongate hypanthium (to $48+\mathrm{mm}$ ); the petals 3 (to $8.5 \mathrm{~mm}$ ), white, conspicuous, with 3 orangish or reddish, papillose staminodes (to $2.4 \mathrm{~mm}$ ); nectaries (3) present; ovary (to $3 \mathrm{~mm}$ ) inferior, styles (to 3.8 $\mathrm{mm}$ ) 3, each with 2-4 lobed stigmas, ovules (to 9) erect; capsules (to $14.5 \mathrm{~mm}$ ) irregularly dehiscent; seeds (to $7.2 \mathrm{~mm}$ ) beaked (to $3.7 \mathrm{~mm}$ ), ellipsoidal

Life history: duration: perennial (whole plants); asexual reproduction: shoot fragments; pollination: insect; sexual condition: dioecious; fruit: capsules (absent); local 
dispersal: shoot fragments (water); long-distance dispersal: shoot fragments (humans, water)

Imperilment: 1. Egeria densa [G5]; E. naias [unranked] Ecology: general: The genus Egeria is entirely aquatic, with all species occurring as submersed growth forms where only the flowers emerge above the water surface. The flowers are unisexual and are arranged in a dioecious condition. They are produced almost continuously when water temperatures are within $15^{\circ} \mathrm{C}-25^{\circ} \mathrm{C}$. The flowers are nectariferous, scented, and appear to be pollinated by small insects such as flies (Insecta: Diptera). However, in at least one species, the nonindigenous North American material is comprised entirely of male plants, thereby lacking any ability for sexual reproduction. Little is known regarding the seed production or germination requirements of the plants in their indigenous range. In North America, the plants are vegetatively vigorous and exclusively reproduce asexually by the production and spread of vegetative shoot fragments.

2.3.2.1. Egeria densa Planch. inhabits still or flowing (e.g., $30 \mathrm{~cm} \mathrm{~s}^{-1}$ ), tidal or non-tidal, brackish to freshwaters (to 3.0 $\mathrm{m}$; to $7.0 \mathrm{~m}$ in its native range) in bayous, canals, channels (drainage), ditches (irrigation), floodplains, lagoons (gravel pit), lakes, ponds (irrigation), pools, puddles, reservoirs, rivers, sloughs, springs, and streams at elevations to $2165 \mathrm{~m}$. The plants can tolerate exposures ranging from full sunlight to deep shade; however, light reduction (e.g., to 25\%) has been observed to reduce relative growth rates. The experimentally determined optimal light intensity is only about 108 lumens and the plants do not acclimate well to higher light intensities. The waters span a broad range of acidity (pH: $6.0-8.9 ; \bar{x}: 7.4)$ and are relatively high in alkalinity $\left(\bar{x}: 38.2 \mathrm{mg} \mathrm{l}^{-1} \mathrm{CaCO}_{3}\right)$ and specific conductance $\left(\bar{x}: 184 \mu \mathrm{S} \mathrm{cm} \mathrm{cm}^{-1}\right)$, but relatively low in inorganic nitrogen $\left(\bar{x}: 100 \mu \mathrm{g}^{-1}\right)$ and phosphorous $\left(\bar{x}: 68 \mu \mathrm{g}^{-1}\right.$ ). The plants are particularly susceptible to iron deficiency. Optimal water temperatures range from $16^{\circ} \mathrm{C}$ to $28^{\circ} \mathrm{C}$, but temperatures up to $35^{\circ} \mathrm{C}$ are tolerated. Fertilization experiments indicate that the plants do not respond positively to increased sediment nutrient levels as do potential competitors such as Hydrilla (Hydrocharitaceae). Growth rates and biomass production generally correlate negatively with $\mathrm{pH}$, which is due to the higher concentrations of free $\mathrm{CO}_{2}$ in more acidic waters. However, the plants are adapted to the lower inorganic carbon levels in waters of higher $\mathrm{pH}$ by their ability to use bicarbonate $\left(\mathrm{HCO}_{3}^{-}\right)$as an alternative carbon source. They also possess a high-affinity nitrate transporter $\left(\mathrm{NRT}_{2}\right)$, which facilitates nitrate uptake, especially by the shoots. Under stressful conditions (high light and temperature), the shoots induce a C4-like photosynthetic mechanism by increasing expression levels of PEP carboxylase and malic enzyme. Studies in the western United States indicate that the lowest total nonstructural carbohydrate reserves (35-51\% starch) occur from March to June. The substrates include boulders, clay, clay loam, logs (submerged), mud (organic), sand (granite), sandy shell, sandy silt, silt, and silty loam (Congaree). In North America the plants flower from March to November; however, only male plants of this dioecious species have been introduced to the United States, making it reliant entirely on asexual reproduction. The plants essentially are evergreen and overwinter on the bottom (even under ice cover) as intact, short, dormant shoot fragments or rootstocks (sometimes more than $113 \mathrm{~m}^{-2}$ ), with their vegetative growth resuming when water temperatures warm to $10^{\circ} \mathrm{C}-15^{\circ} \mathrm{C}$. The starch concentration is highest in leaves (25.4\%) and stems $(22.6 \%)$ during the winter months. Optimal growth (in cultivation) occurs at $20.7^{\circ} \mathrm{C}$ and the plants are strong competitors in warm water environments $\left(20^{\circ} \mathrm{C}-30^{\circ} \mathrm{C}\right)$. Bimodal growth peaks (late spring and fall) have been observed in some areas. Dispersal occurs primarily by the generation of shoot fragments, which float on the water surface and are transported by currents. The fragments average $7.3 \mathrm{~cm}$ in length and $88 \%$ retain full regeneration capacity after 4 weeks. They also survive desiccation well (e.g., during drawdown), especially if mixed among mounds of other stranded vegetation. Fragments on the exposed sediment surface die within 22 days, but $32 \%$ of shoot apices on fragments at the bottom of exposed vegetation mounds have remained viable for more than 34 days. The fragments are tolerant of chlorates $\left(\mathrm{ClO}_{3}{ }^{-}\right)$and significant exposure (to $1,000 \mathrm{mg} \mathrm{l}^{-1}$ ) does not influence their extent of desiccation. Human-mediated transport of the fragments on boating and fishing equipment also facilitates their spread. Surveys of nonindigenous populations using RAPDs markers have shown very limited levels of variation, which indicates that genetic bottlenecks have occurred at the times of introduction, and/or that introduced plants have spread widely as clonally derived ramets. Reported associates (North America): Bidens beckii, Brasenia schreberi, Cabomba caroliniana, Callitriche, Ceratophyllum demersum, Ceratophyllum echinatum, Eichhornia crassipes, Eleocharis acicularis, Eleocharis palustris, Elodea canadensis, Heteranthera, Hydrilla verticillata, Isoetes, Lemna minor, Limnobium spongia, Ludwigia, Myriophyllum heterophyllum, Myriophyllum hippuroides, Myriophyllum spicatum, Najas flexilis, Najas guadalupensis, Nelumbo lutea, Nitella, Nuphar polysepala, Nymphaea capensis, Nymphaea odorata, Peltandra virginica, Pistia stratiotes, Potamogeton crispus, Potamogeton diversifolius, Potamogeton foliosus, Potamogeton richardsonii, Potamogeton robbinsii, Ranunculus aquatilis, Sagittaria montevidensis, Spirodela polyrhiza, Utricularia macrorhiza, Vallisneria americana, Vallisneria neotropicalis, Wolffia, Zizaniopsis miliacea.

2.3.2.2. Egeria naias Planch. is a nonindigenous, submersed perennial, which grows in lakes to depths of $1 \mathrm{~m}$. It occurs preferentially in warmer (optimum temperature: $15^{\circ} \mathrm{C}-26^{\circ} \mathrm{C}$ ), clear to tannin stained, somewhat acidic to alkaline $(\mathrm{pH}$ : 5.2-7.6) waters. In its native range, the plants are more tolerant to low light (compensation point: $6-22 \mu \mathrm{M} \mathrm{m}^{-2} \mathrm{~s}^{-1}$ PAR) and turbid water conditions than are those of the congeneric E. densa (see above). Although they are bicarbonate $\left(\mathrm{HCO}_{3}^{-}\right)$ users, they thrive less in higher bicarbonate/conductivity waters than $E$. densa, which exhibits a higher carbon uptake efficiency under low $\mathrm{CO}_{2}$ conditions. The plants rely on sediment nutrients ( $\mathrm{N}$ and $\mathrm{P}$ ) for optimal growth, but neither nutrient appears to be a growth limiting factor. In the indigenous range, the total number of male flowers ordinarily outnumbers 
Aquatic Monocotyledons of North America

the female flowers by ratios of 3-4:1. Levels of sexual reproduction appear to be reasonably high in native populations, which contain a fair level of genetic variability as indicated by allozyme and RAPD markers. Although the plants can tolerate turbid, eutrophic conditions, the regeneration of vegetative fragments occurs most rapidly in less-turbid, oligotrophic, and sand-dominated sites. Higher growth rates occur in vegetative fragments that retain the apical meristems. In their native range, the plants have exhibited low tolerance to drawdown conditions, which substantially impact the populations. Reported associates (North America): none. This species has only recently been found in Florida (USA) where it is known from a single locality.

Use by wildlife: Egeria densa contains $75.1 \%$ digestible dry matter and $17.4 \%$ crude protein. North American plants are eaten by apple snails (Mollusca: Gastropoda: Ampullariidae: Pomacea), crayfish (Crustacea: Decopoda: Cambaridae: Procambarus acutus, P. spiculifer), grass carp (Vertebrata: Teleostei: Cyprinidae: Ctenopharyngodon idella), larval leafcutter moths (Insecta: Lepidoptera: Crambidae: Parapoynx diminutalis), redbelly tilapia (Vertebrata: Teleostei: Cichlidae: Tilapia zilli), and Suwannee River cooters (Reptilia: Emydidae: Pseudemys concinna suwanniensis). The plants also provide rearing habitat for largemouth bass (Vertebrata: Teleostei: Centrarchidae: Micropterus salmoides). Several species of birds (Aves) intensely forage in Egeria densa beds, including common moorhens (Rallidae: Gallinula chloropus), little blue herons (Ardeidae: Egretta caerulea), and tricolored herons (Ardeidae: Egretta tricolor); they are foraged to a lesser extent by blue-winged teals (Anatidae: Anas discors), great blue herons (Ardeidae: Ardea herodias), pied-billed grebes (Podicipedidae: Podilymbus podiceps), snowy egrets (Ardeidae: Egretta thula), and wood ducks (Anatidae: Aix sponsa).

Economic importance: food: Neither Egeria densa nor $E$. naias is reported to be edible; medicinal: no medicinal uses for Egeria densa or E. naias are known; cultivation: Egeria densa is one of the most common plants sold commercially for freshwater aquariums (see also next). E. naias also is widely grown as an aquarium plant but only recently has become popular in the United States; misc. products: Egeria densa has been used widely as a botanical subject for various physiological experiments pertaining to cyclosis and photosynthesis. Meal made from dried E. densa has been used as a feed for chickens (Aves: Phasianidae: Gallus gallus). Egeria densa is under investigation as a potential renewal energy source (biomethane) via the process of continuous anaerobic digestion. Dead E. densa plants have shown to be effective biosorptives for the removal of copper ions $\left(\mathrm{Cu}_{2}^{+}\right)$from contaminated water; weeds: Egeria densa and E. naias are weedy in their native range and seriously invasive throughout their nonindigenous range; nonindigenous species: Egeria densa was introduced to the United States sometime before 1893 and also has been introduced (with variable persistence) to Africa, Australia, Chile, Denmark, England, France, Germany, Iceland (geothermal springs), Italy, Japan, The Netherlands, New Zealand, Russia, and Spain. The introductions have occurred by the careless disposal of plants used as botanical laboratory specimens or as aquarium ornamentals. The presence of plants in nonindigenous sites has been detected successfully from environmental DNA (eDNA) samples. Egeria naias was first detected in 2017 from a site in west-central Florida, which appears to have resulted from the careless disposal of aquarium plants.

Systematics: The monophyly of Egeria is uncertain, with phylogenetic analyses placing E. densa closer to Elodea than to its congener Egeria najas (Figure 1.8). Without further sampling of Egeria (E. heterostemon) and Elodea species, it is unclear whether Egeria should best be retained as a distinct genus or merged with Elodea (which often has been done in the past). The basic chromosome number of Egeria also is uncertain. Several different cytotypes $(2 n=16,24,46)$ have been attributed to plants identified putatively as Egeria densa, which raises doubts on the identification of the source material, especially because some of the cytotypes $(2 n=16,24)$ also are quite divergent genetically. No natural hybrids involving E. densa or E. najas have been reported. Experimental reciprocal crosses between these two species also have failed to set seed, which indicates the presence of an effective genetic isolating mechanism. Intergeneric crosses involving Elodea, Hydrilla, and Lagarosiphon also have been unsuccessful.

Distribution: Egeria densa occurs sporadically throughout the warmer parts of the United States; E. naias currently is known only in west-central Florida.

References: Baker et al., 2010; Barnes et al., 2013; Bartodziej \& Weymouth, 1995; Bini \& Thomaz, 2005; Blackburn et al., 1961; Boschilia et al., 2012; Boyd \& McGinty, 1981; Carter \& Sytsma, 2001; Catling \& Wojtas, 1986; Catling \& Mitrow, 2001; Conrad et al., 2016; Cook \& Urmi-König, 1984a; Crutchfield, Jr. et al., 1992; De Abreu Pietrobelli et al., 2009; DiTomaso \& Healy, 2003; Dugdale et al., 2012; ErnstSchwarzenbach, 1945; 1953; Fujiwara et al., 2016; Haramoto \& Ikusima, 1988; Haynes, 2000b; Hoyer et al., 1996; Hussner, 2012; Hussner et al., 2010a; 2016; Kasselmann, 2003; Kadono, 2004; Kadono et al., 1997; Koehler \& Bove, 2001; Lagueux et al., 1995; Lara et al., 2002; Les \& Tippery, 2013; Maurice et al., 1984; Mony et al., 2007; Mori et al., 1999; 2012; Mühlberg, 1982; Palma et al., 2013; Parker \& Hay, 2005; Pennington \& Sytsma, 2009; Pierinia \& Thomaz, 2004; Pine \& Anderson, 1991; Pulgar \& Izco, 2005; Redekop et al., 2016; Riis et al., 2012; Rixon et al., 2005; Santos et al., 2011; Silveira et al., 2009; Sultana et al., 2013; Takahashi \& Asaeda, 2014; Takayanagi et al., 2012; Tanaka et al., 2004; Tavechio \& Thomaz, 2003; Thomaz et al., 2007; Umetsu et al., 2012; Wasowicz et al., 2014; Yarrow et al., 2009; Yeo, 1966; Zhen et al., 2016.

\subsubsection{Elodea}

Waterweed; Elodée

Etymology: after the Greek helodes ("wetland") in reference to the habitat

Synonyms: Anacharis; Diplandra; Helodea; Hydora; Philotria; Serpicula; Udora

Distribution: global: Asia*; Australia*; Europe*; New World; New Zealand*; North America: widespread 
Diversity: global: 5 species; North America: 3 species Indicators (USA): obligate wetland (OBL): Elodea bifoliata, E. canadensis, E. nuttallii

Habitat: freshwater; lacustrine, riverine; $\mathbf{p H}$ : 5.6-10.2; depth: 0.1-12 m; life-form(s): submersed (vittate)

Key morphology: stems (to 4+ m) submersed, branching, flexuous, sometimes with turion-like buds and adventitious roots; foliage opposite or in whorls of 3- and 6-ranked, the leaves (to $15.5-24.8 \mathrm{~mm}$ ) sessile, linear to ovate, often clustered apically; plants dioecious; spathes (o to $8.2-42.0 \mathrm{~mm}$; o to $17.6-67.0 \mathrm{~mm}$ ) sessile, with 1-2 flowers; $0^{\star}$ flowers: essentially sessile (to $0.5 \mathrm{~mm}$ ) and detaching or long-pedicelled (to $15+\mathrm{cm})$ and attached, floating and opening at water surface; sepals (to 3.4-6.1 mm) 3, green; petals (to 2.6-6.2 mm) 3, reduced, whitish, translucent; stamens 9; 9 flowers: sepals (to $3.5 \mathrm{~mm}$ ) 3 , green; petals (to $3 \mathrm{~mm}$ ) 3 , reduced, whitish, translucent; staminodia (to $1.4 \mathrm{~mm}$ ) 3, hypanthium elongate (to 32 $\mathrm{cm}$ ); ovary syncarpous (3 carpels), inferior, styles (to $4 \mathrm{~mm}$ ) 3 , recurved, entire or bifid; capsules (to $10 \mathrm{~mm}$ ) irregularly dehiscent, several-seeded (to 10), beaked (to 6.5-20.0 mm); seeds (to $5.7 \mathrm{~mm}$ ) fusiform, smooth or covered by hairs (to $1 \mathrm{~mm})$

Life history: duration: perennial (dormant apices, rhizomes, winter buds); asexual reproduction: rhizomes, shoot fragments, winter buds; pollination: epihydrophily; sexual condition: dioecious; fruit: capsules (rare to common); local dispersal: seeds, shoot fragments (water); long-distance dispersal: shoot fragments (birds, water)

Imperilment: 1. Elodea bifoliata [G4/G5]; S1 (KS, NE, UT); $\mathrm{S} 2$ (Bㅡ, MT, $\underline{\mathrm{SK}}, \mathrm{WY}) ; 2$. E. canadensis [G5]; S1 (AL, NC, UT); S2 (SK, WY); S3 (IL, KY, NS); 3. E. nuttallii [G5]; S1 (KS, MB, NS, PE, WY); S2 (KY, MT, NB, NC, TN); S3 (BC, IL, ON, QC, VT, WV)

Ecology: general: All Elodea species are submersed aquatic plants, which extend only their flowers above the water surface. All three North American species are ranked as OBL indicators throughout their ranges. Although retained as OBL indicators in the National list, Elodea callitrichoides and $E$. schweinitzii have been excluded here. The former was erroneously reported for North America and the latter is not accepted taxonomically as a distinct species (see Systematics). When water clarity is high, the species can colonize depths up to $12 \mathrm{~m}$, which is the greatest maximum depth recorded for any freshwater aquatic angiosperm. All of the species are dioecious perennials, which possess an epihydrophilous water pollination system. The male flowers either detach from the submersed male plants and rise to the surface where they float and open or they remain attached to the male plants by long pedicels and open once they reach the surface. In either case, the pollen is shed from the male flowers onto the water surface, where it is transported by currents to the female plants. The female flowers also float, but remain attached to the maternal plants by an elongate hypanthium; once reaching the surface, they open and extend their stigmas into the water, where the floating pollen grains are encountered. Despite this rather intricate pollination system, there typically are few seeds produced (except in one species) and most of the reproduction is asexual. Vegetative reproduction occurs by the fragmentation of the shoots, which can remain viable having only a few nodes intact. The plants (or at least large fragments) also are known to overwinter readily, even in waters having thick ice cover. Requirements for seed germination have not been elucidated. The seeds and vegetative fragments are dispersed locally by water, and over greater distances by birds (Aves) as well as by human-mediated transport. Phenotypic plasticity is extensive and facilitates adaptation of the plants to variable local conditions. It is strongly advised that the taxonomic issues involving E. canadensis and E. nuttallii (see Systematics) be taken into account before attempting to interpret the ecological data provided for these species.

2.3.3.1. Elodea bifoliata H. St. John inhabits still or slowmoving (e.g., $0.57 \mathrm{~m}^{-3} \mathrm{~s}^{-1}$ ) waters (to $7.0 \mathrm{~m}$ deep) of canals, lakes, ponds, pools, potholes, reservoirs, rivers, sloughs, and streams at elevations to $3088 \mathrm{~m}$. The plants occur in open exposures to partial shade. They often are found floating on the surface of the water, or are washed ashore from sites established in deeper water. The waters are described as alkaline. The substrates have been characterized as mud, rock, sand, and sandy clay. Flowering occurs from July to August with fruiting extending through September. The plants are highly fertile and there has been some suspicion (but no definitive evidence) that they might be monoecious. Further life history information is lacking for this species. Reported associates: Alisma subcordatum, Azolla filiculoides, Carex microptera, Ceratophyllum demersum, Chara, Crypsis schoenoides, Elatine brachysperma, Elatine californica, Elatine rubella, Eleocharis acicularis, Eleocharis palustris, Eleocharis parishii, Glyceria, Gratiola, Lemna minor, Limosella, Marsilea mollis, Myriophyllum sibiricum, Myriophyllum spicatum, Najas guadalupensis, Najas marina, Persicaria amphibia, Persicaria coccinea, Potamogeton diversifolius, Potamogeton foliosus, Potamogeton gramineus, Potamogeton natans, Potamogeton nodosus, Potamogeton pusillus, Potamogeton richardsonii, Potamogeton richardsonii, Ranunculus aquatilis, Ranunculus longirostris, Schoenoplectus acutus, Sparganium, Stuckenia pectinata, Utriculata, Veronica, Wolffia columbiana, Zannichellia palustris.

2.3.3.2. Elodea canadensis Michx. inhabits standing freshwaters (to $12.0 \mathrm{~m}$ deep) in backwashes, backwaters, bays, beaches, bottomlands (river), canals, channels, depressions, ditches (drainage; irrigation; roadside), floodplains, flumes, gravel pits, lagoons, lakes, mudflats, ponds, pools, potholes, reservoirs, rivers, sloughs, springs, and streams at elevations to $3326 \mathrm{~m}$. The plants occur occasionally in slightly brackish water but can tolerate only low salinity levels $(<3.5 \mathrm{ppt})$. Habitats can span a broad range of acidity (pH: 6.5-10.2), but typically are mesotrophic to eutrophic, alkaline waters ( $\mathrm{pH}: \bar{x}$ $=7.6-7.8$ ) of higher alkalinity (to $300 \mathrm{mg} \mathrm{l}^{-1} \mathrm{CaCO}_{3}$ ) and conductivity (to $650 \mu \mathrm{mhos} \mathrm{cm}^{-1}$ ). Optimum water temperatures range from $15^{\circ} \mathrm{C}$ to $20^{\circ} \mathrm{C}$. Exposures range from open sites to partial shade. The plants tolerate relatively high light levels with an optimum near 16,000 lumens $\mathrm{m}^{-2}$. Net photosynthesis is saturated at light intensities from 18,000 to 38,000 
Aquatic Monocotyledons of North America

lumens $\mathrm{m}^{-2}$ (15-30\% of full sunlight). However, they also tolerate deep shade, suffering less than a $20 \%$ decrease in biomass compared to unshaded conditions. Shoot fragments can sustain growth at light levels as low as $90 \%$ shade, at which point they can still survive but without additional growth. The plants also are fairly tolerant of disturbances due to cutting and competition. The shoots take up nutrients and minerals directly from the water and are capable of removing large amounts of nitrogen (e.g., $39.8 \mathrm{~kg} \mathrm{ha}^{-1}$ ) and phosphorous (12.1 $\mathrm{kg} \mathrm{ha}^{-1}$ ). The foliage can concentrate heavy metals (e.g., As: $307 \mathrm{mg} \mathrm{kg}{ }^{-1}$; $\mathrm{Cd}: 32.33 \mu \mathrm{g} \mathrm{g}^{-1}$; Pb: $160.9 \mu \mathrm{g} \mathrm{g}^{-1}$ ) at up to several thousand times their ambient concentrations. The plants are capable of using bicarbonate $\left(\mathrm{HCO}_{3}{ }^{-}\right)$when concentrations of free $\mathrm{CO}_{2}$ are low in the ambient waters. Bicarbonate use is reduced proportionally with increasing $\mathrm{CO}_{2}$ concentrations. The majority of sediment-derived phosphorous (54\%) is translocated from the roots to shoots. The plants are limited by sediment nitrogen (rather than phosphorous) levels. The substrates include alluvium, clay, cobbly sandy loam, gravel, humic soil over clay, loam, marl, muck, mud, ooze, peat, rocks (basalt), sand, sandstone, sandy gravel, sandy muck, silt, silty mud, and stones. Flowering has been observed from June to October; the fruits are seldom encountered but have been reported in August. Most reproduction is asexual and involves the production and dispersal of vegetative shoot fragments, which are produced readily by the relatively brittle stems. The apical foliage often becomes tightly clustered, developing into well-insulated winter buds, which enable the plants to persist throughout the cold season. The plants die back during autumn, releasing manganese and other ions into the water. They decompose rapidly, losing $50 \%$ of their biomass (DM) within a week and $95 \%$ of their biomass within 47-57 days. Spring regrowth occurs from the dormant stem fragments or winter buds. The fragments rapidly regenerate roots and quickly establish, even when in deep (e.g., 94\%) shade. The fragments have high survival rates $(>80 \%)$ whether rooted or not. Their ability to establish on sediments is higher in the autumn than in the spring. Fragments have been observed to be draped around the necks and backs of waterfowl (Aves: Anatidae), which can disperse them over fairly long distances. The fragments are fairly tolerant to desiccation and can remain viable in the open air for at least $23 \mathrm{hr}$. On a dry mass basis, the plants consume $0.2-2.8 \mathrm{mg} \mathrm{O}_{2} \mathrm{~g}^{-1} \mathrm{hr}^{-1}$ while fixing 1.16-2.97 $\mathrm{mg} \mathrm{C} \mathrm{g} \mathrm{gh}^{-1}$ during the growing season. Biomass production (DM) can reach levels to $11.7 \mathrm{~kg} \mathrm{ha}^{-1} \mathrm{day}^{-1}$ for a seasonal total of up to $2320 \mathrm{~kg} \mathrm{ha}^{-1}$. Genetic analyses (microsatellite markers) of introduced populations (where reproduction is entirely asexual) have shown an unexpectedly high level of genetic variation (e.g. 2-5 alleles/locus; 0.19-0.37 expected heterozygosity), which indicates an elevated level of somatic mutation, given a low probability of multiple introductions. The roots are not colonized by mycorrhizal Fungi. Reported associates: Acorus calamus, Alisma subcordatum, Beckmannia syzigachne, Bidens beckii, Brasenia schreberi, Cabomba caroliniana, Callitriche palustris, Carex gynandra, Carex pellita, Cephalanthus occidentalis, Ceratophyllum demersum, Chara, Eleocharis acicularis, Eleocharis palustris, Elodea nuttallii, Equisetum fluviatile, Fontinalis, Glyceria borealis, Gnaphalium, Gratiola, Heteranthera dubia, Hippuris vulgaris, Hydrocharis morsus-ranae, Hydrocotyle vulgaris, Iris pseudacorus, Isoetes bolanderi, Juncus balticus, Juncus marginatus, Justicia americana, Lemna minor, Lemna obscura, Lemna trisulca, Lilaeopsis, Marsilea mollis, Marsilea vestita, Myosotis laxa, Myriophyllum heterophyllum, Myriophyllum sibiricum, Myriophyllum spicatum, Najas flexilis, Najas guadalupensis, Nasturtium officinale, Nitella, Nuphar advena, Nuphar polysepala, Nuphar variegata, Nymphaea odorata, Nyssa, Persicaria amphibia, Persicaria coccinea, Persicaria hydropiper, Phalaris arundinacea, Potamogeton alpinus, Potamogeton amplifolius, Potamogeton berchtoldii, Potamogeton crispus, Potamogeton diversifolius, Potamogeton foliosus, Potamogeton friesii, Potamogeton gramineus, Potamogeton illinoensis, Potamogeton natans, Potamogeton nodosus, Potamogeton perfoliatus, Potamogeton praelongus, Potamogeton pusillus, Potamogeton richardsonii, Potamogeton robbinsii, Potamogeton zosteriformis, Ranunculus aquatilis, Ranunculus flabellaris, Ranunculus flammula, Ranunculus longirostris, Ranunculus subrigidus, Sagittaria cuneata, Sagittaria latifolia, Sagittaria rigida, Schoenoplectus acutus, Schoenoplectus hallii, Schoenoplectus triqueter, Scirpus microcarpus, Sium suave, Sparganium angustifolium, Sparganium emersum, Spiraea douglasii, Spirodela polyrhiza, Stuckenia filiformis, Stuckenia pectinata, Stuckenia vaginata, Typha latifolia, Utricularia gibba, Utricularia macrorhiza, Utricularia minor, Vallisneria americana, Veronica, Zannichellia palustris.

2.3.3.3. Elodea nuttallii (Planch.) H. St. John inhabits flowing or still freshwater, tidal or non tidal waters (to $6.1 \mathrm{~m}$ deep) in backwaters, bayous, bottoms (lake; tank), brooks, canals, ditches (channelized; drainage; roadside), flats (mud; river), gravel pits, lakes, marshes, oxbows (drying), ponds (hatchery; sinkhole; strip mine), pools (channel), potholes, reservoirs, rivers, sloughs, streams, and swamps at elevations to $3201 \mathrm{~m}$. The waters (to $3 \mathrm{~m}$ deep) are described as calcareous (pH: 5.6-9.2; $\bar{x}$ : 6.9-7.0; alkalinity to $160 \mathrm{mg} \mathrm{l}^{-1} \mathrm{CaCO}_{3}$; chloride: to $1.6 \mathrm{ppm}$; conductivity to $310 \mu \mathrm{mhos} \mathrm{cm}^{-1}$ ). The plants are fairly resistant to currents; however, turbulence can decrease their total chlorophyll content by as much as $40 \%$. They typically are found in sunny exposures but are fairly shade tolerant; they are less tolerant of anoxic or hypoxic conditions. The plants are very resistant to desiccation and have been observed to rapidly recolonize a wetland, which had been drawn down for 10 weeks during summer. Increased sediment $\mathrm{PO}_{4}{ }^{3-}$ concentration has been observed to reduce growth, while increasing growth in shoots that have been trimmed; an opposite effect occurs when $\mathrm{PO}_{4}{ }^{3-}$ and $\mathrm{NH}_{4}{ }^{+}$levels are increased simultaneously. Like the preceding species, E. nuttallii similarly possesses the ability to use bicarbonate ions $\left(\mathrm{HCO}_{3}^{-}\right)$during conditions of low free $\mathrm{CO}_{2}$ availability (e.g., at higher $\mathrm{pH}$ levels). The ability to uptake and accumulate heavy metals is similar to that of the preceding species as well. Experiments have indicated a higher overall growth rate in Elodea nuttallii than E. canadensis, but with foliar (vs. root) uptake being greater in the latter. The former also 
is more shade tolerant than the latter. The substrates include cobble (river), gravel, marl, mucky silt, mud, rock, sand, sandy mud, sandy silt, silt, and silty gravel. Flowering has been observed from June to August, with fruiting in August. The species is believed to form a transient soil seed bank, with the seeds persisting for $<1$ year. However, fruiting is rare and most reproduction is asexual, occurring by means of stem fragmentation. During the growing season, the shoots usually do not fragment unless they are subjected to current velocities above $2.4 \mathrm{~m} \mathrm{~s}^{-1}$; however, fragmentation becomes widespread at the end of the season. The fragments (with as few as four nodes) have high survival rates $(>70 \%)$ whether rooted or not. They are known to establish effectively under virtually any light regime including 94\% shade. The fragments survive cold water conditions well and can resume growth when mean daily water temperatures surpass $4^{\circ} \mathrm{C}$. Their ability to establish on sediments is higher in the spring than in the autumn. The plants produce a number of allelochemicals ( $\alpha$-linolenic acid, $\beta$-ionone, dihydroactinidiolide, linoleic acid, pentadecanoic acid, and stearic acid), which inhibit the growth of phytoplankton. Reported associates: Azolla, Brasenia schreberi, Cabomba caroliniana, Callitriche hermaphroditica, Carex diandra, Carex stipata, Carex vesicaria, Cephalanthus occidentalis, Ceratophyllum demersum, Ceratophyllum echinatum, Chara, Eichhornia crassipes, Elatine chilensis, Elatine minima, Elatine triandra, Eleocharis acicularis, Elodea canadensis, Eriocaulon aquaticum, Glossostigma cleistanthum, Gratiola aurea, Heteranthera dubia, Hippuris vulgaris, Isoetes echinospora, Isoetes ×eatoni, Juncus balticus, Juncus bulbosus, Juncus nevadensis, Leersia oryzoides, Lemna minor, Lemna trisulca, Lemna turionifera, Ludwigia palustris, Lythrum salicaria, Menyanthes trifoliata, Myriophyllum heterophyllum, Myriophyllum heterophyllum $\times$ Myriophyllum laxum, Myriophyllum humile, Myriophyllum pinnatum, Myriophyllum sibiricum, Myriophyllum spicatum, Myriophyllum tenellum, Myriophyllum verticillatum, Najas canadensis, Najas flexilis, Najas gracillima, Najas guadalupensis, Najas marina, Najas minor, Nasturtium officinale, Nelumbo lutea, Nuphar polysepala, Nuphar variegata, Nymphaea odorata, Persicaria amphibia, Persicaria glabra, Potamogeton amplifolius, Potamogeton berchtoldii, Potamogeton bicupulatus, Potamogeton crispus, Potamogeton epihydrus, Potamogeton foliosus, Potamogeton gramineus, Potamogeton natans, Potamogeton nodosus, Potamogeton perfoliatus, Potamogeton praelongus, Potamogeton pulcher, Potamogeton pusillus, Potamogeton richardsonii, Potamogeton robbinsii, Potamogeton spirillus, Potamogeton zosteriformis, Proserpinaca palustris, Ranunculus aquatilis, Ranunculus longirostris, Riccia fluitans, Ricciocarpus natans, Sagittaria cuneata, Schoenoplectus acutus, Sparganium eurycarpum, Spirodela polyrhiza, Stuckenia filiformis, Stuckenia pectinata, Typha latifolia, Utricularia gibba, Utricularia macrorhiza, Utricularia minor, Utricularia purpurea, Utricularia radiata, Vallisneria americana, Wolffia brasiliensis, Wolffia columbiana, Zannichellia palustris.

Use by wildlife: Elodea canadensis comprises $18-27 \%$ protein and is consumed by a number of herbivores. The plants are eaten by rusty crayfish (Crustacea: Decapoda: Cambaridae: Orconectes rusticus), muskrats (Mammalia: Cricetidae: Ondatra zibethicus), and mute swans (Aves: Anatidae: Cygnus olor). Insect (Insecta) herbivores include larval caddisflies (Trichoptera: Leptoceridae: Leptocerus americanus, Nectopsyche), flies (Diptera: Ephydridae: Hydrellia discursa, $H$. harti, H. trichaeta), and moths (Lepidoptera: Crambidae: Acentria ephemerella, A. nivea). The plants also are host to several Fungi (Ascomycota: Helotiaceae: Varicosporium elodeae; Chytridiomycota: Chytridiaceae: Chytridium elodeae; Cladochytriaceae: Megachytrium westonii). The presence of E. canadensis can reduce the level of larval mosquitoes (Insecta: Diptera: Culicidae) by as much as 34\%. Dense growths of the plants also interfere with foraging activities of juvenile bluegills (Osteichthyes: Centrarchidae: Lepomis macrochirus) and other fish.

Economic importance: food: Elodea shoots are eaten as a snack in Estonia. However, given the ability of the shoots to concentrate heavy metals, consumption of the plants is inadvisable; medicinal: The Iroquois prepared an infusion from Elodea canadensis, which was used as an emetic. Elodea nuttallii contains $\beta$-sitosterol, which is used to treat enlarged prostates; cultivation: Elodea canadensis and E. nuttallii are widely grown as cold water aquarium plants; misc. products: Elodea canadensis and E. nuttallii are used routinely in various plant physiological experiments. Elodea nuttallii has been used as a co-substrate (with maize silage) for biogas generation. The plants also have been considered for wastewater treatment, where they are capable of achieving high annual removal rates of ammonia (75\%), 5-day biochemical oxygen demand (90\%), total nitrogen (47\%), and total phosphorus (38\%) from primary wastewater; weeds: Elodea canadensis and E. nuttallii are regarded as weeds throughout their nonindigenous range (and often also within their indigenous range); nonindigenous species: Elodea (E. canadensis and/ or E. nuttallii) has been introduced throughout the world, including Africa, Australia ( 1931), Europe [Croatia ( 2006), England ( 1847), France ( 1850), Germany ( 1860), Hungary ( 1870), Ireland ( 1836), Italy ( 1892), Switzerland ( 1869)], New Zealand ( 1872), and Russia ( 1970)].

Systematics: Phylogenetic analyses indicate that Elodea is most closely related to Egeria (Figure 1.9) and somewhat more distantly to Apalanthe. Although some authors have advocated the merger of Elodea and Egeria, crosses between these genera (also between Elodea and Hydrilla or Lagarosiphon) are inviable, which indicates that the genera are well isolated genetically. Accessions of three Elodea species included in phylogenetic analyses resolve as a clade, which substantiates the monophyly of the genus as far as it has been sampled (Figure 1.9). Elodea is extremely difficult taxonomically. Due to their frequent sterility, specimens of E. canadensis and E. nuttallii typically are identified by their leaf morphology (shorter, ovate leaves in the former; elongate, linear leaves in the latter). However, genetic analyses have indicated that many of the specimens observed in the field are E. canadensis $\times E$. nuttallii hybrids, and that "E. canadensis" phenotypes commonly associate with "E. nuttallii" genotypes 


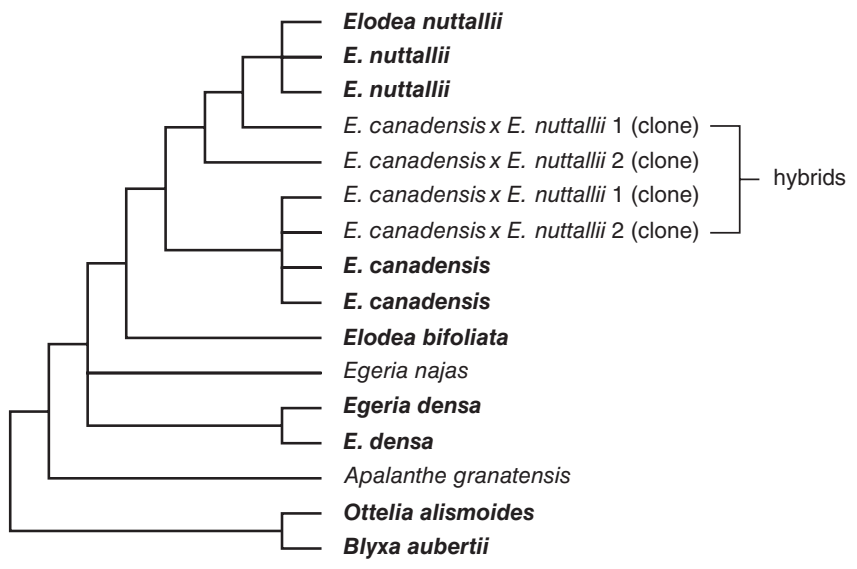

FIGURE 1.9 Phylogenetic relationships of Elodea and related genera as indicated by analysis of nrITS sequence data (adapted from Les \& Tippery, 2013). As sampled, Elodea is monophyletic and closely related to Egeria (the placement of Egeria najas notwithstanding). Many E. canadensis $\times E$. nuttallii hybrids have been detected by the recovery of cloned parental alleles originating from both species. The hybrids can resemble either parental species, at least vegetatively. Taxa designated as OBL North American indicators are highlighted in bold.

and vice versa. The author also has observed phenotypically plastic specimens clearly having "E. canadensis" foliage on one portion of the shoot and distinctly "E. nuttallii" foliage on another part of the same shoot. Consequently, it is virtually impossible to identify material of either taxon morphologically, at least when in vegetative condition. Yet, the two taxa are distinct genetically (Figure 1.9), despite their bewildering mosaic of phenotypic variability. Elodea also is problematic cytologically. The basic chromosome number of Elodea is uncertain but probably is $x=8$, given a $2 n=16$ count reported for the South American Elodea callitrichoides. However, that base number would indicate that E. bifoliata $(2 n=24)$ is triploid, which would be unusual given its relatively high fertility. The counts reported for E. canadensis and E. nuttallii are so variable $(2 n=24,32,40,48,56,64,72,96)$ that their ploidy levels are indeterminable; yet they consistently are based on $x=8$. Extensive somatically derived aneuploidy $(2 n=32,42,43,44,48)$ reportedly has arisen within a single strain of $E$. nuttallii that was cultivated over a 73-year period. Experimental hybridizations involving $E$. callitrichoides $\times E$. canadensis are inviable; however, reciprocal crosses between E. canadensis and E. nuttallii are fully interfertile. Genetically determined hybrids between E. canadensis and E. nuttallii have been collected throughout their range; however, it is not understood whether hybrid plants occur frequently or if their widespread distribution is due to the broad dispersal of fewer ramets. The complete chloroplast genome of E. canadensis has been sequenced.

Distribution: Elodea bifoliata occurs in western North America. Elodea canadensis and E. nuttallii are essentially sympatric throughout much of North America, except for the extreme northern and southern regions where neither is common.
References: Abernethy et al., 1996; Atapaththu \& Asaeda, 2015; Bailey et al., 2008; Barrat-Segretain, 2004; BarratSegretain et al., 2002; Barrat-Segretain \& Cellot, 2007; Beck-Nielsen \& Madsen, 2001; Bishop \& Eighmy, 1989; Catling \& Wojtas, 1986; Ciutti et al., 2011; Cook \& UrmiKönig, 1985; Crow \& Hellquist, 1982; Eighmy et al., 1991; Ernst-Schwarzenbach, 1945; 1953; Eugelink, 1998; Fulmer \& Robinson, 2008; Green, 2016; Greulich \& Tremolieres, 2006; Gross et al., 2001; Harms \& Grodowitz, 2009; Harrel \& Dibble, 2001; Haynes, 2000b; Hoffmann et al., 2014a; Huotari \& Korpelainen, 2012; Huotari et al., 2011; Hussner et al., 2010b; Kalle \& Sõukand, 2013; Kasselmann, 2003; Király et al., 2007; Kočić et al., 2014; Kravtsova et al., 2010; Kunii, 1981; Kuntz et al., 2014; Les \& Philbrick, 1993; Mayes et al., 1977; Mielecki \& Pieczynska, 2005; Löve, 1982; Peters et al., 2008; Preston \& Croft, 1997; Riis et al., 2010; Robinson et al., 2007; Sand-Jensen \& Gordon, 1986; Sheldon \& Boylen, 1977; Spencer \& Ksander, 2003; Thiébaut et al., 2010; Vincent \& Bertola, 2012; Wang et al., 2014a; Zaman \& Asaeda, 2013; Zefferman, 2014.

\subsubsection{Halophila}

Seagrass, star grass

Etymology: from the Greek hals phílos ("salt loving") in reference to the marine habitat

Synonyms: Barkania; Caulinia (in part); Kernera (in part); Lemnopsis; Serpicula (in part); Thalassia (in part); Zostera (in part)

Distribution: global: cosmopolitan; North America: southern (Gulf and Atlantic coasts)

Diversity: global: $10-13$ species; North America: 3 species Indicators (USA): obligate wetland (OBL): Halophila decipiens, H. engelmannii, H. ovalis

Habitat: marine; oceanic; pH: 7.9-8.3; depth: to $90 \mathrm{~m}$; lifeform(s): submersed (vittate)

Key morphology: foliage arising directly from rhizomes or in pseudowhorls (to 8 leaves) from short, erect, unbranched stems, the rhizomes thin or thick (to $2 \mathrm{~mm}$ ), with 2 scales per node; leaves sessile or petiolate (to $12 \mathrm{~cm}$ ), the blades (to $30 \mathrm{~mm}$ ) linear-oblong, linear-lanceolate, oblong, or oblongelliptic, the margins entire or serrulate; flowers unisexual (the plants dioecious or monoecious), enclosed in a spathe; 9 flowers (to $9 \mathrm{~mm}$ ) essentially sessile, styles (to $30 \mathrm{~mm}$ ) 3; ‘ flowers (to $4 \mathrm{~mm}$ ), pedicellate (to $2 \mathrm{~cm}$ ), the pollen released in chains from linear anthers (to $2 \mathrm{~mm}$ ); capsules (to $6 \mathrm{~mm}$ ) ovoid, beaked (to $6 \mathrm{~mm}$ ); seeds (to $0.3 \mathrm{~mm}$ ) few-30, reticulate Life history: duration: perennial (rhizomes); asexual reproduction: rhizomes; pollination: water (hypohydrophily); sexual condition: dioecious, monoecious; fruit: capsules (common); local dispersal: fruits (gravity), shoot fragments (water); long-distance dispersal: fruits (water), seeds (birds, water)

Imperilment: 1. Halophila decipiens [G4/G5]; 2. H. engelmannii [G3/G5]; S1 (LA, MS); 3. H. ovalis [G2]; S2 (FL)

Ecology: general: All Halophila species are submersed, perennial, marine, hydrophilous plants, and all North American taxa are OBL wetland indicators. The genus occurs 
within one of three major clades of "seagrasses," which represent the relatively few angiosperms adapted to life in the ocean. By their ability to survive in saltwater, the species typically encounter salinities of $34-35 \%$ and an alkaline $\mathrm{pH}$ of 8.1. Both features can vary due to freshwater intrusion from rainfall, proximity to freshwater sources, temperature, and other factors. Halophila species can occur in fairly deep waters and have been recorded at depths of up to $90 \mathrm{~m}$. Although these are the smallest of the seagrasses physically, they also exhibit the highest rates of sexual reproduction. All of the species have unisexual flowers (the plants dioecious or monoecious) and are water pollinated. The pollen grains are ellipsoid and form linear moniliform strands, which typically are dispersed while submersed but occasionally float to the water surface. The grains are captured by the elongate, papillate stigmas of the female flowers. The fruits contain from 7 to 60 seeds, which are not particularly buoyant, are released at or below the sediment surface, and typically are dispersed within distances of only a few centimeters. Although the fruits are not particularly vagile, their concentration of stored seeds facilitates the rapid colonization of newly exposed sites. In some cases, the fruits are buoyant and able to float for some distance. Recent studies have shown that the seeds can retain viability after passage through the digestive tract of waterfowl (Aves: Anatidae), which implicates birds as potential vectors for long-distance dispersal. Transient or persistent seed banks can develop at densities of up to 70,000 seeds $\mathrm{m}^{-2}$. The seeds are not dormant but do require light for germination. Rates of natural seed germination range from $12 \%$ to $63 \%$. Like all seagrasses, Halophila species also reproduce asexually by means of rhizomes, and occasionally by stem fragmentation. Although "Halophila johnsonii" is designated as an OBL indicator, that taxon has been merged here with $H$. ovalis in accordance with the results of various systematic investigations (see Systematics). However, the ecological information compiled for this taxon is based primarily on information from reports specifically referencing " $H$. johnsonii."

2.3.4.1. Halophila decipiens Ostenf. inhabits coastal marine communities in waters ranging from $24.3 \%$ o to $38.0 \%$ salinity and extends from subtidal zones to depths as great as 85 $\mathrm{m}$ (in clear waters). The plants are ruderal and able to survive in reduced or fluctuating light; however, deeper water populations are intolerant of high irradiance levels $\left(>1000 \mu \mathrm{E} \mathrm{m}^{-2}\right.$ $\left.\mathrm{s}^{-1}\right)$ and reduced salinity $(<35 \mathrm{ppt})$. Typical water depths are $10-30 \mathrm{~m}$ with temperatures ranging from $21.0^{\circ} \mathrm{C}$ to $36.0^{\circ} \mathrm{C}$. Plant cover diminishes noticeably when illumination falls below $10 \%$ of surface incident light. The plants thrive in sites where disturbance has eliminated competition by ordinarily more persistent species. The substrates can include coral, limestone, muddy coral sand, muddy sand, sand, shell hash, and silt. The plants are monoecious and the flowers are protandrous. Flower density can vary from 50 to $1925 \mathrm{~m}^{-2}$. Pollination is hypohydrophilous, occurring entirely underwater. In North America, flowering has been reported from July to September with fruiting from July to August. The flowers typically are open during a 9-hr period extending from first light until mid-afternoon. On average the fruits contain 36.8 seeds, which readily sink into the substrate. Large seed banks (to 13,500 seeds $\mathrm{m}^{-2}$ ) have been observed within the upper 3 $\mathrm{cm}$ of sediments; more typical values range from 134 to 3,414 seeds $\mathrm{m}^{-2}$. Seed germination has been observed from October to January. Buried seeds germinate well (to 86\%) within 2-9 days after exposure to light, but will remain dormant in the dark at $24^{\circ} \mathrm{C}$. Seed germination occurs at salinities from $25 \%$ to $34 \%$ but is inhibited at $42 \%$. Although the seeds are deposited locally, their movement en masse within large quantities of sediment dislodged by disturbance (e.g. hurricanes) can result in far greater dispersal distances. Seedling densities are highest during the winter. The biomass attained by the plants varies widely, ranging from 0.02 to $12 \mathrm{~g} \mathrm{~m}^{-2}$; it is lowest during fall and winter. Production rates (e.g., $0.023 \mathrm{~g} \mathrm{C} \mathrm{m}^{-2}$ day $^{-1}$ ) can reach a total of $4.56 \times 10^{8} \mathrm{~g} \mathrm{C}$ day $^{-1}$ during the peak growing season. The ratio of aboveground to belowground biomass is higher in shallow sites, with more storage occurring in underground organs at deeper sites. The plants can occupy extensive ranges of $7,500 \mathrm{~km}^{2}$ or more. The foliage decomposes rapidly, losing more than $50 \%$ of its original mass within 3 days. The plants have been cultured successfully in vitro. Reported associates: Halodule wrightii, Halophila engelmannii, Halophila ovalis, Ruppia maritima, Syringodium filiforme, Thalassia testudinum.

2.3.4.2. Halophila engelmannii Asch. inhabits coasts (oceanic), lagoons, and tidal flats at depths to $90 \mathrm{~m}$. The plants can tolerate salinity to $60 \%$ and occur where water temperatures vary from $13.3^{\circ} \mathrm{C}$ during winter to $31.6^{\circ} \mathrm{C}$ during summer. They decline during periods of increased precipitation, which favors species with lower salinity tolerances. The plants are intolerant of ultraviolet-A and UV-B radiation and typically are shaded by epiphytes or occur in the shade of other seagrasses. The substrates include limestone, mud, muddy clay, muddy sand, sand (gray), and sandy mud. The plants are dioecious. Flowering has been observed from March to June; however, under laboratory conditions, flowers have been produced continuously from January to September. The flowers open during a 9-hr period extending from first light until midafternoon. Although typically hypohydrophilous, some pollen has been observed to entrap gas bubbles, which enables them to rise to the water surface, where epihydrophily (surface pollination) conceivably could occur. An extensive seed bank can develop (100-800 $\left.\mathrm{m}^{-2} ; \bar{x}: 74 \mathrm{~m}^{-2}\right)$. Seeds collected from midMay to mid-June are not dormant and have germinated within 4 weeks. Germination requires light and at $24^{\circ} \mathrm{C}-27^{\circ} \mathrm{C}$, initiates within 7-10 days (if collected from November to May) and in 27-33 days if collected in October. Seed collected in June (and stored for 18 weeks in the dark at $24^{\circ} \mathrm{C}-27^{\circ} \mathrm{C}$ ) germinated in the light within 27-38 days; seed stored for 30 weeks in the dark eventually germinated after 9-12 days. Many seeds most likely remain dormant in the sediment until they are exposed to light by disturbance. Seeds stored in the dark can remain viable for at least 2 years. Seedlings that have germinated under laboratory conditions represented a 64:46 ratio of male and female flowers; however, a 42:58 ratio of staminate to pistillate shoots has been observed in a natural population. Biomass has been observed to range 
from 0.25 to $6.0 \mathrm{~g} \mathrm{~m}^{-2}$. The plants have been cultured successfully in vitro. Reported associates: Acetabularia, Caulerpa, Codium, Halimeda, Halodule wrightii, Halophila decipiens, Halophila ovalis, Penicillus, Ruppia maritima, Syringodium filiforme, Thalassia testudinum, Udotea.

2.3.4.3. Halophila ovalis (R. Br.) Hook. f. inhabits the intertidal and subtidal zones (to $3 \mathrm{~m}$ depth) of coastal marine and riverine environments, including channel bottoms, lagoons, sand bars, and sand flats. These physiologically plastic plants are tolerant of higher irradiances, turbidity, fluctuations in salinity and temperature, and contain intracellular UV-absorbing pigments (numerous flavonoids), all factors that enable them to colonize shallower water depths in exclusion of deeper dwelling seagrass taxa. They acclimate rapidly to high UV-B and PAR levels. Their maximum growth occurs at salinities of $30 \mathrm{ppt}$. The plants will experience complete mortality if rapidly exposed to $10 \%$ salinity for 10 days; however, tolerance to $10 \%$ can be maintained if the reduction in salinity occurs gradually or in brief pulses. The substrates have been characterized as mud and sand (coarse). The plants are dioecious, with flowering (in this case o) observed from April to October; no seeds are produced. The North American populations probably are derived from the founding of a single female clone, which is incapable of seed set due to the lack of male plants and associated pollination. The plants can be dispersed vegetatively by fragments; however, these are relatively short-lived and remain viable only for 4-8 days. Radioisotope tracers have shown that the plants store few carbon reserves. Carbon is allocated more to younger portions of a genet and to ramets in proportion to their proximity, but is not allocated preferentially to ramets experiencing stress. These factors make it difficult for the plants to persist vegetatively over unsuitable substrates, which compromise their ability to withstand disturbances resulting in habitat loss. Biomass has been measured at 43.0 (aboveground) and 53.5 (belowground) g $\mathrm{DM} \mathrm{m}^{-2}$. Reported associates (North America): Caulerpa prolifera (Chlorophyta: Caulerpaceae), Halodule wrightii, Halophila decipiens, Halophila engelmannii, Ruppia maritima, Syringodium filiforme, Thalassia testudinum.

Use by wildlife: The queen conch (Mollusca: Gastropoda: Strombidae: Stombus gigas) is known to graze on epiphytes that clothe the foliage of Halophila decipiens. The foliage of $H$. decipiens is low in total protein $(2.5-6.2 \%$ by $\mathrm{DM})$ and soluble carbohydrate $(4.3-8.2 \%)$ but is eaten by green sea turtles (Reptilia: Testudines: Cheloniidae: Chelonia mydas); $H$. engelmannii also is eaten by the turtles. Various organisms graze on the epiphytic algae found on the foliage of $H$. ovalis. Economic importance: food: not edible; medicinal: Crude extracts of Halophila decipiens are inhibitory to some Fungi (Ascomycota: Lulworthiaceae: Lindra thalassiae; Nectriaceae: Fusarium); cultivation: not cultivated; misc. products: none; weeds: none; nonindigenous species: The occurrence of Halophila ovalis along a small portion of the Atlantic coast is enigmatic, given the existence there only of genetically similar female plants, which have spread as asexual ramets. Although these plants have been treated as an endemic, federally (USA) threatened taxon ("H. johnsonii"), it is almost certain that a single female clone was introduced to the region either by natural dispersal vectors or as a consequence of the intense international shipping in that area. Morphologically and genetically similar plants of $H$. ovalis (both with narrower leaves and fewer ovules than typical populations) have been documented in Antigua, indicating at least that the plants are not endemic to Florida.

Systematics: Various phylogenetic analyses have confirmed that Halophila is monophyletic. However, there remains some discrepancy on the number of species in the genus, even though most taxa have now been sampled and included in phylogenetic analyses. The most contentious issue involving North American material is the taxonomic status of "Halophila johnsonii," which was discovered relatively recently (1980) along the Atlantic coast of Florida. These plants consist entirely of genetically similar, female clones and reproduce only asexually. Given its rarity and precarious reproductive issues, $H$. johnsonii was recognized as a threatened endemic species in the United States, following numerous studies which demonstrated its morphological, ecological, and genetic distinctness from the more common $H$. decipiens. However, it was later shown that the Florida plants actually were not only unrelated to $H$. decipiens, but instead were closely related to $H$. ovalis and resolved within that clade in several phylogenetic studies (e.g., Figure 1.10). Although the Florida populations have narrower leaves and fewer ovules than other H. ovalis populations surveyed, they are similar genetically (identical nrITS sequences) and morphologically to $H$. ovalis populations from Antigua. Together, these results indicate that " $H$. johnsonii" should not be regarded as a distinct endemic species, but at best as a thin-leaved variant of the more widely ranging $H$. ovalis. The basic chromosome number of Halophila is $x=9$. Halophila ovalis $(2 n=18)$ is diploid; counts for $H$. decipiens and $H$. engelmannii are unavailable. No hybrids involving any Halophila species have been reported.

Distribution: Halophila decipiens occurs along the Gulf Coast of Florida and H. ovalis occurs along the Atlantic coast of Florida; both are widespread in tropical and subtropical waters worldwide. Halophila engelmannii occurs on the Atlantic coast of Florida and along the Gulf of Mexico coast. References: Ackerman, 2006; Ballantine \& Humm, 1975; Bell et al., 2008; Bird \& Jewett-Smith, 1994; Bird et al., 1998; Bortone, 2000; Dawes et al., 1989; Dean \& Durako, 2007; Duarte, 1991; Duarte \& Chiscano, 1999; Durako et al., 2003; Eiseman \& McMillan, 1980; Fourqurean et al., 2001; Gabriel et al., 2015; Gavin \& Durako, 2011; 2012; 2014; Green \& Short, 2003; Griffin \& Durako, 2012; Hall et al., 2006; Hammerstrom et al., 2006; Hartog, 1970; Haynes, 2000b; Herbert, 1986; Howell, 2012; Humm, 1956; Inglis, 1999; Jewett-Smith \& McMillan, 1990; Jewett-Smith et al., 1997; Josselyn, 1986; Kahn \& Durako, 2008; 2009; Kahn et al., 2013; Kenworthy, 1999; Kunzelman et al., 2005; Larkum, 1995; Les, 1988; Les \& Tippery, 2013; Les et al., 1997a; McDermid et al., 2007; McMillan, 1976; 1987; 1988; 1988a; 1988b; 1989; 1990; 1991; McMillan \& JewettSmith, 1988; Meng et al., 2008; MNFS, 2002; Onuf, 1996; 


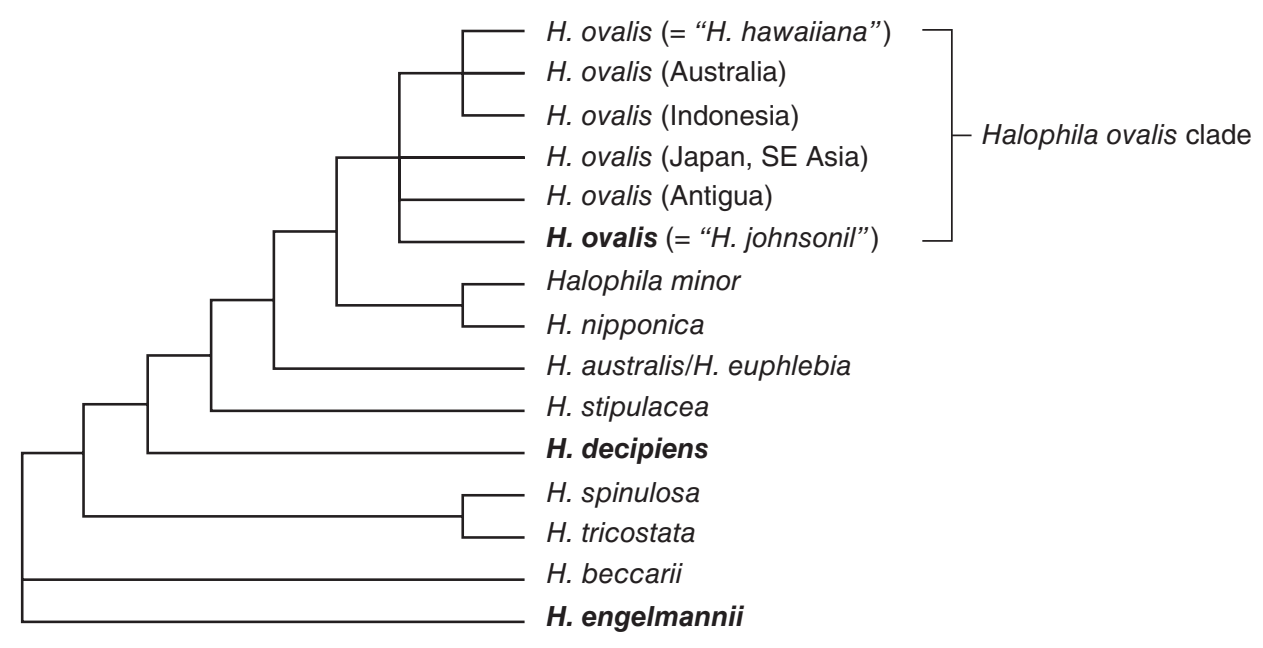

FIGURE 1.10 Phylogenetic tree constructed for Halophila using nrITS sequence data (adapted from Short et al., 2010). These results (and those of Uchimura et al., 2008) show "Halophila johnsonii" to be embedded within a large H. ovalis clade. The nrITS sequence of "H. johnsonii" is identical to material from Antigua, which also is similar morphologically. The three OBL North American Halophila species (in bold) originate from various parts of the tree, indicating a broad phylogenetic diversity in the region.

Orth et al., 2000; 2006; Pettitt \& Jermy, 1974; Phillips, 1960; Phillips \& Meñez, 1988; Ross et al., 2008; Short \& Wyllie-Echeverria, 1996; Short et al., 2010; Torquemada et al., 2005; Trocine et al., 1981; 1982; Uchimura et al., 2008; Waycott et al., 2002; 2006; Wu et al., 2016; Xu et al., 2011; York et al., 2008.

\subsubsection{Hydrilla}

Florida elodea, hydrilla, water thyme; hydrille

Etymology: derived from the Greek Hydra, a mythological lake-dwelling serpent

Synonyms: Elodea (in part); Epigynanthus; Hydora (in part); Hydrospondylus; Ixia (in part); Serpicula (in part); Udora (in part); Vallisneria (in part)

Distribution: global: Africa, Australia, Eurasia, North America*, South America (northern)*; North America: eastern, southern, and western United States

Diversity: global: 1 species; North America: 1 species Indicators (USA): obligate wetland (OBL): Hydrilla verticillata

Habitat: brackish (coastal), freshwater, freshwater (tidal); lacustrine, palustrine, riverine; pH: 5.4-8.6; depth: to $15 \mathrm{~m}$; life-form(s): submersed (vittate)

Key morphology: subterranean shoots horizontal, rhizomatous or stoloniferous, sometimes producing white to brownish turion-like tubers at the stolon termini, roots unbranched; leafy shoots (to $8.5 \mathrm{~m}$ ) submersed, branched or unbranched, erect in water column, sometimes bearing hard, olive-green, conelike turions; leaves cauline, in whorls of 3-8, the blades (to $20 \mathrm{~mm}$ ) linear, sessile, single-nerved, margins finely serrulate, abaxial surface with midvein prickles, base tapering to stem; inflorescences single-flowered, sessile to subsessile (pedicels to $0.5 \mathrm{~mm}$ ), enclosed by a spathe of 2 connate bracts; flowers unisexual (plants dioecious or monoecious), perianth trimerous, translucent or reddish to whitish; ô flowers released under water in bud, rising to surface, the enclosed staminal filaments distinct, springing apart explosively to release pollen from anthers as the free-floating flowers open at water surface; $q$ flowers floating on perianth, attached by an elongate, translucent to purplish floral hypanthium (to 50 $\mathrm{mm}$ ); staminodes (3) minute; ovary tricarpellate, 1-locular, styles (to $0.75 \mathrm{~mm}$ ) 3; fruits indehiscent, cylindrical, smooth or spiny; seeds (to 5) fusiform, smooth

Life history: duration: perennial (rhizomes, stolons, turions, whole plants); asexual reproduction: rhizomes, shoot fragments, stolons, tubers, turions (stem, stolons); pollination: abiotic (ballistic); sexual condition: dioecious, monoecious; fruit: capsular [indehiscent] (rare); local dispersal: shoot fragments, tubers, turions (water, waterfowl); long-distance dispersal: shoot fragments, tubers, turions (humans, water, waterfowl)

\section{Imperilment: 1. Hydrilla verticillata [GNR]}

Ecology: general: Although viewed almost universally as monotypic, Hydrilla represents a complex of cryptic, genetically variable taxa, which exhibit a number of cytological, ecological, and morphological differences. Nevertheless, all of the ecological information assembled for the genus over the past century has been attributed to one single, variable, wideranging species and is summarized below in that respect.

2.3.5.1. Hydrilla verticillata (L. f.) Royle is a nonindigenous species, which inhabits still or flowing, tidal, intertidal, or nontidal, brackish to fresh (0-11\%o salinity) waters in backwaters, bayous, canals, coves, ditches (drainage, irrigation, roadside), gravel pits, lagoons (river), lakes (freshwater), marshes (floating, tidal), ponds (artificial, farm, fire, fish, floodplain, irrigation, koi, retention, sinkhole, stagnant), pools (riverbed, shallow), potholes (drying), reservoirs, spillways, springs, and the margins of channels (bayou, boat), embayments, lakes, rivers, and streams (spring-fed) at elevations (North America) to $860 \mathrm{~m}$. Exposures can range from full sunlight to shade (e.g., along banks). The plants can colonize a variety of still to flowing waters from 0.7 to $15.0 \mathrm{~m}$ deep, with slow flow 
rates $<0.2 \mathrm{~m} \mathrm{~s}^{-1}$ apparently being optimal. They can grow in clear to turbid waters (e.g., Secchi depth: $0.6 \mathrm{~m}$ ) at light levels as low as $10-12 \mu \mathrm{E} \mathrm{m}^{-2} \mathrm{~s}^{-1}$. The plants are known to grow where percent transmittance of light is only 0.46 of that at the surface; they exhibit a decreasing chlorophyll A:B ratio with depth, which is attributed as an adaptation to reduced light levels. Shoot growth has been observed to continue for up to 10 weeks when the plants are kept in total darkness. The substrates (North America) are diverse and include alluvium (clayey, loamy), granite, gravel (limestone), limestone, marl, mud, rocky silt, sand, sandy silt, silt, silty clay, and silty clay loam (Cancienne); however, a high sediment organic content (e.g., $13 \% \mathrm{dw}^{-1}$ ) is deleterious to growth. The plants occur most often in freshwater (salinity $<0.5 \%$ ) with their growth seriously impacted at salinities $>13 \%$. Otherwise, broad spectrum of water conditions is tolerated (water temperature: $18.2^{\circ} \mathrm{C}-18.8^{\circ} \mathrm{C}$; specific conductance: $27.0-400.8 \mu \mathrm{S} \mathrm{cm}{ }^{-1}$; $\bar{x}=183 \mu \mathrm{S} \mathrm{cm}{ }^{-1} ; \mathrm{pH}: 5.4-8.6 ; \bar{x}=7.1$; total alkalinity: $1.7-$ 164.0; $\bar{x}=29.9 \mathrm{mg} \mathrm{l}^{-1} \mathrm{CaCO}_{3}$; total P: $10-106(\bar{x}=49) \mu \mathrm{g} \mathrm{l}^{-1}$; total N: $\left.310-1,820(\bar{x}=900) \mu g 1^{-1}\right)$. Although exhibiting $\mathrm{C}_{3}$ photosynthesis, hydrilla also is capable of fixing $\mathrm{CO}_{2}$ into $\mathrm{C}_{4}$ acids for subsequent decarboxylation through an inducible $\mathrm{C}_{4}$-like mechanism. Flowering (North America) occurs nearly year-round (January-November). Two major genetic strains (commonly referred to as "biotypes") occur in North America, and are represented either by monoecious individuals or as pistillate clones of a dioecious strain (entirely staminate plants remain unknown in North America). The abiotic pollination system of Hydrilla is unique and difficult to characterize. The staminate flowers are released in bud from either male or monoecious shoots, and float individually to the water surface. The stamens remain reflexed under tension until the flower buds reach the surface before opening as distinct, free-floating structures. Concurrently, the pistillate flowers arise from female or monoecious shoots on which they remain attached by an elongate floral hypanthium, which extends them to the water surface. The pistillate flowers open at the water surface, where the stigmatic surfaces are exposed to the air (but are kept dry) within the floating flowers. A sudden release of the stamen filaments from their tensed orientation occurs when the staminate flowers open at the water surface, which results in an explosive, ballistic discharge of pollen in the form of an aerial shower. The fortuitous landing of some grains upon a nearby, receptive stigma is necessary in order to achieve pollination. Both pollen and stigma remain dry during the process. From this description it is easy to see why seed set often is low to non-existent, and seeds rarely are found in (monoecious) North American plants. However, high seed production has occurred in Asian plants and experimentally manipulated crosses using various strains of international provenance also have produced numerous seeds, with a success rate of $71 \%$ between dioecious and monoecious strains. Such crosses have produced highly viable (90\%) seeds characterized by high seedling survival. Detached shoots can remain buoyant for 1-6 days, during which time they can transport attached sexual or vegetative propagules across the water surface. Seeds in Asian populations have germinated within 1 week when incubated in light at $23^{\circ} \mathrm{C}-28^{\circ} \mathrm{C}$. Those stored in darkness (in water or dry) for up to 1 year have germinated readily when brought under light. Hydrilla plants are perennials, which possess an incredible capacity for rapid, vegetative growth and reproduction by means of stem fragmentation, turions, stolons, and tubers (a.k.a. subterranean turions). They are known to reach expansive surface coverages ranging from 8.5 to 405 ha. Biomass estimates up to $2.275 \mathrm{~kg} \mathrm{~m}^{-2}$ (FW) have been reported. The doubling time of shoots is about 19.8 days, but occurs much more rapidly (2.5-11 days) for tubers. Stem fragments comprising a single node are capable of regrowth, with $68 \%+$ regrowth observed for fragments having 3-5 nodes. Tubers and turions can develop from October to April. Individual tuber production can reach 375 month $^{-1}$ resulting in sediment densities of $6046 \mathrm{~m}^{-2}$ and several million ha- ${ }^{-1}$. Alhough the tubers can survive in the sediments for more than 4 years, the turions are thought to live for only a single year. Natural germination rates under drawdown conditions have reached $80 \%$. The tubers germinate best $(88-100 \%)$ in the light at temperatures from $22^{\circ} \mathrm{C}$ to $30^{\circ} \mathrm{C}$; however, low temperatures $\left(15^{\circ} \mathrm{C}\right)$ have resulted in reduced tuber germination in the monoecious $(35-68 \%)$ and dioecious $(\sim 3 \%)$ strains. Both tubers and turions have survived desiccation by maintaining physiological activity after drying (e.g., 16 hr @ 30 C, 40\% RH). However, tolerance to drying increases with the number of leaf whorls present and single node fragments can succumb to drying in as short as $2 \mathrm{hr}$. The tubers survive longer, with $16.7 \%$ viability observed after drying for $64 \mathrm{hr}$; whereas turion viability declines sharply as drying time approaches $8 \mathrm{hr}$. Turion production is enhanced under short photoperiods ( $<12$ hr light) and in free-floating (non-rooted) plants but declines as plant density increases. The subterranean turions of monoecious plants are much more resistant to cold temperatures than intact dioecious plants. When kept in cold $\left(4^{\circ} \mathrm{C}\right)$ water for 105 days, mortality increased to $98 \%$ for dioecious plants but only to $48 \%$ for monoecious turions. Reported associates (North America): Acorus calamus, Alternanthera philoxeroides, Bacopa monnieri, Brasenia schreberi, Cabomba caroliniana, Callitriche, Ceratophyllum demersum, Ceratophyllum echinatum, Chara contraria, Cynodon dactylon, Cyperus strigosus, Echinodorus cordifolius, Egeria densa, Eichhornia crassipes, Elodea nuttallii, Heteranthera dubia, Heteranthera multiflora, Hydrocotyle umbellata, Hygrophila polysperma, Juncus acuminatus, Lemna minor, Lemna perpusilla, Limnobium spongia, Ludwigia grandiflora, Ludwigia octovalvis, Luziola fluitans, Myriophyllum aquaticum, Myriophyllum laxum, Myriophyllum spicatum, Najas flexilis, Najas gracillima, Najas guadalupensis, Najas minor, Nelumbo lutea, Nitella, Nuphar, Nymphaea odorata, Nymphoides aquatica, Nyssa aquatica, Ottelia alismoides, Pistia stratiotes, Pontederia cordata, Potamogeton amplifolius, Potamogeton crispus, Potamogeton diversifolius, Potamogeton foliosus, Potamogeton nodosus, Potamogeton perfoliatus, Potamogeton pusillus, Potamogeton spirillus, Potamogeton zosteriformis, Sagittaria kurziana, Sagittaria latifolia, Salvinia minima, Spirodela polyrrhiza, Stuckenia 
pectinata, Taxodium distichum, Trapa natans, Utricularia foliosa, Utricularia gibba, Vallisneria americana, Xyris.

Use by wildlife: Hydrilla verticillata is grazed by Suwannee cooters (Reptilia: Testudines: Emydidae: Pseudemys concinna suwanniensis), which on average consume $850 \mathrm{~g}$ (WM) [68 g DM] turtle ${ }^{-1}$ day $^{-1}$. Hydrilla collections from the southern United States have documented as many as 131 associated insect (Insecta) species. Of these, the plants are damaged or grazed primarily by aphids (Hemiptera: Aphididae: Rhopalosiphum nymphaeae), caddisflies (Trichoptera: Leptoceridae: Leptocerus americanus, Nectopsyche tavara, Oecetis cinerascens, Triaenodes), midges (Diptera: Chironomidae: Ablabesmyia rhamphe, Apedilum elachistus, Cricotopus bicinctus, C. tricinctus, C. politus, C. sylvestris, Dicrotendipes, Endochironomus, Glyptotendipes, Larsia decolorata, Nanocladius alternantherae, Parachironomus hazelriggi, Pentaneura inconspicua, Pseudochironomus richardsoni, Tanytarsus buckleyi), moths (Lepidoptera: Crambidae: Oxyelophila callista, Paraponyx allionealis, $P$. diminulatis, P. obscuralis, Synclita obliteralis), and shore flies (Diptera: Ephydridae: Hydrellia bilobifera). The plants also are eaten by grass carp (Vertebrata: Teleostei: Cyprinidae: Ctenopharyngodon idella). Although hydrilla typically is viewed as a noxious weed, some studies have found enhanced benthic productivity where the plants have been established in previously unvegetated zones. The plants also have been found to increase foraging access in several bird (Aves) species, including American coots (Rallidae: Fulica americana), ducks (Anatidae), and pied-billed grebes (Podicipedidae: Podilymbus podiceps). Hydrilla is used for nest construction by the invasive brown hoplo catfish (Vertebrata: Teleostei: Callichthyidae: Hoplosternum littorale). Hydrilla plants also host epiphytic Cyanobacteria (Notocales: Hapalosiphonaceae: Aetokthonos hydrillicola), which produce a toxin known to cause avian vacuolar myelinopathy in the federally endangered Florida snail kite (Aves: Accipitridae: Rostrhamus sociabilis).

Economic importance: food: Hydrilla foliage contains about $19-25 \%$ (dw) crude protein and from $0.1 \%$ to $2 \%$ of 16 amino acids (nine essential); however, it has not been used as a human food; medicinal: Hydrilla extracts contain natural antioxidants (free radical scavenging activity: $29.6 \%$ inhibition at $100 \mu \mathrm{g} \mathrm{ml}^{-1}$ ) and exhibit antimicrobial activity (primarily against Gram-positive bacteria); cultivation: Hydrilla verticillata has been popular as an aquarium plant, but due to its aggressive growth characteristics, its cultivation is emphatically discouraged anywhere beyond its indigenous range; misc. products: Hydrilla plants have been used for the phytoremediation of aqueous solutions contaminated by dyes and heavy metals and for domestic wastewater treatment. They also have been evaluated for compost production, biofuel production, and in the phytofabrication of silver nanoparticles. Feed for domestic laying hens (Aves: Phasianidae: Gallus gallus domesticus) has been supplemented by including up to $7.5 \%$ hydrilla without inducing any deleterious dietary effects. Hydrilla plants also have been considered as a viable feed for domestic cattle
(Mammalia: Bovidae: Bos taurus); weeds: Hydrilla verticillata is listed as a Federal noxious weed in the United States and is regarded as a notorious weed throughout its nonindigenous range. Some Florida populations exhibit varying levels of resistance to carotenoid biosynthesis inhibiting herbicides (e.g., Fluridone), which arise from somatic mutations occurring at a single codon in the phytoene desaturase ( $p d s)$ gene; nonindigenous species: Hydrilla is nonindigenous throughout the New World. It was introduced to North America in the mid-20th century ( 1959) through the careless disposal of aquarium plants. The nonindigenous New World range of Hydrilla has expanded southward into Central America and more recently ( 2005) to South America (Brazil). Molecular data indicate that the US "monoecious biotype" originated from China or South Korea, and the US "dioecious biotype" from India. Recently, a third genetic strain has been documented from the United States (Connecticut River, CT), which is similar genetically to plants occurring in Ireland, Japan, Korea, and Latvia. Adventive Hydrilla populations also occur in Ireland, New Zealand, and South Africa. Ecological niche models have predicted a future increase of about $17 \%$ in potential North American hydrilla habitat due to changing climatic conditions.

Systematics: Phylogenetic analyses typically place the monotypic Hydrilla within subfamily Hydrilloideae of Hydrocharitaceae, either in proximity of Nechamandra and Vallisneria (e.g., Figure 1.8), or closer to Najas, depending on the data source and method of analysis implemented. A relationship to Najas has been suspected based on the shared occurrence of unusual abaxial midvein teeth in both genera, a morphological feature that occurs in no other alismatid genus. The genetic structure of Hydrilla verticillata has been studied quite extensively by analyses of various markers (e.g., isozymes, ISSRs, RAPDs) as well as by nuclear and plastid DNA sequence data. Isozyme data provided early genetic evidence for two independent origins of hydrilla plants in North America, which since have been characterized as dioecious and monoecious "biotypes" with respect to their corresponding sexual conditions. These two, distinct, nonindigenous North American strains have been confirmed subsequently by various genetic data; however, recent studies also have discovered a third strain (introduced to New England, USA) for which the sexual condition has not yet been determined (Figure 1.11). Although several Hydrilla haplotypes (5-9) have been described on the basis of plastid sequence data, analyses of nuclear sequence data have disclosed that substantially greater genetic diversity exists in the species due to extensive hybridization, which has occurred among all the strains throughout their Old World range. Even though the US dioecious and monoecious biotypes (Figure 1.11) represent specific haplotypes (i.e., H1/H2 and $\mathrm{H} 5$, respectively), both were derived initially through hybridization involving other Old World haplotypes. However, field studies and genetic analyses conducted at one North American reservoir indicate that hybridization between the dioecious and monoecious strains did not occur there, despite their sympatric occurrence. The basic chromosome 


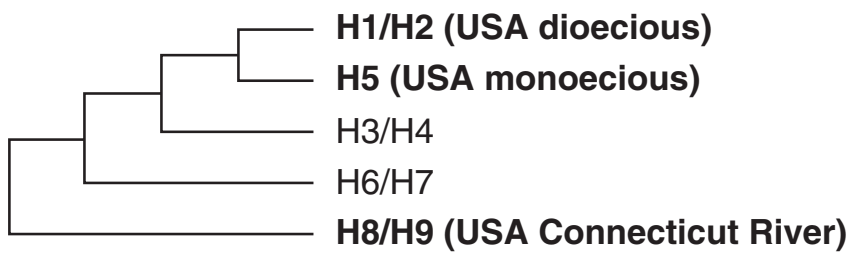

FIGURE 1.11 Genetic substructure in Hydrilla verticillata as illustrated by plastid $t r n L-F$ haplotype sequences (adapted from Tippery et al., 2020). Geographical affinities of coded haplotypes are as follows: H1/H2 (Brazil, Burundi, China, India, Nepal, Pakistan, the United States [dioecious strain], Vietnam); H3/H4 (Australia, China, New Zealand); H5 (China, Korea, the United States [monoecious strain]); H6/H7 (Australia, China, Indonesia, Malaysia, South Africa, Taiwan, Thailand, Vietnam); H8/H9 (China, Ireland, Japan, Korea, Latvia, Poland, the United States [Connecticut River]). The three nonindigenous US strains are highlighted in bold. Extensive hybridization has occurred among these basic strains throughout various portions of the Old World (see text).

number of Hydrilla is $x=8$. Hydrilla verticillata contains diploid, triploid, and tetraploid cytotypes $(2 n=16,24,32)$, with North American populations commonly being triploid. Chromosome variation in Hydrilla originates at least in part by endopolyploidy, which has been indicated by documentation of triploid plants at sites where only diploids had occurred previously, and moreover, by the observation of different polyploid cells $(2 n=16,24,32)$ found within single, clonal populations or even within individual root tips. Hydrilla occurrences recently have been detected successfully from environmental DNA (eDNA) samples.

Distribution: Hydrilla verticillata occurs in the eastern and western United States, with a southward extension into South America (Brazil).

References: Abdul-Alghaffar \& Al-Dhamin, 2016; Adler et al., 2018; Balciunas \& Minno, 1985; Baniszewski et al., 2016; Basiouny et al., 1978; Benoit, 2011; Benoit \& Les, 2013; Benoit et al., 2019; Bianchini, Jr. et al., 2010; Bowes et al., 1977; 1979; Boyd, 1969; Canfield et al., 1985; Cook, 1982; 1996a; Cook \& Lüönd, 1982a; Dodd et al., 2016; Easley \& Shirley, 1974; Esler, 1990; Evans \& Wilkie, 2010; Godfrey \& Wooten, 1979; Grajczyk et al., 2009; Haller et al., 1976; Haug et al., 2019; Haynes, 2000b; Holaday \& Bowes, 1980; Hoyer et al., 1996; Kanabkaew \& Udomphon, 2004; King \& Les, 2016; Lal \& Gopal, 1993; Langeland, 1989; Langeland \& Sutton, 1980; Langeland et al., 1992; Les et al., 1997c; Low et al., 1994; Madeira et al., 2000; Maki \& Galatowitsch, 2008; Matsuhashi et al., 2019; McDowell et al., 1990; Michel et al., 2004; Miller et al., 1993; Ming et al., 1994; Netherland, 1997; Nico \& Muench, 2004; Osborne \& Sassic, 1981; Owens et al., 2001; Pandi \& Rajkumar, 2015; Pieterse, 1981; Posey et al., 1993; Promdee et al., 2018; Reiskind et al., 1997; Sable et al., 2012; Scott \& Osborne, 1981; Simberloff \& Leppanen, 2019; Sousa, 2011; Steward, 1991; 1993; Steward \& Van, 1987; Stratman et al., 2013; Sutton et al., 1992; Tippery et al., 2020; True-Meadows et al., 2016; Van \& Steward, 1990; Van et al., 1977; Verkleij et al., 1983; Williams et al., 2017; Wood \& Netherland, 2017; Zhu et al., 2017.

\subsubsection{Hydrocharis}

Frog-bit; grenouillete, hydrocharide

Etymology: from the Greek hydro chaeri, meaning "water delight"

Synonyms: Bootia (in part); Hydrochaeris; Monochoria (in part); Ottelia (in part); Pontederia (in part)

Distribution: global: Africa, Australia, Eurasia, North America*; North America: northeastern

Diversity: global: 3 species; North America: 1 species

Indicators (USA): obligate wetland (OBL): Hydrocharis morsus-ranae

Habitat: freshwater; lacustrine, palustrine, riverine; $\mathbf{p H}$ : 6.57.8; depth: $<1 \mathrm{~m}$; life-form(s): floating-leaved or free-floating Key morphology: plants floating freely or rooted in sediment; shoots contracted and rosulate or stoloniferous (to 20 $\mathrm{cm}$ ), bearing simple or branched adventitious roots (to $50 \mathrm{~cm}$ ), and terminating in summer buds (to $15 \mathrm{~mm}$ ) or turions (to $9 \mathrm{~mm}$ ); leaves aerenchymatous on underside, the blades (to $6.3 \mathrm{~cm}$ ) orbicular, cordate at base, petioled (to $14 \mathrm{~cm}$ ), with paired, free stipules (to $2.5 \mathrm{~cm}$ ); flowers trimerous, unisexual, the plants dioecious or (rarely) monoecious; ô flowers (1-5) pedicelled (to $4 \mathrm{~cm}$ ), arising from a peduncled (to $5.5 \mathrm{~cm}$ ) spathe (to $1.2 \mathrm{~cm}$ ); sepals (to $5.5 \mathrm{~mm}$ ) greenish or white; petals (to $1.9 \mathrm{~cm}$ ) white, obovate to orbicular; stamens (9-12) in 4 whorls; o flowers solitary, pedicelled (to $9 \mathrm{~cm}$ ); sepals (to 5 $\mathrm{mm}$ ) greenish; petals (to $1.5 \mathrm{~cm}$ ) white, obovate to orbicular, 3 staminodes present, styles (to $5 \mathrm{~mm}$ ) 6 , bifid (to $2 / 3$ of length), ovary spherical, 6-carpelled; capsules (to $1 \mathrm{~cm}$ ) berrylike, with numerous, bluntly papillate seeds (to $1.3 \mathrm{~mm}$ )

Life history: duration: perennial (stolons, turions); asexual reproduction: stolons, tubers, turions (stolons); pollination: insect; sexual condition: dioecious, monoecious; fruit: berrylike capsule (infrequent); local dispersal: seeds, turions (water); long-distance dispersal: whole plants or fragments (birds, humans [boating and fishing equipment]); seeds, turions (water, waterfowl)

Imperilment: 1. Hydrocharis morsus-ranae [GNR]

Ecology: general: All Hydrocharis species are perennial, floating-leaved aquatics. The plants grow either as free-floating rosettes on the water surface or can become rooted in the sediment when in shallower water. The flowers are unisexual and are arranged in a dioecious or monoecious condition; single rosettes mostly bear flowers of the same sex. The flowers of both sexes possess showy perianths, produce nectar ( 9 only), and are pollinated primarily by insects. Vegetative reproduction can occur by the extension of stolons and also by the production of tubers during the summer, and by turions, which detach and overwinter. The characteristics of all three species are quite similar and are exemplified well by the following species.

2.3.6.1. Hydrocharis morsus-ranae $\mathbf{L}$. is a nonindigenous species, which occupies shallow, mesotrophic North American waters (e.g., 0.5-0.6 m) associated with canals, channels, ditches, floodplains, impoundments, lagoons, lakes, marshes, ponds, rivers, streams, and swamps at elevations to $378 \mathrm{~m}$ (to $1500 \mathrm{~m}$ elsewhere). The plants have been observed in open and shaded sites (usually sheltered) and in clear to 
turbid waters, which often are rich in organic matter. Shading has little influence on growth unless levels exceeding 50\% are maintained. The plants have been described as favoring both calcium-poor waters and calcareous waters; North American sites represent circumneutral conditions ( $\mathrm{pH}$ : 6.5-7.8). The plants do not appear to be well adapted to acidic, nutrientpoor (oligotrophic) conditions. They have been reported on substrates described as clay, detritus, mud, and rocky sandy silt. Flowering occurs from mid-June through August (North America). Floral sex expression is quite labile. Typically, the rosettes are unisexual (the plants being dioecious); however, a plant infrequently can produce both male and female rosettes (the plant then monoecious). Plants of a known sex also have been observed to produce plants of the opposite sex, which were derived vegetatively from their turions. The flowers open by early morning, become receptive by mid-day, and are pollinated by insects (see Use by wildlife). Despite the unisexual flowers and prevalent dioecy, genetic data (allozyme markers) have indicated low levels of variation and a relatively high degree of inbreeding. When formed, the maturing fruits are pushed beneath the water surface by a curving peduncle. Seed production often is uncommon (due in part to low pollinator visitation rates), but reportedly initiates in midAugust. It can be locally abundant (over $250 \mathrm{~m}^{-2}$ ), reaching 2,000-3,000 seeds $\mathrm{m}^{-2}$ in some cases; however, few seedlings survive, even in such cases. An average of 26-42 seeds (to a maximum of 74 seeds) is produced per flower. Individual seed production generally is greater (e.g., 55-60 seeds) in high-density mats than in low density mats (e.g., 15-20 seeds). The seeds are enclosed in mucilage and are released when the capsules swell and burst after about 5 weeks following peduncle curvature. The seeds (averaging $0.17 \mathrm{~g}$ ) float upon their release and are dispersed primarily by water currents, although the mucilaginous coating also is suspected to facilitate their attachment to the feet of waterfowl (Aves: Anatidae). The seeds germinate as the water temperatures rise above $15^{\circ} \mathrm{C}$. A fairly high experimental seed germination rate $(69 \%)$ has been achieved after 16 months of cold storage and subsequent exposure to high light levels. The seeds are known to retain viability after 2 months of storage at $-20^{\circ} \mathrm{C}$. The principal means of reproduction is vegetative through the production of stolons and turions. Individual plants can produce up to 150 turions. Between $15^{\circ} \mathrm{C}$ and $25^{\circ} \mathrm{C}$, the turions are initiated by photoperiod, with higher temperatures requiring shorter photoperiods. No turions form below $10^{\circ} \mathrm{C}$, but they develop readily at temperatures above $25^{\circ} \mathrm{C}$ regardless of photoperiod. Turions can remain dormant for at least 2 years, with greater dormancy characteristic of those that initiate at higher temperatures. Mature turions detach and sink to the bottom, where they remain for about 7 months; they cannot withstand prolonged periods of freezing (i.e., >10 days to several weeks). Turions require light for germination unless they have been thoroughly vernalized (i.e., cold stratified). The turions germinate from April to May and float to the surface. Individual turions can develop into fairly large plants (to $1 \mathrm{~m}^{2}$ ) within a single growing season. Great blue herons (Aves: Ardeidae: Ardea herodias) have been seen with whole, entangled plants attached for significant distances (e.g., 2 $\mathrm{km}$ ) and turions (of uncertain viability) have been recovered from the digestive tracts of American black ducks (Anatidae: Anas rubripes). Reported associates (North America): Butomus umbellatus, Carex, Cephalanthus occidentalis, Equisetum fluviatile, Hottonia inflata, Lemna minor, Lythrum salicaria, Myriophyllum sibiricum, Myriophyllum spicatum, Nuphar variegata, Nymphaea odorata, Phalaris arundinacea, Phragmites australis, Pontederia cordata, Potamogeton crispus, Potamogeton epihydrus, Potamogeton pusillus, Potamogeton vaseyi, Sagittaria graminea, Sagittaria rigida, Salix, Scirpus, Sparganium, Spirodela polyrhiza, Trapa natans, Typha angustifolia, Typha latifolia, Utricularia macrorhiza.

Use by wildlife: Hydrocharis morsus-ranae is eaten by various ducks (Aves: Anatidae), grass carp (Teleostei: Cyprinidae: Ctenopharyngodon idella), mice (Mammalia: Rodentia: Muridae), and snails (Mollusca: Gastropoda: Lymnaeidae: Lymnaea; Physidae: Physa; Planorbidae: Helisoma). The leaves also are eaten by larval moths (Insecta: Lepidoptera: Crambidae: Elophila icciusalis, Synclita occidentalis). In North America, the flowers are visited by numerous insects (Insecta) including aphids (Hemiptera: Aphididae) and flies (Diptera: Ephydridae: Hydrellia, Notiphila), although the principal pollinators appear to be fairly specialized hover flies (Diptera: Syrphidae: Toxomerus marginatus) and solitary bees (Hymenoptera: Halictidae: Lasioglossum).

Economic importance: food: Hydrocharis plants contain from $22 \%$ to $24 \%$ crude protein, but have been described as "almost tasteless" and are of little culinary interest. They impart a reddish coloration to cooking water; medicinal: no uses reported; cultivation: Hydrocharis morsus-ranae is grown as an ornamental aquarium and water garden plant; misc. products: Hydrocharis morsus-ranae is easily cultivated and has been used as an experimental plant for physiological and developmental studies; weeds: Hydrocharis morsus-ranae can develop into dense floating mats and has been reported as a nuisance in Canada (Ontario and Quebec) and the United States (New York); nonindigenous species: In North America, Hydrocharis morsus-ranae was originally cultivated by an arboretum in Ottawa, Canada from material sent from Zürich, Switzerland in 1932; it was first observed as an escape in the region in 1939. The subsequent spread of plants through North America (at a rate of roughly $17 \mathrm{~km}$ year $^{-1}$ ) has been facilitated by their dispersal on boats and boat trailers. Plants also have been observed for sale at some local retail shops in the United States, and likely also have escaped from cultivation in water gardens.

Systematics: Analyses of DNA sequence data for two of the three Hydrocharis species indicate that the genus is related most closely to (but not necessarily distinct from) Limnobium (Figure 1.8). However, a simultaneous phylogenetic analysis of all three Hydrocharis species and both Limnobium species will be necessary to determine whether these two genera actually resolve as distinct sister clades, which appears to be the case when fewer exemplars are evaluated (Figure 1.12). Such an analysis also is necessary to determine the interspecific 


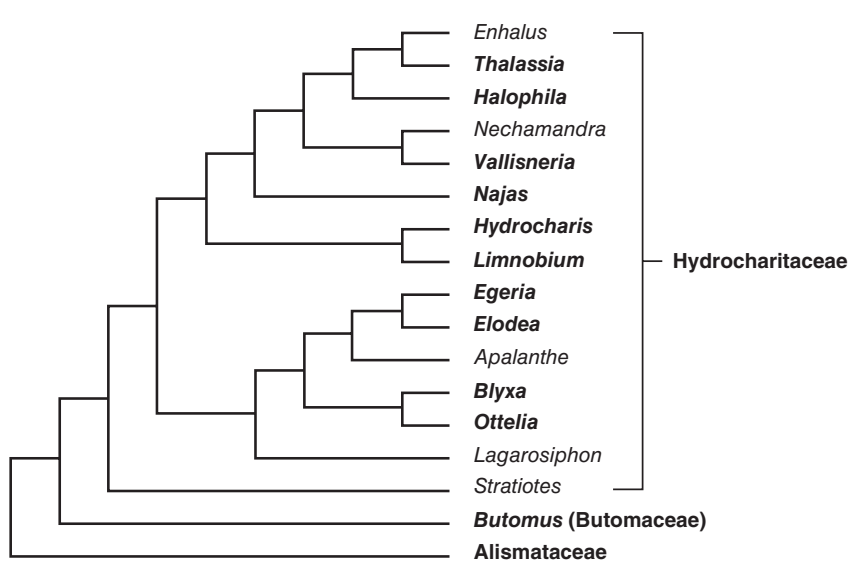

FIGURE 1.12 Intergeneric relationships in Hydrocharitaceae based on analysis of complete cpDNA gene sequence data (adapted from Ross et al., 2016). Although only those taxa designated as OBL in North America are indicated in bold, the entire group shown comprises aquatic species.

relationships in Hydrocharis. DNA sequence data indicate that Hydrocharis and Limnobium have diverged approximately 11.7 million years before present (MYBP). The base chromosome number of Hydrocharis is $x=7$ or 8 . Hydrocharis morsus-ranae $(2 n=28)$ presumably is tetraploid. No hybrids involving any member of the genus have been reported, due at least in part to the highly allopatric distributions of the three species.

Distribution: Hydrocharis morsus-ranae occurs in northeastern North America.

References: Casper \& Krausch, 1980; Catling \& Dore, 1982; Catling \& Porebski, 1995; Catling et al., 1988; 2003; Cook \& Lüönd, 1982b; Dore, 1954; 1968; Haynes, 2000b; Lamoureux, 1987; Les \& Tippery, 2013; Les et al., 2003; Mühlberg, 1982; Scribailo \& Posluszny, 1983; 1984; 1985; Scribailo et al., 1984; Zhu, 2014; Zhu et al., 2014.

\subsubsection{Limnobium}

American frog-bit, American spongeplant

Etymology: from the Greek limno bios ("lake living") in reference to the typical habitat

Synonyms: Hydrocharella; Hydrocharis (in part); Hydromystria; Jalambicea; Rhizakenia; Trianea

Distribution: global: New World (Americas); North America: southeastern United States

Diversity: global: 2 species; North America: 1 species Indicators (USA): obligate wetland (OBL): Limnobium spongia

Habitat: freshwater; lacustrine, palustrine, riverine; pH: 5.6-8.6; depth: $<1 \mathrm{~m}$; life-form(s): emergent, floating-leaved, free-floating

Key morphology: plants floating freely or rooted in sediment; shoots dimorphic: contracted and rosulate, bearing branched adventitious roots (to $60 \mathrm{~cm}$ ), or stoloniferous (to $15+\mathrm{cm}$ ), terminating in new rosettes or compact winter buds; foliage dimorphic: aerial leaves with flat, leathery blades, and long, erect petioles (to $40 \mathrm{~cm}$ ); floating leaves with thick spongy pad of tissue on lower surface, and shorter petioles (0.8-12 $\mathrm{cm}$ ); blades (to $10 \mathrm{~cm}$ ), broadly ovate, apex acute, the base often cordate, stipules median, conspicuous (to $8 \mathrm{~cm}$ ), longer on erect leaves; flowers trimerous, unisexual, the rosettes unisexual or monoecious; $\sigma^{\tau}$ flowers (to 25), pedicelled (to $9 \mathrm{~cm}$ ), arising from a peduncled (to $3.5 \mathrm{~cm}$ ) spathe (to $6.3 \mathrm{~cm}$ ); sepals (to $9 \mathrm{~mm}$ ) greenish or yellowish, becoming reflexed; petals (to $9.4 \mathrm{~mm}$ ) whitish, linear to lanceolate, stamens (3-16) inserted on a column, in 5-6 whorls, the latter three usually staminodal; 9 flowers (to 6) pedicelled (to $12 \mathrm{~cm}$, but elongating further in fruit), arising from a peduncled (to $1.5 \mathrm{~cm}$ ) spathe (to $5.5 \mathrm{~cm}$ ); sepals (to $9.3 \mathrm{~mm}$ ) elliptical, spreading; petals (to $14 \mathrm{~mm}$ ) spreading, greenish-white; staminodes (to $3.3 \mathrm{~mm}$ ) 2-6; ovary (to $8.5 \mathrm{~mm}$ ) unilocular, styles (to $20 \mathrm{~mm}$ ) 6-9, divided to $1 / 4$ their length; capsule (to $18 \mathrm{~mm}$ ) oblong, berrylike; seeds (to $2.3 \mathrm{~mm}$ ) numerous (to 200 ), covered by spikelike trichomes (to $0.4 \mathrm{~mm}$ )

Life history: duration: perennial (stolons, turions, whole plants); asexual reproduction: stolons, turions; pollination: wind; sexual condition: dioecious, monoecious; fruit: capsule (berrylike) (common); local dispersal: water (seeds, turions); long-distance dispersal: waterfowl (seeds, seedlings)

Imperilment: 1. Limnobium spongia [G4]; S1 (IL, IN, MD, NJ, WV); S2 (DE, KY, MO, NC); S3 (GA, VA)

Ecology: general: Both Limnobium species are perennial, emergent or floating-leaved aquatics. As in Hydrocharis, the plants can float freely as rosettes on the water surface (and grow in mats of other floating vegetation), or become rooted in the sediment when growing in sufficiently shallow water or on exposed substrates. Floating leaves develop on plants growing in more than $10 \mathrm{~cm}$ of water; the roots can anchor in the substratum when the water depth is below $60 \mathrm{~cm}$. Vegetative plasticity (e.g., see above description) can be fairly extensive and represents an adaptive response to the various habitats (e.g., exposed sites vs. inundated sites) in which the plants may be found. The root caps are easily removed without damage, and are thought to facilitate the liberation of rooted plants from the sediment as water levels rise. The flowers are unisexual and although primarily of mixed sexes (the plants then monoecious), a single rosette also can be unisexual (individual plants, or at least separate ramets, then potentially dioecious). Unlike Hydrocharis, the flowers are not showy, lack nectar, and are pollinated abiotically by the wind.

2.3.7.1. Limnobium spongia (Bosc) Rich. ex Steud. grows in shallow (e.g., $0.5-100 \mathrm{~cm}$ ), still or slowly moving waters, or on exposed, saturated substrates associated with baygalls, bayous, borrow pits, bottomlands, canals, channels (roadside), ditches (roadside), flats, floodplains, gravel bars, lakes, marshes (depression), meadows (flooded), mudflats, ponds, prairies, reservoirs, rivers, roadsides, shell pits, sinkholes, sloughs, springs (edges), streams, swales, and swamps at elevations to $204 \mathrm{~m}$. Site exposures can range from full sun to shaded conditions. The substrates have been characterized as alluvium, clay, entisols (loamy), gravel, muck (Barbary, organic, Shenks), mud, Nittau (typic argiaquolls), peat, sand (coarse), silt, and silty clay. The plants are variable phenotypically, producing long-stalked, erect, coriaceous leaves 


\section{References}

Aalto, M. 1970. Potamogetonaceae fruits. I. Recent and subfossil endocarps of the Fennoscandian species. Acta Bot. Fenn. 88: $1-85$.

Aalto, M. 1974. Potamogetonaceae fruits. II. Potamogeton robbinsii, a seldom fruiting North American pondweed species. Ann. Bot. Fenn. 11: 29-33.

Abbitt, R. J. \& J. M. Scott. 2001. Examining differences between recovered and declining endangered species. Conserv. Biol. 15: $1274-1284$.

Abbott, J. M., K. DuBois, R. K. Grosberg, S. L. Williams \& J. J. Stachowicz. 2018. Genetic distance predicts trait differentiation at the subpopulation but not the individual level in eelgrass, Zostera marina. Ecol. Evol. 8: 7476-7489.

Abdel-Hamid, A. A., M. A. Al-Ghobashy, M. Fawzy, M. B. Mohamed \& M. M. S. A. Abdel-Mottaleb. 2013. Phytosynthesis of Au, $\mathrm{Ag}$, and $\mathrm{Au}-\mathrm{Ag}$ bimetallic nanoparticles using aqueous extract of sago pondweed (Potamogeton pectinatus L.). ACS Sustain. Chem. Eng. 1: 1520-1529.

Abdul-Alghaffar, H. N. \& A. S. Al-Dhamin. 2016. Phytoremediation of chromium and copper from aqueous solutions using Hydrilla verticillata. Iraqi J. Sci. 57: 78-86.

Abernethy, V. J., M. R. Sabbatini \& K. J. Murphy. 1996. Response of Elodea canadensis Michx. and Myriophyllum spicatum L. to shade, cutting and competition in experimental culture. Hydrobiologia 340: 219-224.

Abideen, Z., A. Hameed, H.-W. Koyro, B. Gul, R. Ansari \& M. A. Khan. 2014. Sustainable biofuel production from non-food sources - an overview. Emir. J. Food Agric. 26: 1057-1066.

Abou-Donia, A. H., S. M. Toaima, H. M. Hammoda, E. Shawky, E. Kinoshita \& H. Takayama. 2008. Phytochemical and biological investigation of Hymenocallis littoralis Salisb. Chem. Biodivers. 5: 332-340.

Aboul-Enein, A. M., A. M. Al-Abd, E. Shalaby, F. Abul-Ela, A. A. Nasr-Allah, A. M. Mahmoud \& H. A. El-Shemy. 2011. Eichhornia crassipes (Mart) solms: from water parasite to potential medicinal remedy. Plant Signal. Behav. 6: 834-836.

Aceto, S. \& L. Gaudio. 2011. The MADS and the beauty: genes involved in the development of orchid flowers. Curr. Genomics 12: 342-356.

Aceto, S. \& L. Gaudio. 2016. The MADS-box genes involved in orchid flower development. Pp. 113-142 In: Atta-ur-Rahman (ed.), Advances in Genome Science. Volume 4: Genes in Health and Disease. Bentham Science Publishers, Sharjah, United Arab Emirates.

Ackerman, J. D. 1986. Mechanisms and evolution of food-deceptive pollination systems in orchids. Lindleyana 1: 108-113.

Ackerman, J. D. 1995. Convergence of filiform pollen morphologies in seagrasses: functional mechanisms. Evol. Ecol. 9: 139-153.

Ackerman, J. D. 1997a. Submarine pollination in the marine angiosperm Zostera marina (Zosteraceae). I. The influence of floral morphology on fluid flow. Am. J. Bot. 84: 1099-1109.

Ackerman, J. D. 1997b. Submarine pollination in the marine angiosperm Zostera marina (Zosteraceae). II. Pollen transport in flow fields and capture by stigmas. Am. J. Bot. 84: 1110-1119.

Ackerman, J. D. 2002. Ponthieva R. Brown. Pp. 547-548 In: Flora North America Editorial Committee (eds.), Flora of North America North of Mexico, Vol. 26: Magnoliophyta: Liliidae: Liliales and Orchidales. Oxford University Press, New York, NY.
Ackerman, J. D. 2006. Sexual reproduction of seagrasses: pollination in the marine context. Pp. 89-109 In: A. W. D. Larkum, R. J. Orth \& C. M. Duarte (eds.), Seagrasses: Biology, Ecology and Conservation. Springer-Verlag, Dordrecht, The Netherlands.

Adair, S. E., J. L. Moore \& C. P. Onuf. 1994. Distribution and status of submerged vegetation in estuaries of the upper Texas coast. Wetlands 14: 110-121.

Adair, R. J., B. R. Keener, R. M. Kwong, J. L. Sagliocco \& G. E. Flower. 2012. The biology of Australian weeds 60. Sagittaria platyphylla (Engelmann) J. G. Smith and Sagittaria calycina Engelmann. Plant Prot. Q. 27: 47-58.

Adamec, L. 2018. Ecophysiological characteristics of turions of aquatic plants: a review. Aquat. Bot. 148: 64-77.

Adams, J. 1927. The germination of the seeds of some plants with fleshy fruits. Am. J. Bot. 14: 415-428.

Adams, P. \& R. K. Godfrey. 1961. Observations on the Sagittaria subulata complex. Rhodora 63: 247-266.

Adams, J. B. \& G. C. Bate. 1994a. The tolerance to desiccation of the submerged macrophytes Ruppia cirrhosa (Petagna) Grande and Zostera capensis Setchell. J. Exp. Mar. Biol. Ecol. 183: 53-62.

Adams, J. B. \& G. C. Bate. 1994b. The ecological implications of tolerance to salinity by Ruppia cirrhosa (Petagna) Grande and Zostera capensis Setchell. Bot. Mar. 37: 449-456.

Adams, M., F. Gmünder \& M. Hamburger. 2007. Plants traditionally used in age related brain disorders - a survey of ethnobotanical literature. J. Ethnopharmacol. 113: 363-381.

Adams, L. D., S. Buchmann, A. D. Howell \& J. Tsang. 2010. A study of insect pollinators associated with DoD TER-S flowering plants, including identification of habitat types where they cooccur by military installation in the southeastern United States. No. LRMP-09-391. U.S. Department of Defense, Legacy Resource Management Program, Arlington, VA. 83 pp.

Adams, M., S. Gschwind, S. Zimmermann, M. Kaiser \& M. Hamburger. 2011. Renaissance remedies: antiplasmodial protostane triterpenoids from Alisma plantago-aquatica $\mathrm{L}$. (Alismataceae). J. Ethnopharmacol. 135: 43-47.

Adebayo, A. A., E. Briski, O. Kalaci, M. Hernandez, S. Ghabooli, B. Beric, F. T. Chan, A. Zhan, E. Fifield, T. Leadley \& H. J. MacIsaac. 2011. Water hyacinth (Eichhornia crassipes) and water lettuce (Pistia stratiotes) in the Great Lakes: playing with fire? Aquat. Invasions 6: 91-96.

Adey, W. H., M. Finn, P. Kangas, L. Lange, C. Luckett \& D. M. Spoon. 1996. A Florida Everglades mesocosm—model veracity after four years of self-organization. Ecol. Eng. 6: 171-224.

Adis, J. 1983. Eco-entomological observations from the Amazon. IV. Occurrence and feeding habits of the aquatic caterpillar Palustra laboulbeni Bar, 1873 (Arctiidae: Lepidoptera) in the vicinity of Manaus. Acta Amazon. 13: 31-36.

Adler, L. S. 2000. The ecological significance of toxic nectar. Oikos 91: 409-420.

Adler, J. M., S. C. Barry, G. R. Johnston, C. A. Jacoby \& T. K. Frazer. 2018. An aggregation of turtles in a Florida spring yields insights into effects of grazing on vegetation. Freshw. Sci. 37: 397-403.

Aerne-Hains, L. \& M. G. Simpson. 2017. Vegetative anatomy of the Haemodoraceae and its phylogenetic significance. Int. J. Plant. Sci. 178: 117-156.

Afton, A. D., R. H. Hier \& L. Paulus. 1991. Lesser scaup diets during migration and winter in the Mississippi flyway. Can. J. Zool. 69: $328-333$ 
Agami, M. \& Y. Waisel. 1984. Germination of Najas marina L. Aquat. Bot. 19: 37-44.

Agami, M. \& Y. Waisel. 1986. The role of mallard ducks (Anas platyrhynchos) in distribution and germination of seeds of the submerged hydrophyte Najas marina L. Oecologia 68: 473-475.

Agami, M. \& Y. Waisel. 1988. The role of fish in distribution and germination of seeds of the submerged macrophytes Najas marina L. and Ruppia maritima L. Oecologia 76: 83-88.

Agami, M., S. Beer \& Y. Waisel. 1980. Growth and photosynthesis of Najas marina L. as affected by light intensity. Aquat. Bot. 9: 285-289.

Agami, M., S. Beer \& Y. Waisel. 1984. Seasonal variations in the growth capacity of Najas marina $\mathrm{L}$. as a function of various water depths at the Yarkon Springs, Israel. Aquat. Bot. 19: 45-51.

Agami, M., A. Eshel \& Y. Waisel. 1984a. Najas marina in Israel: it is a halophyte or a glycophyte? Physiol. Plant. 61: 634-636.

Agami, M., S. Beer \& Y. Waisel. 1986. The morphology and physiology of turions in Najas marina L. in Israel. Aquat. Bot. 26: 371-376.

Ahee, J. E., W. E. Van Drunen \& M. E. Dorken. 2015. Analysis of pollination neighbourhood size using spatial analysis of pollen and seed production in broadleaf cattail (Typha latifolia). Botany 93: 91-100.

Ahmad, Z., N. S. Hossain, S. G. Hussain \& A. H. Khan. 1990. Effect of duckweed (Lemna minor) as complement to fertilizer nitrogen on the growth and yield of rice. Int. J. Trop. Agric. 8: 72-79.

Ahmadi, M., H. Saki, A. Takdastan, M. Dinarvand, S. Jorfi \& B. Ramavandi. 2017. Advanced treatment of saline municipal wastewater by Ruppia maritima: a data set. Data Brief 13: 545-549.

Aikens, C. M. 1986. Archaeology of Oregon, 2nd ed. U.S. Department of the Interior, Bureau of Land Management, Oregon State Office, Portland, OR. 133 pp.

Ailstock, S. \& D. Shafer. 2004. Restoration potential of Ruppia maritima and Potamogeton perfoliatus by seed in the midChesapeake Bay. Technical Report No. ERDC/EL-TN-04-02. Engineer Research and Development Center, Vicksburg, MS. 8 pp.

Ailstock, S. \& D. Shafer. 2006. Protocol for large-scale collection, processing, and storage of seeds of two mesohaline submerged aquatic plant species. Technical Report No. ERDC/ TN-SAV-06-3. Engineer Research and Development Center, Vicksburg, MS. 8 pp.

Ailstock, M. S., D. J. Shafer \& A. D. Magoun. 2010a. Effects of planting depth, sediment grain size, and nutrients on Ruppia maritima and Potamogeton perfoliatus seedling emergence and growth. Restor. Ecol. 18: 574-583.

Ailstock, M. S., D. J. Shafer \& A. D. Magoun. 2010b. Protocols for use of Potamogeton perfoliatus and Ruppia maritima seeds in large-scale restoration. Restor. Ecol. 18: 560-573.

Ainsworth, C. (ed.). 2006. Flowering and Its Manipulation. Annual Plant Reviews, Volume 20. Blackwell Publishing, Oxford, United Kingdom. 320 pp.

Airaksinen, M. M., P. Peura, L. Ala-Fossi-Salokangas, S. Antere, J. Lukkarinen, M. Saikkonen \& F. Stenbäck. 1986. Toxicity of plant material used as emergency food during famines in Finland. J. Ethnopharmacol. 18: 273-296.

Akkol, E. K., I. Süntar, H. Keles \& E. Yesilada. 2011. The potential role of female flowers inflorescence of Typha domingensis Pers. in wound management. J. Ethnopharmacol. 133: 1027-1032.

Akridge, R. E. \& P. J. Fonteyn. 1981. Naturalization of Colocasia esculenta (Araceae) in the San Marcos River, Texas. Southwest. Nat. 26: 210-211.
Alam, Z., M. M. Huq, A. Jabbar \& C. M. Hasan. 1999. Potamogeton nodosus: an aquatic source for bioactive compounds. Fitoterapia 70: 523-525.

Albanese, B. 2000. Reproductive behavior and spawning microhabitat of the flagfin shiner Pteronotropis signipinnis. Am. Midl. Nat. 143: 84-94.

Alderson, H. E. \& A. G. Rawlins. 1925. Rice workers' dermatitis. Cal. West. Med. 23: 42-45.

Alderton, E., C. D. Sayer, R. Davies, S. J. Lambert \& J. C. Axmacher. 2017. Buried alive: aquatic plants survive in 'ghost ponds' under agricultural fields. Biol. Conserv. 212: 105-110.

Aldrich, J. R. \& M. A. Homoya. 1983. Natural barrens and post oak flatwoods in Posey and Spencer counties. Proc. Indiana Acad. Sci. 93: 291-302.

Aldrich, J. R., L. A. Casebere, M. A. Homoya \& H. Starcs. 1985. The discovery of native rare vascular plants in northern Indiana. Proc. Indiana Acad. Sci. 95: 421-428.

Alexander, M. L. \& C. T. Phillips. 2012. Habitats used by the endangered fountain darter (Etheostoma fonticola) in the San Marcos River, Hays County, Texas. Southwest. Nat. 57: 449-452.

Alexander, S. A., K. A. Hobson, C. L. Gratto-Trevor \& A. W. Diamond. 1996. Conventional and isotopic determinations of shorebird diets at an inland stopover: the importance of invertebrates and Potamogeton pectinatus tubers. Can. J. Zool. 74: 1057-1068.

Algar, A. F. C., A. B. Umali \& R. R. P. Tayobong. 2019. Physicochemical and functional properties of starch from Philippine edible canna (Canna indica L.) rhizomes. J. Microbiol. Biotechnol. Food Sci. 9: 34-37.

Aliferis, K. A., S. Materzok, G. N. Paziotou \& M. ChrysayiTokousbalides. 2009. Lemna minor L. as a model organism for ecotoxicological studies performing $1 \mathrm{H}$ NMR fingerprinting. Chemosphere 76: 967-973.

Alix, M. S. \& R. W. Scribailo. 2006. First report of Potamogeton $\times$ undulatus $(P$. crispus $\times P$. praelongus, Potamogetonaceae) in North America, with notes on morphology and stem anatomy. Rhodora 108: 329-346.

Allard, H. A. 1951. The ratios of clockwise and counterclockwise spirality observed in the phyllotaxy of some wild plants. Castanea 16: 1-6.

Allen, L., J. D. Johnson \& K. Vujnovic. 2002a. Small Patch Communities of La Butte Creek Wildland Provincial Alberta. Natural Heritage Information Centre, Alberta Community Development, Edmonton, AB. 38 pp.

Allen, G. M., M. D. Bond \& M. B. Main. 2002b. 50 common native plants important in Florida's ethnobotanical history. Circular 1439. Florida Cooperative Extension Service, Institute of Food and Agricultural Sciences, University of Florida, Gainseville, FL. 21 pp.

Allen, C., R. Erwin, J. McMillian \& J. McMillian. 2013. A quantitative study of the vegetation surrounding a Xanthorhiza simplicissima (Ranunculaceae) population at Fort Polk in West Central Louisiana. J. Bot. Res. Inst. Texas 7: 519-528.

Allen, A. C., C. A. Beck, R. K. Bonde, J. A. Powell \& N. A. Gomez. 2017. Diet of the Antillean manatee (Trichechus manatus manatus) in Belize, Central America. J. Mar. Biol. Assoc. U. K. doi: 10.1017/S0025315417000182.

Almquist, H. \& A. J. K. Calhoun. 2003. A coastal, southern-outlier patterned fen: Lily Fen, Swans Island, Maine. Northeast. Nat. 10: $119-130$.

Altrichter, K. M., E. S. DeKeyser, B. Kobiela \& C. L. M. Hargiss. 2018. A comparison of five wetland communities in a North Dakota fen complex. Nat. Areas J. 38: 275-285.

Alvarado, S., M. Guédez, M. P. Lué-Merú, G. Nelson, A. Alvaro, A. C. Jesús \& Z. Gyula. 2008. Arsenic removal from waters 
by bioremediation with the aquatic plants water hyacinth (Eichhornia crassipes) and lesser duckweed (Lemna minor). Bioresour. Technol. 99: 8436-8440.

Alves, T. L. S., O. Chauveau, L. Eggers \& T. T. de Souza-Chies. 2014. Species discrimination in Sisyrinchium (Iridaceae): assessment of DNA barcodes in a taxonomically challenging genus. Mol. Ecol. Resour.Molec. Ecol. Resources 14: 324-335.

Alves Pagotto, M., R. D. M. L. Silveira, C. N. D. Cunha \& I. FantinCruz. 2011. Distribution of herbaceous species in the soil seed bank of a flood seasonality area, northern Pantanal, Brazil. Int. Rev. Hydrobiol. 96: 149-163.

Amano, M., S. Iida \& K. Kosuge. 2011. Comparative studies of thermotolerance: different modes of heat acclimation between tolerant and intolerant aquatic plants of the genus Potamogeton. Ann. Bot. 109: 443-452.

Ames, O. 1903. Natural hybrids in Spiranthes and Habenaria. Rhodora 5: 261-264.

Amoroso, J. L. \& W. S. Judd. 1995. A floristic study of the Cedar Key Scrub State Reserve, Levy County, Florida. Castanea 60: 210-232.

Andersen, R. \& J. S. Price. 2012. Microbial communities in boreal peatlands of the Athabasca region, Canada: building a reference for fen creation. Extended abstract No. 251. 14th International Peat Congress, Stockholm, Sweden. 6 pp.

Anderson, E. 1928. The problem of species in the northern blue flags, Iris versicolor L. and Iris virginica L. Ann. Missouri Bot. Gard. 15: 241-332.

Anderson, E. 1936. The species problem in Iris. Ann. Missouri Bot. Gard. 23: 457-509.

Anderson, W. A. 1943. A fen in northwestern Iowa. Am. Midl. Nat. 29: 787-791.

Anderson, H. G. 1959. Food habits of migratory ducks in Illinois. Illinois Nat. Hist. Surv. Bull. 27: 288-344.

Anderson, R. R. 1969. Temperature and rooted aquatic plants. Chesapeake Sci. 10: 157-164.

Anderson, L. W. J. 1978a. Abscisic acid induces formation of floating leaves in the heterophyllous aquatic angiosperm Potamogeton nodosus. Science 201: 1135-1138.

Anderson, M. G. 1978b. Distribution and production of sago pondweed (Potamogeton pectinatus L.) on a northern prairie marsh. Ecology 59: 154-160.

Anderson, L. W. J. 1982. Effects of abscisic acid on growth and leaf development in American pondweed (Potamogeton nodosus Poir.). Aquat. Bot. 13: 29-44.

Anderson, L. C. 1991. Noteworthy plants from north Florida. V. Sida 14: 467-474.

Anderson, M. K. 1997. From tillage to table: the indigenous cultivation of geophytes for food in California. J. Ethnobiol. 17: 149-169.

Anderson, L. W. J. 2003. A review of aquatic weed biology and management research conducted by the United States Department of Agriculture-Agricultural Research Service. Pest Manag. Sci. 59: 801-813.

Anderson, L. C. 2007. Noteworthy plants from north Florida. VIII. J. Bot. Res. Inst. Texas 1: 741-751.

Anderson, J. M. \& S. C. H. Barrett. 1986. Pollen tube growth in tristylous Pontederia cordata (Pontederiaceae). Can. J. Bot. 64: 2602-2607.

Anderson, M. R. \& J. Kalff. 1986. Regulation of submerged aquatic plant distribution in a uniform area of a weedbed. J. Ecol. 74: 953-961.

Anderson, L. C. \& R. Kral. 2008. Xyris panacea (Xyridaceae)—a new yellow-eyed grass from the Florida Panhandle. J. Bot. Res. Inst. Texas 2: 1-5.

Anderson, N. O. \& R. T. Olsen. 2015. A vast array of beauty: the accomplishments of the father of American ornamental breeding, Luther Burbank. HortScience 50: 161-188.
Anderson, R. R., R. G. Brown \& R. D. Rappleye. 1968. Water quality and plant distribution along the upper Patuxent River, Maryland. Chesapeake Sci. 9: 145-156.

Anderson, L. C., C. D. Zeis \& S. F. Alam. 1974. Phytogeography and possible origins of Butomus in North America. Bull. Torrey Bot. Club 101: 292-296.

Anderson, R. C., J. S. Fralish \& J. M. Baskin (eds.). 1999. Savannas, Barrens, and Rock Outcrop Plant Communities of North America. Cambridge University Press, New York, NY. $470 \mathrm{pp}$.

Andersson, L. 1981. Revision of the Thalia geniculata complex (Marantaceae). Nordic J. Bot. 1: 48-56.

Andersson, L. 1998. Marantaceae. Pp. 278-293 In: K. Kubitzki, H. Huber, P. J. Rudall, P. S. Stevens \& T. Stützel (eds.), The Families and Genera of Vascular Plants, Vol. IV. Flowering Plants, Monocotyledons: Alismatanae and Commelinanae (Except Gramineae). Springer-Verlag, Berlin, Germany.

Andersson, E., C. Nilsson \& M. E. Johansson. 2000. Plant dispersal in boreal rivers and its relation to the diversity of riparian flora. J. Biogeogr. 27: 1095-1106.

Andreas, B. K. \& G. R. Bryan. 1990. The vegetation of three Sphagnum-dominated basin-type bogs in northeastern Ohio. Ohio J. Sci. 90: 54-66.

Andrews, O. V. 1915. An ecological survey of Lake Butte des Morts bog, Oshkosh, Wisconsin. Bull. Wisconsin Nat. Hist. Soc. 13: 196-211.

Anning, A. K., P. E. Korsah \& P. Addo-Fordjour. 2013. Phytoremediation of wastewater with Limnocharis flava, Thalia geniculata and Typha latifolia in constructed wetlands. Int. J. Phytoremed. 15: 452-464.

Ansari, R. \& N. P. Balakrishnan. 1994. The Family Eriocaulaceae in India. Bishen Singh Mahendra Pal Singh, Dehra Dun. $195 \mathrm{pp}$.

Anuradha, J., T. Abbasi \& S. A. Abbasi. 2015. An eco-friendly method of synthesizing gold nanoparticles using an otherwise worthless weed pistia (Pistia stratiotes L.). J. Adv. Res. 6: $711-720$.

Angier, B. 1974. Field Guide to Edible Wild Plants. Stackpole Books, Mechanicsburg, PA. 255 pp.

Ankutowicz, E. J. \& R. A. Laird. 2018. Offspring of older parents are smaller-but no less bilaterally symmetrical-than offspring of younger parents in the aquatic plant Lemna turionifera. Ecol. Evol. 8: 679-687.

APG. 2003. An update of the Angiosperm Phylogeny Group classification for the orders and families of flowering plants: APG II. Bot. J. Linn. Soc. 141: 399-436.

APG. 2009. An update of the Angiosperm Phylogeny Group classification for the orders and families of flowering plants: APG III. Bot. J. Linn. Soc. 161: 105-121.

APG. 2016. An update of the Angiosperm Phylogeny Group classification for the orders and families of flowering plants: APG IV. Bot. J. Linn. Soc. 181: 1-20.

Appenroth, K.-J. 2002. Co-action of temperature and phosphate in inducing turion formation in Spirodela polyrhiza (great duckweed). Plant Cell Environ. 25: 1079-1085.

Appenroth, K.-J. \& G. Nickel. 2010. Turion formation in Spirodela polyrhiza: the environmental signals that induce the developmental process in nature. Physiol. Plant. 138: 312-320.

Appenroth, K.-J., J. Opfermann, W. Hertel \& H. Augsten. 1989. Photophysiology of turion germination in Spirodela polyrhiza (L.) Schleiden. II. Influence of after-ripening on germination kinetics. J. Plant Physiol. 135: 274-279.

Appenroth, K.-J., W. Hertel \& H. Augsten. 1990a. Phytochrome control of turion formation in Spirodela polyrhiza L. Schleiden. Ann. Bot. 66: 163-168. 
Appenroth, K.-J., W. Hertel \& H. Augsten. 1990b. Photophysiology of turion germination in Spirodela polyrhiza (L.) Schleiden. The cause of germination inhibition by overcrowding. Biol. Plant. 32: 420-428.

Appenroth, K.-J., H. Augsten \& H. Mohr. 1992. Photophysiology of turion germination in Spirodela polyrhiza (L.) Schleiden. X. Role of nitrate in the phytochrome-mediated response. Plant Cell Environ. 15: 743-748.

Appenroth, K.-J., N. Borisjuk \& E. Lam. 2013a. Telling duckweed apart: genotyping technologies for the Lemnaceae. Chin. J. Appl. Environ. Biol. 19: 1-10.

Appenroth, K.-J., L. Palharini \& P. Ziegler. 2013b. Low-molecular weight carbohydrates modulate dormancy and are required for post-germination growth in turions of Spirodela polyrhiza. Plant Biol. 15: 284-291.

Appenroth, K.-J., D. J. Crawford \& D. H. Les. 2015. After the genome sequencing of duckweed-how to proceed with research on the fastest growing angiosperm? Plant Biol. 17: 1-4.

Appenroth, K.-J., K. S. Sree, V. Böhm, S. Hammann, W. Vetter, M. Leiterer \& G. Jahreis. 2017. Nutritional value of duckweeds (Lemnaceae) as human food. Food Chem. 217: 266-273.

Arata, A. A. 1959. Ecology of muskrats in strip-mine ponds in southern Illinois. J. Wildl. Manag. 23: 177-186.

Archer, S. K., E. W. Stoner \& C. A. Layman. 2015. A complex interaction between a sponge (Halichondria melanadocia) and a seagrass (Thalassia testudinum) in a subtropical coastal ecosystem. J. Exp. Mar. Biol. Ecol. 465: 33-40.

Archibald, J. K., S. R. Kephart, K. E. Theiss, A. L. Petrosky \& T. M. Culley. 2015. Multilocus phylogenetic inference in subfamily Chlorogaloideae and related genera of Agavaceae-Informing questions in taxonomy at multiple ranks. Mol. Phylogenet. Evol. 84: 266-283.

Ardenghi, N. M. G., W. P. Armstrong \& D. Paganelli. 2017. Wolffia columbiana (Araceae, Lemnoideae): first record of the smallest alien flowering plant in southern Europe and Italy. Bot. Lett. 164: 121-127.

Arditti, J. 1966. Orchids. Sci. Am. 214(1): 70-81.

Arditti, J. \& T. R. Pray. 1969. Dormancy factors in iris (Iridaceae) seeds. Am. J. Bot. 56: 254-259.

Arditti, J. \& A. K. A. Ghani. 2000. Tansley review no. 110. Numerical and physical properties of orchid seeds and their biological implications. New Phytol. 145: 367-421.

Arditti, J., J. D. Michaud \& P. L. Healey. 1979. Morphometry of orchid seeds. I. Paphiopedilum and native California and related species of Cypripedium. Am. J. Bot. 66: 1128-1137.

Arditti, J., J. D. Michaud \& P. L. Healey. 1980. Morphometry of orchid seeds. II. Native California and related species of Calypso, Cephalanthera, Corallorhiza and Epipactis. Am. J. Bot. 67: 347-360.

Arditti, J., J. D. Michaud \& A. P. Oliva. 1981. Seed germination of North American orchids. I. Native California and related species of Calypso, Epipactis, Goodyera, Piperia, and Platanthera. Bot. Gaz. 142: 442-453.

Arditti, J., J. D. Michaud \& A. P. Oliva. 1982. Practical germination of North American and related orchids. I. Epipactis atrorubens, Epipactis gigantea and Epipactis helleborine. Am. Orchid Soc. Bull. 51: 162-171.

Aremu, A. \& J. van Staden. 2013. The genus Tulbaghia (Alliaceae) a review of its ethnobotany, pharmacology, phytochemistry and conservation needs. J. Ethnopharmacol. 149: 387-400.

Arenas, P. \& R. M. Azorero. 1977. Plants used as means of abortion, contraception, sterilization and fecundation by Paraguayan indigenous people. Econ. Bot. 31: 302-306.
Aresco, M. J. 2010. Competitive interactions of two species of freshwater turtles, a generalist omnivore and an herbivore, under low resource conditions. Herpetologica 66: 259-268.

Arft, A. M. \& T. A. Ranker. 1998. Allopolyploid origin and population genetics of the rare orchid Spiranthes diluvialis. Am. J. Bot. 85: 110-122.

Argue, C. L. 2011. The Pollination Biology of North American Orchids: Volume 1: North of Florida and Mexico. Springer, New York, NY. 228 pp.

Argue, C. L. 2012a. Tribe Arethuseae (Calopogon R. Brown and Arethusa L.) and subfamily Vanilloideae (part one) (Pogonia Jussieu). Pp. 147-164 In: The Pollination Biology of North American Orchids: Volume 2. Springer, New York, NY.

Argue, C. L. 2012b. Sections Irapeana and Bifolia. Pp. 75-78 In: The Pollination Biology of North American Orchids: Volume 1. Springer, New York, NY.

Argue, C. L. 2012c. Section Cypripedium. Pp. 47-62 In: The Pollination Biology of North American Orchids: Volume 1. Springer, New York, NY.

Argue, C. L. 2012d. Tribe Neottieae. Pp. 55-83 In: The Pollination Biology of North American Orchids: Volume 2. Springer, New York, NY.

Argue, C. L. 2012e. Tribe Malaxideae. Pp. 91-104 In: The Pollination Biology of North American Orchids: Volume 2. Springer, New York, NY.

Argue, C. L. 2012f. Subtribes Goodyerinae and Cranichidinae. Pp. 3-18 In: The Pollination Biology of North American Orchids: Volume 2. Springer, New York, NY.

Argue, C. L. 2012g. Subtribe Spiranthinae. Pp. 19-52 In: The Pollination Biology of North American Orchids: Volume 2. Springer, New York, NY.

Argus, G. W. 1968. Contributions to the flora of boreal Saskatchewan. Rhodora 70: 200-214.

Arlen-Pouliot, Y. \& S. Payette. 2015. The influence of climate on pool inception in boreal fens. Botany 93: 637-649.

Armellina, A. D., C. R. Bezic \& O. A. Gajardo. 1996. Propagation and mechanical control of Potamogeton illinoensis Morong in irrigation canals in Argentina. J. Aquat. Plant Manag. 34: $12-14$.

Armentano, T. V., D. T. Jones, M. S. Ross \& B. W. Gamble. 2002. Vegetation pattern and process in tree islands of the southern Everglades and adjacent areas. Pp. 225-281 In: F. H. Sklar \& A. van der Valk (eds.), Tree Islands of the Everglades. Springer, Dordrecht, The Netherlands.

Armitage, J. \& B. Phillips. 2011. A hybrid swamp lantern. Plantsman 10: $155-157$.

Armstrong, M. 1915. Field Book of Western Wild Flowers. The Knickerbocker Press, New York, NY. 598 pp.

Armstrong, W. P. 2012. Wolffia. Watermeal. Pp. 1301-1302 In: B. G. Baldwin, D. H. Goldman, D. J. Keil, R. Patterson, T. J. Rosatti \& D. H. Wilken (eds.), The Jepson Manual: Vascular Plants of California, 2nd ed. University of California Press, Berkeley, CA.

Armstrong, R. \& D. M. Moore. 1957. Botanical aspects of Massard Prairie Arkansas. J. Arkansas Acad. Sci. 10: 44-57.

Armstrong, W. P. \& R. F. Thorne. 1984. The genus Wolffia (Lemnaceae) in California. Madroño 31: 171-179.

Armstrong, W. P., W. Kelley \& D. H. Wilken. 1989. Noteworthy collections. Madroño 36: 283-286.

Armstrong, N., D. Planas \& E. Prepas. 2003. Potential for estimating macrophyte surface area from biomass. Aquat. Bot. 75: 173-179.

Arnett, M., A. M. Huber, K. M. Stevenson \& S. Haultain. 2014. Vascular flora of Devils Postpile National Monument, Madera County, California. Madroño 61: 367-388. 
Arnold, M. L. 1993. Iris nelsonii (Iridaceae): origin and genetic composition of a homoploid hybrid species. Am. J. Bot. 80: 577-583.

Arnold, M. L. 1994. Natural hybridization and Louisiana irises. BioScience 44: 141-147.

Arnold, M. L. 2000. Anderson's paradigm: Louisiana irises and the study of evolutionary phenomena. Mol. Ecol. 9: 1687-1698.

Arnold, M. L., J. L. Hamrick \& B. D. Bennett. 1990. Allozyme variation in Louisiana irises: a test for introgression and hybrid speciation. Heredity 65: 297-306.

Arnold, M. L., C. M. Buckner \& J. J. Robinson. 1991. Pollenmediated introgression and hybrid speciation in Louisiana irises. Proc. Natl. Acad. Sci. U.S.A. 88: 1398-1402.

Arnold, M. L., J. L. Hamrick \& B. D. Bennett. 1993. Interspecific pollen competition and reproductive isolation in Iris. J. Hered. 84: $13-16$.

Arnold, M. L., S. Tang, S. J. Knapp \& N. H. Martin. 2010. Asymmetric introgressive hybridization among Louisiana Iris species. Genes 1: 9-22.

Arnold, T., C. Mealey, H. Leahey, A. W. Miller, J. M. Hall-Spencer, M. Milazzo \& K. Maers. 2012. Ocean acidification and the loss of phenolic substances in marine plants. PLoS One 7(4): e35107.

Aronson, J. A. 1989. HALOPH: A Data Base of Salt Tolerant Plants of the World. Office of Arid Lands Studies, The University of Arizona, Tuscon, AZ. 77 pp.

Arsenault, J. 1984. Field trip reports. Bartonia 50: 71.

Arts, G. H. P., J. G. M. Roelofs \& M. J. H. De Lyon. 1990. Differential tolerances among soft-water macrophyte species to acidification. Can. J. Bot. 68: 2127-2134.

Asamoah, S. A. \& E. W. Bork. 2010. Drought tolerance thresholds in cattail (Typha latifolia): a test using controlled hydrologic treatments. Wetlands 30: 99-110.

Ashton, M. J. \& J. B. Layzer. 2010. Summer microhabitat use by adult and young-of-year snail darters (Percina tanasi) in two rivers. Ecol. Freshw. Fish 19: 609-617.

Aston, H. I. 1967. Aquatic angiosperms: records of four introduced species new to Victoria. Muelleria 1: 169-174.

Aston, H. I. \& S. W. L. Jacobs. 1980. Hydrocleys nymphoides (Butomaceae) in Australia. Muelleria 4: 285-293.

Atapaththu, K. S. S. \& T. Asaeda. 2015. Growth and stress responses of Nuttall's waterweed Elodea nuttallii (Planch) St. John to water movements. Hydrobiologia 747: 217-233.

Atwood, E. L. 1950. Life history studies of nutria, or coypu, in coastal Louisiana. J. Wildl. Manag. 14: 249-265.

Atwood, Jr., J. T. 1984. The relationships of the slipper orchids (subfamily Cypripedioideae, Orchidaceae). Selbyana 7: 129-247.

Auclair, A. N., A. Bouchard \& J. Pajaczkowski. 1973. Plant composition and species relations on the Huntingdon Marsh, Quebec. Can. J. Bot. 51: 1231-1247.

Aulbach-Smith, C. A. \& S. J. de Kozlowski. 1996. Aquatic and Wetland Plants of South Carolina, 2nd ed. South Carolina Department of Natural Resources, Columbia, SC. 128 pp.

Aust, W. M., S. H. Schoenholtz, T. W. Zaebst \& B. A. Szabo. 1997. Recovery status of a tupelo-cypress wetland seven years after disturbance: silvicultural implications. For. Ecol. Manag. 90: 161-169.

Austin, D. F. 1998. Plant adaptations in the Fakahatchee. Palmetto 18(3): 7-8.

Austin, D. F. 2004. Florida Ethnobotany. CRC Press, Boca Raton, FL. 952 pp.

Austin, G. \& D. J. Cooper. 2016. Persistence of high elevation fens in the Southern Rocky Mountains, on Grand Mesa, Colorado, U.S.A. Wetl. Ecol. Manag. 24: 317-334.
Avis, P., B. Brown, K. Buscher, F. Coskun, P. Coulling, S. Hanford, J. Harrod, J. Horn, C. Mankoff, B. Peet, L. Prince, A. Stanford, S. Seiberling, R. White \& K. Wurdack. 1997. Proceedings. UNC sometimes annual phytogeographical excusion to the Florida panhandle. March 8-14, 1997. Available online: http://labs. bio.unc.edu/Peet/PEL/PGE/PGE1997_report.pdf [accessed 16 March, 2019].

Ayyad, S.-E. N., A. S. Judd, W. T. Shier \& T. R. Hoye. 1998. Otteliones A and B: potently cytotoxic 4-methylene-2-cyclohexenones from Ottelia alismoides. J. Organic Chem. 63: 8102-8106.

Azuma, H. \& H. Tobe. 2011. Molecular phylogenetic analyses of Tofieldiaceae (Alismatales): family circumscription and intergeneric relationships. J. Plant Res. 124: 349-357.

Azuma, H. \& M. Toyota. 2012. Floral scent emission and new scent volatiles from Acorus (Acoraceae). Biochem. Syst. Ecol. 41: $55-61$.

Babayemi, O. J., M. A. Bamikole \& A. B. Omojola. 2006. Evaluation of the nutritive value and free choice intake of two aquatic weeds (Nephrolepis biserrata and Spirodela polyrhiza) by West African dwarf goats. Trop. Subtrop. Agroecosyst. 6: 15-21.

Back, A. J., P. Kron \& S. C. Stewart. 1996. Phenological regulation of opportunities for within-inflorescence geitonogamy in the clonal species, Iris versicolor (Iridaceae). Am. J. Bot. 83: 1033-1040.

Backman, T. W. H. 1991. Genotypic and phenotypic variability of Zostera marina on the west coast of North America. Can. J. Bot. 69: 1361-1371.

Baden, III, J., W. T. Batson \& R. Stalter. 1975. Factors affecting the distribution of vegetation of abandoned rice fields, Georgetown Co., South Carolina. Castanea 40: 171-184.

Badzinski, S. S., C. D. Ankney \& S. A. Petrie. 2006. Influence of migrant tundra swans (Cygnus columbianus) and Canada geese (Branta canadensis) on aquatic vegetation at Long Point, Lake Erie, Ontario. Hydrobiologia 567: 195-211.

Bailey, D. E., J. E. Perry \& D. A. DeBerry. 2006. Aeschynomene virginica (Fabaceae) habitat in a tidal marsh, James City County, Virginia. Banisteria 27: 3-9.

Bailey, M., S. A. Petrie \& S. S. Badzinski. 2008. Diet of mute swans in lower Great Lakes coastal marshes. J. Wildl. Manag. 72: 726-732.

Bains, J. S., V. Dhuna, J. Singh, S. S. Kamboj, K. K. Nijjar \& J. N. Agrewala. 2005. Novel lectins from rhizomes of two Acorus species with mitogenic activity and inhibitory potential towards murine cancer cell lines. Int. Immunopharmacol. 5: 1470-1478.

Bajwa, D. S., E. D. Sitz, S. G. Bajwa \& A. R. Barnick. 2015. Evaluation of cattail (Typha spp.) for manufacturing composite panels. Ind. Crops Prod. 75: 195-199.

Bakenhaster, M. D. \& J. S. Knight-Gray. 2016. New diet data for Mola mola and Masturus lanceolatus (Tetraodontiformes: Molidae) off Florida's Atlantic coast with discussion of historical context. Bull. Mar. Sci. 92: 497-511.

Baker, F. C. 1910. The ecology of the Skokie Marsh area, with special reference to the Mollusca. Illinois Nat. Hist. Surv. Bull. 8: 441-499.

Baker, H. G. 1972. A fen on the northern California coast. Madroño 21: 405-416.

Baker, F. C. 1975. The littoral macrophyte vegetation of southeastern Devils Lake. Trans. Wisconsin Acad. Sci. 63: 66-71.

Baker, P., F. Zimmanck \& S. M. Baker. 2010. Feeding rates of an introduced freshwater gastropod Pomacea insularum on native and nonindigenous aquatic plants in Florida. J. Molluscan Stud. 76: 138-143. 
Balci, P. \& J. H. Kennedy. 2003. Comparison of chironomids and other macroinvertebrates associated with Myriophyllum spicatum and Heteranthera dubia. J. Freshw. Ecol. 18: 235-247.

Balciunas, J. K. \& M. C. Minno. 1985. Insects damaging hydrilla in the USA. J. Aquat. Plant Manag. 23: 77-83.

Baldridge, A. K. \& D. M. Lodge. 2014. Long-term studies of crayfish-invaded lakes reveal limited potential for macrophyte recovery from the seed bank. Freshw. Sci. 33: 788-797.

Baldwin, W. K. W. 1961. Malaxis paludosa (L.) Sw. in the Hudson Bay lowlands. Can. Field-Nat. 75: 74-77.

Baldwin, Jr., J. T. \& B. M. Speese. 1955. Chromosomes of taxa of the Alismataceae in the range of Gray's Manual. Am. J. Bot. 42: 406-411.

Baldwin, J. R. \& J. R. Lovvorn. 1994. Expansion of seagrass habitat by the exotic Zostera japonica, and its use by dabbling ducks and brant in Boundary Bay, British Columbia. Mar. Ecol. Prog. Ser. 103: 119-127.

Baldwin, A. H. \& I. A. Mendelssohn. 1998. Effects of salinity and water level on coastal marshes: an experimental test of disturbance as a catalyst for vegetation change. Aquat. Bot. 61: 255-268.

Baldwin, B. G., D. H. Goldman, D. J. Keil, R. Patterson, T. J. Rosatti \& D. H. Wilken (eds.). 2012. The Jepson Manual: Vascular Plants of California, 2nd ed. University of California Press, Berkeley, CA. 1,568 pp.

Ball, D. \& J. R. Freeland. 2013. Synchronous flowering times and asymmetrical hybridization in Typha latifolia and T. angustifolia in northeastern North America. Aquat. Bot. 104: 224-227.

Ballantine, D. \& H. J. Humm. 1975. Benthic algae of the Anclote Estuary I. Epiphytes of seagrass leaves. Florida Sci. 38: $150-162$.

Baltisberger, M., A. Kocyan, V. V. Chepinoga, A. A. Gnutikov \& I. V. Enushchenko. 2010. IAPT/IOPB chromosome data 9. Taxon 59: 1298-1302.

Bance, H. M. 1946. A comparative account of the structure of Potamogeton filiformis Pers. and P. pectinatus L. in relation to the identity of a supposed hybrid of these species. Trans. Bot. Soc. Edinburgh 34: 361-367.

Bando, K. J. 2006. The roles of competition and disturbance in a marine invasion. Biol. Invasions 8: 755-763.

Baniszewski, J., J. P. Cuda, S. A. Gezan, S. Sharma \& E. N. I. Weeks. 2016. Stem fragment regrowth of Hydrilla verticillata following desiccation. J. Aquat. Plant Manag. 54: 53-60.

Barabe, D. \& M. Labrecque. 1985. Vascularisation de la fleur d'Orontium aquaticum L. (Aracées). Bull. Soc. Bot. France 132: 133-145.

Baranowski, R. M. 1979. Notes on the biology of Ischnodemus oblongus and I. fulvipes with descriptions of the immature stages (Hemiptera: Lygaeidae). Ann. Entomol. Soc. Am. 72: $655-658$.

Barber, B. J. \& P. J. Behrens. 1985. Effects of elevated temperature on seasonal in situ leaf productivity of Thalassia testudinum Banks ex König and Syringodium filiforme Kützing. Aquat. Bot. 22: 61-69.

Barbolani, E., M. Clauser, F. Pantani \& R. Gellini. 1986. Residual heavy metal ( $\mathrm{Cu}$ and $\mathrm{Cd})$ removal by Iris Pseudacorus. Water Air Soil Pollut. 28: 277-282.

Barbour, M. G. \& S. R. Radosevich. 1979. ${ }^{14} \mathrm{C}$ Uptake by the marine angiosperm Phyllospadix scouleri. Am. J. Bot. 66: 301-306.

Barbour, M. G., A. I. Solomeshch, R. F. Holland, C. W. Witham, R. L. Macdonald, S. S. Cilliers, J. A. Molina, J. J. Buck \& J. M. Hillman. 2005. Vernal pool vegetation of California: communities of long-inundated deep habitats. Phytocoenologia 35: 177-200.
Barbour, M. G., T. Keeler-Wolf \& A. A. Schoenherr. 2007. Terrestrial Vegetation of California, 3rd ed. University of California Press, Berkeley, CA. 712 pp.

Barcelos, A. R., P. E. D. Bobrowiec, T. M. Sanaiotti \& R. Gribel. 2013. Seed germination from lowland tapir (Tapirus terrestris) fecal samples collected during the dry season in the northern Brazilian Amazon. Integr. Zool. 8: 63-73.

Barker, A., U. Schaffner \& J.-L. Boevé. 2002. Host specificity and host recognition in a chemically-defended herbivore, the tenthredinid sawfly Rhadinoceraea nodicornis. Entomol. Exp. Appl. 104: $61-68$

Barko, J. W. \& R. M. Smart. 1983. Effects of organic matter additions to sediment on the growth of aquatic plants. J. Ecol. 71: $161-175$.

Barko, J. W., D. G. Hardin \& M. S. Matthews. 1982. Growth and morphology of submersed freshwater macrophytes in relation to light and temperature. Can. J. Bot. 60: 877-887.

Barks, P. M., Z. W. Dempsey, T. M. Burg \& R. A. Laird. 2018. Among-strain consistency in the pace and shape of senescence in duckweed. J. Ecol. 106: 2132-2145.

Barksdale, L. 1937. The occurrence of Liparis loeselii and Habenaria bracteata in North Carolina. J. Elisha Mitchell Sci. Soc. 53: $137-138$.

Barnard, J. 1882. Economic value of the aquatic plant Typha latifolia. Pap. Proc. Royal Soc. Tasmania 17: 163-167.

Barnes, J. K. 1976. Effect of temperature on development, survival, oviposition, and diapause in laboratory populations of Sepedon fuscipennis (Diptera: Sciomyzidae). Environ. Entomol. 5: 1089-1098.

Barnes, M. A., C. L. Jerde, D. Keller, W. L. Chadderton, J. G. Howeth \& D. M. Lodge. 2013. Viability of aquatic plant fragments following desiccation. Invasive Plant Sci. Manag. 6: 320-325.

Barnett, O. W. 1986. Iris fulva mosaic virus. In: J. Antoniw \& M. Adams (eds.), Descriptions of Plant Viruses. Association of Applied Plant Biologists. Available online: http://www. dpvweb.net/dpv/showdpv.php?dpvno=310 [accessed 28 January, 2019].

Baron, J. L. \& M. L. Ostrofsky. 2010. The effects of macrophyte tannins on the epiphytic macroinvertebrate assemblages in Sandy Lake, Pennsylvania. J. Freshw. Ecol. 25: 457-465.

Barrat-Segretain, M.-H. 1996. Strategies of reproduction, dispersion, and competition in river plants: a review. Vegetatio 123: 13-37.

Barrat-Segretain, M.-H. 2004. Growth of Elodea canadensis and Elodea nuttallii in monocultures and mixture under different light and nutrient conditions. Archiv Hydrobiol. 161: 133-144.

Barrat-Segretain, M.-H. \& G. Bornette. 2000. Regeneration and colonization abilities of aquatic plant fragments: effect of disturbance seasonality. Hydrobiologia 421: 31-39.

Barrat-Segretain, M.-H. \& B. Cellot. 2007. Response of invasive macrophyte species to drawdown: the case of Elodea sp. Aquat. Bot. 87: 255-261.

Barrat-Segretain, M.-H., G. Bornette \& A. Hering-Vilas-Bôas. 1998. Comparative abilities of vegetative regeneration among aquatic plants growing in disturbed habitats. Aquat. Bot. 60: 201-211.

Barrat-Segretain, M.-H., A. Elger, P. Sagnes \& S. Puijalon. 2002. Comparison of three life-history traits of invasive Elodea canadensis Michx. and Elodea nuttallii (Planch.) H. St. John. Aquat. Bot. 74: 299-313.

Barrett, S. C. H. 1978. Floral biology of Eichhornia azurea (Swartz) Kunth (Pontederiaceae). Aquat. Bot. 5: 217-228.

Barrett, S. C. H. 1980a. Sexual reproduction in Eichhornia crassipes (water hyacinth). I. Fertility of clones from diverse regions. $J$. Appl. Ecol. 17: 101-112. 
Barrett, S. C. H. 1980b. Sexual reproduction in Eichhornia crassipes (water hyacinth). II. Seed production in natural populations. $J$. Appl. Ecol. 17: 113-124.

Barrett, S. C. H. 1985. Floral trimorphism and monomorphism in continental and island populations of Eichhornia paniculata (Spreng.) Solms (Pontederiaceae). Biol. J. Linn. Soc. 25: 41-60.

Barrett, S. C. H. 1988. Evolution of breeding systems in Eichhornia (Pontederiaceae): a review. Ann. Missouri Bot. Gard. 75: 741-760.

Barrett, S. C. H. \& J. L. Strother. 1978. Taxonomy and natural history of Bacopa (Scrophulariaceae) in California. Syst. Bot. 3: 408-419.

Barrett, S. C. H. \& D. E. Seaman. 1980. The weed flora of Californian rice fields. Aquat. Bot. 9: 351-376.

Barrett, S. C. H. \& I. W. Forno. 1982. Style morph distribution in new world populations of Eichhornia crassipes (Mart.) SolmsLaubach (water hyacinth). Aquat. Bot. 13: 299-306.

Barrett, S. C. H. \& S. W. Graham. 1997. Adaptive radiation in the aquatic plant family Pontederiaceae: insights from phylogenetic analysis. Pp. 225-258 In: T. J. Givnish \& K. J. Sytsma (eds.), Molecular Evolution and Adaptive Radiation. Cambridge University Press, New York, NY.

Barrett, S. C. H. \& B. C. Husband. 1997. Ecology and genetics of ephemeral plant populations: Eichhornia paniculata (Pontederiaceae) in northeast Brazil. J. Hered. 88: 277-284.

Barrett, S. C. H., S. D. Price \& J. S. Shore. 1983. Male fertility and anisoplethic population structure in tristylous Pontederia cordata (Pontederiaceae). Evolution 37: 745-759.

Barrett, S. C. H., B. C. Husband \& W. W. Cole. 1993. Variation in outcrossing rates in Eichhornia paniculata: temporal changes in populations of contrasting style morph structure. Plant Species Biol. 8: 141-148.

Barrett, S. C. H., L. D. Harder \& W. W. Cole. 1994. Effects of flower number and position on self-fertilization in experimental populations of Eichhornia paniculata (Pontederiaceae). Funct. Ecol. 8: 526-535.

Barrett, S. C. H., R. I. Colautti \& C. G. Eckert. 2008. Plant reproductive systems and evolution during biological invasion. Mol. Ecol. 17: 373-383.

Barrett, C. F., W. J. Baker, J. R. Comer, J. G. Conran, S. C. Lahmeyer, J. H. Leebens-Mack, J. Li, G. S. Lim, D. R. Mayfield-Jones, L. Perez, J. Medina, J. C. Pires, C. Santos, D. W. Stevenson, W. B. Zomlefer \& J. I. Davis. 2016. Plastid genomes reveal support for deep phylogenetic relationships and extensive rate variation among palms and other commelinid monocots. New Phytol. 209: 855-870.

Barriault, I., M. Gibernau \& D. Barabe. 2009. Flowering period, thermogenesis, and pattern of visiting insects in Arisaema triphyllum (Araceae) in Quebec. Botany 87: 324-329.

Barry, S. C., T. K. Frazer \& C. A. Jacoby. 2013. Production and carbonate dynamics of Halimeda incrassata (Ellis) Lamouroux altered by Thalassia testudinum Banks and Soland ex König. J. Exp. Mar. Biol. Ecol. 444: 73-80.

Bart, H. L. 1989. Fish habitat association in an Ozark stream. Environ. Biol. Fishes 24: 173-186.

Bartgis, R. L. 1992. The endangered sedge Scirpus ancistrochaetus and the flora of sinkhole ponds in Maryland and West Virginia. Castanea 57: 46-51.

Bartgis, R. L. 1997. The distribution of the endangered plant Ptilimnium nodosum (Rose) Mathias (Apiaceae) in the Potomac River drainage. Castanea 62: 55-59.

Barthlott, W., B. Große-Veldmann \& N. Korotkova. 2014. Orchid seed diversity. Englera 32: 1-245.
Bartholomew, C. S., D. Prowell \& T. Griswold. 2006. An annotated checklist of bees (Hymenoptera: Apoidea) in longleaf pine savannas of southern Louisiana and Mississippi. J. Kansas Entomol. Soc. 79: 184-198.

Bartling, F. T. 1830. Ordines Naturales Plantarum eorumque Characteres et Affinitates adjecta Generum Enumeratione. Sumtibus Dieterichianis, Gottingae. 498 pp.

Bartodziej, W. I. \& G. Weymouth. 1995. Waterbird abundance and activity on waterhyacinth and egeria in the St. Marks River, Florida. J. Aquat. Plant Manag. 33: 19-22.

Bartonek, J. C. \& J. J. Hickey. 1969. Food habits of canvasbacks, redheads, and lesser scaup in Manitoba. Condor 71: 280-290.

Basinger, M. A., J. S. Huston, R. J. Gates \& P. A. Robertson. 1997. Vascular flora of Horseshoe Lake Conservation Area, Alexander County, Illinois. Castanea 62: 82-99.

Basiouny, F. M., W. T. Haller \& L. A. Garrard. 1978. Survival of hydrilla (Hydrilla verticillata) plants and propagules after removal from the aquatic habitat. Weed Sci. 26: 502-504.

Baskin, C. C. \& J. M. Baskin. 1998. Seeds: Ecology, Biogeography, and Evolution of Dormancy and Germination. Academic Press, San Diego, CA. 666 pp.

Baskin, C. C. \& J. M. Baskin. 2003. Seed germination and propagation of Xyris tennesseensis, a federal endangered wetland species. Wetlands 23: 116-124.

Baskin, J. M. \& C. C. Baskin. 2015. Inbreeding depression and the cost of inbreeding on seed germination. Seed Sci. Res. 25 : 355-385.

Baskin, C. C., J. M. Baskin \& W. W. McDearman. 1993. Seed germination ecophysiology of two Zigadenus (Liliaceae) species. Castanea 58: 45-53.

Baskin, C. C., J. M. Baskin \& E. W. Chester. 2003. Ecological aspects of seed dormancy-break and germination in Heteranthera limosa (Pontederiaceae), a summer annual weed of rice fields. Weed Res. 43: 103-107.

Bateman, R. M., P. M. Hollingsworth, J. Preston, L. Yi-Bo, A. M. Pridgeon \& M. W. Chase. 2003. Molecular phylogenetics and evolution of Orchidinae and selected Habenariinae (Orchidaceae). Bot. J. Linn. Soc. 142: 1-40.

Bateman, R. M., K. E. James, Y.-B. Luo, R. K. Lauri, T. Fulcher, P. J. Cribb \& M. W. Chase. 2009. Molecular phylogenetics and morphological reappraisal of the Platanthera clade (Orchidaceae: Orchidinae) prompts expansion of the generic limits of Galearis and Platanthera. Ann. Bot. 104: 431-445.

Batista, J. A. N., K. S. Borges, M. W. F. de Faria, K. Proite, A. J. Ramalho, G. A. Salazar \& C. van den Berg. 2013. Molecular phylogenetics of the species-rich genus Habenaria (Orchidaceae) in the New World based on nuclear and plastid DNA sequences. Mol. Phylogenet. Evol. 67: 95-109.

Battauz, Y. S., S. B. José de Paggi \& J. C. Paggi. 2017. Macrophytes as dispersal vectors of zooplankton resting stages in a subtropical riverine floodplain. Aquat. Ecol. 51: 191-201.

Batygina, T. B., E. A. Bragina \& V. E. Vasilyeva. 2003. The reproductive system and germination in orchids. Acta Biol. Cracov. Ser. Bot. 45: 21-34.

Bauder, E. T. 1994. Vernal Pool Habitat Restoration: Eastgate Mall, NAS Miramar, San Diego, California. California Department of Fish and Game, Sacramento, CA. 33 pp.

Bauder, E. T. 2000. Inundation effects on small-scale plant distributions in San Diego, California vernal pools. Aquat. Ecol. 34: 43-61.

Baxter, R. 2007. Hydrogeologic characterization of the bunched arrowhead, Sagittaria fasciculata. Geological Society of America, Southeastern Section, 56th Annual Meeting (29-30 March, 2007). [Abstract]. 
Beal, E. O. 1960. Sparganium (Sparganiaceae) in the southeastern United States. Brittonia 12: 176-181.

Beal, E. O. 1977. A manual of marsh and aquatic vascular plants of North Carolina with habitat data. Technical Bulletin No. 247. North Carolina Agricultural Experiment Station, Raleigh, NC. 298 pp.

Beal, E. O., J. W. Wooten \& R. B. Kaul. 1982. Review of the Sagittaria engelmanniana complex (Alismataceae) with environmental correlations. Syst. Bot. 7: 417-432.

Beare, P. A. \& J. B. Zedler. 1987. Cattail invasion and persistence in a coastal salt marsh: the role of salinity reduction. Estuaries 10: $165-170$.

Beas, B. J., L. M. Smith, K. R. Hickman, T. G. LaGrange \& R. Stutheit. 2013. Seed bank responses to wetland restoration: do restored wetlands resemble reference conditions following sediment removal? Aquat. Bot. 108: 7-15.

Beasley, V. 1999. Plants of the Araceae family (plants containing oxalate crystals and histamine releasers). In: V. Beasley (ed.), Veterinary Toxicology. International Veterinary Information Service, Ithaca, NY.

Beattie, A. J., D. E. Breedlove \& P. R. Ehrlich. 1973. The ecology of the pollinators and predators of Frasera speciosa. Ecology 54: 81-91.

Beatty, J. \& E. C. Desjardins. 2009. Natural selection and history. Biol. Philos. 24: 231-246.

Beaven, G. F. \& H. J. Oosting. 1939. Pocomoke swamp: a study of a cypress swamp on the eastern shore of Maryland. Bull. Torrey Bot. Club 66: 367-389.

Beck, J. L. \& J. M. Peek. 2004. Herbage productivity and ungulate use of northeastern Nevada mountain meadows. J. Range Manag. 57: 376-383.

Beck, M. W. \& J. Alahuhta. 2017. Ecological determinants of Potamogeton taxa in glacial lakes: assemblage composition, species richness, and species-level approach. Aquat. Sci. 79: $427-441$.

Becker, R. 2017. Biologia reprodutiva de Crinum americanum L. - Amaryllidaceae. B.S. thesis. Universidade Federal do Rio Grande do Sul, Porto Alegre, Brazil. 16 pp.

Beckett, D. C., T. P. Aartila \& A. C. Miller. 1992a. Invertebrate abundance on Potamogeton nodosus: effects of plant surface area and condition. Can. J. Zool. 70: 300-306.

Beckett, D. C., T. P. Aartila \& A. C. Miller. 1992. Contrasts in density of benthic invertebrates between macrophyte beds and open littoral patches in Eau Galle Lake, Wisconsin. Am. Midl. Nat. 127: 77-90.

Becking, R. W. 1986. Hastingsia atropurpurea (Liliaceae: Asphodeleae). A new species from southwestern Oregon. Madroño 33: 175-181.

Becking, R. W. 1989. Segregation of Hastingsia serpentinicola, sp. nov. from Hastingsia alba (Liliaceae: Asphodeleae). Madroño 36: $208-216$.

Becking, R. W. 2002. Hastingsia S. Watson. Pp. 310-312 In: Flora North America Editorial Committee (eds.), Flora of North America North of Mexico, Vol. 26: Magnoliophyta: Liliidae: Liliales and Orchidales. Oxford University Press, New York, NY.

Beck-Nielsen, D. \& T. V. Madsen. 2001. Occurrence of vesiculararbuscular mycorrhiza in aquatic macrophytes from lakes and streams. Aquat. Bot. 71: 141-148.

Beecher, C. W. W., T. M. Sarg \& J. M. Edwards. 1983. Occurrence and biosynthesis of 9-phenylphenalenones in callus tissue of Lachnanthes tinctoria. J. Nat. Prod. 46: 932-933.

Beer, S. \& R. G. Wetzel. 1982a. Photosynthetic carbon fixation pathways in Zostera marina and three Florida seagrasses. Aquat. Bot. 13: 141-146.
Beer, S. \& R. G. Wetzel. 1982b. Photosynthesis in submersed macrophytes of a temperate lake. Plant Physiol. 70: 488-492.

Beer, S. \& J. Rehnberg. 1997. The acquisition of inorganic carbon by the seagrass Zostera marina. Aquat. Bot. 56: 277-283.

Beer, S., M. Bjork, F. Hellblom \& L. Axelsson. 2002. Inorganic carbon utilization in marine angiosperms (seagrasses). Funct. Plant Biol. 29: 349-354.

Begum, M., A. S. Juraimi, S. O. O. B. S. Rastan, R. Amartalingam \& A. B. Man. 2006. Seedbank and seedling emergence characteristics of weeds in ricefield soils of the muda granary area in north-west peninsular Malaysia. Biotropia 13: 11-21.

Behera, S., S. Rath, M. S. Akhtar \& S. K. Naik. 2018. Biotechnological intervention through tissue culture in Hedychium coronarium: a potential anticancer plant. Pp. 551-564 In: M. Akhtar \& M. Swamy (eds.), Anticancer Plants: Natural Products and Biotechnological Implements. Springer, Singapore.

Belden, R. C., W. B. Frankenberger, R. T. McBride \& S. T. Schwikert. 1988. Panther habitat use in southern Florida. J. Wildl. Manag. 52: 660-663.

Bell, S. S., M. S. Fonseca \& W. J. Kenworthy. 2008. Dynamics of a subtropical seagrass landscape: links between disturbance and mobile seed banks. Landscape Ecol. 23: 67-74.

Bellis, E. D. 1962. Cover value and escape habits of the wood frog in a Minnesota bog. Herpetologica 17: 228-231.

Bellrose, F. C. 1941. Duck food plants of the Illinois River Valley. Bull. Illinois. Nat. Hist. Surv. 21: 237-280.

Bellrose, F. C. \& L. G. Brown. 1941. The effect of fluctuating water levels on the muskrat population of the Illinois River Valley. J. Wildl. Manag. 5: 206-212.

Belyakov, E. A. \& A. G. Lapirov. 2015. Fruit germination of some representatives of the family Sparganiaceae Rudolphi under laboratory conditions. Inland Water Biol. 8: 33-37.

Bembower, W. 1911. Pollination notes from the Cedar Point region. Ohio Nat. 11: 378-383.

Bendix, M., T. Tornbjerg \& H. Brix. 1994. Internal gas transport in Typha latifolia L. and Typha angustifolia L. 1. Humidityinduced pressurization and convective throughflow. Aquat. Bot. 49: 75-89.

Benedict, N. B. 1983. Plant associations of subalpine meadows, Sequoia National Park, California. Arct. Alp. Res. 15: 383-396.

Bengtson, J. L. 1983. Estimating food consumption of free-ranging manatees in Florida. J. Wildl. Manag. 47: 1186-1192.

Bennett A. 1901. Potamogeton polygonifolius in Newfoundland. Bot. Gaz. 32: 58-59.

Bennett, B. D. \& J. B. Grace. 1990. Shade tolerance and its effect on the segregation of two species of Louisiana iris and their hybrids. Am. J. Bot. 77: 100-107.

Bennett, D. H. \& J. M. DuPont. 1993. Fish habitat associations of the Pend Oreille River, Idaho. Project Report: Project F-73-R-15, Subproject VI, Study VII. University of Idaho, Moscow, ID. $124 \mathrm{pp}$.

Benoit, L. K. 2011. Cryptic speciation, genetic diversity and herbicide resistance in the invasive aquatic plant Hydrilla verticillata (L.f.) Royle (Hydrocharitaceae). Ph.D. dissertation. University of Connecticut, Storrs, CT. 117 pp.

Benoit, L. K. \& D. H. Les. 2013. Rapid identification and molecular characterization of phytoene desaturase mutations in fluridone-resistant hydrilla (Hydrilla verticillata). Weed Sci. 61: 32-40.

Benoit, L. K., D. H. Les, U. M. King, H. R. Na, L. Chen \& N. P. Tippery. 2019. Extensive interlineage hybridization in the predominantly clonal Hydrilla verticillata (Hydrocharitaceae). Am. J. Bot. 106: 1622-1637. 
Benson, E. R., J. M. O'Neil \& W. C. Dennison. 2008. Using the aquatic macrophyte Vallisneria americana (wild celery) as a nutrient bioindicator. Hydrobiologia 596: 187-196.

Bentley, B. \& T. S. Elias (eds.). 1983. The Biology of Nectaries. Columbia University Press, New York, NY. 259 pp.

Benton, Jr., A. R., W. P. James \& J. W. Rouse, Jr. 1978. Evaoptranspiration from water hyacinth (Eichhomia crassipes (Mart.) Solms) in Texas reservoirs. J. Am. Water Resour. Assoc. 14: 919-930.

Berdnikov, V. A., O. E. Kosterin \& V. S. Bogdanova. 2002. Mortality of pollen grains may result from errors of meiosis: study of pollen tetrads in Typha latifolia L. Heredity 89: 358-362.

Berkowitz, J. F., S. Page \& C. V. Noble. 2014. Potential disconnect between observations of hydrophytic vegetation, wetland hydrology indicators, and hydric soils in unique pitcher plant bog habitats of the southern Gulf Coast. Southeast. Nat. 13: 721-735.

Beshear, R. J. \& J. O. Howell. 1976. A new species of Pseudothrips, with a key to the North American species. Ann. Entomol. Soc. Am. 69: 1082-1084.

Bezona, N., D. Hensley, J. Yogi, J. Tavares, F. Rauch, R. Iwata, M. Kellison, M. Won \& P. Clifford. 2009. Salt and wind tolerance of landscape plants for Hawai'i. Document L13. Cooperative Extension Service, University of Hawai'i at Mānoa, Honolulu, HI. 9 pp.

Bercu, R. 2015. Histoanatomical features of the aquatic plant Helanthium tenellum (Mart.) Britt. (Alismataceae). Ann. West Univ. Timişoara, Ser. Biol. 18: 67-72.

Berg, C. O. 1949. Limnological relations of insects to plants of the genus Potamogeton. Trans. Am. Microsc. Soc. 68: 279-291.

Berg, C. O. 1950a. Biology of certain Chironomidae reared from Potamogeton. Ecol. Monogr. 20: 83-101.

Berg, C. O. 1950b. Hydrellia (Ephydridae) and some other acalyptrate Diptera reared from Potamogeton. Ann. Entomol. Soc. Am. 43: 374-398.

Berger, M., R. O. Stephenson, P. Karczmarczyk \& C. C. Gates. 1995. Habitat Inventory of the Yukon Flats as Potential Wood Bison Range. Alaska Department of Fish and Game, Fairbanks, AK. $38 \mathrm{pp}$.

Bergeron, A. L. \& S. T. Pellerin. 2014. Carex $\times$ cayouettei (Cyperaceae), a new intersectional sedge hybrid from southern Québec, Canada. Phytoneuron 52: 1-11.

Bergersen, E. P. 1969. Some factors affecting fish forage production in four Arizona lakes. M.S. thesis. University of Arizona, Tuscon, AZ. 89 pp.

Bergerud, A. T. 1972. Food habits of Newfoundland caribou. J. Wildl. Manag. 36: 913-923.

Bergey, E. A., S. F. Balling, J. N. Collins, G. A. Lamberti \& V. H. Resh. 1992. Bionomics of invertebrates within an extensive Potamogeton pectinatus bed of a California marsh. Hydrobiologia 234: 15-24.

Bergman, R. D. 1973. Use of southern boreal lakes by postbreeding canvasbacks and redheads. J. Wildl. Manag. 37: 160-170.

Bergman, B. G. \& J. K. Bump. 2014. Mercury in aquatic forage of large herbivores: impact of environmental conditions, assessment of health threats, and implications for transfer across ecosystem compartments. Sci. Total Environ. 479: 66-76.

Bergmann, B. A., J. Cheng, J. Classen \& A.-M. Stomp. 2000. In vitro selection of duckweed geographical isolates for potential use in swine lagoon effluent renovation. Bioresour. Technol. 73: 13-20.

Bergstrom, B. J., T. Farley, H. L. Hill, Jr. \& T. Hon. 2000. Ecology and conservation of a frontier population of the round-tailed muskrat (Neofiber alleni). Pp. 74-82 In: B. R. Chapman \&
J. Laerm (eds.), Fourth Colloquium on the Conservation of Mammals in the Southeastern United States. Occasional Paper Number 12. North Carolina Museum of Natural Sciences and the North Carolina Biological Survey, Raleigh, NC.

Berkowitz, J. F., S. Page \& C. V. Noble. 2014. Potential disconnect between observations of hydrophytic vegetation, wetland hydrology indicators, and hydric soils in unique pitcher plant bog habitats of the southern Gulf Coast. Southeast. Nat. 13: 721-735.

Bernard, J. M. \& F. A. Bernard. 1973. Winter biomass in Typha glauca Godr. and Sparganium eurycarpum Engelm. Bull. Torrey Bot. Club 100: 125-127.

Bernard, J. M. \& F. A. Bernard. 1977. Winter standing crop and nutrient contents in five central New York wetlands. Bull. Torrey Bot. Club 104: 57-59.

Bernardello, L. M. \& E. A. Moscone. 1986. The karyotype of Limnobium spongia (Hydrocharitaceae). Plant Syst. Evol. 153: 31-36.

Bernhardt, E. A. \& J. M. Duniway. 1985. A new Papulaspora species from the pondweeds Potamogeton nodosus and P. crispus in California. Can. J. Bot. 63: 429-431.

Bertsch, C. \& G. R. Barreto. 2008. Diet of the yellow-knobbed curassow in the central Venezuelan llanos. Wilson J. Ornithol. 120: $767-778$.

Bérubé, V., L. Rochefort \& C. Lavoie. 2017. Fen restoration: defining a reference ecosystem using paleoecological stratigraphy and present-day inventories. Botany 95: 731-750.

Besançon, T. E. 2019. Carolina Redroot (Lachnanthes caroliniana) in cranberry: assessment of shoot and rhizome control with POST herbicides. Weed Technol. 33: 210-216.

Bezdek, J. C., J. M. Keller, R. Krishnapuram, L. I. Kuncheva \& N. R. Pal. 1999. Will the real iris data please stand up? IEEE Trans. Fuzzy Syst. 7: 368-369.

Bhalla, P. R. \& P. S. Sabharwal. 1972. Induction of flowering in Lemna minor by EDDHA. Acta Bot. Neerl. 21: 200-202.

Bhanthumnavin, K. \& M. G. McGarry. 1971. Wolffia arrhiza as a possible source of inexpensive protein. Nature 232: 495.

Bharathan, G., G. Lambert \& D. W. Galbraith. 1994. Nuclear DNA content of monocotyledons and related taxa. Am. J. Bot. 81: 381-386.

Bhardwaj, M. \& C. G. Eckert. 2001. Functional analysis of synchronous dichogamy in flowering rush, Butomus umbellatus (Butomaceae). Am. J. Bot. 88: 2204-2213.

Bhatia, H. L. 1970. Grass carps can control aquatic weeds. Indian Farming 20: 36-37.

Bhunia, D. \& A. K. Mondal. 2014. The free amino acids (FAA) composition of seeds among some members of Blyxa Thou. (Hydrocharitaceae): a systematic approach. Int. J. Curr. Res. 6: $10437-10445$.

Bianchini, I., M. B. Cunha-Santino, J. A. M. Milan, C. J. Rodrigues \& J. H. P. Dias. 2010. Growth of Hydrilla verticillata (L.f.) Royle under controlled conditions. Hydrobiologia 644: 301-312.

Biber, P. D. \& H. J. Cho. 2017. Shoalgrass in the Gulf of Mexico: a Mississippi perspective. Southeast Geogr. 57: 203-206.

Bick, G. H., J. C. Bick \& L. E. Hornuff. 1976. Behavior of Chromagrion conditum (Hagen) adults (Zygoptera: Coenagrionidae). Odonatologica 5: 129-141.

Bicknell, E. P. 1901. Studies in Sisyrinchium-IX: the species of Texas and the southwest. Bull. Torrey Bot. Club 28: 570-592.

Bidartondo, M. I., B. Burghardt, G. Gebauer, T. D. Bruns \& D. J. Read. 2004. Changing partners in the dark: isotopic and molecular evidence of ectomycorrhizal liaisons between forest orchids and trees. Proc. Roy. Soc. London Ser. B Biol. Sci. 271: 1799-1806. 
Bielefeld, R. R. \& A. D. Afton. 1992. Canvasback food density in the Mississippi River Delta, Louisiana: habitat and temporal differences. Proc. Ann. Conf. S. E. Assoc. Game Fish Agencies 46: 97-103.

Bigley, R. E. 1981. The population biology of two intertidal seagrasses, Zostera japonica and Ruppia maritima, at Roberts Bank, British Columbia. M.S. thesis. University of British Columbia, Vancouver, BC. 205 pp.

Bigley, R. E. \& J. L. Barreca. 1982. Evidence for synonymizing Zostera americana den Hartog with Zostera japonica Aschers. \& Graebn. Aquat. Bot. 14: 349-356.

Bigley, R. E. \& P. G. Harrison. 1986. Shoot demography and morphology of Zostera japonica and Ruppia maritima from British Columbia, Canada. Aquat. Bot. 24: 69-82.

Bini, L. M. \& S. M. Thomaz. 2005. Prediction of Egeria najas and Egeria densa occurrence in a large subtropical reservoir (Itaipu Reservoir, Brazil-Paraguay). Aquat. Bot. 83: 227-238.

Bintz, J. C. \& S. W. Nixon. 2001. Responses of eelgrass Zostera marina seedlings to reduced light. Mar. Ecol. Prog. Ser. 223: 133-141.

Birchenko, I. V. 2001. Genetic diversity and microsite characterization of the rare monkeyface orchid, Platanthera integrilabia (Orchidaceae), in the southeastern United States. M.S. thesis. Ohio University, Athens, OH. 61 pp.

Bird, K. T. \& J. Jewett-Smith. 1994. Development of a medium and culture system for in vitro propagation of the seagrass Halophila engelmannii. Can. J. Bot. 72: 1503-1510.

Bird, K. T., J. Jewett-Smith \& M. S. Fonseca. 1994. Use of in vitro propagated Ruppia maritima for seagrass meadow restoration. J. Coast. Res. 10: 732-737.

Bird, K. T., J. R. Johnson \& J. Jewett-Smith. 1998. In vitro culture of the seagrass Halophila decipiens. Aquat. Bot. 60: 377-387.

Birkenholz, D. E. 1963. A study of the life history and ecology of the round-tailed muskrat (Neofiber alleni True) in north-central Florida. Ecol. Monogr. 33: 255-280.

Birks, H. H. 2002. Plant macrofossils. Pp. 49-74 In: J. P. Smol, H. J. B. Birks \& W. M. Last (eds.), Tracking Environmental Change Using Lake Sediments, Vol. 3: Terrestrial, Algal, and Siliceous Indicators. Kluwer Academic Publishers, Dordrecht, The Netherlands.

Bishop, P. L. \& T. T. Eighmy. 1989. Aquatic wastewater treatment using Elodea nuttallii. J. Water Pollut. Control Fed. 61: 641-648.

Bitton, G., M. Ward \& R. Dagan. 2005. Determination of the heavy metal binding capacity (HMBC) of environmental samples. Pp. 215-231 In: C. Blaise \& J.-F. Férard (eds.), Small-Scale Freshwater Toxicity Investigations. Springer, Dordrecht, The Netherlands.

Björk, C. R. \& P. W. Dunwiddie. 2004. Floristics and distribution of vernal pools on the Columbia Plateau of eastern Washington. Rhodora 106: 327-347.

Björkqvist, I. 1967. Studies in Alisma L. I. Distribution, variation and germination. Opera Bot. 17: 1-128.

Björkqvist, I. 1968. Studies in Alisma L. II. Chromosome studies, crossing experiments and taxonomy. Opera Bot. 19: 1-138.

Bjorndal, K. A. 1996. Foraging ecology and nutrition of sea turtles. Pp. 199-231 In: P. L. Lutz \& J. A. Musick (eds.), The Biology of Sea Turtles, Volume 1. CRC Press, Boca Raton, FL.

Bjorndal, K. A. \& A. B. Bolten. 1992. Body size and digestive efficiency in a herbivorous freshwater turtle: advantages of small bite size. Physiol. Zool. 65: 1028-1039.

Black, R. J. 1985. Salt tolerant plants for Florida. Document ENH26. University of Florida Cooperative Extension Service, Institute of Food and Agriculture Sciences, Gainesville, FL. 10 pp.
Black, M., K. J. Bradford \& J. Vázquez-Ramos. 2000. Seed Biology: Advances and Applications: Proceedings of the Sixth International Workshop on Seeds, Mérida, México, 1999. CABI Publishing, Cambridge, MA. 508 pp.

Blackburn, R. D., J. M. Lawrence \& D. E. Davis. 1961. Effects of light intensity and quality on the growth of Elodea densa and Heteranthera dubia. Weeds 9: 251-257.

Blackwell, Jr., W. H. \& K. P. Blackwell. 1974. The taxonomy of Peltandra (Araceae). J. Elisha Mitchell Sci. Soc. 90: 137-140.

Blair, W. F. 1936. The Florida marsh rabbit. J. Mammal. 17: 197-207.

Blair, A. 1975. Karyotypes of five plant species with disjunct distributions in Virginia and the Carolinas. Am. J. Bot. 62: 833-837.

Blake, S. F. 1912. The forms of Peltandra virginica. Rhodora 14: 102-106.

Blanchette, C. A., S. E. Worcester, D. Reed \& S. J. Holbrook. 1999. Algal morphology, flow, and spatially variable recruitment of surfgrass Phyllospadix torreyi. Mar. Ecol. Prog. Ser. 184: 119-128.

Blanchette, C. A., C. M. Miner, P. T. Raimondi, D. Lohse, K. E. K. Heady \& B. R. Broitman. 2008. Biogeographical patterns of rocky intertidal communities along the Pacific coast of North America. J. Biogeogr. 35: 1593-1607.

Blaney, S., D. Mazerolle, S. Robinson \& A. Belliveau. 2014. Ecological Surveys and Vascular Plant Inventory of the Bay of Islands Conservation Area. Atlantic Canada Conservation Data Centre, Sackville, NB. 83 pp.

Blankinship, J. W. 1903. The plant-formations of eastern Massachusetts. Rhodora 5: 124-137.

Blanton, F. S. 1939. Notes on some thrips collected in the vicinity of Babylon, Long Island, NY. J. New York Entomol. Soc. 47: 83-94.

Blazey, E. B. \& J. W. McClure. 1968. The distribution and taxonomic significance of lignin in the Lemnaceae. Am. J. Bot. 55: 1240-1245.

Bleuel, M. T. 1923. Some unusual food plants. School Sci. Math. 23: 369-376.

Bliss, S. A. \& P. H. Zedler. 1998. The germination process in vernal pools: sensitivity to environmental conditions and effects on community structure. Oecologia 113: 67-73.

Bliss, B. J. \& J. Y. Suzuki. 2012. Genome size in Anthurium evaluated in the context of karyotypes and phenotypes. AoB Plants 2012. doi: 10.1093/aobpla/pls006.

Block, T. A. \& A. F. Rhoads. 2011. Aquatic Plants of Pennsylvania. A Complete Reference Guide. University of Pennsylvania Press, Philadelphia, PA. 308 pp.

Block, T. A. \& A. F. Rhoads. 2013. Critical Resources of Bald Mountain Section Lehigh Gorge State Park. Research Works (Botany) 7. Western Pennsylvania Conservancy and the Pennsylvania Department of Conservation and Natural Resources, Bureau of State Parks, Harrisburg, PA. 24 pp.

Block, T. A., A. F. Rhoads \& C. Loeffler. 2013. Resource recovery plan for glade spurge Euphorbia purpurea (Raf.) Fernald in Pennsylvania. Res. Works (Botany) 17. Available online: https://repository.upenn.edu/morrisarboretum_botanyworks/17. [accessed 4 February, 2020].

Blomquist, H. L. 1955. The genus Xyris L. in North Carolina. J. Elisha Mitchell Sci. Soc. 71: 35-46.

Błońska, A., D. Halabowski \& A. Sowa. 2016. Population structure of Liparis loeselii (L.) Rich. in relation to habitat conditions in the Warta River valley (Poland). Biodivers. Res. Conserv. 43: 41-52.

Blüm [Bluem], V. \& F. Paris. 2001. Aquatic food production modules in bioregenerative life support systems based on higher plants. Adv. Space Res. 27: 1513-1522. 
Blüm, V., M. Andriske, M. Eichhorn, K. Kreuzberg \& M. P. Schreibman. 1995. A controlled aquatic ecological life support system (CAELSS) for combined production of fish and higher plant biomass suitable for integration into a lunar or planetary base. Acta Astronautica 37: 361-371.

Blumenthal, A., H. R. Lerner, E. Werker \& A. Poljakoff-Mayber. 1986. Germination preventing mechanisms in Iris seeds. Ann. Bot. 58: 551-561.

Board, V. V., C. Allen \& A. Reeves. 1993. Botanical survey of a cypress-tupelo swamp. J. Arkansas Acad. Sci. 47: 20-22.

Bodkin, N. L. \& F. H. Utech. 2002. Melanthium Linnaeus. Pp. 77-79 In: Flora North America Editorial Committee (eds.), Flora of North America North of Mexico, Vol. 26: Magnoliophyta: Liliidae: Liliales and Orchidales. Oxford University Press, New York, NY.

Bodner, M. 1994. Inorganic carbon source for photosynthesis in the aquatic macrophytes Potamogeton natans and Ranunculus fluitans. Aquat. Bot. 48: 109-120.

Boedeltje, G. 2005. The role of dispersal, propagule banks and abiotic conditions in the establishment of aquatic vegetation. Doctoral dissertation. Radboud University, Nijmegen, The Netherlands. 224 pp.

Boedeltje, G., G. N. J. Ter Heerdt \& J. P. Bakker. 2002. Applying the seedling-emergence method under waterlogged conditions to detect the seed bank of aquatic plants in submerged sediments. Aquat. Bot. 72: 121-128.

Boedeltje, G., J. P. Bakker \& G. N. J. ter Heerdt. 2003a. Potential role of propagule banks in the development of aquatic vegetation in backwaters along navigation canals. Aquat. Bot. 77: 53-69.

Boedeltje, G., J. P. Bakker, R. M. Bekker, J. M. Van Groenendael \& M. Soesbergen. 2003b. Plant dispersal in a lowland stream in relation to occurrence and three specific life-history traits of the species in the species pool. J. Ecol. 91: 855-866.

Boedeltje, G. E. R., J. P. Bakker, A. T. Brinke, J. M. Van Groenendael \& M. Soesbergen. 2004. Dispersal phenology of hydrochorous plants in relation to discharge, seed release time and buoyancy of seeds: the flood pulse concept supported. J. Ecol. 92: 786-796.

Boedeltje, G., T. Spanings, G. Flik, B. J. A. Pollux, F. A. Sibbing \& W. C. E. P. Verberk. 2015. Effects of seed traits on the potential for seed dispersal by fish with contrasting modes of feeding. Freshw. Biol. 60: 944-959.

Boedeltje, G., E. Jongejans, T. Spanings \& W. C. E. P. Verberk. 2016. Effect of gut passage in fish on the germination speed of aquatic and riparian plants. Aquat. Bot. 132: 12-16.

Boehm, R., C. Kruse, D. Voeste, S. Barth \& H. Schnabl. 2001. A transient transformation system for duckweed (Wolffia columbiana) using Agrobacterium-mediated gene transfer. J. Appl. Bot. 75: 107-111.

Boese, B. L., K. E. Alayan, E. F. Gooch \& B. D. Robbins. 2003. Desiccation index: a measure of damage caused by adverse aerial exposure on intertidal eelgrass (Zostera marina) in an Oregon (USA) estuary. Aquat. Bot. 76: 329-337.

Boese, B. L., B. D. Robbins \& G. Thursby. 2005. Desiccation is a limiting factor for eelgrass (Zostera marina L.) distribution in the intertidal zone of a northeastern Pacific (USA) estuary. Bot. Mar. 48: 274-283.

Boestfleisch, C. \& J. Papenbrock. 2017. Changes in secondary metabolites in the halophytic putative crop species Crithmum maritimum L., Triglochin maritima L. and Halimione portulacoides (L.) Aellen as reaction to mild salinity. PLoS One 12(4): e0176303.

Bog, M., H. Baumbach, U. Schween, F. Hellwig, E. Landolt \& K.J. Appenroth. 2010. Genetic structure of the genus Lemna L. (Lemnaceae) as revealed by amplified fragment length polymorphism. Planta 232: 609-619.
Bog, M., P. Schneider, F. Hellwig, S. Sachse, E. Z. Kochieva, E. Martyrosian, E. Landolt \& K.-J. Appenroth. 2013. Genetic characterization and barcoding of taxa in the genus Wolffia Horkel ex Schleid. (Lemnaceae) as revealed by two plastidic markers and amplified fragment length polymorphism (AFLP). Planta 237: 1-13.

Bog, M., U. Lautenschlager, M. F. Landrock, E. Landolt, J. Fuchs, K. S. Sree, C. Oberprieler \& K.-J. Appenroth. 2015. Genetic characterization and barcoding of taxa in the genera Landoltia and Spirodela (Lemnaceae) by three plastidic markers and amplified fragment length polymorphism (AFLP). Hydrobiologia 749: 169-182.

Bog, M., M. F. Landrock, D. Drefahl, K. S. Sree \& K.-J. Appenroth. 2018. Fingerprinting by amplified fragment length polymorphism (AFLP) and barcoding by three plastidic markers in the genus Wolffiella Hegelm. Plant Syst. Evol. 304: 373-386.

Bogner, J. 2009. The free-floating Aroids (Araceae) - living and fossil. Zitteliana 48/49: 113-128.

Bogner, J. \& S. J. Mayo. 1998. Acoraceae. Pp. 7-11 In: K. Kubitzki, H. Huber, P. J. Rudall, P. S. Stevens \& T. Stützel (eds.), The Families and Genera of Vascular Plants, Vol. IV. Flowering Plants, Monocotyledons: Alismatanae and Commelinanae (Except Gramineae). Springer-Verlag, Berlin, Germany.

Bohlmann, H., J. Apple, N. Burnett \& S. Shull. 2018. Warm water temperature regimes in eelgrass beds (Z. marina and Z. japonica) of Padilla Bay, WA. Salish Sea Ecosystem Conference, Western Washington University, Bellingham, WA. [Abstract].

Bokhari, S. H., I. Ahmad, M. Mahmood-Ul-Hassan \& A. Mohammad. 2016. Phytoremediation potential of Lemna minor L. for heavy metals. Int. J. Phytoremed. 18: 25-32.

Boland, J. T. \& P. J. Scott. 1991. Ecological aspects of Arethusa bulbosa, Calopogon tuberosus, and Pogonia ophioglossoides (Orchidaceae) in eastern Newfoundland. I. Flowering and fruiting patterns. Rhodora 93: 248-255.

Boland, W. \& C. J. Burk. 1992. Some effects of acidic growing conditions on three emergent macrophytes: Zizania aquatica, Leersia oryzoides and Peltandra virginica. Environ. Pollut. 76: 211-217.

Boland, J. T. \& P. J. Scott. 1992. Ecological aspects of Arethusa bulbosa, Calopogon tuberosus and Pogonia ophioglossoides (Orchidaceae) in eastern Newfoundland. II. Partitioning of the microhabitat. Rhodora 94: 374-380.

Bolda, E. \& R. C. Anderson. 2011. Southeast Wisconsin's Pewaukee Lake aquatic plant survey 2010. Technical Bulletin 013. Wisconsin Lutheran College, Milwaukee, WI. 22 pp.

Bolduan, B. R., G. C. Van Eeckhout, H. W. Quade \& J. E. Gannon. 1994. Potamogeton crispus - The other invader. Lake Reserv. Manag. 10: 113-125.

Bolen, E. G. \& J. J. Beecham. 1970. Notes on the foods of juvenile black-bellied tree ducks. Wilson Bull. 82: 325-326.

Bolin, J. F. 2007. Seed bank response to wet heat and the vegetation structure of a Virginia pocosin1. J. Torrey Bot. Soc. 134: 80-89.

Bolin, J. F., K. U. Tennakoon, M. B. A. Majid \& D. D. Cameron. 2017. Isotopic evidence of partial mycoheterotrophy in Burmannia coelestis (Burmanniaceae). Plant Species Biol. 32: 74-80.

Bonanno, G. \& G. L. Cirelli. 2017. Comparative analysis of element concentrations and translocation in three wetland congener plants: Typha domingensis, Typha latifolia and Typha angustifolia. Ecotoxicol. Environ. Saf. 143: 92-101.

Bonnewell, V., W. L. Koukkari \& D. C. Pratt. 1983. Light, oxygen, and temperature requirements for Typha latifolia seed germination. Can. J. Bot. 61: 1330-1336. 
Bontrager, M., K. Webster, M. Elvin \& I. M. Parker. 2014. The effects of habitat and competitive/facilitative interactions on reintroduction success of the endangered wetland herb, Arenaria paludicola. Plant Ecol. 215: 467-478.

Boonyapookana, B., E. S. Upatham, M. Kruatrachue, P. Pokethitiyook \& S. Singhakaew. 2002. Phytoaccumulation and phytotoxicity of cadmium and chromium in duckweed Wolffia globosa. Int. J. Phytoremed. 4: 87-100.

Borchardt, J. R., D. L. Wyse, C. C. Sheaffer, K. L. Kauppi, R. G. Fulcher, N. J. Ehlke, D. D. Biesboer \& R. F. Bey. 2008. Antioxidant and antimicrobial activity of seed from plants of the Mississippi river basin. J. Med. Plant Res. 2: 81-93.

Borisjuk, N., P. Chu, R. Gutierrez, H. Zhang, K. Acosta, N. Friesen, K. S. Sree, C. Garcia, K. J. Appenroth \& E. Lam. 2015. Assessment, validation and deployment strategy of a twobarcode protocol for facile genotyping of duckweed species. Plant Biol. 17: 42-49.

Borkent, C. J. \& E. I. Schlinger. 2008. Pollen loads and pollen diversity on bodies of Eulonchus tristis (Diptera: Acroceridae): implications for pollination and flower visitation. Can. Entomol. 140: 257-264.

Borman, S., R. Korth \& J. Temte. 1997. Through the Looking Glass: A Field Guide to Aquatic Plants. FH-207-97. Department of Natural Resources. University of Wisconsin, Stevens Point, WI. 248 pp.

Bornette, G. \& S. Puijalon. 2011. Response of aquatic plants to abiotic factors: a review. Aquat. Sci. 73: 1-14.

Bortone, S. A. (ed.). 2000. Seagrasses: Monitoring, Ecology, Physiology, and Management. CRC Press, Boca Raton, FL. $336 \mathrm{pp}$.

Borum, J., O. Pedersen, T. M. Greve, T. A. Frankovich, J. C. Zieman, J. W. Fourqurean \& C. J. Madden. 2005. The potential role of plant oxygen and sulphide dynamics in die-off events of the tropical seagrass, Thalassia testudinum. J. Ecol. 93: 148-158.

Boschilia, S. M., E. F. de Oliveira \& A. Schwarzbold. 2012. The immediate and long-term effects of water drawdown on macrophyte assemblages in a large subtropical reservoir. Freshw. Biol. 57: 2641-2651.

Bosserman, R. W. 1981. Elemental composition of aquatic plants from Okefenokee Swamp. J. Freshw. Ecol. 1: 307-320.

Botero, J. E. \& D. H. Rusch. 1994. Foods of blue-winged teal in two neotropical wetlands. J. Wildl. Manag. 58: 561-565.

Botkin, D. B., P. A. Jordan, A. S. Dominski, H. S. Lowendorf \& G. E. Hutchinson. 1973. Sodium dynamics in a northern ecosystem. Proc. Natl. Acad. Sci. U.S.A. 70: 2745-2748.

Bottum, E. 2005. Wetland Conservation Strategy for the Weiser River Basin, Idaho. Idaho Conservation Data Center, Idaho Department of Fish and Game, Boise, ID. 156 pp.

Bouchard, S. S. \& K. A. Bjorndal. 2005. Microbial fermentation in juvenile and adult pond slider turtles, Trachemys scripta. J. Herpetol. 39: 321-324.

Bouchard, A., S. Hay, Y. Bergeron \& A. Leduc. 1991. The vascular flora of Gros Morne National Park, Newfoundland: a habitat classification approach based on floristic, biogeographical and life-form data. Pp. 123-157 In: P. L. Nimis \& T. J. Crovello (eds.), Quantitative Approaches to Phytogeography. Springer, Dordrecht, The Netherlands.

Bouetard, A., P. Lefeuvre, R. Gigant, S. Bory, M. Pignal, P. Besse \& M. Grisoni. 2010. Evidence of transoceanic dispersion of the genus Vanilla based on plastid DNA phylogenetic analysis. Mol. Phylogenet. Evol. 55: 621-630.

Boughton, E. H. \& R. K. Boughton. 2014. Modification by an invasive ecosystem engineer shifts a wet prairie to a monotypic stand. Biol. Invasions 16: 2105-2114.
Boughton, E. H., R. K. Boughton, C. Griffith \& J. Bernath-Plaisted. 2016. Reproductive traits of Lachnanthes caroliniana (Lam.) Dandy related to patch formation following feral swine rooting disturbance. J. Torrey Bot. Soc. 143: 265-274.

Boutin, C., B. Jobin, L. Bélanger \& L. Choinière. 2002. Plant diversity in three types of hedgerows adjacent to cropfields. Biodivers. Conserv. 11: 1-25.

Bowden, W. M. 1945. A list of chromosome numbers in higher plants. II. Menispermaceae to Verbenaceae. Am. J. Bot. 32: 191-201.

Bowers, F. D. 1972. The existence of Heterotheca ruthii (Compositae). Castanea 37: 130-132.

Bowes, G., T. K. Van, L. A. Garrard \& W. T. Haller. 1977. Adaptation to low light levels by hydrilla. J. Aquat. Plant Manag. 15: 32-35.

Bowes, G., A. S. Holaday \& W. T. Haller. 1979. Seasonal variation in the biomass, tuber density, and photosynthetic metabolism of hydrilla in three Florida lakes. J. Aquat. Plant Manag. 17: 61-65.

Bowes, G., S. K. Rao, G. M. Estavillo \& J. B. Reiskind. 2002. C $_{4}$ mechanisms in aquatic angiosperms: comparisons with terrestrial $\mathrm{C}_{4}$ systems. Funct. Plant Biol. 29: 379-392.

Bowker, R. G. 1991. Kral's Water-Plantain (Sagittaria secundifolia) Recovery Plan. United States Fish and Wildlife Service, Jackson, MS. 15 pp.

Bowles, M. L. 1983. The tallgrass prairie orchids Platanthera leucophaea (Nutt.) Lindl. and Cypripedium candidum Muhl. ex Willd.: some aspects of their status, biology, and ecology, and implications toward management. Nat. Areas J. 3: 14-37.

Bowles, M. L. 1991. Some aspects of the status and ecology of seven rare wetland plant species in the Chicago region of northeastern Illinois. Erigenia 11: 52-66.

Bowles, M. L. 1999. Eastern Prairie Fringed Orchid Platanthera leucophaea (Nuttall) Lindley Recovery Plan. U.S. Fish \& Wildlife Service, Region 3, Fort Snelling, MN. 58 pp.

Bowles, D. E. 2013. Missouri: first record of Limnobium spongia from the Ozarks physiographic region. Castanea 78: 137.

Bowles, D. E. \& B. D. Bowles. 2015. Non-native species of the major spring systems of Texas, USA. Texas J. Sci. 67: 51-78.

Bowles, D. E. \& H. R. Dodd. 2015. Floristics and community ecology of aquatic vegetation occurring in seven large springs at Ozark National Scenic Riverways, Missouri (USA), 20072012. J. Bot. Res. Inst. Texas 9: 235-249.

Bowles, M. L., R. Flakne \& R. Dombeck. 1992. Status and population fluctuations of the eastern prairie fringed orchid [Platanthera leucophaea (Nutt.) Lindl] in Illinois. Erigenia 12: 26-40.

Bowles, M. L., K. A. Jacobs, L. W. Zettler \& T. W. Delaney. 2002. Crossing effects on seed viability and experimental germination of the federal threatened Platanthera leucophaea (Orchidaceae). Rhodora 104: 14-30.

Bowles, M., L. Zettler, T. Bell \& P. Kelsey. 2005. Relationships between soil characteristics, distribution and restoration potential of the federal threatened eastern prairie fringed orchid, Platanthera leucophaea (Nutt.) Lindl. Am. Midl. Nat. 154: 273-286.

Bown, D. 2000. Aroids. Plants of the Arum Family, 2nd ed. Timber Press, Portland, OR. 392 pp.

Bowyer, M. W., J. D. Stafford, A. P. Yetter, C. S. Hine, M. M. Horath \& S. P. Havera. 2005. Moist-soil plant seed production for waterfowl at Chautauqua National Wildlife Refuge, Illinois. Am. Midl. Nat. 154: 331-341.

Boxell, V. 2014. Edible and Useful Plants for the Swan Coastal Plain. Lulu.com. Morrisville, NC. 168 pp.

Boyd, C. E. 1968. Fresh-water plants: a potential source of protein. Econ. Bot. 22: 359-368. 
Boyd, C. E. 1969. The nutritive value of three species of water weeds. Econ. Bot. 23: 123-127.

Boyd, C. E. 1970a. Vascular aquatic plants for mineral nutrient removal from polluted waters. Econ. Bot. 24: 95-103.

Boyd, C. E. 1970b. Amino acid, protein, and caloric content of vascular aquatic macrophytes. Ecology 51: 902-906.

Boyd, C. E. 1975. Competition for light by aquatic plants in fish ponds. Circular 215. Agricultural Experiment Station, Auburn University, Auburn, AL. 19 pp.

Boyd, C. E. 1987. Evapotranspiration/evaporation (E/Eo) ratios for aquatic plants. J. Aquat. Plant Manag. 25: 1-3.

Boyd, C. E. \& R. D. Blackburn. 1970. Seasonal changes in the proximate composition of some common aquatic weeds. Hyacinth Control J. 8: 42-44.

Boyd, C. E. \& L. W. Hess. 1970. Factors influencing shoot production and mineral nutrient levels in Typha latifolia. Ecology 51: 296-300.

Boyd, C. E. \& C. P. Goodyear. 1971. Nutritive quality of food in ecological systems. Arch. Hydrobiol. 69: 256-270.

Boyd, C. E. \& W. W. Walley. 1972. Studies of the biogeochemistry of boron. I. Concentrations in surface waters, rainfall and aquatic plants. Am. Midl. Nat. 88: 1-14.

Boyd, C. E. \& P. S. McGinty. 1981. Percentage digestible dry matter and crude protein in dried aquatic weeds. Econ. Bot. 35: 296-299.

Boyd, R. S. \& J. M. Moffett, Jr. 2003. Management of Xyris tennesseensis, a federally-endangered plant species. GDOT Research Project No. 2003; Final Report. Georgia Department of Transportation, Atlanta, GA. 24 pp.

Boyd, R. S., A. Teem \& M. A. Wall. 2011. Floral biology of an Alabama population of the federally endangered plant, Xyris tennesseensis Kral (Xyridaceae). Castanea 76: 255-265.

Boyd, J. N., G. A. Raymond, G. P. Call \& M. J. Pistrang. 2016. Ecophysiological performance of the rare terrestrial orchid Platanthera integrilabia across contrasting habitats. Plant Ecol. 217: 1259-1272.

Boylen, C. W. \& R. B. Sheldon. 1976. Submergent macrophytes: growth under winter ice cover. Science 194: 841-842.

Brackney, A. \& T. A. Bookhout. 1982. Population ecology of common gallinules in southwestern Lake Erie marshes. Ohio J. Sci. 82: 229-237.

Bradfield, G. E. \& G. L. Porter. 1982. Vegetation structure and diversity components of a Fraser estuary tidal marsh. Can. J. Bot. 60: $440-451$.

Bragg, L. H. \& C. McMillan. 1986. SEM comparison of fruits of a seagrass, Halodule (Cymodoceaceae), from Australia and Texas. Am. J. Bot. 73: 815-821.

Brahma, S., H. Narzary \& S. Basumatary. 2013. Wild edible fruits of Kokrajhar district of Assam, North-East India. Asian J. Plant Sci. Res. 3: 95-100.

Brain, R. A., D. J. Johnson, S. M. Richards, H. Sanderson, P. K. Sibley \& K. R. Solomon. 2004. Effects of 25 pharmaceutical compounds to Lemna gibba using a seven-day static-renewal test. Environ. Toxicol. Chem. 23: 371-382.

Brant, A. E. 2018. Thelypteris noveboracensis (New York fern) new to Missouri from the Southeastern Missouri Ozarks. Missouriensis 36: 18-20.

Braselton, J. P. 1983. The plasmodiophoromycete parasitic on Heteranthera dubia. Can. J. Bot. 61: 45-52.

Bratton, S. P. 1974. The effect of the European wild boar (Sus scrofa) on the high-elevation vernal flora in Great Smoky Mountains National Park. Bull. Torrey Bot. Club 101: 198-206.

Bräuchler, C. 2015. Towards a better understanding of the Najas marina complex: notes on the correct application and typification of the names $N$. intermedia, $N$. major, and $N$. marina. Taxon 64: 1028-1030.
Braun, U., P. W. Crous \& C. Nakashima. 2014. Cercosporoid fungi (Mycosphaerellaceae) 2. Species on monocots (Acoraceae to Xyridaceae, excluding Poaceae). IMA Fungus 5: 203-390.

Breden, T. F., Y. R. Alger, K. S. Walz \& A. G. Windisch. 2001. Classification of Vegetation Communities of New Jersey: Second Iteration. Association for Biodiversity Information and New Jersey Natural Heritage Program, Office of Natural Lands Management, Division of Parks and Forestry, New Jersey Department of Environmental Protection, Trenton, NJ. $230 \mathrm{pp}$.

Brewer, C. A. 1995. The submersed aquatic plant community in Jackson Lake, Grand Teton National Park, Wyoming. Univ. Wyoming Natl. Park Serv. Res. Center Ann. Rep. 19: 14-18.

Brewer, J. S. 1998. Patterns of plant species richness in a wet slash-pine (Pinus elliottii) savanna. J. Torrey Bot. Soc. 125: 216-224.

Brewer, C. A. \& M. Parker. 1990. Adaptations of macrophytes to life in moving water: upslope limits and mechanical properties of stems. Hydrobiologia 194: 133-142.

Brewer, J. S., D. J. Baker, A. S. Nero, A. L. Patterson, R. S. Roberts \& L. M. Turner. 2011. Carnivory in plants as a beneficial trait in wetlands. Aquat. Bot. 94: 62-70.

Brewis, A. 1975. Sagittaria subulata (L.) Buch. in the British Isles. Watsonia 10: 411.

Bridges, E. L. 2005. Assessment of Biodiversity and Conservation Status Priorities for Pitcher Plant Bogs and Wetland Savannas of the Apalachicola National Forest. E. L. Bridges, Bremerton, WA. 93 pp.

Bridges, E. L. \& S. L. Orzell. 1987. A new species of Xyris (sect. Xyris) from the Gulf Coastal Plain. Phytologia 64: 56-61.

Bridges, E. L. \& S. L. Orzell. 1989. Syngonanthus flavidulus (Eriocaulaceae) new to Mississippi. Sida 13: 512-515.

Bridges, E. L. \& S. L. Orzell. 1992a. The rediscovery of Rhynchospora solitaria Harper (Cyperaceae) in Georgia. Phytologia 72: 369-372.

Bridges, E. L. \& S. L. Orzell. 1992b. Xyris isoetifolia Kral (Xyridaceae) new to Alabama and its range and habitats in Florida. Phytologia 72: 152-156.

Bridges, E. L. \& S. L. Orzell. 2002. Euphorbia (Euphorbiaceae) section Tithymalus subsection Inundatae in the southeastern United States. Lundellia 5: 59-79.

Bridges, E. L. \& S. L. Orzell. 2003. Two new species and a new combination in southeastern United States Xyris (Xyridaceae) from Florida. Novon 13: 16-25.

Brim-DeForest, W. B., K. Al-Khatib, B. A. Linquist \& A. J. Fischer. 2017a. Weed community dynamics and system productivity in alternative irrigation systems in California rice. Weed Sci. 65: 177-188.

Brim-DeForest, W. B., K. Al-Khatib \& A. J. Fischer. 2017b. Predicting yield losses in rice mixed-weed species infestations in California. Weed Sci. 65: 61-72.

Brinckmann-Voss, A. 1996. Seasonality of hydroids (Hydrozoa, Cnidaria) from an inter-tidal pool and adjacent subtidal habitats at Race Rocks, off Vancouver Island, Canada. Sci. Mar. 60: 89-97.

Brinckmann-Voss, A., D. M. Lickey \& C. E. Mills. 1993. Rhysia fletcheri (Cnidaria, Hydrozoa, Rhysiidae), a new species of colonial hydroid from Vancouver Island (British Columbia, Canada) and the San Juan Archipelago (Washington, U.S.A.). Can. J. Zool. 71: 401-406.

Broadhurst, L. \& C. Chong. 2011. Examining clonal propagation of the aquatic weed Sagittaria platyphylla. RIRDC Publication No. 11/020. CSIRO Plant Industry, Canberra, ACT. 17 pp. 
Brochet, A.-L., M. Guillemain, H. Fritz, M. Gauthier-Clerc \& A. J. Green. 2009. The role of migratory ducks in the long-distance dispersal of native plants and the spread of exotic plants in Europe. Ecography 32: 919-928.

Brochet, A.-L., M. Guillemain, M. Gauthier-Clerc, H. Fritz \& A. J. Green. 2010a. Endozoochory of Mediterranean aquatic plant seeds by teal after a period of desiccation: determinants of seed survival and influence of retention time on germinability and viability. Aquat. Bot. 93: 99-106.

Brochet, A. L., M. Guillemain, H. Fritz, M. Gauthier-Clerc \& A. J. Green. 2010b. Plant dispersal by teal (Anas crecca) in the Camargue: duck guts are more important than their feet. Freshw. Biol. 55: 1262-1273.

Brochet, A.-L., J.-B. Mouronval, P. Aubry, M. Gauthier-Clerc, A. J. Green, H. Fritz \& M. Guillemain. 2012. Diet and feeding habitats of Camargue dabbling ducks: what has changed since the 1960s? Waterbirds 35: 555-576.

Brodie, B. S., A. Renyard, R. Gries, H. Zhai, S. Ogilvie, J. Avery \& G. Gries. 2018. Identification and field testing of floral odorants that attract the rove beetle Pelecomalium testaceum (Mannerheim) to skunk cabbage, Lysichiton americanus (L.). Arthropod-Plant Interact. 12: 591-599.

Brook, I. M. 1978. Comparative macrofaunal abundance in turtlegrass (Thalassia testudinum) communities in south Florida characterized by high blade density. Bull. Mar. Sci. 28: 212-217.

Brooks, T. L. 1954. Host range of the burrowing nematode internationally and in Florida. Citrus Industry 35(7-8): 14-15.

Brooks, A. R., E. S. Nixon \& J. A. Neal. 1993. Woody vegetation of wet creek bottom communities in eastern Texas. Castanea 58: 185-196.

Brooks, R. P. \& D. H. Wardrop (eds.). 2013. Mid-Atlantic Freshwater Wetlands: Advances in Wetlands Science, Management, Policy, and Practice. Springer, New York, NY. 491 pp.

Brophy, T. E. 1980. Food habits of sympatric larval Ambystoma tigrinum and Notophthalmus viridescens. J. Herpetol. 14: 1-6.

Broschat, T. K. 1994. Palm seed propagation. Acta Hort. 360: 141-147.

Broschat, T. K. 2011a. Uptake and distribution of boron in coconut and paurotis palms. HortScience 46: 1683-1686.

Broschat, T. K. 2011b. Iron deficiency in palms. Document ENH 1013. IFAS Extension, University of Florida, Gainesville, FL. 3 pp.

Broschat, T. K. \& W. G. Latham. 1994. Oxalate content of palm fruit mesocarp. Biochem. Syst. Ecol. 22: 389-392.

Brotherson, J. D. 1981. Aquatic and semiaquatic vegetation of Utah Lake and its bays. Great Basin Nat. Mem. 5: 68-84.

Brousil, M., C. Humann \& D. Fischer. 2015. Plant-pollinator interactions in a northwest Arum related to plant traits but not riparian forest management. Northwest Sci. 89: 297-307.

Brouwer, E., R. Bobbink \& J. G. M. Roelofs. 2002. Restoration of aquatic macrophyte vegetation in acidified and eutrophied softwater lakes: an overview. Aquat. Bot. 73: 405-431.

Brown, W. V. 1942. A note on Sagittaria kurziana. Rhodora 44: 211-213.

Brown, C. J. 1995. An investigation of environmental parameters influencing the distribution of Platanthera blephariglottis (Willdenow) Lindley and P. clavellata (Michaux) Luer (Orchidaceae) in peatlands, and some aspects of their population dynamics. Ph.D. dissertation. Memorial University of Newfoundland, St. John's, NF. 114 pp.

Brown, P. M. 2005. Wild Orchids of Florida, expanded ed. University Press of Florida, Gainesville, FL. 409 pp.

Brown, P. M. 2006. Resurrection of the genus Gymnadeniopsis Rydberg. North Am. Native Orchid J. 12: 33-40.
Brown, P. M. 2008. Hybrids in the genus Calopogon. North Am. Native Orchid J. 14: 177-182.

Brown, J. H. \& W. McDonald. 1995. Livestock grazing and conservation on southwestern rangelands. Conserv. Biol. 9: 1644-1647.

Brown, C. J. \& P. J. Scott. 1997. Environmental parameters influencing the distribution of Platanthera blephariglottis and Platanthera clavellata (Orchidaceae) in peatlands on the Avalon Peninsula, Newfoundland. Can. J. Bot. 75: 974-980.

Brown, P. M. \& G. W. Argus. 2002. Epipactis Zinn. Pp. 584-586 In: Flora North America Editorial Committee (eds.), Flora of North America North of Mexico, Vol. 26: Magnoliophyta: Liliidae: Liliales and Orchidales. Oxford University Press, New York, NY.

Brown, J. S. \& C. G. Eckert. 2005. Evolutionary increase in sexual and clonal reproductive capacity during biological invasion in an aquatic plant Butomus umbellatus (Butomaceae). Am. J. Bot. 92: 495-502.

Brown, W. Y., M. Choct \& J. R. Pluske. 2013. Duckweed (Landoltia punctata) in dog diets decreases digestibility but improves stool consistency. Anim. Prod. Sci. 53: 1188-1194.

Brown, M. T., T. Boyer, R. J. Sindelar, S. Arden, A. Persaud \& S. Brandt-Williams. 2018. A floating island treatment system for the removal of phosphorus from surface waters. Engineering. doi: 10.1016/j.eng.2018.08.002.

Brugiolo, A. S. S., C. C. de Souza Alves, A. C. C. Gouveia, A. T. Dias, M. F. Rodrigues, L. G. G. Pacífico, B. J. V. Aarestrup, M. A. Machado, R. Domingues, H. C. Teixeira, J. Gameiro \& A. P. Ferreira. 2011. Effects of aqueous extract of Echinodorus grandiflorus on the immune response in ovalbumin-induced pulmonary allergy. Ann. Allergy Asthma Immunol. 106: 481-488.

Brumback, W. E. 2001. Carex garberi Fern. (Garber's Sedge) and Triantha glutinosa (Michx.) Baker (Sticky False Asphodel) Conservation Plan. New England Wild Flower Society, Framingham, MA. 43 pp.

Brunel, S. 2009. Pathway analysis: aquatic plants imported in 10 EPPO countries. EPPO Bull. 39: 201-213.

Brunton, D. F. 1986. Status of giant helleborine, Epipactis gigantea (Orchidaceae) in Canada. Can. Field-Nat. 100: 414-417.

Brunton, D. F. \& D. M. Britton. 1993. Isoetes prototypus (Isoetaceae) in the United States. Rhodora 95: 122-128.

Brunton, D. F., D. M. Britton \& W. C. Taylor. 1994. Isoetes hyemalis, sp. nov. (Isoetaceae): a new quillwort from the southeastern United States. Castanea 59: 12-21.

Brux, H., D. Todeskino \& G. Wiegleb. 1987. Growth and reproduction of Potamogeton alpinus Balbis growing in disturbed habitats. Arch. Hydrobiol. 27: 115-127.

Bryson, C. T., J. R. MacDonald \& R. Warren. 1994. Notes on Carex (Cyperaceae), with $C$. godfreyi new to Alabama and C. scoparia new to Mississippi (USA). Sida 16: 355-360.

Brzosko, E., B. Ostrowiecka, J. Kotowicz, M. Bolesta, A. Gromotowicz, M. Gromotowicz, A. Orzechowska, J. Orzolek \& M. Wojdalska. 2017. Seed dispersal in six species of terrestrial orchids in Biebrza National Park (NE Poland). Acta Soc. Bot. Poloniae 86: 3557.

Buchmann, S., L. D. Adams, A. D. Howell \& M. Weiss. 2010. A study of insect pollinators associated with DoD TER-S flowering plants, including identification of habitat types where they co-occur by military installation in the Western United States. No. LRMP-PN-08-391. U.S. Department of Defense, Legacy Resource Management Program, Arlington, VA. 67 pp.

Buchsbaum, R., I. Valiela \& T. Swain. 1984. The role of phenolic compounds and other plant constituents in feeding by Canada geese in a coastal marsh. Oecologia 63: 343-349. 
Buckel, C. A., C. A. Blanchette, R. R. Warner \& S. D. Gaines. 2012. Where a male is hard to find: consequences of male rarity in the surfgrass Phyllospadix torreyi. Mar. Ecol. Prog. Ser. 449: $121-132$.

Buckingham, G. R. 1989. Lemnaphila scotlandae (Diptera: Ephydridae) and three of its parasites discovered in Florida. Florida Entomol. 72: 219-221.

Buckingham, G. R. \& C. A. Bennett. 1989. Dyscinetus morator (Fab.)(Coleoptera: Scarabaeidae) adults attack waterhyacinth, Eichhornia crassipes (Pontederiaceae). Coleopt. Bull. 43: 27-33.

Buckley, R. A. \& E. A. Hicks. 1962. An analysis of mite populations in muskrat houses. Proc. Iowa Acad. Sci. 69: 541-556.

Buddington, R. K. 1979. Digestion of an aquatic macrophyte by Tilapia zillii (Gervais). J. Fish Biol. 15: 449-455.

Buell, M. F. 1946. Jerome Bog, a peat-filled "Carolina bay." Bull. Torrey Bot. Club 73: 24-33.

Buffington, K. J., B. D. Dugger \& K. M. Thorne. 2018. Climaterelated variation in plant peak biomass and growth phenology across Pacific Northwest tidal marshes. Estuar. Coast. Shelf Sci. 202: 212-221.

Bukliev, R. 1980. Heteranthera limosa Vahl - new adventive species for the flora of Yugoslavia and Europe. Fragmenta Balcanica 11: 11-17.

Bull, J. S., D. C. Reed \& S. J. Holbrook. 2004. An experimental evaluation of different methods of restoring Phyllospadix torreyi (surfgrass). Restor. Ecol. 12: 70-79.

Bullard, A. J. \& C. M. Allen. 2013. Synopsis of the woody species of Smilax in the Eastern United States north of peninsular Florida. J. North Carolina Acad. Sci. 129: 37-43.

Bunghez, I. R., R. M. Ion, S. Pop, M. Ghiurea, I. Dumitriu \& R. C. Fierascu. 2010. Silver nanoparticles fabrication using marine plant (Mayaca fluviatilis) resources. Analele Sti. Univ. "Al. I. Cuza” Iasi, Sect. 2.a, Genet. Biol. Mol. 11: 89-94.

Burbanck, M. P. \& R. B. Platt. 1964. Granite outcrop communities of the Piedmont Plateau in Georgia. Ecology 45: 292-306.

Burbanck, M. P. \& D. L. Phillips. 1983. Evidence of plant succession on granite outcrops of the Georgia Piedmont. Am. Midl. Nat. 109: 94-104.

Burchill, C. A. \& N. C. Kenkel. 1991. Vegetation-environment relationships of an inland boreal salt pan. Can. J. Bot. 69: 722-732.

Burge, D. O. 2014. The role of soil chemistry in the geographic distribution of Ceanothus otayensis (Rhamnaceae). Madroño 61: 276-289.

Burgess, T. E. 1970. Foods and habitat of four anatinids wintering on the Fraser Delta tidal marshes. M.S. thesis. University of British Columbia, Vancouver, BC. 124 pp.

Burk, C. J. 1962. The North Carolina Outer Banks: a floristic interpretation. J. Elisha Mitchell Sci. Soc. 78: 21-28.

Burkhalter, J. R. \& J. C. Wright. 1989. Fourteen additions to the known stranded seeds and fruits of Northwest Florida beaches. Sida 13: 345-349.

Burkholder, J. M., H. B. Glasgow, Jr. \& J. E. Cooke. 1994. Comparative effects of water-column nitrate enrichment on eelgrass Zostera marina, shoalgrass Halodule wrightii, and widgeongrass Ruppia maritima. Mar. Ecol. Prog. Ser. 105: 121-138.

Burks, K. C. 1995. Noteworthy collections: Florida. Castanea 60: 169-170.

Burlakova, L. E., A. Y. Karatayev, D. K. Padilla, L. D. Cartwright \& D. N. Hollas. 2009. Wetland restoration and invasive species: apple snail (Pomacea insularum) feeding on native and invasive aquatic plants. Restor. Ecol. 17: 433-440.

Burnham, S H. 1917. The Naiadales of the flora of the Lake George region. Torreya 17: 80-84.
Burns, G. P. 1911. A botanical survey of the Huron river valley. VIII. Edaphic conditions in peat bogs of southern Michigan. Bot. Gaz. 52: 105-125.

Burns, Jr., J. W., M. A. Poirrier \& K. P. Preston. 1995. The status of Potamogeton perfoliatus (Potamogetonaceae) in Lake Pontchartrain, Louisiana. Sida 16: 757-763.

Burns, J. H., R. B. Faden \& S. J. Steppan. 2011. Phylogenetic studies in the Commelinaceae subfamily Commelinoideae inferred from nuclear ribosomal and chloroplast DNA sequences. Syst. Bot. 36: 268-276.

Bursik, R. J. \& R. K. Moseley. 1992. Vegetation and Water Chemistry Monitoring and Twenty-Year Floristic Changes at Huff Lake fen, Kaniksu National Forest. Conservation Data Center, Idaho Department of Fish and Game, Boise, ID. 17 pp.

Bush, E. M. 1988. A floristic study of a wet meadow in Barbour County, West Virginia. Castanea 53: 132-139.

Bush, C. M., D. Rollins \& G. L. Smith. 2010. The phylogeny of the southeastern United States Hymenocallis (Amaryllidaceae) based on ISSR fingerprinting and morphological data. Castanea 75: 368-380.

Bushmann, P. J. \& M. S. Ailstock. 2006. Antibacterial compounds in estuarine submersed aquatic plants. J. Exp. Mar. Biol. Ecol. 331: 41-50.

Bushnell, Jr., J. H. 1966. Environmental relations of Michigan Ectoprocta, and dynamics of natural populations of Plumatella repens. Ecol. Monogr. 36: 95-123.

Bushnell, Jr., J. H. \& T. W. Porter. 1967. The occurrence, habitat, and prey of Craspedacusta sowerbyi (particularly polyp stage) in Michigan. Trans. Am. Microsc. Soc. 86: 22-27.

Buthod, A. K. \& B. W. Hoagland. 2011. New to Oklahoma: Leptochloa panicoides (Poaceae). Phytoneuron 2011-55: $1-2$.

Buthod, A. K. \& B. W. Hoagland. 2013a. Noteworthy collections: Oklahoma. Castanea 78: 213-215.

Buthod, A. K. \& B. W. Hoagland. 2013b. New to Oklahoma: Murdannia keisak (Commelinaceae). Phytoneuron 2013-93: $1-3$.

Buzgo, M., D. E. Soltis, P. S. Soltis, S. Kim, H. Ma, B. A. Hauser, J. Lebens-Mack \& B. Johansen. 2006. Perianth development in the basal monocot Triglochin maritima (Juncaginaceae). Aliso 22: $107-125$.

Buznego, M. T. \& H. Pérez-Saad. 2006. Behavioral and antiepileptic effect of acute administration of the extract of the aquatic plant Echinodorus berteroi (Sprengel) Fassett (upright burhead). Epilepsy Behav. 9: 40-45.

Buzzelli, C., R. Robbins, P. Doering, Z. Chen, D. Sun, Y. Wan, B. Welch \& A. Schwarzschild. 2012. Monitoring and modeling of Syringodium filiforme (manatee grass) in southern Indian River lagoon. Estuaries Coast. 35: 1401-1415.

Byng, J. W., M. W. Chase, M. J. M. Christenhusz, M. F. Fay, W. S. Judd, D. J. Mabberley, A. N. Sennikov, D. E. Soltis, P. S. Soltis \& P. F. Stevens. 2016. An update of the Angiosperm Phylogeny Group classification for the orders and families of flowering plants: APG IV. Bot. J. Linn. Soc. 181: 1-20.

Bytnerowicz, T. A. \& R. I. Carruthers. 2014. Germination characteristics of Zannichellia palustris from a northern California spring-fed river. Aquat. Bot. 119: 44-50.

Cabaço, S., R. Santos \& C. M. Duarte. 2008. The impact of sediment burial and erosion on seagrasses: a review. Estuar. Coast. Shelf Sci. 79: 354-366.

Cabrera, L. I., G. A. Salazar, M. W. Chase, S. J. Mayo, J. Bogner \& P. Dávila. 2008. Phylogenetic relationships of aroids and duckweeds (Araceae) inferred from coding and noncoding plastid DNA. Am. J. Bot. 95: 1153-1165. 
Caffrey, J. M. \& W. M. Kemp. 1990. Nitrogen cycling in sediments with estuarine populations of Potamogeton perfoliatus and Zostera marina. Mar. Ecol. Prog. Ser. 66: 147-160.

Caffrey, J. M. \& W. M. Kemp. 1991. Seasonal and spatial patterns of oxygen production, respiration and root-rhizome release in Potamogeton perfoliatus L. Zostera marina L. Aquat. Bot. 40: 109-128.

Caffrey, J. M. \& W. M. Kemp. 1992. Influence of the submersed plant, Potamogeton perfoliatus, on nitrogen cycling in estuarine sediments. Limnol. Oceanogr. 37: 1483-1495.

Caicedo, J. R., N. P. Van der Steen, O. Arce \& H. J. Gijzen. 2000. Effect of total ammonia nitrogen concentration and $\mathrm{pH}$ on growth rates of duckweed (Spirodela polyrrhiza). Water Res. 34: 3829-3835.

Caillet, M., J. F. Campbell, K. C. Vaughn \& D. Vercher. 2000. The Louisiana Iris: The Taming of a Native American Wildflower, 2nd ed. Timber Press, Portland, OR. 211 pp.

Cain, S. A. 1931. Ecological studies of the vegetation of the Great Smoky Mountains of North Carolina and Tennessee. I. Soil reaction and plant distribution. Bot. Gaz. 91: 22-41.

Calazza, N. \& D. E. Fairbrothers. 1980. Threatened and Endangered Vascular Plant Species of the New Jersey Pinelands and Their Habitats. New Jersey Pinelands Commission, Pemberton, NJ. $38 \mathrm{pp}$.

Calderón, A. I., M. Cubilla, A. Espinosa \& M. P. Gupta. 2010. Screening of plants of Amaryllidaceae and related families from Panama as sources of acetylcholinesterase inhibitors. Pharm. Biol. 48: 988-993.

Calha, I. M., C. Machado \& F. Rocha. 1998. New Alisma spp. biotypes resistant to sulfonylurea herbicides. Pp. 245-248 In: A. Monteiro, T. Vasconcelos \& L. Catarino (eds.), Management and Ecology of Aquatic Plants. Proceedings of the 10th EWRS International Symposium on Aquatic Weeds, Lisbon, Portugal, 21-25 September 1998. European Weed Research Society, Poznañ, Poland.

Calhoun, A. \& G. M. King. 1998. Characterization of root-associated methanotrophs from three freshwater macrophytes: Pontederia cordata, Sparganium eurycarpum, and Sagittaria latifolia. Appl. Environ. Microbiol. 64: 1099-1105.

Calicioglu, O. \& R. A. Brennan. 2018. Sequential ethanol fermentation and anaerobic digestion increases bioenergy yields from duckweed. Bioresour. Technol. 257: 344-348.

Calvo-Polanco, M., M. A. Equiza, J. Señorans \& J. J. Zwiazek. 2014. Responses of rat root (Acorus americanus Raf.) plants to salinity and pH conditions. J. Environ. Qual. 43: 578-586.

Camazine, S. \& K. J. Niklas. 1984. Aerobiology of Symplocarpus foetidus: interactions between the spathe and spadix. Am. J. Bot. 71: 843-850.

Cameron, K. M. 2005. Leave it to the leaves: a molecular phylogenetic study of Malaxideae (Epidendroideae, Orchidaceae). Am. J. Bot. 92: 1025-1032.

Cameron, K. M. 2009. On the value of nuclear and mitochondrial gene sequences for reconstructing the phylogeny of vanilloid orchids (Vanilloideae, Orchidaceae). Ann. Bot. 104: 377-385.

Cameron, K. M. 2010. On the value of taxonomy, phylogeny, and systematics to orchid conservation: implications for China's Yachang Orchid Reserve. Bot. Rev. 76: 165-173.

Cameron, K. M. \& M. W. Chase. 1999. Phylogenetic relationships of Pogoniinae (Vanilloideae, Orchidaceae): an herbaceous example of the eastern North America-eastern Asia phytogeographic disjunction. J. Plant Res. 112: 317-329.

Cameron, K. M. \& C. Fu. 2006. A nuclear rDNA phylogeny of Smilax (Smilacaceae). Aliso 22: 598-605.
Cameron, K. M. \& M. C. Molina. 2006. Photosystem II gene sequences of $p s b B$ and $p s b C$ clarify the phylogenetic position of Vanilla (Vanilloideae, Orchidaceae). Cladistics 22: 239-248.

Camill, P. 1999. Patterns of boreal permafrost peatland vegetation across environmental gradients sensitive to climate warming. Can. J. Bot. 77: 721-733.

Camp, W. H. 1933. Distribution and flowering in Wolffia papulifera. Ohio J. Sci. 33: 163.

Campanella, J. J., P. A. X. Bologna, M. Carvalho, J. V. Smalley, M. Elakhrass, R. W. Meredith \& N. Zaben. 2015. Clonal diversity and connectedness of turtle grass (Thalassia testudinum) populations in a UNESCO Biosphere Reserve. Aquat. Bot. 123: 76-82.

Campbell, D. H. 1897. A morphological study of Naias and Zannichellia. Proc. Calif. Acad. Sci. Ser. 3 1: 1-61.

Campbell, R. W. \& D. Stirling. 1968. Notes on the vertebrate fauna associated with a Brandt's Cormorant colony in British Columbia. Murrelet 49: 7-9.

Campbell, H. W. \& A. B. Irvine. 1977. Feeding ecology of the West Indian manatee Trichechus manatus Linnaeus. Aquaculture 12: $249-251$.

Campbell, D. \& J. Bergeron. 2012. Natural revegetation of winter roads on peatlands in the Hudson Bay lowland, Canada. Arct. Antarct. Alp. Res. 44: 155-163.

Campbell, L. M. \& L. J. Dorr. 2013. A synopsis of Harperocallis (Tofieldiaceae, Alismatales) with ten new combinations. PhytoKeys 21: 37-52.

Campbell, J. E. \& J. W. Fourqurean. 2013. Mechanisms of bicarbonate use influence the photosynthetic carbon dioxide sensitivity of tropical seagrasses. Limnol. Oceanogr. 58: 839-848.

Campbell, J. W., A. M. Starring \& G. L. Smith. 2014. Flower visitors of Hymenocallis coronaria (rocky shoals spider-lily) of Landsford Canal State Park - South Carolina, USA. Nat. Areas J. 34: 332-337.

Canfield, D. E., K. A. Langeland, S. B. Linda \& W. T. Haller. 1985. Relations between water transparency and maximum depth of macrophyte colonization in lakes. J. Aquat. Plant Manag. 23: 25-28.

Cangiano, T., M. DellaGreca, A. Fiorentino, M. Isidori, P. Monaco \& A. Zarrelli. 2001. Lactone diterpenes from the aquatic plant Potamogeton natans. Phytochemistry 56: 469-473.

Cannings, S. G. 2003. Status of river jewelwing (Calopteryx aequabilis Say) in British Columbia. Wildlife Bulletin No. B-110. British Columbia Ministry of Water, Land and Air Protection, Biodiversity Branch, Victoria, BC. 10 pp.

Cannings, R. A. \& J. P. Simaika. 2005. Lestes disjunctus and L. forcipatus (Odonata: Lestidae): an evaluation of status and distribution in British Columbia. J. Entomol. Soc. British Columbia 102: 57-64.

Cao, H. X., G. T. H. Vu, W. Wang, K. J. Appenroth, J. Messing \& I. Schubert. 2016. The map-based genome sequence of Spirodela polyrhiza aligned with its chromosomes, a reference for karyotype evolution. New Phytol. 209: 354-363.

Capers, R. S. 2003a. Macrophyte colonization in a freshwater tidal wetland (Lyme, CT, USA). Aquat. Bot. 77: 325-338.

Capers, R. S. 2003b. Six years of submerged plant community dynamics in a freshwater tidal wetland. Freshw. Biol. 48: 1640-1651.

Capers, R. S. \& D. H. Les. 2005. Plant community structure in a freshwater tidal wetland. Rhodora 107: 386-407.

Capers, R. S., R. Selsky \& G. J. Bugbee. 2010. The relative importance of local conditions and regional processes in structuring aquatic plant communities. Freshw. Biol. 55: 952-966. 
Cappers, R. T. J. 1993. Seed dispersal by water: a contribution to the interpretation of seed assemblages. Veg. Hist. Archaeobot. 2: 173-186.

Caprio, A. C. \& D. L. Taylor. 1984. Effect of frost on a subtropical Muhlenbergia prairie in south Florida. Florida Sci. 47: 27-32.

Carefoot, T. H. 1973. Feeding, food preference, and the uptake of food energy by the supralittoral isopod Ligia pallasii. Mar. Biol. 18: 228-236.

Carlquist, S. 1967. The biota of long-distance dispersal. V. Plant dispersal to Pacific Islands. Bull. Torrey Bot. Club 94: 129-162.

Carlquist, S. \& E. L. Schneider. 2014. Origins and nature of vessels in Monocotyledons. 14. Vessellessness in Orontioideae (Araceae): adaptation or relictualism? Nordic J. Bot. 32: 493-502.

Carlsen, M. M., T. Fér, R. Schmickl, J. Leong-Škorničková, M. Newman \& W. J. Kress. 2018. Resolving the rapid plant radiation of early diverging lineages in the tropical Zingiberales: pushing the limits of genomic data. Mol. Phylogenet. Evol. 128: 55-68.

Carlson, M. C. 1938. Origin and development of shoots from the tips of roots of Pogonia ophioglossoides. Bot. Gaz. 100: 215-225.

Carlson, M. C. 1943. The morphology and anatomy of Calopogon pulchellus. Bull. Torrey Bot. Club 70: 349-368.

Carlson, M. L., R. Lipkin, M. Sturdy \& J. A. Michaelson. 2004. Kenai Fjords National Park vascular plant inventory. Final technical report. NPS Report: NPS/AKR/SWAN/NRTR2004/02. National Park Service, Southwest Alaska Network, Anchorage, AK. 29 [+40 Appendix] pp.

Carlson, M. L., R. Lipkin, C. Roland \& A. E. Miller. 2013. New and important vascular plant collections from south-central and southwestern Alaska: a region of floristic convergence. Rhodora 115: 61-95.

Carpenter, S. R. \& J. E. Titus. 1984. Composition and spatial heterogeneity of submersed vegetation in a softwater lake in Wisconsin. Vegetatio 57: 153-165.

Carpenter, J. S. \& E. W. Chester. 1987. Vascular flora of the Bear Creek Natural Area, Stewart County, Tennessee. Castanea 52: 112-128.

Carr, L. G. 1940. Further notes on coastal floral elements in the bogs of Augusta County, Virginia. Rhodora 42: 86-93.

Carr, S. C. 2007. Floristic and environmental variation of pyrogenic pinelands in the Southeastern Coastal Plain: description, classification, and restoration. Ph.D. dissertation. University of Florida, Gainesville, FL. 184 pp.

Carr, S. C., K. M. Robertson \& R. K. Peet. 2010. A vegetation classification of fire-dependent pinelands of Florida. Castanea 75: 153-189.

Carrillo, D., D. Amalin, F. Hosein, A. Roda, R. E. Duncan \& J. E. Peña. 2012. Host plant range of Raoiella indica (Acari: Tenuipalpidae) in areas of invasion of the New World. Exp. Appl. Acarol. 57: 271-289.

Carroll, S., R. L. Miller \& P. D. Whitson. 1984. Status of four orchid species at Silver Lake Fen complex. Proc. Iowa Acad. Sci. 91: 132-139.

Carter, J. W. 1982. Natural history observations on the gastropod shell-using amphipod Photis conchicola Alderman, 1936. J. Crustacean Biol. 2: 328-341.

Carter, Jr., J. W. \& S. B. Jones, Jr. 1968. The vascular flora of Johnson State Park, Mississippi. Castanea 33: 194-205.

Carter, V. \& N. Rybicki. 1986. Resurgence of submersed aquatic macrophytes in the tidal Potomac River, Maryland, Virginia, and the District of Columbia. Estuaries Coast. 9: 368-375.

Carter, M. C. \& M. D. Sytsma. 2001. Comparison of the genetic structure of North and South American populations of a clonal aquatic plant. Biol. Invasions 3: 113-118.
Carter, R., M. W. Morris \& C. T. Bryson. 1990. Some rare or otherwise interesting vascular plants from the Delta Region of Mississippi. Castanea 55: 40-55.

Carter, R. E., M. D. MacKenzie, D. H. Gjerstad \& D. Jones. 2004. Species composition of fire disturbed ecological land units in the southern loam hills of south Alabama. Southeast. Nat. 3: 297-309.

Carter, R., W. W. Baker \& M. W. Morris. 2009. Contributions to the flora of Georgia, USA. Vulpia 8: 1-54.

Carvalho, K. M. \& D. F. Martin. 2001. Removal of aqueous selenium by four aquatic plants. J. Aquat. Plant Manag. 39: 33-36.

Carvalho, A. T., S. Dötterl \& C. Schlindwein. 2014. An aromatic volatile attracts oligolectic bee pollinators in an interdependent bee-plant relationship. J. Chem. Ecol. 40: 1126-1134.

Carville, J. S. 1997. Hiking Tahoe's Wildflower Trails. Lone Pine Publishing, Vancouver, BC. 352 pp.

Casadoro, G., N. Rascio, M. Pagiusco \& N. Ravagnan. 1982. Flowers of Orontium aquaticum L.: membrane rearrangement in chloroplast—chromoplast interconversions. J. Ultrastruct. Res. 81: 202-208.

Case, M. A. 1994. Extensive variation in the levels of genetic diversity and degree of relatedness among five species of Cypripedium (Orchidaceae). Am. J. Bot. 81: 175-184.

Case, F. W. \& R. B. Case. 1974. Sarracenia alabamensis, a newly recognized species from central Alabama. Rhodora 76: 650-665.

Casierra-Posada, F., M. M. Blanke \& J. C. Guerrero-Guío. 2014. Iron tolerance in calla lilies (Zantedeschia aethiopica). Gesunde Pflanzen 66: 63-68.

Caslake, L. F., S. S. Harris, C. Williams \& N. M. Waters. 2006. Mercury-resistant bacteria associated with macrophytes from a polluted lake. Water Air Soil Pollut. 174: 93-105.

Casper, S. J. \& H.-D. Krausch. 1980. Süsswasserflora von Mitteleuropa. Band 23: Pteridophyta und Anthophyta. 1. Teil: Lycopodiaceae bis Orchidaceae. Gustav Fischer Verlag, Stuttgart, Germany. 403 pp.

Cassani, J. R. 1981. Feeding behaviour of underyearling hybrids of the grass carp, Ctenopharyngodon idella 9 and the bighead, Hypophthalmicthys nobilis ${ }^{\star}$ on selected species of aquatic plants. J. Fish Biol. 18: 127-133.

Cassani, J. R., W. E. Caton \& T. H. Hansen, Jr. 1982. Culture and diet of hybrids grass carp fingerlings. J. Aquat. Plant Manag. 20: $30-32$.

Cassani, J. R., D. H. Habeck \& D. L. Matthews. 1990. Life history and immature stages of a plume moth Sphenarches anisodactylus (Lepidoptera: Pterophoridae) in Florida. Florida Entomol. 73: 257-266.

Castellanos, D. L. \& L. P. Rozas. 2001. Nekton use of submerged aquatic vegetation, marsh, and shallow unvegetated bottom in the Atchafalaya River Delta, a Louisiana tidal freshwater ecosystem. Estuaries 24: 184-197.

Catling, P. M. 1980. Rain-assisted autogamy in Liparis loeselii (L.) L. C. Rich. (Orchidaceae). Bull. Torrey Bot. Club 107: 525-529.

Catling, P. M. 1982. Breeding systems of northeastern North American Spiranthes (Orchidaceae). Can. J. Bot. 60: 3017-3039.

Catling, P. M. 1983a. Autogamy in eastern Canadian Orchidaceae: a review of current knowledge and some new observations. Nat. Can. 110: $37-54$.

Catling, P. M. 1983b. Pollination of northeastern North American Spiranthes (Orchidaceae). Can. J. Bot. 61: 1080-1093.

Catling, P. M. 1984. Self-pollination and probable autogamy in chamisso's orchid Platanthera chorisiana (Cham.) Reichb. f. Naturaliste Can. 111: 451-453.

Catling, P. M. \& G. Knerer. 1980. Pollination of the small white lady's-slipper (Cypripedium candidum) in Lambton County, Southern Ontario. Can. Field-Nat. 94: 435-438. 
Catling, P. M. \& W. G. Dore. 1982. Status and identification of Hydrocharis morsus-ranae and Limnbobium spongia (Hydrocharitaceae) in Northeastern North America. Rhodora 84: 523-545.

Catling, P. M. \& I. Dobson. 1985. The biology of Canadian weeds. 69. Potamogeton crispus L. Can. J. Plant Sci. 65: 655-668.

Catling, P. M. \& W. Wojtas. 1986. The waterweeds (Elodea and Egeria, Hydrocharitaceae) in Canada. Can. J. Bot. 64: 1525-1541.

Catling, P. M. \& V. R. Catling. 1989. Observations on the pollination of Platanthera huronensis in southwest Colorado. Lindleyana 4: 78-84.

Catling, P. M. \& V. R. Catling. 1991. A synopsis of breeding systems and pollination in North American orchids. Lindleyana 6: $187-210$

Catling, P. M. \& Z. S. Porebski. 1995. The spread and current distribution of European Frogbit, Hydrocharis morsus-ranae L., in North America. Can. Field-Nat. 109: 236-241.

Catling, P. M. \& V. R. Brownell. 1999. Platanthera lacera $\times$ leucophaea, a new cryptic natural hybrid, and a key to northeastern North American fringed-orchids. Can. J. Bot. 77: 1144-1149.

Catling, P. M. \& G. Mitrow. 2001. Egeria najas at the Canadian border and its separation from the related aquatic weeds Egeria densa and Hydrilla verticillata (Hydrocharitaceae). Bot. Electronic Newslett. 278: 1-3.

Catling, P. M. \& L. K. Magrath. 2002. Malaxis Solander ex Swartz. Pp. 627-631 In: Flora North America Editorial Committee (eds.), Flora of North America North of Mexico, Vol. 26: Magnoliophyta: Liliidae: Liliales and Orchidales. Oxford University Press, New York, NY.

Catling, P. M. \& B. Kostiuk. 2011a. Some observations on the pollination of round-leaf orchid, Galearis (Amerorchis) rotundifolia, near Jasper, Alberta. Can. Field-Nat. 125: 47-54.

Catling, P. M. \& B. Kostiuk. 2011b. Some wild Canadian orchids benefit from woodland hiking trails-and the implications. Can. Field-Nat. 125: 105-115.

Catling, P. M., B. Freedman \& Z. Lucas. 1984. The vegetation and phytogeography of Sable Island, Nova Scotia. Proc. Nova Scotian Inst. Sci. 34: 181-247.

Catling, P. M., B. Freedman, C. Stewart, J. J. Kerekes \& L. P. Lefkovitch. 1986. Aquatic plants of acid lakes in Kejimkujik National Park, Nova Scotia; floristic composition and relation to water chemistry. Can. J. Bot. 64: 724-729.

Catling, P. M., K. W. Spicer \& L. P. Lefkovitch. 1988. Effects of the floating Hydrocharis morsus-ranae (Hydrocharitaceae), on some North American aquatic macrophytes. Naturaliste Can. 115: $131-137$.

Catling, P. M., K. W. Spicer, M. Biernacki \& J. Lovett Doust. 1994. The biology of Canadian weeds. 103. Vallisneria americana Michx. Can. J. Plant Sci. 74: 883-897.

Catling, P. M., G. Mitrow, E. Haber, U. Posluszny \& W. A. Charlton. 2003. The biology of Canadian weeds. 124. Hydrocharis morsus-ranae L. Can. J. Plant Sci. 83: 1001-1016.

Cattaneo, A. \& J. Kalff. 1978. Seasonal changes in the epiphyte community of natural and artificial macrophytes in Lake Memphremagog (Que. \& Vt.). Hydrobiologia 60: 135-144.

Cázares, E., J. M. Trappe \& A. Jumpponen. 2005. Mycorrhiza-plant colonization patterns on a subalpine glacier forefront as a model system of primary succession. Mycorrhiza 15: 405-416.

Cedergreen, N. \& T. V. Madsen. 2002. Nitrogen uptake by the floating macrophyte Lemna minor. New Phytol. 155: 285-292.

Celdran, D. 2017. Photosynthetic activity detected in the seed epidermis of Thalassia testudinum. Aquat. Bot. 136: 39-42.

Cellot, B., F. Mouillot \& C. P. Henry. 1998. Flood drift and propagule bank of aquatic macrophytes in a riverine wetland. J. Veg. Sci. 9: 631-640.
Center, T. D. \& N. R. Spencer. 1981. The phenology and growth of water hyacinth (Eichhornia crassipes (Mart.) Solms) in a eutrophic north-central Florida lake. Aquat. Bot. 10: 1-32.

Cervantes-Alcalá, R., A. A. Arrocha-Arcos, L. A. Peralta-Peláez \& L. A. Ortega-Clemente. 2012. Electricity generation in sediment plant microbial fuel cells (SPMFC) in warm climates using Typha domingensis Pers. Int. Res. J. Biotechnol. 3: 166-173.

César, N. R., M. A. Pereira-da-Silva, V. R. Botaro \& A. J. de Menezes. 2015. Cellulose nanocrystals from natural fiber of the macrophyte Typha domingensis: extraction and characterization. Cellulose 22: 449-460.

Ceschin, S., I. Leacche, S. Pascucci \& S. Abati. 2016. Morphological study of Lemna minuta Kunth, an alien species often mistaken for the native L. minor L. (Araceae). Aquat. Bot. 131: 51-56.

Ceschin, S., S. Abati, N. T. W. Ellwood \& V. Zuccarello. 2018. Riding invasion waves: spatial and temporal patterns of the invasive Lemna minuta from its arrival to its spread across Europe. Aquat. Bot. 150: 1-8.

Ceska, A. \& P. D. Warrington. 1976. Myriophyllum farwellii (Haloragaceae) in British Columbia. Rhodora 78: 75-78.

Ceska, O., A. Ceska \& P. D. Warrington. 1986. Myriophyllum quitense and Myriophyllum ussuriense (Haloragaceae) in British Columbia, Canada. Brittonia 38: 73-81.

Chabreck, R. H. 1958. Beaver-forest relationships in St. Tammany Parish, Louisiana. J. Wildl. Manag. 22: 179-183.

Chabreck, R. H. \& A. W. Palmisano. 1973. The effects of Hurricane Camille on the marshes of the Mississippi River delta. Ecology 54: 1118-1123.

Chabreck, R. H., R. K. Yancey \& L. McNease. 1974. Duck usage of management units in the Louisiana coastal marsh. Proc. S. E. Assoc. Game Fish Commiss. Conf. 28: 507-516.

Chadde, S. W., J. S. Shelly, R. J. Bursik, R. K. Moseley, A. G. Evenden, M. Mantas, F. Rabe \& B. Heidel. 1998. Peatlands on national forests of the northern Rocky Mountains: ecology and conservation. General Technical Report RMRS-GTR-11. USDA Forest Service, Rocky Mountain Research Station, Ogden, UT. 75 pp.

Chadin, I., V. Volodin, P. Whiting, T. Shirshova, N. Kolegova \& L. Dinan. 2003. Ecdysteroid content and distribution in plants of genus Potamogeton. Biochem. Syst. Ecol. 31: 407-415.

Chafin, L. G. 2007. Field Guide to the Rare Plants of Georgia. University of Georgia Press, Athens, GA. 526 pp.

Chai, T.-T., M.-J. Chiam, C.-H. Lau, N. I. M. Ismail, H.-C. Ong, F. A. Manan \& F.-C. Wong. 2015. Alpha-glucosidase inhibitory and antioxidant activity of solvent extracts and fractions of Typha domingensis (Typhaceae) fruit. Trop. J. Pharmaceut. Res. 14: 1983-1990.

Chaïr, H., R. E. Traore, M.-F. Duval, R. Rivallan, A. Mukherjee, L. M. Aboagye, W. J. Van Rensburg, V. Andrianavalona, M. A. A. Pinheiro de Carvalho, F. Saborio, M. S. Prana, B. Komolong, F. Lawac \& V. Lebot. 2016. Genetic diversification and dispersal of taro (Colocasia esculenta (L.) Schott). PLoS One 11(6): $\mathrm{e} 0157712$.

Chamberlain, J. L. 1959. Gulf coast marsh vegetation as food of wintering waterfowl. J. Wildl. Manag. 23: 97-102.

Chambers, P. A. \& J. Kalff. 1987. Light and nutrients in the control of aquatic plant community structure. I. In situ experiments. $J$. Ecol. 75: 611-619.

Chambers, P. A., E. E. Prepas, H. R. Hamilton \& M. L. Bothwell. 1991a. Current velocity and its effect on aquatic macrophytes in flowing waters. Ecol. Appl. 1: 249-257.

Chambers, P. A., J. M. Hanson \& E. E. Prepas. 1991b. The effect of aquatic plant chemistry and morphology on feeding selectivity by the crayfish, Orconectes virilis. Freshw. Biol. 25: 339-348. 
Champion, P. D., J. S. Clayton \& D. E. Hofstra. 2010. Nipping aquatic plant invasions in the bud: weed risk assessment and the trade. Hydrobiologia 656: 167-172.

Chan, K. L. \& J. R. Linley. 1989. A new Florida species of Forcipomyia (Euprojoannisia) (Diptera: Ceratopogonidae) from leaves of the water lettuce, Pistia stratiotes. Florida Entomol. 72: 252-262.

Chan, E. W. C. \& S. K. Wong. 2015. Phytochemistry and pharmacology of ornamental gingers, Hedychium coronarium and Alpinia purpurata: a review. J. Integrat. Med. 13: 368-379.

Chandler, D. C. 1937. Fate of typical lake plankton in streams. Ecol. Monogr. 7: 445-479.

Chandler, C. M. \& O. M. McDougal. 2014. Medicinal history of North American Veratrum. Phytochem. Rev. 13: 671-694.

Chandran, R. \& T. Parimelazhagan. 2012. Nutritional assessment of Monochoria vaginalis, a wild edible vegetable supplement to the human diet. Int. J. Veg. Sci. 182: 199-207.

Chandran, R., P. Thangaraj, S. Shanmugam, S. Thankarajan \& A. Karuppusamy. 2012. Antioxidant and anti-inflammatory potential of Monochoria vaginalis (Burm. f.) C. Presl.: a wild edible plant. J. Food Biochem. 36: 421-431.

Chang, E. R., R. L. Jefferies \& T. J. Carleton. 2001. Relationship between vegetation and soil seed banks in an arctic coastal marsh. J. Ecol. 89: 367-384.

Chang, I.-H., K.-T. Cheng, P.-C. Huang, Y.-Y. Lin, L.-J. Cheng \& T.-S. Cheng. 2012. Oxidative stress in greater duckweed (Spirodela polyrhiza) caused by long-term $\mathrm{NaCl}$ exposure. Acta Physiol. Plant. 34: 1165-1176.

Chantiratikul, A., O. Chinrasri, P. Chantiratikul, A. Sangdee, U. Maneechote \& C. Bunchasak. 2010. Effect of replacement of protein from soybean meal with protein from wolffia meal [Wolffia globosa (L). Wimm.] on performance and egg production in laying hens. Int. J. Poult. Sci. 9: 283-287.

Chanton, J. P., G. J. Whiting, W. J. Showers \& P. M. Crill. 1992. Methane flux from Peltandra virginica: stable isotope tracing and chamber effects. Global Biogeochem. Cycles 6: 15-31.

Chapman, W. K. 1997. Orchids of the Northeast: A Field Guide. Syracuse University Press, Syracuse, NY. 200 pp.

Charalambidou, I. \& L. Santamaría. 2002. Waterbirds as endozoochorous dispersers of aquatic organisms: a review of experimental evidence. Acta Oecol. 23: 165-176.

Charalambidou, I., L. Santamaria \& O. Langevoord. 2003. Effect of ingestion by five avian dispersers on the retention time, retrieval and germination of Ruppia maritima seeds. Funct. Ecol. 17: 747-753.

Chareontesprasit, N. \& W. Jiwyam. 2001. An evaluation of Wolffia meal (Wolffia arrhiza) in replacing soybean meal in some formulated rations of Nile tilapia (Oreochromis niloticus L.). Pak. J. Biol. Sci. 4: 618-620.

Charlton, W. A. 1979. Studies in the Alismataceae. VII. Disruption of phyllotactic and organogenetic patterns in pseudostolons of Echinodorus tenellus by means of growth-active substances. Can. J. Bot. 57: 215-222.

Charlton, W. A. \& U. Posluszny. 1991. Meristic variation in Potamogeton flowers. Bot. J. Linn. Soc. 106: 265-293.

Chartier, M., M. Gibernau \& S. S. Renner. 2014. The evolution of pollinator-plant interaction types in the Araceae. Evolution 68 : 1533-1543.

Chase, S. S. 1947. Preliminary studies in the genus Najas in the United States. Ph.D. dissertation. Cornell University, Ithaca, NY. 118 pp.

Chase, J. M. 2003. Strong and weak trophic cascades along a productivity gradient. Oikos 101: 187-195.

Chase, J. M. 2007. Drought mediates the importance of stochastic community assembly. Proc. Natl. Acad. Sci. U.S.A. 104: 17430-17434.
Chase, M. W., K. M. Cameron, J. V. Freudenstein, A. M. Pridgeon, G. Salazar, C. Van den Berg \& A. Schuiteman. 2015. An updated classification of Orchidaceae. Bot. J. Linn. Soc. 177: 151-174.

Chase, M. W., D. E. Soltis, R. G. Olmstead, D. Morgan, D. H. Les, B. D. Mishler, M. R. Duvall, R. A. Price, H. G. Hills, Y.-L. Qiu, K. A. Kron, J. H. Rettig, E. Conti, J. D. Palmer, J. R. Manhart, K. J. Sytsma, H. J. Michaels, W. J. Kress, K. G. Karol, W. D. Clark, M. Hedren, B. S. Gaut, R. K. Jansen, K.-J. Kim, C. F. Wimpee, J. F. Smith, G. R. Furnier, S. H. Strauss, Q.-Y. Xiang, G. M. Plunkett, P. S. Soltis, S. M. Swensen, S. E. Williams, P. A. Gadek, C. J. Quinn, L. E. Eguiarte, E. Golenberg, G. H. Learn, Jr., S. W. Graham, S. C. H. Barrett, S. Dayanandan \& V. A. Albert. 1993. Phylogenetics of seed plants: an analysis of nucleotide sequences from the plastid gene $r b c L$. Ann. Missouri Bot. Gard. 80: 528-580.

Chase, M. W., M. R. Duvall, H. G. Hills, J. G. Conran, A. V. Cox, L. E. Eguiarte, J. Hartwell, M. F. Fay, L. R. Caddick, K. M. Cameron \& S. Hoot. 1995. Molecular phylogenetics of Lilianae. Pp. 109-137 In: P. J. Rudall, P. J. Cribb, D. F. Cutler \& C. J. Humphries (eds.), Monocotyledons: Systematics and Evolution. Royal Botanic Gardens, Kew, United Kingdom.

Chase, M. W., J. L. Reveal \& M. F. Fay. 2009. A subfamilial classification for the expanded asparagalean families Amaryllidaceae, Asparagaceae and Xanthorrhoeaceae. Bot. J. Linn. Soc. 161: 132-136.

Chathurangani, D., K. Yakandawala \& D. Yakandawala. 2016. A study on competition between Hydrilla verticillata and Mayaca fluviatilis. J. Environ. Profess. Sri Lanka 5: 11-22.

Chauveau, O., L. Eggers, C. Raquin, A. Silvério, S. Brown, A. Couloux, C. Cruaud, E. Kaltchuk-Santos, R. Yockteng, T. T. Souza-Chies \& S. Nadot. 2011. Evolution of oil-producing trichomes in Sisyrinchium (Iridaceae): insights from the first comprehensive phylogenetic analysis of the genus. Ann. Bot. 107: $1287-1312$.

Chee, W.-L. \& D. H. Vitt. 1989. The vegatation, surface water chemistry and peat chemistry of moderate-rich fens in central Alberta, Canada. Wetlands 9: 227-261.

Chen, P.-H. \& W. H. J. Kuo. 1995. Germination conditions for the non-dormant seeds of Monochoria vaginalis. Taiwania 40: 419-432.

Chen, S.-C., Y.-X. Qiu, A.-L. Wang, K. M. Cameron \& C.-X. Fu. 2005. A phylogenetic analysis of the Smilacaceae based on morphological data. J. Syst. Evol. 44: 113-125.

Chen, Y.-Y., X.-L. Li, L.-Y. Yin \& W. Li. 2008. Genetic diversity of the threatened aquatic plant Ottelia alismoides in the Yangtze River. Aquat. Bot. 88: 10-16.

Chen, H., M. F. Zamorano \& D. Ivanoff. 2010. Effect of flooding depth on growth, biomass, photosynthesis, and chlorophyll fluorescence of Typha domingensis. Wetlands 30: 957-965.

Chen, Q., Y. Jin, G. Zhang, Y. Fang, Y. Xiao \& H. Zhao. 2012. Improving production of bioethanol from duckweed (Landoltia punctata) by pectinase pretreatment. Energies 5: 3019-3032.

Chen, L.-Y., G. W. Grimm, Q.-F. Wang \& S. S. Renner. 2015a. A phylogeny and biogeographic analysis for the Cape-Pondweed family Aponogetonaceae (Alismatales). Mol. Phylogenet. Evol. 82: 111-117.

Chen, L., Y. Fang, Y. Jin, Q. Chen, Y. Zhao, Y. Xiao \& H. Zhao. 2015b. Biosorption of $\mathrm{Cd}^{2+}$ by untreated dried powder of duckweed Lemna aequinoctialis. Desalin. Water Treat. 53: 183-194.

Chen, N., Y. Ji, W. Zhang, Y. Xu, X. Yan, Y. Sun, H. Song. 2016. Chemical constituents from Hymenocallis littoralis. Lett. Org. Chem. 13: 536-539.

Chen, P., Y. Cao, B. Bao, L. Zhang \& A. Ding. 2017. Antioxidant capacity of Typha angustifolia extracts and two active flavonoids. Pharm. Biol. 55: 1283-1288. 
Chen, L., S. Huang, C. Y. Li, F. Gao \& X. L. Zhou. 2018. Pyrrolizidine alkaloids from Liparis nervosa with antitumor activity by modulation of autophagy and apoptosis. Phytochemistry 153: 147-155.

Cheng, S. 2004. Forest Service research natural areas in California. General Technical Paper PSW-GTR-188. U.S. Department of Agriculture, Forest Service, Pacific Southwest Research Station, Albany, CA. 338 pp.

Cheng, T.-S. 2011. NaCl-induced responses in giant duckweed (Spirodela polyrhiza). Can. J. Bot. 59: 104-105.

Cheng, J. J. \& A.-M. Stomp. 2009. Growing duckweed to recover nutrients from wastewaters and for production of fuel ethanol and animal feed. Clean-Soil Air Water 37: 17-26.

Cheplick, G. P. 2006. A modular approach to biomass allocation in an invasive annual (Microstegium vimineum; Poaceae). Am. J. Bot. 93: 539-545.

Cherry, J. A. \& L. Gough. 2006. Temporary floating island formation maintains wetland plant species richness: the role of the seed bank. Aquat. Bot. 85: 29-36.

Cheruvelil, K. S., P. A. Soranno \& J. D. Madsen. 2001. Epiphytic macroinvertebrates along a gradient of Eurasian watermilfoil cover. J. Aquat. Plant Manag. 39: 67-72.

Chester, K. S. 1930. The Phytophthora disease of the calla in America. J. Arnold Arbor. 11: 169-171.

Chester, E. W. \& K. Souza. 1984. Echinodorus tenellus var. parvulus (Alismataceae) in Kentucky. Sida 10: 262-263.

Chester, E. W. \& B. L. Palmer-Ball. 2011. Second county records for two Kentucky endangered species, Echinodorus tenellus (Alismataceae) and Schoenoplectus hallii (Cyperaceae). Phytoneuron 2011-43: 1-4.

Chinnappa, C. C. \& J. G. Chmielewski. 1987. Documented plant chromosome numbers 1987: 1. Miscellaneous counts from western North America. Sida 12: 409-417.

Cho, H. R. \& H.-S. Choi. 2003. Effects of anticoagulant from Spirodela polyrhiza in rats. Biosci. Biotechnol. Biochem. 67: 881-883.

Cho, H. J. \& M. A. Poirrier. 2005. Seasonal growth and reproduction of Ruppia maritima L. s.l. in Lake Pontchartrain, Louisiana, USA. Aquat. Bot. 81: 37-49.

Cho, H. J. \& C. A. May. 2008. Short-term spatial variations in the beds of Ruppia maritima (Ruppiaceae) and Halodule wrightii (Cymodoceaceae) at Grand Bay National Estuarine Research Reserve, Mississippi, USA. J. Mississippi Acad. Sci. 53: 133-145.

Cho, H. J. \& Y. L. Sanders. 2009. Note on organic dormancy of estuarine Ruppia maritima L. seeds. Hydrobiologia 617: 197-201.

Cho, T. O., S. Fredericq \& K. K. Yates. 2002. Characterization of macroalgal epiphytes on Thalassia testudinum in Tampa Bay, Florida. J. Phycol. 38: 4.

Cho, H. J., A. Lu, P. Biber \& J. D. Caldwell. 2012. Aquatic plants of the Mississippi Coast. J. Mississippi Acad. Sci. 57: 240-249.

Choate, C. M. 1963. Ordination of the alpine plant communities at Logan Pass Glacier National Park Montana. M.A. thesis. Montana State University, Bozeman, MT. 106 pp.

Choi, K. S., K. T. Park \& S. J. Park. 2017. The chloroplast genome of Symplocarpus renifolius: a comparison of chloroplast genome structure in Araceae. Genes 8(11): 324.

Cholewa, A. F. \& D. M. Henderson. 1994. Iridaceae Iris family: part one Sisyrinchium L. J. Arizona-Nevada Acad. Sci. 27: 215-218.

Cholewa, A. F. \& D. M. Henderson. 2002. Sisyrinchium Linnaeus. Pp. 351-371 In: Flora North America Editorial Committee (eds.), Flora of North America North of Mexico, Vol. 26: Magnoliophyta: Liliidae: Liliales and Orchidales. Oxford University Press, New York, NY.
Chollett, I., D. Bone \& D. Pérez. 2007. Effects of heavy rainfall on Thalassia testudinum beds. Aquat. Bot. 87: 189-195.

Chouhan, A. P. S. \& A. K. Sarma. 2013. Biodiesel production from Jatropha curcas L. oil using Lemna perpusilla Torrey ash as heterogeneous catalyst. Biomass Bioenergy 55: 386-389.

Christenhusz, M. J. M. \& J. W. Byng. 2016. The number of known plants species in the world and its annual increase. Phytotaxa 261: 201-217.

Christenhusz, M. J. M., M. F. Fay \& M. W. Chase. 2017. Plants of the World: An Illustrated Encyclopedia of Vascular Plants. University of Chicago Press, Chigago, IL. 816 pp.

Christopher, J. 1983. Cytology of Monochoria vaginalis complex Presl. Cytologia 48: 627-631.

Christy, J. A. 1994. Noteworthy collections - Washington. Madroño 41: 332 .

Christy, J. A. 2004. Native Freshwater Wetland Plant Associations of Northwestern Oregon. Oregon Natural Heritage Information Center, Oregon State University, Corvallis, OR. 246 pp.

Christy, J. A. 2013. Wet Meadow Plant Associations, Malheur National Wildlife Refuge, Harney County, Oregon. Oregon Biodiversity Information Center, Institute for Natural Resources, Portland State University, Portland, OR. 73 pp.

Christy, J. A. \& M. Garvey. 2015. Existing Vegetation and Site Observations at Killin Wetland, Washington County, Oregon. The Wetlands Conservancy and Oregon Biodiversity Information Center. Institute for Natural Resources, Portland State University, Portland, OR. 23 pp.

Chung, M.-C. 2015. Chromosome techniques and FISH. Pp. 287309 In: E. C. T. Yeung, C. Stasolla, M. J. Sumner \& B. Q. Huang (eds.), Plant Microtechniques and Protocols. Springer International Publishing, Basel, Switzerland.

Chupov, V. S., E. O. Punina, E. M. Machs \& A. V. Rodionov. 2007. Nucleotide composition and $\mathrm{CpG}$ and $\mathrm{CpNpG}$ content of ITS1, ITS2, and the $5.8 \mathrm{~S}$ rRNA in representatives of the phylogenetic branches Melanthiales-Liliales and MelanthialesAsparagales (Angiospermae, Monocotyledones) reflect the specifics of their evolution. Molec. Biol. 41: 737-755.

Churchill, A. C. 1983. Field studies on seed germination and seedling development in Zostera marina L. Aquat. Bot. 16: 21-29.

Churchill, A. C. \& M. I. Riner. 1978. Anthesis and seed production in Zostera marina L. from Great South Bay, New York, USA. Aquat. Bot. 4: 83-93.

Cicero, P., J. Kiser, J. Dunlavy \& J. Daly. 2011. Aquatic Plant Management Plan for Lower Spring Lake, 2011. Jefferson County Land and Water Conservation Department, Jefferson, WI. 48 pp.

Ciotir, C. \& J. Freeland. 2016. Cryptic intercontinental dispersal, commercial retailers, and the genetic diversity of native and non-native cattails (Typha spp.) in North America. Hydrobiologia 768: 137-150.

Ciotir, C., H. Kirk, J. R. Row \& J. R. Freeland. 2013. Intercontinental dispersal of Typha angustifolia and T. latifolia between Europe and North America has implications for Typha invasions. Biol. Invasions 15: 1377-1390.

Ciutti, F., M. E. Beltrami, I. Confortini, S. Cianfanelli \& C. Cappelletti. 2011. Non-indigenous invertebrates, fish and macrophytes in Lake Garda (Italy). J. Limnol. 70: 315-320.

Claassen, P. W. 1918. Observations on the life history and biology of Agromyza laterella Zetterstedt. (Diptera). Ann. Entomol. Soc. Am. 11: 9-16.

Claassen, P. W. 1921. Typha Insects: Their Ecological Relationships. Memoir 47. Agricultural Experiment Station, Cornell University, Ithaca, NY. 531 pp.

Clark, W. A. 1956. Plant distribution in the Western Isles. Proc. Linn. Soc. London 167: 96-103. 
Clark, C. F. 1990. Movements of northern pike tagged in waters tributary to Lake Erie. Ohio J. Sci. 90: 41-45.

Clark, M. A., J. Siegrist \& P. A. Keddy. 2008. Patterns of frequency in species-rich vegetation in pine savannas: effects of soil moisture and scale. Ecoscience 15: 529-535.

Clarke, A. L. \& G. H. Dalrymple. 2003. \$7.8 billion for Everglades restoration: why do environmentalists look so worried? Popul. Environ. 24: 541-569.

Clausen, R. T. 1936. Studies in the genus Najas in the northern United States. Rhodora 38: 333-345.

Clawson, A. B. \& E. A. Moran. 1937. Toxicity of arrowgrass for sheep and remedial treatment. Technical Bulletin No. 580. U.S. Department of Agriculture, Washington, DC. 16 pp.

Clayton, J. S. 1996. Aquatic weeds and their control in New Zealand lakes. Lake Reserv. Manag. 12: 477-486.

Cleall, E., J. Wadman, J. Wadman, J. Baker, J. Pinney, J. Chaffey, W. Bond, W. Baine \& A. Anderson. 1807. Papers in colonies and trade. Trans. Soc. London Encour. Arts 25: 143-212.

Cleland, C. F. \& W. R. Briggs. 1967. Flowering responses of the longday plant Lemna gibba G3. Plant Physiol. 42: 1553-1561.

Cleland, C. F., O. Tanaka \& L. J. Feldman. 1982. Influence of plant growth substances and salicylic acid on flowering and growth in the Lemnaceae (duckweeds). Aquat. Bot. 13: 3-20.

Clinton, G. P. 1901. Two new smuts on Eriocaulon septangulare. Rhodora 28: 79-82.

Clough, K. S. \& G. R. Best. 1991. Wetland Macrophyte Production and Hydrodynamics in Hopkins Prairie, Ocala National Forest, Florida March 1989-December-1990. Center for Wetlands, University of Florida, Gainesville, FL. 87 pp.

Clouse, R. M., B. Ferster \& M. A. Deyrup. 1997. Observations of insects associated with an infestation of sand pine (Pinus clausa) by the aphid Cinara pinivora. Florida Sci. 60: 89-93.

Coan, A. I., T. Stützel \& V. L. Scatena. 2010. Comparative embryology and taxonomic considerations in Eriocaulaceae (Poales). Feddes Repert. 121: 268-284.

Cody, W. J. 1961. Iris pseudacorus L. escaped from cultivation in Canada. Can. Field-Nat. 75: 139-142.

Cody, W. J., K. L. Reading \& J. M. Line. 2003. Additions and range extensions to the vascular plant flora of the continental Northwest Territories and Nunavut, Canada, II. Can. FieldNat. 117: 448-465.

Cohen, S., R. Braham \& F. Sanchez. 2004. Seed bank viability in disturbed longleaf pine sites. Restor. Ecol. 12: 503-515.

Cole, F. R. \& D. H. Firmage. 1984. The floral ecology of Platanthera blephariglottis. Am. J. Bot. 71: 700-710.

Cole, C. T. \& M. I. Voskuil. 1996. Population genetic structure in duckweed (Lemna minor, Lemnaceae). Can. J. Bot. 74: 222-230.

Coleman, R. A. 2002. The Wild Orchids of Arizona and New Mexico. Cornell University Press, Ithaca, NY. 248 pp.

Coleman, T. S. \& D. A. Boag. 1987. Canada goose foods: their significance to weight gain. Wildfowl 38: 82-88.

Coleman, R. A., D. H. Wilkin \& W. F. Jennings. 2012. Orchidaceae. Orchid family. Pp. 1398-1405 In: B. G. Baldwin, D. H. Goldman, D. J. Keil, R. Patterson, T. J. Rosatti \& D. H. Wilken (eds.), The Jepson Manual, 2nd ed. University of California Press, Berkeley, CA.

Coler, R. A. \& H. B. Gunner. 1969. The rhizosphere of an aquatic plant (Lemna minor). Can. J. Microbiol. 15: 964-966.

Colle, D. E., J. V. Shireman \& R. W. Rottmann. 1978. Food selection by grass carp fingerlings in a vegetated pond. Trans. Am. Fish. Soc. 107: 149-152.

Collectanea, M. 1976. Aquatic crops vs. organic soil subsidence. Proc. Florida State Hort. Soc. 89: 125-129.
Collins, F. S. 1905. Chlorochytrium lemnae in America. Rhodora 7: 97-99.

Collins, B. \& G. Wein. 1995. Seed bank and vegetation of a constructed reservoir. Wetlands 15: 374-385.

Collins, C. D., R. B. Sheldon \& C. W. Boylen. 1987. Littoral zone macrophyte community structure: distribution and association of species along physical gradients in Lake George, New York, USA. Aquat. Bot. 29: 177-194.

Collon, E. G. \& J. Velasquez. 1989. Dispersion, germination and growth of seedlings of Sagittaria lancifolia L. Folia Geobot. 24: 37-49.

Colt, L. C. \& C. B. Hellquist. 1974. The role of some Haloragaceae in algal ecology. Rhodora 76: 446-459.

Colt, L. C., C. B. Hellquist \& W. J. L. Zubrin. 1971. An interesting association of rare aquatic plants from New Hampshire. Rhodora 73: 296-299.

Colwell, M. A. \& L. W. Oring. 1988. Habitat use by breeding and migrating shorebirds in southcentral Saskatchewan. Wilson Bull. 100: 554-566.

Colwell, A. E. L., C. J. Sheviak \& P. E. Moore. 2007. A new Platanthera (Orchidaceae) from Yosemite National Park, California. Madroño 54: 86-94.

Combroux, I., G. Bornette, N. J. Willby \& C. Amoros. 2001. Regenerative strategies of aquatic plants in disturbed habitats: the role of the propagule bank. Archiv. Hydrobiol. 152: 215-235.

Comes, R. D., V. F. Bruns \& A. D. Kelley. 1978. Longevity of certain weed and crop seeds in fresh water. Weed Sci. 26: 336-344.

Conard, H. S. 1935. The plant associations of central Long Island. A study in descriptive plant sociology. Am. Midl. Nat. 16: 433-516.

Conover, D. \& S. Pelikan. 2010. Earlier flowering in a restored wetland-prairie correlated with warmer temperatures (Ohio). Ecol. Restor. 28: 428-430.

Conrad, J. L., A. J. Bibian, K. L. Weinersmith, D. De Carion, M. J. Young, P. Crain, E. L. Hestir, M. J. Santos \& A. Sih. 2016. Novel species interactions in a highly modified estuary: association of largemouth bass with Brazilian Waterweed Egeria densa. Trans. Am. Fish. Soc. 145: 249-263.

Cook, R. S. 1979. Determination that Harperocallis flava is an endangered species. Fed. Reg. 44: 56862-56863.

Cook, C. D. K. 1982. Pollination mechanisms in the Hydrocharitaceae. Pp. 1-15 In: J. J. Symoens, S. S. Hooper \& P. Compère (eds.), Studies on Aquatic Vascular Plants. Proceedings of the International Colloquium on Aquatic Vascular Plants (Brussels, 23-25 January, 1981). Royal Botanical Society of Belgium, Brussels.

Cook, C. D. K. 1985. Range extensions of aquatic vascular plant species. J. Aquat. Plant Manag. 23: 1-6.

Cook, C. D. K. 1988. Wind pollination in aquatic angiosperms. Ann. Missouri Bot. Gard. 75: 768-777.

Cook, C. D. K. 1996a. Aquatic Plant Book. SPB Academic Publishing bv, Amsterdam, The Netherlands. 228 pp.

Cook, C. D. K. 1996b. Aquatic and Wetland Plants of India: A Reference Book and Identification Manual for the Vascular Plants Found in Permanent or Seasonal Fresh Water in the Subcontinent of India South of the Himalayas. Oxford University Press, New York, NY. 385 pp.

Cook, C. D. K. 2004. Aquatic and Wetland Plants of Southern Africa. Backhuys Publishers BV, Leiden, The Netherlands. $281 \mathrm{pp}$.

Cook, C. D. K. \& R. Lüönd. 1982a. A revision of the genus Hydrilla (Hydrocharitaceae). Aquat. Bot. 13: 485-504.

Cook, C. D. K. \& R. Lüönd. 1982b. A revision of the genus Hydrocharis (Hydrocharitaceae). Aquat. Bot. 14: 177-204. 
Cook, C. D. K. \& R. Lüönd. 1983. A revision of the genus Blyxa (Hydrocharitaceae). Aquat. Bot. 15: 1-52.

Cook, C. D. K. \& K. Urmi-König. 1983. A revision of the genus Limnobium (Hydrocharitaceae). Aquat. Bot. 17: 1-27.

Cook, C. D. K. \& K. Urmi-König. 1984a. A revision of the genus Egeria (Hydrocharitaceae). Aquat. Bot. 19: 73-96.

Cook, C. D. K. \& K. Urmi-König. 1984b. A revision of the genus Ottelia (Hydrocharitaceae). 2. The species of Eurasia, Australasia, and America. Aquat. Bot. 20: 131-177.

Cook, C. D. K. \& K. Urmi-König. 1985. A revision of the genus Elodea (Hydrocharitaceae). Aquat. Bot. 21: 111-156.

Cook, C. D. K. \& M. S. Nicholls. 1986. A monographic study of the genus Sparganium. Part 1: subgenus Xanthosparganium. Bot. Helvet. 96: 213-267.

Cook, C. D. K. \& M. S. Nicholls. 1987. A monographic study of the genus Sparganium. Part 2: subgenus Sparganium. Bot. Helvet. 97: 1-44.

Cook, C. D. K., J.-J. Symoens \& K. Urmi-König. 1984. A revision of the genus Ottelia (Hydrocharitaceae) I. Generic considerations. Aquat. Bot. 18: 263-274.

Cook, R. T. A., A. J. Inman \& C. Billings. 1997. Identification and classification of powdery mildew anamorphs using light and scanning electron microscopy and host range data. Mycol. Res. 101: $975-1002$.

Cooke, W. B. 1949. Western Fungi-I. Mycologia 41: 601-622.

Cooke, R. G. 1970. Phenylnaphthalene pigments of Lachnanthes tinctoria. Phytochemistry 9: 1103-1106.

Cooke, S. S. (ed.). 1997. A Field Guide to the Common Wetland Plants of Western Washington and Northwestern Oregon. Trailside Series. Seattle Audubon Society, Seattle, WA. 417 pp.

Cooper, D. J. 1996. Water and soil chemistry, floristics, and phytosociology of the extreme rich High Creek fen, in South Park, Colorado, USA. Can. J. Bot. 74: 1801-1811.

Cooper, L. W. \& C. P. McRoy. 1988a. Anatomical adaptations to rocky substrates and surf exposure by the seagrass genus Phyllospadix. Aquat. Bot. 32: 365-381.

Cooper, L. W. \& C. P. McRoy. 1988b. Stable carbon isotope ratio variations in marine macrophytes along intertidal gradients. Oecologia 77: 238-241.

Cooper, D. J. \& R. E. Andrus. 1994. Patterns of vegetation and water chemistry in peatlands of the west-central Wind River Range, Wyoming, U.S.A. Can. J. Bot. 72: 1586-1597.

Cooper, D. J. \& L. H. MacDonald. 2000. Restoring the vegetation of mined peatlands in the southern Rocky Mountains of Colorado, USA. Restor. Ecol. 8: 103-111.

Cooperrider, T. S. 1955. The Ophioglossaceae of Iowa. Am. Fern J. 45: $156-159$.

Coops, H. \& G. Van der Velde. 1995. Seed dispersal, germination and seedling growth of six helophyte species in relation to waterlevel zonation. Freshw. Biol. 34: 13-20.

Coops, H., M. A. A. de la Haye \& F. W. B. van der Brink. 1994. Studies on germination and growth of a river macrophyte (Potamogeton nodosus Poir.) in relation to substrate type and water quality. Verh. Int. Vereinigung Limnol. 25: 2247-2250.

Cope, R. B. 2005. Allium species poisoning in dogs and cats. Veterin. Med. 100: 562-566.

Cordero, G. A. \& C. W. Swarth. 2010. Notes on the movement and aquatic behavior of some kinosternid turtles. Acta Zool. Mexicana 26: 233-235.

Core, E. L. 1941. Butomus umbellatus in America. Ohio J. Sci. 41: 79-85.

Core, E. L. 1967. Ethnobotany of the southern Appalachian aborigines. Econ. Bot. 21: 199-214.

Core, E. L., J. M. Fogg \& R. H. Torrey. 1937. Field trips of the club. Torreya 37: 130-137.
Corogin, P. T. \& W. S. Judd. 2009. Floristic inventory of Tiger Creek preserve and Saddle Blanket Scrub preserve, Polk County, Florida. Rhodora 111: 449-503.

Correll, D. S. \& H. B. Correll. 1975. Aquatic and Wetland Plants of Southwestern United States. 2 volumes. Stanford University Press, Stanford, CA. 1777 pp.

Corriveau, J. L. \& A. W. Coleman. 1988. Rapid screening method to detect potential biparental inheritance of plastid DNA and results for over 200 angiosperm species. Am. J. Bot. 75: 1443-1458.

Cortinovis, C. \& F. Caloni. 2013. Epidemiology of intoxication of domestic animals by plants in Europe. Veterin. J. 197: 163-168.

COSEWIC. 2005. COSEWIC Assessment and Update Status Report on the Hill's Pondweed Potamogeton hillii in Canada. Committee on the Status of Endangered Wildlife in Canada. Ottawa, ON. vi + 19 pp.

Cosgriff, R., V. J. Anderson \& S. Monson. 2004. Restoration of communities dominated by false hellebore. J. Range Manag. 57: 365-370.

Costa, J. Y. 2004. A triploid cytotype of Echinodorus tenellus. Aquat. Bot. 79: 325-332.

Cottam, C. 1939. Food habits of North American diving ducks. USDA Tech. Bull. 643: 1-129.

Cottam, C., J. J. Lynch \& A. L. Nelson. 1944. Food habits and management of American sea brant. J. Wildl. Manag. 8: 36-56.

Coughlan, N. E., T. C. Kelly, J. Davenport \& M. A. K. Jansen. 2015a. Humid microclimates within the plumage of mallard ducks (Anas platyrhynchos) can potentially facilitate long distance dispersal of propagules. Acta Oecol. 65: 17-23.

Coughlan, N. E., T. C. Kelly \& M. A. K. Jansen. 2015b. Mallard duck (Anas platyrhynchos)-mediated dispersal of Lemnaceae: a contributing factor in the spread of invasive Lemna minuta? Plant Biol. 17: 108-114.

Coughlan, N. E., T. C. Kelly, J. Davenport \& M. A. K. Jansen. 2017a. Up, up and away: bird-mediated ectozoochorous dispersal between aquatic environments. Freshw. Biol. 62: 631-648.

Coughlan, N. E., T. C. Kelly \& M. A. K. Jansen. 2017b. "Step by step": high frequency short-distance epizoochorous dispersal of aquatic macrophytes. Biol. Invasions 19: 625-634.

Coughlan, N. E., R. N. Cuthbert, T. C. Kelly \& M. A. K. Jansen. 2018. Parched plants: survival and viability of invasive aquatic macrophytes following exposure to various desiccation regimes. Aquat. Bot. 150: 9-15.

Coulter, M. W. 1955. Spring food habits of surface-feeding ducks in Maine. J. Wildl. Manag. 19: 263-267.

Countryman, W. D. 1968. Alisma gramineum in Vermont. Rhodora 70: $577-579$.

Countryman, W. D. 1970. The history, spread and present distribution of some immigrant aquatic weeds in New England. Hyacinth Control J. 8: 50-52.

Cowell, B. C. \& C. H. Resico, Jr. 1975. Life history patterns in the coastal shiner, Notropis petersoni, Fowler. Florida Sci. 38: 113-121.

Cox, R. J. \& G. C. Smart, Jr. 1994. Nematodes associated with plants from naturally acidic wetlands soil. J. Nematol. 26: 535-537.

Cox, T. E. \& S. N. Murray. 2006. Feeding preferences and the relationships between food choice and assimilation efficiency in the herbivorous marine snail Lithopoma undosum (Turbinidae). Mar. Biol. 148: 1295-1306.

Cox, P. A., T. Elmqvist \& P. B. Tomlinson. 1990. Submarine pollination and reproductive morphology in Syringodium filiforme (Cymodoceaceae). Biotropica 22: 259-265.

Cox, P. A., P. B. Tomlinson \& K. Nieznanski. 1992a. Hydrophilous pollination and reproductive morphology in the seagrass Phyllospadix scouleri (Zosteraceae). Plant Syst. Evol. 180: 65-75. 
Cox, P. A., R. H. Laushman \& M. H. Ruckelshaus. 1992b. Surface and submarine pollination in the seagrass Zostera marina $\mathrm{L}$. Bot. J. Linn. Soc. 109: 281-291.

Coyer, J. A., K. A. Miller, J. M. Engle, J. Veldsink, A. Cabello-Pasini, W. T. Stam \& J. L. Olsen. 2008. Eelgrass meadows in the California Channel Islands and adjacent coast reveal a mosaic of two species, evidence for introgression and variable clonality. Ann. Bot. 101: 73-87.

Coyer, J. A., G. Hoarau, J. Kuo, A. Tronholm, J. Veldsink \& J. L. Olsen. 2013. Phylogeny and temporal divergence of the seagrass family Zosteraceae using one nuclear and three chloroplast loci. Syst. Biodivers. 11: 271-284.

Craig, C., S. Wyllie-Echeverria, E. Carrington \& D. Shafer. 2008. Short-term sediment burial effects on the seagrass Phyllospadix scouleri. EMRRP Technical Notes Collection (ERDC TN-EMRRP-EI-03). U.S. Army Engineer Research and Development Center, Vicksburg, MS. 10 pp.

Cranfill, R. 1981. Bog clubmosses (Lycopodiella) in Kentucky. Am. Fern J. 71: 97-100.

Cranfill, R. 1991. Flora of Hardin County, Kentucky. Castanea 56: 228-267.

Craven, S. R. \& R. A. Hunt. 1984. Food habits of Canada Geese on the coast of Hudson Bay. J. Wildl. Manag. 48: 567-569.

Crawford, D. J. 2010. Progenitor-derivative species pairs and plant speciation. Taxon 59: 1413-1423.

Crawford, D. J. \& E. Landolt. 1993. Allozyme studies in Spirodela (Lemnaceae): variation among conspecific clones and divergence among the species. Syst. Bot. 18: 389-394.

Crawford, D. J. \& E. Landolt. 1995. Allozyme divergence among species of Wolffia (Lemnaceae). Plant Syst. Evol. 197: 59-69.

Crawford, D. J., E. Landolt \& D. H. Les. 1996. An allozyme study of two sibling species of Lemna (Lemnaceae) with comments on their morphology, ecology and distribution. Bull. Torrey Bot. Club 123: 1-6.

Crawford, D. J., E. Landolt, D. H. Les \& E. Tepe. 1997. Allozyme variation and the taxonomy of Wolffiella (Lemnaceae). Aquat. Bot. 58: 43-54.

Crawford, D. J., E. Landolt, D. H. Les \& R. T. Kimball. 2001. Allozyme studies in Lemnaceae: variation and relationships in Lemna sections Alatae and Biformes. Taxon 50: 987-999.

Crawford, D. J., E. Landolt, D. H. Les, R. T. Kimball \& J. K. Archibald. 2005. Allozyme variation within and divergence between Lemna gibba and L. disperma (Lemnaceae): systematic and biogeographic implications. Aquat. Bot. 83: 119-128.

Crawford, D. J., E. Landolt, D. H. Les \& R. T. Kimball. 2006. Speciation in duckweeds (Lemnaceae): phylogenetic and ecological inferences. Aliso 22: 231-242.

Crema, L. C., V. M. F. da Silva \& M. T. F. Piedade. 2019. Riverine people's knowledge of the Vulnerable Amazonian manatee Trichechus inunguis in contrasting protected areas. Oryx 831: $1-10$.

Crespo, M. B., M. Martínez-Azorín \& E. V. Mavrodiev. 2015. Can a rainbow consist of a single colour? A new comprehensive generic arrangement of the 'Iris sensu latissimo' clade (Iridaceae), congruent with morphology and molecular data. Phytotaxa 232: 1-78.

Crişan, I. \& M. Cantor. 2016. New perspectives on medicinal properties and uses of Iris sp. Hop Med. Plants 24: 24-36.

Crişan, I., R. Vidican, I. Oltean, A. Stoie \& V. Stoian. 2018. Iris spp. flower visitors: pollinators or nectar thieves? Romanian J. Grassland Forage Crops 17: 11-19.

Crocker, W. 1907. Germination of seeds of water plants. Bot. Gaz. 44: 375-380.

Crocker, W. 1938. Life-span of seeds. Bot. Rev. 4: 235-274.
Crombie, L. 1999. Natural product chemistry and its part in the defence against insects and fungi in agriculture. Pestic. Sci. 55: 761-774.

Cronan, Jr., J. M. 1957. Food and feeding habits of the scaups in Connecticut waters. Auk 74: 459-468.

Cronin, G. \& D. M. Lodge. 2003. Effects of light and nutrient availability on the growth, allocation, carbon/nitrogen balance, phenolic chemistry, and resistance to herbivory of two freshwater macrophytes. Oecologia 137: 32-41.

Cronin, G., D. M. Lodge, M. E. Hay, M. Miller, A. M. Hill, T. Horvath, R. C. Bolser, N. Lindquist \& M. Wahl. 2002. Crayfish feeding preferences for freshwater macrophytes: the influence of plant structure and chemistry. J. Crustacean Biol. 22: 708-718.

Cronk, K. L., D. T. L. Myers \& M. L. Claucherty. 2015. Mullett Lake Partial Aquatic Plant Survey 2015. Tip of the Mitt Watershed Council, Petoskey, MI. 49 pp.

Cronquist, A. 1981. An Integrated System of Classification of Flowering Plants. Columbia University Press, New York, NY. 1262 pp.

Cropley, T. G. 2006. The "army itch:" A dermatological mystery of the American civil War. J. Am. Acad. Dermatol. 55: 302-308.

Cross, A. F. 1991. Vegetation of two southeastern Arizona desert marshes. Madroño 38: 185-194.

Cross, A. T., L. M. Skates, L. Adamec, C. M. Hammond, P. M. Sheridan \& K. W. Dixon. 2015. Population ecology of the endangered aquatic carnivorous macrophyte Aldrovanda vesiculosa at a naturalised site in North America. Freshw. Biol. 60: 1772-1783.

Crothers, G. M. 2012. Early woodland ritual use of caves in eastern North America. Am. Antiquity 77: 524-541.

Crouch, C. A. 1991. Infaunal polychaetes of a rocky intertidal surfgrass bed in southern California. Bull. Mar. Sci. 48: 386-394.

Crouch, V. E. \& M. S. Golden. 1997. Floristics of a bottomland forest and adjacent uplands near the Tombigbee River, Choctaw County, Alabama. Castanea 62: 219-238.

Crow, G. E. 1969. An ecological analysis of a southern Michigan bog. Michigan Bot. 8: 11-27.

Crow, J. H. 1979. Distribution and ecological characteristics of Zannichellia palustris L. along the Alaska Pacific coast. Bull. Torrey Bot. Club 106: 346-349.

Crow, G. E. \& C. B. Hellquist. 1981. Aquatic vascular plants of New England: Part 2. Typhaceae and Sparganiaceae. Station Bulletin 517. New Hampshire Agricultural Experiment Station, University of New Hampshire, Durham, NH. 21 pp.

Crow, G. E. \& C. B. Hellquist. 1982. Aquatic vascular plants of New England: part 4. Juncaginaceae, Scheuchzeriaceae, Butomaceae, Hydrocharitaceae. Station Bulletin 520. New Hampshire Agricultural Experiment Station, University of New Hampshire, Durham, NH. 20 pp.

Crow, G. E. \& C. B. Hellquist. 2000. Aquatic and Wetland Plants of Northeastern North America, Volume Two: Angiosperms: Monocotyledons. The University of Wisconsin Press, Madison, WI. 400 pp.

Crow, W. T. \& N. R. Walker. 2003. Diagnosis of Peltamigratus christiei, a plant-parasitic nematode associated with warm-season turfgrasses in the southern United States. Plant Health Progr. 4: $1-8$.

Crowder, A. A., J. M. Bristow, M. R. King \& S. Vanderkloet. 1977a. Distribution, seasonality, and biomass of aquatic macrophytes in Lake Opinicon (Eastern Ontario). Naturaliste Can. 104: $451-456$.

Crowder, A. A., J. M. Bristow, M. R. King \& S. Vanderkloet. 1977b. The aquatic macrophytes of some lakes in southeastern Ontario. Naturaliste Can. 104: 457-464. 
Crowe, E. A., B. L. Kovalchik \& M. J. J. Kerr. 2004. Riparian and Wetland Vegetation of Central and Eastern Oregon. Oregon Natural Heritage Information Center, Institute for Natural Resources, Oregon State University, Corvallis, OR. 483 pp.

Cruden, R. W. 1988. Temporal dioecism: systematic breadth, associated traits, and temporal patterns. Bot. Gaz. 149: 1-15.

Cruden, R. W. 1991. A revision of Isidrogalvia (Liliaceae): recognition for Ruiz and Pavon's genus. Syst. Bot. 16: 270-282.

Cruden, R. W. \& D. L. Lyon. 1985. Patterns of biomass allocation to male and female functions in plants with different mating systems. Oecologia 66: 299-306.

Cruden, R. W. \& R. M. Lloyd. 1995. Embryophytes have equivalent sexual phenotypes and breeding systems: why not a common terminology to describe them? Am. J. Bot. 82: 816-825.

Crutchfield, Jr., J. U., D. H. Schiller, D. D. Herlong \& M. A. Mallin. 1992. Establishment and impact of redbelly tilapia in a vegetated cooling reservoir. J. Aquat. Plant Manag. 30: 28-35.

Cruz, A. J. U., E. V. Hernández, R. N. Carbó \& M. L. López. 1998. The Najadaceae of Cuba. Anales Jard. Bot. Madrid 56: 85-94.

Cruzan, M. B., J. L. Hamrick, M. L. Arnold \& B. D. Bennett. 1994. Mating system variation in hybridizing irises: effects of phenology and floral densities on family outcrossing rates. Heredity 72: 95-105.

Cuenca, A., G. Petersen \& O. Seberg. 2013. The complete sequence of the mitochondrial genome of Butomus umbellatus-a member of an early branching lineage of Monocotyledons. PLoS One 8(4): e61552.

Cui, W., J. Xu, J. J. Cheng \& A. M. Stomp. 2011. Starch accumulation in duckweed for bioethanol production. Biol. Eng. Trans. 3: 187-197.

Cui, X., X. Dai, K. Y. Khan, T. Li, X. Yang \& Z. He. 2016. Removal of phosphate from aqueous solution using magnesium-alginate/chitosan modified biochar microspheres derived from Thalia dealbata. Bioresour. Technol. 218: 1123-1132.

Cullain, N., R. McIver, A. L. Schmidt \& H. K. Lotze. 2018. Spatial variation of macroinfaunal communities associated with Zostera marina beds across three biogeographic regions in Atlantic Canada. Estuaries Coast. 41: 1381-1396.

Culley, T. M., J.-F. Leng, S. R. Kephart, F. J. Cartieri \& K. E. Theiss. 2013. Development of 16 microsatellite markers within the Camassia (Agavaceae) species complex and amplification in related taxa. Appl. Plant Sci. 1: 1300001.

Culling, D. E. \& D. B. Cichowski. 2017. Boreal Caribou (Rangifer tarandus) in British Columbia: 2017 Science Review. British Columbia Oil and Gas Research and Innovation Society, Victoria, BC. $141 \mathrm{pp}$.

Cunningham, D. D. 1887. On the phenomenon of gaseous evolution from the flowers of Ottelia alismoides. Sci. Mem. Med. Officers Army India 2: 39-46.

Currah, R. S., L. Sigler \& S. Hambleton. 1987. New records and new taxa of fungi from the mycorrhizae of terrestrial orchids of Alberta. Can. J. Bot. 65: 2473-2482.

Currah, R. S., L. W. Zettler \& T. M. McInnis. 1997. Epulorhiza inquilina sp. nov. from Platanthera (Orchidaceae) and a key to Epulorhiza species. Mycotaxon 61: 335-342.

Curtis, J. T. 1939. The relation of specificity of orchid mycorrhizal fungi to the problem of symbiosis. Am. J. Bot. 26: 390-399.

Curtis, J. T. 1943. Germination and seedling development in five species of Cypripedium L. Am. J. Bot. 30: 199-206.

Curtis, J. T. 1946. Use of mowing in management of white ladyslipper. J. Wildl. Manag. 10: 303-308.

Cusick, A. W. 1970. Noteworthy Mississippi plant records. Castanea 35: $322-324$.
Cusimano, N., J. Bogner, S. J. Mayo, P. C. Boyce, S. Y. Wong, M. Hesse, W. L. A. Hetterscheid, R. C. Keating \& J. C. French. 2011. Relationships within the Araceae: comparison of morphological patterns with molecular phylogenies. Am. J. Bot. 98: 654-668.

Custer, C. M. \& T. W. Custer. 1986. Food habits of diving ducks in the Great Lakes after the zebra mussel invasion. J. Field Ornithol. 67: 86-99.

Cutler, A. J., W. Hösel, M. Sternberg \& E. E. Conn. 1981. The in vitro biosynthesis of taxiphyllin and the channeling of intermediates in Triglochin maritima. J. Biol. Chem. 256: 4253-4258.

Cutter, V. M. 1943. An undescribed Lagenidium parasitic upon Potamogeton. Mycologia 35: 2-12.

Cypert, E. 1961. The effects of fires in the Okefenokee Swamp in 1954 and 1955. Am. Midl. Nat. 66: 485-503.

Cypert, E. 1972a. The origin of houses in the Okefenokee prairies. Am. Midl. Nat. 87: 448-458.

Cypert, E. 1972b. Plant succession on burned areas in Okefenokee swamp following the fires of 1954 and 1955. Proc. Annual Tall Timbers Fire Ecol. Conf. 12: 199-217.

Da Cunha, N. L. \& E. Fischer. 2009. Breeding system of tristylous Eichhornia azurea (Pontederiaceae) in the southern Pantanal, Brazil. Plant Syst. Evol. 280: 53-58.

Da Silva, S. L., K. M. Magalhães \& R. de Carvalho. 2017. Karyotype variations in seagrass (Halodule wrightii AschersonCymodoceaceae). Aquat. Bot. 136: 52-55.

Dahlgren, R. M. T. \& H. T. Clifford. 1982. The Monocotyledons: A Comparative Study. Academic Press, London, UK. 378 pp.

Dalby, R. 2000. A trio of spring bee plants: prairie crocus, skunk cabbage, and manzanita. Am. Bee J. 140: 147-149.

Dale, H. M. \& T. J. Gillespie. 1977. The influence of submersed aquatic plants on temperature gradients in shallow water bodies. Can. J. Bot. 55: 2216-2225.

Dammer, U. 1888. Beiträge zur Kenntnis der vegetativen Organe von Limnobium stoloniferum Grisebach nebst einigen betrachtungen über die phylogenetische Dignität von Diclinie und Hermaphroditismus. Becker \& Hornberg, Berlin, Germany. 20 pp.

Daniëls, F. J. A., S. S. Talbot, S. L. Talbot \& W. B. Schofield. 1998. Geobotanical aspects of Simeonof Island, Shumagin Islands, southwestern Alaska. Ber. Reinh. Tüxen Ges. 10: 125-138.

Daoust, R. J. \& D. L. Childers. 1998. Quantifying aboveground biomass and estimating net aboveground primary production for wetland macrophytes using a non-destructive phenometric technique. Aquat. Bot. 62: 115-133.

Daoust, R. J. \& D. L. Childers. 1999. Controls on emergent macrophyte composition, abundance, and productivity in freshwater Everglades wetland communities. Wetlands 19: 262-275.

Darnell, R. M. 1958. Food habits of fishes and large invertebrate of Lake Pontchartrain, Louisiana, an estuarine community. Publ. Inst. Mar. Sci. Univ. Texas 5: 353-416.

Darnell, K. M. \& K. H. Dunton. 2015. Consumption of turtle grass seeds and seedlings by crabs in the western Gulf of Mexico. Mar. Ecol. Prog. Ser. 520: 153-163.

Darnell, K. M. \& K. H. Dunton. 2016. Reproductive phenology of the subtropical seagrasses Thalassia testudinum (turtle grass) and Halodule wrightii (shoal grass) in the northwest Gulf of Mexico. Bot. Mar. 59: 473-483.

Darnell, K. M. \& K. H. Dunton. 2017. Plasticity in turtle grass (Thalassia testudinum) flower production as a response to porewater nitrogen availability. Aquat. Bot. 138: 100-106.

Darst, M. R., H. M. Light \& L. J. Lewis. 2002. Ground-cover vegetation in wetland forests of the lower Suwannee River floodplain, Florida, and potential impacts of flow reductions. Water Resources Investigations Report 02-4027. U.S. Geological Survey, Tallahassee, FL. 46 pp. 
Daru, B. H. \& K. Yessoufou. 2016. A search for a single DNA barcode for seagrasses of the world. Pp. 313-330 In: S. Trivedi, A. Ansari, S. Ghosh \& H. Rehman (eds.), DNA Barcoding in Marine Perspectives. Springer International Publishing, Basel, Switzerland.

Darwin, C. 1869. Notes on the fertilization of orchids. Ann. Mag. Nat. Hist. 4: 143-159.

Darwin, C. 1872. The Origin of Species by Means of Natural Selection or the Preservation of Favored Races in the Struggle for Life and the Descent of Man and Selection in Relation to Sex. Modern Library, New York, NY. 1000 pp.

Darwin, C. 1877. On the Various Contrivances by Which British and Foreign Orchids Are Fertilised by Insects, and on the Good Effects of Intercrossing, 2nd ed. John Murray, London. 300 pp.

Das, R. R. \& B. Gopal. 1969. Vegetative propagation in Spirodela polyrhiza. Trop. Ecol. 10: 270-277.

Das, N. J., S. P. Saikia, S. Sarkar \& K. Devi. 2006. Medicinal plants of North-Kamrup district of Assam used in primary healthcare system. Indian J. Tradit. Knowl. 5: 489-493.

das Neves, H. J. C. \& M. S. S. Pais. 1980. Identification of a spathe regreening factor in Zantedeschia aethiopica. Biochem. Biophys. Res. Commun. 95: 1387-1392.

Dash, P. R. 2016. Phytochemical Screening and Pharmacological Investigations on Hedychium coronarium. Anchor Academic Publishing, Hamburg, Germany. 72 pp.

Daubs, E. H. 1962. The occurrence of Spirodela oligorrhiza in the United States. Rhodora 64: 83-85.

Daubs, E. H. 1965. A Monograph of Lemnaceae. Illinois Biological Monographs 34. The University of Illinois Press, Urbana, IL. $118 \mathrm{pp}$.

David, P. G. 1996. Changes in plant communities relative to hydrologic conditions in the Florida Everglades. Wetlands 16: 15-23.

Davidson, R. A. 1960. Plant communities of southeastern Iowa. Proc. Iowa Acad. Sci. 67: 162-173.

Davidson, D. \& J.-P. Simon. 1981. Thermal adaptation and acclimation of ecotypic populations of Spirodela polyrhiza (L.) Schleid. (Lemnaceae): morphology and growth rates. J. Therm. Biol. 6: $121-128$.

Davidson, D. W., R. D. Gitar \& D. S. Anderson. 2008. Floristic and ecological studies on the Nelson Mitigation Site, near Grantsburg, Burnett County, Wisconsin. Wulfenia 15: 25-34.

Davies, P., C. Morvan, O. Sire \& C. Baley. 2007. Structure and properties of fibres from sea-grass (Zostera marina). J. Mater. Sci. 42: 4850-4857.

Davis, J. J. 1903. Third supplementary list of parasitic fungi of Wisconsin. Trans. Wisconsin Acad. Sci. 14: 83-106.

Davis, F. W. 1985. Historical changes in submerged macrophyte communities of upper Chesapeake Bay. Ecology 66: 981-993.

Davis, M. A. 1987. The role of flower visitors in the explosive pollination of Thalia geniculata (Marantaceae), a Costa Rican marsh plant. Bull. Torrey Bot. Club 114: 134-138.

Davis, A. F. 1993. Rare wetland plants and their habitats in Pennsylvania. Proc. Acad. Nat. Sci. Philadelphia 144: 254-262.

Davis, J. L., D. L. Childers \& D. N. Kuhn. 1999. Clonal variation in a Florida Bay Thalassia testudinum meadow: molecular genetic assessment of population structure. Mar. Ecol. Prog. Ser. 186: 127-136.

Davis, J. I., D. W. Stevenson, G. Petersen, O. Seberg, L. M. Campbell, J. V. Freudenstein, D. H. Goldman, C. R. Hardy, F. A. Michelangeli, M. P. Simmons \& C. D. Specht. 2004. A phylogeny of the monocots, as inferred from $r b c L$ and atpA sequence variation, and a comparison of methods for calculating jackknife and bootstrap values. Syst. Bot. 29: 467-510.
Davy, A. J. \& G. F. Bishop. 1991. Triglochin maritima L. J. Ecol. 79: $531-555$.

Dawe, N. K., W. S. Boyd, R. Buechert \& A. C. Stewart. 2011. Recent, significant changes to the native marsh vegetation of the Little Qualicum River estuary, British Columbia; a case of too many Canada Geese (Branta canadensis)? Br. Columbia Birds 21: 11-31.

Dawes, C. J. 1986. Seasonal proximate constituents and caloric values in seagrasses and algae on the west coast of Florida. $J$. Coast. Res. 2: 25-32.

Dawes, C. J. \& J. M. Lawrence. 1980. Seasonal changes in the proximate constituents of the seagrasses Thalassia testudinum, Halodule wrightii, and Syringodium filiforme. Aquat. Bot. 8: 371-380.

Dawes, C. J., C. S. Lobban \& D. A. Tomasko. 1989. A comparison of the physiological ecology of the seagrasses Halophila decipiens Ostenfeld and H. johnsonii Eiseman from Florida. Aquat. Bot. 33: 149-154.

Dawes, C. J., D. Hanisak \& J. W. Kenworthy. 1995. Seagrass biodiversity in the Indian River lagoon. Bull. Mar. Sci. 57: 59-66.

Day, R. T., P. A. Keddy, J. M. T. J. McNeill \& T. Carleton. 1988. Fertility and disturbance gradients: a summary model for riverine marsh vegetation. Ecology 69: 1044-1054.

Dayton, P. K. 1975. Experimental evaluation of ecological dominance in a rocky intertidal algal community. Ecol. Monogr. 45: 137-159.

De Abreu Pietrobelli, J. M. T., A. N. Módenes, F. R. EspinozaQuiñones, M. R. Fagundes-Klen \& A. Kroumov. 2009. Removal of copper ions by non-living aquatic macrophytes Egeria densa. Bioautomation 12: 21-32.

De Almeida, J. D. \& H. Freitas. 2006. Exotic naturalized flora of continental Portugal - a reassessment. Bot. Complut. 30: 117-130.

De Andrade, M. J. G., A. M. Giulietti, A. Rapini, L. P. de Queiroz, A. de Souza Conceição, P. R. M. de Almeida \& C. van den Berg. 2010. A comprehensive phylogenetic analysis of Eriocaulaceae: evidence from nuclear (ITS) and plastid ( $p s b A-$ trnH and trnL-F) DNA sequences. Taxon 59: 379-388.

De Borges, R. L. B., F. D. A. R. dos Santos \& A. M. Giulietti. 2009. Comparative pollen morphology and taxonomic considerations in Eriocaulaceae. Rev. Palaeobot. Palynol. 154: 91-105.

De Castro, W. A. C., M. L. Moitas, G. M. Lobato, M. B. da CunhaSantino \& D. M. da Silva Matos. 2013. First record of herbivory of the invasive macrophyte Hedychium coronarium J. König (Zingiberaceae). Biota Neotrop. 13: 368-370.

De Cock, A. W. A. M. 1980. Flowering, pollination and fruiting in Zostera marina L. Aquat. Bot. 9: 201-220.

De Castro, W. A. C., R. V. Almeida, M. B. Leite, R. H. Marrs \& D. M. S. Matos. 2016. Invasion strategies of the white ginger lily Hedychium coronarium J. König (Zingiberaceae) under different competitive and environmental conditions. Environ. Exp. Bot. 127: 55-62.

Dechant, J. A., M. L. Sondreal, D. H. Johnson, L. D. Igl, C. M. Goldade, A. L. Zimmerman \& B. R. Euliss. 2004. Effects of management practices on grassland birds: American Bittern. USGS Northern Prairie Wildlife Research Center, Jamestown, ND. 14 pp.

De Faria Garcia, E., M. A. de Oliveira, A. M. Godin, W. C. Ferreira, L. F. S. Bastos, M. de Matos Coelho \& F. C. Braga. 2010. Antiedematogenic activity and phytochemical composition of preparations from Echinodorus grandiflorus leaves. Phytomedicine 18: 80-86.

De Gruchy, J. H. B. 1938. Preliminary study of the larger aquatic plants of Oklahoma with special reference to their value in fish culture. Technical Bulletin No. 4. Oklahoma Agricultural and Mechanical College, Agricultural Experiment Station, Stillwater, OK. 31 pp. 
De la Vega, E. L., J. R. Cassani \& H. Allaire. 1993. Seasonal relationship between southern Naiad and associated periphyton. $J$. Aquat. Plant Manag. 31: 84-88.

de Lange, L. \& E. Westinga. 1979. The distinction between Lemna gibba L. and Lemna minor L. on the basis of vegetative characters. Acta Bot. Neerl. 28: 169-176.

De Oliveira, P. C., J. M. D. Torezan \& C. N. da Cunha. 2015. Effects of flooding on the spatial distribution of soil seed and spore banks of native grasslands of the Pantanal wetland. Acta Bot. Brasilica 29: 400-407.

De Oliveira Pellegrini, M. O., R. B. Faden \& R. F. de Almeida. 2016. Taxonomic revision of Neotropical Murdannia Royle (Commelinaceae). PhytoKeys 74: 35-78.

De Pauw, M. A. \& W. R. Remphrey. 1993. In vitro germination of three Cypripedium species in relation to time of seed collection, media, and cold treatment. Can. J. Bot. 71: 879-885.

De Pauw, M. A., W. R. Remphrey \& C. E. Palmer. 1995. The cytokinin preference for in vitro germination and protocorm growth of Cypripedium candidum. Ann. Bot. 75: 267-275.

De Steven, D. \& C. A. Harrison. 2006. Hydrology, vegetation, and landscape distribution of depression wetlands on the Francis Marion National Forest. Final Report 11/16/2005. United States Forest Service, Southern Research Station, Stoneville, MS. 24 pp.

De Vos, A. 1958. Summer observations on moose behavior in Ontario. J. Mammal. 39: 128-139.

De Vynck, J. C., B.-E. Van Wyk \& R. M. Cowling. 2016. Indigenous edible plant use by contemporary Khoe-San descendants of South Africa's Cape South Coast. S. Afr. J. Bot. 102: 60-69.

De Wit, H. C. D. 1964. Aquarium Plants. Blandford Press, London. $255 \mathrm{pp}$.

Dean, R. J. \& M. J. Durako. 2007. Carbon sharing through physiological integration in the threatened seagrass Halophila johnsonii. Bull. Mar. Sci. 81: 21-35.

DeBerry, J. W. \& R. B. Atkinson. 2014. Aboveground forest biomass and litter production patterns in Atlantic white cedar swamps of differing hydroperiods. Southeast. Nat. 13: 673-691.

DeBusk, T. A., J. E. Peterson \& K. R. Reddy. 1995. Use of aquatic and terrestrial plants for removing phosphorus from dairy wastewaters. Ecol. Eng. 5: 371-390.

Dechant, J. A., M. L. Sondreal, D. H. Johnson, L. D. Igl, C. M. Goldade, A. L. Zimmerman \& B. R. Euliss. 1999 (revised 2002). Effects of Management Practices on Grassland Birds: American Bittern. Northern Prairie Wildlife Research Center, Jamestown, ND. 14 pp.

Dee, S. M. \& C. Ahn. 2012. Soil properties predict plant community development of mitigation wetlands created in the Virginia Piedmont, USA. Environ. Manage. 49: 1022-1036.

Degani, N., E. Ben-Hur \& E. Riklis. 1980. DNA damage and repair: induction and removal of thymine dimers in ultraviolet light irradiated intact water plants. Photochem. Photobiol. 31: 31-36.

Del Fosse, E. S. \& B. D. Perkins. 1977. Discovery and bioassay of a kairomone from waterhyacinth, Eichhornia crassipes. Florida Entomol. 60: 217-222.

del Moral, R. \& A. F. Watson. 1978. Vegetation on the Stikine Flats, southeast Alaska. Northwest Sci. 52: 137-150.

Delahoussaye, J., C. Allen, S. Huskins \& A. Dauzart. 2014. A quantitative study of the vegetation surrounding populations of Zigadenus densus (Melianthiaceae) at Fort Polk in west Central Louisiana, USA. J. Bot. Res. Inst. Texas 8: 253-259.

Delany, M. F. \& S. B. Linda. 1998. Characteristics of Florida grasshopper sparrow nests. Wilson Bull. 110: 136-139.
Delesalle, V. A. \& S. Blum. 1994. Variation in germination and survival among families of Sagittaria latifolia in response to salinity and temperature. Int. J. Plant Sci. 155: 187-195.

Delgado, E. S. 1999. Flora Acuática y Subacuática de Aguascalientes, 2nd ed. Universidad Autonoma De Aguascalientes, Aguascalientes, Mexico. 75 pp.

Delgado, G. 2013. South Florida microfungi: a new species of Ellisembia (Hyphomycetes) with new records from the USA. Mycotaxon 123: 445-450.

Delgado, G. 2014. South Florida microfungi: Linkosia longirostrata, a new hyphomycete on paurotis palm. Mycotaxon 129: 41-46.

Delisle, F., C. Lavoie, M. Jean \& D. Lachance. 2003. Reconstructing the spread of invasive plants: taking into account biases associated with herbarium specimens. J. Biogeogr. 30: 1033-1042.

DellaGreca, M., A. Fiorentino, M. Isidori, P. Monaco \& A. Zarrellia. 2000. Antialgal ent-labdane diterpenes from Ruppia maritima. Phytochemistry 55: 909-913.

DellaGreca, M., A. Fiorentino, P. Monaco \& A. Zarrelli. 2001a. Two new polyhydroxylated sterols from Ruppia maritima. Nat. Prod. Lett. 15: 111-118.

DellaGreca, M., A. Fiorentino, M. Isidori, P. Monaco, F. Temussi \& A. Zarrelli. 2001b. Antialgal furano-diterpenes from Potamogeton natans L. Phytochemistry 58: 299-304.

DeMarco, K. E., E. R. Hillmann \& M. G. Brasher. 2016. Brackish marsh zones as a waterfowl habitat resource in submerged aquatic vegetation beds in the northern Gulf of Mexico. $J$. Southeast. Assoc. Fish Wildl. Agen. 3: 261-269.

Deng, J., G. Gao, Y. Zhang, F. He, X. Luo, F. Zhang, X. Liao, K. S. Ahmad \& R. Yang. 2016. Phylogenetic and ancestral area reconstruction of Zingiberales from plastid genomes. Biochem. Syst. Ecol. 66: 123-128.

Denley, K. K., C. T. Bryson \& R. A. Stewart. 2002. Vascular flora of Yalobusha County, Mississippi. Castanea 67: 402-415.

Dennis, W. M. 1980. Sarracenia oreophila (Kearny) Wherry in the Blue Ridge Province of Northeastern Georgia. Castanea 45 : 101-103.

Dennis, W. M., A. M. Evans \& B. E. Wofford. 1979. Disjunct populations of Isoëtes macrospora in southeastern Tennessee. Am. Fern J. 69: 97-99.

Dennison, W. C. \& R. S. Alberte. 1985. Role of daily light period in the depth distribution of Zostera marina (eelgrass). Mar. Ecol. Prog. Ser. 25: 51-61.

Dennison, W. C., G. J. Marshall \& C. Wigand. 1989. Effect of "brown tide" shading on eelgrass (Zostera marina L.) distributions. Pp. 675-692 In: E. M. Cosper, V. M. Bricelj \& E. J. Carpenter (eds.), Novel Phytoplankton Blooms. Springer, Berlin, Germany.

Deno, N. C. 1993. Seed Germination, Theory and Practice, 2nd ed. 139 Lenor Drive, State College, PA. 242 pp.

Denslow, M. W., G. L. Katz \& W. F. Jennings. 2011. First record of Iris pseudacorus (Iridaceae) from Colorado. J. Bot. Res. Inst. Texas 5: 327-329.

Dethier, M. N. 1984. Disturbance and recovery in intertidal pools: maintenance of mosaic patterns. Ecol. Monogr. 54: 99-118.

Dethier, M. N. \& D. O. Duggins. 1988. Variation in strong interactions in the intertidal zone along a geographical gradient: a Washington-Alaska comparison. Mar. Ecol. Prog. Ser. 50: 97-105.

Deutsch, G. 2002. Ponthieva orchioides Schlechter (OrchidaceaeSpiranthoideae): in vitro-propagation, culture and chromosome number. Stapfia 80: 327-331.

DeVere, E. N. 1970. Habitat selection and species interactions of some marsh passerines. M.S. thesis. Iowa State University, Ames, IA. 75 pp. 
DeVlaming, V. \& V. W. Proctor. 1968. Dispersal of aquatic organisms: viability of seeds recovered from the droppings of captive killdeer and mallard ducks. Am. J. Bot. 55: 20-26.

DeVelice, C. J. Hubbard, K. Boggs, S. Boudreau, M. Potkin, T. Boucher \& C. Wertheim. 1999. Plant community types of the Chugach National Forest: southcentral Alaska. Technical Publication R10-TP-76. United States Department of Agriculture Forest Service, Chugach National Forest, Alaska Region, Anchorage, AK.

Dewanji, A., S. Chanda, L. Si, S. Barik \& S. Matai. 1997. Extractability and nutritional value of leaf protein from tropical aquatic plants. Plant Foods Hum. Nutr. 50: 349-357.

Deyrup, M. \& L. Deyrup. 2008. Flower visitation by adult shore flies at an inland site in Florida (Diptera: Ephydridae). Florida Entomol. 91: 504-507.

Deyrup, M., J. Edirisinghe \& B. Norden. 2002. The diversity and floral hosts of bees at the Archbold Biological Station, Florida (Hymenoptera: Apoidea). Insecta Mundi 16: 87-120.

Diamond, A. R. 2016. Range extension and first record of Fimbristylis perpusilla (Cyperaceae) for Alabama. Phytoneuron 2016-10: $1-4$.

Dias, T. L., I. L. Rosa \& J. K. Baum. 2002. Threatened fishes of the world: Hippocampus erectus Perry, 1810 (Syngnathidae). Environ. Biol. Fishes 65: 326.

Dibble, E. D. \& S. L. Harrel. 1997. Largemouth bass diets in two aquatic plant communities. J. Aquat. Plant Manag. 35: 74-78.

Dickerman, J. A. \& R. G. Wetzel. 1985. Clonal growth in Typha latifolia: population dynamics and demography of the ramets. $J$. Ecol. 73: 535-552.

Dickinson, M. B. \& T. E. Miller. 1998. Competition among small, free-floating, aquatic plants. Am. Midl. Nat. 140: 55-67.

Dieffenbacher-Krall, A. \& W. Halteman. 2000. The relationship of modern plant remains to water depth in alkaline lakes in New England, USA. J. Paleolimnol. 24: 213-229.

Dighton, J., T. Gordon, R. Mejia \& M. Sobel. 2013. Mycorrhizal status of Knieskern's beaked sedge (Rhynchospora knieskernii) in the New Jersey Pine Barrens. Bartonia 66: 24-27.

Dilday, R. H., P. Nastasi \& R. J. Smith, Jr. 1989. Allelopathic observations in rice (Oryza sativa L.) to ducksalad (Heteranthera limosa). J. Arkansas Acad. Sci. 43: 21-22.

Dillingham, C. 2005. Conservation assessment for Meesia triquetra (L.) Aongstr. (three-anked hump-moss) and Meesia uliginosa Hedwig (broad-nerved hump-moss) in California with a focus on the Sierra Nevada bioregion. Internal Document, USDA Forest Service, VMS Enterprise Team, Quincy, CA. $29 \mathrm{pp}$.

Dindorf, C. \& C. Kjelland. 2006. Lake George Aquatic Plant Survey, Anoka County, MN. August 2 - 3, 2006. Fortin Consulting, Inc., Hamel, MN. 12 pp.

Ding, Y., Y. Fang, L. Guo, Z. Li, K. He, Y. Zhao \& H. Zhao. 2017a. Phylogenic [sic!] study of Lemnoideae (duckweeds) through complete chloroplast genomes for eight accessions. PeerJ 5: e4186.

Ding, Y., D. Qu, K.-M. Zhang, X.-X. Cang, Z.-N. Kou, W. Xiao \& J.-B. Zhu. 2017b. Phytochemical and biological investigations of Amaryllidaceae alkaloids: a review. J. Asian Nat. Prod. Res. 19: $53-100$.

Dirrigl, Jr., F. J. \& R. H. Mohlenbrock. 2012. Land snails in ephemeral pools at Ottine Swamp, Gonzales County, Texas. Southwest. Nat. 57: 353-355.

Dissanayake, C., M. Hettiarachchi \& M. C. M. Iqbal. 2007. Sustainable use of Cryptocoryne wendtii and Echinodorus cordifolius in the aquaculture industry of Sri Lanka by micropropagation. Sri Lanka J. Aquat. Sci. 12: 89-101.
Dister, D. C. 2017. The vascular flora of Ludington State Park, Mason County, Michigan. Great Lakes Bot. 56: 52-90.

DiTomaso, J. M. \& E. A. Healy. 2003. Aquatic and riparian weeds of the west. Publication 3421. Agriculture and Natural Resources, University of California, Oakland, CA. 442 pp.

Dixon, R. B. 1905. The Northern Maidu. Bull. Am. Mus. Nat. Hist. 17: 119-346.

Dixon, L. K. \& J. R. Leverone. 1995. Light requirements of Thalassia testudinum in Tampa Bay, Florida. Final report. Mote Technical Report No. 425. Mote Marine Laboratory, Sarasota, FL. 77 pp.

do Vale, A. A., B. L. Lau, B. S. S. Leal, J. A. N. Batista, E. L. Borba \& K. Proite. 2016. Development and transferability of microsatellite markers in Habenaria nuda and H. repens (Orchidaceae). Brazilian J. Bot. 39: 387-392.

Dodd, J. D. \& R. T. Coupland. 1966. Vegetation of saline areas in Saskatchewan. Ecology 47: 958-968.

Dodd, S. R., R. S. Haynie, S. M. Williams \& S. B. Wilde. 2016. Alternate food-chain transfer of the toxin linked to Avian Vacuolar Myelinopathy and implications for the endangered Florida snail kite (Rostrhamus sociabilis). J. Wildl. Dis. 52: 335-344.

Dodds, D. G. 1960. Food competition and range relationships of moose and snowshoe hare in Newfoundland. J. Wildl. Manag. 24: 52-60.

Doering, P. H. \& R. H. Chamberlain. 2000. Experimental studies on the salinity tolerance of turtle grass, Thalassia testudinum. Pp. 81-98 In: S. A. Bortone (ed.), Seagrasses: Monitoring, Ecology, Physiology, and Management. CRC Press, Boca Raton, FL.

Doering, M. \& D. Coxson. 2010. Riparian alder ecosystems as epiphytic lichen refugia in sub-boreal spruce forests of British Columbia. Botany 88: 144-157.

Doherty, J. M., J. C. Callaway \& J. B. Zedler. 2011. Diversity-function relationships changed in a long-term restoration experiment. Ecol. Appl. 21: 2143-2155.

Dolan, R. W. 2014. Bacon's Swamp - ghost of a central Indiana natural area past. Proc. Indiana Acad. Sci. 123: 138-160.

Donnermeyer, G. N. \& M. M. Smart. 1985. The biomass and nutritive potential of Vallisneria americana Michx in navigation pool 9 of the upper Mississippi River. Aquat. Bot. 22: 33-44.

Dooley, F. D., S. Wyllie-Echeverria, E. Gupta \& P. D. Ward. 2015. Tolerance of Phyllospadix scouleri seedlings to hydrogen sulfide. Aquat. Bot. 123: 72-75.

Dore, W. G. 1954. European frogbit (Hydrocharis morsus-ranae L.) in the Ottawa River. Can. Field-Nat. 68: 180-181.

Dore, W. G. 1968. Progress of the European frogbit in Canada. Can. Field-Nat. 82: 76-84.

Dorken, M. E. \& S. C. Barrett. 2003. Life-history differentiation and the maintenance of monoecy and dioecy in Sagittaria latifolia (Alismataceae). Evolution 57: 1973-1988.

Dorken, M. E. \& S. C. Barrett. 2004a. Phenotypic plasticity of vegetative and reproductive traits in monoecious and dioecious populations of Sagittaria latifolia (Alismataceae): a clonal aquatic plant. J. Ecol. 92: 32-44.

Dorken, M. E. \& S. C. Barrett. 2004b. Sex determination and the evolution of dioecy from monoecy in Sagittaria latifolia (Alismataceae). Proc. Biol. Sci. 271: 213-219.

Dorken, M. E. \& S. C. Barrett. 2004c. Chloroplast haplotype variation among monoecious and dioecious populations of Sagittaria latifolia (Alismataceae) in eastern North America. Mol. Ecol. 13: 2699-2707.

Dorken, M. E., J. Friedman \& S. C. H. Barrett. 2002. The evolution and maintenance of monoecy and dioecy in Sagittaria latifolia (Alismataceae). Evolution 56: 31-41. 
Dostine, P. L. \& S. R. Morton. 1989. Food of the black-winged Stilt Himantopus himantopus in the Alligator Rivers Region, Northern Territory. Emu-Austral Ornith. 89: 250-253.

Douglas, N. A., W. A. Wall, Q.-Y. Xiang, W. A. Hoffmann, T. R. Wentworth, J. B. Gray \& M. G. Hohmann. 2011. Recent vicariance and the origin of the rare, edaphically specialized Sandhills lily, Lilium pyrophilum (Liliaceae): evidence from phylogenetic and coalescent analyses. Mol. Ecol. 20: 2901-2915.

Doumlele, D. G. 1981. Primary production and seasonal aspects of emergent plants in a tidal freshwater marsh. Estuaries 4: 139-142.

Downing, J. A. 1981. In situ foraging responses of three species of littoral cladocerans. Ecol. Monogr. 51: 85-104.

Doyle, R. D. 2000. Expansion of the exotic aquatic plant Cryptocoryne beckettii (Araceae) in the San Marcos River, Texas. Sida 19: 1027-1038.

Doyle, R. D. 2001. Effects of waves on the early growth of Vallisneria americana. Freshw. Biol. 46: 389-397.

Doyle, G. J. \& J. G. Duckett. 1985. The occurrence of Lysichiton americanus Hultén \& St. John on Woodfield Bog, County Offaly (H18). Ir. Nat. J. 21: 536-538.

Doyle, R. D. \& R. M. Smart. 1998. Competitive reduction of noxious Lyngbya wollei mats by rooted aquatic plants. Aquat. Bot. 61: $17-32$.

Doyle, R. D. \& R. M. Smart. 2001. Impacts of water column turbidity on the survival and growth of Vallisneria americana winterbuds and seedlings. Lake Reserv. Manag. 17: 17-28.

Doyle, R., S. Hester \& C. Williams. 2014. Edwards Aquifer Authority: 2014 ecomodeling: vegetation percent cover to biomass. Report of Research Activities. Center For Reservoir and Aquatic Systems Research, Baylor University, Waco, TX. 13 pp.

Dozier, H. L. 1945. Sex ratio and weights of muskrats from the Montezuma National Wildlife Refuge. J. Wildl. Manag. 9: 232-237.

Dray, Jr., F. A. \& T. D. Center. 1989. Seed production by Pistia stratiotes L. (water lettuce) in the United States. Aquat. Bot. 33: $155-160$.

Dray, Jr., F. A., C. R. Thompson, D. H. Habeck, J. K. Balciunas \& T. D. Center. 1988. A survey of the fauna associated with Pistia stratiotes L. (water lettuce) in Florida. Technical Report A-88-6. US Army Engineer Waterways Experiment Station, Vicksburg, MS. 36 pp.

Dray, Jr., F. A., F. Allen, T. D. Center \& D. H. Habeck. 1993. Phytophagous insects associated with Pistia stratiotes in Florida. Environ. Entomol. 22: 1146-1155.

Drescher, B. 2017. An ecological examination of Johnson Bayou (Pass Christian, MS) with a reproductive histological analysis of Rangia cuneata, and a comparative morphological study of the foot and shell of Rangia cuneata and Polymesoda caroliniana. Ph.D. dissertation. University of Southern Mississippi, Hattiesburg, MS. 176 pp.

Dressler, R. L., D. W. Hall, K. D. Perkins \& N. H. Williams. 1987. Identification Manual for Wetland Plant Species of Florida. Publication SP-35.Institute of Food and Agricultural Sciences, University of Florida, Gainesville, FL. 297 pp.

Drewa, P. B., W. J. Platt \& E. B. Moser. 2002. Community structure along elevation gradients in headwater regions of longleaf pine savannas. Plant Ecol. 160: 61-78.

Driever, S. M., E. H. van Nes \& R. M. M. Roijackers. 2005. Growth limitation of Lemna minor due to high plant density. Aquat. Bot. 81: 245-251.

Drobney, R. D. \& L. H. Fredrickson. 1979. Food selection by wood ducks in relation to breeding status. J. Wildl. Manag. 43: 109-120.
Drouet, F. 1933. Algal vegetation of the large Ozark springs. Trans. Am. Microsc. Soc. 52: 83-100.

Drummond, D. C. 1960. The food of Rattus norvegicus Berk. in an area of sea wall, saltmarsh and mudflat. J. Anim. Ecol. 29: 341-347.

Drysdale, F. R. \& M. G. Barbour. 1975. Response of the marine angiosperm Phyllospadix torreyi to certain environmental variables: a preliminary study. Aquat. Bot. 1: 97-106.

Du, Y., J. Feng, R. Wang, H. Zhang \& J. Liu. 2015. Effects of flavonoids from Potamogeton crispus L. on proliferation, migration, and invasion of human ovarian cancer cells. PLoS One 10: 0130685 .

Duarte, C. M. 1991. Seagrass depth limits. Aquat. Bot. 40: 363-377.

Duarte, C. M. \& C. L. Chiscano. 1999. Seagrass biomass and production: a reassessment. Aquat. Bot. 65: 159-174.

Dubbe, D. R., E. G. Garver \& D. C. Pratt. 1988. Production of cattail (Typha spp.) biomass in Minnesota, USA. Biomass 17: 79-104.

DuBois, R. B., J. M. Pleski, W. A. Smith \& E. J. Epstein. 2009. Odonata of coastal peatland habitats adjacent to Lake Superior in Wisconsin. Great Lakes Entomol. 42: 52-66.

Dudley, W. R. 1893. The genus Phyllospadix. Pp. 403-418 In: Wilder Quarter-Century Book. Comstock, Ithaca, NY.

Dudley, W. R. 1894. Phyllospadix, its systematic characters and distribution. Zoe 4: 381-385.

Dudley, M. G. 1937. Morphological and cytological studies of Calla palustris. Bot. Gaz. 98: 556-571.

Dudley, J. L. 1987. Turion formation in strains of Lemna minor (6591) and Lemna turionifera (6573, A). Aquat. Bot. 27: 207-215.

Dueck, L. A. \& K. Cameron. 2007. Sequencing re-defines Spiranthes relationships, with implications for rare and endangered taxa. Lankesteriana 7: 190-195.

Dueck, L. A., D. Aygoren \& K. M. Cameron. 2014. A molecular framework for understanding the phylogeny of Spiranthes (Orchidaceae), a cosmopolitan genus with a North American center of diversity. Am. J. Bot. 101: 1551-1571.

Duffy, W. G. 1994. Demographics of Lestes disjunctus disjunctus (Odonata: Zygoptera) in a riverine wetland. Can. J. Zool. 72: 910-917.

Dugdale, T. M., D. Clements \& T. D. Hunt. 2012. Survival of a submerged aquatic weed (Egeria densa) during lake drawdown within mounds of stranded vegetation. Lake Reserv. Manag. 28: $153-157$.

Duggal, S. C. 1971. Orchids in human affairs (a review). Quart. J. Crude Drug Res. 11: 1727-1734.

Duke, J. A. 2000. Handbook of Edible Weeds. CRC Press, Boca Raton, FL. 256 pp.

Duncan, B. L. \& D. L. DeGiusti. 1976. Three new lissorchiid Cercariaea of the Mutabile group from Laevapex fuscus (Adams, 1841) and Ferrisia rivularis (Say, 1917). Proc. Helminthol. Soc. Washington 43: 1-9.

Dunford, J. C., D. K. Young \& S. J. Krauth. 2006. Stethobaris ovata (LeConte) (Curculionidae) on eastern prairie fringed orchid [Platanthera leucophaea (Nuttall) Lindley] in Wisconsin. Coleopterists Bull. 60: 51-53.

Dunham, R. M., A. M. Ray \& R. S. Inouye. 2003. Growth, physiology, and chemistry of mycorrhizal and nonmycorrhizal Typha latifolia seedlings. Wetlands 23: 890-896.

Dunn, C. P. \& R. R. Sharitz. 1990. The history of Murdannia keisak (Commelinaceae) in the southeastern United States. Castanea 55: $122-129$.

Dunn, C. P. \& R. R. Sharitz. 1991. Population structure, biomass allocation, and phenotypic plasticity in Murdannia keisak (Commelinaceae). Am. J. Bot. 78: 1712-1723. 
Dunton, K. H. 1990. Production ecology of Ruppia maritima L. s.1. and Halodule wrightii Aschers, in two subtropical estuaries. J. Exp. Mar. Biol. Ecol. 143: 147-164.

Dunton, K. H. 1994. Seasonal growth and biomass of the subtropical seagrass Halodule wrightii in relation to continuous measurements of underwater irradiance. Mar. Biol. 120: 479-489.

Dunton, K. H. 1996. Photosynthetic production and biomass of the subtropical seagrass Halodule wrightii along an estuarine gradient. Estuaries Coast. 19: 436-447.

Duong, T. P. \& J. M. Tiedje. 1985. Nitrogen fixation by naturally occurring duckweed-cyanobacterial associations. Can. J. Microbiol. 31: 327-330.

Durako, M. J. \& M. D. Moffler. 1985. Observations on the reproductive ecology of Thalassia testudinum (Hydrocharitaceae). III. Spatial and temporal variations in reproductive patterns within a seagrass bed. Aquat. Bot. 22: 265-276.

Durako, M. J. \& M. D. Moffler. 1987. Factors affecting the reproductive ecology of Thalassia testudinum (Hydrocharitaceae). Aquat. Bot. 27: 79-95.

Durako, M. J. \& J. F. Howarth. 2017. Leaf spectral reflectance shows Thalassia testudinum seedlings more sensitive to hypersalinity than hyposalinity. Front. Plant Sci. 28. doi: 10.3389/ fpls.2017.01127.

Durako, M. J., J. I. Kunzelman, W. J. Kenworthy \& K. K. Hammerstrom. 2003. Depth-related variability in the photobiology of two populations of Halophila johnsonii and Halophila decipiens. Mar. Biol. 142: 1219-1228.

Dutton, B. E. \& R. D. Thomas. 1991. The vascular flora of Cameron Parish, Louisiana. Castanea 56: 1-37.

Duvall, M. R., G. H. Learn, L. E. Eguiarte \& M. T. Clegg. 1993a. Phylogenetic analysis of $r b c L$ sequences identifies Acorus calamus as the primal extant monocotyledon. Proc. Natl. Acad. Sci. U.S.A. 90: 4641-4644.

Duvall, M. R., M. T. Clegg, M. W. Chase, W. D. Clark, W. J. Kress, H. G. Hills, L. E. Eguiarte, J. F. Smith, B. S. Gaut, E. A. Zimmer \& G. H. Learn, Jr. 1993b. Phylogenetic hypotheses for the monocotyledons constructed from $r b c L$ sequence data. Ann. Missouri Bot. Gard. 80: 607-619.

Dworaczek, E. \& R. Claßen-Bockhoff. 2016. 'False resupination' in the flower-pairs of Thalia (Marantaceae). Flora 221: 65-74.

Dyer, A. F., T. H. N. Ellis, E. Lithgow, S. Lowther, I. Mason \& D. Williams. 1976. The karyotype of Iris pseudacorus L. Trans. Bot. Soc. Edinburgh 42: 421-429.

Earnst, S. L \& T. C. Rothe. 2004. Habitat selection by Tundra Swans on northern Alaska breeding grounds. Waterbirds 27: 224-233.

Easley, J. F. \& R. L. Shirley. 1974. Nutrient elements for livestock in aquatic plants. Hyacinth Control J. 12: 82-85.

Easley, M. C. \& W. S. Judd. 1993. Vascular flora of Little Talbot Island, Duval County, Florida. Castanea 58: 162-177.

East, E. M. 1940. The distribution of self-sterility in the flowering plants. Proc. Am. Philos. Soc. 82: 449-518.

Ebinger, J. E. \& J. A. Bacone. 1980. Vegetation survey of hillside seeps at Turkey Run State Park. Proc. Indiana Acad. Sci. 90: 390-394.

Echternacht, L., P. T. Sano, C. Bonillo, C. Cruaud, A. Couloux \& J.-Y. Dubuisson. 2014. Phylogeny and taxonomy of Syngonanthus and Comanthera (Eriocaulaceae): evidence from expanded sampling. Taxon 63: 47-63.

Eckardt, N. A. \& D. D. Biesboer. 1988. A survey of nitrogen fixation (acetylene reduction) associated with Typha in Minnesota. Can. J. Bot. 66: 2419-2423.

Eckenwalder, J. E. \& S. C. H. Barrett. 1986. Phylogenetic systematics of Pontederiaceae. Syst. Bot. 11: 373-391.
Eckert, C. G., B. Massonnet \& J. J. Thomas. 2000. Variation in sexual and clonal reproduction among introduced populations of flowering rush, Butomus umbellatus (Butomaceae). Can. J. Bot. 78: 437-446.

Edelman, S. M. 2017. Morphology, architecture and growth of a clonal palm, Acoelorrhaphe wrightii. Ph.D. dissertation. Florida International University, Miama, FL. 187 pp.

Edelman, S. \& J. H. Richards. 2018a. Morphology and architecture of the threatened Florida palm Acoelorrhaphe wrightii (Arecaceae: Coryphoideae). Candollea 73: 49-59.

Edelman, S. \& J. H. Richards. 2018b. Germination and juvenile growth of the clonal palm, Acoelorrhaphe wrightii, under different water and light treatments: a mesocosm study. Feddes Repert. 129: 92-104.

Edgerton, E. A. 2014. Prevention and management of aquatic invasive plants in Texas. Ph.D. dissertation. Texas A\&M University, College Station, TX. 254 pp.

Edwards, T. I. 1933. The germination and growth of Peltandra virginica in the absence of oxygen. Bull. Torrey Bot. Club 60 : $573-581$.

Edwards, T. I. 1934. Seed frequencies in Cytisus and Peltandra. Am. Nat. 68: 283-286.

Edwards, P. 1980. Food Potential of Aquatic Macrophytes. ICLARM Studies and Reviews No 5. International Center for Living Aquatic Resources Management, Manila, Philippines. 51 pp.

Edwards, A. L. \& R. R. Sharitz. 2000. Population genetics of two rare perennials in isolated wetlands: Sagittaria isoetiformis and S. teres (Alismataceae). Am. J. Bot. 87: 1147-1158.

Edwards, A. L. \& R. R. Sharitz. 2003. Clonal diversity in two rare perennial plants: Sagittaria isoetiformis and Sagittaria teres (Alismataceae). Int. J. Plant Sci. 164: 181-188.

Edwards, J. M. \& U. Weiss. 1970. Perinaphthenone pigments from the fruit capsules of Lachnanthes tinctoria. Phytochemistry 9: $1653-1657$.

Edwards, J. M. \& U. Weiss. 1974. Phenalenone pigments of the root system of Lachnanthes tinctoria. Phytochemistry 13: 1597-1602.

Egertson, C. J., J. A. Kopaska \& J. A. Downing. 2004. A century of change in macrophyte abundance and composition in response to agricultural eutrophication. Hydrobiologia 524: 145-156.

Eggeling, O. \& F. Ehrenberg. 1908. The Freshwater Aquarium and Its Inhabitants: A Guide for the Amateur Aquarist. Henry Holt \& Company, New York, NY. 352 pp.

Eichler, L. 2009. Aquatic Vegetation of Lake Luzerne, NY. Lake Luzerne Association, Lake Luzerne, NY. $18+45$ pp.

Eichler, L. 2011. An Assessment of Aquatic Plant Growth in Galway Lake, Saratoga County, New York. Darrin Fresh Water Institute, Bolton Landing, NY. $14+21$ pp.

Eichler, L. \& C. Boylen. 2013. Aquatic vegetation of Canada Lake, West Lake and Green Lake, Town of Caroga, New York. DFWI Technical Report 2013-6. Darrin Fresh Water Institute, Bolton Landing, NY. 27 pp.

Eichler, L. W., L. E. Ahrens-Franklin \& C. W. Boylen. 2006. A survey of tributaries to Lake George, New York for the presence of Eurasian watermilfoil. DFWI Technical Report 2006-7. Darrin Fresh Water Institute, Bolton Landing, NY. $14+29$ pp.

Eickwort, G. C., P. F. Kukuk \& F. R. Wesley. 1986. The nesting biology of Dufourea novaeangliae (Hymenoptera: Halictidae) and the systematic position of the Dufoureinae based on behavior and development. J. Kansas Entomol. Soc. 59: 103-120.

Eid, E. M., T. M. Galal, M. A. Dakhil \& L. M. Hassan. 2016. Modeling the growth dynamics of Pistia stratiotes L. populations along the water courses of south Nile Delta, Egypt. Rend. Fis. Accad. Lincei 27: 375-382. 
Eighmy, T. T., L. S. Jahnke \& W. R. Fagerberg. 1991. Studies of Elodea nuttallii grown under photorespiratory conditions. II. Evidence for bicarbonate active transport. Plant Cell Environ. 14: 157-165.

Eilers, L. J. \& D. M. Roosa. 1994. The Vascular Plants of Iowa: An Annotated Checklist and Natural History. University of Iowa Press, Iowa City, IA. 304 pp.

Eiseman, N. J. \& C. McMillan. 1980. A new species of seagrass, Halophila johnsonii, from the Atlantic coast of Florida. Aquat. Bot. 9: 15-19.

Ekstam, B. \& Å. Forseby. 1999. Germination response of Phragmites australis and Typha latifolia to diurnal fluctuations in temperature. Seed Sci. Res. 9: 157-163.

Elam, C. E., J. M. Stucky, T. R. Wentworth \& J. D. Gregory. 2009. Vascular flora, plant communities, and soils of a significant natural area in the middle Atlantic coastal plain (Craven County, North Carolina). Castanea 74: 53-77.

Elder, C. L. 1997. Reproductive biology of Darlingtonia californica. M.A. thesis. Humboldt State University, Arcata, CA. 67 pp.

Eleuterius, L. N. 1972. The marshes of Mississippi. Castanea 37: $153-168$.

Eleuterius, L. N. 1980. An illustrated guide to tidal marsh plants of Mississippi and adjacent states. Publication No. MASGP77-039. Mississippi-Alabama Sea Grant Consortium, Ocean Springs, MS. 131 pp.

Eleuterius, L. N. 1990. Tidal Marsh Plants. Pelican Publishing Company, Inc., Gretna, LA. 168 pp.

Eleuterius, L. N. \& S. McDaniel. 1978. The salt marsh flora of Mississippi. Castanea 43: 86-95.

Eleuterius, L. N. \& J. D. Caldwell. 1984. Flowering phenology of tidal marsh plants in Mississippi. Castanea 49: 172-179.

Elger, A. \& N. J. Willby. 2003. Leaf dry matter content as an integrative expression of plant palatability: the case of freshwater macrophytes. Funct. Ecol. 17: 58-65.

El-Hady, H. H., S. M. Daboor \& A. E. Ghoniemy. 2007. Nutritive and antimicrobial profiles of some seagrasses from Bardawil Lake, Egypt. Egypt. J. Aquat. Res. 33: 103-110.

Ellis, E. A. 1965. The Broads. Collins, London. 401 pp.

Ellis, J. B. \& B. M. Everhart. 1885. New fungi. J. Mycol. 1: 148-154.

Ellis, J. B. \& A. B. Langlois. 1890. New species of Louisiana fungi. J. Mycol. 6: 35-37.

Elmore, A. J., K. A. Engelhardt, D. Cadol \& C. M. Palinkas. 2016. Spatial patterns of plant litter in a tidal freshwater marsh and implications for marsh persistence. Ecol. Appl. 26: 846-860.

Elser, J. J., C. Junge \& C. R. Goldman. 1994. Population structure and ecological effects of the crayfish Pacifastacus leniusculus in Castle Lake, California. Great Basin Nat. 54: 162-169.

El-Shafai, S. A., F. A. El-Gohary, J. A. J. Verreth, J. W. Schrama \& H. J. Gijzen. 2004. Apparent digestibility coefficient of duckweed (Lemna minor), fresh and dry for Nile tilapia (Oreochromis niloticus L.). Aquac. Res. 35: 574-586.

El-Shamy, M. A., A. H. M. El-Feky \& N. Y. L. Eliwa. 2009. Propagation of calla lily (Zantedeschia aethiopica Spreng) plants by tissue culture technique. Bull. Fac. Agric. Cairo Univ. 60: 99-105.

Elzenga, J. T. M., L. De Lange \& A. H. Pieterse. 1980. Further indications that ethylene is the gibbosity regulator of the Lemna gibba/Lemna minor complex in natural waters. Acta Bot. Neerl. 29: 225-229.

Emerson, F. W. 1921. Subterranean organs of bog plants. Bot. Gaz. 72: $359-374$.

Emms, S. K. 1993. Andromonoecy in Zigadenus paniculatus (Liliaceae): spatial and temporal patterns of sex allocation. Am. J. Bot. 80: 914-923.
Enders, R. K. 1932. Food of the muskrat in summer. Ohio J. Sci. 32: 21-30.

Enerstvedt, K. H., A. Lundberg \& M. Jordheim. 2017. Characterization of polyphenolic content in the aquatic plants Ruppia cirrhosa and Ruppia maritima - a source of nutritional natural products. Molecules 23(1): 16. doi: 10.3390/molecules23010016.

Engel, S. \& S. A. Nichols. 1994. Aquatic macrophyte growth in a turbid windswept lake. J. Freshw. Ecol. 9: 97-109.

Engelhardt, K. A. M. \& M. E. Ritchie. 2001. Effects of macrophyte species richness on wetland ecosystem functioning and services. Nature 411: 687-689.

Engelhardt, K. A. M. \& M. E. Ritchie. 2002. The effect of aquatic plant species richness on wetland ecosystem processes. Ecology 83: 2911-2924.

Engeman, R. M., T. Guerrant, G. Dunn, S. F. Beckerman \& C. Anchor. 2014. Benefits to rare plants and highway safety from annual population reductions of a "native invader," whitetailed deer, in a Chicago-area woodland. Environ. Sci. Pollut. Res. 21: 1592-1597.

Enser, R. W. \& C. A. Caljouw. 1989. Plant conservation concerns in Rhode Island-a reappraisal. Rhodora 91: 121-130.

Ensign, S. H., C. R. Hupp, G. B. Noe, K. W. Krauss \& C. L. Stagg. 2014. Sediment accretion in tidal freshwater forests and oligohaline marshes of the Waccamaw and Savannah Rivers, USA. Estuaries Coast. 37: 1107-1119.

Epler, J. H. 2016. A new species of Dicrotendipes (Diptera: Chironomidae) from Florida. Zootaxa 4208: 77-83.

Erfanzadeh, R., A. Garbutt, J. Pétillon, J.-P. Maelfait \& M. Hoffmann. 2010. Factors affecting the success of early salt-marsh colonizers: seed availability rather than site suitability and dispersal traits. Plant Ecol. 206: 335-347.

Eriksson, O. \& K. Kainulainen. 2011. The evolutionary ecology of dust seeds. Perspect. Plant Ecol. Evol. Syst. 13: 73-87.

Ernst-Schwarzenbach, M. 1945. Kreuzungsversuche an Hydrocharitaceen. Arch. Julius Klaus Stiftung (Zürich) 20: 22-41.

Ernst-Schwarzenbach, M. 1953. Zur Kompatibilitiit von Art- und Gattungs-Bastardierungen bei Hydrocharitaceae. Oester. Bot. Z. 100: 403-423.

Esau, K. 1977. Anatomy of Seed Plants, 2nd ed. John Wiley \& Sons, New York, NY. 550 pp.

Escher, R. L. \& L. P. Lounibos. 1993. Insect associates of Pistia stratiotes (Arales: Araceae) in southeastern Florida. Florida Entomol. 76: 473-500.

Eshel, A. \& S. Beer. 1986. Inorganic carbon assimilation by Spirodela polyrrhiza. Hydrobiologia 131: 149-153.

Esler, D. 1990. Avian community responses to hydrilla invasion. Wilson Bull. 102: 427-440.

Espinosa-García, F. J., J. L. Villaseñor \& H. Vibrans. 2006. Mexico: biodiversity, distribution, and possible economic impact of exotic weeds. Pp. 43-52 In: T. R. Van Devender, F. J. EspinosaGarcía, B. L. Harper-Lore \& T. Hubbard (eds.), Invasive Plants on the Move: Controlling Them in North America. ArizonaSonora Desert Museum Press, Tucson, AZ.

Essomo, S. E., B. A. Fonge, E. E. Bechem, P. T. Tabot \& B. D. Arrey. 2016. Flowering phenology and reproductive success of the orchids of Mt. Cameroon in relation to a changing environment. Int. J. Curr. Res. Biosci. Plant Biol. 3: 21-35.

Estes, D. \& R. L. Small. 2007. Two new species of Gratiola (Plantaginaceae) from eastern North America and an updated circumscription for Gratiola neglecta. J. Bot. Res. Inst. Texas 1: 149-170.

Eugelink, A. H. 1998. Phosphorus uptake and active growth of Elodea canadensis Michx. and Elodea nuttallii (Planch.) St. John. Water Sci. Technol. 37: 59-65. 
Evans, G. A. 2008. The Whiteflies (Hemiptera: Aleyrodidae) of the World and Their Host Plants and Natural Enemies. Version 2008-09-23. USDA Animal Plant Health Inspection Service (APHIS), Riverdale, MD. 703 pp.

Evans, J. M. 2013. Pistia stratiotes L. in the Florida Peninsula: biogeographic evidence and conservation implications of native tenure for an 'invasive' aquatic plant. Conserv. Soc. 11: 233-246.

Evans, J. M. \& A. C. Wilkie. 2010. Life cycle assessment of nutrient remediation and bioenergy production potential from the harvest of hydrilla (Hydrilla verticillata). J. Environ. Manag. 91: 2626-2631.

Evans, A. S., K. L. Webb \& P. A. Penhale. 1986. Photosynthetic temperature acclimation in two coexisting seagrasses, Zostera marina L. and Ruppia maritima L. Aquat. Bot. 24: 185-197.

Evans, T. M., K. J. Sytsma, R. B. Faden \& T. J. Givnish. 2003. Phylogenetic relationships in the Commelinaceae: II. A cladistic analysis of $r b c L$ sequences and morphology. Syst. Bot. 28: 270-292.

Everett, P. C. 2012. A Second Summary of the Horticulture and Propagation of California Native Plants at the Rancho Santa Ana Botanic Garden, 1950-1970. Version 1.1. Rancho Santa Ana Botanic Garden, Claremont, CA. 514 pp.

Everitt, J. H., D. L. Drawe \& R. I. Lonard. 1999. Field Guide to the Broad-Leaved Herbaceous Plants of South Texas: Used by Livestock and Wildlife. Texas Tech University Press, Lubbock, TX. 277 pp.

Ewanchuk, P. J. \& S. L. Williams. 1996. Survival and re-establishment of vegetative fragments of eelgrass (Zostera marina). Can. J. Bot. 74: 1584-1590.

Ewel, K. C. \& S. Atmosoedirdjo. 1987. Flower and fruit production in three north Florida ecosystems. Florida Sci. 50: 216-222.

Ewing, J. 1924. Plant successions of the brush-prairie in north-western Minnesota. J. Ecol. 12: 238-266.

Expósito, A. B., A. Siverio, L. A. Bermejo \& E. Sobrino-Vesperinas. 2018. Checklist of alien plant species in a natural protected area: Anaga Rural Park (Tenerife, Canary Islands); effect of human infrastructures on their abundance. Plant Ecol. Evol. 151: $142-152$.

Eyjólfssson, R. 1970. Isolation and structure determination of triglochinin, a new cyanogenic glucoside from Triglochin maritimum. Phytochemistry 9: 845-851.

Faber-Langendoen, D. (ed.). 2001. Plant Communities of the Midwest: Classification in an Ecological Context. Association for Biodiversity Information, Arlington, VA. $61 \mathrm{pp}+$ appendix (705 pp).

Fachinetto, J., E. Kaltchuk-Santos, C. D. Inácio, L. Eggers \& T. T. de Souza-Chies. 2018. Multidisciplinary approaches for species delimitation in Sisyrinchium (Iridaceae). Plant Species Biol. 33: 3-15.

Faden, R. B. 1998. Commelinaceae. Pp. 109-128 In: K. Kubitzki, H. Huber, P. J. Rudall, P. S. Stevens \& T. Stützel (eds.), The Families and Genera of Vascular Plants, Vol. IV. Flowering Plants, Monocotyledons: Alismatanae and Commelinanae (Except Gramineae). Springer-Verlag, Berlin, Germany.

Faden, R. B. 2000a. Commelinaceae R. Brown. Spiderwort family. Pp. 170-197 In: Flora North America Editorial Committee (eds.), Flora of North America North of Mexico, Vol. 22: Magnoliophyta: Alismatidae, Arecidae, Commelinidae (in Part), and Zingiberidae. Oxford University Press, New York, NY.

Faden, R. B. 2000b. Mayacaceae Kunth. Mayaca or bog-moss family. Pp. 168-169 In: Flora North America Editorial Committee (eds.), Flora of North America North of
Mexico, Vol. 22: Magnoliophyta: Alismatidae, Arecidae, Commelinidae (in Part), and Zingiberidae. Oxford University Press, New York, NY.

Fagúndez, G. A. \& M. A. Caccavari. 2006. Pollen analysis of honeys from the central zone of the Argentine province of Entre Ríos. Grana 45: 305-320.

Fahn, A. 1982. Plant Anatomy, 3rd ed. Pergamon Press, New York, NY. 544 pp.

Fairman, C. E. 1918. New or noteworthy ascomycetes and lower fungi from New Mexico. Mycologia 10: 239-264.

Fang, Y. Y., O. Babourina, Z. Rengel, X. E. Yang \& P. M. Pu. 2007. Ammonium and nitrate uptake by the floating plant Landoltia punctata. Ann. Bot. 99: 365-370.

Farmer, J. A., E. B. Webb, R. A. Pierce \& K. W. Bradley. 2017. Evaluating the potential for weed seed dispersal based on waterfowl consumption and seed viability. Pest Manag. Sci. 73: 2592-2603.

Farney, R. A. \& T. A. Bookhout. 1982. Vegetation changes in a Lake Erie marsh (Winous Point, Ottawa County, Ohio) during high water years. Ohio J. Sci. 82: 103-107.

Farrell, J. M., B. A. Murry, D. J. Leopold, A. Halpern, M. B. Rippke, K. S. Godwin \& S. D. Hafner. 2010. Water-level regulation and coastal wetland vegetation in the upper St. Lawrence River: inferences from historical aerial imagery, seed banks, and Typha dynamics. Hydrobiologia 647: 127-144.

Fasakin, E. A., A. M. Balogun \& B. E. Fasuru. 1999. Use of duckweed, Spirodela polyrrhiza L. Schleiden, as a protein feedstuff in practical diets for tilapia, Oreochromis niloticus L. Aquacult. Res. 30: 313-318.

Fassett, N. C. 1955. Echinodorus in the American tropics. Rhodora 57: $133-156$.

Fassett, N. C. 1957. A Manual of Aquatic Plants. With Revision Appendix by E. C. Ogden. The University of Wisconsin Press, Madison, WI. 405 pp.

Fassett, N. C. \& B. Calhoun. 1952. Introgression between Typha latifolia and T. angustifolia. Evolution 6: 367-379.

Faust, M. \& J. A. Harrington. 2016. Pilot study: limitations to pollination and ovary development in the small white lady's-slipper (Cypripedium candidum). N. Am. Prairie Conf. Proc. 11: 96-103.

Favre-Bac, L., B. Lamberti-Raverot, S. Puijalon, A. Ernoult, F. Burel, L. Guillard \& C. Mony. 2017. Plant dispersal traits determine hydrochorous species tolerance to connectivity loss at the landscape scale. J. Veg. Sci. 28: 605-615.

Fehr, A. W. 1989. Environmental factors limiting success of revegetation on man-made waterfowl nesting islands in east-central Alberta. Ph.D. dissertation. University of British Columbia, Vancouver, BC. 192 pp.

Feijoó, C. S. \& R. J. Lombardo. 2007. Baseline water quality and macrophyte assemblages in Pampean streams: a regional approach. Water Res. 41: 1399-1410.

Feinstein, L. 1952. Insecticides from plants. Pp. 222-229 In: F. C. Bishopp, G. J. Haeussler, H. L. Haller, W. L. Popham, B. A. Porter, E. R. Sasscer and J. S. Wade (eds.), Insects. The Yearbook of Agriculture 1952. Superintendent of Documents, Washington, DC.

Feitoza, L. L., L. P. Felix, A. A. J. F. Castro \& R. Carvalho. 2009. Cytogenetics of Alismatales ss: chromosomal evolution and C-banding. Plant Syst. Evol. 280: 119-131.

Felger, R. \& M. B. Moser. 1973. Eelgrass (Zostera marina L.) in the Gulf of California. Science 181: 355-356.

Felix, L. P. \& M. Guerra. 1998. Cytogenetic studies on species of Habenaria (Orchidoideae: Orchidaceae) occurring in the northeast of Brazil. Lindleyana 13: 224-230. 
Felix, L. P. \& M. Guerra. 2005. Basic chromosome numbers of terrestrial orchids. Plant Syst. Evol. 254: 131-148.

Felix, L. P. \& M. Guerra. 2010. Variation in chromosome number and the basic number of subfamily Epidendroideae (Orchidaceae). Bot. J. Linn. Soc. 163: 234-278.

Fell, E. W. 1957. Plants of a northern Illinois sand deposit. Am. Midl. Nat. 58: 441-451.

Fell, P. E., R. S. Warren, J. K. Light, R. L. Rawson \& S. M. Fairley. 2003. Comparison of fish and macroinvertebrate use of Typha angustifolia, Phragmites australis, and treated Phragmites marshes along the lower Connecticut River. Estuaries 26: 534-551.

Fennell, C. W. \& J. Van Staden. 2001. Crinum species in traditional and modern medicine. J. Ethnopharmacol. 78: 15-26.

Ferasol, J., L. Lovett Doust, J. Lovett Doust \& M. Biernacki. 1995. Seed germination in Vallisneria americana: effects of cold stratification, scarification, seed coat morphology and PCB concentration. Ecoscience 2: 368-376.

Ferguson, E. \& R. P. Wunderlin. 2006. A vascular plant inventory of Starkey Wilderness Preserve, Pasco County, Florida. Sida 22: 635-659.

Ferguson, R. L., B. T. Pawlak \& L. L. Wood. 1993. Flowering of the seagrass Halodule wrightii in North Carolina, USA. Aquat. Bot. 46: 91-98.

Fernald, M. L. 1907. The soil preferences of certain alpine and subalpine plants. Rhodora 9: 149-193.

Fernald, M. L. 1911. A botanical expedition to Newfoundland and southern Labrador. Contr. Gray Herb. Harvard Univ. 40: 109-162.

Fernald, M. L. 1923a. Notes on the distribution of Najas in northeastern America. Rhodora 25: 105-109.

Fernald, M. L. 1923b. The American variety of Scheuchzeria palustris. Rhodora 25: 177-179.

Fernald, M. L. 1932. The linear-leaved North American species of Potamogeton section Axillares. Memoirs of the Gray Herbarium of Harvard University III. Mem. Am. Acad. Arts Sci. 17: 1-183.

Fernald, M. L. 1939. Last survivors in the flora of tidewater Virginia (continued). Rhodora 41: 529-559.

Fernald, M. L. 1941. Elatine americana and E. triandra. Rhodora 43: 208-211.

Fernald, M. L. 1946. The North American representatives of Alisma plantago-aquatica. Rhodora 48: 86-88.

Fernald, M. L. \& K. M. Wiegand. 1914. The genus Ruppia in eastern North America. Rhodora 16: 119-127.

Fernald, M. L. \& A. C. Kinsey. 1943. Edible Wild Plants of Eastern North America. Idlewild Press, Cornwall-On-Hudson, New York, NY. 452 pp.

Fernández-Pascual, E., B. Jiménez-Alfaro \& T. E. Díaz. 2013. The temperature dimension of the seed germination niche in fen wetlands. Plant Ecol. 214: 489-499.

Fernando, D. D. \& D. D. Cass. 1996. Genotypic differentiation in Butomus umbellatus (Butomaceae) using isozymes and random amplified polymorphic DNAs. Can. J. Bot. 74: 647-652.

Ferren, Jr., W. R. 1973. Range extensions of Sagittaria montevidensis in the Delaware River system. Bartonia 42: 1-4.

Ferren, Jr., W. R. \& A. E. Schuyler. 1980. Intertidal vascular plants of river systems near Philadelphia. Proc. Acad. Nat. Sci. Philadelphia 132: 86-120.

Ferren, Jr., W. R., R. E. Good, R. Walker \& J. Arsenault. 1981. Vegetation and flora of Hog Island, a brackish wetland in the Mullica River, New Jersey. Bartonia 48: 1-10.

Feuchtmayr, H., R. Moran, K. Hatton, L. Connor, T. Heyes, B. Moss, I. Harvey \& D. Atkinson. 2009. Global warming and eutrophication: effects on water chemistry and autotrophic communities in experimental hypertrophic shallow lake mesocosms. $J$. Appl. Ecol. 46: 713-723.
Fiala, K. 1978. Underground organs of Typha angustifolia and Typha latifolia, their growth, propagation and production. Acta Sci. Nat. Acad. Sci. Bohem. Brno 12: 1-43.

Fields, J. R., T. R. Simpson, R. W. Manning \& F. L. Rose. 2003. Food habits and selective foraging by the Texas river cooter (Pseudemys texana) in Spring Lake, Hays County, Texas. J. Herpetol. 37: 726-729.

Figuerola, J. \& A. J. Green. 2002. Dispersal of aquatic organisms by waterbirds: a review of past research and priorities for future studies. Freshw. Biol. 47: 483-494.

Figuerola, J. \& A. J. Green. 2004. Effects of seed ingestion and herbivory by waterfowl on seedling establishment: a field experiment with wigeongrass Ruppia maritima in Doñana, south-west Spain. Plant Ecol. 173: 33-38.

Firmage, D. H. \& F. R. Cole. 1988. Reproductive success and inflorescence size of Calopogon tuberosus (Orchidaceae). Am. J. Bot. 75: 1371-1377.

Fishbein, M., D. Gori \& D. Meggs. 1999. Prescribed burning as a management tool for Sky Island bioregion wetlands with reference to the management of the endangered orchid Spiranthes delitescens. Pp. 468-477 In: L. F. DeBano (ed.), Biodiversity and the Management of the Madrean Archipelago: The Sky Islands of Southwestern United States and Northwestern Mexico. Gen. Tech. Rep. RM-GTR-264. U.S. Department of Agriculture, Forest Service, Rocky Mountain Forest and Range Experiment Station, Fort Collins, CO.

Fisher, R. A. 1936. The use of multiple measurements in taxonomic problems. Ann. Eugen. 7: 179-188.

Fisher, J. B. \& K. Jayachandran. 2005. Presence of arbuscular mycorrhizal fungi in South Florida native plants. Mycorrhiza 15: $580-588$.

Fishman, J. R. \& R. J. Orth. 1996. Effects of predation on Zostera marina L. seed abundance. J. Exp. Mar. Biol. Ecol. 198: 11-26.

Fleming, R. C. 1970. Food plants of some adult sphinx moths (Lepidoptera: Sphingidae). Great Lakes Entomol. 3: 17-23.

Fleming, G. P. \& N. E. Van Alstine. 1999. Plant communities and floristic features of sinkhole ponds and seepage wetlands in southeastern Augusta County, Virginia. Banisteria 13: 67-94.

Fleming, J. P., J. D. Madsen \& E. D. Dibble. 2011. Macrophyte reestablishment for fish habitat in Little Bear Creek Reservoir, Alabama, USA. J. Freshw. Ecol. 26: 105-114.

Flensburg, T. \& J. H. Sparling. 1973. The algal microflora of a string mire in relation to the chemical composition of water. Can. J. Bot. 51: 743-749.

Flinn, K. M., M. J. Lechowicz \& M. J. Waterway. 2008. Plant species diversity and composition of wetlands within an upland forest. Am. J. Bot. 95: 1216-1224.

Flint, L. H. 1943. Note on the germination of seeds of the spider lily (Hymenocallis occidentalis). Louisiana Acad. Sci. 7: 20-23.

Flint, L. H. \& C. F. Moreland. 1943. Note on photosynthetic activity in seeds of the spider lily. Am. J. Bot. 30: 315-317.

Flint, N. A. \& J. D. Madsen. 1995. The effect of temperature and daylength on the germination of Potamogeton nodosus tubers. J. Freshw. Ecol. 10: 125-128.

Floden, A. J. \& E. E. Schilling. 2018. Trautvetteria fonticalcarea (Ranunculaceae: Ranunculeae), a new tassel rue species endemic to calcareous seepage habitats in Tennessee, USA. Nordic J. Bot. 36: e01738.

Flory, W. S. 1976. Distribution, chromosome numbers and types of various species and taxa of Hymenocallis. Nucleus 19: 204-227.

Floyd, R. H., S. Ferrazzano, B. W. Josey, A. L. Garey \& J. R. Applegate. 2018. Helonias bullata (swamp pink) habitat characteristics under different landscape settings at Fort AP Hill, Virginia. Southeast. Nat. 17: 484-512. 
FNA. 2000. Flora of North America Editorial Committee (eds.), Flora of North America North of Mexico, Vol. 22: Magnoliophyta: Alismatidae Arecidae, Commelinidae (in Part), and Zingiberidae. Oxford University Press, New York, NY. 352 pp.

FNA. 2003. Flora of North America Editorial Committee (eds.), Flora of North America North of Mexico, Vol. 26: Magnoliophyta: Liliidae: Liliales and Orchidales. Oxford University Press, New York, NY. 723 pp.

Foerste, A. F. 1883. Plants of Belle Isle, Michigan. Bot. Gaz. 8: 202-203.

Folsom, J. P. 1984. A reinterpretation of the status of relationships of taxa of the yellow-fringed orchid complex. Orquidea 9: 320-345.

Fonseca, M. S. \& J. A. Cahalan. 1992. A preliminary evaluation of wave attenuation by four species of seagrass. Estuar. Coast. Shelf Sci. 35: 565-576.

Fonseca, M. S., J. C. Zieman, G. W. Thayer \& J. S. Fisher. 1983. The role of current velocity in structuring eelgrass (Zostera marina L.) meadows. Estuar. Coast. Shelf Sci. 17: 367-380.

Fonseca, M. S., W. J. Kenworthy, K. M. Cheap, C. A. Currin \& G. W. Thayer. 1984. A low-cost transplanting technique for shoalgrass (Halodule wrightii) and manatee grass (Syringodium filiforme). Final report. Instruction Report EL-84-1. U.S. Army Engineer Waterways Experiment Station, Vicksburg, MS. 16 pp.

Forbes, H. C., W. R. Ferren, Jr. \& J. R. Haller. 1988. The vegetation and flora of Fish Slough and vicinity, Inyo and Mono Counties, California. Pp. 99-138 In: C. Hall and V. Doyle-Jones (eds.), Plant Biology of Eastern California. University of California, Los Angeles, CA.

Forbes, M. R. L., H. P. Barkhouse \& P. C. Smith. 1989. Nest-site selection by Pied-billed Grebes Podilymbus podiceps. Ornis Scand. 20: 211-218.

Ford, B. A. \& P. W. Ball. 1988. A reevaluation of the Triglochin maritimum complex (Juncaginaceae) in eastern and central North America and Europe. Rhodora 90: 313-337.

Forest, H. S. 1977. Study of submerged aquatic vascular plants in northern glacial lakes (New York State, USA). Folia Geobot. Phytotax. 12: 329-341.

Forrest, A. D., M. L. Hollingsworth, P. M. Hollingsworth, C. Sydes \& R. M. Bateman. 2004. Population genetic structure in European populations of Spiranthes romanzoffiana set in the context of other genetic studies on orchids. Heredity 92: 218-227.

Fournier, M. A. \& J. E. Hines. 2001. Breeding ecology of sympatric greater and lesser scaup (Aythya marila and Aythya affinis) in the subarctic Northwest Territories. Arctic 54: 444-456.

Forni-Martins, E. R. \& K. P. Calligaris. 2002. Chromosomal studies on Neotropical Limnocharitaceae (Alismatales). Aquat. Bot. 74: $33-41$.

Fortner, S. L. \& D. S. White. 1988. Interstitial water patterns: a factor influencing the distributions of some lotic aquatic vascular macrophytes. Aquat. Bot. 31: 1-12.

Foster, R. C. 1945. Studies in the Iridaceae, III. Contr. Gray Herb. 155: 3-54.

Foster, C. H., G. D. Renaud \& K. L. Hays. 1973. Some effects of the environment on oviposition by Chrysops (Diptera: Tabanidae). Environ. Entomol. 2: 1048-1050.

Fourqurean, J. W., G. V. N. Powell, W. J. Kenworthy \& J. C. Zieman. 1995. The effects of long-term manipulation of nutrient supply on competition between the seagrasses Thalassia testudinum and Halodule wrightii in Florida Bay. Oikos 72: 349-358.

Fourqurean, J. W., A. Willsie, C. D. Rose \& L. M. Rutten. 2001. Spatial and temporal pattern in seagrass community composition and productivity in south Florida. Mar. Biol. 138: 341-354.
Fowler, J. A. 2005. Wild Orchids of South Carolina: A Popular Natural History. University of South Carolina Press, Columbia, SC. 242 pp.

Fox, C. H., R. El-Sabaawi, P. C. Paquet \& T. E. Reimchen. 2014. Pacific herring Clupea pallasii and wrack macrophytes subsidize semi-terrestrial detritivores. Mar. Ecol. Prog. Ser. 495 : 49-64.

Fox, C. H., P. C. Paquet \& T. E. Reimchen. 2018. Pacific herring spawn events influence nearshore subtidal and intertidal species. Mar. Ecol. Prog. Ser. 595: 157-169.

França, G. M. de O., F. Melo, C. M. Pereira, G. A. Faria, F. V. S. T. de Melo \& J. G. dos Santos. 2009. Nutritional value of Lemna valdiviana Phil (Araceae) submitted to different concentrations of fertilization with excrement of birds. Biotemas 22: 19-26.

France, R. L. \& P. M. Stokes. 1988. Isoetid-zoobenthos associations in acid-sensitive lakes in Ontario, Canada. Aquat. Bot. 32: 99-114.

Francis, A. W., I. C. Stocks, T. R. Smith, A. J. Boughton, C. M. Mannion \& L. S. Osborne. 2016. Host plants and natural enemies of rugose spiraling whitefly (Hemiptera: Aleyrodidae) in Florida. Florida Entomol. 99: 150-153.

Francois, R., F. T. Short \& J. H. Weber. 1989. Accumulation and persistence of tributyltin in eelgrass (Zostera marina L.) tissue. Environ. Sci. Technol. 23: 191-196.

Frank, P. A. 1966. Dormancy in winter buds of American pondweed, Potamogeton nodosus Poir. J. Exp. Bot. 17: 546-555.

Frankovich, T. A., E. E. Gaiser, J. C. Zieman \& A. H. Wachnicka. 2006. Spatial and temporal distributions of epiphytic diatoms growing on Thalassia testudinum Banks ex König: relationships to water quality. Hydrobiologia 569: 259-271.

Fraser, D. \& H. Hristienko. 1983. Effects of moose, Alces alces, on aquatic vegetation in Sibley Provincial Park, Ontario. Can. Field-Nat. 97: 57-61.

Fraser, D., D. Arthur, J. K. Morton \& B. K. Thompson. 1980. Aquatic feeding by moose Alces alces in a Canadian lake. Ecography 3: $218-223$.

Fraser, D., B. K. Thompson \& D. Arthur. 1982. Aquatic feeding by moose: seasonal variation in relation to plant chemical composition and use of mineral licks. Can. J. Zool. 60: 3121-3126.

Fraser, D., E. R. Chavez \& J. E. Palohelmo. 1984. Aquatic feeding by moose: selection of plant species and feeding areas in relation to plant chemical composition and characteristics of lakes. Can. J. Zool. 62: 80-87.

Fraser, L. H., K. Mulac \& F. B.-G. Moore. 2014. Germination of 14 freshwater wetland plants as affected by oxygen and light. Aquat. Bot. 114: 29-34.

Freedman, R. L. 1976. Native North American food preparation techniques. Bol. Bibliogr. Antropol. Am. 38: 101-159.

Freeland, J., C. Ciotir \& H. Kirk. 2013. Regional differences in the abundance of native, introduced, and hybrid Typha spp. in northeastern North America influence wetland invasions. Biol. Invasions 15: 2651-2665.

Freeman, C. W. \& R. A. Urban. 2012. Sediment oxidation capabilities of four submersed aquatic macrophytes. J. Freshw. Ecol. 27: 259-271.

French, J. C., M. G. Chung \& Y. K. Hur. 1995. Chloroplast DNA phylogeny of the Ariflorae. Pp. 255-275 In: P. J. Rudall, P. J. Cribb, D. F. Cutler \& C. J. Humphries (eds.), Monocotyledons: Systematics and Evolution. Royal Botanic Gardens, Kew, United Kingdom.

Freudenstein, J. V. \& F. N. Rasmussen. 1997. Sectile pollinia and relationships in the Orchidaceae. Plant Syst. Evol. 205: 125-146.

Friar, E., M. Falk \& D. W. Mount. 1996. Use of random amplified polymorphic DNA (RAPD) markers for genetic analysis of Lilium parryi, a rare Arizona plant. Pp. 86-91 In: J. Maschinski, 
J., H. D. Hammond \& L. Holter (eds.), Southwestern Rare and Endangered Plants: Proceedings of the Second Conference. General Technical Report RM-GTR-283. USDA Forest Service, Rocky Mountain Forest and Range Experiment Station, Fort Collins, CO.

Frick, H. 1994. Heterotrophy in the Lemnaceae. J. Plant Physiol. 144: 189-193.

Friedman, M. 2013. Thyroid autoimmune disease. J. Restorative Med. 2: 70-81.

Friesen, N., R. M. Fritsch \& F. R. Blattner. 2006. Phylogeny and new intrageneric classification of Allium (Alliaceae) based on nuclear ribosomal DNA ITS sequences. Aliso 22: 372-395.

Frodge, J. D., G. L. Thomas \& G. B. Pauley. 1990. Effects of canopy formation by floating and submergent aquatic macrophytes on the water quality of two shallow Pacific Northwest lakes. Aquat. Bot. 38: 231-248.

Froehlich, S. 2019. Blue-eyed grass. NatureNorth.com. Available online: http://www.naturenorth.com/spring/flora/begrass/ Blue-eyed_Grass.html [accessed 9 February, 2019].

From, M. M. 2007. Drought, peril, and survival in the Great Plains: Cypripedium candidum. North Am. Native Orchid J. 13: 66-74.

Frost, C. C. 1980. State record for Potamogeton confervoides in South Carolina. Castanea 45: 146-147.

Frost, C. C. 1995. Presettlement fire regimes in southeastern marshes, peatlands, and swamps. Pp. 39-60 In: S. I. Cerulean \& R. T. Engstrom (eds.), Fire in Wetlands: A Management Perspective. Proceedings of the Tall Timbers Fire Ecology Conference, No. 19. Tall Timbers Research Station, Tallahassee, FL.

Frost, C. C. \& L. J. Musselman. 1987. History and vegetation of the Blackwater Ecologic Preserve. Castanea 52: 16-46.

Frost, P. C. \& A. L. Hicks. 2012. Human shoreline development and the nutrient stoichiometry of aquatic plant communities in Canadian Shield lakes. Can. J. Fish. Aquat. Sci. 69: 1642-1650.

Frost-Christensen, H. \& K. Sand-Jensen. 1995. Comparative kinetics of photosynthesis in floating and submerged Potamogeton leaves. Aquat. Bot. 51: 121-134.

Fruet, A. C., L. N. Seito, V. L. M. Rall \& L. C. Di Stasi. 2012. Dietary intervention with narrow-leaved cattail rhizome flour (Typha angustifolia $\mathrm{L}$.) prevents intestinal inflammation in the trinitrobenzenesulphonic acid model of rat colitis. BMC Complement. Altern. Med. 12: 62.

Fry, B. 1983. Leaf growth in the seagrass Syringodium filiforme Kütz. Aquat. Bot. 16: 361-368.

Fry, B. \& R. W. Virnstein. 1988. Leaf production and export of the seagrass Syringodium filiforme Kütz. In Indian river Lagoon, Florida. Aquat. Bot. 30: 261-266.

Fryer, A., A. Bennett \& A. H. Evans. 1915. The Potamogetons (Pond Weeds) of the British Isles, with Descriptions of all the Species, Varieties and Hybrids. L. Reeve \& Co., Ltd., Ashford, Kent. 94 pp [+ 60 plates].

Fryxell, P. A. 1957. Mode of reproduction of higher plants. Bot. Rev. 23: $135-233$.

Fu, L., M. Huang, B. Han, X. Sun, K. S. Sree, K.-J. Appenroth \& J. Zhang. 2017. Flower induction, microscope-aided cross-pollination, and seed production in the duckweed Lemna gibba with discovery of a male-sterile clone. Sci. Rep. 7: 3047.

Fuentes, T. L. 2007. Collection history of Platanthera chorisiana (Orchiddaceae) in Washington State. Madroño 54: 164-167.

Fujita, K. \& P. Hallock. 1999. A comparison of phytal substrate preferences of Archaias angulatus and Sorites orbiculus in mixed macroalgal-seagrass beds in Florida Bay. J. Foraminiferal Res. 29: 143-151.

Fujita, M., K. Mori \& T. Kodera. 1999. Nutrient removal and starch production through cultivation of Wolffia arrhiza. J. Biosci. Bioeng. 87: 194-198.
Fujiwara, A., S. Matsuhashi, H. Doi, S. Yamamoto \& T. Minamoto. 2016. Use of environmental DNA to survey the distribution of an invasive submerged plant in ponds. Freshw. Sci. 35: 748-754.

Fulmer, J. E. \& A. T. Robinson. 2008. Aquatic plant species distributions and associations in Arizona's reservoirs. J. Aquat. Plant Manag. 46: 100-106.

Funderburk, J., L. Mound \& J. Sharma. 2007. Thysanoptera inhabiting native terrestrial orchids in northern Florida and southern Georgia. J. Entomol. Sci. 42: 573-581.

Funston, F. 1896. Botany of Yakutat Bay, Alaska. I. Field report. Contr. U.S. Natl. Herb. 3: 325-333.

Furlow, B. M. \& K. L. Hays. 1972. Some influences of aquatic vegetation on the species and number of Culicidae (Diptera) in small pools of water. Mosquito News 32: 595-599.

Fuse, S. \& M. N. Tamura. 2000. A phylogenetic analysis of the plastid $m a t K$ gene with emphasis on Melanthiaceae sensu lato. Plant Biol. 2: 415-427.

Fuse, S. \& M. N. Tamura. 2016. Biosystematic studies on the genus Heloniopsis (Melanthiaceae) I. Phylogeny inferred from plastid DNA sequences and taxonomic implications. Nordic J. Bot. 34: 584-595.

Fuse, S., N. S. Lee \& M. N. Tamura. 2012. Biosystematic studies on the family Nartheciaceae (Dioscoreales) I. Phylogenetic relationships, character evolution and taxonomic re-examination. Plant Syst. Evol. 298: 1575-1584.

Futyma, R. P. \& N. G. Miller. 2001. Postglacial history of a marl fen: vegetational stability at Byron-Bergen Swamp, New York. Can. J. Bot. 79: 1425-1438.

Fyson, A. 2000. Angiosperms in acidic waters at pH 3 and below. Hydrobiologia 433: 129-135.

Gabela, F. J. A. 1974. Biology of mudplantain (Heteranthera reniformis Ruiz et Pavon) and its control in flooded rice. M.S. thesis. Oregon State University, Corvallis, OR. 212 pp.

Gabriel, B. C. \& A. A. de la Cruz. 1974. Species composition, standing stock, and net primary production of a salt marsh community in Mississippi. Chesapeake Sci. 15: 72-77.

Gabriel, C., D. W. Kerstetter \& A. C. Hirons. 2015. Trophic linkages of Intracoastal Waterway seagrass beds in Broward County, Florida. Florida Sci. 78: 156-166.

Gaddy, L. L. 1982. The floristics of three South Carolina pine savannahs. Castanea 47: 393-402.

Galán Demera, A. \& E. De Castro. 2003. Heteranthera Ruiz \& Pav. (Pontederiaceae) en la Península Ibérica. An. Jard. Bot. Madr. 60: $241-242$.

Galatowitsch, S. M. \& A. G. van der Valk. 1996. The vegetation of restored and natural prairie wetlands. Ecol. Appl. 6: 102-112.

Galatowitsch, S. M. \& L. A. Biederman. 1998. Vegetation and seedbank composition of temporarily flooded Carex meadows and implications for restoration. Int. J. Ecol. Environ. Sci. 24: 253-270.

Gallardo-Williams, M. T., V. A. Whalen, R. F. Benson \& D. F. Martin. 2002. Accumulation and retention of lead by cattail (Typha domingensis), hydrilla (Hydrilla verticillata), and duckweed (Lemna obscura). J. Environ. Sci. Health 37: 1399-1408.

Gallegos, M., M. Menno, A. Rodriguez, N. Marba \& C. M. Duarte. 1994. Growth patterns and demography of pioneer Caribbean seagrasses (Halodule wrightii and Syringodium filiforme). Mar. Ecol. Prog. Ser. 109: 99-104.

Gallon, C., C. Munger, S. Prémont \& P. G. C. Campbell. 2004. Hydroponic study of aluminum accumulation by aquatic plants: effects of fluoride and pH. Water Air Soil Pollut. 153: 135-155.

Gama, L. R., C. Domit, M. K. Broadhurst, M. M. P. B. Fuentes \& R. B. Millar. 2016. Green turtle Chelonia mydas foraging ecology at $25^{\circ} \mathrm{S}$ in the western Atlantic: evidence to support a feeding model driven by intrinsic and extrinsic variability. Mar. Ecol. Prog. Ser. 542: 209-219. 
Gandhi, K. N., J. H. Wiersema \& L. Brouillet. 2012. Validation of the name Wolffia borealis (Lemnaceae). Harvard Pap. Bot. 17: $47-50$.

Ganie, A. H., Z. A. Reshi \& B. A. Wafai. 2016. Reproductive ecology of Potamogeton pectinatus L. (= Stuckenia pectinata (L.) Börner) in relation to its spread and abundance in freshwater ecosystems of the Kashmir Valley, India. Trop. Ecol. 57: 787-803.

Ganter, B. 2000. Seagrass (Zostera spp.) as food for brent geese (Branta bernicla): an overview. Helgoland Mar. Res. 54: 63-70.

Gao, L., N. Liu, B. Huang \& X. Hu. 2008. Phylogenetic analysis and genetic mapping of Chinese Hedychium using SRAP markers. Sci. Hort. 117: 369-377.

García, K. L. G., O. V. Iglesias, A. Laguna, M. D. Martínez \& J. A. G. Lavaut. 2011. Efecto antioxidante y contenido polifenólico de Syringodium filiforme (Cymodoceaceae). Revista Biol. Trop. 59: 465-472.

García, K. L. G., M. Rodríguez, Á. Concepción, O. Valdés, J. G. Marrero, M. Macías-Alonso, O. Valdés-Iglesias, Y. H. Rivera, A. Fagundo, I. Rodeiro \& R. G. Cuesta. 2017. Phytochemical profile and evaluation of photoprotective potential of Syringodium filiforme Kützing. Biotecnia 19: 18-22.

García, T. E., R. Menéndez, F. Rivera, A. Garateix, R. A. Morales, E. Regalado, J. C. Rodríguez \& F. Dajas. 2017. Neuroprotective effects of Thalassia testudinum leaf extract BM-21 on focal ischemia in rats. J. Pharm. Pharmacogn. Res. 5: 174-186.

Garcias-Bonet, N., T. D. Sherman, C. M. Duarte \& N. Marbà. 2011. Distribution and pathogenicity of the protist Labyrinthula sp. in western Mediterranean seagrass meadows. Estuaries Coast. 34: 1161. doi: 10.1007/s12237-011-9416-4.

Garland, M. A., G. L. Smith \& P. J. Anderson. 2013. The spider lilies (Hymenocallis) native to Florida. Botany Circular No. 39. FDACS-P-01843. Florida Department of Agriculture and Consumer Services, Division of Plant Industry, Gainesville, FL. 5 pp.

Garner, K. M. 1963. Some new nutria foods. J. Mammal. 44: 261.

Garon-Labrecque, M.-È., É. Léveillé-Bourret, K. Higgins \& O. Sonnentag. 2016. Additions to the boreal flora of the Northwest Territories with a preliminary vascular flora of Scotty Creek. Can. Field-Nat. 129: 349-367.

Garrote-Moreno, A., A. McDonald, T. D. Sherman, J. L. SánchezLizaso, K. L. Heck \& J. Cebrian. 2015. Short-term impacts of salinity pulses on ionic ratios of the seagrasses Thalassia testudinum and Halodule wrightii. Aquat. Bot. 120: 315-321.

Garvin, E. M., C. F. Bridge \& M. S. Garvin. 2018. Edible wild plants growing in contaminated floodplains: implications for the issuance of tribal consumption advisories within the Grand Lake watershed of northeastern Oklahoma, USA. Environ. Geochem. Health 40: 999-1025.

Gaskin, J. F., M. L. Pokorny \& J. M. Mangold. 2016. An unusual case of seed dispersal in an invasive aquatic; yellow flag iris (Iris pseudacorus). Biol. Invasions 18: 2067-2075.

Gates, F. C. 1910. The plant associations of the recent and fossil beaches of Lake Michigan, between Kenosha, Wisconsin and Waukegan, Illinois. B.A. thesis. University of Illinois, UrbanaChampaign, IL. 97 pp.

Gates, F. C. 1911. A bog in central Illinois. Torreya 11: 205-211.

Gavin, N. M. \& M. J. Durako. 2011. Localization and antioxidant capacity of flavonoids from intertidal and subtidal Halophila johnsonii and Halophila decipiens. Aquat. Bot. 95: 242-247.

Gavin, N. M. \& M. J. Durako. 2012. Localization and antioxidant capacity of flavonoids in Halophila johnsonii in response to experimental light and salinity variation. J. Exp. Mar. Biol. Ecol. 416: 32-40.
Gavin, N. M. \& M. J. Durako. 2014. Population-based variation in resilience to hyposalinity stress in Halophila johnsonii. Bul. Mar. Sci. 90: 781-794.

Ge, X., J. Liu \& R. Wang. 2013. Effects of flooding on the germination of seed banks in the Nansi Lake wetlands, China. $J$. Freshw. Ecol. 28: 225-237.

Gehrs, C. W. 1974. Horizontal distribution and abundance of Diaptomus clavipes Schacht in relation to Potamogeton foliosus in a pond and under experimental conditions. Limnol. Oceanogr. 19: 100-104.

Geiger, D. R. \& M. G. Banker. 2012. Resolution of sweet flag species identity provides basis for managing contrasting impacts of native and introduced sweet flag in North American ecosystems. Ecol. Restor. 30: 160-162.

Genaust, H. 1999. Calla--an enigmatic aroid taxon and its etymological solution. Aroideana 22: 7-9.

George, C. J., C. W. Boylen \& R. B. Sheldon. 1977. The presence of the red-spotted newt, Notophthalmus viridescens Rafinesque (Amphibia, Urodela, Salamandridae), in waters exceeding 12 meters in Lake George, New York. J. Herpetol. 11: 87-90.

Gerloff, G. C. \& P. H. Krombholz. 1966. Tissue analysis as a measure of nutrient availability for the growth of angiosperm aquatic plants. Limnol. Oceanogr. 11: 529-537.

Gerritsen, J. \& H. S. Greening. 1989. Marsh seed banks of the Okefenokee swamp: effects of hydrologic regime and nutrients. Ecology 70: 750-763.

Gesti, J., A. Badosa \& X. D. Quintana. 2005. Reproductive potential in Ruppia cirrhosa (Petagna) Grande in response to water permanence. Aquat. Bot. 81: 191-198.

Gettys, L. A. \& D. S. Wofford. 2007. Inheritance of flower color in pickerelweed (Pontederia cordata L.). J. Hered. 98: 629-632.

Gettys, L. A. \& R. K. Dumroese. 2009. Optimum storage and germination conditions for seeds of pickerelweed (Pontederia cordata L.) from Florida. Native Plant J. 10: 4-12.

Gettys, L. A. \& K. A. Moore. 2018. Greenhouse culture and production of four ornamental native wetland plants. HortTechnology 28: $332-336$.

Getz, L. L. 1959. Notes on the ecology of slugs: Arion circumscriptus, Deroceras reticulatum, and D. laeve. Am. Midl. Nat. 61: 485-498.

Getz, L. L. 1961. Factors influencing the local distribution of shrews. Am. Midl. Nat. 65: 67-88.

Ghimire, B. K., C. Y. Yu, H. J. Kim \& I. M. Chung. 2012. Karyotype and nucleic acid content in Zantedeschia aethiopica Spr. and Zantedeschia elliottiana Engl. Afr. J. Biotechnol. 11: 11604-11609.

Giardelli, M. L. 1935. Las flores de Wolffiella oblonga. Revista Argent. Agron. 2: 17-20.

Gibemau, M. 2011. Pollinators and visitors of aroid inflorescences: an addendum. Aroideana 34: 70-83.

Gibernau, M. 2003. Pollinators and visitors of aroid inflorescences. Aroideana 26: 73-91.

Gibernau, M. 2016. Pollinators and visitors of Aroid inflorescences III-phylogenetic \& chemical insights. Aroideana 39: 4-22.

Gibson, G. D. \& F.-S. Chia. 1989. Description of a new species of Haminoea, Haminoea callidegenita (Mollusca: Opisthobranchia), with a comparison with two other Haminoea species found in the northeast Pacific. Can. J. Zool. 67: 914-922.

Gibson, C. M., L. E. Chasmer, D. K. Thompson, W. L. Quinton, M. D. Flannigan \& D. Olefeldt. 2018. Wildfire as a major driver of recent permafrost thaw in boreal peatlands. Nat. Commun. 9: 3041 .

Gifford, J. 1893. Indian relics in south Jersey. Science 552: 113-114. 
Gil, H.-Y., Y.-H. Ha, K. S. Choi, J. S. Lee, K. S. Chang \& K. Choi. 2019. The chloroplast genome sequence of an aquatic plant, Sparganium eurycarpum subsp. coreanum (Typhaceae). Mitochondrial DNA Part B 4: 684-685.

Giles, Ba. E. 1977. A preliminary study of the MDH variability in Lemna minor/Lemna turionifera. M.S. thesis. Brock University, St. Catharines, ON. 186 pp.

Gill, D. A. 2000. Landscaping with native plants. D. A. Gill, Charlotte, NC. 40 pp. Unpublished compilation. Available online: http://citeseerx.ist.psu.edu/viewdoc/download?doi=10. 1.1.387.9223\&rep=rep1\&type $=$ pdf [accessed 8 April, 2019].

Gill, K. M. \& K. M. Hoppa. 2016. Evidence for an Island Chumash geophyte-based subsistence economy on the Northern Channel Islands. J. Calif. Gt. Basin Anthropol. 36: 51-71.

Gilman, B., J. Foust \& B. Zhu. 2008. Composition, seasonal standing crop biomass and estimated annual productivity of macrophyte communities in Owasco Lake. Pp. 1-17 In: J. D. Halfman, M. E. Balyszak \& S. A. Meyer (eds.), A 2007 Water Quality Study of Owasco Lake, New York. Finger Lakes Institute, Hobart and William Smith Colleges, Geneva, NY.

Gilmour, C. N., J. R. Starr \& R. F. C. Naczi. 2013. Calliscirpus, a new genus for two narrow endemics of the California Floristic Province, C. criniger and C. brachythrix sp. nov. (Cyperaceae). Kew Bull. 68: 85-105.

Giulietti, N., A. M. Giulietti, J. R. Pirani \& N. L. Menezes. 1988. Estudos em sempre-vivas: importância econômica do extrativismo em Minas Gerais, Brasil. Acta Bot. Brasilica 1: 179-193.

Giulietti, N., V. L. Scatena, P. T. Sano, L. Parra, L. P. Queiroz, R. M. Harley, N. L. Menezes, A. M. B. Ysepon, A. Salatino, M. L. Salatino, W. Vilegas, L. C. Santos, C. V. Ricci, M. C. P. Bonfim \& E. B. Miranda. 2000. Multidisciplinary studies on neotropical Eriocaulaceae. Pp. 580-589 In: K. L. Wilson \& D. A. Morrison (eds.), Monocots: Systematics and Evolution. CSIRO, Melbourne, VIC.

Givnish, T. J., A. Zuluaga, I. Marques, V. K. Y. Lam, M. S. Gomez, W. J. D. Iles, M. Ames, D. Spalink, J. R. Moeller, B. G. Briggs, S. P. Lyon, D. W. Stevenson, W. Zomlefer \& S. W. Graham. 2016. Phylogenomics and historical biogeography of the monocot order Liliales: out of Australia and through Antarctica. Cladistics 32: 581-605.

Givnish, T. J., A. Zuluaga, D. Spalink, M. S. Gomez, V. K. Y. Lam, J. M. Saarela, C. Sass, W. J. D. Iles, D. J. L. de Sousa, J. LeebensMack, J. C. Pires, W. B. Zomlefer, M. A. Gandolfo, J. I. Davis, D. W. Stevenson, C. dePamphilis, C. D. Specht, S. W. Graham, C. F. Barrett \& C. Ané. 2018. Monocot plastid phylogenomics, timeline, net rates of species diversification, the power of multi-gene analyses, and a functional model for the origin of monocots. Am. J. Bot. 105: 1-23.

Glaettli, M. \& S. C. H. Barrett. 2008. Pollinator responses to variation in floral display and flower size in dioecious Sagittaria latifolia (Alismataceae). New Phytol. 179: 1193-1201.

Glaser, P. H. 1992. Raised bogs in eastern North America-regional controls for species richness and floristic assemblages. J. Ecol. 80: $535-554$.

Glaser, P. H., G. A. Wheeler, E. Gorham \& H. E. Wright, Jr. 1981. The patterned mires of the Red Lake peatland, northern Minnesota: vegetation, water chemistry and landforms. $J$. Ecol. 69: 575-599.

Glaser, P. H., J. A. Janssens \& D. I. Siegel. 1990. The response of vegetation to chemical and hydrological gradients in the Lost River peatland, northern Minnesota. J. Ecol. 78: 1021-1048.

Glawe, D. A., F. M. Dugan, Y. Liu \& J. D. Rogers. 2005. First record and characterization of a powdery mildew on a member of the Juncaginaceae: Leveillula taurica on Triglochin maritima. Mycol. Progr. 4: 291-298.
Gleason, H. A. 1912. An isolated prairie grove and its phytogeographical significance. Bot. Gaz. 53: 38-49.

Gleason, H. A. 1917. A prairie near Ann Arbor, Michigan. Rhodora 19: $163-165$.

Gleason, R. A., N. H. Euliss, Jr., D. E. Hubbard \& W. G. Duffy. 2003. Effects of sediment load on emergence of aquatic invertebrates and plants from wetland soil egg and seed banks. Wetlands 23: 26-34.

Gledhill, D. 2002. The Names of Plants, 3rd ed. Cambridge University Press, Cambridge, United Kingdom. 326 pp.

Glenn, S. 2008. Field trip reports. J. Torrey Bot. Soc. 135: 149-153.

Glenn, E., T. L. Thompson, R. Frye, J. Riley \& D. Baumgartner. 1995. Effects of salinity on growth and evapotranspiration of Typha domingensis Pers. Aquat. Bot. 52: 75-91.

Glover, D. E. \& S. C. H. Barrett. 1986. Variation in the mating system of Eichhornia paniculata (Spreng.) Solms (Pontederiaceae). Evolution 40: 1122-1131.

Glover, D. E. \& S. C. H. Barrett. 1987. Genetic variation in continental and island populations of Eichhornia paniculata (Pontederiaceae). Heredity 59: 7-17.

Glück, H. 1924. Biologische und morphologische Untersuchungen über Wasser- und Sumpfgewächse. Teil IV. Untergetauchte und Schwimmblattflora. Verlag von Gustav Fischer, Jena. 746 pp.

Gluck, H. 1927. A new Sagittaria from Florida: Sagittaria kurziana. Bull. Torrey Bot. Club 54: 257-261.

Godfrey, R. K. \& P. Adams. 1964. The identity of Sagittaria isoetiformis (Alismataceae). Sida 1: 269-273.

Godfrey, R. K. \& J. W. Wooten. 1979. Aquatic and Wetland Plants of Southeastern United States. Vol. I: Monocotyledons. University of Georgia Press, Athens, GA. 712 pp.

Godt, M. J., J. L. Hamrick \& S. Bratton. 1995. Genetic diversity in a threatened wetland species, Helonias bullata (Liliaceae). Conserv. Biol. 9: 596-604.

Godt, M. J. W., J. Walker \& J. L. Hamrick. 1997. Genetic diversity in the endangered lily Harperocallis flava and a close relative, Tofieldia racemosa. Conserv. Biol. 11: 361-366.

Godziemba-Czyż, J. 1970. Characteristic of vegetative and resting forms in Wolffia arrhiza (L.) Wimm. II. Anatomy, physical and physiological properties. Acta Soc. Bot. Polon. 39: 421-443.

Goecker, M. E., K. L. Heck, Jr. \& J. F. Valentine. 2005. Effects of nitrogen concentrations in turtlegrass Thalassia testudinum on consumption by the bucktooth parrotfish Sparisoma radians. Mar. Ecol. Prog. Ser. 286: 239-248.

Goldberg, B. 1941. Life history of Peltandra virginica. Bot. Gaz. 102: 641-662.

Goldblatt, P. 1975. Revision of the bulbous Iridaceae of North America. Brittonia 27: 373-385.

Goldblatt, P. 2002a. Iridaceae Jussieu. Pp. 348-349 In: Flora North America Editorial Committee (eds.), Flora of North America North of Mexico, Vol. 26: Magnoliophyta: Liliidae: Liliales and Orchidales. Oxford University Press, New York, NY.

Goldblatt, P. 2002b. Nemastylis Nuttall. Pp. 398-400. In: Flora North America Editorial Committee (eds.), Flora of North America North of Mexico, Vol. 26: Magnoliophyta: Liliidae: Liliales and Orchidales. Oxford University Press, New York, NY.

Goldblatt, P. \& M. Takei. 1997. Chromosome cytology of Iridaceaepatterns of variation, determination of ancestral base numbers, and modes of karyotype change. Ann. Missouri Bot. Gard. 84: 285-304.

Goldblatt, P. \& J. C. Manning. 2008. The Iris Family: Natural History and Classification. Timber Press, Portland, OR. 290 pp.

Goldblatt, P., P. Rudall \& J. E. Henrich. 1990. The genera of the Sisyrinchium alliance (Iridaceae: Iridoideae): phylogeny and relationships. Syst. Bot. 15: 497-510. 
Goldblatt, P., A. Rodriguez, M. P. Powell, J. T. Davies, J. C. Manning, M. Van der Bank \& V. Savolainen. 2008. Iridaceae 'out of Australasia'? Phylogeny, biogeography, and divergence time based on plastid DNA sequences. Syst. Bot. 33: 495-508.

Goldman, D. H., J. V. Freudenstein, P. J. Kores, M. Molvray, D. C. Jarrell, W. M. Whitten, K. M. Cameron, R. K. Jansen \& M. W. Chase. 2001. Phylogenetics of Arethuseae (Orchidaceae) based on plastid matK and $r b c L$ sequences. Syst. Bot. 26: 670-695.

Goldman, D. H., L. K. Magrath \& P. M. Catling. 2002. Calopogon R. Brown. Pp. 597-601. In: Flora North America Editorial Committee (eds.), Flora of North America North of Mexico, Vol. 26: Magnoliophyta: Liliidae: Liliales and Orchidales. Oxford University Press, New York, NY.

Goldman, D. H., R. K. Jansen, C. van den Berg, I. J. Leitch, M. F. Fay \& M. W. Chase. 2004a. Molecular and cytological examination of Calopogon (Orchidaceae, Epidendroideae): circumscription, phylogeny, polyploidy, and possible hybrid speciation. Am. J. Bot. 91: 707-723.

Goldman, D. H., C. Van den Berg \& M. P. Griffith. 2004b. Morphometric circumscription of species and infraspecific taxa in Calopogon R. Br. (Orchidaceae). Plant Syst. Evol. 247: $37-60$.

Goldsborough, W. J. \& W. M. Kemp. 1988. Light responses of a submersed macrophyte: implications for survival in turbid tidal waters. Ecology 69: 1775-1786.

Goleniowski, M. E., G. A. Bongiovanni, L. Palacio, C. O. Nuñez \& J. J. Cantero. 2006. Medicinal plants from the "Sierra de Comechingones", Argentina. J. Ethnopharmacol. 107: 324-341.

Golley, F. B., G. A. Petrides \& J. F. McCormick. 1965. A survey of the vegetation of the Boiling Springs Natural Area, South Carolina. Bull. Torrey Bot. Club 92: 355-363.

Gonzalez, J., E. Garcia \& M. Perdomo. 1983. Important rice weeds in Latin America. Pp. 119-132 In: International Rice Research Institute and International Weed Science Society (eds.), Proceedings of the Conference on Weed Control in Rice. Los Baños, Laguna, Philippines.

González-Soriano, E., O. Delgado-Hernández \& G. L. Harp. 2004. Biological notes on Neoerythromma gladiolatum Williamson \& Williamson, 1930 with description of its female (Zygoptera: Coenagrionidae). Odonatologica 33: 327-331.

Good, J. A. 1986. Insect visitors to Iris pseudacorus (Iridaceae) in Ireland. Ir. Nat. J. 22: 71-74.

Göppner, D. \& M. Leverkus. 2011. Basal cell carcinoma: from the molecular understanding of the pathogenesis to targeted therapy of progressive disease. J. Skin Cancer 2011: 650258.

Gordón, E. 1997. Notas sobre la ecología de Echinodorus grandiflorus (Cham. et Shl.) Mich. (Alismataceae). Ecotropicos 10: 33-39.

Gordon, T. 2002. 1997-1999 field trips. Bartonia 61: 155-173.

Gordon, T. 2004. 2000-2002 field trips. Bartonia 62: 113-128.

Gordon, T. 2011. 2007-2008 field trips. Bartonia 65: 126-147.

Gordon, T. \& M. Demitroff. 2009. Sprungs, cripples, blue holes, and savannahs (savannas) of the pine barrens of Atlantic and Gloucester counties, New Jersey. Bartonia 64: 59-62.

Gordon, T. \& J. Arsenault. 2016. Flora of Burden Hill Forest: a checklist for a Salem County, New Jersey landscape. Bartonia 69: $20-46$.

Gordon, D. H., B. T. Gray, R. D. Perry, M. B. Prevost, T. H. Strange \& R. K. Williams. 1989. South Atlantic coastal wetlands. Pp. 57-92 In: L. M. Smith, R. L. Pederson \& R. M. Kaminski (eds.), Habitat Management for Migrating and Wintering Waterfowl in North America. Texas Tech University Press, Lubbock, TX. 560 pp.
Goremykin, V. V., B. Holland, K. I. Hirsch-Ernst \& F. H. Hellwig. 2005. Analysis of Acorus calamus chloroplast genome and its phylogenetic implications. Mol. Biol. Evol. 22: 1813-1822.

Gorham, E. \& W. H. Pearsall. 1956. Acidity, specific conductivity and calcium content of some bog and fen waters in northern Britain. J. Ecol. 44: 129-141.

Gorham, E., J. A. Janssens, G. A. Wheeler \& P. H. Glaser. 1987. The natural and anthropogenic acidification of peatlands. Pp. 493512 In: T. C. Hutchinson \& K. M. Meema (eds.), Effects of Atmospheric Pollutants on Forests, Wetlands and Agricultural Ecosystems. NATO ASI Series (Series G: Ecological Sciences), vol 16. Springer, Berlin, Germany.

Gorman, T. A., S. D. Powell, K. C. Jones \& C. A. Haas. 2014. Microhabitat characteristics of egg deposition sites used by reticulated flatwoods salamanders. Herpetol. Conserv. Biol. 9: 543-550.

Gortner, R. A. 1934. Lake vegetation as a possible source of forage. Science 80: 531-533.

Goslee, S. C., R. P. Brooks \& C. A. Cole. 1997. Plants as indicators of wetland water source. Plant Ecol. 131: 199-206.

Gosse, J. W. \& B. J. Hearn. 2005. Seasonal diets of Newfoundland martens, Martes americana atrata. Can. Field-Nat. 119: 43-47.

Gotceitas, V., S. Fraser \& J. A. Brown. 1997. Use of eelgrass beds (Zostera marina) by juvenile Atlantic cod (Gadus morhua). Can. J. Fish. Aquat. Sci. 54: 1306-1319.

Goulet, R. R., J. D. Lalonde, C. Munger, S. Dupuis, G. DumontFrenette, S. Prémont \& P. G. C. Campbell. 2005. Phytoremediation of effluents from aluminum smelters: a study of $\mathrm{Al}$ retention in mesocosms containing aquatic plants. Water Res. 39: 2291-2300.

Grabowski, A. 1973. The biomass, organic matter contents and calorific values of macrophytes in the lakes of the Szeszupa drainage area. Polsk. Arch. Hydrobiol. 20: 269-282.

Grabowski, J. M. 2001. Observations on seed propagation of 5 Mississippi wetland species. Native Plant J. 2: 67-68.

Grabowski, J. M. 2002. Three Mississippi ecotypes of wetland plants. Pp. 94-97 In: M. M. Holland, M. L. Warren \& J. A. Stanturf (eds.), Proceedings of a Conference on Sustainability of Wetlands and Water Resources: How Well Can Riverine Wetlands Continue to Support Society into the 21st Century? Gen. Tech. Rep. SRS-50. U.S. Department of Agriculture, Forest Service, Southern Research Station, Asheville, NC.

Grace, J. B. 1983. Autotoxic inhibition of seed germination by Typha latifolia: an evaluation. Oecologia 59: 366-369.

Grace, J. B. 1984. Effects of tubificid worms on the germination and establishment of Typha. Ecology 65: 1689-1693.

Grace, J. B. 1988. The effects of nutrient additions on mixtures of Typha latifolia L. and Typha domingensis Pers. along a waterdepth gradient. Aquat. Bot. 31: 83-92.

Grace, J. B. 1989. Effects of water depth on Typha latifolia and Typha domingensis. Am. J. Bot. 76: 762-768.

Grace, J. B. 1993. The adaptive significance of clonal reproduction in angiosperms: an aquatic perspective. Aquat. Bot. 44: 159-180.

Grace, S. L. 2000. Short-term response of plant species of special concern and exotics to the 1998 Florida wildfires. Final Report. U.S. Geological Survey, National Wetlands Research Center, Lafayette, LA. 13 pp.

Grace, J. B. \& R. G. Wetzel. 1981a. Habitat partitioning and competitive displacement in cattails (Typha): experimental field studies. Am. Nat. 118: 463-474.

Grace, J. B. \& R. G. Wetzel. 1981b. Effects of size and growth rate on vegetative reproduction in Typha. Oecologia 50: 158-161.

Grace, J. B. \& R. G. Wetzel. 1982. Niche differentiation between two rhizomatous plant species: Typha latifolia and Typha angustifolia. Can. J. Bot. 60: 46-57. 
Grace, J. B. \& J. S. Harrison. 1986. The biology of Canadian weeds: 73. Typha latifolia L., Typha angustifolia L. and Typha $\times$ glauca Godr. Can. J. Plant Sci. 66: 361-379.

Grace, J. B. \& M. A. Ford. 1996. The potential impact of herbivores on the susceptibility of the marsh plant Sagittaria lancifolia to saltwater intrusion in coastal wetlands. Estuaries Coast. 19: 13-20.

Grace, J. B. \& R. G. Wetzel. 1998. Long-term dynamics of Typha populations. Aquat. Bot. 61: 137-146.

Graenicher, S. 1935. Bee-fauna and vegetation of Wisconsin. Ann. Entomol. Soc. Am. 28: 285-310.

Graham, S. P. 2010. Visitors to southeastern hawkmoth flowers. Southeast. Nat. 9: 413-426.

Graham, S. W. \& S. C. H. Barrett. 1995. Phylogenetic systematics of Pontederiales: implications for breeding-system evolution. Pp. 415-441 In: P. J. Rudall, P. J. Cribb, D. F. Cutler \& C. J. Humphries (eds.), Monocotyledons: Systematics and Evolution. Royal Botanic Gardens, Kew, United Kingdom.

Graham, S. W., J. R. Kohn, B. R. Morton, J. E. Eckenwalder \& S. C. H. Barrett. 1998. Phylogenetic congruence and discordance among one morphological and three molecular data sets from Pontederiaceae. Syst. Biol. 47: 545-567.

Graham, S. W., R. G. Olmstead \& S. C. H. Barrett. 2002. Rooting phylogenetic trees with distant outgroups: a case study from the commelinoid monocots. Molec. Biol. Evol. 19: 1769-1781.

Graham, E. E., J. F. Tooker \& L. M. Hanks. 2012. Floral host plants of adult beetles in central Illinois: an historical perspective. Ann. Entomol. Soc. Am. 105: 287-297.

Graham, J. R., E. Willcox \& J. D. Ellis. 2015. The potential management of a ground-nesting, solitary bee: Anthophora abrupta (Hymenoptera: Apidae). Florida Entomol. 98: 528-535.

Grainger, J. 1947. Nutrition and flowering of water plants. J. Ecol. 35: 49-64.

Grajczyk, A. M., W. A. Overholt, J. P. Cuda, S. D. Brown \& D. A. Williams. 2009. Characterization of microsatellite loci in Hydrilla verticillata. Mol. Ecol. Resour. 9: 1460-1559.

Grant, W. T. 1864. Indigenous medicinal plants. Confederate States Med. Surg. J. 1(6): 84.

Grant, K. A. 1966. A hypothesis concerning the prevalence of red coloration in California hummingbird flowers. Am. Nat. 100: 85-97.

Grant, V. 1983. The systematic and geographical distribution of hawkmoth flowers in the temperate North American flora. Bot. Gaz. 144: 439-449.

Grant, V. \& K. A. Grant. 1966. Records of hummingbird pollination in the western American flora: I. Some California plant species. Aliso 6: 51-66.

Grant, V. \& K. A. Grant. 1967. Records of hummingbird pollination in the western American flora: II. Additional California records. Aliso 6: 103-105.

Grant, T. A., P. Henson \& J. A. Cooper. 1994. Feeding ecology of trumpeter swans breeding in south central Alaska. J. Wildl. Manag. 58: 774-780.

Grau, C. R. \& K. J. Leonard. 1978. Zea mays, a new host for Ligniera junci (Plasmodiophorales). Mycologia 70: 41-46.

Graves, A. H. 1908. The morphology of Ruppia maritima. Trans. Connecticut Acad. Arts Sci. 14: 59-170.

Graves, H. B. 1984. Behavior and ecology of wild and feral swine (Sus scrofa). J. Anim. Sci. 58: 482-492.

Graves, G R. 2001. Factors governing the distribution of Swainson's Warbler along a hydrological gradient in Great Dismal Swamp. Auk 118: 650-664.

Gray, A. 1862. Fertilization of orchids through the agency of insects. Am. J. Sci. 34: 420-429.
Gray, J. B., B. A. Sorrie \& W. Wall. 2016. Canebrakes of the Sandhills region of the Carolinas and Georgia: fire history, canebrake area, and species frequency. Castanea 81: 280-291.

Grayum, M. H. 1987. A summary of evidence and arguments supporting the removal of Acorus from the Araceae. Taxon 36: 723-729.

Grear, J. W. 1966. Cytogeography of Orontium aquaticum (Araceae). Rhodora 68: 25-34.

Grear, Jr., J. W. 1973. Observations on the stomatal apparatus of Orontium aquaticum (Araceae). Bot. Gaz. 134: 151-153.

Green, A. J. 2016. The importance of waterbirds as an overlooked pathway of invasion for alien species. Divers. Distrib. 22: 239-247.

Green, E. P. \& F. T. Short. 2003. World Atlas of Seagrasses. University of California Press, Berkeley, CA. 298 pp.

Green, A. J., M. Soons, A.-L. Brochet \& E. Kleyheeg. 2016. Dispersal of plants by waterbirds. Pp. 147-195 In: Ç. H. Sekercioglu, D. G. Wenny \& C. J. Whelan (eds.), Why Birds Matter: Avian Ecological Function and Ecosystem Services. University of Chicago Press, Chicago, IL.

Greenwood, M. E. \& P. J. DuBowy. 2005. Germination characteristics of Zannichellia palustris from New South Wales, Australia. Aquat. Bot. 82: 1-11.

Gregg, K. B. 1991. Defrauding the deceitful orchid: pollen collection by pollinators of Cleistes divaricata and C. bifaria. Lindleyana 6: $214-220$.

Gregg, K. B. \& L. H. Klotz. 2015. The flora of Beavers' Meadow, Barbour County, West Virginia, revisited after a quarter century. Castanea 80: 130-143.

Gregory, C., R. Braham, G. Blank \& J. Stucky. 2010. Habitat and search criteria of the rare sandhills lily, Lilium pyrophilum $\mathrm{M}$. W. Skinner and Sorrie. Castanea 75: 198-204.

Greimler, J., T. F. Stuessy, U. Swenson, P. López-Sepúlveda \& C. M. Baeza. 2017. Invasive species. Pp. 134-148 In: T. F. Stuessy, D. J. Crawford, P. López-Sepúlveda, C. M. Baeza \& E. A. Ruiz (eds.), Plants of Oceanic Islands: Evolution, Biogeography, and Conservation of the Flora of the Juan Fernández (Robinson Crusoe) Archipelago. Cambridge University Press, New York, NY.

Greulich, S. \& M. Tremolieres. 2006. Present distribution of the genus Elodea in the Alsatian Upper Rhine floodplain (France) with a special focus on the expansion of Elodea nuttallii St. John during recent decades. Hydrobiologia 570: 249-255.

Grewell, B. J. 2008. Parasite facilitates plant species coexistence in a coastal wetland. Ecology 89: 1481-1488.

Grewell, B. J., J. C. Callaway, W. R. Ferren \& R. Wayne. 2007. Estuarine wetlands. Pp. 124-154 In: M. Barbour, T. Keeler-Wolf, A. A. Schoenherr (eds.), Terrestrial Vegetation of California, 3rd ed. University of California Press, Berkeley, CA.

Grier, N. M. 1916. A new species of Opercularia. Trans. Am. Microsc. Soc. 35: 138-139.

Griese, H. J., R. A. Ryder \& C. E. Braun. 1980. Spatial and temporal distribution of rails in Colorado. Wilson Bull. 92: 96-102.

Griffen, K. O. 1975. Vegetation studies and modern pollen spectra from the Red Lake Peatland, northern Minnesota. Ecology 56: 531-546.

Griffin, N. E. \& M. J. Durako. 2012. The effect of pulsed versus gradual salinity reduction on the physiology and survival of Halophila johnsonii Eiseman. Mar. Biol. 159: 1439-1447.

Griffin, A. D., F. E. Durbian, D. A. Easterla \& R. L. Bell. 2009. Spatial ecology of breeding Least Bitterns in northwest Missouri. Wilson J. Ornithol. 121: 521-528.

Grimaldi, D. \& J. Jaenike. 1983. The Diptera breeding on skunk cabbage, Symplocarpus foetidus (Araceae). J. New York Entomol. Soc. 91: 83-89. 
Grippo, M. A., I. Hlohowskyj, L. Fox, B. Herman, J. Pothoff, C. Yoe \& J. Hayse. 2017. Aquatic nuisance species in the great lakes and Mississippi river basin - a risk assessment in support of GLMRIS. Environ. Manage. 59: 154-173.

Grisé, D., J. E. Titus \& D. J. Wagner. 1986. Environmental pH influences growth and tissue chemistry of the submersed macrophyte Vallisneria americana. Can. J. Bot. 64: 306-310.

Grittinger, T. F. 1970. String bog in southern Wisconsin. Ecology 51: 928-930.

Grootjen, C. J. \& F. Bouman. 1988. Seed structure in Cannaceae: taxonomic and ecological implications. Ann. Bot. 61: 363-371.

Gross, A. O. 1944. Food of the snowy owl. Auk 61: 1-18.

Gross, E. M., R. L. Johnson \& N. G. Hairston, Jr. 2001. Experimental evidence for changes in submersed macrophyte species composition caused by the herbivore Acentria ephemerella (Lepidoptera). Oecologia 127: 105-114.

Gu, D., H. Xu, Y. He, F. Zhao \& M. Huang. 2015. Remediation of urban river water by Pontederia cordata combined with artificial aeration: organic matter and nutrients removal and root-adhered bacterial communities. Int. J. Phytoremed. 17: 1105-1114.

Guard, B. J. 1995. Wetland Plants of Oregon and Washington. Lone Pine Publishing, Redmond, WA. 239 pp.

Guerra, I. R., S. L. Hernandez, I. Hernandez, S. A. Padron, J. A. Herrera, S. Olguin, R. Camacho, M. D. Ronquillo, M. D. Fernandez, R. Menendez \& J. Espinosa-Aguirre. 2014. Thalassia testudinum extract modulates hepatic cytochome P450 system in Wistar rats. J. Fed. Am. Soc. Exp. Biol. 28: 657.16.

Guisinger, M. M., T. W. Chumley, J. V. Kuehl, J. L. Boore \& R. K. Jansen. 2010. Implications of the plastid genome sequence of Typha (Typhaceae, Poales) for understanding genome evolution in Poaceae. J. Mol. Evol. 70: 149-166.

Gulnaz, O., A. Sahmurova \& S. Kama. 2011. Removal of Reactive Red 198 from aqueous solution by Potamogeton crispus. Chem. Eng. J. 174: 579-585.

Gunderson, L. H. \& W. F. Loftus. 1993. The Everglades. Pp. 199255 In: W. E. Martin, S. G. Boyce \& A. C. Echternacht (eds.), Biodiversity of the Southeastern United States. Volume 2: Lowland Terrestrial Communities. John Wiley \& Sons, Inc., New York, NY.

Gunderson, M. D., K. L. Kapuscinski, D. P. Crane \& J. M. Farrell. 2016. Habitats colonized by non-native flowering rush Butomus umbellatus (Linnaeus, 1753) in the Niagara River, USA. Aquat. Invasions 11: 369-380.

Guo, Y.-H. \& C. D. K. Cook. 1989. Pollination efficiency of Potamogeton pectinatus L. Aquat. Bot. 34: 381-384.

Guo, Y.-H., R. Sperry, C. D. K. Cook \& P. A. Cox. 1990. The pollination ecology of Zannichellia palustris L. (Zannichelliaceae). Aquat. Bot. 38: 341-356.

Guo, L. D., K. D. Hyde \& E. C. Y. Liew. 2001. Detection and taxonomic placement of endophytic fungi within frond tissues of Livistona chinensis based on rDNA sequences. Mol. Phylogenet. Evol. 20: 1-13.

Guppy, H. B. 1906. Observations of a Naturalist in the Pacific Between 1896 and 1899. Volume II. Plant-Dispersal. Macmillan and Company, Limited, London, UK. 627 pp.

Gupta, A. L. K. A. \& V. N. Pandey. 2014. Herbal remedies of aquatic macrophytes of Gorakhpur district, Uttar Pradesh (India). Int. J. Pharm. Bio. Sci. 5: 300-308.

Gupta, M. P., S. S. Handa, G. Longo \& D. D. Rakesh (eds.). 2011. Compendium of Medicinal and Aromatic Plants: The Americas. The International Centre for Science and High Technology, Trieste, Italy. 411 pp.
Gupta, A., R. Maurya, R. K. Roy, S. V. Sawant \& H. K. Yadav. 2013. AFLP based genetic relationship and population structure analysis of Canna-An ornamental plant. Sci. Hort. 154: 1-7.

Gusain, R. \& S. Suthar. 2017. Potential of aquatic weeds (Lemna gibba, Lemna minor, Pistia stratiotes and Eichhornia sp.) in biofuel production. Process Saf. Environ. Prot. 109: 233-241.

Gustafson, F. G. 1942. Parthenocarpy: natural and artificial. Bot. Rev. 8: 599-654.

Gut, L. J., R. A. Schlising \& C. E. Stopher. 1977. Nectar-sugar concentrations and flower visitors in the western Great Basin. Great Basin Nat. 37: 523-529.

Guterres-Pazin, M. G., M. Marmontel, F. C. W. Rosas, V. F. V. Pazin \& E. M. Venticinque. 2014. Feeding ecology of the Amazonian manatee (Trichechus inunguis) in the Mamiraua and Amana sustainable development reserves, Brazil. Aquat. Mamm. 40: 139-149.

Gutierrez, R. M. P. 2010. Orchids: a review of uses in traditional medicine, its phytochemistry and pharmacology. J. Med. Plant Res. 4: 592-638.

Gutierrez, M. A., A. A. Cardona \& D. L. Smee. 2010. Growth patterns of shoal grass Halodule wrightii and manatee grass Syringodium filiforme in the western Gulf of Mexico. Gulf Caribbean Res. 22: 71-75.

Guy, C. J. 1988. A seasonal investigation of nonstructural carbohydrates in submerged macrophytes of Shoal Lake in relation to water depth. M.S thesis. University of Manitoba, Winnipeg, MB. 311 pp.

Guzmán del Próo, S. A., E. Serviere-Zaragoza \& D. A. S. Beltrones. 2003. Natural diet of juvenile abalone Haliotis fulgens and $H$. corrugata (Mollusca: Gastropoda) in Bahia Tortugas, Mexico. Pac. Sci. 57: 319-324.

Haag, R. W. 1983. Emergence of seedlings of aquatic macrophytes from lake sediments. Can. J. Bot. 61: 148-156.

Haag, R. W. \& P. R. Gorham. 1977. Effects of thermal effluent on standing crop and net production of Elodea canadensis and other submerged macrophytes in Lake Wabamun, Alberta. $J$. Appl. Ecol. 14: 835-851.

Haag, K. H., T. M. Lee, D. C. Herndon, P. County \& T. B. Water. 2005. Bathymetry and vegetation in isolated marsh and cypress wetlands in the Northern Tampa Bay Area, 2000-2004. Scientific Investigations Report 2005-5109. U.S. Department of the Interior, Geological Survey, Tampa, FL. 49 pp.

Habeck, R. J. 1992. Maianthemum stellatum. In: Fire Effects Information System. U.S. Department of Agriculture, Forest Service, Rocky Mountain Research Station, Fire Sciences Laboratory (Producer). Available online: https://www.fs.fed. us/database/feis/plants/forb/maiste/all.html [accessed 23 January, 2019].

Hafez, M. B., N. Hafez \& Y. S. Ramadan. 1992. Uptake of cerium, cobalt and cesium by Potamogeton crispus. J. Chem. Technol. Biotechnol. 54: 337-340.

Hagley, C. A., D. Wright, C. J. Owen, P. Eiler \& M. Banks. 1996. Changes in aquatic macrophytes after liming Thrush Lake, Minnesota. Restor. Ecol. 4: 307-312.

Hahn, A. T., C. A. Rosa, A. Bager \& L. Krause. 2014. Dietary variation and overlap in D'Orbigny's slider turtles Trachemys dorbigni (Duméril and Bibron 1835) (Testudines: Emydidae). J. Nat. Hist. 48: 721-728.

Haines, A. 2000a. Taxonomy and distribution of Acorus in Maine. Bot. Notes 2: 4-6.

Haines, A. 2000b. Eriocaulon parkeri Robinson Parker's Pipewort. New England Plant Conservation Program Conservation and Research Plan. New England Wild Flower Society, Framingham, MA. 15 pp. 
Haines, A. 2001. Eleocharis aestuum (Cyperaceae), a new tidal river shore spikesedge of the Eastern United States. Novon 11: 45-49.

Hakim, L. \& H. Miyakawa. 2015. Exotic plant species in the restoration project area in Ranupani recreation forest, Bromo Tengger Semeru National Park (Indonesia). Biodiv. J. 6: 831-836.

Halbritter, D. A., J. C. Daniels, D. C. Whitaker \& L. Huang. 2015. Reducing mowing frequency increases floral resource and butterfly (Lepidoptera: Hesperioidea and Papilionoidea) abundance in managed roadside margins. Florida Entomol. 98: 1081-1092.

Halder, S. \& P. Venu. 2012. The taxonomy and report of flowering in Lemna L. (Lemnaceae) in India. Curr. Sci. 102: 1629-1632.

Hale, E. M. 1867. Homoeopathic Materia Medica of the New Remedies: Their Botanical Description, Medical History, Pathogenetic Effects and Therapeutical Application in Homoeopathic Practice. Dr. E. A. Lodge, Detroit, MI. 1142 pp.

Hall, T. F. \& W. T. Penfound. 1943. Cypress-gum communities in the Blue Girth Swamp near Selma, Alabama. Ecology 24: 208-217.

Hall, J. B. \& D. U. U. Okali. 1974. Phenology and productivity of Pistia stratiotes L. on the Volta Lake, Ghana. J. Appl. Ecol. 11: 709-725.

Hall, D. J. \& E. E. Werner. 1977. Seasonal distribution and abundance of fishes in the littoral zone of a Michigan lake. Trans. Am. Fish. Soc. 106: 545-555.

Hall, M. O. \& S. S. Bell. 1993. Meiofauna on the seagrass Thalassia testudinum: population characteristics of harpacticoid copepods and associations with algal epiphytes. Mar. Biol. 116: 137-146.

Hall, J. A. \& G. H. Walter. 2011. Does pollen aerodynamics correlate with pollination vector? Pollen settling velocity as a test for wind versus insect pollination among cycads (Gymnospermae: Cycadaceae: Zamiaceae). Biol. J. Linn. Soc. 104: 75-92.

Hall, E. C., J. L. Rodda \& J. A. Small. 1938. Field trips of the club. Torreya 38: 129-133.

Hall, L. M., M. D. Hanisak \& R. W. Virnstein. 2006. Fragments of the seagrasses Halodule wrightii and Halophila johnsonii as potential recruits in Indian River Lagoon, Florida. Mar. Ecol. Prog. Ser. 310: 109-117.

Haller, W. T., D. L. Sutton \& W. C. Barlowe. 1974. Effects of salinity on growth of several aquatic macrophytes. Ecology 55: 891-894.

Haller, W. T., J. L. Miller \& L. A. Garrard. 1976. Seasonal production and germination of hydrilla vegetative propagules. J. Aquat. Plant Manag. 14: 26-29.

Halloran, A. F. 1943. Management of deer and cattle on the Aransas National Wildlife Refuge, Texas. J. Wildl. Manag. 7: 203-216.

Halpern, C. B. 1986. Montane meadow plant associations of Sequoia National Park, California. Madroño 33: 1-23.

Halpin, K. M. 2011. A chloroplast phylogeny of Agavaceae subfamily Chlorogaloideae with a focus on species relationships in Hastingsia. M.S. thesis. Oklahoma State University, Stillwater, OK. 95 pp.

Halpin, K. M. \& M. Fishbein. 2013. A chloroplast phylogeny of Agavaceae subfamily Chlorogaloideae: implications for the tempo of evolution on serpentine soils. Syst. Bot. 38: 996-1011.

Hamel, P. B. \& M. U. Chiltoskey. 1975. Cherokee Plants and Their Uses - A 400 Year History. Herald Publishing, Sylva, NC. 59 pp.

Hamel, K. S. \& J. K. Parsons. 2001. Washington's aquatic plant quarantine. J. Aquat. Plant Manag. 39: 72-75.

Hamerstrom, Jr., F. N. \& J. Blake. 1939. Central Wisconsin muskrat study. Am. Midl. Nat. 21: 514-520.

Hamlin, J. A. P. \& M. L. Arnold. 2014. Determining population structure and hybridization for two iris species. Ecol. Evol. 4: $743-755$.
Hamlin, J. A. P., T. J. Simmonds \& M. L. Arnold. 2017. Niche conservatism for ecological preference in the Louisiana iris species complex. Biol. J. Linn. Soc. 120: 144-154.

Hammer, U. T. \& J. M. Heseltine. 1988. Aquatic macrophytes in saline lakes of the Canadian prairies. Pp. 101-116 In: J. M. Melack (ed.), Saline Lakes. Dr. W. Junk Publishers, Dordrecht, The Netherlands.

Hammerstrom, K. K., W. J. Kenworthy, M. S. Fonseca \& P. E. Whitfield. 2006. Seed bank, biomass, and productivity of Halophila decipiens, a deep water seagrass on the west Florida continental shelf. Aquat. Bot. 84: 110-120.

Han, B., G. Tan, Z. Hu, Y. Wang, Y. Liu, R. Zhou \& Q. Zhou. 2019. The complete chloroplast genome of Eriocaulon sexangulare (Eriocaulaceae). Mitochondrial DNA Part B 4: 666-667.

Handa, I. T., R. Harmsen \& R. L. Jefferies. 2002. Patterns of vegetation change and the recovery potential of degraded areas in a coastal marsh system of the Hudson Bay lowlands. J. Ecol. 90: 86-99.

Handley, R. J. \& A. J. Davy. 2000. Discovery of male plants of Najas marina L. (Hydrocharitaceae) in Britain. Watsonia 23: 331-334.

Handley, R. J. \& A. J. Davy. 2002. Seedling root establishment may limit Najas marina L. to sediments of low cohesive strength. Aquat. Bot. 73: 129-136.

Handley, J. \& B. Heidel. 2005. Amerorchis rotundifolia (Banks ex Pursh) Hultén (roundleaf orchid): a technical conservation assessment. USDA Forest Service, Rocky Mountain Region. Available online: http://www.fs.fed.us/r2/projects/scp/assessments/amerorchisrotundifolia.pdf [accessed 19 February, 2019].

Handley, R. J. \& A. J. Davy. 2005. Temperature effects on seed maturity and dormancy cycles in an aquatic annual, Najas marina, at the edge of its range. J. Ecol. 93: 1185-1193.

Hangelbroek, H. H., N. J. Ouborg, L. Santamaría \& K. Schwenk. 2002. Clonal diversity and structure within a population of the pondweed Potamogeton pectinatus foraged by Bewick's swans. Mol. Ecol. 11: 2137-2150.

Hangelbroek, H. H., L. Santamaría \& T. De Boer. 2003. Local adaptation of the pondweed Potamogeton pectinatus to contrasting substrate types mediated by changes in propagule provisioning. J. Ecol. 91: 1081-1092.

Hanley, T. A., M. P. Gillingham \& K. L. Parker. 2014. Composition of diets selected by Sitka black-tailed deer on Channel Island, central southeast Alaska. Research Note PNW-RN-570. U.S. Department of Agriculture, Forest Service, Pacific Northwest Research Station, Portland, OR. 21 pp.

Hanlon, S. G., M. V. Hoyer, C. E. Cichra \& D. E. Canfield. 2000. Evaluation of macrophyte control in 38 Florida lakes using triploid grass carp. J. Aquat. Plant Manag. 38: 48-54.

Hann, J. H. 1986. The use and processing of plants by Indians of Spanish Florida. Southeast. Archaeol. 5: 91-102.

Hann, B. J. 1995. Invertebrate associations with submersed aquatic plants in a prairie wetland. UFS (Delta Marsh) Ann. Rep. 30: $78-84$.

Hanson, H. C. 1951. Characteristics of some grassland, marsh, and other plant communities in western Alaska. Ecol. Monogr. 21: 317-378.

Hanson, B. A., N. H. Euliss, Jr. \& D. M. Mushet. 2002. First records of loosely coiled valve snail in North Dakota. Prairie Nat. 34: 63-65.

Hanson, L., R. L. Brown, A. Boyd, M. A. T. Johnson \& M. D. Bennett. 2003. First nuclear DNA C-values for 28 angiosperm genera. Ann. Bot. 91: 31-38.

Hapeman, J. R. \& K. Inoue. 2000. Plant-pollinator interactions and floral radiation in Platanthera (Orchidaceae). Pp. 433-454 In: T. J. Givnish \& K. J. Sytsma (eds.), Molecular Evolution and Adaptive Radiation. Cambridge University Press, Cambridge, United Kingdom. 
Hara, A., S. Ebina, A. Kondo \& T. Funaguma. 1985. A new type of phytase from pollen of Typha latifolia L. Agric. Biol. Chem. 49: 3539-3544.

Haramoto, T. \& I. Ikusima. 1988. Life cycle of Egeria densa Planch., an aquatic plant naturalized in Japan. Aquat. Bot. 30: 389-403.

Harder, L. D. 2000. Pollen dispersal and the floral diversity of monocotyledons. Pp. 243-257 In: K. L. Wilson \& D. A. Morrison (eds.), Monocots: Systematics and Evolution. CSIRO Publishing, Melbourne, VIC.

Harder, L. D. \& S. C. H. Barrett. 1992. The energy cost of bee pollination for Pontederia cordata (Pontederiaceae). Funct. Ecol. 6: $226-233$.

Harder, L. D. \& S. C. H. Barrett. 1993. Pollen removal from tristylous Pontederia cordata: effects of anther position and pollinator specialization. Ecology 74: 1059-1072.

Hardy, L. M. \& L. R. Raymond. 1991. Observations on the activity of the pickerel frog, Rana palustris (Anura: Ranidae), in northern Louisiana. J. Herpetol. 25: 220-222.

Harley, K. L. S. 1990. Production of viable seeds by water lettuce, Pistia stratiotes L., in Australia. Aquat. Bot. 36: 277-279.

Harley, M. T. \& S. Findlay. 1994. Photosynthesis-irradiance relationships for three species of submersed macrophytes in the tidal freshwater Hudson River. Estuaries 17: 200-205.

Harlin, M. M. 1973. "Obligate" algal epiphyte: Smithora naidaum grows on a synthetic substrate. J. Phycol. 9: 230-232.

Harlow, R. F. 1961. Fall and winter foods of Florida white-tailed deer. Quart. J. Florida Acad. Sci. 24: 19-38.

Harman, W. N. 1974. Phenology and physiognomy of the hydrophyte community in Otsego Lake, NY. Rhodora 76: 497-508.

Harms, V. L. 1973. Taxonomic studies of North American Sparganium. I. S. hyperboreum and S. minimum. Can. J. Bot. 51: $1629-1641$.

Harms, N. E. \& M. J. Grodowitz. 2009. Insect herbivores of aquatic and wetland plants in the United States: a checklist from literature. J. Aquat. Plant Manag. 47: 73-96.

Harms, N. E. \& J. F. Shearer. 2015. Apparent herbivory and indigenous pathogens of invasive flowering rush (Butomus umbellatus L.) in the Pacific Northwest. ERDC/TN APCRP-BC-35. U.S. Army Corps of Engineers, Vicksburg, MS. 11 pp.

Harms, N., M. Grodowitz \& J. Kennedy. 2011. Insect herbivores of water stargrass (Heteranthera dubia) in the US. J. Freshw. Ecol. 26: 185-194.

Harper, R. M. 1900. Notes on the flora of south Georgia. Bull. Torrey Bot. Club 27: 413-436.

Harper, R. M. 1903. Botanical explorations in Georgia during the summer of 1901.-II. Noteworthy species. Bull. Torrey Bot. Club 30: 319-342.

Harper, R. M. 1905a. Phytogeographical explorations in the coastal plain of Georgia in 1904. Bull. Torrey Bot. Club 32: 451-467.

Harper, R. M. 1905b. Two misinterpreted species of Xyris. Torreya 5: $128-130$.

Harper, R. M. 1906. Some more coastal plain plants in the Palaeozoic Region of Alabama. Torreya 6: 111-117.

Harper, R. M. 1911. Early spring aspects of the coastal plain vegetation of South Carolina, Georgia, and northeastern Florida. Bull. Torrey Bot. Club 38: 223-236.

Harper, R. M. 1916. Habenaria repens and Piaropus crassipes in Leon County, Florida. Torreya 16: 267-270.

Harper, F. 1920. The Florida water-rat (Neofiber alleni) in Okefinokee Swamp, Georgia. J. Mammal. 1: 65-66.

Harper, R. M. 1922. Some pine-barren bogs in central Alabama. Torreya 22: 57-60.

Harper, H. J. \& H. A. Daniel. 1934. Chemical composition of certain aquatic plants. Bot. Gaz. 96: 186-189.
Harper, M. G., A.-M. Trame \& M. G. Hohman. 1998. Management of herbaceous seeps and wet savannas for threatened and endangered species. Technical Report 98/70. U.S. Army Corps of Engineers, Construction Engineering Research Lab. Champaign, IL, 83 pp.

Harrel, S. L. \& E. D. Dibble. 2001. Foraging efficiency of juvenile bluegill, Lepomis macrochirus, among different vegetated habitats. Environ. Biol. Fishes 62: 441-453.

Harris, J. A. 1927. The cat tail, Typha angustifolia, in Utah. Torreya 27: 9-11.

Harris, S. A. 1990. Dynamics and origin of saline soils on the Slims River delta, Kluane National Park, Yukon Territory. Arctic 43: 159-175.

Harris, D. D. \& M. P. Gutzmer. 1996. Macrophyte production, fish herbivory, and water quality in a tailwater reservoir-Lake Ogallala, Nebraska. Trans. Nebraska Acad. Sci. 23: 29-35.

Harrison, P. G. 1979. Reproductive strategies in intertidal populations of two co-occurring seagrasses (Zostera spp.). Can. J. Bot. 57: 2635-2638.

Harrison, P. G. 1982a. Comparative growth of Zostera japonica Aschers. \& Graebn. and Z. marina L. under simulated intertidal and subtidal conditions. Aquat. Bot. 14: 373-379.

Harrison, P. G. 1982b. Seasonal and year-to-year variations in mixed intertidal populations of Zostera japonica Aschers. \& Graebn. and Ruppia maritima L. s.1. Aquat. Bot. 14: 357-371.

Harrison, M. L. 2002. The Patterson bundle. HerbalGram 55: $35-41$.

Harrison, P. G. \& R. E. Bigley. 1982. The recent introduction of the seagrass Zostera japonica Aschers. and Graebn. to the Pacific coast of North America. Can. J. Fish. Aquat. Sci. 39: 1642-1648.

Harrison, J. W. \& W. M. Knapp. 2010 [2015]. Ecological Classification of Groundwater-Fed Seepage Wetlands of the Maryland Coastal Plain. Maryland Department of Natural Resources, Wildlife and Heritage Service, Natural Heritage Program, Annapolis, MD. 98 pp.

Hart, K. A. 2006. Evaluation of the nutrient removal efficiency of a constructed wetland system. M.S. thesis. Texas A\&M University, College Station, TX. 103 pp.

Hartke, K. M., K. H. Kriegel, G. M. Nelson \& M. T. Merendino. 2009. Abundance of wigeongrass during winter and use by herbivorous waterbirds in a Texas coastal marsh. Wetlands 29: 288-293.

Hartley, T. G. 1959. Notes on some rare plants of Wisconsin. Trans. Wisconsin Acad. Sci. 8: 57-64.

Hartley, T. G. 1960. Plant communities of the LaCrosse area in western Wisconsin. Proc. Iowa Acad. Sci. 67: 174-188.

Hartman, G. 1985. Foods of male Mallard, before and during moult, as determined by faecal analysis. Wildfowl 36: 65-71.

Hartman, R. T. \& S. M. English. 1959. Wolffiella floridana in western Pennsylvania. Castanea 24: 45-47.

Hartog, C. D. 1970. The Sea-Grasses of the World. Verhandelingen der Koninklijke Nederlandse Akademie van Wetenschappen, Afd. Natuurkunde Tweede Reeks, Deel 59, No 1. NorthHolland Publishing Co., Amsterdam, The Netherlands. 294 pp.

Hartog, C. D. 1989. Distribution of Plasmodiophora bicaudata, a parasitic fungus on small Zostera species. Dis. Aquat. Organ. 6: $227-229$.

Hartog, C. D. \& F. V. D. Plas. 1970. A synopsis of the Lemnaceae. Blumea 18: 355-368.

Hartog, C. D., P. J. Van Loenhoud, J. G. M. Roelofs \& J. C. P. M. Van De Sande. 1979. Chromosome numbers of three seagrasses from The Netherlands Antilles. Aquat. Bot. 7: 267-271.

Harvey, R. M. \& J. L. Fox. 1973. Nutrient removal using Lemna minor. J. Water Pollut. Control Fed. 45: 1928-1938. 
Harvey, L. \& A. Haines. 2003. Sagittaria teres (Alismataceae) in New Hampshire. Rhodora 105: 282-285.

Harwell, M. C. \& R. J. Orth. 2002. Long-distance dispersal potential in a marine macrophyte. Ecology 83: 3319-3330.

Hassan, M. S. \& P. Edwards. 1992. Evaluation of duckweed (Lemna perpusilla and Spirodela polyrrhiza) as feed for Nile tilapia (Oreochromis niloticus). Aquaculture 104: 315-326.

Hauber, D. P. \& L. Lege. 1999. A survey of allozymic variation among three members of the Sagittaria graminea complex (Alismataceae) from the southeastern United States. J. Torrey Bot. Soc. 126: 181-187.

Haug, E. J., J. T. Harris \& R. J. Richardson. 2019. Monoecious Hydrilla verticillata development in complete darkness. Aquat. Bot. 154: 28-34.

Haukos, D. A. \& L. M. Smith. 1994. Composition of seed banks along an elevational gradient in playa wetlands. Wetlands 14: 301-307.

Haukos, D. A. \& L. M. Smith. 1997. Common Flora of the Playa Lakes. Texas Tech University Press, Lubbock, TX. 196 pp.

Haukos, D. A. \& L. M. Smith. 2001. Temporal emergence patterns of seedlings from playa wetlands. Wetlands 21: 274-280.

Haustein, A. T., R. H. Gilman, P. W. Skillicorn, H. Hannan, F. Diaz, V. Guevara, V. Vergara, A. Gastanaduy \& J. B. Gilman. 1994. Performance of broiler chickens fed diets containing duckweed (Lemna gibba). J. Agric. Sci. 122: 285-289.

Havera, S. P. 1986. Completion of Illinois Waterfowl Studies. Illinois Department of Conservation, Division of Wildlife Resources, Springfield, IL. 103 pp.

Hawkes, A. D. 1950. Studies in Florida Botany 8. The genus Habenaria in Florida. Am. Midl. Nat. 44: 622-629.

Hay, F. R. \& J. S. Muir. 2000. Low temperature survival of slender naiad (Najas flexilis) seeds. Cryo Lett. 21: 271-278.

Haynes, R. R. 1974. A revision of North American Potamogeton subsection Pusilli (Potamogetonaceae). Rhodora 76: 564-649.

Haynes, R. R. 1979. Revision of North and Central American Najas (Najadaceae). Sida 8: 34-56.

Haynes, R. R. 1985a. A new species of Najas (Najadaceae) from the southeastern U.S.A. Brittonia 37: 392-393.

Haynes, R. R. 1985b. A revision of the clasping-leaved Potamogeton (Potamogetonaceae). Sida 11: 173-188.

Haynes, R. R. 1988. Reproductive biology of selected aquatic plants. Ann. Missouri Bot. Gard. 75: 805-810.

Haynes, R. R. 2000a. Butomaceae Linnaeus. Pp. 3-4 In: Flora North America Editorial Committee (eds.), Flora of North America North of Mexico, Vol. 22: Magnoliophyta: Alismatidae, Arecidae, Commelinidae (in Part), and Zingiberidae. Oxford University Press, New York, NY.

Haynes, R. R. 2000b. Hydrocharitaceae Jussieu. Pp. 26-38 In: Flora North America Editorial Committee (eds.), Flora of North America North of Mexico, Vol. 22: Magnoliophyta:Alismatidae, Arecidae, Commelinidae (in Part), and Zingiberidae. Oxford University Press, New York, NY.

Haynes, R. R. 2000c. Najadaceae Jussieu. Pp. 77-83 In: Flora North America Editorial Committee (eds.), Flora of North America North of Mexico, Vol. 22: Magnoliophyta: Alismatidae, Arecidae, Commelinidae (in Part), and Zingiberidae. Oxford University Press, New York, NY.

Haynes, R. R. 2000d. Ruppiaceae Hutchinson. Pp. 75-76 In: Flora North America Editorial Committee (eds.), Flora of North America North of Mexico, Vol.22: Magnoliophyta:Alismatidae, Arecidae, Commelinidae (in Part), and Zingiberidae. Oxford University Press, New York, NY.

Haynes, R. R. 2000e. The aquatic vascular flora of the southeastern United States: endemism and origins. Sida 18: 23-28.
Haynes, R. R. 2000f. Cymodoceaceae N. Taylor. Pp. 86-89 In: Flora North America Editorial Committee (eds.), Flora of North America North of Mexico, Vol.22: Magnoliophyta: Alismatidae, Arecidae, Commelinidae (in Part), and Zingiberidae. Oxford University Press, New York, NY.

Haynes, R. R. 2000g. Zosteraceae Dumortier. Pp. 90-94 In: Flora North America Editorial Committee (eds.), Flora of North America North of Mexico, Vol. 22: Magnoliophyta: Alismatidae, Arecidae, Commelinidae (in Part), and Zingiberidae. Oxford University Press, New York, NY.

Haynes, R. R. 2004. Limnocharitaceae. Pp. 456-457 In: N. Smith, S. A. Mori, A. Henderson, D. W. Stevenson \& S. V. Heald (eds.), Flowering Plants of the Neotropics. Princeton University Press, Princeton, NJ.

Haynes, R. R. \& L. B. Holm-Nielsen. 1992. The Limnocharitaceae. Monograph 56, Flora Neotropica. The New York Botanical Garden, Bronx, NY. 34 pp.

Haynes, R. R. \& L. B. Holm-Nielsen. 1994. The Alismataceae. Monograph 64, Flora Neotropica. The New York Botanical Garden, Bronx, NY. 112 pp.

Haynes, R. R. \& J. R. Burkhalter. 1998. A new species of Echinodorus (Alismataceae) from the United States of America. Castanea 63: $180-182$.

Haynes, R. R. \& C. B. Hellquist. 2000a. Alismataceae Ventenat. Pp. 7-25 In: Flora North America Editorial Committee (eds.), Flora of North America North of Mexico, Vol. 22: Magnoliophyta: Alismatidae, Arecidae, Commelinidae (in Part), and Zingiberidae. Oxford University Press, New York, NY.

Haynes, R. R. \& C. B. Hellquist. 2000b. Juncaginaceae Richard. Pp. 43-46 In: Flora North America Editorial Committee (eds.), Flora of North America North of Mexico, Vol. 22: Magnoliophyta: Alismatidae, Arecidae, Commelinidae (in Part), and Zingiberidae. Oxford University Press, New York, NY.

Haynes, R. R. \& C. B. Hellquist. 2000c. Potamogetonaceae Dumortier. Pp. 47-74 In: Flora North America Editorial Committee (eds.), Flora of North America North of Mexico, Vol. 22: Magnoliophyta: Alismatidae, Arecidae, Commelinidae (in Part), and Zingiberidae. Oxford University Press, New York, NY.

Haynes, R. R. \& D. H. Les. 2004. Alismatales. In: Nature Encyclopedia of Life Sciences. Nature Publishing Group, London. doi: 10.1038/npg.els.0003702.

Haynes, R. R., D. H. Les \& L. B. Holm-Nielsen. 1998a. Alismataceae. Pp. 11-18 In: K. Kubitzki (ed.), The Families and Genera of Vascular Plants, Vol. IV, Flowering Plants: Monocotyledons, Alismatanae and Commelinanae (Except Gramineae). Springer-Verlag, Berlin, Germany.

Haynes, R. R., D. H. Les \& L. B. Holm-Nielsen. 1998b. Limnocharitaceae. Pp. 271-275 In: K. Kubitzki (ed.), The Families and Genera of Vascular Plants, Vol. IV, Flowering Plants: Monocotyledons, Alismatanae and Commelinanae (Except Gramineae). Springer-Verlag, Berlin, Germany.

Haynes, R. R., L. B. Holm-Nielsen \& D. H. Les. 1998c. Najadaceae. Pp. 301-306 In: K. Kubitzki (ed.), The Families and Genera of Vascular Plants, Vol. IV, Flowering Plants: Monocotyledons, Alismatanae and Commelinanae (Except Gramineae). Springer-Verlag, Berlin, Germany.

Haynes, R. R., L. B. Holm-Nielsen \& D. H. Les. 1998d. Potamogetonaceae. Pp. 408-415 In: K. Kubitzki (ed.), The Families and Genera of Vascular Plants, Vol. IV, Flowering Plants: Monocotyledons, Alismatanae and Commelinanae (Except Gramineae). Springer-Verlag, Berlin, Germany. 
Haynes, R. R., D. H. Les \& M. Král. 1998e. Two new combinations in Stuckenia, the correct name for Coleogeton (Potamogetonaceae). Novon 8: 241.

Haynes, R. R., D. H. Les \& L. B. Holm-Nielsen. 1998 f. Scheuchzeriaceae. Pp. 449-451 In: K. Kubitzki (ed.), The Families and Genera of Vascular Plants, Vol. IV, Flowering Plants: Monocotyledons, Alismatanae and Commelinanae (Except Gramineae). Springer-Verlag, Berlin, Germany.

Hays, J. F. 2010. Agalinis flexicaulis sp. nov. (Orobanchaceae: Lamiales), a new species from northeast Florida. J. Bot. Res. Inst. Texas 4: 1-6.

Hazen, T. 1918. The trimorphism and insect visitors of Pontederia. Mem. Torrey Bot. Club 17: 459-484.

Hazlett, B. T. 1988. Aquatic vegetation and flora of Sleeping Bear Dunes National Lakeshore, Benzie and Leelanau Counties, Michigan. Technical Report No. 15. Douglas Lake, Pellston, MI. 66 pp.

He, M.-X., Q. Hu, Q. Zhu, K. Pan \& Q. Li. 2015. The feasibility of using constructed wetlands plants to produce bioethanol. Environ. Prog. Sustain. Energy 34: 276-281.

Heal, R. E., E. F. Rogers, R. T. Wallace \& O. Starnes. 1950. A survey of plants for insecticidal activity. Lloydia 13: 89-162.

Heaven, J. B., F. E. Gross \& A. T. Gannon. 2003. Vegetation comparison of a natural and a created emergent marsh wetland. Southeast. Nat. 2: 195-207.

Heck, Jr., K. L. \& G. S. Wetstone. 1977. Habitat complexity and invertebrate species richness and abundance in tropical seagrass meadows. J. Biogeog. 4: 135-142.

Heck, Jr., K. L. \& R. J. Orth. 1980. Structural components of eelgrass (Zostera marina) meadows in the lower Chesapeake Baydecapod Crustacea. Estuaries 3: 289-295.

Heck, Jr., K. L., F. J. Fodrie, S. Madsen, C. J. Baillie \& D. A. Byron. 2015. Seagrass consumption by native and a tropically associated fish species: potential impacts of the tropicalization of the northern Gulf of Mexico. Mar. Ecol. Prog. Ser. 520: 165-173.

Heckscher, S. 1984. Potamogeton confervoides in Cumberland County, New Jersey. Bartonia 50: 63-64.

Hedeen, Stanley E. 1972. Food and feeding behavior of the mink frog, Rana septentrionalis Baird, in Minnesota. Am. Midl. Nat. 88: $291-300$.

Heenatigala, P. P. M., J. Yang, Z. Sun, G. Li, S. Kumar, S. Hu, Z. Wu, W. Lin, L. Yao, P. Duan \& H. Hou. 2018. Development of efficient protocols for stable and transient gene transformation for Wolffia globosa using Agrobacterium. Front. Chem. 6: 227.

Heffernan, J. J. \& R. A. Gibson. 1983. A comparison of primary production rates in Indian River, Florida seagrass systems. Florida Sci. 46: 295-306.

Hegazy, A. K., N. T. Abdel-Ghani \& G. A. El-Chaghaby. 2011. Phytoremediation of industrial wastewater potentiality by Typha domingensis. Int. J. Environ. Sci. Technol. 8: 639-648.

Hegelmaier, F. 1868. Die Lemnaceen. Eine monographische Untersuchung. Verlag von Wilhelm Engelmann, Leipzig. 169 pp.

Hegnauer, R. \& H. W. L. Ruijgrok. 1971. Lilaea scilloides und Juncus bulbosus zwei neue cyanogene pflanzen. Phytochemistry 10: 2121-2124.

Heidbüchel, P., K. Kuntz \& A. Hussner. 2016. Alien aquatic plants do not have higher fragmentation rates than native species: a field study from the River Erft. Aquat. Sci. 78: 767-777.

Heilman, M. A. \& R. G. Carlton. 2001. Ebullitive release of lacunar gases from floral spikes of Potamogeton angustifolius and Potamogeton amplifolius: effects on plant aeration and sediment $\mathrm{CH}_{4}$ flux. Aquat. Bot. 71: 19-33.
Heimbinder, E. 2001. Revegetation of a San Francisco coastal salt marsh. Native Plant J. 2(1): 54-59.

Heinrich, B. 2015. Rapid flower-opening in Iris pseudacorus. Northeast. Nat. 22: N11-N14.

Heinrich, B. 2016. A note on Iris flower anthesis: mechanism and meaning of sudden flower opening. Northeast. Nat. 23: N12-N17.

Heisey, R. M. \& A. W. H. Damman. 1982. Biomass and production of Pontederia cordata and Potamogeton epihydrus in three Connecticut rivers. Am. J. Bot. 69: 855-864.

Hellblom, F. \& L. Axelsson. 2003. External $\mathrm{HCO}_{3}{ }^{-}$dehydration maintained by acid zones in the plasma membrane is an important component of the photosynthetic carbon uptake in Ruppia cirrhosa. Photosynth. Res. 77: 173-181.

Hellquist, C. B. 1971. Vascular flora of Ossipee Lake, New Hampshire and its shoreline. Rhodora 73: 249-261.

Hellquist, C. B. 1972. Range extensions of vascular aquatic plants in New England. Rhodora 74: 131-141.

Hellquist, C. B. 1975. Correlation of selected dissolved substances and the distribution of Potamogeton in New England. Ph.D. dissertation. Univeristy of New Hampshire, Durham, NH. 269 pp.

Hellquist, C. B. 1977. Observations on some uncommon vascular aquatic plants in New England. Rhodora 79: 445-452.

Hellquist, C. B. 1980. Correlation of alkalinity and the distribution of Potamogeton in New England. Rhodora 82: 331-344.

Hellquist, C. B. 1984. Observations of Potamogeton hillii Morong in North America. Rhodora 86: 101-111.

Hellquist, C. B. 1997. A Guide to Invasive Non-Native Aquatic Plants in Massachusetts. Massachusetts Department of Environmental Management, Lakes \& Ponds Program, Boston, MA. 15 pp.

Hellquist, C. B. \& G. E. Crow. 1980. Aquatic vascular plants of New England: part 1. Zosteraceae, Potamogetonaceae, Zannichelliaceae, Najadaceae. Station Bulletin 515. New Hampshire Agricultural Experiment Station, University of New Hampshire, Durham, NH. 68 pp.

Hellquist, C. B. \& G. E. Crow. 1981. Aquatic vascular plants of New England: part 3. Alismataceae. Station Bulletin 518. New Hampshire Agricultural Experiment Station, University of New Hampshire, Durham, NH. 32 pp.

Hellquist, C. B. \& G. E. Crow. 1982. Aquatic vascular plants of New England: part 5. Araceae, Lemnaceae, Xyridaceae, Eriocaulaceae, and Pontederiaceae. Station Bulletin 523. New Hampshire Agricultural Experiment Station, University of New Hampshire, Durham, NH. 46 pp.

Hellquist, C. B. \& R. L. Hilton. 1983. A new species of Potamogeton (Potamogetonaceae) from northeastern United States. Syst. Bot. 8: 86-92.

Hellquist, C. B. \& R. R. Haynes. 2000. Aponogetonaceae J. Agardh. Pp. 39-40 In: Flora North America Editorial Committee (eds.), Flora of North America North of Mexico, Vol. 22: Magnoliophyta: Alismatidae, Arecidae, Commelinidae (in Part), and Zingiberidae. Oxford University Press, New York, NY.

Hellquist, C. B. \& A. R. Pike. 2004. Potamogeton strictifolius A. Bennett (Straight-Leaf Pondweed) Conservation and Research Plan for New England. New England Plant Conservation Program, Framingham, MA. 24 pp.

Hellquist, C. B., C. T. Philbrick \& R. L. Hilton. 1988. The taxonomic status of Potamogeton lateralis Morong (Potamogetonaceae). Rhodora 90: 15-20.

Hellquist, C. B., R. F. Thorne \& R. R. Haynes. 2012. Potamogetonaceae. Pondweed family. Pp. 1500-1503 In: B. G. Baldwin, D. H. Goldman, D. J. Keil, R. Patterson, T. J. Rosatti \& D. H. Wilken (eds.), The Jepson Manual: Vascular Plants of California, 2nd ed. University of California Press, Berkeley, CA. 
Hellquist, C. E., C. B. Hellquist \& J. J. Whipple. 2014. New records for rare and under-collected aquatic vascular plants of Yellowstone National Park. Madroño 61: 159-176.

Henderson, D. M. 1976. A biosystematic study of Pacific Northwestern blue-eyed grasses (Sisyrinchium, Iridaceae). Brittonia 28: 149-176.

Henderson, N. 2002. Iris Linnaeus. Pp. 371-395 In: Flora North America Editorial Committee (eds.), Flora of North America North of Mexico, Vol. 26: Magnoliophyta: Liliidae: Liliales and Orchidales. Oxford University Press, New York, NY.

Henderson, A., G. Galeano-Garces \& R. Bernal. 1997. Field Guide to the Palms of the Americas. Princeton University Press, Princeton, NJ. 352 pp.

Hendricks, A. J. 1957. A revision of the genus Alisma (Dill.) L. Am. Midl. Nat. 58: 470-493.

Hendricks, E. L. \& M. H. Goodwin, Jr. 1952. Observations on surface-water temperatures in limesink ponds and evaporation pans in southwestern Georgia. Ecology 33: 385-397.

Henriquez, C. L., T. Arias, J. C. Pires, T. B. Croat \& B. A. Schaal. 2014. Phylogenomics of the plant family Araceae. Mol. Phylogenet. Evol. 75: 91-102.

Henry-Silva, G. G., A. F. M. Camargo \& M. M. Pezzato. 2008. Growth of free-floating aquatic macrophytes in different concentrations of nutrients. Hydrobiologia 610: 153-160.

Herb, W. R. \& H. G. Stefan. 2003. Integral growth of submersed macrophytes in varying light regimes. Ecol. Modell. 168: 77-100.

Herbert, D. A. 1986. The growth dynamics of Halophila hawaiiana. Aquat. Bot. 23: 351-360.

Herndon, A. 1987. A morphometric comparison of Hymenocallis palmeri and Hymenocallis floridana (Amaryllidaceae) in southern Florida. Sida 12: 295-305.

Herrera-Silveira, J. A. 1994. Phytoplankton productivity and submerged macrophyte biomass variation in a tropical coastal lagoon with groundwater discharge. Vie Milieu 44: 257-266.

Herring, J. L. 1950. The aquatic and semiaquatic Hemiptera of northern Florida. Part 1: Gerridae. Florida Entomol. 33: 23-32.

Herring, B. J. \& W. S. Judd. 1995. A floristic study of Ichetucknee Springs State Park, Suwannee and Columbia Counties, Florida. Castanea 60: 318-369.

Hertweck, K. L., M. S. Kinney, S. A. Stuart, O. Maurin, S. Mathews, M. W. Chase, M. A. Gandolfo \& J. C. Pires. 2015. Phylogenetics, divergence times and diversification from three genomic partitions in monocots. Bot. J. Linn. Soc. 178: 375-393.

Herzka, S. Z. \& K. H. Dunton. 1998. Light and carbon balance in the seagrass Thalassia testudinum: evaluation of current production models. Mar. Biol. 132: 711-721.

Herzog, M. P. \& J. S. Sedinger. 2004. Dynamics of foraging behavior associated with variation in habitat and forage availability in captive black Brant (Branta bernicla nigricans) goslings in Alaska. Auk 121: 210-223.

Heslop-Harrison, J. W. 1952. Occurrence of the American pondweed, Potamogeton epihydrus Raf., in the Hebrides. Nature 169: 548.

Hesse, M. 2006. Pollen wall ultrastructure of Araceae and Lemnaceae in relation to molecular classifications. Aliso 22: 204-208.

Hestand, R. S. \& C. C. Carter. 1974. The effects of a winter drawdown on aquatic vegetation in a shallow water reservoir. Hyacinth Control J. 12: 9-12.

Heuschele, D. J. \& F. K. Gleason. 2014. Two stages of dormancy in turions of Potamogeton crispus L. Aquat. Bot. 119: 100-104.

Heyn, M. W. 1992. A review of the systematic position of the North American species of the genus Glyptotendipes. Netherlands $J$. Aquat. Ecol. 26: 129-137.

Hicks, L. E. 1932a. Flower production in the Lemnaceae. Ohio J. Sci. 32: 115-131.
Hicks, L. E. 1932b. Ranges of pH-tolerance of the Lemnaceae. Ohio J. Sci. 32: 237-244.

Hicks, L. E. 1937. The Lemnaceae of Indiana. Am. Midl. Nat. 18: 774-789.

Hicks, A. 2007. On the germination and subsequent culture of Spiranthes delitescens Sheviak in sterile culture. Orch. Dig. 71(3): 158-160.

Hicks, A. 2016. Growing the elusive Canelo Hills lady's tresses of Arizona's cienegas (Spiranthes delitescens Sheviak). Plant Press 39(2): 14-15.

Hicks, B. J., M. S. Wipfli, D. W. Lang \& M. E. Lang. 2005. Marinederived nitrogen and carbon in freshwater-riparian food webs of the Copper River Delta, southcentral Alaska. Oecologia 144: 558-569.

Hidalgo, O., S. Garcia, T. Garnatje, M. Mumbrú, A. Patterson, J. Vigo \& J. Vallès. 2015. Genome size in aquatic and wetland plants: fitting with the large genome constraint hypothesis with a few relevant exceptions. Plant Syst. Evol. 301: 1927-1936.

Hidding, B., B. A. Nolet, M. R. van Eerden, M. Guillemain \& M. Klaassen. 2009. Burial depth distribution of fennel pondweed tubers (Potamogeton pectinatus) in relation to foraging by Bewick's swans. Aquat. Bot. 90: 321-327.

Hiebert, R. D., D. A. Wilcox \& N. B. Pavlovic. 1986. Vegetation patterns in and among pannes (calcareous intradunal ponds) at the Indiana Dunes National Lakeshore, Indiana. Am. Midl. Nat. 116: $276-281$.

Hilaire, L. S. 2002. Amerorchis rotundifolia (Banks ex Pursh) Hultén. Small Round-Leaved Orchis. Conservation and Research Plan for New England, New England Conservation Program, Framingham, MA. 48 pp.

Hildebrand, T. 2012. Correlation between wetland vegetative and microbial community diversity of Bryce Canyon National Park's southern regions-Phase I. Colorado Plateau Cooperative Ecosystems Studies Unit; Agreement No.: H1200-09-0005; 30 December 2012. Bryce Canyon National Park \& Southern Utah University, Bryce/Cedar City, UT. 48 pp.

Hill, E. J. 1898. Potamogeton robbinsii. Bot. Gaz. 25: 195-196.

Hill, B. H. 1987. Typha productivity in a Texas pond: implications for energy and nutrient dynamics in freshwater wetlands. Aquat. Bot. 27: 385-394.

Hill, S. R. 2003. Conservation Assessment for twining screwstem (Bartonia paniculata (Michx.) Muhl.). Technical Report 2003 (7). Illinois Natural History Survey, Center for Biodiversity, Champaign, IL. 32 pp.

Hill, S. R. 2006. Conservation assessment for the Kidneyleaf Mudplantain (Heteranthera reniformis Ruiz \& Pavon). Technical Report 2006 (5). Illinois Natural History Survey, Center for Wildlife and Plant Ecology, Champaign, IL. 34 pp.

Hill, S. R. 2007. Conservation Assessment for the Green Wood Orchid Platanthera clavellata (Michx.) Luer. USDA Forest Service, Eastern Region (Region 9), Shawnee and Hoosier National Forests, Milwaukee, WI. 48 pp.

Hillman, W. S. 1961. The Lemnaceae, or duckweeds. Bot. Rev. 27: 221-287.

Hinman, S. E. \& J. S. Brewer. 2007. Responses of two frequentlyburned wet pine savannas to an extended period without fire. $J$. Torrey Bot. Soc. 134: 512-526.

Hiramatsu, M., K. Ii, H. Okubo, K. L. Huang \& C. W. Huang. 2001. Biogeography and origin of Lilium longiflorum and L. formosanum (Liliaceae) endemic to the Ryukyu Archipelago and Taiwan as determined by allozyme diversity. Am. J. Bot. 88: 1230-1239.

Hitchcock, C. L. 1944. The Tofieldia glutinosa complex of western North America. Am. Midl. Nat. 31: 487-498. 
Hitchin, G. G., I. Wile, G. E. Miller \& N. D. Yan. 1984. Macrophyte data from 46 southern Ontario soft-water lakes of varying pH. Data Report DR 84/2. Water Resources Branch, Ontario Ministry of the Environment, Dorset, ON. 132 pp.

Ho, J.-C. 2011. Antimicrobial, mosquito larvicidal and antioxidant properties of the leaf and rhizome of Hedychium coronarium. J. Chin. Chem. Soc. 58: 563-567.

Hoagland, B. W. \& A. Buthod. 2007. Updated Oklahoma Ozark flora. Oklahoma Nat. Plant Rec. 7: 54-66.

Hoagland, B. W. \& A. K. Buthod. 2017. Vascular flora of the Deep Fork National Wildlife Refuge, Okmulgee County, Oklahoma. Castanea 82: 32-45.

Hoagland, B. W., I. H. Butler \& N. A. McCarty. 2001. Identification and Assessment of Ecologically Significant Wetland Communities in North Central, Northwestern, and the Panhandle of Oklahoma: Final Report. Oklahoma Biological Survey, University of Oklahoma, Norman, OK. 42 pp.

Hoang, P. T. N. \& I. Schubert. 2017. Reconstruction of chromosome rearrangements between the two most ancestral duckweed species Spirodela polyrhiza and S. intermedia. Chromosoma 126: 729-739.

Hochbach, A., H. P. Linder \& M. Röser. 2018. Nuclear genes, matK and the phylogeny of the Poales. Taxon 67: 521-536.

Hodgdon, A. R., P. Giguere, S. B. Krochmal \& A. Riel. 1952. New Potamogeton records in New Hampshire. Rhodora 54: 237-246.

Hoffman, C. E. 1940. Limnological relationships of some northern Michigan Donaciini (Chrysomelidae; Coleoptera). Trans. Am. Microsc. Soc. 59: 259-274.

Hoffmann, M. A., U. Raeder \& A. Melzer. 2014a. Influence of environmental conditions on the regenerative capacity and the survivability of Elodea nuttallii fragments. J. Limnol. 74: 12-20.

Hoffmann, M. A., U. Raeder \& A. Melzer. 2014b. Influence of the gender on growth and phenology of the dioecious macrophyte Najas marina ssp. intermedia. Hydrobiologia 727: 167-176.

Hofmann, J. E., E. Gardner \& M. J. Morris. 1990. Distribution, abundance, and habitat of the marsh rice rat (Oryzomys palustris) in southern Illinois. Trans. Illinois State Acad. Sci. 83: 162-180.

Hofstra, D. E., K. D. Adam \& J. S. Clayton. 1995. Isozyme variation in New Zealand populations of Myriophyllum and Potamogeton species. Aquat. Bot. 52: 121-131.

Hogsden, K. L., E. P. S. Sager \& T. C. Hutchinson. 2007. The impacts of the non-native macrophyte Cabomba caroliniana on littoral biota of Kasshabog Lake, Ontario. J. Great Lakes Res. 33: 497-504.

Hohman, W. L. \& C. D. Ankney. 1994. Body size and condition, age, plumage quality, and foods of prenesting male cinnamon teal in relation to pair status. Can. J. Zool. 72: 2172-2176.

Hohman, W. L., D. W. Woolington \& J. H. Devries. 1990. Food habits of wintering canvasbacks in Louisiana. Can. J. Zool. 68: 2605-2609.

Hohman, W. L., T. M. Stark \& J. L. Moore. 1996. Food availability and feeding preferences of breeding fulvous whistling-ducks in Louisiana ricefields. Wilson Bull. 108: 137-150.

Holaday, A. S. \& G. Bowes. 1980. $\mathrm{C}_{4}$ acid metabolism and dark $\mathrm{CO}_{2}$ fixation in a submersed aquatic macrophyte (Hydrilla verticillata). Plant Physiol. 65: 331-335.

Holbrook, S. J., D. C. Reed, K. Hansen \& C. A. Blanchette. 2000. Spatial and temporal patterns of predation on seeds of the surfgrass Phyllospadix torreyi. Mar. Biol. 136: 739-747.

Holbrook, S. J., D. C. Reed \& J. S. Bull. 2002. Survival experiments with outplanted seedlings of surfgrass (Phyllospadix torreyi) to enhance establishment on artificial structures. ICES J. Mar. Sci. 59(suppl.): S350-S355.
Holder, G. L., M. K. Johnson \& J. L. Baker. 1980. Cattle grazing and management of dusky seaside sparrow habitat. Wildl. Soc. Bull. 8: 105-109.

Hollingsworth, P. M., C. D. Preston \& R. J. Gornall. 1996a. Isozyme evidence for the parentage and multiple origins of Potamogeton $\times$ suecicus $(P$. pectinatus $\times$ P. filiformis, Potamogetonaceae). Plant Syst. Evol. 202: 219-232.

Hollingsworth, P. M., C. D. Preston \& R. J. Gornall. 1996b. Genetic variability in two hydrophilous species of Potamogeton, $P$. pectinatus and P. filiformis (Potamogetonaceae). Plant Syst. Evol. 202: 233-254.

Hollingsworth, P. M., C. D. Preston \& R. J. Gornall. 1998a. Euploid and aneuploid evolution in Potamogeton (Potamogetonaceae): a factual basis for interpretation. Aquat. Bot. 60: 337-358.

Hollingsworth, P. M., C. D. Preston \& R. J. Gornall. 1998b. Lack of detectable isozyme variability in British populations of Potamogeton epihydrus (Potamogetonaceae). Aquat. Bot. 60: 433-437.

Holm, T. 1891. Contributions to the knowledge of the germination of some North American plants. Mem. Torrey Bot. Club 2: 57-108.

Holm, T. 1904. The root-structure of North American terrestrial Orchideae. Am. J. Sci. 18: 197-212.

Holmes, W. C. 1978. Range extension for Ottelia alismoides (L.) Pers. (Hydrocharitaceae). Castanea 43: 193-194.

Holmes, W. C. 2002a. Crinum Linnaeus. Pp. 278-279 In: Flora North America Editorial Committee (eds.), Flora of North America North of Mexico, Vol. 26: Magnoliophyta: Liliidae: Liliales and Orchidales. Oxford University Press, New York, NY.

Holmes, W. C. 2002b. Smilacaceae Ventenat. Catbrier family. Pp. 468-478 In: Flora North America Editorial Committee (eds.), Flora of North America North of Mexico, Vol. 26: Magnoliophyta: Liliidae: Liliales and Orchidales. Oxford University Press, New York, NY.

Holmes, W. C., A. E. Rushing \& J. R. Singhurst. 2005. Taxonomy and identification of Isoetes (Isoetaceae) in Texas based on megaspore features. Lundellia 2005: 1-7.

Holsinger, K. E. \& L. E. Wallace. 2004. Bayesian approaches for the analysis of population genetic structure: an example from Platanthera leucophaea (Orchidaceae). Mol. Ecol. 13: 887-894.

Holt, C. R., G. W. Folkerts \& D. R. Folkerts. 2011. A floristic study of a steephead stream in northwestern Florida. Southeast. Nat. 10: 289-302.

Homoya, M. A. 1982. Additions to the flora of southern Indiana. Proc. Indiana Acad. Sci. 92: 379-382.

Homoya, M. A. 1983. A floristic survey of acid seep springs in Martin and Dubois countries, Indiana. Proc. Indiana Acad. Sci. 93: 323-332.

Homoya, M. A. \& C. L. Hedge. 1982. The upland sinkhole swamps and ponds of Harrison County, Indiana. Proc. Indiana Acad. Sci. 92: 383-388.

Homoya, M. A., D. B. Abrell, J. A. Aldrich \& T. W. Post. 1984. The natural regions of Indiana. Proc. Indiana Acad. Sci. 94: 245-268.

Hooper, F. F. 1951. Limnological features of a Minnesota seepage lake. Am. Midl. Nat. 46: 462-481.

Hootsmans, M. J. M., J. E. Vermaat \& W. Van Vierssen. 1987. Seedbank development, germination and early seedling survival of two seagrass species from The Netherlands: Zostera marina L. and Zostera noltii Hornem. Aquat. Bot. 28: 275-285.

Hoover, R. F. 1939. A revision of the genus Brodiaea Am. Midl. Nat. 22: 551-574. 
Hopfensperger, K. N. \& A. H. Baldwin. 2009. Spatial and temporal dynamics of floating and drift-line seeds at a tidal freshwater marsh on the Potomac River, USA. Plant Ecol. 201: 677-686.

Hopkins, C. E. O. 1969. Vegetation of fresh-water springs of Southern Illinois. Castanea 34: 121-145.

Hopper, S. D., M. F. Fay, M. Rossetto \& M. W. Chase. 1999. A molecular phylogenetic analysis of the bloodroot and kangaroo paw family, Haemodoraceae: taxonomic, biogeographic and conservation implications. Bot. J. Linn. Soc. 131: 285-299.

Hopper, S. D., R. J. Smith, M. F. Fay, J. C. Manning \& M. W. Chase. 2009. Molecular phylogenetics of Haemodoraceae in the Greater Cape and southwest Australian floristic regions. Mol. Phylogenet. Evol. 51: 19-30.

Horn, C. N. 1983a. The annual growth cycle of Heteranthera dubia in Ohio. Michigan Bot. 23: 29-34.

Horn, M. H. 1983b. Optimal diets in complex environments: feeding strategies of two herbivorous fishes from a temperate rocky intertidal zone. Oecologia 58: 345-350.

Horn, C. N. 1988. Developmental heterophylly in the genus Heteranthera (Pontederiaceae). Aquat. Bot. 31: 197-209.

Horn, C. N. 1998. Pontederiaceae. Pickerelweed family. J. ArizonaNevada Acad. Sci. 30: 133-136.

Horn, C. N. 2002. Pontederiaceae Kunth. Pp. 37-46 In: Flora North America Editorial Committee (eds.), Flora of North America North of Mexico, Vol. 26: Magnoliophyta: Liliidae: Liliales and Orchidales. Oxford University Press, New York, NY.

Horn, C. N. \& E. McClintock. 2012. Pontederiaceae. Pp. 1498-1500 In: B. G. Baldwin, D. H. Goldman, D. J. Keil, R. Patterson, T. J. Rosatti \& D. H. Wilken (eds.), The Jepson Manual: Vascular Plants of California, 2nd ed. University of California Press, Berkeley, CA.

Hornbeck, J. H., D. Reyher, C. H. Sieg \& R. W. Crook. 2003. Conservation Assessment for Southern Maidenhair Fern and Stream Orchid in the Black Hills National Forest South Dakota and Wyoming. USDA Forest Service, Rocky Mountain Region, Custer, SD. 41 pp.

Hosack, D. 1811. Hortus Elginensis: Or Catalogue of Plants Indigenous and Exotic, Cultivated in the Elgin Botanic Garden in the Vicinity of the City of New York, Established in 1801. T. \& J. Swords, New York, NY. 65 pp.

Hossain, M. M. 2011. Therapeutic orchids: traditional uses and recent advances — an overview. Fitoterapia 82: 102-140.

Hossain, M. L., S. Sarker \& N. J. Sarker. 2010. Food habits and feeding behaviour of Bengal eyed turtle Morenia petersi (Anderson: 1879) in Bangladesh. Bangladesh J. Zool. 38: 213-222.

Hossell, J. C. \& J. H. Baker. 1979. Estimation of the growth rates of epiphytic bacteria and Lemna minor in a river. Freshw. Biol. 9: 319-327.

Hotchkiss, N. \& R. E. Stewart. 1947. Vegetation of the patuxent research refuge, Maryland. Am. Midl. Nat. 38: 1-75.

Hothem, R. L. \& H. M. Ohlendorf. 1989. Contaminants in foods of aquatic birds at Kesterson Reservoir, California, 1985. Arch. Environ. Contam. Toxicol. 18: 773-786.

Houle, G. \& D. L. Phillips. 1988. The soil seed bank of granite outcrop plant communities. Oikos 52: 87-93.

Houle, G. \& D. L. Phillips. 1989a. Seasonal variation and annual fluctuation in granite outcrop plant communities. Vegetatio $\mathbf{8 0}$ : $25-35$.

Houle, G. \& D. L. Phillips. 1989b. Seed availability and biotic interactions in granite outcrop plant communities. Ecology 70: 1307-1316.

Houle, G. \& A. Delwaide. 1991. Population structure and growthstress relationship of Pinus taeda in rock outcrop habitats. $J$. Veg. Sci. 2: 47-58.
Howard, R. J. \& I. A. Mendelssohn. 1995. Effect of increased water depth on growth of a common perennial freshwaterintermediate marsh species in coastal Louisiana. Wetlands 15: 82-91.

Howard, F. W. \& S. Halbert. 2005. Flatid planthopper, Oormenaria rufifascia (Walker) (Insecta: Hemiptera: Auchenorrhyncha: Flatidae). Document EENY351. IFAS Extension, University of Florida, Gainesville, FL. 5 pp.

Howard, R. J. \& C. J. Wells. 2009. Plant community establishment following drawdown of a reservoir in southern Arkansas, USA. Wetl. Ecol. Manag. 17: 565-583.

Howe, H. F. \& J. Smallwood. 1982. Ecology of seed dispersal. Ann. Rev. Ecol. Syst. 13: 201-228.

Howell, L. N. 2012. Ontogenetic shifts in diet and habitat by juvenile green sea turtles (Chelonia mydas) along the middle and lower Texas coast. M.S. thesis. Texas A\&M University, Galveston, TX. 87 pp.

Howell, N., A. Krings \& R. R. Braham. 2016. Guide to the littoral zone vascular flora of Carolina bay lakes (U.S.A.). Biodivers. Data J. 2016(4). doi: 10.3897/BDJ.4.e7964.

Howells, R. G., L. E. Burlakova, A. Y. Karatayev, R. K. Marfurt \& R. L. Burks. 2006. Native and introduced Ampullariidae in North America: history, status, and ecology. Pp. 73-112 In: R. C. Joshi \& L. S. Sebastian (eds.), Global Advances in the Ecology and Management of Golden Apple Snails. Philippine Rice Research Institute, Muñoz, Nueva Ecija, Philippines. 588 pp.

Howie, S. A. \& I. van Meerveld. 2016. Classification of vegetative lagg types and hydrogeomorphic lagg forms in bogs of coastal British Columbia, Canada. Can. Geogr. 60: 123-134.

Hoyer, M. V., D. E. Canfield, Jr., C. A. Horsburgh \& K. Brown. 1996. Florida Freshwater Plants: A Handbook of Common Aquatic Plants in Florida Lakes. University of Florida, Institute of Food \& Agricultural Sciences, Gainesville, FL. 264 pp.

Hroudová, Z. \& P. Zákravský. 1993. Ecology of two cytotypes of Butomus umbellatus II. Reproduction, growth and biomass production. Folia Geobot. 28: 413-424.

Hroudová, Z. \& P. Zákravský. 2003. Germination responses of diploid Butomus umbellatus to light, temperature and flooding. Funct. Ecol. Plants 198: 37-44.

Hroudová, Z., P. Zákravský \& O. Čechurová. 2004. Germination of seed of Alisma gramineum and its distribution in the Czech Republic. Preslia 76: 97-118.

Hsiao, Y.-Y., Z.-J. Pan, C.-C. Hsu, Y.-P. Yang, Y.-C. Hsu, Y.-C. Chuang, H.-H. Shih, W.-H. Chen, W.-C. Tsai \& H.-H. Chen. 2011. Research on orchid biology and biotechnology. Plant Cell Physiol. 52: 1467-1486.

Hua, K.-F., H.-Y. Hsu, Y.-C. Su, I.-F. Lin, S.-S. Yang, Y.-M. Chen \& L. K. Chao. 2006. Study on the antiinflammatory activity of methanol extract from seagrass Zostera japonica. J. Agric. Food Chem. 54: 306-311.

Huang, S.-Q. 2003. Flower dimorphism and the maintenance of andromonoecy in Sagittaria guyanensis ssp. lappula (Alismataceae). New Phytol. 15: 357-364.

Huang, S.-Q. \& X.-X. Tang. 2008. Discovery of gynoecium color polymorphism in an aquatic plant. J. Integr. Plant Biol. 50: 1178-1182.

Huang, S.-Q., N. Song, Q. Wang, L.-L. Tang \& X.-F. Wang. 2000. Sex expression and the evolutionary advantages of male flowers in an andromonoecious species, Sagittaria guyanensis subsp. lappula (Alismataceae). Acta Bot. Sin. 36: 310-316.

Huang, S.-Q., Y.-H. Guo, G. W. Robert, Y.-H. Shi \& K. Sun. 2001. Mechanism of underwater pollination in Najas marina (Najadaceae). Aquat. Bot. 70: 67-78. 
Huang, S., X.-L. Zhou, C.-J. Wang, Y.-S. Wang, F. Xiao, L.-H. Shan, Z.Y. Guo \& J. Weng. 2013. Pyrrolizidine alkaloids from Liparis nervosa with inhibitory activities against LPS-induced NO production in RAW264. 7 macrophages. Phytochemistry 93: 154-161.

Hubbard, J. R. \& W. S. Judd. 2013. Floristics of Silver River State Park, Marion County, Florida. Rhodora 115: 250-280.

Hubert, B. \& J. Maton. 1939. Parthenocarpie en Groeistof. Natuurw. Tijdschr. Antwerp. 21: 339-348.

Hudon, C. 1997. Impact of water level fluctuations on St. Lawrence River aquatic vegetation. Can. J. Fish. Aquat. Sci. 54: 2853-2865.

Hudon, C. 2004. Shift in wetland plant composition and biomass following low-level episodes in the St. Lawrence River: looking into the future. Can. J. Fish. Aquat. Sci. 61: 603-617.

Huffman, R. T. \& R. I. Lonard. 1983. Successional patterns on floating vegetation mats in a southwestern Arkansas bald cypress swamp. Castanea 48: 73-78.

Huffman, R. T. \& G. E. Tucker. 1984. Preliminary guide to the onsite identification and delineation of the wetlands of Alaska. Technical Report Y-78-9. U.S. Army Engineer Waterways Experiment Station, Vicksburg, MS. 88 pp.

Huffman, J. M. \& W. S. Judd. 1998. Vascular flora of Myakka River State Park, Sarasota and Manatee Counties, Florida. Castanea 63: $25-50$

Hughes, J. H. \& E. L. Young. 1982. Autumn foods of dabbling ducks in southeastern Alaska. J. Wildl. Manag. 46: 259-263.

Hughes, A. R. \& J. J. Stachowicz. 2009. Ecological impacts of genotypic diversity in the clonal seagrass Zostera marina. Ecology 90: $1412-1419$.

Hughes, B. A. \& M. E. Kane. 2018. Seed cryopreservation of selected Florida native orchid species. Seed Sci. Technol. 46: 431-446.

Huiskes, A. H. L., B. P. Koutstaal, P. M. J. Herman, W. G. Beeftink, M. M. Markusse \& W. De Munck. 1995. Seed dispersal of halophytes in tidal salt marshes. J. Ecol. 83: 559-567.

Humaida, N., K. Krisdianto \& S. B. Peran. 2016. Estimation of carbon storage in water lettuce (Pistia stratiotes) at freshwater swamps. Trop. Wetland J. 2: 38-46.

Humbert, L., D. Gagnon, D. Kneeshaw \& C. Messier. 2007. A shade tolerance index for common understory species of northeastern North America. Ecol. Indicators 7: 195-207.

Humm, H. J. 1956. Sea grasses of the northern Gulf Coast. Bull. Mar. Sci. 6: 305-308.

Humphreys, E. R., P. M. Lafleur, L. B. Flanagan, N. Hedstrom, K. H. Syed, A. J. Glenn \& R. Granger. 2006. Summer carbon dioxide and water vapor fluxes across a range of northern peatlands. J. Geophys. Res. Biogeosci. 111: G04011. doi: 10.1029/2005JG000111.

Humphreys, E. R., C. Charron, M. Brown \& R. Jones. 2014. Two bogs in the Canadian Hudson Bay lowlands and a temperate bog reveal similar annual net ecosystem exchange of CO. Arct. Antarct. Alp. Res. 46: 103-113.

Huneycutt, M. B. \& M. D. Floyd. 1999. Ponthieva racemosa (Orchidaceae) in Trace State Park, Pontotoc County, Mississippi. J. Mississippi Acad. Sci. 44: 229-230.

Hunt, K. W. 1943. Floating mats on a southeastern coastal plain reservoir. Bull. Torrey Bot. Club 70: 481-488.

Hunt, J. 1992. Feeding ecology of valley pocket gophers (Thomomys bottae sanctidiegi) on a California coastal grassland. Am. Midl. Nat. 127: 41-51.

Hunt, D. M., K. B. Searcy, R. E. Zaremba \& C. R. Lombardi. 1995. The vascular plants of Fort Devens, Massachusetts. Rhodora 97: 208-244.

Hunter, Jr., M. L., J. J. Jones \& J. W. Witham. 1986. Biomass and species richness of aquatic macrophytes in four Maine (U.S.A.) lakes of different acidity. Aquat. Bot. 24: 91-95.
Huotari, T. \& H. Korpelainen. 2012. Complete chloroplast genome sequence of Elodea canadensis and comparative analyses with other monocot plastid genomes. Gene 508: 96-105.

Huotari, T., H. Korpelainen, E. Leskinen \& K. Kostamo. 2011. Population genetics of the invasive water weed Elodea canadensis in Finnish waterways. Plant Syst. Evol. 294: 27-37.

Husband, B. C. \& M. Hickman. 1989. The frequency and local abundance of Ruppia occidentalis in relation to sediment texture and lake salinity. Can. J. Bot. 67: 2444-2449.

Husband, B. C. \& S. C. H. Barrett. 1992. Pollinator visitation in populations of tristylous Eichhornia paniculata in northeastern Brazil. Oecologia 89: 365-371.

Husband, B. C. \& S. C. H. Barrett. 1993. Multiple origins of self-fertilization in tristylous Eichhornia paniculata (Pontederiaceae): inferences from style morph and isozyme variation. J. Evol. Biol. 6: 591-608.

Husband, B. C. \& S. C. H. Barrett. 1995. Estimates of gene flow in Eichhornia paniculata (Pontederiaceae): effects of range substructure. Heredity 75: 549-560.

Husband, B. C. \& S. C. H. Barrett. 1998. Population genetic structure in the tropical plant Eichhornia paniculata: implications for gene flow in ephemeral habitats. Am. J. Bot. 85: 60-61.

Hussner, A. 2012. Alien aquatic plant species in European countries. Weed Res. 52: 297-306.

Hussner, A., H. P. Hoelken \& P. Jahns. 2010a. Low light acclimated submerged freshwater plants show a pronounced sensitivity to increasing irradiances. Aquat. Bot. 93: 17-24.

Hussner, A., K. van de Weyer, E. M. Gross \& S. Hilt. 2010 b. Comments on increasing number and abundance of non-indigenous aquatic macrophyte species in Germany. Weed Res. 50: 519-526.

Hussner, A., P. Heidbuechel \& S. Heiligtag. 2014. Vegetative overwintering and viable seed production explain the establishment of invasive Pistia stratiotes in the thermally abnormal Erft River (North Rhine-Westphalia, Germany). Aquat. Bot. 119: $28-32$.

Hussner, A., T. Mettler-Altmann, A. P. M. Weber \& K. Sand-Jensen. 2016. Acclimation of photosynthesis to supersaturated $\mathrm{CO}_{2}$ in aquatic plant bicarbonate users. Freshw. Biol. 61: 1720-1732.

Hussey, J. S. 1974. Some useful plants of early New England. Econ. Bot. 28: 311-337.

Hutchings, M. J. \& P. J. Russell. 1989. The seed regeneration dynamics of an emergent salt marsh. J. Ecol. 77: 615-637.

Hutton, E. E. 1974. A large vegetational formation of Cretaceous and Tertiary origin in West Virginia. Castanea 39: 71-76.

Hutton, E. E. \& R. B. Clarkson. 1961. Two plants new for North America and some new or otherwise interesting plants in West Virginia. Castanea 26: 84-88.

Iida, S., K. Kosuge \& Y. Kadono. 2004. Molecular phylogeny of Japanese Potamogeton species in light of noncoding chloroplast sequences. Aquat. Bot. 80: 115-127.

Iida, S., A. Miyagi, S. Aoki, M. Ito, Y. Kadono \& K. Kosuge. 2009. Molecular adaptation of $r b c L$ in the heterophyllous aquatic plant Potamogeton. PLoS One, 4(2): e4633.

Ikusima, I. \& J. G. Gentil. 1993. Vegetative growth and productivity of Eichhornia azurea with special emphasis on leaf dynamics. Ecol. Res. 8: 287-295.

Ileperuma, V., S. Udage, D. Yakandawala, L. Jayasinghe, S. Kumar \& A. Ratnatilleke. 2015. Does ingestion of plants from a phenetic group of Monochoria ('Diyahabarala') cause hepatotoxicity? Ceylon Med. J. 60: 28-30.

Iler, A. M. \& D. W. Inouye. 2013. Effects of climate change on mastflowering cues in a clonal montane herb, Veratrum tenuipetalum (Melanthiaceae). Am. J. Bot. 100: 519-525. 
Iles, W. J. D., S. Y. Smith \& S. W. Graham. 2013. A well-supported phylogenetic framework for the monocot order Alismatales reveals multiple losses of the plastid NADH dehydrogenase complex and a strong long-branch effect. Pp. 1-28 In: P. Wilkin \& S. J. Mayo (eds.), Early Events in Monocot Evolution. Cambridge University Press, Cambridge, United Kingdom.

Illyés, Z., S. Rudnóy \& Z. Bratek. 2005. Aspects of in situ, in vitro germination and mycorrhizal partners of Liparis loeselii. Acta Biol. Szegediensis 49: 137-139.

Iltis, H. H. 1950. Studies in Virginia plants I. List of bryophytes from the vicinity of Fredericksburg, Virginia. Castanea 15: 38-50.

Imaizumi, T., G. X. Wang, T. Ohsako \& T. Tominaga. 2008a. Genetic diversity of sulfonylurea-resistant and-susceptible Monochoria vaginalis populations in Japan. Weed Res. 48: 187-196.

Imaizumi, T., G.-X. Wang \& T. Tominaga. 2008b. Pollination of chasmogamous flowers and the effects of light and emergence time on chasmogamy and cleistogamy in Monochoria vaginalis. Weed Biol. Manag. 8: 260-266.

Inácio, C. D., O. Chauveau, T. T. Souza-Chies, H. Sauquet \& L. Eggers. 2017. An updated phylogeny and infrageneric classification of the genus Sisyrinchium (Iridaceae): challenges of molecular and morphological evidence. Taxon 66 : 1317-1348.

Incardona, J. P., W. Gaffield, R. P. Kapur \& H. Roelink. 1998. The teratogenic Veratrum alkaloid cyclopamine inhibits sonic hedgehog signal transduction. Development 125: 3553-3562.

Inglis, G. J. 1999. Variation in the recruitment behaviour of seagrass seeds: implications for population dynamics and resource management. Pac. Conserv. Biol. 5: 251-259.

Inoue, K. I. 1983. Systematics of the genus Platanthera (Orchidaceae) in Japan and adjacent regions with special reference to pollination. J. Fac. Sci. Univ. Tokyo, Sect. 3, Bot. 13: 285-374.

Inoue, K., T. Kato, H. Kunitake \& T. Yabuya. 2004. Efficient production of polyploid plants via protoplast culture of Iris fulva. Cytologia 69: 327-333.

Inserra, R. N., J. D. Stanley, J. H. O’Bannon \& R. P. Esser. 2005. Nematode quarantine and certification programmes implemented in Florida. Nematol. Medit. 33: 113-123.

In't Veen, J. 1981. Cryptocorynen. Wissenswertes über die Pflege asiatischer Wasserkelche im Aquarium. Lehrmeister Bücherei Nr. 68. Albrecht Philler Verlag, Minden. 136 pp.

Irwin, R. E., D. Cook, L. L. Richardson, J. S. Manson \& D. R. Gardner. 2014. Secondary compounds in floral rewards of toxic rangeland plants: impacts on pollinators. J. Agric. Food Chem. 62: 7335-7344.

Ismail, B. S. \& K. Phaik-Hong. 2004. A study of weed populations and their buried seeds in the soil of MARDI research station and at farmers' rice fields in Sungai Burung, Tanjung Karang, Selangor, Malaysia. Pertanika J. Trop. Agric. Sci. 27: 113-120.

Ismail Sahid, Z. \& N. K. Ho. 1995. Weed populations and their buried seeds in rice fields of the Muda area, Kedah, Malaysia. Pertanika J. Trop. Agric. Sci. 18: 21-28.

Ito, K. 1999. Isolation of two distinct cold-inducible cDNAs encoding plant uncoupling proteins from the spadix of skunk cabbage (Symplocarpus foetidus). Plant Sci. 149: 167-173.

Ito, Y. \& N. Tanaka. 2011. Hybridisation in a tropical seagrass genus, Halodule (Cymodoceaceae), inferred from plastid and nuclear DNA phylogenies. Telopea 13: 219-231.

Ito, Y., T. Ohi-Toma, J. Murata \& N. Tanaka. 2010. Hybridization and polyploidy of an aquatic plant, Ruppia (Ruppiaceae), inferred from plastid and nuclear DNA phylogenies. Am. J. Bot. 97: 1156-1167.
Ito, Y., T. Ohi-Toma, J. Murata \& N. Tanaka. 2013. Comprehensive phylogenetic analyses of the Ruppia maritima complex focusing on taxa from the Mediterranean. J. Plant Res. 126: $753-762$.

Ito, Y., T. Ohi-Toma, N. Tanaka, J. Murata \& A. M. Muasya. 2015. Phylogeny of Ruppia (Ruppiaceae) revisited: molecular and morphological evidence for a new species from Western Cape, South Africa. Syst. Bot. 40: 942-949.

Ito, Y., N. Tanaka, P. García-Murillo \& A. M. Muasya. 2016a. A new delimitation of the Afro-Eurasian plant genus Althenia to include its Australasian relative, Lepilaena (Potamogetonaceae)-evidence from DNA and morphological data. Mol. Phylogenet. Evol. 98: 261-270.

Ito, Y., N. Tanaka, C. Kim, R. B. Kaul \& D. C. Albach. 2016 b. Phylogeny of Sparganium (Typhaceae) revisited: nonmonophyletic nature of S. emersum sensu lato and resurrection of S. acaule. Plant Syst. Evol. 302: 129-135.

Ito, Y., N. Tanaka, S. W. Gale, O. Yano \& J. Li. 2017a. Phylogeny of Najas (Hydrocharitaceae) revisited: implications for systematics and evolution. Taxon 66: 309-323.

Ito, Y., T. Ohi-Toma, C. Nepi, A. Santangelo, A. Stinca, N. Tanaka \& J. Murata. 2017b. Towards a better understanding of the Ruppia maritima complex (Ruppiaceae): notes on the correct application and typification of the names $R$. cirrhosa and $R$. Spiralis. Taxon 66: 167-171.

Itokawa, H., H. Morita, I. Katou, K. Takeya, A. J. Cavalheiro, R. C. B. de Oliveira, M. Ishige \& M. Motidome. 1988. Cytotoxic diterpenes from the rhizomes of Hedychium coronarium. Plant Med. 54: 311-315.

Ivancic, A. \& V. Lebot. 2000. The Genetics and Breeding of Taro. CIRAD, Montpellier, France. 194 pp.

Ivancic, A., V. Lebot, O. Roupsard, J. Q. Garcia \& T. Okpul. 2004. Thermogenic flowering of taro (Colocasia esculenta, Araceae). Can. J. Bot. 82: 1557-1565.

Iverson, S. J., J. E. McDonald, Jr. \& L. K. Smith. 2001. Changes in the diet of free-ranging black bears in years of contrasting food availability revealed through milk fatty acids. Can. J. Zool. 79: 2268-2279.

Izzati, M. 2016. Salt tolerance of several aquatic plants. Proc. Int. Conf. Glob. Resour. Conserv. 6: 154-157.

Jackson, L. E. \& L. C. Bliss. 1982. Distribution of ephemeral herbaceous plants near treeline in the Sierra Nevada, California, USA. Arct. Alp. Res. 14: 33-43.

Jackson, S. T. \& D. F. Charles. 1988. Aquatic macrophytes in Adirondack (New York) lakes: patterns of species composition in relation to environment. Can. J. Bot. 66: 1449-1460.

Jacobson, A. \& M. Hedrén. 2007. Phylogenetic relationships in Alisma (Alismataceae) based on RAPDs, and sequence data from ITS and trnL. Pl. Syst. Evol. 265: 27-44.

Jacobs, D. L. 1947. An ecological life-history of Spirodela polyrhiza (Greater Duckweed) with emphasis on the turion phase. Ecol. Monogr. 17: 437-469.

Jacobs, S. W. L. \& D. H. Les. 2009. New combinations in Zostera (Zosteraceae). Telopea 12: 419-423.

Jacobsen, N. 1982. Cryptocorynen. Alfred Kernen Verlag, Stuttgart. $112 \mathrm{pp}$.

Jacobson, M. 1958. Insecticides from Plants. Agriculture Handbook No. 154. U.S. Government Printing Office, Washington, DC. 299 pp.

Jacobson, G. L., H. Almquist-Jacobson \& J. C. Winne. 1991. Conservation of rare plant habitat: insights from the recent history of vegetation and fire at Crystal Fen, northern Maine, USA. Biol. Conserv. 57: 287-314.

Jacono, C. C. 2001. Scleria lacustris (Cyperaceae), an aquatic and wetland sedge introduced to Florida. Sida 19: 1163-1170. 
Jacono, C. C. 2002. Cryptocoryne beckettii complex (Araceae) introduced at a Florida spring. Sida 20: 819-832.

Jagathesan, G. \& P. Rajiv. 2018. Biosynthesis and characterization of iron oxide nanoparticles using Eichhornia crassipes leaf extract and assessing their antibacterial activity. Biocatal. Agric. Biotechnol. 13: 90-94.

Jäger, E. 1964. Zur Deutung des Arealbildes von Wolffia arrhiza (L.) Wimm. Ber. Deutsch. Bot. Ges. 77: 101-111.

Jain, S. K., M. R. Jacob, L. A. Walker \& B. L. Tekwani. 2016. Screening North American plant extracts in vitro against Trypanosoma brucei, the causative agent for Human African Trypanosomiasis. BMC Complement. Altern. Med. 16: 131.

James, L. F. \& W. Binns. 1966. Effects of feeding wild onions (Allium validum) to bred ewes. J. Am. Veterin. Med. Assoc. 149: $512-514$.

Janousek, C. N. \& C. L. Folger. 2013. Inter-specific variation in salinity effects on germination in Pacific Northwest tidal wetland plants. Aquat. Bot. 111: 104-111.

Jansen, M. A. K., R. E. van den Noort, S. J. Boeke, S. A. M. Huggers \& J. H. de Haan. 1999. Differences in UV-B tolerance among Spirodela punctata ecotypes. J. Photochem. Photobiol. B 48: 194-199.

Jarvis, J. C. \& K. A. Moore. 2008. Influence of environmental factors on Vallisneria americana seed germination. Aquat. Bot. 88: 283-294.

Jarvis, J. C. \& K. A. Moore. 2010. The role of seedlings and seed bank viability in the recovery of Chesapeake Bay, USA, Zostera marina populations following a large-scale decline. Hydrobiologia 649: 55-68.

Jauzein, P. 1991. Eclipta prostrata (L.) L. a weed of rice fields in the Camargue. Monde Plantes 86: 15-16.

Jayanthi, P., P. Lalitha, R. Sujitha \& A. Thamaraiselvi. 2013. Antiinflammatory activity of the various solvent extracts of Eichhornia crassipes (Mart.) Solms. Int. J. Pharmtech Res. 5: 641-644.

Jeanmonod, D., A. Schlüssel \& J. Gamisans. 2011. Status and trends in the alien flora of Corsica. EPPO Bull. 41: 85-99.

Jeglum, J. K. 1971. Plant indicators of $\mathrm{pH}$ and water level in peatlands at Candle Lake, Saskatchewan. Can. J. Bot. 49: 1661-1676.

Jekyll, G. 1903. Lilies for English Gardens: A Guide for Amateurs, 2nd ed. Country Life, Covent Garden, England. 72 pp.

Jelinski, D. E. 1989. Seasonal differences in habitat use and fat reserves in an arctic muskrat population. Can. J. Zool. 67: 305-313.

Jennings, O. E. 1919. Potamogeton vaseyi in northeastern Ohio. Ohio J. Sci. 19: 343.

Jensen, A. S. 2000. Eight new species of Macrosiphum Passerini (Hemiptera: Aphididae) from western North America, with notes on four other poorly known species. Proc. Entomol. Soc. Washington 102: 427-472.

Jensen, K. 2004. Dormancy patterns, germination ecology, and seed-bank types of twenty temperate fen grassland species. Wetlands 24: 152-166.

Jersáková, J., S. D. Johnson \& P. Kindlmann. 2006. Mechanisms and evolution of deceptive pollination in orchids. Biol. Rev. 81: 219-235.

Jervis, R. A. 1969. Primary production in the freshwater marsh ecosystem of Troy Meadows, New Jersey. Bull. Torrey Bot. Club 96: 209-231.

Jesson, L. K. \& S. C. H. Barrett. 2002. Enantiostyly: solving the puzzle of mirror-image flowers. Nature 417: 707.

Jesson, L. K., J. Kang, S. L. Wagner, S. C. H. Barrett \& N. G. Dengler. 2003a. The development of enantiostyly. Am. J. Bot. 90: $183-195$.

Jesson, L. K., S. C. H. Barrett \& T. Day. 2003b. A theoretical investigation of the evolution and maintenance of mirror-image flowers. Am. Nat. 161: 916-930.
Jewett-Smith, J. \& C. McMillan. 1990. Germination and seedling development of Halophila engelmannii Aschers. (Hydrocharitaceae) under axenic conditions. Aquat. Bot. 36: 167-177.

Jewett-Smith, J., C. McMillan, W. J. Kenworthy \& K. Bird. 1997. Flowering and genetic banding patterns of Halophila johnsonii and conspecifics. Aquat. Bot. 59: 323-331.

Jha, K. K. \& S. Chaudhary. 2011. Resource production and consumption system: focus on wetland biodiversity of Uttar Pradesh. Pp. 9-23 In: National Conference on Forest Biodiversity: Earth's Living Treasure, 22 May, 2011. Uttar Pradesh Biodiversity Board, Lucknow, India.

Ji, Y.-B., N. Chen, H.-W. Zhu, N. Ling, W.-L. Li, D.-X. Song, S.Y. Gao, W.-C. Zhang \& N.-N. Ma. 2014. Alkaloids from beach spider lily (Hymenocallis littoralis) induce apoptosis of HepG-2 cells by the fas-signaling pathway. Asian Pac. J. Cancer Prev. 15: 9319-9325.

Jiang, M. \& Y. Kadono. 2001a. Seasonal growth and reproductive ecology of two threatened aquatic macrophytes, Blyxa aubertii and B. echinosperma (Hydrocharitaceae), in irrigation ponds of south-western Japan. Ecol. Res. 16: 249-256.

Jiang, M. \& Y. Kadono. 2001b. Growth and reproductive characteristics of an aquatic macrophyte Ottelia alismoides (L.) Pers. (Hydrocharitaceae). Ecol. Res. 16: 687-695.

Jiang, K., H. Gao, N.-N. Xu, E. P. K. Tsang \& X.-Y. Chen. 2011. A set of microsatellite primers for Zostera japonica (Zosteraceae). Am. J. Bot. 98: e236-e238.

Jiang, X., X. Song, Y. Chen \& W. Zhang. 2014. Research on biogas production potential of aquatic plants. Renew. Energy 69: 97-102.

Jiang, Y.-L., Z. Huang, J.-Q. Liao, H.-X. Song, X.-M. Luo, S.-P. Gao, T. Lei, M.-Y. Jiang, Y. Jia, Q.-B. Chen, X.-F. Yu \& Y.-H. Zhou. 2018. Phylogenetic analysis of Iris L. from China on [sic!] chloroplast trnL-F sequences. Biologia 73: 459-466.

Jin, H.-J., J.-H. Kim, C. H. Sohn, R. E. DeWreede, T.-J. Choi, G. H. N. Towers, J. B. Hudson \& Y.-K. Hong. 1997. Inhibition of Taq DNA polymerase by seaweed extracts from British Columbia, Canada and Korea. J. Appl. Phycol. 9: 383-388.

Jin, X.-H., Z.-X. Ren, S.-Z. Xu, H. Wang, D.-Z. Li \& Z.-Y. Li. 2014. The evolution of floral deception in Epipactis veratrifolia (Orchidaceae): from indirect defense to pollination. $B M C$ Plant Biol. 14(1): 63.

Joanen, T. \& L. McNease. 1975. Notes on the reproductive biology and captive propagation of the American alligator. Proc. Southeast Assoc. Game Fish Comm. 29: 407-414.

Johansen, B. \& H. Rasmussen. 1992. Ex situ conservation of orchids. Opera Bot. 113: 43-48.

Johansson, R., W. Avery, K. B. Hennenfent \& J. J. Pacowta. 2009. Restoration of seagrass habitat in Tampa Bay using large manatee grass (Syringodium filiforme) sod units and a discussion of planting site sediment elevation dynamics. Reports $\mathbf{5 2}$. University of South Florida, Tampa, FL. accessed 4 February, 2020. Available online: http://scholarcommons.usf.edu/ basgp_report/52.

Johnson, L. N. 1892. Notes on the flora of southwestern Connecticut. Bull. Torrey Bot. Club 19: 88-91.

Johnson, K. R. 1941. Vegetation of some mountain lakes and shores in northwestern Colorado. Ecology 22: 306-316.

Johnson, T. 1999. CRC Ethnobotany Desk Reference. CRC Press, Boca Raton, FL. 1211 pp.

Johnson, S. D. 2018. Reproductive biology of Canna species naturalized in southern Africa. M.S. thesis. University of KwaZuluNatal, Pietermaritzburg, South Africa. 84 pp.

Johnson, W. E. \& A. R. Martin. 1969. Nonteratogenicity of Veratrum californicum in rabbits. J. Pharm. Sci. 58: 1165-1166. 
Johnson, A. S. \& J. L. Landers. 1978. Fruit production in slash pine plantations in Georgia. J. Wildl. Manag. 42: 606-613.

Johnson, W. P. \& F. C. Rohwer. 2000. Foraging behavior of greenwinged teal and mallards on tidal mudflats in Louisiana. Wetlands 20: 184-188.

Johnson, J. B. \& D. A. Steingraeber. 2003. The vegetation and ecological gradients of calcareous mires in the South Park valley, Colorado. Can. J. Bot. 81: 201-219.

Johnson, R. K. \& M. L. Ostrofsky. 2004. Effects of sediment nutrients and depth on small-scale spatial heterogeneity of submersed macrophyte communities in Lake Pleasant, Pennsylvania. Can. J. Fish. Aquat. Sci. 61: 1493-1502.

Johnson, A. \& S. Johnson. 2006. Primefact 359: Garden Plants Poisonous to People. New South Wales Department of Primary Industries, Orange, NSW, Australia. $12 \mathrm{pp}$.

Johnson, E. A. \& K. S. Walz. 2013. Integrated Management Guidelines for Four Habitats and Associated State Endangered Plants and Wildlife Species of Greatest Conservation Need in the Skylands and Pinelands Landscape Conservation Zones of the New Jersey State Wildife Action Plan. Center for Biodiversity and Conservation and New Jersey Department of Environmental Protection, Natural Heritage Program, for NatureServe, Arlington, VA. 140 pp.

Johnson, E. A., T. F. Breden \& R. J. Cartica. 1998. Monitoring of Helonias bullata Populations in Camden and Gloucester Counties, New Jersey. New Jersey Department of Environmental Protection, Division of Parks and Forestry, Office of Natural Lands Management, Trenton, NJ. 71 pp.

Johnson, M. K., K. E. Alexander, N. Lindquist \& G. Loo. 1999. A phenolic antioxidant from the freshwater orchid, Habenaria repens. Comp. Biochem. Physiol., C, Toxicol. Pharmacol. Endocrinol. 122: 211-214.

Johnson, T., J. M. Cruse-Sanders \& G. S. Pullman. 2012. Micropropagation and seed cryopreservation of the critically endangered species Tennessee yellow-eye grass, Xyris tennesseensis Kral. In Vitro Cell. Dev. Biol. Plant. 48: 369-376.

Johnson-Green, P. C., N. C. Kenkel \& T. Booth. 1995. The distribution and phenology of arbuscular mycorrhizae along an inland salinity gradient. Can. J. Bot. 73: 1318-1327.

Johnston, C. A., B. L. Bedford, M. Bourdaghs, T. Brown, C. Frieswyk, M. Tulbure, L. Vaccaro \& J. B. Zedler. 2007. Plant species indicators of physical environment in Great Lakes coastal wetlands. J. Great Lakes Res. 33: 106-124.

Johnston, R. F. 1956a. Predation by short-eared owls on a Salicornia salt marsh. Wilson Bull. 68: 91-102.

Johnston, R. F. 1956b. Population structure in salt marsh song sparrows: part I. Environment and annual cycle. Condor 58: 24-44.

Johri, B. M. (ed.). 1984. Embryology of Angiosperms. SpringerVerlag, NY. 830 pp.

Jomjun, N., T. Siripen, S. Maliwan, N. Jintapat, T. Prasak, C. Somporn \& P. Petch. 2010. Phytoremediation of arsenic in submerged soil by wetland plants. Int. J. Phytoremed. 13: 35-46.

Jones, P. S. 1998. Aspects of the population biology of Liparis loeselii (L.) Rich. var. ovata Ridd. ex Godfery (Orchidaceae) in the dune slacks of South Wales, UK. Bot. J. Linn. Soc. 126: 123-139.

Jones, G. P. 2000. 1999 survey of BLM-managed lands along the Snake River in Jackson Hole, Wyoming for Ute ladies tresses (Spiranthes diluvialis). Bureau of Land Management, Wyoming State Office, Cheyenne, WY. 18 pp.

Jones, G. P. 2004. Inventory and Mapping of Plant Communities in the Sweetwater Canyon Wilderness Study Area, Fremont County, Wyoming. Wyoming Natural Diversity Database, University of Wyoming, Laramie, WY. 103 pp.
Jones, J. J. \& R. D. Drobney. 1986. Winter feeding ecology of scaup and common goldeneye in Michigan. J. Wildl. Manag. 50: 446-452.

Jones, R. L., C. T. Witsell \& G. L. Nesom. 2008. Distribution and taxonomy of Symphyotrichum sericeum and $S$. pratense (Asteraceae: Astereae). J. Bot. Res. Inst. Texas 2: 731-739.

Jones, J., H. B. Massicotte \& A. L. Fredeen. 2016. Calcium and pH co-restrict abundance of Drosera rotundifolia (Droseraceae) in a Sphagnum bog in central British Columbia. Botany 94: 139-146.

Jordan, W. C., M. W. Courtney \& J. E. Neigel. 1996. Low levels of intraspecific genetic variation at a rapidly evolving chloroplast DNA locus in North American duckweeds (Lemnaceae). Am. J. Bot. 83: 430-439.

Jordan, F., H. L. Jelks \& W. M. Kitchens. 1997. Habitat structure and plant community composition in a northern Everglades wetland landscape. Wetlands 17: 275-283.

Jorgenson, T. \& C. Ely. 2001. Topography and flooding of coastal ecosystems on the Yukon-Kuskokwim Delta, Alaska: implications for sea-level rise. J. Coast. Res. 17: 124-136.

Josselyn, M. 1986. Biomass, production and decomposition of a deep water seagrass, Halophila decipiens Ostenf. Aquat. Bot. 25: 47-61.

Jovet, P. \& S. Jovet-Ast. 1967. Floraison, fructification, germination du Lemna valdiviana au lac Marion (B. P.). Bull. Cent. Etud. Rech. Sci., Biarritz 6: 729-734.

Joy, B., A. Rajan \& E. Abraham. 2007. Antimicrobial activity and chemical composition of essential oil from Hedychium coronarium. Phytother. Res. 21: 439-443.

Joye, D. B. \& G. L. Smith. 1993. Biosystematic investigations of a hybrid between Hymenocallis occidentalis and Hymenocallis coronaria. Cancas 39: 95-103.

Jozghasemi, S., V. Rabiei, A. Soleymani \& A. Khalighi. 2016. Karyotype analysis of seven Iris species native to Iran. Caryologia 69: 351-361.

Juday, G. P. 1992. Alaska research natural areas: 3. Serpentine slide. Gen. Tech. Rep. PNW-GTR-271. U.S. Department of Agriculture, Forest Service, Pacific Northwest Research Station, Portland, OR. 66 pp.

Judd, W. W. 1953. A study of the population of insects emerging as adults from the Dundas Marsh, Hamilton, Ontario, during 1948. Am. Midl. Nat. 49: 801-824.

Judd, W. W. 1961. Insects and other invertebrates associated with flowering skunk cabbage, Symplocarpus foetidus (L.) Nutt., at Fanshawe Lake, Ontario. Can. Entomol. 93: 241-249.

Judd, W. W. 1964. A study of the population of insects emerging as adults from Saunders Pond at London, Ontario. Am. Midl. Nat. 71: 402-414.

Judd, W. W. 1968. Studies of the Byron bog in southwestern Ontario. XXX. Distribution of orchids in the bog. Rhodora 70: 193-199.

Judd, W. S. 1998. The Smilacaceae in the southeastern United States. Harvard Pap. Bot. 3: 147-169.

Judd, W. S., C. S. Campbell, E. A. Kellogg, P. F. Stevens \& M. J. Donoghue. 2016. Plant Systematics: A Phylogenetic Approach, 4th ed. Sinauer Associates, Inc., Sunderland, MA. 677 pp.

Julien, M. H., M. W. Griffiths \& A. D. Wright. 1999. Biological Control of Water Hyacinth. Australian Centre for International Agricultural Research (ACIAR), Canberra, ACT. 87 pp.

June-Wells, M., F. Gallagher, J. Gibbons \& G. Bugbee. 2013. Water chemistry preferences of five nonnative aquatic macrophyte species in Connecticut: a preliminary risk assessment tool. Lake Reserv. Manag. 29: 303-316.

Jung, M. E., J. W. Hong, J. I. Lee, C.-S. Kong, J.-S. Chang \& Y. Seo. 2012. Inhibitory effect of Zostera japonica on growth of human cancer cells. Ocean Polar Res. 34: 385-394. 
Jupp, B. J. \& D. H. N. Spence. 1977. Limitations of macrophytes in a eutrophic lake, Loch Leven: II. Wave action, sediments and waterfowl grazing. J. Ecol. 65: 431-446.

Juraimi, A. S., M. S. Ahmad-Hamdani, A. R. Anuar, M. Azmi, M. P. Anwar \& M. K. Uddin. 2012. Effect of water regimes on germination of weed seeds in a Malaysian rice field. Aust. J. Crop Sci. 6: 598-605.

Juras, P. 1997. The presettlement piedmont savanna: a model for landscape design and management. M.S. thesis. University of Georgia, Athens, GA. 98 pp.

Jutila, H. M. 2002. Seed banks of river delta meadows on the west coast of Finland. Ann. Bot. Fenn. 39: 49-61.

Kadlec, J. A. \& L. M. Smith. 1984. Marsh plant establishment on newly flooded salt flats. Wildl. Soc. Bull. 12: 388-394.

Kadono, Y. 1980. Photosynthetic carbon sources in some Potamogeton species. Bot. Mag. (Tokyo) 93: 185-194.

Kadono, Y. 1982. Occurrence of aquatic macrophytes in relation to $\mathrm{pH}$, alkalinity, $\mathrm{Ca}^{++}, \mathrm{Cl}^{-}$and conductivity. Jap. J. Ecol. 32: 39-44.

Kadono, Y. 1984. Comparative ecology of Japanese Potamogeton: an extensive survey with special reference to growth form and life cycle. Jap. J. Bot. 34: 161-172.

Kadono, Y. 2004. Alien aquatic plants naturalized in Japan: history and present status. Glob. Environ. Res. 8: 163-169.

Kadono, Y., T. Nakamura \& T. Suzuki. 1997. Genetic uniformity of two aquatic plants, Egeria densa Planch. and Elodea nuttallii (Planch.) St. John, introduced in Japan. Jap. J. Limnol. 58: 197-203.

Kahn, A. E. \& M. J. Durako. 2005. The effect of salinity and ammonium on seed germination in Ruppia maritima from Florida Bay. Bull. Mar. Sci. 77: 453-458.

Kahn, A. E. \& M. J. Durako. 2006. Thalassia testudinum seedling responses to changes in salinity and nitrogen levels. J. Exp. Mar. Biol. Ecol. 335: 1-12.

Kahn, A. E. \& M. J. Durako. 2008. Photophysiological responses of Halophila johnsonii to experimental hyposaline and hyperCDOM conditions. J. Exp. Mar. Biol. Ecol. 367: 230-235.

Kahn, A. E. \& M. J. Durako. 2009. Wavelength-specific photosynthetic responses of Halophila johnsonii from marineinfluenced versus river-influenced habitats. Aquat. Bot. 91: 245-249.

Kahn, A. E., J. L. Beal \& M. J. Durako. 2013. Diurnal and tidal variability in the photobiology of the seagrass Halophila johnsonii in a riverine versus marine habitat. Estuaries Coast. 36: 430-443.

Kaisar, M. I., R. K. Adhikary, M. Dutta \& S. Bhowmik. 2016. Diversity of aquatic weeds at Noakhali Sadar in Bangladesh. Am. J. Sci. Ind. Res. 7: 117-128.

Kaldy, J. E. 2006. Production ecology of the non-indigenous seagrass, dwarf eelgrass (Zostera japonica Ascher. \& Graeb.), in a Pacific Northwest estuary, USA. Hydrobiologia 553: 201-217.

Kaldy, J. E. \& K. H. Dunton. 1999. Ontogenetic photosynthetic changes, dispersal and survival of Thalassia testudinum (turtle grass) seedlings in a sub-tropical lagoon. J. Exp. Mar. Biol. Ecol. 240: 193-212.

Kaldy, J. E. \& D. J. Shafer. 2013. Effects of salinity on survival of the exotic seagrass Zostera japonica subjected to extreme high temperature stress. Bot. Mar. 56: 75-82.

Kaldy, J. E., D. J. Shafer, M. S. Ailstock \& A. D. Magoun. 2015a. Effects of temperature, salinity and seed age on induction of Zostera japonica germination in North America, USA. Aquat. Bot. 126: 73-79.

Kaldy, J. E., D. J. Shafer \& A. D. Magoun. 2015b. Duration of temperature exposure controls growth of Zostera japonica: implications for zonation and colonization. J. Exp. Mar. Biol. Ecol. 464: 68-74.
Kalimuthu, K., C. Panneerselvam, C. Chou, L.-C. Tseng, K. Murugan, K.-H. Tsai, A. A. Alarfaj, A. Higuchi, A. Canale, J.-S. Hwang \& G. Benelli. 2017. Control of dengue and Zika virus vector Aedes aegypti using the predatory copepod Megacyclops formosanus: synergy with Hedychium coronarium-synthesized silver nanoparticles and related histological changes in targeted mosquitoes. Process Saf. Environ. Prot. 109: 82-96.

Kalkman, L. \& R. J. Van Wijk. 1984. On the variation in chromosome number in Potamogeton pectinatus L. Aquat. Bot. 20: 343-349.

Kalle, R. \& R. Sõukand. 2013. Wild plants eaten in childhood: a retrospective of Estonia in the 1970s-1990s. Bot. J. Linn. Soc. 172: 239-253.

Kalmbacher, R. S., K. R. Long \& F. G. Martin. 1984a. Seasonal mineral concentration in diets of esophageally fistulated steers on three range areas. J. Range Manag. 37: 36-39.

Kalmbacher, R. S., K. R. Long, M. K. Johnson \& F. G. Martin. 1984b. Botanical composition of diets of cattle grazing south Florida rangeland. J. Range Manag. 37: 334-340.

Kalmbacher, R., N. Cellinese \& F. Martin. 2005. Seeds obtained by vacuuming the soil surface after fire compared with soil seedbank in a flatwoods plant community. Native Plant J. 6: 233-240.

Kaltenecker, J. H. 1993. Field Investigation of Allium madidum (Swamp Onion), a USFS Region 4 Sensitive Species, on the Payette National Forest. Idaho Conservation Data Center, Idaho Department of Fish and Game, Boise, ID. 11 pp.

Kaminski, A., B. Bober, E. Chrapusta \& J. Bialczyk. 2014. Phytoremediation of anatoxin-a by aquatic macrophyte Lemna trisulca L. Chemosphere 112: 305-310.

Kan, J. \& S. Song. 2008. Effects of dehydration, chilling, light, phytohormones and nitric oxide on germination of Pistia stratiotes seeds. Seed Sci. Technol. 36: 38-45.

Kanabkaew, T. \& P. Udomphon. 2004. Aquatic plants for domestic wastewater treatment: lotus (Nelumbo nucifera) and hydrilla (Hydrilla verticillata) systems. Songklanakarin J. Sci. Technol. 26: 749-756.

Kandalepas, D., K. J. Stevens, G. P. Shaffer \& W. J. Platt. 2010. How abundant are root-colonizing fungi in Southeastern Louisiana's degraded marshes? Wetlands 30: 189-199.

Kandeler, R. 1984. Flowering in the Lemna system. Phyton 24: 113-124.

Kangas, P. C. \& G. L. Hannan. 1985. Vegetation on muskrat mounds in a Michigan marsh. Am. Midl. Nat. 113: 392-396.

Kankam, C. K. \& B. Odum-Ewuakye. 2000. Flexural strength and behavior of babadua-reinforced concrete beams. J. Mater. Civil Eng. 12: 39-45.

Kantrud, H. A. 1990. Sago pondweed (Potamogeton pectinatus L.): a literature review. Resource Publication 176. United States Department of the Interior, Fish and Wildlife Service. Washington, DC. 89 pp.

Kantrud, H. A. 1991. Wigeongrass (Ruppia maritima L.): a literature review. Fish Wildl. Res. 10: 1-58.

Kanwal, H., M. Hameed, N. Akhter, A. Ilyas, A. Mahmood \& N. Noreen. 2018. Ecological and taxonomic significance of root anatomy in some species and cultivars of Canna L. Int. J. Agric. Environ. Res. 5: 128-137.

Kao, J. T., J. E. Titus \& W.-X. Zhu. 2003. Differential nitrogen and phosphorus retention by five wetland plant species. Wetlands 23: 979-987.

Kaplan, Z. 2002. Phenotypic plasticity in Potamogeton (Potamogetonaceae). Folia Geobot. 37: 141-170.

Kaplan, Z. 2008. A taxonomic revision of Stuckenia (Potamogetonaceae) in Asia, with notes on the diversity and variation of the genus on a worldwide scale. Folia Geobot. 43: 159-234. 
Kaplan, Z. \& J. Štěpánek. 2003. Genetic variation within and between populations of Potamogeton pusillus agg. Plant Syst. Evol. 239: 95-112.

Kaplan, Z. \& J. L. Reveal. 2013. Taxonomic identity and typification of selected names of North American Potamogetonaceae. Brittonia 65: 452-468.

Kaplan, Z., J. Fehrer \& C. B. Hellquist. 2009. New hybrid combinations revealed by molecular analysis: the unknown side of North American pondweed diversity (Potamogeton). Syst. Bot. 34: 625-642.

Kaplan, Z., V. Jarolímová \& J. Fehrer. 2013. Revision of chromosome numbers of Potamogetonaceae: a new basis for taxonomic and evolutionary implications. Preslia 85 : 421-482.

Kaplan, Z., J. Fehrer, V. Bambasová \& C. B. Hellquist. 2018. The endangered Florida pondweed (Potamogeton floridanus) is a hybrid: why we need to understand biodiversity thoroughly. PLoS One 13: e0195241.

Kapoor, B. M. \& S. Ramcharitar. 1982. IOPB chromosome number reports LXXVI. Taxon 31: 596-597.

Kapoor, T. \& M. R. Vijayaraghavan. 1991. Seed biology of Potamogeton nodosus Poir. Aquat. Bot. 40: 261-273.

Kapuscinski, K. L., J. M. Farrell, S. V. Stehman, G. L. Boyer, D. D. Fernando, M. A. Teece \& T. J. Tschaplinski. 2014. Selective herbivory by an invasive cyprinid, the rudd Scardinius erythrophthalmus. Freshw. Biol. 59: 2315-2327.

Karadeniz, A., G. Alexie, H. J. Greten, K. Andersch \& T. Efferth. 2015. Cytotoxicity of medicinal plants of the WestCanadian Gwich' in Native Americans towards sensitive and multidrug-resistant cancer cells. J. Ethnopharmacol. 168: 191-200.

Karlen, S. D., H. C. A. Free, D. Padmakshan, B. G. Smith, J. Ralph \& P. J. Harris. 2018. Commelinid monocotyledon lignins are acylated by p-coumarate. Plant Physiol. 177: 513-521.

Karlin, E. F. \& L. M. Lynn. 1988. Dwarf-shrub bogs of the southern Catskill Mountain region of New York State: geographic changes in the flora of peatlands in northern New Jersey and southern New York. Bull. Torrey Bot. Club 115: 209-217.

Karling, J. S. 1931. Studies in the Chytridiales VI. The occurrence and life history of a new species of Cladochytrium in cells of Eriocaulon septangulare. Am. J. Bot. 18: 526-557.

Karling, J. S. 1941. Texas chytrids. Torreya 41: 105-108.

Karol, K. G., P. M. Skawinski, R. M. McCourt, M. E. Nault, R. Evans, M. E. Barton, M. S. Berg, D. J. Perleberg \& J. D. Hall. 2017. First discovery of the charophycean green alga Lychnothamnus barbatus (Charophyceae) extant in the New World. Am. J. Bot. 104: 1108-1116.

Karthikeyan, R., O. S. Koushik, P. S. Babu \& J. Chunduru. 2016. Anti-inflammatory activity of ethanolic extract of flowers [sic!] Hymenocallis littoralis (Jacq.) Salisb. by HRBC membrane stabilization method. Transl. Biomed. 7: 2.

Kaskey, J. B. \& D. R. Tindall. 1979. Physiological aspects of growth and heteroblastic development of Nasturtium officinale under natural conditions. Aquat. Bot. 7: 209-229.

Kasselmann, C. 2001. Echinodorus. Die beliebtesten Aquarienpflanzen. Dähne Verlag, Ettlingen, Germany. 168 pp.

Kasselmann, C. 2003. Aquarium Plants. Krieger Publishing Co., Malabar, FL. 518 pp.

Karst, L. \& C. A. Wilson. 2012. Phylogeny of the New World genus Sisyrinchium (Iridaceae) based on analyses of plastid and nuclear DNA sequence data. Syst. Bot. 37: 87-95.

Kato, M. \& R. Miura. 1996. Flowering phenology and anthophilous insect community at a threatened natural lowland marsh at Nakaikemi in Tsuruga, Japan. Contr. Biol. Lab. Kyoto Univ. 29: $1-48$.
Kato, M., Y. Kosaka, A. Kawakita, Y. Okuyama, C. Kobayashi, T. Phimminith \& D. Thongphan. 2008. Plant-pollinator interactions in tropical monsoon forests in Southeast Asia. Am. J. Bot. 95: $1375-1394$.

Kauffman, C. H. 1916. Unreported Michigan fungi 1911, 1912, 1913 and 1914. Ann. Rep. Michigan Acad. Sci. 17: 194-216.

Kaul, R. B. 1969. Morphology and development of the flowers of Boottia cordata, Ottelia alismoides, and their synthetic hybrid (Hydrocharitaceae). Am. J. Bot. 56: 951-959.

Kaul, R. B. 1970. Evolution and adaptation of inflorescences in the Hydrocharitaceae. Am. J. Bot. 57: 708-715.

Kaul, R. B. 1972. Adaptive leaf architecture in emergent and floating Sparganium. Am. J. Bot. 59: 270-278.

Kaul, R. B. 1976. Conduplicate and specialized carpels in the Alismatales. Am. J. Bot. 63: 175-182.

Kaul, R. B. 1978. Morphology of germination and establishment of aquatic seedlings in Alismataceae and Hydrocharitaceae. Aquat. Bot. 5: 139-147.

Kaul, R. B. 1979. Inflorescence architecture and flower sex ratios in Sagittaria brevirostra (Alismataceae). Am. J. Bot. 66: 1062-1066.

Kaul, R. B. 1985. Reproductive phenology and biology in annual and perennial Alismataceae. Aquat. Bot. 22: 153-164.

Kaul, R. B. 1991. Foliar and reproductive responses of Sagittaria calycina and Sagittaria brevirostra (Alismataceae) to varying natural conditions. Aquat. Bot. 40: 47-59.

Kaul, R. B. 1993. Meristic and organogenetic variation in Ruppia occidentalis and R. maritima. Int. J. Plant Sci. 154: 416-424.

Kaul, R. B. 2000. Sparganiaceae F. Rudolphi. Pp. 270-277 In: Flora of North America Editorial Committee (eds.), Flora of North America North of Mexico, Vol. 22: Magnoliophyta: Alismatidae Arecidae, Commelinidae (in Part), and Zingiberidae. Oxford University Press, New York, NY.

Kaur, R., T. A. Rush, D. M. Ferrin \& M. C. Aime. 2011. First report of Puccinia thaliae rust on canna lily in Louisiana. Plant Dis. 95: 353-353.

Kausch, A. P., J. L. Seago, Jr. \& L. C. Marsh. 1981. Changes in starch distribution in the overwintering organs of Typha latifolia (Typhaceae). Am. J. Bot. 68: 877-880.

Kauth, P. J. \& M. E. Kane. 2009. In vitro ecology of Calopogon tuberosus var. tuberosus (Orchidaceae) seedlings from distant populations: implications for assessing ecotypic differentiation. J. Torrey Bot. Soc. 136: 433-444.

Kauth, P. J. \& P. D. Biber. 2015. Moisture content, temperature, and relative humidity influence seed storage and subsequent survival and germination of Vallisneria americana seeds. Aquat. Bot. 120: 297-303.

Kauth, P. J., W. A. Vendrame \& M. E. Kane. 2006. In vitro seed culture and seedling development of Calopogon tuberosus. Plant Cell Tissue Organ Cult. 85: 91-102.

Kauth, P. J., M. E. Kane, W. A. Vendrame \& C. Reinhardt-Adams. 2008. Asymbiotic germination response to photoperiod and nutritional media in six populations of Calopogon tuberosus var. tuberosus (Orchidaceae): evidence for ecotypic differentiation. Ann. Bot. 102: 783-793.

Kauth, P. J., M. E. Kane \& W. A. Vendrame. 2011a. Comparative in vitro germination ecology of Calopogon tuberosus var. tuberosus (Orchidaceae) across its geographic range. In Vitro Cell. Dev. Biol.-Plant 47: 148-156.

Kauth, P. J., M. E. Kane \& W. A. Vendrame. 2011b. Chilling relieves corm dormancy in Calopogon tuberosus (Orchidaceae) from geographically distant populations. Environ. Exp. Bot. 70: 283-288.

Kautsky, L. 1987. Life-cycles of three populations of Potamogeton pectinatus $\mathrm{L}$. at different degrees of wave exposure in the Askö area, northern Baltic proper. Aquat. Bot. 27: 177-186. 
Kautsky, L. 1988. Life strategies of aquatic soft bottom macrophytes. Oikos 53: 126-135.

Kautsky, L. 1990. Seed and tuber banks of aquatic macrophytes in the Askö area, northern Baltic proper. Ecography 13: 143-148.

Kautsky, L. 1991. In situ experiments on interrelationships between six brackish macrophyte species. Aquat. Bot. 39: 159-172.

Kawano, S. \& H. H. Iltis. 1966. Cytotaxonomy of the genus Smilacina (Liliaceae) II. Cytologia 31: 12-28.

Keane, B., S. Pelikan, G. P. Toth, M. K. Smith \& S. H. Rogstad. 1999. Genetic diversity of Typha latifolia (Typhaceae) and the impact of pollutants examined with tandem-repetitive DNA probes. Am. J. Bot. 86: 1226-1238.

Kearney, T. H. 1901. Report on a Botanical Survey of the Dismal Swamp Region. U.S. Department of Agriculture, Washington, DC. 585 pp.

Keddy, P. A. 1983. Shoreline vegetation in Axe Lake, Ontario: effects of exposure on zonation patterns. Ecology 64: 331-344.

Keddy, C. J. 1987. Reproduction of annual eelgrass: variation among habitats and comparison with perennial eelgrass (Zostera marina L.). Aquat. Bot. 27: 243-256.

Keddy, P. A. \&. A. A. Reznicek. 1982. The role of seed banks in the persistence of Ontario's coastal plain flora. Am. J. Bot. 69: 13-22.

Keddy, P. A. \& T. H. Ellis. 1985. Seedling recruitment of 11 wetland plant species along a water level gradient: shared or distinct responses? Can. J. Bot. 63: 1876-1879.

Keddy, P. A. \& P. Constabel. 1986. Germination of ten shoreline plants in relation to seed size, soil particle size and water level: an experimental study. J. Ecol. 74: 133-141.

Keddy, P. A. \&. A. A. Reznicek. 1986. Great Lakes vegetation dynamics: the role of fluctuating water levels and buried seeds. J. Great Lakes Res. 12: 25-36.

Kee, N. L. A., N. Mnonopi, H. Davids, R. J. Naudé \& C. L. Frost. 2008. Antithrombotic/anticoagulant and anticancer activities of selected medicinal plants from South Africa. Afr. J. Biotechnol. 7: 217-223.

Keel, B. G., L. W. Zettler \& B. A. Kaplin. 2011. Seed germination of Habenaria repens (Orchidaceae) in situ beyond its range, and its potential for assisted migration imposed by climate change. Castanea 76: 43-54.

Keeler, R. F. 1975. Teratogenic effects of cyclopamine and jervine in rats, mice and hamsters. Proc. Soc. Exp. Biol. Med. 149: 302-306.

Keeler-Wolf, T. 1982. An ecological survey of the proposed Cedar Basin research natural area, Shasta-Trinity National Forest, California. Unpublished Report. Available online: https:// www.fs.fed.us/psw/rna/publications_pdf/psw:1982_rna_es_ cedar_basin.pdf [accessed 9 February, 2019].

Keeler-Wolf, T. 1991. Ecological survey of the proposed Mountaineer Creek research natueral area, Sequoia National Forest, Tulare, County, California. Unpublished Report. Available online: https://www.fs.fed.us/psw/rna/publications_pdf/22south_ mountaineer_creek_es.pdf [accessed 19 March, 2019].

Keener, B. R. 2005. Molecular systematics and revision of the aquatic monocot genus Sagittaria (Alismataceae). Ph.D. dissertation. The University of Alabama, Tuscaloosa, AL. 336 pp.

Keer, G. H. \& J. B. Zedler. 2002. Salt marsh canopy architecture differs with the number and composition of species. Ecol. Appl. 12: 456-473.

Keil, D. J. 2012. Juncaginaceae. Arrow-grass family. Pp. 1375-1377 In: B. G. Baldwin, D. H. Goldman, D. J. Keil, R. Patterson, T. J. Rosatti \& D. H. Wilken (eds.), The Jepson Manual: Vascular Plants of California, 2nd ed. University of California Press, Berkeley, CA.

Keith, L. B. 1961. A study of waterfowl ecology on small impoundments in southeastern Alberta. Wildl. Monogr. 6: 3-88.
Keith, L. B. \& R. P. Stanislawski. 1960. Stomach contents and weights of some flightless adult pintails. J. Wildl. Manag. 24: 95-96.

Kejkar, P. K. \& N. D. Polara. 2015. Effect of N, P and K on growth, bulb yield and nutrient content in ratoon spider lily (Hymenocallis littoralis L.) cv. local. HortFlora Res. Spectr. 4: 22-27.

Kellerman, W. A. 1905. Ohio Fungi. Fascicle X. J. Mycol. 11: 38-45.

Kelley, A. P. 1922. Plant indicators of soil types. Soil Sci. 13: 411-423.

Kelley, A. D. \& V. F. Bruns. 1975. Dissemination of weed seeds by irrigation water. Weed Sci. 23: 486-493.

Kellogg, C. H., S. D. Bridgham \& S. A. Leicht. 2003. Effects of water level, shade and time on germination and growth of freshwater marsh plants along a simulated successional gradient. J. Ecol. 91: 274-282.

Kelly, C. M. 2001. Prehistoric land-use patterns in the North Santiam subbasin on the western slopes of the Oregon Cascade Range. M.A. thesis. Oregon State University, Corvallis, OR. 231 pp.

Kelly, J. P. \& G. Fletcher. 1994. Habitat correlates and distribution of Cordylanthus maritimus (Scrophulariaceae) on Tomales Bay, California. Madroño 41: 316-327.

Kelso, S., L. Fugere, M. Kummel \& S. Tsocanos. 2014. Vegetation and vascular flora of tallgrass prairie and wetlands, Black Squirrel Creek drainage, south-central Colorado: perspectives from the 1940s and 2011. J. Bot. Res. Inst. Texas 8: 203-225.

Kemp, A. C., S. E. Engelhart, S. J. Culver, A. Nelson, R. W. Briggs \& P. J. Haeussler. 2013. Modern salt-marsh and tidal-flat foraminifera from Sitkinak and Simeonof Islands, southwestern Alaska. J. Foraminif. Res. 43: 88-98.

Keddy, P. A. 1976. Lakes as islands: the distributional ecology of two aquatic plants, Lemna minor L. and L. trisulca L. Ecology 57: 353-359.

Kendall, M. S., T. Battista \& Z. Hillis-Starr. 2004. Long term expansion of a deep Syringodium filiforme meadow in St. Croix, US Virgin Islands: the potential role of hurricanes in the dispersal of seeds. Aquat. Bot. 78: 15-25.

Kendrick, G. A., M. Waycott, T. J. B. Carruthers, M. L. Cambridge, R. Hovey, S. L. Krauss, P. S. Lavery, D. H. Les, R. J. Lowe, O. Mascaró I Vidal, J. L. S. Ooi, R. J. Orth, D. O. Rivers, L. Ruiz-Montoya, E. A. Sinclair, J. Statton, J. K. van Dijk \& J. J. Verduin. 2012. The central role of dispersal in the maintenance and persistence of seagrass populations. BioScience 62: 56-65.

Kendrick, G. A., R. J. Orth, J. Statton, R. Hovey, L. Ruiz Montoya, R. J. Lowe, S. L. Krauss \& E. A. Sinclair. 2017. Demographic and genetic connectivity: the role and consequences of reproduction, dispersal and recruitment in seagrasses. Biol. Rev. 92: 921-938.

Kennedy, K. 1994a. Little Aguja Pondweed (Potamogeton clystocarpus) Recovery Plan. U.S. Fish and Wildlife Service, Albuquerque, NM. 78 pp.

Kennedy, K. 1994b. Endangered and threatened wildlife and plants; 90-day finding for a petition to delist the plant Potamogeton clystocarpus (Little Aguja Pondweed). Fed. Reg. 59: 67267-67268.

Kennedy, H. 2000. Marantaceae Petersen in Engler \& Prantl, Arrowroot or Prayer-plant Family, maranta. Pp. 315-319 In: Flora North America Editorial Committee (eds.), Flora of North America North of Mexico, Vol. 22: Magnoliophyta: Alismatidae, Arecidae, Commelinidae (in part), and Zingiberidae. Oxford University Press, New York, NY.

Kennedy, M. A. 2016. Impacts of wintering Redhead ducks (Aythya americana) on shoal grass (Halodule wrightii) and widgeon grass (Ruppia maritima) in the northern Gulf of Mexico. M.S. thesis. University of South Alabama, Mobile, AL. 64 pp. 
Kenow, K. P. \& J. E. Lyon. 2009. Composition of the seed bank in drawdown areas of Navigation Pool 8 of the Upper Mississippi River. River Res. Appl. 25: 194-207.

Kenton, A. 1981. A Robertsonian relationship in the chromosomes of two species of Hydrocleys (Butomaceae sens. lat.). Kew Bull. 36: 487-492.

Kenton, A. Y., P. J. Rudall \& A. R. Johnson. 1986. Genome size variation in Sisyrinchium L. (Iridaceae) and its relationship to phenotype and habitat. Bot. Gaz. 147: 342-354.

Kentula, M. E. \& C. D. McIntire. 1986. The autecology and production dynamics of eelgrass (Zostera marina L.) in Netarts Bay, Oregon. Estuaries 9: 188-199.

Kentula, M. E. \& T. H. DeWitt. 2003. Abundance of seagrass (Zostera marina L.) and macroalgae in relation to the salinitytemperature gradient in Yaquina Bay, Oregon, USA. Estuaries 26: $1130-1141$.

Kenworthy, W. J. 1999. The role of sexual reproduction in maintaining populations of Halophila decipiens: implications for the biodiversity and conservation of tropical seagrass ecosystems. Pac. Conserv. Biol. 5: 260-268.

Kenworthy, W. J. \& M. S. Fonseca. 1996. Light requirements of seagrasses Halodule wrightii and Syringodium filiforme derived from the relationship between diffuse light attenuation and maximum depth distribution. Estuaries 19: 740-750.

Kenworthy, W. J. \& A. C. Schwarzschild. 1998. Vertical growth and short-shoot demography of Syringodium filiforme in outer Florida Bay, USA. Mar. Ecol. Prog. Ser. 173: 25-37.

Keppner, L. A. \& L. C. Anderson. 2008. Notes on Harper's beauty, Harperocallis flava (Tofieldiaceae), in Bay County, Florida. Southeast. Nat. 7: 180-184.

Kevan, P. G. 1989. How honey bees forage for pollen at skunk cabbage, Symplocarpus foetidus (Araceae). Apidologie 20: 485-490.

Kevan, P. G., J. D. Ambrose \& J. R. Kemp. 1991. Pollination in an understorey vine, Smilax rotundifolia, a threatened plant of the Carolinian forests in Canada. Can. J. Bot. 69: 2555-2559.

Khan, M. A. \& I. A. Ungar. 1997. Effects of light, salinity, and thermoperiod on the seed germination of halophytes. Can. J. Bot. 75: 835-841.

Khan, M. A. \& I. A. Ungar. 1999. Effect of salinity on seed germination of Triglochin maritima under various temperature regimes. Great Basin Nat. 59: 144-150.

Khan, M. A. \& I. A. Ungar. 2001. Seed germination of Triglochin maritima as influenced by salinity and dormancy relieving compounds. Biol. Plant. 44: 301-303.

Khan, M. A., B. Gul \& D. J. Weber. 2001. Germination of dimorphic seeds of Suaeda moquinii under high salinity stress. Aust. J. Bot. 49: 185-192.

Khan, M. A., K. B. Marwat, B. Gul, F. Wahid, H. Khan \& S. Hashim. 2014. Pistia stratiotes L. (Araceae): phytochemistry, use in medicines, phytoremediation, biogas and management options. Pak. J. Bot. 46: 851-860.

Khokar, S. \& G. R. Fenwick. 2003. Onions and related crops. Pp. 4267-4272 In: L. Trugo \& P. M. Finglas (eds.), Encyclopedia of Food Sciences and Nutrition, 2nd ed. Academic Press, New York, NY.

Khoshoo, T. N. \& I. Mukherjee. 1970. Genetic-evolutionary studies on cultivated cannas. Theoret. Appl. Genet. 40: 204-217.

Khurana, J. P. \& S. C. Maheshwari. 1980. Some effects of salicylic acid on growth and flowering in Spirodela polyrrhiza SP20. Plant Cell Physiol. 21: 923-927.

Khuroo, A. A., I. Rashid, Z. Reshi, G. H. Dar \& B. A. Wafai. 2007. The alien flora of Kashmir Himalaya. Biol. Invasions 9: 269-292.
Khvatkov, P., M. Chernobrovkina, A. Okuneva, A. Pushin \& S. Dolgov. 2015. Transformation of Wolffia arrhiza (L.) Horkel ex Wimm. Plant Cell Tissue Organ Cult. 123: 299-307.

Khvatkov, P., A. Firsov, A. Shvedova, L. Shaloiko, O. Kozlov, M. Chernobrovkina, A. Pushin, I. Tarasenko, I. Chaban \& S. Dolgov. 2018. Development of Wolffia arrhiza as a producer for recombinant human granulocyte colony-stimulating factor. Front. Chem. 6: 304.

Keith, E. L. \& N. R. Carrie. 2002. Effects of fire on two pitcher plant bogs with comments on several rare and interesting plants. Sida 20: 387-395.

Kihara, M., T. Koike, Y. Imakura, K. Kida, T. Shingu \& S. Kobayashi. 1987. Alkaloidal constituents of Hymenocallis rotata Herb. (Amaryllidaceae). Chem. Pharmaceut. Bull. 35: 1070-1075.

Kikuta, K., L. D. Whitney \& G. K. Parris. 1938. Seeds and seedlings of the taro, Colocasia esculenta. Am. J. Bot. 25: 186-188.

Kilgen, R. H. \& R. O. Smitherman. 1971. Food habits of the white amur stocked in ponds alone and in combination with other species. Progr. Fish-Cult. 33: 123-127.

Kilgo, J. C. \& R. F. Labisky. 1995. Nutritional quality of three major deer forages in pine flatwoods of northern Florida. Florida Sci. 58: $327-334$.

Kilham, L. 1976. Winter foraging and associated behavior of pileated woodpeckers in Georgia and Florida. Auk 93: 15-24.

Kim, J. S. \& B. L. Mercado. 1987. Viability and emergence of buried seeds of Echinochloa glabrescens, Monochoria vaginalis and Cyperus difformis. Pp. 469-476 In: Proceedings, 11th Asian Pacific Weed Science Society Conference, Volume 2. Asian Pacific Weed Science Society, Taipei, China.

Kim, S.-C. \& N. S. Lee. 2007. Generic delimitation and biogeography of Maianthemum and Smilacina (Ruscaceae sensu lato): preliminary results based on partial $3^{\prime}$ mat $K$ gene and trnK $3^{\prime}$ intron sequences of cpDNA. Plant Syst. Evol. 265: 1-12.

Kim, C. \& H.-K. Choi. 2011. Molecular systematics and character evolution of Typha (Typhaceae) inferred from nuclear and plastid DNA sequence data. Taxon 60: 1417-1428.

Kim, J. S. \& J.-H. Kim. 2018. Updated molecular phylogenetic analysis, dating and biogeographical history of the lily family (Liliaceae: Liliales). Bot. J. Linn. Soc. 187: 579-593.

Kim, J.-P., I.-S. Lee, J.-J. Seo, M.-Y. Jung, Y.-H. Kim, N.-H. Yim \& K.-H. Bae. 2010. Vitexin, orientin and other flavonoids from Spirodela polyrhiza inhibit adipogenesis in 3T3-L1 cells. Phytother. Res. 24: 1543-1548.

Kim, J.-L., H. M. Li, Y.-H. Kim, Y.-J. Lee, J.-H. Shim, S. S. Lim \& Y.-H. Kang. 2012. Osteogenic activity of yellow flag Iris (Iris pseudacorus) extract modulating differentiation of osteoblasts and osteoclasts. Am. J. Chinese Med. 40: 1289-1305.

Kim, W.-S., J.-S. Lee, G.-Y. Bae, J.-J. Kim, Y.-W. Chin, Y. Y. Bahk, H. G. Min \& H.-J. Cha. 2013. Extract of Aneilema keisak inhibits transforming growth factor- $\beta$-dependent signalling by inducing Smad2 downregulation in keloid fibroblasts. Exp. Dermatol. 22: 69-71.

Kim, M.-J., N.-Y. Bae, K.-B.-W.-R. Kim, J.-H. Park, S.-H. Park, Y.-J. Cho \& D.-H. Ahn. 2015. Anti-inflammatory effect of Zostera marina ethanolic extract on LPS-induced RAW264. 7 cells and mouse model. Korean Soc. Biotechnol. Bioeng. J. 30: 182-190.

Kim, S.-C., J. S. Kim, M. W. Chase, M. F. Fay \& J.-H. Kim. 2016. Molecular phylogenetic relationships of Melanthiaceae (Liliales) based on plastid DNA sequences. Bot. J. Linn. Soc. 181: 567-584.

Kim, C., K. M. Cameron \& J.-H. Kim. 2017. Molecular systematics and historical biogeography of Maianthemum s.s. Am. J. Bot. 104: 939-952. 
Kim, S.-H., M.-S. Cho, P. Li \& S.-C. Kim. 2018. Phylogeography and ecological niche modeling reveal reduced genetic diversity and colonization patterns of skunk cabbage (Symplocarpus foetidus; Araceae) from glacial refugia in eastern North America. Front. Plant Sci. 9: 648.

Kimball, R. T., D. J. Crawford, D. H. Les \& E. Landolt. 2003. Out of Africa: molecular phylogenetics and biogeography of Wolffiella (Lemnaceae). Biol. J. Linn. Soc. 79: 565-576.

Kimber, A., A. G. van der Valk \& C. E. Korschgen. 1995. The distribution of Vallisneria americana seeds and seedling light requirements in the Upper Mississippi River. Can. J. Bot. 73: 1966-1973.

Kimble, R. B. \& A. Ensminger. 1959. Duck food habits in southwestern Louisiana marshes following a hurricane. J. Wildl. Manag. 23: 453-455.

Kindscher, K. \& D. P. Hurlburt. 1998. Huron Smith's ethnobotany of the Hocąk (Winnebago). Econ. Bot. 52: 352-372.

King, J. R. \& L. R. Mewaldt. 1987. The summer biology of an unstable insular population of White-crowned Sparrows in Oregon. Condor 89: 549-565.

King, U. M. \& D. H. Les. 2016. A significant new record for Hydrilla verticillata (Hydrocharitaceae) in central Connecticut. Rhodora 118: 306-309.

King, U. M., D. H. Les, E. Peredo \& L. K. Benoit. 2017. Adaptive evolution of the chloroplast genome in the submersed monocotyledon Najas (Hydrocharitaceae). Pp. 52-68 In: L. M. Campbell, J. I. Davis, A. W. Meerow, R. F. C. Naczi, D. W. Stevenson \& W. W. Thomas (eds.), Diversity and Phylogeny of the Monocotyledons. New York Botanical Garden Press, Bronx, NY.

Kinupp, V. F. \& I. B. I. de Barros. 2008. Protein and mineral contents of native species, potential vegetables, and fruits. Food Sci. Technol. 28: 846-857.

Kipriyanova, L. M., L. A. Dolmatova, B. B. Bazarova, B. B. Naydanov, R. E. Romanov, G. T. Tsybekmitova \& A. V. Dyachenko. 2017. On the ecology of some species of genus Stuckenia (Potamogetonaceae) in lakes of Zabaykalsky krai and the Republic of Buryatia. Inland Water Biol. 10: 73-82.

Király, G., D. Steták \& Á. Bányász. 2007. Spread of invasive macrophytes in Hungary. Neobiota 7: 123-131.

Kirby, L. J. \& N. H. Ringler. 2015. Associations of epiphytic macroinvertebrates within four assemblages of submerged aquatic vegetation in a recovering urban lake. Northeast. Nat. 22: 672-689.

Kirk, H., C. Connolly \& J. R. Freeland. 2011. Molecular genetic data reveal hybridization between Typha angustifolia and Typha latifolia across a broad spatial scale in eastern North America. Aquat. Bot. 95: 189-193.

Kirkman, L. K., P. C. Goebel, L. West, M. B. Drew \& B. J. Palik. 2000. Depressional wetland vegetation types: a question of plant community development. Wetlands 20: 373-385.

Kirschner, J. \& Z. Kaplan. 2002. Taxonomic monographs in relation to global Red Lists. Taxon 51: 155-158.

Kirsten, J. H., C. J. Dawes \& B. J. Cochrane. 1998. Randomly amplified polymorphism detection (RAPD) reveals high genetic diversity in Thalassia testudinum banks ex König (Turtlegrass). Aquat. Bot. 61: 269-287.

Kishima, J., S. Harada \& R. Sakurai. 2011. Suitable water temperature for seed storage of Zostera japonica for subtropical seagrass bed restoration. Ecol. Eng. 37: 1416-1419.

Kissoon, L. T. T., D. L. Jacob, M. A. Hanson, B. R. Herwig, S. E. Bowe \& M. L. Otte. 2013. Macrophytes in shallow lakes: relationships with water, sediment and watershed characteristics. Aquat. Bot. 109: 39-48.
Kissoon, L. T. T., D. L. Jacob, M. A. Hanson, B. R. Herwig, S. E. Bowe \& M. L. Otte. 2015. Multi-elements in waters and sediments of shallow lakes: relationships with water, sediment, and watershed characteristics. Wetlands 35: 443-457.

Kitamura, H., M. Mori, Y. Nishibori \& H. Ohtani. 2008. A study on the mass propagation of skunk cabbages (Symplocarpus foetidus). Bull. Shiga Prefect. Agric. Technol. Promotion Center 46. Available online: http://agris.fao.org/agris-search/search. do?recordID=JP2008003781.

Kitner, M., R. Prausova \& L. Adamec. 2013. Present status of genetic diversity of Potamogeton praelongus populations in the Czech Republic. Phyton 53: 73-86.

Kittiwongwattana, C. \& C. Thawai. 2014. Rhizobium lemnae sp. nov., a bacterial endophyte of Lemna aequinoctialis. Int. J. Syst. Evol. Microbiol. 64: 2455-2460.

Kittiwongwattana, C. \& C. Thawai. 2015. Paenibacillus lemnae sp. nov., an endophytic bacterium of duckweed (Lemna aequinoctialis). Int. J. Syst. Evol. Microbiol. 65: 107-112.

Kiviniemi, K. 1996. A study of adhesive seed dispersal of three species under natural conditions. Acta Bot. Neerl. 45: 73-83.

Kiviniemi, K. \& A. Telenius. 1998. Experiments on adhesive dispersal by wood mouse: seed shadows and dispersal distances of 13 plant species from cultivated areas in southern Sweden. Ecography 21: 108-116.

Kjellmark, E. W., P. D. McMillan \& R. K. Peet. 1998. Longleaf pine vegetation of the South Carolina and Georgia Coastal Plain: A preliminary classification. Final Report, USDA Forest Service, Southern Forest Experiment Station, Asheville, NC. 84 pp.

Kleyheeg, E. \& C. H. A. van Leeuwen. 2015. Regurgitation by waterfowl: an overlooked mechanism for long-distance dispersal of wetland plant seeds. Aquat. Bot. 127: 1-5.

Klier, K., M. J. Leoschke \& J. F. Wendel. 1991. Hybridization and introgression in white and yellow ladyslipper orchids (Cypripedium candidum and C. pubescens). J. Hered. 82: 305-318.

Kline, L. \& B. McCune. 1987. Factors influencing the distribution ol Wolffia columbiana and Wolffia punctata (Lemnaceae). Northwest Sci. 61: 41-43.

Kling, G. W. 1986. The physicochemistry of some dune ponds on the Outer Banks, North Carolina. Hydrobiologia 134: 3-10.

Klinka, K., V. J. Krajina, A. Ceska \& A. M. Scagel. 1989. Indicator Plants of Coastal British Columbia. UBC Press, Vancouver, BC. 296 pp.

Klotz, L. H. 1992. On the biology of Orontium aquaticum L. (Araceae), golden club or floating arum. Aroideana 15: 25-33.

Klotzsch, J. F. 1852. Über Pistia. Abh. Königl. Akad. Wiss. Berlin 1852: 329-359.

Knapp, W. M., R. F. C. Naczi, W. D. Longbottom, C. A. Davis, W. A. McAvoy, C. T. Frye, J. W. Harrison \& P. Stango, III. 2011. Floristic discoveries in Delaware, Maryland, and Virginia. Phytoneuron 2011-64: 1-26.

Knapton, R. W. \& K. Pauls. 1994. Fall food habits of American wigeon at Long Point, Lake Erie, Ontario. J. Great Lakes Res. 20: $271-276$.

Knapton, R. W. \& S. A. Petrie. 1999. Changes in distribution and abundance of submerged macrophytes in the inner bay at Long Point, Lake Erie: implications for foraging waterfowl. J. Great Lakes Res. 25: 783-798.

Kneitel, J. M. \& T. E. Miller. 2002. Resource and top-predator regulation in the pitcher plant (Sarracenia purpurea) inquiline community. Ecology 83: 680-688.

Knight, R. R. 1965. Vegetative characteristics and waterfowl usage of a Montana water area. J. Wildl. Manag. 29: 782-788. 
Knight, N. S., C. Prentice, M. Tseng \& M. I. O’Connor. 2015. A comparison of epifaunal invertebrate communities in native eelgrass Zostera marina and nonnative Zostera japonica at Tsawwassen, BC. Mar. Biol. Res. 11: 564-571.

Knobloch, I. W. 1972. Intergeneric hybridization in flowering plants. Taxon 21: 97-103.

Knollenberg, W. G., R. W. Merritt \& D. L. Lawson. 1985. Consumption of leaf litter by Lumbricus terrestris (Oligochaeta) on a Michigan woodland floodplain. Am. Midl. Naturalist 113: $1-6$.

Knudsen, J. T. \& L. Tollsten. 1993. Trends in floral scent chemistry in pollination syndromes: floral scent composition in mothpollinated taxa. Bot. J. Linn. Soc. 113: 263-284.

Knuth, P. 1906. Handbook of Flower Pollination: Vol. I. Clarendon Press, Oxford, United Kingdom. 382 pp.

Knuth, P. 1909. Handbook of Flower Pollination. Vol. III. Translated by J. R. Ainsworth Davis. Clarendon Press, Oxford, United Kingdom. 644 pp.

Knutson, R. M. 1972. Temperature measurements of the spadix of Symplocarpus foetidus (L.) Nutt. Am. Midl. Nat. 88: 251-254.

Koca Çalişkan, U., C. Aka \& E. Bor. 2017. Melationin in edible and non-edible plants. Turkish J. Pharmaceut. Sci. 14: 75-83.

Kočić, A., J. Horvatić \& S. D. Jelaska. 2014. Distribution and morphological variations of invasive macrophytes Elodea nuttallii (Planch.) H. St. John and Elodea canadensis Michx in Croatia. Acta Bot. Croatica 73: 437-446.

Koch, R. G. 1970. The vascular flora of Cowley County, Kansas. Trans. Kansas Acad. Sci. 73: 135-168.

Koch, E. W. \& C. J. Dawes. 1991. Influence of salinity and temperature on the germination of Ruppia maritima L. from the North Atlantic and Gulf of Mexico. Aquat. Bot. 40: 387-391.

Koch, M. S. \& P. S. Rawlik. 1993. Transpiration and stomatal conductance of two wetland macrophytes (Cladium jamaicense and Typha domingensis) in the subtropical Everglades. Am. J. Bot. 80: 1146-1154.

Koch, M. S., S. A. Schopmeyer, C. Kyhn-Hansen, C. J. Madden \& J. S. Peters. 2007. Tropical seagrass species tolerance to hypersalinity stress. Aquat. Bot. 86: 14-24.

Koch, E. W., M. S. Ailstock, D. M. Booth, D. J. Shafer \& A. D. Magoun. 2010. The role of currents and waves in the dispersal of submersed angiosperm seeds and seedlings. Restor. Ecol. 18: 584-595.

Koch, M., G. Bowes, C. Ross \& X.-H. Zhang. 2013. Climate change and ocean acidification effects on seagrasses and marine macroalgae. Glob. Chang. Biol. 19: 103-132.

Koecke, V., S. von Mering, L. Mucina \& J. W. Kadereit. 2010. Revision of the Mediterranean and southern African Triglochin bulbosa complex (Juncaginaceae). Edinburgh J. Bot. 67: 353-398.

Koehler, S. \& C. P. Bove. 2001. Hydrocharitaceae from central Brazil: a new species of Egeria and a note on Apalanthe granatensis. Novon 11: 63-66.

Kohn, J. R., S. W. Graham, B. R. Morton, J. J. Doyle \& S. C. H. Barrett. 1996. Reconstruction of the evolution of reproductive characters in Pontederiaceae using phylogenetic evidence from chloroplast DNA restriction-site variation. Evolution 50: 1454-1469.

Konkel, D. 2006. Changes in the Aquatic Plant Community of Round Lake, Chippewa County, Wisconsin: 1988-2004. Wisconsin Department of Natural Resources, West Central Region, Eau Claire, WI. 53 pp.

Kopec, D. 2015. Cazenovia Lake: a comprehensive management plan. Occasional Paper No. 50. State University of New York College at Oneonta, Cooperstown, NY. 102 pp.
Kopecko, K. J. P. \& E. W. Lathrop. 1975. Vegetation zonation in a vernal marsh on the Santa Rosa Plateau of Riverside County, California. Aliso 8: 281-288.

Korfhage, R. C., J. R. Nelson \& J. M. Skovlin. 1980. Summer diets of Rocky Mountain elk in northeastern Oregon. J. Wildl. Manag. 44: 746-750.

Körner, S. \& J. E. Vermaat. 1998. The relative importance of Lemna gibba L., bacteria and algae for the nitrogen and phosphorus removal in duckweed-covered domestic wastewater. Water Res. 32: 3651-3661.

Körner, S., S. K. Das, S. Veenstra \& J. E. Vermaat. 2001. The effect of $\mathrm{pH}$ variation at the ammonium/ammonia equilibrium in wastewater and its toxicity to Lemna gibba. Aquat. Bot. 71: 71-78.

Kornfeld, J. M. \& J. M. Edwards. 1972. An investigation of the photodynamic pigments in extracts of Lachnanthes tinctoria. Biochim. Biophys. Acta 286: 88-90.

Koropchak, S. \& D. Vitt. 2013. Survivorship and growth of Typha latifolia L. across a $\mathrm{NaCl}$ gradient: a greenhouse study. Int. J. Min. Reclam. Environ. 27: 143-150.

Korschgen, L. J. \& D. L. Moyle. 1955. Food habits of the bullfrog in central Missouri farm ponds. Am. Midl. Nat. 54: 332-341.

Korschgen, C. E., L. S. George \& W. L. Green. 1988. Feeding ecology of canvasbacks staging on Pool 7 of the Upper Mississippi River. Pp. 237-249 In: M. W. Weller (ed.), Waterfowl in Winter: Selected Papers from Symposium and Workshop Held in Galvestion, Texas, 7-10 January 1985. University of Minnesota Press, Minneapolis, MN.

Korschgen, C. E., W. L. Green \& K. P. Kenow. 1997. Effects of irradiance on growth and winter bud production by Vallisneria americana and consequences to its abundance and distribution. Aquat. Bot. 58: 1-9.

Koryak, M. 1978. Emergent aquatic plants in the upper Ohio River and major navigable tributaries, West Virginia and Pennsylvania. Castanea 43: 228-237.

Koschnick, T. J., W. T. Haller \& L. Glasgow. 2006. Documentation of landoltia (Landoltia punctata) resistance to diquat. Weed Sci. 54: 615-619.

Kowalski, J. L. \& H. R. DeYoe. 2016. Flowering and seed production in the subtropical seagrass, Halodule wrightii (shoal grass). Bot. Mar. 59: 193-199.

Kowarik, I. 2003. Human agency in biological invasions: secondary releases foster naturalisation and population expansion of alien plant species. Biol. Invasions 5: 293-312.

Kozen, E. N. 2013. The scent of eastern skunk cabbage, Symplocarpus foetidus (Araceae): qualification of floral volatiles and sex differences in floral scent composition. M.S. thesis. Indiana University of Pennsylvania, Indiana, PA. 59 pp.

Krajnčić, B. \& Z. Devidé. 1982. Photoperiodic responses in Lemnaceae from North Croatia. Acta Bot. Croatica 41: 57-63.

Kral, R. 1960. The genus Xyris in Florida. Rhodora 62: 295-319.

Kral, R. 1966a. Eriocaulaceae of continental North America north of Mexico. Sida 2: 285-332.

Kral, R. 1966b. Observations on the flora of the southeastern United States with special reference to northern Louisiana. Sida 2: 395-408.

Kral, R. 1966c. Xyris (Xyridaceae) of the continental United States and Canada. Sida 2: 177-260.

Kral, R. 1973. Some notes on the flora of the southern states, particularly Alabama and middle Tennessee. Rhodora 75: 366-410.

Kral, R. 1978. A new species of Xyris (sect. Xyris) from Tennessee and northwestern Georgia. Rhodora 80: 444-447.

Kral, R. 1982. A new phyllodial-leaved Sagittaria (Alismaceae) from Alabama. Brittonia 34: 12-17. 
Kral, R. 1989. The genera of Eriocaulaceae in the southeastern United States. J. Arnold Arbor. 70: 131-142.

Kral, R. 1998. Xyridaceae. Pp. 461-469 In: K. Kubitzki, H. Huber, P. J. Rudall, P. S. Stevens \& T. Stützel (eds.), The Families and Genera of Vascular Plants, Vol. IV. Flowering Plants, Monocotyledons: Alismatanae and Commelinanae (Except Gramineae). Springer-Verlag, Berlin, Germany.

Kral, R. 1999. A revised taxonomy for two north american Rhynchospora (Cyperaceae) and for two north american Xyris (Xyridaceae). Novon 9: 205-219.

Kral, R. 2000. Eriocaulaceae Palisot de Beauvois ex Desvaux. Pp. 198-210 In: Flora North America Editorial Committee (eds.), Flora of North America North of Mexico, Vol. 22: Magnoliophyta: Alismatidae, Arecidae, Commelinidae (in Part), and Zingiberidae. Oxford University Press, New York, NY.

Kramer, J. P. 1967. A taxonomic study of the brachypterous North American leafhoppers of the genus Lonatura (Homoptera: Cicadellidae: Deltocephalinae). Trans. Am. Entomol. Soc. 93: 433-462.

Krapu, G. L. 1974. Foods of breeding pintails in North Dakota. J. Wildl. Manag. 38: 408-417.

Krattinger, K. 1975. Genetic mobility in Typha. Aquat. Bot. 1: 57-70.

Krattinger, K., D. Rast \& H. Karesch. 1979. Analysis of pollen proteins of Typha species in relation to identification of hybrids. Biochem. Syst. Ecol. 7: 125-128.

Kratzer, L. A. 2014. Effect of herbivory on the growth and competitive ability of reed canary grass (Phalaris arundinacea). M.S. thesis. Rochester Institute of Technology, Rochester, NY. 30 pp.

Krausse, A. F. W. 1783. Catalogus von perennirenden Pflanzen, welche um billige preise zu haben. Botanischer Garten und Botanisches Museum Berlin, Berlin, Germany. 71 pp.

Kravtsova, L. S., L. A. Izhboldina, I. V. Mekhanikova, G. V. Pomazkina \& O. I. Belykh. 2010. Naturalization of Elodea canadensis Mich. in Lake Baikal. Russ. J. Biol. Invasions 1: 162-171.

Krawczyk, K., J. Wiland-Szymańska, K. Buczkowska-Chmielewska, M. Drapikowska, M. Maślak, K. Myszczyński, M. Szczecińska, M. Ślipiko \& J. Sawicki. 2018. The complete chloroplast genome of a rare orchid species Liparis loeselii (L.). Conserv. Genet. Resour. 10: 305-308.

Krecker, F. H. 1939. A comparative study of the animal population of certain submerged aquatic plants. Ecology 20: 553-562.

Kreiling, R. M., Y. Yin \& D. T. Gerber. 2007. Abiotic influences on the biomass of Vallisneria americana Michx. in the Upper Mississippi River. River Res. Appl. 23: 343-349.

Kress, W. J. 1990. The phylogeny and classification of the Zingiberales. Ann. Missouri Bot. Gard. 77: 698-721.

Kress, W. J. 1995. Phylogeny of the Zingiberanae: morphology and molecules. Pp. 443-460 In: P. J. Rudall, P. J. Cribb, D. F. Cutler \& C. J. Humphries (eds.), Monocotyledons: Systematics and Evolution. Royal Botanic Gardens, Kew, United Kingdom.

Kress, W. J. \& L. M. Prince. 2000. Cannaceae Jussieu. Canna family. Pp. 310-314 In: Flora North America Editorial Committee (eds.), Flora of North America North of Mexico, Vol. 22: Magnoliophyta: Alismatidae, Arecidae, Commelinidae (in Part), and Zingiberidae. Oxford University Press, New York, NY.

Kress, W. J., L. M. Prince, W. J. Hahn \& E. A. Zimmer. 2001. Unraveling the evolutionary radiation of the families of the Zingiberales using morphological and molecular evidence. Syst. Biol. 50: 926-944.

Krock, S. 2016. Effects of sowing time and relative prairie quality on first year establishment of 23 native prairie species. M.E.S. thesis. Evergreen State College, Olympia, WA. 88 pp.
Kron, P. \& S. C. Stewart. 1994. Variability in the expression of a rhizome architecture model in a natural population of Iris versicolor (Iridaceae). Am. J. Bot. 81: 1128-1138.

Kron, P., S. C. Stewart \& A. Back. 1993. Self-compatibility, autonomous self-pollination, and insect-mediated pollination in the clonal species Iris versicolor. Can. J. Bot. 71: 1503-1509.

Krull, J. N. 1969. Factors affecting plant die-offs in shallow water areas. Am. Midl. Nat. 82: 293-295.

Krull, J. N. 1970. Aquatic plant-macroinvertebrate associations and waterfowl. J. Wildl. Manag. 34: 707-718.

Krull, J. N. 1976. Abundance and diversity of benthos during the spring waterfowl migration. Am. Midl. Nat. 95: 459-462.

Kruse, C., R. Boehm, D. Voeste, S. Barth \& H. Schnabl. 2002. Transient transformation of Wolffia columbiana by particle bombardment. Aquat. Bot. 72: 175-181.

Ktita, S. R., A. Chermiti \& M. Mahouachi. 2010. The use of seaweeds (Ruppia maritima and Chaetomorpha linum) for lamb fattening during drought periods. Small Rumin. Res. 91: 116-119.

Ktita, S. R., A. Chermiti \& M. Mahouachi. 2014. The use of marine plants for growing rabbits. Livest. Res. Rural Dev. 26: 209. Retrieved February 12, 2018 from: http://www.lrrd.org/ lrrd26/11/rjib26209.html.

Kubitzki, K. 1998. Cannaceae. Pp. 103-106 In: K. Kubitzki, H. Huber, P. J. Rudall, P. S. Stevens \& T. Stützel (eds.), The Families and Genera of Vascular Plants, Vol. IV. Flowering Plants, Monocotyledons: Alismatanae and Commelinanae (Except Gramineae). Springer-Verlag, Berlin, Germany.

Kuehdorf, K. \& K.-J. Appenroth. 2012. Influence of salinity and high temperature on turion formation in the duckweed Spirodela polyrhiza. Aquat. Bot. 97: 69-72.

Kuehdorf, K., G. Jetschke, L. Ballani \& K.-J. Appenroth. 2014. The clonal dependence of turion formation in the duckweed Spirodela polyrhiza — an ecogeographical approach. Physiol. Plant. 150: 46-54.

Kuehn, M. M., J. E. Minor \& B. N. White. 1999. An examination of hybridization between the cattail species Typha latifolia and Typha angustifolia using random amplified polymorphic DNA and chloroplast DNA markers. Mol. Ecol. 8: 1981-1990.

Kuehne, L. M., J. D. Olden \& E. S. Rubenson. 2016. Multi-trophic impacts of an invasive aquatic plant. Freshw. Biol. 61: 1846-1861.

Kujawski, J. \& R. Thompson. 2000. Propagation of redhead grass (Potamogeton perfoliatus L.) transplants for restoration projects. Native Plant J. 1: 124-127.

Kuk, Y. I., H. I. Jung, O. D. Kwon, N. R. Burgos \& J. O. Guh. 2003. Rapid diagnosis of resistance to sulfonylurea herbicides in monochoria (Monochoria vaginalis). Weed Sci. 51: 305-311.

Kukula-Koch, W., E. Sieniawska, J. Widelski, O. Urjin, P. Głowniak \& K. Skalicka-Woźniak. 2015. Major secondary metabolites of Iris spp. Phytochem. Rev. 14: 51-80.

Kula, R. R. \& G. Zolnerowich. 2008. Revision of New World Chaenusa Haliday sensu lato (Hymenoptera: Braconidae: Alysiinae), with new species, synonymies, hosts, and distribution records. Proc. Entomol. Soc. Washington 110: 1-60.

Kullberg, R. G. 1974. Distribution of aquatic macrophytes related to paper mill effluents in a southern Michigan stream. Am. Midl. Nat. 91: 271-281.

Kumar, K. \& M. Singh. 2015. Chromosomal diversity among different ecotypes of Acorus calamus L. reported from Ranchi Jharkhand, India. Int. J. Bioassays 4: 3656-3658.

Kunii, H. 1981. Characteristics of the winter growth of detached Elodea nuttallii (Planch.) St. John in Japan. Aquat. Bot. 11: 57-66. 
Kuntz, K., P. Heidbüchel \& A. Hussner. 2014. Effects of water nutrients on regeneration capacity of submerged aquatic plant fragments. Int. J. Limnol. 50: 155-162.

Kunze, H. 1985. Comparative studies of the flowers in Cannaceae and Marantaceae. Flora (Jena) 175: 301-318.

Kunzelman, J. I., M. J. Durako, W. J. Kenworthy, A. Stapleton \& J. L. C. Wright. 2005. Irradiance-induced changes in the photobiology of Halophila johnsonii. Mar. Biol. 148: 241-250.

Kuo, J. 2013. Chromosome numbers of the Australian Cymodoceaceae. Plant Syst. Evol. 299: 1443-1448.

Kuoh, C.-S., M.-J. Yang \& G.-I. Liao. 2000. The flower structure and anther dehiscence of Wolffia arrhiza (Lemnaceae). Taiwania 45: $30-37$.

Kurugundla, C. N. 2014. Seed dynamics and control of Pistia stratiotes in two aquatic systems in Botswana. Afr. J. Aquat. Sci. 39: 209-214.

Kurz, H. \& D. Crowson. 1948. The flowers of Wolffiella floridana (JD Sm.) Thompson. Quart. J. Florida Acad. Sci. 11: 87-98.

Kuzmina, M. L., T. W. A. Braukmann \& E. V. Zakharov. 2018. Finding the pond through the weeds: eDNA reveals underestimated diversity of pondweeds. Appl. Plant Sci. 6(5): e1155.

Kwembeya, E. G., C. S. Bjorå, B. Stedje \& I. Nordal. 2007. Phylogenetic relationships in the genus Crinum (Amaryllidaceae) with emphasis on tropical African species: evidence from $\operatorname{trn} L-F$ and nuclear ITS DNA sequence data. Taxon 56: 801-810.

Laberge, V., S. Hugron, L. Rochefort \& M. Poulin. 2015. Influence of different bryophyte carpets on vascular plant establishment around pools in restored peatlands. Land Degrad. Dev. 26: 813-818.

Labisky, R. F., C. C. Hurd, M. K. Oli \& R. S. Barwick. 2003. Foods of white-tailed deer in the Florida Everglades: the significance of Crinum. Southeast. Nat. 2: 261-270.

Lacor, M. A. M. 1968. Flowering of Spirodela polyrhiza (L.) Schleiden. Acta Bot. Neerl. 17: 357-359.

Lacor, M. A. M. 1969. On the influence of gibberellic acid and kinetin on the germination of turions of Spirodela polyrhiza (L.) Schleiden. Acta Bot. Neerl. 18: 550-557.

Lacor, M. A. M. 1970. Some physiological and morphogenetic aspects of flowering of Spirodela polyrhiza (L.) Schleiden. Acta Bot. Neerl. 19: 53-60.

Lacoul, P. \& B. Freedman. 2006. Relationships between aquatic plants and environmental factors along a steep Himalayan altitudinal gradient. Aquat. Bot. 84: 3-16.

Lacoul, P., B. Freedman \& T. Clair. 2011. Effects of acidification on aquatic biota in Atlantic Canada. Environ. Rev. 19: 429-460.

Lacroix, C. R. \& J. R. Kemp. 1997. Developmental morphology of the androecium and gynoecium in Ruppia maritima L.: considerations for pollination. Aquat. Bot. 59: 253-262.

Ladd, D. 2014. Ecologically appropriate fire in the Missouri landscape: a 35 year reflection. Missouri Nat. Areas Newslett. 14(1): 31-35.

Lafabrie, C., K. M. Major, C. S. Major, M. M. Miller \& J. Cebrián. 2011. Comparison of morphology and photo-physiology with metal/metalloid contamination in Vallisneria neotropicalis. $J$. Hazard. Mater. 191: 356-365.

Lafferty, K. D., R. F. Hechinger, J. C. Shaw, K. L. Whitney \& A. M. Kuris. 2006. Food webs and parasites in a salt marsh ecosystem. Pp. 119-134 In: S. Collinge \& C. Ray (eds.), Disease Ecology: Community Structure and Pathogen Dynamics. Oxford University Press, Oxford, United Kingdom.

LaFrankie, J. V. 1985. A note on seedling morphology and establishment growth in the genus Smilacina (Liliaceae). Bull. Torrey Bot. Club 112: 313-317.
LaFrankie, J. V. 1986a. Transfer of the species of Smilacina to Maianthemum (Liliaceae). Taxon 35: 584-589.

LaFrankie, J. V. 1986b. Morphology and taxonomy of the New World species of Maianthemum (Liliaceae). J. Arnold Arbor. 67: 371-439.

LaFrankie, J. V. 2002. Maianthemum F. H. Wiggers. Pp. 206-207 In: Flora North America Editorial Committee (eds.), Flora of North America North of Mexico, Vol. 26: Magnoliophyta: Liliidae: Liliales and Orchidales. Oxford University Press, New York, NY.

Lagler, K. F. 1943. Food habits and economic relations of the turtles of Michigan with special reference to fish management. Am. Midl. Nat. 29: 257-312.

Lagnika, L., B. Attioua, B. Weniger, M. Kaiser, A. Sanni \& C. Vonthron-Senecheau. 2008. Phytochemical study and antiprotozoal activity of compounds isolated from Thalia geniculata. Pharm. Biol. 46: 162-165.

Lagueux, C. J., K. A. Bjorndal, A. B. Bolten \& C. L. Campbell. 1995. Food habits of Pseudemys concinna suwanniensis in a Florida spring. J. Herpetol. 29: 122-126.

Laguna, E. \& P. F. Gallego. 2009. Canna glauca L. (Cannaceae), un nuevo taxón naturalizado para la Flora Peninsular Ibérica. Lagascalia 29: 292-295.

Lahring, H. 2003. Water and Wetland Plants of the Prairie Provinces. Canadian Plains Research Center, University of Regina, Regina, Saskatchewan. 327 pp.

Laidig, K. J. 2012. Simulating the effect of groundwater withdrawals on intermittent-pond vegetation communities. Ecohydrology 5 : $841-852$.

Laidig, K. J. \& R. A. Zampella. 1996. Stream Vegetation Data for Twenty Long-Term Study Sites in the New Jersey Pinelands. Pinelands Commission, New Lisbon, NJ. 78 pp.

Laidig, K. J., R. A. Zampella, J. F. Bunnell, C. L. Dow \& T. M. Sulikowski. 2001. Characteristics of Selected Pine Barrens Treefrog Ponds in the New Jersey Pinelands. Pinelands Commission, New Lisbon, NJ. 43 pp.

Laidig, K. J., R. A. Zampella \& C. Popolizio. 2009. Hydrologic regimes associated with Helonias bullata L. (swamp pink) and the potential impact of simulated water-level reductions. J. Torrey Bot. Soc. 136: 221-233.

Laing, K. K. \& D. G. Raveling. 1993. Habitat and food selection by emperor goose goslings. Condor 95: 879-888.

Lakela, O. 1941. Sparganium glomeratum in Minnesota. Rhodora 43: 83-85.

Lakshmi, N. 1978. Cytological studies in two allopolyploid species of the genus Hymenocallis. Cytologia 43: 555-563.

Lal, C. \& B. Gopal. 1993. Production and germination of seeds in Hydrilla verticillata. Aquat. Bot. 45: 257-261.

Lamb, E. G. \& W. Megill. 2003. The shoreline fringe forest and adjacent peatlands of the southern central British Columbia coast. Can. Field-Nat. 117: 209-217.

Lamont, E. E. 1998. Status of Schizaea pusilla in New York, with notes on some early collections. Am. Fern J. 88: 158-164.

Lamont, E. E. \& R. Stalter. 2007. Orchids of Atlantic coast barrier islands from North Carolina to New York. J. Torrey Bot. Soc. 134: 540-552.

Lamont, E. E., R. Sivertsen, C. Doyle \& L. Adamec. 2013. Extant populations of Aldrovanda vesiculosa (Droseraceae) in the New World. J. Torrey Bot. Soc. 140: 517-522.

LaMontagne, J. M., L. J. Jackson \& R. M. R. Barclay. 2003. Compensatory growth responses of Potamogeton pectinatus to foraging by migrating trumpeter swans in spring stop over areas. Aquat. Bot. 76: 235-244.

Lamoureux, G. (ed.). 1987. Plantes sauvages des lacs, rivières et tourbières. Guide d'identification Fleurbec. Fleurbec, SaintAugustin (Portneuf), QC. 399 pp. 
Lampe, K. F. 1986. Dermatitis-producing plants of south Florida and Hawaii. Clin. Dermatol. 4: 83-93.

Landers, J. L., A. S. Johnson, P. H. Morgan \& W. P. Baldwin. 1976. Duck foods in managed tidal impoundments in South Carolina. J. Wildl. Manag. 40: 721-728.

Landers, J. L., T. T. Fendley \& A. S. Johnson. 1977. Feeding ecology of wood ducks in South Carolina. J. Wildl. Manag. 41: $118-127$.

Landers, J. L., R. J. Hamilton, A. S. Johnson \& R. L. Marchinton. 1979. Foods and habitat of black bears in southeastern North Carolina. J. Wildl. Manag. 43: 143-153.

Landesman, L., N. C. Parker, C. B. Fedler \& M. Konikoff. 2005. Modeling duckweed growth in wastewater treatment systems. Livest. Res. Rural Dev. 17: 1-8.

Landman, G. B. \& E. S. Menges. 1999. Dynamics of woody bayhead invasion into seasonal ponds in south central Florida. Castanea 64: $130-137$.

Landman, G. B., R. K. Kolka \& R. R. Sharitz. 2007. Soil seed bank analysis of planted and naturally revegetating thermally-disturbed riparian wetland forests. Wetlands 27: 211-223.

Landolt, E. 1975. Morphological differentiation and geographical distribution of the Lemna gibba-Lemna minor group. Aquat. Bot. 1: 345-363.

Landolt, E. 1981. Distribution pattern of the family Lemnaceae in North Carolina. Veröff. Geobot. Inst. E. T. H. Stiftung Rübel Zürich 77: 112-148.

Landolt, E. 1986. Biosystematic investigations in the family of duckweeds (Lemnaceae), vol. 2. The family of Lemnaceae - a monographic study, vol. 1. Veröff. Geobot. Inst. E. T. H. Stiftung Rübel Zürich 71: 1-566.

Landolt, E. 1994. Taxonomy and ecology of the section Wolffia of the genus Wolffia (Lemnaceae). Ber. Geobot. Inst. E. T. H., Stiftung Rübel 60: 137-151.

Landolt, E. 1997. How do Lemnaceae (duckweed family) survive dry conditions? Bull. Geobot. Inst. E. T. H. Zürich 63: 25-31.

Landolt, E. 1998. Lemna yungensis, a new duckweed species from rocks of the Andean Yungas in Bolivia. Bull. Geobot. Inst. E. T. H. Zürich 64: 15-21.

Landolt, E. 1998. Lemnaceae. Pp. 264-270 In: K. Kubitzki (ed.), The Families and Genera of Vascular Plants, Vol. IV, Flowering Plants: Monocotyledons, Alismatanae and Commelinanae (Except Gramineae). Springer-Verlag, Berlin, Germany.

Landolt, E. 2000. Lemnaceae Gray. Duckweed family. Pp. 143-153 In: Flora North America Editorial Committee (eds.), Flora of North America North of Mexico, Vol. 22: Magnoliophyta: Alismatidae, Arecidae, Commelinidae (in Part), and Zingiberidae. Oxford University Press, New York, NY.

Landolt, E. \& O. Wildi. 1977. Ökologische Felduntersuchungen bei Wasserlinsen (Lemnaceae) in den südwestlichen Staaten der USA. Ber. Geobot. Inst. E. T. H. Stiftung Rübel Zürich 44: 104-146.

Landolt, E. \& R. Kandeler. 1987. Biosystematic investigations in the family of duckweeds (Lemnaceae), vol. 4. The family of Lemnaceae - a monographic study, vol. 2. Veröff. Geobot. Inst. E. T. H. Stiftung Rübel Zürich 95: 1-638.

Landolt, E., I. Jäger-Zürn \& R. A. A. Schnell. 1998. Extreme Adaptations in Angiospermous Hydrophytes. Gebrüder Borntraeger, Berlin, Germany. 290 pp.

Lang, F. A. \& P. F. Zika. 1997. A nomenclatural note on Hastingsia bracteosa and Hastingsia atropurpurea. Madroño 44: 189-192.

Langeland, K. A. 1989. Karyotypes of hydrilla (Hydrocharitaceae) populations in the United States. J. Aquat. Plant Manag. 27: 111-115.
Langeland, K. A. \& D. L. Sutton. 1980. Regrowth of hydrilla from axillary buds. J. Aquat. Plant Manag. 18: 27-29.

Langeland, K. A., D. G. Shilling, J. L. Carter, F. B. Laroche, K. K. Steward \& P. T. Madiera. 1992. Chromosome morphology and number in various populations of Hydrilla verticillata (L.f.) Royle. Aquat. Bot. 42: 253-263.

Lansdown, R. V. 2008. Red duckweed (Lemna turionifera Landolt) new to Britain. Watsonia 27: 127-130.

Lansdown, R. V., P. Anastasiu, Z. Barina, I. Bazos, H. Çakan, D. Caković, P. Delipetrou, V. Matevski, B. Mitić, E. Ruprecht, G. Tomović, A. Tosheva \& G. Király. 2016. Review of alien freshwater vascular plants in south-east Europe. Pp. 137-154 In: M. Rat, T. Trichkova, R. Scalera, R. Tomov \& A. Uludag (eds.), State of the Art of Invasive Alien Species in South-Eastern Europe. ESENIAS, IBER BAS, Sofia, Bulgaria.

Lantz, D. E. 1910. The muskrat. Farmers' Bulletin 396. U.S. Department of Agriculture, Government Printing Office, Washington, DC. 38 pp.

La Peyre, M. K. \& S. Rowe. 2003. Effects of salinity changes on growth of Ruppia maritima L. Aquat. Bot. 77: 235-241.

Lapolli, F. R., M. A. Lobo-Recio, P. B. Filho, J. B. R. Rodrigues \& F. A. Tavares. 2008. Performance of the macrophyte Lemna valdiviana in tertiary pig waste treatment and its contribution to the sustainability of swine production. Biotemas 21: 17-27.

Lara, M. V., P. Casati \& C. S. Andreo. 2002. $\mathrm{CO}_{2}$-concentrating mechanisms in Egeria densa, a submersed aquatic plant. Physiol. Plant. 115: 487-495.

Larkin, P., T. Schonacher, M. Barrett \& M. Paturzzio. 2012. Development and characterization of microsatellite markers for the seagrass Halodule wrightii. Conserv. Genet. Res. 4: 511-513.

Larkin, P. D., T. J. Maloney, S. Rubiano-Rincon \& M. M. Barrett. 2017. A map-based approach to assessing genetic diversity, structure, and connectivity in the seagrass Halodule wrightii. Mar. Ecol. Prog. Ser. 567: 95-107.

Larkin, D. J., A. K. Monfils, A. Boissezon, R. S. Sleith, P. M. Skawinski, C. H. Welling, B. C. Cahill \& K. G. Karol. 2018. Biology, ecology, and management of starry stonewort (Nitellopsis obtusa; Characeae): a red-listed Eurasian green alga invasive in North America. Aquat. Bot. 148: 15-24.

Larkum, A. W. D. 1995. Halophila capricorni (Hydrocharitaceae): a new species of seagrass from the Coral Sea. Aquat. Bot. 51: 319-328.

Larned, S. T. 2003. Effects of the invasive, nonindigenous seagrass Zostera japonica on nutrient fluxes between the water column and benthos in a NE Pacific estuary. Mar. Ecol. Prog. Ser. 254: 69-80.

Laroche, V., S. Pellerin \& L. Brouillet. 2012. White fringed orchid as indicator of Sphagnum bog integrity. Ecol. Indicators 14: $50-55$.

Larsen, K., J. M. Lock, H. Maas \& P. J. M. Maas. 1998. Zingiberaceae. Pp. 474-495 In: K. Kubitzki (ed.), The Families and Genera of Vascular Plants, Vol. IV, Flowering Plants: Monocotyledons, Alismatanae and Commelinanae (Except Gramineae). Springer-Verlag, Berlin, Germany.

Larson, K. S. \& R. J. Larson. 1990. Lure of the locks: showiest ladies-tresses orchids, Spiranthes romanzoffiana, affect bumblebee, Bombus spp., foraging behavior. Can. Field-Nat. 104: 519-525.

Larson, J. S. \& K. B. Searcy. 2007. Lemna minuta (Lemnaceae) discovered in Massachusetts. Rhodora 109: 456-458.

Lastra, M., H. M. Page, J. E. Dugan, D. M. Hubbard \& I. F. Rodil. 2008. Processing of allochthonous macrophyte subsidies by sandy beach consumers: estimates of feeding rates and impacts on food resources. Mar. Biol. 154: 163-174. 
Lastrucci, L., R. Calamassi, G. Ferretti, G. Galasso \& B. Foggi. 2012. Contributo alla conoscenza della flora esotica dell' Isola di Capraia (Arcipelago Toscano, Italia). Nat. Hist. Sci. 153: 127-134.

Latham, R. E., J. E. Thompson, S. A. Riley \& A. W. Wibiralske. 1996. The Pocono till barrens: shrub savanna persisting on soils favoring forest. Bull. Torrey Bot. Club 123: 330-349.

Laublin, G. \& M. Cappadocia. 1992. In vitro ovary culture of some apogon garden irises (Iris pseudacorus L., I. setosa Pall., I. versicolor L.). Bot. Acta 105: 319-322.

Lauer, N., M. Yeager, A. E. Kahn, D. R. Dobberfuhl \& C. Ross. 2011. The effects of short term salinity exposure on the sublethal stress response of Vallisneria americana Michx. (Hydrocharitaceae). Aquat. Bot. 95: 207-213.

Lavoie, C., M. Jean, F. Delisle \& G. Létourneau. 2003. Exotic plant species of the St Lawrence River wetlands: a spatial and historical analysis. J. Biogeogr. 30: 537-549.

Lay, D. W. 1965. Fruit utilization by deer in southern forests. J. Wildl. Manag. 29: 370-375.

Layne, J. N. \& B. S. Johns. 1965. Present status of the beaver in Florida. Quart. J. Florida Acad. Sci. 28: 212-220.

Leach, G. J. 2017. A revision of Australian Eriocaulon (Eriocaulaceae). Telopea 20: 205-259.

LeBlond, R. J. \& B. A. Sorrie. 2001. Additions to and noteworthy records for the flora of the coastal plain of North Carolina. Castanea 66: 288-302.

Leck, M. A. \& K. J. Graveline. 1979. The seed bank of a freshwater tidal marsh. Am. J. Bot. 66: 1006-1015.

Leck, M. A. \& R. L. Simpson. 1987. Seed bank of a freshwater tidal wetland: turnover and relationship to vegetation change. Am. J. Bot. 74: 360-370.

Leck, M. A. \& R. L. Simpson. 1993. Seeds and seedlings of the Hamilton Marshes, a Delaware River tidal freshwater wetland. Proc. Acad. Nat. Sci. Philadelphia 144: 267-281.

Leck, M. A. \& R. L. Simpson. 1995. Ten-year seed bank and vegetation dynamics of a tidal freshwater marsh. Am. J. Bot. 82: 1547-1557.

Leck, M. A., R. L. Simpson, D. F. Whigham \& C. F. Leck. 1988. Plants of the Hamilton Marshes: a Delaware River freshwater tidal wetland. Bartonia 54: 1-17.

Lee, W. L. 1966. Color change and the ecology of the marine isopod Idothea (Pentidothea) montereyensis Maloney, 1933. Ecology 47: 930-941.

Lee, P. F. 1987. Ecological relationships of wild rice, Zizania aquatica. 5. Enhancement of wild rice production by Potamogeton robbinsii. Can. J. Bot. 65: 1433-1438.

Lee, D. W. \& D. E. Fairbrothers. 1969. A serological and disc electrophoretic study of North American Typha. Brittonia 21: 227-243.

Lee, D. W. \& D. E. Fairbrothers. 1972. Taxonomic placement of the Typhales within the monocotyledons: preliminary serological investigation. Taxon 21: 39-44.

Lee, K.-S. \& K. H. Dunton. 1999. Influence of sediment nitrogenavailability on carbon and nitrogen dynamics in the seagrass Thalassia testudinum. Mar. Biol. 134: 217-226.

Lee, C.-L., T. C. Wang, C.-K. Lin \& H.-K. Mok. 1999. Heavy metals removal by a promising locally available aquatic plant, Najas graminea Del., in Taiwan. Water Sci. Technol. 39: 177-181.

Lee, A., G. Gordon, R. T. Saucier, B. D. Maygarden \& M. Godzinski. 2000. Cultural Resource Survey for the West Bank Vicinity of New Orleans, Louisiana, Hurricane Protection Project. Earth Search Inc., New Orleans, LA. 57 pp.

Lee, C. S., S.-C. Kim, S. H. Yeau \& N. S. Lee. 2011. Major lineages of the genus Lilium (Liliaceae) based on nrDNA ITS sequences, with special emphasis on the Korean species. J. Plant Biol. 54: 159-171.
Lee, H. J., M. H. Kim, Y. Y. Choi, E. H. Kim, J. Hong, K. Kim \& W. M. Yang. 2016. Improvement of atopic dermatitis with topical application of Spirodela polyrhiza. J. Ethnopharmacol. 180: 12-17.

Lefebvre, L. W., J. A. Provancha, D. H. Slone \& W. J. Kenworthy. 2017. Manatee grazing impacts on a mixed species seagrass bed. Mar. Ecol. Prog. Ser. 564: 29-45.

Legner, E. F. \& T. W. Fisher. 1980. Impact of Tilapia zillii (Gervais) on Potamogeton pectinatus L., Myriophyllum spicatum var. exalbescens Jepson, and mosquito reproduction in lower Colorado Desert irrigation canals. Acta Oecol. 1: 3-14.

Lehman, R. L., R. O'Brien \& T. White. 2009. Plants of the Texas Coastal Bend. Texas A\&M University Press, College Station, TX. 368 pp.

Lehmann, N. L. \& R. Sattler. 1992. Irregular floral development in Calla palustris (Araceae) and the concept of homeosis. Am. J. Bot. 79: 1145-1157.

Lehmiller, D. J. 1992. Interspecific hybrids of Crinum americanum L. (Amaryllidaceae). Acta Hort. 325: 591-596.

Lehtonen, S. 2007. Natural History of Echinodorus (Alismataceae). Turun Yliopisto, Turku, Finland. 120 pp.

Lehtonen, S. 2009. Systematics of the Alismataceae-a morphological evaluation. Aquat. Bot. 91: 279-290.

Lehtonen, S. 2009a. On the origin of Echinodorus grandiflorus (Alismataceae) in Florida ("E. floridanus"), and its estimated potential as an invasive species. Hydrobiologia 635: 107-112.

Lehtonen, S. \& L. Myllys. 2008. Cladistic analysis of Echinodorus (Alismataceae): simultaneous analysis of molecular and morphological data. Cladistics 24: 218-239.

Leidolf, A. \& S. McDaniel. 1998. A floristic study of black prairie plant communities at sixteen section prairie, Oktibbeha County, Mississippi. Castanea 63: 51-62.

Leif, J. W. \& E. A. Oelke. 1990. Growth and development of giant burreed (Sparganium eurycarpum). Weed Technol. 4: 849-854.

Leighton, D. \& R. A. Boolootian. 1963. Diet and growth in the black abalone, Haliotis cracerodii. Ecology 44: 227-238.

Leitch, I. J., I. Kahandawala, J. Suda, L. Hanson, M. J. Ingrouille, M. W. Chase \& M. F. Fay. 2009. Genome size diversity in orchids: consequences and evolution. Ann. Bot. 104: 469-481.

Leitch, I. J., J. M. Beaulieu, M. W. Chase, A. R. Leitch \& M. F. Fay. 2010. Genome size dynamics and evolution in monocots. $J$. Bot. 2010: 862516.

Lemay, M.-A., L. De Vriendt, S. Pellerin \& M. Poulin. 2015. Ex situ germination as a method for seed viability assessment in a peatland orchid, Platanthera blephariglottis. Am. J. Bot. 102: 390-395.

Lemke, D. E. 1989. Aquatic macrophytes of the upper San Marcos River, Hays Co., Texas. Southwest. Nat. 34: 289-291.

Lemon, P. C. 1949. Successional responses of herbs in the longleafslash pine forest after fire. Ecology 30: 135-145.

Lemon, G. D., U. Posluszny \& B. C. Husband. 2001. Potential and realized rates of vegetative reproduction in Spirodela polyrhiza, Lemna minor, and Wolffia borealis. Aquat. Bot. 70: 79-87.

Lentz, D. L. 1993. Medicinal and other economic plants of the Paya of Honduras. Econ. Bot. 47: 358-370.

Leonard, S. W. \& W. W. Baker. 1983. Additional populations of Harperocallis flava McDaniel (Liliaceae). Castanea 48: 151-152.

LeResche, R. E. \& J. L. Davis. 1973. Importance of nonbrowse foods to moose on the Kenai Peninsula, Alaska. J. Wildl. Manag. 37: 279-287.

Lerman, J. C. \& E. M. Cigliano. 1971. New carbon-14 evidence for six hundred years old Canna compacta seed. Nature 232: 568-570. 
Les, D. H. 1983. Taxonomic implications of aneuploidy and polyploidy in Potamogeton (Potamogetonaceae). Rhodora 85: 301-323.

Les, D. H. 1988. Breeding systems, population structure, and evolution in hydrophilous angiosperms. Ann. Missouri Bot. Gard. 75: 819-835.

Les, D. H. 2017. Aquatic Dicotyledons of North America: Ecology, Life History, and Systematics. CRC Press, Boca Raton, FL. $1334 \mathrm{pp}$.

Les, D. H. \& D. J. Sheridan. 1990. Biochemical heterophylly and flavonoid evolution in North American Potamogeton (Potamogetonaceae). Am. J. Bot. 77: 453-465.

Les, D. H. \& C. T. Philbrick. 1993. Studies of hybridization and chromosome number variation in aquatic plants: evolutionary implications. Aquat. Bot. 44: 181-228.

Les, D. H. \& R. R. Haynes. 1995. Systematics of subclass Alismatidae: a synthesis of approaches. Pp. 353-377 In: P. J. Rudall, P. J. Cribb, D. F. Cutler \& C. J. Humphries (eds.), Monocotyledons: Systematics and Evolution. Royal Botanic Gardens, Kew, United Kingdom.

Les, D. H. \& R. R. Haynes. 1996. Coleogeton (Potamogetonaceae), a new genus of pondweeds. Novon 6: 389-391.

Les, D.H.\& R. S. Capers. 1999. Limnobium spongia (Hydrocharitaceae) discovered in New England. Rhodora 101: 419-423.

Les, D. H. \& D. J. Crawford. 1999. Landoltia (Lemnaceae), a new genus of duckweeds. Novon 9: 530-533.

Les, D. H. \& L. J. Mehrhoff. 1999. Introduction of nonindigenous aquatic vascular plants in southern New England: a historical perspective. Biol. Invasions 1: 281-300.

Les, D. H. \& N. Tippery. 2013. In time and with water ... the systematics of alismatid monocotyledons. Pp. 118-164 In: P. Wilkin \& S. J. Mayo (eds.), Early Events in Monocot Evolution. Cambridge University Press, Cambridge, United Kingdom.

Les, D. H., D. K. Garvin \& C. F. Wimpee. 1993. Phylogenetic studies in the monocot subclass Alismatidae: evidence for a reappraisal of the aquatic order Najadales. Mol. Phylogenet. Evol. 2: 304-314.

Les, D. H., M. A. Cleland \& M. Waycott. 1997a. Phylogenetic studies in Alismatidae, II: evolution of marine angiosperms ('seagrasses') and hydrophily. Syst. Bot. 22: 443-463.

Les, D. H., E. Landolt \& D. J. Crawford. 1997b. Systematics of Lemnaceae: inferences from micromolecular and morphological data. Plant Syst. Evol. 204: 161-177.

Les, D. H., L. J. Mehrhoff, M. A. Cleland \& J. D. Gabel. 1997c. Hydrilla verticillata (Hydrocharitaceae) in Connecticut. J. Aquat. Plant Manag. 35: 10-14.

Les, D. H., D. J. Crawford, E. Landolt, J. D. Gabel \& R. T. Kimball. 2002. Phylogeny and systematics of Lemnaceae, the duckweed family. Syst. Bot. 27: 221-240.

Les, D. H., D. J. Crawford, R. T. Kimball, M. L. Moody \& E. Landolt. 2003. Biogeography of discontinuously distributed hydrophytes: a molecular appraisal of intercontinental disjunctions. Int. J. Plant Sci. 164: 917-932.

Les, D. H., M. L. Moody \& S. W. L. Jacobs. 2005. Phylogeny and systematics of Aponogeton (Aponogetonaceae): the Australian species. Syst. Bot. 30: 503-519.

Les, D. H., M. L. Moody \& C. Soros. 2006a. A reappraisal of phylogenetic relationships in the monocotyledon family Hydrocharitaceae. Aliso 22: 211-230.

Les, D. H., R. S. Capers \& N. P. Tippery. 2006b. Introduction of Glossostigma (Phrymaceae) to North America: a taxonomic and ecological overview. Am. J. Bot. 93: 927-939.

Les, D. H., S. W. L. Jacobs, N. Tippery, L. Chen, M. L. Moody \& M. Wilstermann. 2008. Systematics of Vallisneria L. (Hydrocharitaceae Juss.). Syst. Bot. 33: 49-65.
Les, D. H., N. M. Murray \& N. P. Tippery. 2009. Systematics of two imperiled pondweeds (Potamogeton vaseyi, P. gemmiparus) and taxonomic ramifications for subsection Pusilli (Potamogetonaceae). Syst. Bot. 34: 643-651.

Les, D. H., S. P. Sheldon \& N. P. Tippery. 2010. Hybridization in hydrophiles: natural interspecific hybrids in Najas L. (Hydrocharitaceae). Syst. Bot. 35: 736-744.

Les, D. H., N. P. Tippery \& H. Razifard. 2012a. Noteworthy collections. California. Najas minor. Madroño 59: 232.

Les, D. H., N. P. Tippery \& H. Razifard. 2012b. Noteworthy collections. Texas. Najas minor. Madroño 59: 232-233.

Les, D. H., E. L. Peredo, L. K. Benoit, N. P. Tippery, U. M. King \& S. P. Sheldon. 2013. Phytogeography of Najas gracillima (Hydrocharitaceae) in North America and its cryptic introduction to California. Am. J. Bot. 100: 1905-1915.

Les, D. H., E. L. Peredo, N. P. Tippery, L. K. Benoit, H. Razifard, U. M. King, H. R. Na, H.-K. Choi, L. Chen, R. K. Shannon \& S. P. Sheldon. 2015a. Najas minor (Hydrocharitaceae) in North America: a reappraisal. Aquat. Bot. 126: 60-72.

Les, D. H., E. L. Peredo, U. M. King, L. K. Benoit, N. P. Tippery, C. J. Ball \& R. K. Shannon. 2015b. Through thick and thin: cryptic sympatric speciation in the submersed genus Najas (Hydrocharitaceae). Mol. Phylogenet. Evol. 82: 15-30.

Les, D. H., A. M. Les, U. M. King \& E. L. Peredo. 2015c. Najas flexilis (Hydrocharitaceae) in Alaska: a reassessment. Rhodora 117: 354-370.

Lesica, P. 1986. Vegetation and flora of Pine Butte Fen, Teton County, Montana. Great Basin Nat. 46: 22-32.

Leslie, K. A. \& M. P. Burbanck. 1979. Vegetation of granitic outcroppings at Kennesaw Mountain, Cobb County, Georgia. Castanea 44: 80-87.

Lessa, M. A., C. V. Araújo, M. A. Kaplan, D. Pimenta, M. R. Figueiredo \& E. Tibirica. 2008. Antihypertensive effects of crude extracts from leaves of Echinodorus grandiflorus. Fundam. Clin. Pharmacol. 22: 161-168.

Letty, C. 1973. The genus Zantedeschia. Bothalia 11: 5-26.

Léveillé-Bourret, É., M.-È. Garon-Labrecque \& E. Thomson. 2017. Le statut de la naïade grêle (Najas gracillima, Najadaceae) au Québec. Naturaliste Can. 141: 6-14.

Levey, D. J., H. A. Bissell \& S. F. O'Keefe. 2000. Conversion of nitrogen to protein and amino acids in wild fruits. J. Chem. Ecol. 26: 1749-1763.

Levine, J. M. 2000. Complex interactions in a streamside plant community. Ecology 81: 3431-3444.

Lewis, C. E. 1970. Responses to chopping and rock phosphate on south Florida ranges. J. Range Manag. 23: 276-282.

Lewis III, R. R. 1989. Creation and restoration of coastal plain wetlands in Florida. Pp. 73-94 In: J. A. Kusler \& M. E. Kentula (eds.), Wetland Creation and Restoration: The Status of the Science. Volume 1. United States Environmental Protection Agency, Environmental Research Laboratory, Corvallis, OR.

Lewis, J. R. 1990. Amaryllidaceae alkaloids. Nat. Prod. Rep. 7: 549-556.

Lewis, D. Q. 2002. Burmanniaceae Blume. Burmannia Family. Pp. 486-488 In: Flora North America Editorial Committee (eds.), Flora of North America North of Mexico, Vol. 26: Magnoliophyta: Liliidae: Liliales and Orchidales. Oxford University Press, New York, NY.

Lewis, F. J. \& E. S. Dowding. 1926. The vegetation and retrogressive changes of peat areas ("muskegs") in central Alberta. J. Ecol. 14: 317-341.

Lewis, R. R. \& R. C. Phillips. 1980. Occurrence of seeds and seedlings of Thalassia testudinum Banks ex König in the Florida Keys (USA). Aquat. Bot. 9: 377-380. 
Lewis, J. B. \& C. E. Hollingworth. 1982. Leaf epifauna of the seagrass Thalassia testudinum. Mar. Biol. 71: 41-49.

Lewis, F. J., E. S. Dowding \& E. H. Moss. 1928. The vegetation of Alberta: II. The swamp, moor and bog forest vegetation of central Alberta. J. Ecol. 16: 19-70.

Ley, A. C. \& R. Claßen-Bockhoff. 2012. Floral synorganization and its influence on mechanical isolation and autogamy in Marantaceae. Bot. J. Linn. Soc. 168: 300-322.

Lichvar, R. W., D. L. Banks, W. N. Kirchner \& N. C. Melvin. 2016. The national wetland plant list: 2016 wetland ratings. Phytoneuron 2016-30: 1-15.

Li, H. \& P. C. Boyce. 2010. Colocasia Schott. Pp. 73-76 In: Flora of China Editorial Committee (eds.), Flora of China. Vol. 23 (Acoraceae Through Cyperaceae). Science Press, Beijing/Missouri Botanical Garden Press, St. Louis, MO.

Li, W. G., J. J. Shen \& J. B. Wang. 2005. Genetic diversity of the annual weed Monochoria vaginalis in southern China detected by random amplified polymorphic DNA and inter-simple sequence repeat analyses. Weed Res. 45: 424-430.

Li, S., I. A. Mendelssohn, H. Chen \& W. H. Orem. 2009. Does sulphate enrichment promote the expansion of Typha domingensis (cattail) in the Florida Everglades? Freshw. Biol. 54: 1909-1923.

Li, J.-H., Z.-J. Liu, G. A. Salazar, P. Bernhardt, H. Perner, Y. Tomohisa, X.-H. Jin, S.-W. Chung \& Y.-B. Luo. 2011. Molecular phylogeny of Cypripedium (Orchidaceae: Cypripedioideae) inferred from multiple nuclear and chloroplast regions. Mol. Phylogenet. Evol. 61: 308-320.

Li, J., Q.-F. Wang, R. W. Gituru, C.-F. Yang \& Y.-H. Guo. 2012. Reversible anther opening enhances male fitness in a dichogamous aquatic plant Butomus umbellatus L., the flowering rush. Aquat. Bot. 99: 27-33.

Li, Z., W. Lu, L. Yang, X. Kong \& X. Deng. 2015. Seed weight and germination behavior of the submerged plant Potamogeton pectinatus in the arid zone of northwest China. Ecol. Evol. 5: 1504-1512.

Liang, W., X. Guo, D. G. Nagle, W.-D. Zhang \& X.-H. Tian. 2019. Genus Liparis: a review of its traditional uses in China, phytochemistry and pharmacology. J. Ethnopharmacol. 234: 154-171.

Lichthardt, J., R. K. Moseley \& J. Mallet. 2000. Ecological Assessment of Howellia aquatilis Habitat at the HarvardPalouse River Flood Plain Site, Idaho. Idaho Department of Fish and Game, Idaho Conservation Data Center, Boise, ID. $32 \mathrm{pp}$.

Lieffers, V. J. 1984. Emergent plant communities of oxbow lakes in northeastern Alberta: salinity, water-level fluctuation, and succession. Can. J. Bot. 62: 310-316.

Liehrmann, O., F. Jégoux, M.-A. Guilbert, F. Isselin-Nondedeu, S. Saïd, Y. Locatelli \& C. Baltzinger. 2018. Epizoochorous dispersal by ungulates depends on fur, grooming and social interactions. Ecol. Evol. 8: 1582-1594.

Lien, E. J.-C., L. L.-M. Lien, R. Wang \& J. Wang. 2012. Phytochemical analysis of medicinal plants with kidney protective activities. Chin. J. Integ. Med. 18: 790-800.

Lieneman, C. 1929. A host index to the North American species of the genus Cercospora. Ann. Missouri Bot. Gard. 16: 1-52.

Liggio, J. \& A. O. Liggio. 2010. Wild Orchids of Texas. University of Texas Press, Austin, TX. 240 pp.

Light, H. M., M. R. Darst, M. T. MacLaughlin \& S. W. Sprecher. 1993. Hydrology, vegetation, and soils of four north Florida river flood plains with an evaluation of state and federal wetland determinations. Water Resources Investigation Report 93-4033. U.S. Geological Survey, Tallahassee, FL. 94 pp.
Lillie, R. A. 1986. The spread of Eurasian watermilfoil Myriophyllum spicatum in Devils Lake, Sauk County, Wisconsin. Lake Reserv. Manage. 2: 64-68.

Lim, K. Y., R. Matyasek, A. Kovarik \& A. Leitch. 2007. Parental origin and genome evolution in the allopolyploid Iris versicolor. Ann. Bot. 100: 219-224.

Lin, Y.-L. \& B.-K. Li. 2016. Removal of pharmaceuticals and personal care products by Eichhornia crassipes and Pistia stratiotes. J. Taiwan Inst. Chem. Eng. 58: 318-323.

Lin, L.-Z., S.-F. Hu, H.-B. Chai, T. Pengsuparp, J. M. Pezzuto, G. A. Cordell \& N. Ruangrungsi. 1995. Lycorine alkaloids from Hymenocallis littoralis. Phytochemistry 40: 1295-1298.

Lind, C. T. \& G. Cottam. 1969. The submerged aquatics of University Bay: a study in eutrophication. Am. Midl. Nat. 81: 353-369.

Lindig-Cisneros, R. \& J. B. Zedler. 2002. Halophyte recruitment in a salt marsh restoration site. Estuaries 25: 1174-1183.

Lindqvist, C., J. De Laet, R. R. Haynes, L. Aagesen, B. R. Keener \& V. A. Albert. 2006. Molecular phylogenetics of an aquatic plant lineage, Potamogetonaceae. Cladistics 22: 568-588.

Lindström, B. \& B. Lüning. 1971. Studies on orchidaceae alkaloids. 23. Alkaloids from Liparis loeselii (L.) LC Rich. and Hammarbya paludosa (L.) OK. Acta Chem. Scand. 25: 895-897.

Lindström, B. \& B. Lüning. 1972. Studies on Orchidaceae alkaloids XXXV. Alkaloids from Hammarbya paludosa (L.) OK and Liparis keitaoensis Hay. Acta Chem. Scand. 25: 895-897.

Linhart, Y. B. \& A. C. Premoli. 1994. Genetic variation in central and disjunct populations of Lilium parryi. Can. J. Bot. 72: 79-85.

Linke, Jr., W. R. 1963. Drosera filiformis in Connecticut. Rhodora 65: 273.

Linn, J. G., E. J. Staba, R. D. Goodrich, J. C. Meiske \& D. E. Otterby. 1975. Nutritive value of dried or ensiled aquatic plants. I. Chemical composition. J. Animal Sci. 41: 601-609.

Linn, J. G., R. D. Goodrich, J. C. Meiske \& E. J. Staba. 1973. Aquatic plants from Minnesota. Part 4 - nutrient composition. Bulletin 73. Water Resources Research Center, University of Minnesota, Minneapolis, MN. 22 pp.

Little, Jr., E. L. 1938. The vegetation of Muskogee County, Oklahoma. Am. Midl. Nat. 19: 559-572.

Littlefield, C. D. 2001. Sandhill crane nest and egg characteristics at Malheur National Wildlife Refuge, Oregon. Proc. N. Am. Crane Workshop 8: 40-44.

Littler, M. M. \& D. S. Littler. 1981. Intertidal macrophyte communities from Pacific Baja California and the upper Gulf of California: relatively constant vs. environmentally fluctuating systems. Mar. Ecol. Prog. Ser. 4: 145-158.

Littler, M. M., D. R. Martz \& D. S. Littler. 1983. Effects of recurrent sand deposition on rocky intertidal organisms: importance of substrate heterogeneity in a fluctuating environment. Mar. Ecol. Prog. Ser. 11: 129-139.

Liu, G.-H., W. Li, J. Zhou, W.-Z. Liu, D. Yang \& A. J. Davy. 2006. How does the propagule bank contribute to cyclic vegetation change in a lakeshore marsh with seasonal drawdown? Aquat. Bot. 84: 137-143.

Liu, L., Q.-M. Yin, X.-W. Zhang, W. Wang, X.-Y. Dong, X. Yan \& R. Hu. 2016. Bioactivity-guided isolation of biphenanthrenes from Liparis nervosa. Fitoterapia 115: 15-18.

Liu, Y., T. Sanguanphun, W. Yuan, J. J. Cheng \& M. Meetam. 2017. The biological responses and metal phytoaccumulation of duckweed Spirodela polyrhiza to manganese and chromium. Environ. Sci. Pollut. Res. 24: 19104-19113.

Lloyd, M. W., K. A. M. Engelhardt \& M. C. Neel. 2009. Development of 11 polymorphic microsatellite markers in a macrophyte of conservation concern, Vallisneria americana Michaux (Hydrocharitaceae). Mol. Ecol. Resour. 9: 1427-1429. 
Lloyd, M. W., R. K. Burnett, K. A. M. Engelhardt \& M. C. Neel. 2012. Does genetic diversity of restored sites differ from natural sites? A comparison of Vallisneria americana (Hydrocharitaceae) populations within the Chesapeake Bay. Conserv. Genet. 13: 753-765.

Lobel, P. S. \& J. C. Ogden. 1981. Foraging by the herbivorous parrotfish Sparisoma radians. Mar. Biol. 64: 173-183.

Lock, I. E., L. D. Ashurkova, O. A. Belova, I. G. Kvasha, N. B. Chashkina, M. V. Remizowa \& D. D. Sokoloff. 2009. A continuum between open and closed inflorescences? Inflorescence tip variation in Potamogeton (Potamogetonaceae: Alismatales). Wulfenia 16: 33-50.

Locky, D. A., S. E. Bayley \& D. H. Vitt. 2005. The vegetational ecology of black spruce swamps, fens, and bogs in southern boreal Manitoba, Canada. Wetlands 25: 564-582.

Loczy, S., R. Carignan \& D. Planas. 1983. The role of roots in carbon uptake by the submersed macrophytes Myriophyllum spicatum, Vallisneria americana, and Heteranthera dubia. Hydrobiologia 98: 3-7.

Lodge, D. M., M. W. Kershner, J. E. Aloi \& A. P. Covich. 1994. Effects of an omnivorous crayfish (Orconectes rusticus) on a freshwater littoral food web. Ecology 75: 1265-1281.

Loeffler, C. C. \& B. C. Wegner. 2000. Demographics and deer browsing in three Pennsylvania populations of the globally rare glade spurge, Euphorbia purpurea (Raf.) Fern. Castanea 65: 273-290.

Loffland, H. L., J. S. Polasik, M. W. Tingley, E. A. Elsey, C. Loffland, G. Lebuhn \& R. B. Siegel. 2017. Bumble bee use of post-fire chaparral in the central Sierra Nevada. J. Wildl. Manag. 81: 1084-1097.

Lohammar, G. 1954. Bulbils in the inflorescences of Butomus umbellatus. Svensk Bot. Tidskr. 48: 485-488.

Lokker, C., D. Susko, L. Lovett-Doust \& J. Lovett-Doust. 1994. Population genetic structure of Vallisneria americana, a dioecious clonal macrophyte. Am. J. Bot. 81: 1004-1012.

Lokker, C., L. Lovett-Doust \& J. Lovett-Doust. 1997. Seed output and the seed bank in Vallisneria americana (Hydrocharitaceae). Am. J. Bot. 84: 1420-1420.

Lombardi, T., T. Fochetti, A. Bertacchi \& A. Onnis. 1997. Germination requirements in a population of Typha latifolia. Aquat. Bot. 56: 1-10.

Lombardo, P. 1997. Predation by Enallagma nymphs (Odonata, Zygoptera) under different conditions of spatial heterogeneity. Hydrobiologia 356: 1-9.

Lomolino, M. V. \& K. C. Ewel. 1984. Digestive efficiencies of the West Indian manatee (Trichechus manatus). Florida Sci. 47: 176-179.

Londonkar, R. L., U. M. Kattegouga, K. Shivsharanappa \& J. V. Hanchinalmath. 2013. Phytochemical screening and in vitro antimicrobial activity of Typha angustifolia Linn leaves extract against pathogenic gram negative microorganisms. J. Pharm. Res. 6: 280-283.

Longcore, J. E. 1995. Morphology and zoospore ultrastructure of Entophlyctis luteolus sp. nov. (Chytridiales): implications for chytrid taxonomy. Mycologia 87: 25-33.

Looman, J. 1969. The fescue grasslands of western Canada. Vegetatio 19: $128-145$.

Looman, J. 1976. Biological flora of the Canadian Prairie Provinces: IV. Triglochin L., the genus. Can. J. Plant Sci. 56: 725-732.

Looman, J. 1983. Water meal, Wolffia arrhiza (Lemnaceae) in Saskatchewan. [actually refers to Wolffia columbiana]. Can. Field-Nat. 97: 220-222.

López-Mendilaharsu, M., S. C. Gardner, J. A. Seminoff \& R. Riosmena-Rodriguez. 2005. Identifying critical foraging habitats of the green turtle (Chelonia mydas) along the Pacific coast of the Baja California peninsula, Mexico. Aquat. Conserv. Mar. Freshw. Ecosyst. 15: 259-269.
Lorenzen, B., H. Brix, K. L. McKee, I. A. Mendelssohn \& S. L. Miao. 2000. Seed germination of two Everglades species, Cladium jamaicense and Typha domingensis. Aquat. Bot. 66: 169-180.

Lorenzen, B., H. Brix, I. A. Mendelssohn, K. L. McKee \& S. L. Miao. 2001. Growth, biomass allocation and nutrient use efficiency in Cladium jamaicense and Typha domingensis as affected by phosphorus and oxygen availability. Aquat. Bot. 70: $117-133$.

Lot, A., A. Novelo-Retana, M. Olvera García \& P. Ramírez-García. 1999. Catálogo de Angiospermas Acuáticas de México. Hidrófitas Estrictas Emergentes, Sumergidas y flotantes. Cuardernos del Instituto de Biología 33. Instituto de Biología, Universidad Nacional Autónoma de México, México. 161 pp.

Lot, A., F. Ramos \& P. Ramírez-García. 2002. Sagittaria demersa (Alismataceae) en la Sierra Tarahumara, México. Anales Inst. Biol. Univ. Nac. Autón. México, Bot. 73: 95-97.

Lot-Helgueras, A. 2004. Flora and vegetation of freshwater wetlands in the coastal zone of the Gulf of Mexico. Pp. 314-339 In: M. Caso, I. Pisanty \& E. Ezcurra (eds.), Environmental Analysis of the Gulf of Mexico. Harte Research Institute for Gulf of Mexico Studies, Texas A\&M University, Corpus Christi, TX. $710 \mathrm{pp}$.

Lotspeich, F. B., J. B. Secor, R. Okazaki \& H. W. Smith. 1961. Vegetation as a soil-forming factor on the Quillayute physiographic unit in western Clallam County, Washington. Ecology 42: 53-68.

Lougheed, V. L., B. Crosbie \& P. Chow-Fraser. 2001. Primary determinants of macrophyte community structure in 62 marshes across the Great Lakes basin: latitude, land use, and water quality effects. Can. J. Fish. Aquat. Sci. 58: 1603-1612.

Loughmiller, C., L. Loughmiller \& J. Marcus. 2018. Texas Wildflowers: A Field Guide. University of Texas Press, Austin, TX. 488 pp.

Löve, Á. 1971. IOPB chromosome number reports XXXII. Taxon 20: $349-356$.

Löve, Á. 1981. Chromosome number reports LXXII. Taxon 30: 694-708.

Löve, Á. 1982. IOPB chromosome number reports LXXV. Taxon 31: 363-364.

Löve, A. \& D. Löve. 1954. Vegetation of a prairie marsh. Bull. Torrey Bot. Club 81: 16-34.

Löve, A. \& D. Löve. 1958. The American element in the flora of the British Isles. Bot. Not. 111: 376-388.

Löve, D. \& H. Lieth. 1961. Triglochin gaspense, a new species of arrow grass. Can. J. Bot. 39: 1261-1272.

Löve, A. \& D. Löve. 1982. IOPB chromosome number reports LXXVII. Taxon 31: 766-768.

Loveless, C. M. 1959. A study of the vegetation in the Florida Everglades. Ecology 40: 1-9.

Love, R. 1975. The primary production of submersed macrophytes in West Blue Lake, Manitoba. M.S. thesis. University of Manitoba, Winnipeg, MB. 111 pp.

Lovell, J. H. 1899. The colors of northern monocotyledonous flowers. Am. Nat. 33: 493-504.

Lovell, J. H. 1905. Some Maine species of Halictus. Can. Entomol. 37: 299-300.

Lovett Doust, J. \& G. Laporte. 1991. Population sex ratios, population mixtures and fecundity in a clonal dioecious macrophyte, Vallisneria americana. J. Ecol. 79: 477-489.

Lovett Doust, L., J. Lovett Doust \& M. Biernacki. 1994. American wildcelery, Vallisneria americana, as a biomonitor of organic contaminants in aquatic ecosystems. J. Great Lakes Res. 20: 333-354. 
Lovvorn, J. R. \& J. R. Baldwin. 1996. Intertidal and farmland habitats of ducks in the Puget Sound region: a landscape perspective. Biol. Conserv. 77: 97-114.

Low, J. B. \& F. C. Bellrose, Jr. 1944. The seed and vegetative yield of waterfowl food plants in the Illinois River valley. $J$. Wildl. Manag. 8: 7-22.

Low, K. S., C. K. Lee \& L. L. Heng. 1994. Sorption of basic dyes by Hydrilla verticillata. Environ. Technol. 15: 115-124.

Low-Décarie, E., C. Chivers \& M. Granados. 2014. Rapidly spreading seagrass invades the Caribbean with unknown ecological consequences. Ecology 69: 974-83.

Lowden, R. M. 1973. Revision of the genus Pontederia L. Rhodora 75: 426-487.

Lowden, R. M. 1982. An approach to the taxonomy of Vallisneria L. (Hydrocharitaceae). Aquat. Bot. 13: 269-298.

Lowden, R. M. 1986. Taxonomy of the genus Najas L. (Najadaceae) in the Neotropics. Aquat. Bot. 24: 147-184.

Lowden, R. M. 1992. Floral variation and taxonomy of Limnobium LC Richard (Hydrocharitaceae). Rhodora 94: 111-134.

Lowry, P. P., P. Goldblatt \& H. Tobe. 1987. Notes on the floral biology, cytology, and embryology of Campynemanthe (Liliales: Campynemataceae). Ann. Missouri Bot. Gard. 74: 573-576.

Lucas, C., T. Thangaradjou \& J. Papenbrock. 2012. Development of a DNA barcoding system for seagrasses: successful but not simple. PLoS One 7: e29987.

Luckenbach, M. W. \& R. J. Orth. 1999. Effects of a deposit-feeding invertebrate on the entrapment of Zostera marina L. seeds. Aquat. Bot. 62: 235-247.

Ludwig, J. C., J. B. Wright \& N. E. Van Alstine. 1991. The rare plants of False Cape State Park, Virginia Beach City, Virginia. Pp. 249-256 In: H. G. Marshall \& M. D. Norman (eds.), Proceedings of the Back Bay Ecological Symposium. Old Dominion University, Norfolk, VA.

Lui, K., F. L. Thompson \& C. G. Eckert. 2005. Causes and consequences of extreme variation in reproductive strategy and vegetative growth among invasive populations of a clonal aquatic plant, Butomus umbellatus L. (Butomaceae). Biol. Invasions 7: 427-444.

Luken, J. O. 2005a. Dionaea muscipula (Venus flytrap) establishment, release, and response of associated species in mowed patches on the rims of Carolina bays. Restor. Ecol. 13: 678-684.

Luken, J. O. 2005b. Habitats of Dionaea muscipula (Venus' fly trap), Droseraceae, associated with Carolina bays. Southeast. Nat. 4: 573-585.

Luken, J. O. \& W. Thieret. 2001. Floristic relationships of mud flats and shorelines at Cave Run Lake, Kentucky. Castanea 66: 336-351.

Lunau, K. 2006. Stamens and mimic stamens as components of floral colour patterns. Bot. Jahrb. 127: 13-41.

Luo, Y., P.-F. Ma, H.-T. Li, J.-B. Yang, H. Wang \& D.-Z. Li. 2016. Plastid phylogenomic analyses resolve Tofieldiaceae as the root of the early diverging monocot order Alismatales. Genome Biol. Evol. 8: 932-945.

Luo, B., Y. Liu, B. Liu, S. Liu, B. Zhang, L. Zhang, C. Lin, Y. Liu, E. J. Kennelly, Z. Guo \& C. Long. 2018. Yao herbal medicinal market during the Dragon Boat Festival in Jianghua County, China. J. Ethnobiol. Ethnomed. 14: 61.

Lüning, K. \& W. Freshwater. 1988. Temperature tolerance of northeast Pacific marine algae. J. Phycol. 24: 310-315.

Lupoae, P., V. Cristea, D. Borda, M. Lupoae, G. Gurau \& R. M. Dinica. 2015. Phytochemical screening: antioxidant and antibacterial properties of Potamogeton species in order to obtain valuable feed additives. J. Oleo Sci. 64: 1111-1123.

Lutz, P. E. \& A. R. Pittman. 1968. Oviposition and early developmental stages of Lestes eurinus (Odonata: Lestidae). Am. Midl. Nat. 80: 43-51.
Lynch, P. S. \& W. B. Zomlefer. 2016. Vascular plant flora of the south Atlantic coastal plain limestone forest: a globally imperiled association endemic to central Georgia. Southeast. Nat. 15: 331-346.

Lynch, J. J., T. O’Neil \& D. W. Lay. 1947. Management significance of damage by geese and muskrats to Gulf Coast marshes. $J$. Wildl. Manag. 11: 50-76.

Lynn, L. M. 1984. The vegetation of Little Cedar Bog, southeastern New York. Bull. Torrey Bot. Club 111: 90-95.

Lynn, L. M. \& E. F. Karlin. 1985. The vegetation of the low-shrub bogs of northern New Jersey and adjacent New York: ecosystems at their southern limit. Bull. Torrey Bot. Club 112: 436-444.

Lyon, J. \& T. Eastman. 2006. Macrophyte species assemblages and distribution in a shallow, eutrophic lake. Northeast. Nat. 13: 443-453.

Ma, Q. \& J. Liang. 2019. The first complete chloroplast genome of Pontederia cordata (Pontederiaceae). Mitochondrial DNA Part B 4: 555-557.

Maass, W. S. G. 1966. Studies on the taxonomy and distribution of Sphagnum I. Sphagnum pylaesii and Sphagnum angermanicum in Quebec and some phytogeographic considerations. Bryologist 69: 95-100.

Maass, W. S. G. 1967. Studies on the taxonomy and distribution of Sphagnum III. Observations on Sphagnum macrophyllum in the northern part of its range. Bryologist 70: 177-192.

Mabbott, D. C. 1920. Food habits of seven species of American shoalwater ducks. Bulletin No. 862. U.S. Department of Agriculture. Government Printing Office, Washington, DC. 68 pp.

Maberly, S. C. 1993. Morphological and photosynthetic characteristics of Potamogeton obtusifolius from different depths. J. Aquat. Plant Manag. 31: 34-34.

Maberly, S. C. \& D. H. N. Spence. 1983. Photosynthetic inorganic carbon use by freshwater plants. J. Ecol. 71: 705-724.

Mabona, U., A. Viljoen, E. Shikanga, A. Marston \& S. Van Vuuren. 2013. Antimicrobial activity of southern African medicinal plants with dermatological relevance: from an ethnopharmacological screening approach, to combination studies and the isolation of a bioactive compound. J. Ethnopharmacol. 148: 45-55.

MacGillivray, A. D. 1903. Aquatic Chrysomelidae and a table of the families of Coleopterous larvae. New York State Museum Bulletin 68. State Museum of New York, Albany, NY. 44 pp.

Mach, M. E., S. Wyllie-Echeverria \& K. M. A. Chan. 2014. Ecological effect of a nonnative seagrass spreading in the Northeast Pacific: a review of Zostera japonica. Ocean Coast. Manag. 102: 375-382.

Mack, R. N. 1981. Initial effects of ashfall from Mount St. Helens on vegetation in eastern Washington and adjacent Idaho. Science 213: $537-539$.

Mack, R. N. 1991. The commercial seed trade: an early disperser of weeds in the United States. Econ. Bot. 45: 257-273.

MacRae, I. V., N. N. Winchester \& R. A. Ring. 1990. Feeding activity and host preference of the milfoil midge, Cricotopus myriophylli Oliver (Diptera: Chironomidae). J. Aquat. Plant Manag. 28: 89-92.

MacRoberts, M. H. \& B. R. MacRoberts. 1995. Noteworthy vascular plant collections on the Kisatchie National Forest, Louisiana. Phytologia 78: 291-313.

MacRoberts, M. H. \& B. R. MacRoberts. 2005. The ecology of Trillium texanum (Trilliaceae) on the Angelina National Forest, Texas. Sida 21: 1893-1903.

MacRoberts, M. H. \& B. R. MacRoberts. 2010. Hydrocleys nymphoides (Limnocharitaceae): new to Louisiana. Phytoneuron 29: $1-2$. 
MacRoberts, B. R., M. H. MacRoberts, D. C. Rudolph \& D. W. Peterson. 2014. Floristics of ephemeral ponds in east-central Texas. Southeast. Nat. 13: 15-25.

Mader, E., W. Van Vierssen \& K. Schwenk. 1998. Clonal diversity in the submerged macrophyte Potamogeton pectinatus L. inferred from nuclear and cytoplasmic variation. Aquat. Bot. 62: $147-160$.

Madeira, P. T., C. C. Jacono \& T. K. Van. 2000. Monitoring hydrilla using two RAPD procedures and the Nonindigenous Aquatic Species database. J. Aquat. Plant Manag. 38: 33-40.

Madineni, M. N., S. Faiza, R. S. Surekha, R. Ravi \& M. Guha. 2012. Morphological, structural, and functional properties of maranta (Maranta arundinacea L) starch. Food Sci. Biotechnol. 21: 747-752.

Madsen, J. D. 1991. Resource allocation at the individual plant level. Aquat. Bot. 41: 67-86.

Madsen, J. D. \& M. S. Adams. 1988. The germination of Potamogeton pectinatus tubers: environmental control by temperature and light. Can. J. Bot. 66: 2523-2526.

Madsen, J. D. \& M. S. Adams. 1989. The light and temperature dependence of photosynthesis and respiration in Potamogeton pectinatus L. Aquat. Bot. 36: 23-31.

Madsen, J. D. \& R. M. Wersal. 2009. Aquatic plant community and Eurasian watermilfoil (Myriophyllum spicatum L.) management assessment in Lake Pend Oreille, Idaho for 2008. Geosystems Research Institute Report 5032. Geosystems Research Institute, Mississippi State, MS. 65 pp.

Madsen, J. D., C. F. Hartleb \& C. W. Boylen. 1991. Photosynthetic characteristics of Myriophyllum spicatum and six submersed aquatic macrophyte species native to Lake George, New York. Freshw. Biol. 26: 233-240.

Madsen, J. D., M. S. Adams \& W. Kleindl. 1992. The aquatic macrophyte community of Black Earth Creek, Wisconsin: 1981 to 1986. Trans. Wisconsin Acad. Sci. 80: 101-114.

Madsen, J. D., R. M. Wersal, M. Tyler \& P. D. Gerard. 2006. The distribution and abundance of aquatic macrophytes in Swan Lake and Middle Lake, Minnesota. J. Freshw. Ecol. 21: 421-429.

Madsen, J. D., R. M. Wersal, M. D. Marko \& J. G. Skogerboe. 2012. Ecology and management of flowering rush (Butomus umbellatus) in the Detroit Lakes, Minnesota. Geosystems Research Institute Report 5054. Mississippi State University, Mississippi State, MS. 43 pp.

Madsen, J. D., R. M. Wersal \& M. D. Marko. 2016. Distribution and biomass allocation in relation to depth of flowering rush (Butomus umbellatus) in the Detroit Lakes, Minnesota. Invasive Plant Sci. Manag. 9: 161-170.

Maehr, D. S. \& J. R. Brady. 1984. Food habits of Florida black bears. J. Wildl. Manag. 48: 230-235.

Magallán, F., M. Martínez, L. Hernández-Sandoval, A. GonzálezRodríguez \& K. Oyama. 2013. Diversidad genética de Lilaea scilloides (Juncaginaceae) en el centro de México. Revista Mexicana Biodiversidad 84: 240-248.

Magrath, L. K. 2002. Liparis Richard. Pp. 624-626 In: Flora North America Editorial Committee (eds.), Flora of North America North of Mexico, Vol. 26: Magnoliophyta: Liliidae: Liliales and Orchidales. Oxford University Press, New York, NY.

Magrath, L. K. 2014. Native orchids of Oklahoma. Oklahoma Nat. Plant Rec. 1: 39-66.

Maheshwari, S. C. 1958. Spirodela polyrrhiza: the link between the aroids and the duckweeds. Nature 181: 1745-1746.

Mahmood, M. S. \& M. Strack. 2011. Methane dynamics of recolonized cutover minerotrophic peatland: implications for restoration. Ecol. Eng. 37: 1859-1868.

Mains, E. B. 1934. Host specialization in the rust of Iris, Puccinia iridis. Am. J. Bot. 21: 23-33.
Maisch, J. M. 1872. Pharmacognostical notes. Am. J. Pharm. (May, 1872). Available online: https://ezproxy.lib.uconn.edu/ login?url=https://search.proquest.com/docview/89684270?acc ountid=14518 [accessed 16 February, 2019].

Maia, V. H., M. A. Gitzendanner, P. S. Soltis, G. K.-S. Wongand \& D. E. Soltis. 2014. Angiosperm phylogeny based on $18 \mathrm{~S} / 26 \mathrm{~S}$ rDNA sequence data: constructing a large dataset using nextgeneration sequence data. Int. J. Plant Sci. 175: 613-650.

Majak, W., R. E. McDiarmid, A. Van Ryswyk \& J. W. Hall. 1980. Seasonal variation in the cyanide potential of arrowgrass (Triglochin maritima). Can. J. Plant Sci. 60: 1235-1241.

Majka, C. \& D. Langor. 2010. Contributions towards an understanding of the Cryptophaginae (Coleoptera, Cryptophagidae) of Atlantic Canada. ZooKeys 35: 13-35.

Majumdar, K. \& B. K. Datta. 2009. Folklore herbal formulations by the tribes of Tripura. Pp. 155-162 In: S. D. Ramashankar \& B. K. Sharma (eds.), Proceeding on Traditional Healing Practices in North East India. North Eastern Institute of Folk Medicine (NEIFM), Pasighat, Arunachal Pradesh, India.

Majure, L. C., J. Hill, C. Doffitt \& T. C. Majure. 2011. The vascular flora of Lauderdale County, Mississippi, USA. Rhodora 113: 365-418.

Maki, K. \& S. Galatowitsch. 2004. Movement of invasive aquatic plants into Minnesota (USA) through horticultural trade. Biol. Conserv. 118: 389-396.

Maki, K. C. \& S. M. Galatowitsch. 2008. Cold tolerance of the axillary turions of two biotypes of Hydrilla and northern watermilfoil. J. Aquat. Plant Manag. 46: 42-50.

Makkay, K., F. R. Pick \& L. Gillespie. 2008. Predicting diversity versus community composition of aquatic plants at the river scale. Aquat. Bot. 88: 338-346.

Malek, L. 1981. The effect of drying on Spirodela polyrhiza turion germination. Can. J. Bot. 59: 104-105.

Mali, P. R. \& D. Datta. 2018. Experimental evaluation of bamboo reinforced concrete slab panels. Constr. Build. Mater. 188: 1092-1100.

Maliakal, S. K., E. S. Menges \& J. S. Denslow. 2000. Community composition and regeneration of Lake Wales Ridge wiregrass flatwoods in relation to time-since-fire. J. Torrey Bot. Soc. 127: 125-138.

Mallik, S., M. Nayak, B. B. Sahu, A. K. Panigrahi \& B. P. Shaw. 2011. Response of antioxidant enzymes to high $\mathrm{NaCl}$ concentration in different salt-tolerant plants. Biol. Plant. 55: 191-195.

Mallin, M. A., S. H. Ensign, T. L. Wheeler \& D. B. Mayes. 2002. Pollutant removal efficacy of three wet detention ponds. $J$. Environ. Qual. 31: 654-660.

Malanson, G. P. 1982. The assembly of hanging gardens: effects of age, area, and location. Am. Nat. 119: 145-150.

Manandhar, N. P. 1985. Ethnobotanical notes on certain medicinal plants used by Tharus of Dang-Deokhuri District, Nepal. Int. J. Crude Drug Res. 23: 153-159.

Mancera, J. E., G. C. Meche, P. P. Cardona-Olarte, E. CastañedaMoya, R. L. Chiasson, N. A. Geddes, L. M. Schile, H. G. Wang, G. R. Guntenspergen \& J. B. Grace. 2005. Fine-scale spatial variation in plant species richness and its relationship to environmental conditions in coastal marshlands. Plant Ecol. 178: $39-50$.

Mandal, R. N., A. K. Datta, N. Sarangi \& P. K. Mukhopadhyay. 2010. Diversity of aquatic macrophytes as food and feed components to herbivorous fish - a review. Indian J. Fish. 57: 65-73.

Mandossian, A. \& R. P. McIntosh. 1960. Vegetation zonation on the shore of a small lake. Am. Midl. Nat. 64: 301-308.

Manguin, S., D. R. Roberts, E. L. Peyton, E. Rejmankova \& J. Pecor. 1996. Characterization of Anopheles pseudopunctipennis larval habitats. J. Am. Mosq. Control Assoc. 12: 619-626. 
Manning, M. E. \& W. G. Padgett. 1995. Riparian community type classification for Humboldt and Toiyabe National Forests, Nevada and eastern California. R4-Ecol-95-01. U.S. Department of Agriculture, Forest Service, Intermountain Region, Ogden, UT. 306 pp.

Manolis, T. 2016. Odonate exuviae used for roosts and nests by Sassacus vitis and other jumping spiders (Araneae: Salticidae). Peckhamia 142(1): 1-17.

Mansfield, D. 1996. The unique botany of Steens Mountain: the rare and endemic plants. Kalmiopsis 5: 10-17.

Mansor, M. 1996. Noxious floating weeds of Malaysia. Hydrobiologia 340: 121-125.

Mantas, M. 1993. Ecology and reproductive biology of Epipactis gigantea Doug. (Orchidaceae) in northwestern Montana. M.S. thesis. University of Idaho, Moscow, ID. 73 pp.

Marburger, J. E. 1993. Biology and management of Sagittaria latifolia Willd (broad-leaf arrow-head) for wetland restoration and creation. Restor. Ecol. 1: 248-255.

Marchant, C. J. 1970. Chromosome variation in Araceae: I: Pothoeae to Stylochitoneae. Kew Bull. 24: 315-322.

Marco-Méndez, C., P. Prado, L. M. Ferrero-Vicente, C. Ibáñez \& J. L. Sánchez-Lizaso. 2015. Seasonal effects of waterfowl grazing on submerged macrophytes: the role of flowers. Aquat. Bot. 120: $275-282$.

Marcus, B. A. 1981. Hydropsyche larvae (Trichoptera: Hydropsychidae) from a lake weedbed. J. New York Entomol. Soc. 89: 56-58.

Mardanov, A. V., N. V. Ravin, B. B. Kuznetsov, T. H. Samigullin, A. S. Antonov, T. V. Kolganova \& K. G. Skyabin. 2008. Complete sequence of the duckweed (Lemna minor) chloroplast genome: structural organization and phylogenetic relationships to other angiosperms. J. Mol. Evol. 66: 555-564.

Marie-Victorin, F. 1943. Les Vallisnéries américaines. Contr. Inst. Bot. Univ. Montréal 46: 1-38.

Marion, C., J.-L. Fernandez, S.-M. d'Hères, F. D. Prehsler, J. Schönenberger \& M. Gibernau. 2017. Note on the pollination of Calla palustris L. (Araceae). Aroideana 40: 71-83.

Markle, M. S. 1915. The phytecology of peat bogs near Richmond, Indiana. Proc. Indiana Acad. Sci. 25: 359-376.

Markwith, S. H. \& M. J. Scanlon. 2006. Characterization of six polymorphic microsatellite loci isolated from Hymenocallis coronaria (J. LeConte) Kunth (Amaryllidaceae). Mol. Ecol. Notes 6: 72-74.

Markwith, S. H. \& K. C. Parker. 2007. Conservation of Hymenocallis coronaria genetic diversity in the presence of disturbance and a disjunct distribution. Conserv. Genet. 8: 949-963.

Markwith, S. H. \& M. J. Scanlon. 2007. Multiscale analysis of Hymenocallis coronaria (Amaryllidaceae) genetic diversity, genetic structure, and gene movement under the influence of unidirectional stream flow. Am. J. Bot. 94: 151-160.

Markwith, S. H. \& D. S. Leigh. 2008. Subaqueous hydrochory: open-channel hydraulic modelling of non-buoyant seed movement. Freshw. Biol. 53: 2274-2286.

Markwith, S. H. \& D. S. Leigh. 2012. Comparison of estimated and experimental subaqueous seed transport. Ecohydrology 5: 346-350.

Markwith, S. H., L. J. Davenport, J. Shelton, K. C. Parker \& M. J. Scanlon. 2009. Ichthyochory, closure of the Suwannee Strait, and population divergence in Hymenocallis coronaria. Florida Sci. 72: 28-36.

Marler, J. E. 1969. A study of the germination process of seeds of Heteranthera limosa. Ph.D. dissertation. Louisiana State University, Baton Rouge, LA. 92 pp.

Marles, R. J. 2001. Non-timber forest products and Aboriginal traditional knowledge. Pp. 53-65 In: I. Davidson-Hunt, L. C. Duchesne \& J. C. Zasada (eds.), Forest Communities in the
Third Millennium: Linking Research, Business, and Policy Toward a Sustainable Non-Timber Forest Product Sector. Gen. Tech. Rep. NC-217. U.S. Department of Agriculture, Forest Service, North Central Research Station, St. Paul, MN.

Marsden, J. E. \& B. J. Ladago. 2017. The Champlain Canal as a non-indigenous species corridor. J. Great Lakes Res. 43: 1173-1180.

Marsden, B. W., K. A. M. Engelhardt \& M. C. Neel. 2013. Genetic rescue versus outbreeding depression in Vallisneria americana: implications for mixing seed sources for restoration. Biol. Conserv. 167: 203-214.

Marsh, Jr., J. A., W. C. Dennison \& R. S. Alberte. 1986. Effects of temperature on photosynthesis and respiration in eelgrass (Zostera marina L.). J. Exp. Mar. Biol. Ecol. 101: 257-267.

Marshal, J. P., V. C. Bleich, N. G. Andrew \& P. R. Krausman. 2004. Seasonal forage use by desert mule deer in southeastern California. Southwest. Nat. 49: 501-506.

Martin, G. 1886. The Phyllostictas of North America. J. Mycol. 2: 25-27.

Martin, R. D. C. 1939. Life histories of Agrion aequabile and Agrion maculatum. Ann. Entomol. Soc. Am. 32: 601-619.

Martin, M. A. 1978. A unique natural area in Dane county, Wisconsin. Pp. 187-189 In: R. L. Stuckey \& K. J. Reese (eds.), The Prairie Peninsula--In the 'Shadow' of Transeau: Proceedings of the Sixth North American Prairie Conference. Ohio Biological Survey Biological Notes No. 15. Columbus, OH.

Martin, A. C. \& F. M. Uhler. 1951. Food of game ducks in the United States and Canada. Research Report 30. Fish \& Wildlife Service, U.S. Department of the Interior, Washington, DC. 308 pp.

Martin, P. G. \& J. M. Dowd. 1986. A phylogenetic tree for some monocotyledons and gymnosperms derived from protein sequences. Taxon 35: 469-475.

Martin, K. \& J. Sauerborn. 2000. An aquatic wild plant as a keystone species in a traditional Philippine rice growing system: its agroecological implications. Ann. Trop. Res. 22: 1-15.

Martin, S. B. \& G. P. Shaffer. 2005. Sagittaria biomass partitioning relative to salinity, hydrologic regime, and substrate type: implications for plant distribution patterns in coastal Louisiana, United States. J. Coast. Res. 21: 167-174.

Martin, T. H., L. B. Crowder, C. F. Dumas \& J. M. Burkholder. 1992. Indirect effects of fish on macrophytes in Bays Mountain Lake: evidence for a littoral trophic cascade. Oecologia 89: 476-481.

Martine, C. T., S. F. Langdon, T. M. Shearman, C. Binggeli \& T. B. Mihuc. 2015. European frogbit (Hydrocharis morsus-ranae) in the Champlain/Adirondack region: recent inferences. Rhodora 117: 499-504.

Martínez-Garrido, J., E. A. Serrão, A. H. Engelen, C. J. Cox, P. García-Murillo \& M. González-Wangüemert. 2016. Multilocus genetic analyses provide insight into speciation and hybridization in aquatic grasses, genus Ruppia. Biol. J. Linn. Soc. 117: 177-191.

Martínez-Garrido, J., R. Bermejo, E. A. Serrão, J. Sánchez-Lizaso \& M. González-Wangüemert. 2017a. Regional genetic structure in the aquatic macrophyte Ruppia cirrhosa suggests dispersal by waterbirds. Estuaries Coast. 40: 1705-1716.

Martínez-Garrido, J., J. C. Creed, S. Martins, C. H. Almada \& E. A. Serrão. 2017b. First record of Ruppia maritima in West Africa supported by morphological description and phylogenetic classification. Bot. Mar. 60: 583-589.

Martirosyan, E. V., N. N. Ryzhova, E. Z. Kochieva \& K. G. Skryabin. 2009. Analysis of chloroplast rps16 intron sequences in Lemnaceae. Mol. Biol. 43: 32-38.

Marx, E. J. F. 1957. A review of the subgenus Donacia in the Western Hemisphere (Coleoptera, Donaciidae). Bull. Am. Mus. Nat. Hist. 112: 191-278. 
Maschinski, J. 2001. Impacts of ungulate herbivores on a rare willow at the southern edge of its range. Biol. Conserv. 101: 119-130.

Mashburn, S. J., R. R. Sharitz \& M. H. Smith. 1978. Genetic variation among Typha populations of the southeastern United States. Evolution 32: 681-685.

Mason, H. L. 1938. The flowering of Wolffiella lingulata (Hegelm.) Hegelm. Madroño 4: 241-251.

Mason, H. L. 1957. A Flora of the Marshes of California. University of California Press, Berkeley, CA. 878 pp.

Massey, A. B. 1953. Orchids in Virginia. Castanea 18: 107-115.

Massoud, M. S. 2012. Mycoflora associated with aquatic plants in ponds and lakes in central west of Florida, USA. Sci. Res. Rep. 2: $1-6$.

Mata, J. L. \& J. Cebrián. 2013. Fungal endophytes of the seagrasses Halodule wrightii and Thalassia testudinum in the north-central Gulf of Mexico. Bot. Mar. 56: 541-545.

Matsuda, H., T. Morikawa, Y. Sakamoto, I. Toguchida \& M. Yoshikawa. 2002. Labdane-type diterpenes with inhibitory effects on increase in vascular permeability and nitric oxide production from Hedychium coronarium. Bioorg. Med. Chem. 10: $2527-2534$.

Matsuhashi, S., T. Minamoto \& H. Doi. 2019. Seasonal change in environmental DNA concentration of a submerged aquatic plant species. Freshw. Sci. 38: 654-660.

Matteson, S. W., T. A. Andryk \& J. Wetzel. 1986. Wisconsin trumpeter swan recovery plan. Passeng. Pigeon 50: 119-130.

Matthews, E. R., R. K. Peet \& A. S. Weakley. 2007. Natural vegetation of the Carolinas: classification and description of Piedmont alluvial plant communities of the Cape Fear River Basin. Unpublished Report. Carolina Vegetation Survey, University of North Carolina, Chapel Hill, NC. 29 pp.

Mathis, W. 1947. Biology of the Florida red scale in Florida. Florida Entomol. 29: 13-35.

Mathur, A. C. \& B. P. Saxena. 1975. Induction of sterility in male houseflies by vapors of Acorus calamus L. oil. Naturwissenschaften 62: 576-577.

Mattila, J., G. Chaplin, M. R. Eilers, K. L. Heck, Jr., J. P. O’Neal \& J. F. Valentine. 1999. Spatial and diurnal distribution of invertebrate and fish fauna of a Zostera marina bed and nearby unvegetated sediments in Damariscotta River, Maine (USA). J. Sea Res. 41: 321-332.

Mattson, R. A., J. H. Epler \& M. K. Hein. 1995. Description of benthic communities in karst, spring-fed streams of north central Florida. J. Kansas Entomol. Soc. 68: 18-41.

Mattson, D. J., S. R. Podruzny \& M. A. Haroldson. 2005. Consumption of pondweed rhizomes by Yellowstone grizzly bears. Ursus 16: 41-46.

Matulewich, V. A. \& M. S. Finstein. 1978. Distribution of autotrophic nitrifying bacteria in a polluted river (the Passaic). Appl. Environ. Microbiol. 35: 67-71.

Mauermann, K. J. 1995. Feeding and habitat preferences of the redeared slider, Trachemys scripta elegans Wied. M.S. thesis. Texas Woman's University, Denton, TX. 106 pp.

Maurice, D. V., J. E. Jones, C. R. Dillon \& J. M. Weber. 1984. Chemical composition and nutritional value of Brazilian elodea (Egeria densa) for the chick. Poult. Sci. 63: 317-323.

Mavrodiev, E. V., M. Martínez-Azorín, P. Dranishnikov \& M. B. Crespo. 2014. At least 23 genera instead of one: the case of Iris L. s.l. (Iridaceae). PLoS One 9(8): e106459.

Maycock, P. F. 1956. Composition of an upland conifer community in Ontario. Ecology 37: 846-848.

Mayes, R. A., A. W. MacIntosh \& V. L. Anderson. 1977. Uptake of cadmium and lead by a rooted aquatic macrophyte (Elodea canadensis). Ecology 58: 1176-1180.
Mayo, S. J., J. Bogner \& P. C. Boyce. 1998a. Araceae. Pp. 26-74 In: K. Kubitzki (ed.), The Families and Genera of Vascular Plants, Vol. IV, Flowering Plants: Monocotyledons, Alismatanae and Commelinanae (Except Gramineae). Springer-Verlag, Berlin, Germany.

Mayo, S. J., J. Bogner \& P. C. Boyce. 1998b. The genera of Araceae project. Acta Bot. Yunnan. Suppl. X: 4-11.

Mazerolle, D., S. Blaney \& A. Belliveau. 2014. Rare Vascular Plant Surveys in the Polletts Cove and LaHave River Areas of Nova Scotia. Atlantic Canada Conservation Data Centre, Sackville, NB, Canada. $71 \mathrm{pp}$.

McAllister, C. T., M. B. Leite \& R. Tumlison. 2017. The fishes of Chadron Creek, Dawes County, Nebraska. J. Arkansas Acad. Sci. 71: 62-68.

McAtee, W. L. 1913. Some local names of plants. Torreya 13: 225-236.

McAtee, W. L. 1916. Plants collected on Matinicus Island, Maine, in late fall, 1915. Rhodora 18: 29-45.

McAtee, W. L. 1918. Food habits of the mallard ducks of the United States. U.S. Department of Agriculture Bulletin No. 720. Government Printing Office, Washington, DC. 36 pp.

McAtee, W. L. 1922. Notes on food habits of the shoveller or spoonbill duck (Spatula clypeata). Auk 39: 380-386.

McAtee, W. L. 1925. Notes on drift, vegetable balls, and aquatic insects as a food product of inland waters. Ecology 6: 288-302.

McAtee, W. L. 1939. Wildfowl Food Plants. Collegiate Press, Inc., Ames, IA. $141 \mathrm{pp}$.

McAuley, D. G. \& J. R. Longcore. 1988. Foods of juvenile ringnecked ducks: relationship to wetland $\mathrm{pH}$. J. Wildl. Manag. 52: 177-185.

McAvoy, W. A. \& R. M. Wilson. 2014. Rediscovery of Lobelia boykinii (Campanulaceae) in Delaware. Phytoneuron 23: 1-4.

McCabe, T. L. \& C. J. Sheviak. 1980. Platanthera cristata (Michx.) Lindl., a new host for the red-banded leaf roller. J. New York Entomol. Soc. 88: 197-198.

McCall, D. D. \& C. F. Rakocinski. 2007. Grass shrimp (Palaemonetes spp.) play a pivotal trophic role in enhancing Ruppia maritima. Ecology 88: 618-624.

McCann, M. J. 2016. Response diversity of free-floating plants to nutrient stoichiometry and temperature: growth and resting body formation. PeerJ 4: e1781.

McClaran, M. P. \& P. C. Sundt. 1992. Population dynamics of the rare orchid, Spiranthes delitescens. Southwest. Nat. 37: 299-303.

McClure, J. W. \& R. E. Alston. 1966. A chemotaxonomic study of Lemnaceae. Am. J. Bot. 53: 849-860.

McColl, J. G. \& J. Burger. 1976. Chemical inputs by a colony of Franklin's gulls nesting in cattails. Am. Midl. Nat. 96: 270-280.

McCormick, J. 1998. The vegetation of the New Jersey Pine Barrens. Pp. 229-243 In: R. T. T. Forman (ed.), Pine Barrens: Ecosystem and Landscape. Rutgers University Press, New Brunswick, NJ. 601 pp.

McCormick, M. K. \& H. Jacquemyn. 2014. What constrains the distribution of orchid populations? New Phytol. 202: 392-400.

McCormick, P. V., J. W. Harvey \& E. S. Crawford. 2011. Influence of changing water sources and mineral chemistry on the Everglades ecosystem. Crit. Rev. Environ. Sci. Technol. 41(S1): 28-63.

McDaniel, S. 1968. Harperocallis, a new genus of the Liliaceae from Florida. J. Arnold Arbor. 49: 35-40.

McDermid, K. J., B. Stuercke \& G. H. Balazs. 2007. Nutritional composition of marine plants in the diet of the green sea turtle (Chelonia mydas) in the Hawaiian Islands. Bull. Mar. Sci. 81: 55-71. 
McDermott, J. J. 1988. The role of hoplonemerteans in the ecology of seagrass communities. Pp. 1-11 In: P. Sundberg, R. Gibson \& G. Berg (eds.), Recent Advances in Nemertean Biology. Dr. W. Junk, Publishers, Dordrecht, The Netherlands.

McDonald, C. 1991. Endangered and threatened wildlife and plants; final rule to list Potamogeton clystocarpus (Little Aguja pondweed) as endangered. Fed. Reg. 56: 57844-57849.

McDowell, L. R., L. C. Lizama, J. E. Marion \& C. J. Wilcox. 1990. Utilization of aquatic plants Elodea canadensis and Hydrilla verticillata in diets for laying hens. 1. Performance and eggyolk pigmentation. Poult. Sci. 69: 673-678.

McFarland, D. 2006. Reproductive ecology of Vallisneria americana Michaux. SAV Technical Notes Collection (ERDC/TN SAV06-4). U.S. Army Engineer Research and Development Center, Vicksburg, MS. 27 pp.

McFarland, D. G. \& S. J. Rogers. 1998. The aquatic macrophyte seed bank in Lake Onalaska, Wisconsin. J. Aquat. Plant Manag. 36: 33-39.

McFarland, D. G., J. W. Barko \& N. J. McCreary. 1992. Effects of sediment fertility and initial plant density on growth of Hydrilla verticillata (LF) Royle and Potamogeton nodosus Poiret. J. Freshw. Ecol. 7: 191-200.

McFerren, M. A. 2006. Useful plants of dermatology. VIII. The false hellebore (Veratrum californicum). J. Am. Acad. Dermatol. 54: 718-720.

McGaha, Y. J. 1952. The limnological relations of insects to certain aquatic flowering plants. Trans. Am. Microsc. Soc. 71: 355-381.

McGilvrey, F. B. 1966. Fall food habits of ducks near Santee Refuge, South Carolina. J. Wildl. Manag. 30: 577-580.

McGovern, T. M. \& K. Blankenhorn. 2007. Observation of fruit production by the seagrass Halodule wrightii in the northeastern Gulf of Mexico. Aquat. Bot. 87: 247-250.

McIlraith, A. L., G. G. C. Robinson \& J. M. Shay. 1989. A field study of competition and interaction between Lemna minor and Lemna trisulca. Can. J. Bot. 67: 2904-2911.

McIlroy, S. K. \& B. H. Allen-Diaz. 2012. Plant community distribution along water table and grazing gradients in montane meadows of the Sierra Nevada Range (California, USA). Wetl. Ecol. Manag. 20: 287-296.

McIntyre, S. \& M. R. Newnham. 1988. Distribution and spread of the Alismataceae in the rice-growing region of New South Wales. Cunninghamia 2: 25-38.

McKain, M. R., J. R. McNeal, P. R. Kellar, L. E. Eguiarte, J. C. Pires \& J. Leebens-Mack. 2016a. Timing of rapid diversification and convergent origins of active pollination within Agavoideae (Asparagaceae). Am. J. Bot. 103: 1717-1729.

McKain, M. R., H. Tang, J. R. McNeal, S. Ayyampalayam, J. I. Davis, C. W. dePamphilis, T. J. Givnish, J. C. Pires, D. W. Stevenson \& J. H. Leebens-Mack. 2016b. A phylogenomic assessment of ancient polyploidy and genome evolution across the Poales. Genome Biol. Evol. 8: 1150-1164.

McKee, K. L. \& I. A. Mendelssohn. 1989. Response of a freshwater marsh plant community to increased salinity and increased water level. Aquat. Bot. 34: 301-316.

McKenzie, R. J. \& P. H. Lovell. 1992. Flower senescence in monocotyledons: a taxonomic survey. New Zealand J. Crop Hort. Sci. 20: 67-71.

McKenzie, P. M., C. T. Witsell, L. R. Phillippe, C. S. Reid, M. A. Homoya, S. B. Rolfsmeier \& C. A. Morse. 2009. Status assessment of Eleocharis wolfii (Cyperaceae) in the United States. J. Bot. Res. Inst. Texas 3: 831-854.

McKenzie, P. M., T. Nagel, D. Ashley \& N. Paothong. 2012. A second recent record of eastern prairie-fringed orchid (Platanthera leucophaea) for Missouri. Missouriensis 31: 5-8.
McKenzie-Gopsill, A., H. Kirk, W. Van Drunen, J. R. Freeland \& M. E. Dorken. 2012. No evidence for niche segregation in a North American cattail (Typha) species complex. Ecol. Evol. 2: 952-961.

McKnight, D. T., A. C. Jones \& D. B. Ligon. 2015. The omnivorous diet of the western chicken turtle (Deirochelys reticularia miaria). Copeia 103: 322-328.

McLaughlin, W. T. 1932. Atlantic coastal plain plants in the sand barrens of northwestern Wisconsin. Ecol. Monogr. 2: 335-383.

McLaughlin, S. P., E. L. Geiger \& J. E. Bowers. 2001. Flora of the Appleton-Whittell Research Ranch, northeastern Santa Cruz County, Arizona. J. Arizona-Nevada Acad. Sci. 33: 113-131.

McLay, C. L. 1974. The distribution of duckweed Lemna perpusilla in a small southern California lake: an experimental approach. Ecology 55: 262-276.

McLay, C. L. 1976. The effect of $\mathrm{pH}$ on the population growth of three species of duckweed: Spirodela oligorrhiza, Lemna minor and Wolffia arrhiza. Freshw. Biol. 6: 125-136.

McMahan, C. A. 1970. Food habits of ducks wintering on Laguna Madre, Texas. J. Wildl. Manag. 34: 946-949.

McMaster, R. T. 2001. The population biology of Liparis loeselii, Loesel's twayblade, in a Massachusetts wetland. Northeast. Nat. 8: 163-179.

McMillan, J. F. 1953. Some feeding habits of moose in Yellowstone Park. Ecology 34: 102-110.

McMillan, C. 1956. The edaphic restriction of Cupressus and Pinus in the coast ranges of central California. Ecol. Monogr. 26: 177-212.

McMillan, C. 1959. Salt tolerance within a Typha population. Am. J. Bot. 46: 521-526.

McMillan, C. 1976. Experimental studies on flowering and reproduction in seagrasses. Aquat. Bot. 2: 87-92.

McMillan, C. 1979. Differentiation in response to chilling temperatures among populations of three marine spermatophytes, Thalassia testudinum, Syringodium filiforme and Halodule wrightii. Am. J. Bot. 66: 810-819.

McMillan, C. 1980. Reproductive physiology in the seagrass, Syringodium filiforme, from the Gulf of Mexico and the Caribbean. Am. J. Bot. 67: 104-110.

McMillan, C. 1981. Seed reserves and seed germination for two seagrasses, Halodule wrightii and Syringodium filiforme, from the western Atlantic. Aquat. Bot. 11: 279-296.

McMillan, C. 1982. Reproductive physiology of tropical seagrasses. Aquat. Bot. 14: 245-258.

McMillan, C. 1983. Seed germination in Halodule wrightii and Syringodium filiforme from Texas and the U.S. Virgin Islands. Aquat. Bot. 15: 217-220.

McMillan, C. 1984. The distribution of tropical seagrasses with relation to their tolerance of high temperatures. Aquat. Bot. 19: 369-379.

McMillan, C. 1985. The seed reserve for Halodule wrightii, Syringodium filiforme and Ruppia maritima in Laguna Madre, Texas. Contrib. Mar. Sci. 28: 141-149.

McMillan, C. 1987. Seed germination and seedling morphology of the seagrass, Halophila engelmannii (Hydrocharitaceae). Aquat. Bot. 28: 179-188.

McMillan, C. 1988. The seed reserve of Halophila engelmannii (Hydrocharitaceae) in Redfish Bay, Texas. Aquat. Bot. 30: 253-259.

McMillan, C. 1988a. The seed reserve of Halophila decipiens Ostenfeld (Hydrocharitaceae) in Panama. Aquat. Bot. 31: 177-182.

McMillan, C. 1988b. Seed germination and seedling development of Halophila decipiens Ostenfeld (Hydrocharitaceae) from Panama. Aquat. Bot. 31: 169-176. 
McMillan, C. 1989. Timing of anthesis for staminate flowers on Halophila engelmannii Aschers. from Texas and Halophila decipiens Ostenfeld from Panama. Aquat. Bot. 33: 141-147.

McMillan, C. 1990. Testing the influence of night length on the anthesis of staminate flowers of Halophila engelmannii Aschers. (Hydrocharitaceae). Aquat. Bot. 37: 383-385.

McMillan, C. 1991. The longevity of seagrass seeds. Aquat. Bot. 40: 195-198.

McMillan, C. \& R. C. Phillips. 1981. Morphological variation and isozymes of North American Phyllospadix (Potamogetonaceae). Can. J. Bot. 59: 1494-1500.

McMillan, C. \& J. Jewett-Smith. 1988. The sex ratio and fruit production of laboratory-germinated seedlings of Halophila engelmannii Aschers. (Hydrocharitaceae) from Redfish Bay, Texas. Aquat. Bot. 32: 329-339.

McMillan, C., S. C. Williams, L. Escobar \& O. Zapata. 1981. Isozymes, secondary compounds and experimental cultures of Australian seagrasses in Halophila, Halodule, Zostera, Amphibolis and Posidonia. Aust. J. Bot. 29: 247-260.

McMillan, P. D. \& R. D. Porcher. 2005. Noteworthy collections: South Carolina. Castanea 70: 237-240.

McMillan, P. D., R. K. Peet, R. D. Porcher \& B. A. Sorrie. 2002. Noteworthy botanical collections from the fire-maintained pineland and wetland communities of the coastal plain of the Carolinas and Georgia. Castanea 67: 61-83.

McMullan, J. J., R. J. Gornall \& C. D. Preston. 2011. ITS rDNA polymorphism among species and hybrids of Potamogeton subgenus Coleogeton (Potamogetonaceae) in north-western Europe. New J. Bot. 1: 111-115.

McNair, D. B. \& C. Cramer-Burke. 2006. Breeding ecology of American and Caribbean coots at Southgate Pond, St. Croix: use of woody vegetation. Wilson J. Ornithol. 118: 208-217.

McNair, D. M. \& M. H. Alford. 2014. Blyxa aubertii (Hydrocharitaceae) new to Mississippi, USA. J. Bot. Res. Inst. Texas 8: 267-270.

McNamara, J. P., D. I. Siegel, P. H. Glaser \& R. M. Beck. 1992. Hydrogeologic controls on peatland development in the Malloryville Wetland, New York (USA). J. Hydrol. 140: 279-296.

McNaughton, S. J. 1966. Ecotype function in the Typha communitytype. Ecol. Monogr. 36: 297-325.

McNaughton, S. J. 1968. Autotoxic feedback in relatin to germination and seedling growth in Typha latifolia. Ecology 49: 367-369.

McNaughton, S. J. \& L. W. Fullem. 1970. Photosynthesis and photorespiration in Typha latifolia. Plant Physiol. 45: 703-707.

McNeal, D. W. 1995. Report on Allium. Columbia Basin scientific assessment project. Unpublished Report. Available online: https://www.google.com/url?sa=t\&rct=j\&q=\&esrc=s\&so urce $=$ web \&cd $=2 \& v e d=2$ ahUKEwjG_ZWY8_rgAhXFme AKHQFBA6IQFjABegQICRAC\&url=https\%3A\%2F\%2F www.fs.fed.us $\% 2$ Fr6\% 2Ficbemp $\% 2$ Fscience $\% 2$ Fmcneal. pdf\&usg=AOvVaw0f_MCBdjQSCzdgMlEUZOHi [accessed 11 February, 2019], $21 \mathrm{pp}$.

McNeal, D. W. 2012a. Alliaceae. Onion or garlic family. Pp. 1395-1398 In: B. G. Baldwin, D. H. Goldman, D. J. Keil, R. Patterson, T. J. Rosatti \& D. H. Wilken (eds.), The Jepson Manual, 2nd ed. University of California Press, Berkeley, CA.

McNeal, D. W. 2012b. Melanthiaceae. False hellebore family. Pp. 1289-1297 In: B. G. Baldwin, D. H. Goldman, D. J. Keil, R. Patterson, T. J. Rosatti \& D. H. Wilken (eds.), The Jepson Manual, 2nd ed. University of California Press, Berkeley, CA.
McNeal, Jr., D. W. \& T. D. Jacobsen. 2002. Allium Linnaeus. Pp. $224-$ 276 In: Flora North America Editorial Committee (eds.), Flora of North America North of Mexico, Vol. 26: Magnoliophyta: Liliidae: Liliales and Orchidales. Oxford University Press, New York, NY.

McNeal, Jr., D. W. \& A. D. Shaw. 2002. Veratrum Linnaeus. Pp. 7276 In: Flora North America Editorial Committee (eds.), Flora of North America North of Mexico, Vol. 26: Magnoliophyta: Liliidae: Liliales and Orchidales. Oxford University Press, New York, NY.

McNeal, D. W. \& W. B. Zomlefer. 2010. Documentation of the chromosome number for the California endemic, Toxicoscordion exaltatum (Liliales: Melanthiaceae). Madroño 57: 180-184.

McNeal, D. W. \& W. B. Zomlefer. 2012. Toxicoscordion. Death camus. Pp. 1395-1396 In: B. G. Baldwin, D. H. Goldman, D. J. Keil, R. Patterson, T. J. Rosatti \& D. H. Wilken (eds.), The Jepson Manual, 2nd ed. University of California Press, Berkeley, CA.

McNulty, A. K., W. R. Cummins \& A. Pellizzari. 1988. A field survey of respiration rates in leaves of arctic plants. Arctic 41: 1-5.

McPherson, J. E. \& S. M. Paskewitz. 1984. Laboratory rearing of Amaurochrous cinctipes (Hemiptera: Pentatomidae: Podopinae) with descriptions of immature stages. J. New York Entomol. Soc. 92: 61-68.

McShane, D. \& K. Mehigan. 2012. Aquatic Macrophyte Survey of Otsego Lake. SUNY Oneonta Biological Field Station, Cooperstown, NY. 23 pp.

Meanley, B. 1953. Nesting of the King Rail in the Arkansas rice fields. Auk 70: 261-269.

Meanley, B. \& J. S. Webb. 1961. Distribution of winter redwinged blackbird populations on the Atlantic Coast. Bird-Banding 32: 94-97.

Meehan, T. 1901. Smilax walteri. Meehan's Monthly 12(12): 181-182.

Meeker, J. E., D. A. Wilcox \& A. G. Harris. 2018. Changes in wetland vegetation in regulated lakes in northern Minnesota, USA ten years after a new regulation plan was implemented. Wetlands. doi: 10.1007/s13157-017-0986-1.

Mead, B. R. 1995. Plant biomass in the Tanana River basin, Alaska. Research Paper PNW-RP-477. U.S. Department of Agriculture, Forest Service, Pacific Northwest Research Station, Portland, OR. 78 pp.

Meerow, A. W. 2004. Palm seed germination. Document BUL274. IFAS Extension, University of Florida, Gainesville, FL. 11 pp.

Meerow, A. W. 2012. Taxonomy and phylogeny. Pp. 17-56 In: R. Kamenetsky \& H. Okubo (eds.), Ornamental Geophytes: Basic Science to Sustainable Production. CRC Press, Boca Raton, FL.

Meerow, A. W. \& D. A. Snijman. 2001. Phylogeny of Amaryllidaceae tribe Amaryllideae based on nrDNA ITS sequences and morphology. Am. J. Bot. 88: 2321-2330.

Meerow, A. W. \& D. A. Snijman. 2006. The never-ending story: multigene approaches to the phylogeny of Amaryllidaceae. Aliso 22: $355-366$.

Meerow, A. W., C. L. Guy, Q.-B. Li \& S.-L. Yang. 2000. Phylogeny of the American Amaryllidaceae based on nrDNA ITS sequences. Syst. Bot. 25: 708-726.

Meerow, A. W., H. M. Donselman \& T. K. Broschat. 2001. Native Trees for South Florida. Florida Cooperative Extension Service, Institute of Food and Agricultural Sciences, University of Florida, Gainesville, FL. 17 pp.

Meerow, A. W., C. L. Guy, Q.-B. Li \& J. R. Clayton. 2002. Phylogeny of the tribe Hymenocallideae (Amaryllidaceae) based on morphology and molecular characters. Ann. Missouri Bot. Gard. 89: $400-413$. 
Meerow, A. W., D. J. Lehmiller \& J. R. Clayton. 2003. Phylogeny and biogeography of Crinum L. (Amaryllidaceae) inferred from nuclear and limited plastid non-coding DNA sequences. Bot. J. Linn. Soc. 141: 349-363.

Meerow, A. W., J. L. Reveal, D. A. Snijman \& J. H. Dutilh. 2007a. Proposal to conserve the name Amaryllidaceae against Alliaceae, a "superconservation" proposal. Taxon 56: 1299-1300.

Meerow, A. W., M. Gideon, D. N. Kuhn, J. C. Motamayor \& K. Nakamura. 2007b. Genetic structure and gene flow among south Florida populations of Iris hexagona Walt. (Iridaceae) assessed with 19 microsatellite DNA loci. Int. J. Plant Sci. 168: 1291-1309.

Meerow, A. W., M. Gideon, D. N. Kuhn, S. Mopper \& K. Nakamura. 2011. The genetic mosaic of Iris series Hexagonae in Florida: inferences on the Holocene history of the Louisiana irises and anthropogenic effects on their distribution. Int. J. Plant Sci. 172: $1026-1052$.

Meerow, A. W., M. Gideon \& K. Nakamura. 2017. Hybridization between ecotypes in a phenotypically and ecologically heterogeneous population of Iris savannarum (Iridaceae) in Florida. Plant Species Biol. 32: 309-322.

Megateli, S., S. Semsari \& M. Couderchet. 2009. Toxicity and removal of heavy metals (cadmium, copper, and zinc) by Lemna gibba. Ecotoxicol. Environ. Saf. 72: 1774-1780.

Megonigal, J. P. \& W. H. Schlesinger. 1997. Enhanced $\mathrm{CH}_{4}$ emission from a wetland soil exposed to elevated $\mathrm{CO}_{2}$. Biogeochemistry 37: 77-88.

Megonigal, J. P., C. D. Vann \& A. A. Wolf. 2005. Flooding constraints on tree (Taxodium distichum) and herb growth responses to elevated $\mathrm{CO}_{2}$. Wetlands 25: 430-438.

Mehringer, Jr., P. J., S. F. Arno \& K. L. Petersen. 1977. Postglacial history of lost trail pass bog, Bitterroot Mountains, Montana. Arct. Alp. Res. 9: 345-368.

Meinshausen, K. F. 1895. Das genus Sparganium L. Systematische Beschreibung der Arten nebst Darstellung ihrer Verbreitung auf Grundlage ihres Vorkommens im Gouv. St. Petersburg. Bull. Acad. Imper. Sci. St. Petersburg 36: 21-41.

Mejbel, H. S. \& A. M. Simons. 2018. Aberrant clones: birth order generates life history diversity in Greater Duckweed, Spirodela polyrhiza. Ecol. Evol. 8: 2021-2031.

Mellinger, M. B. 1966. Some plant associations of Pinckneya pubens. Castanea 31: 310-313.

Melnyk, J. P., S. Wang \& M. F. Marcone. 2010. Chemical and biological properties of the world's most expensive spice: Saffron. Food Res. Int. 43: 1981-1989.

Mendall, H. L. 1949. Food habits in relation to black duck management in Maine. J. Wildl. Manag. 13: 64-101.

Mendall, H. L. \& J. S. Gashwiler. 1940. Water bulrush as a food of waterfowl. Auk 57: 245-246.

Menéndez, M. 2002. Net production of Ruppia cirrhosa in the Ebro Delta. Aquat. Bot. 73: 107-113.

Menéndez, M. \& F. A. Comín. 1989. Seasonal patterns of biomass variation of Ruppia cirrhosa (Petagna) Grande and Potamogeton pectinatus L. in a coastal lagoon. Sci. Mar. 53: 633-638.

Meng, Y., A. J. Krzysiak, M. J. Durako, J. I. Kunzelman \& J. L. C. Wright. 2008. Flavones and flavone glycosides from Halophila johnsonii. Phytochemistry 69: 2603-2608.

Merckx, V., P. Schols, H. Maas-van de Kamer, P. Maas, S. Huysmans \& E. Smets. 2006. Phylogeny and evolution of Burmanniaceae (Dioscoreales) based on nuclear and mitochondrial data. Am. J. Bot. 93: 1684-1698.

Merckx, V., L. W. Chatrou, B. Lemaire, M. N. Sainge, S. Huysmans \& E. F. Smets. 2008a. Diversification of myco-heterotrophic angiosperms: evidence from Burmanniaceae. BMC Evol. Biol. 8: 178.
Merckx, V., P. Schols, K. Geuten, S. Huysmans \& E. Smets. 2008b. Phylogenetic relationships in Nartheciaceae (Dioscoreales), with focus on pollen and orbicule morphology. Belg. J. Bot. 141: 64-77.

Merckx, V., M. Stöckel, A. Fleischmann, T. D. Bruns \& G. Gebauer. 2010. ${ }^{15} \mathrm{~N}$ and ${ }^{13} \mathrm{C}$ natural abundance of two mycoheterotrophic and a putative partially mycoheterotrophic species associated with arbuscular mycorrhizal fungi. New Phytol. 188: 590-596.

Meriläinen, J. 1968. Najas minor All. in North America. Rhodora 70: $161-175$.

Merrill, A. G., T. L. Benning \& J. A. Fites. 2006. Factors controlling structural and floristic variation of riparian zones in a mountainous landscape of the western United States. West. N. Am. Nat. 66: 137-155.

Merz, J. E., J. R. Smith, M. L. Workman, J. D. Setka \& B. Mulchaey. 2008. Aquatic macrophyte encroachment in Chinook salmon spawning beds: lessons learned from gravel enhancement monitoring in the Lower Mokelumne River, California. North Am. J. Fish. Manag. 28: 1568-1577.

Messner, T. C. \& B. Schindler. 2010. Plant processing strategies and their affect [sic!] upon starch grain survival when rendering Peltandra virginica (L.) Kunth, Araceae edible. J. Archaeol. Sci. 37: 328-336.

Meyer, M. D., C. A. Davis \& D. Dvorett. 2015. Response of wetland invertebrate communities to local and landscape factors in north central Oklahoma. Wetlands 35: 533-546.

Miano, A. J., J. P. Leblanc \& J. M. Farrell. 2019. Laboratory evaluation of spawning substrate type on potential egg predation by round goby (Neogobius melanostomus). J. Great Lakes Res. 45: 390-393.

Michael, T. P., D. Bryant, R. Gutierrez, N. Borisjuk, P. Chu, H. Zhang, J. Xia, J. Zhou, H. Peng, M. E. Baidouri, B. ten Hallers, A. R. Hastie, T. Liang, K. Acosta, S. Gilbert, C. McEntee, S. A. Jackson, T. C. Mockler, W. Zhang \& E. Lam. 2017. Comprehensive definition of genome features in Spirodela polyrhiza by high-depth physical mapping and short-read DNA sequencing strategies. Plant J. 89: 617-635.

Michel, L. U. C., J. G. Baldwin \& H. Arnold. 1986. Pratylenchus morettoi n. sp. (Nemata: Pratylenchidae). Rev. Nematol. 9: 119-123.

Michel, A., R. S. Arias, B. E. Scheffler, S. O. Duke, M. Netherland \& F. E. Dayan. 2004. Somatic mutation-mediated evolution of herbicide resistance in the nonindigenous invasive plant hydrilla (Hydrilla verticillata). Mol. Ecol. 13: 3229-3237.

Middleton, B. A. 1989. Succession and goose herbivory in monsoonal wetlands of the Keoladeo National Park, Bharatpur, India. Ph.D. dissertation. Iowa State University, Ames, IA. 144 pp.

Middleton, B. A. 1995. Seed banks and species richness potential of coal slurry ponds reclaimed as wetlands. Restor. Ecol. 3: 311-318.

Middleton, B. A. 2009. Regeneration potential of Taxodium distichum swamps and climate change. Plant Ecol. 202: 257-274.

Miduno, T. 1940. Chromosomenstudien an Orchidazeen. Cytologia 11: $179-185$.

Mielecki, M. \& E. Pieczynska. 2005. The influence of fragmentation on the growth of Elodea canadensis Michx. in different light conditions. Polish J. Ecol. 53: 155-164.

Mifsud, S. 2010. First occurences of Lemna minuta Kunth (fam. Lemnaceae) in the Maltese islands. Cent. Mediterr. Nat. 5: 1-4.

Miguel, V., J. A. Otero, B. Barrera, I. Rodeiro, J. G. Prieto, G. Merino \& A. I. Álvarez. 2015. ABCG2/BCRP interaction with the sea grass Thalassia testudinum. Drug Metab. Pers. Ther. 30: 251-256. 
Miki, S. 1934. On fresh water plants new to Japan. Jap. J. Pharmacogn. 48: 326-337.

Miller, M. R. 1987. Fall and winter foods of northern pintails in the Sacramento Valley, California. J. Wildl. Manag. 51: 405-414.

Miller, T. G. \& H. M. Hoven. 2007. Ecological and Beneficial Use Assessment of Farmington Bay Wetlands: Assessment and Site-Specific Nutrient Criteria. U.S. Environmental Protection Agency (Region VIII), Denver, CO. 32 pp (plus appendices).

Miller, J. D., W. T. Haller \& M. S. Glenn. 1993. Turion production by dioecious hydrilla in north Florida. J. Aquat. Plant Manag. 31: 101-105.

Miller, M. M., S. W. Phipps, C. S. Major \& K. M. Major. 2011. Effects of environmental variation and non-point source (NPS) nutrient pollution on aquatic plant communities in Weeks Bay National Estuarine Research Reserve (WBNERR), AL. Estuaries Coast. 34: 1182-1193.

Mills, J. E., J. A. Reinartz, G. A. Meyer \& E. B. Young. 2009. Exotic shrub invasion in an undisturbed wetland has little communitylevel effect over a 15-year period. Biol. Invasions 11: 1803-1820.

Millsap, B. A. 2009. Endangered and threatened wildlife and plants; 5-year reviews of 23 southwestern species. Fed. Reg. 74: 6917-6919.

Millspaugh, C. F. 1887. American Medicinal Plants: An Illustrated and Descriptive Guide to the American Plants Used as Homopathic Remedies: Their History, Preparation, Chemistry and Physiological Effects. Boericke \& Tafel, New York, NY. [irregular pagination].

Minayeva, T. Y. 2010. The peculiarities of seed reproduction biology of some monocotyledonous peatland plant species. Bot. Zhurn. 95: 482-495.

Minciullo, P. L., E. Fazio, M. Patafi \& S. Gangemi. 2007. Allergic contact dermatitis due to Zantedeschia aethiopica. Cont. Dermat. 56: 46-46.

Minckley, W. L. \& D. R. Tindall. 1963. Ecology of Batrachospermum sp. (Rhodophyta) in Doe Run, Meade County, Kentucky. Bull. Torrey Bot. Club 90: 391-400.

Ming, W., S. Zhe \& L. Qinzhong. 1994. Study of Hydrilla verticillata (L.F.) Royle as protein resource. 1. Analysis of the biological characters and nutrition elements of Hydrilla verticilata (L. F.) Royle. J. Hunan Agric. College 20: 457-463.

Minno, M. C. \& C. Slaughter. 2003. New record of the endangered lakeside sunflower, Helianthus carnosus (Asteraceae), from Putnam County, Florida. Florida Sci. 66: 291-293.

Miretzky, P., A. Saralegui \& A. F. Cirelli. 2004. Aquatic macrophytes potential for the simultaneous removal of heavy metals (Buenos Aires, Argentina). Chemosphere 57: 997-1005.

Mishra, V. K. \& B. D. Tripathi. 2009. Accumulation of chromium and zinc from aqueous solutions using water hyacinth (Eichhornia crassipes). J. Hazard. Mater. 164: 1059-1063.

Misnikov, O. S. 2006. Physicochemical principles of hydrophobization of mineral binders by additives produced from peat raw material. Theor. Found. Chem. Eng. 40: 423-430.

Misnikov, O. 2018. The hydrophobic modification of gypsum binder by peat products: physico-chemical and technological basis. Mires Peat 21: 1-14.

Misra, M. P. 1974. Cytological studies in Ottelia alismoides Pers. Cytologia 39: 419-427.

Mitchell, E. 1926. Germination of seeds of plants native to Dutchess County, New York. Bot. Gaz. 81: 108-112.

Mitchell, D. K. 2011. Wet flatwoods restoration after decades of fire suppresion [sic!]. M.S. thesis. University of Florida, Gainesville, FL. 77 pp.

Mitchell, C. C. \& W. A. Niering. 1993. Vegetation change in a topogenic bog following beaver flooding. Bull. Torrey Bot. Club 120: $136-147$.
Mitchell, C. A., T. W. Custer \& P. J. Zwank. 1994. Herbivory on shoalgrass by wintering redheads in Texas. J. Wildl. Manag. 58: $131-141$.

Mitchell, M. E., S. C. Lishawa, P. Geddes, D. J. Larkin, D. Treering \& N. C. Tuchman. 2011. Time-dependent impacts of cattail invasion in a Great Lakes coastal wetland complex. Wetlands 31: 1143-1149.

Mitsch, W. J., D. F. Fink \& L. Zhang. 2004. Net primary productivity of macrophyte communities after eight growing seasons in experimental planted and unplanted marshes. Pp. 43-48 In: W. J. Mitsch, L. Zhang \& C. J. Anderson (eds.), Macrophyte Production. Annual Report 2004. The Olentangy River Wetland Research Park, The Ohio State University, Columbus, $\mathrm{OH}$.

Miyazawa, M., H. Nakahashi, Y. Kashima, R. Motooka, N. Hara, H. Nakagawa, T. Yoshii, A. Usami \& S. Marumoto. 2015. Chemical composition and aroma evaluation of essential oils from skunk cabbage (Symplocarpus foetidus). J. Oleo Sci. 64: 1329-1336.

Mkandawire, M., J. A. Teixeira da Silva \& E. G. Dudel. 2014. The Lemna bioassay: contemporary issues as the most standardized plant bioassay for aquatic ecotoxicology. Crit. Rev. Environ. Sci. Technol. 44: 154-197.

M'Mahon, B. 1804. A Catalogue of American Seeds \&c. Sold by Bernard M'Mahon, Seedsman, Philadelphia. 1804. Bartholomew Graves, Philadelphia, PA. 30 pp.

Mnayer, D., A.-S. Fabiano-Tixier, E. Petitcolas, T. Hamieh, N. Nehme, C. Ferrant, X. Fernandez \& F. Chemat. 2014. Chemical composition, antibacterial and antioxidant activities of six essentials oils from the Alliaceae family. Molecules 19: 20034-20053.

MNFS (National Marine Fisheries Service). 2002. Recovery plan for Johnson's seagrass (Halophila johnsonii). Prepared by the Johnson's Seagrass Recovery Team for the National Marine Fisheries Service, Silver Spring, MD. 134 pp.

Moeller, R. W. 1984. The Ivory Pond mastodon project. N. Am. Archaeol. 5: 1-12.

Moeller, R. E., J. M. Burkholder \& R. G. Wetzel. 1988. Significance of sedimentary phosphorus to a rooted submersed macrophyte (Najas flexilis (Willd.) Rostk. and Schmidt) and its algal epiphytes. Aquat. Bot. 32: 261-281.

Moen, T. 1953. Food habits of the carp in northwest Iowa lakes. Proc. Iowa Acad. Sci. 60: 665-686.

Moffett, Jr., J. M. 2008. Xyris tennesseensis: status survey, habitat restoration/management concerns, and relation to a new xyrid, Xyris spathifolia. Ph.D. dissertation. Auburn University, Auburn, AL. 178 pp.

Moffett, Jr., J. M. \& R. S. Boyd. 2013. Management of a population of the federally endangered Xyris tennesseensis (Tennessee yellow-eyed grass). Castanea 78: 198-212.

Mohagheghzadeh, A., P. Faridi, M. Shams-Ardakani \& Y. Ghasemi. 2006. Medicinal smokes. J. Ethnopharmacol. 108: 161-184.

Mohanty, P., S. Behera, S. S. Swain, D. P. Barik \& S. K. Naik. 2013. Micropropagation of Hedychium coronarium J. Koenig through rhizome bud. Physiol. Mol. Biol. Plant. 19: 605-610.

Mohlenbrock, R. H. 1959a. A floristic study of a southern Illinois swampy area. Ohio J. Sci. 59: 89-100.

Mohlenbrock, R. H. 1959b. Plant communities in Jackson County, Illinois. Bull. Torrey Bot. Club 86: 109-119.

Mohlenbrock, R. H. 1962. On the occurrence of Lilium superbum L. in Illinois. Castanea 27: 173-176.

Mohlenbrock, R. H. 1976. Woody plants of the Ocala National Forest, Florida. Castanea 41: 309-319.

Mohlenbrock, R. H., G. E. Dillard \& T. S. Abney. 1961. A survey of southern Illinois aquatic vascular plants. Ohio J. Sci. 61: 262-273. 
Mohr, C. T. 1901. Plant life of Alabama. Contrib. U.S. Natl. Herb. 6: $1-921$.

Moisan, C. \& S. Pellerin. 2013. Factors associated with the presence of flowering individuals of Arethusa bulbosa (Orchidaceae) in peatlands of southern Quebec. Ecoscience 20: 1-8.

Mokni, R. E. \& M. H. E. Aouni. 2012. Zantedeschia aethiopica (Araceae) a new species naturalized in the Northwest of Tunisia. Fl. Medit. 22: 191-196.

Moldenke, H. N. 1936. The flora of the Watchung Mountains. Part II-the Flora. Torreya 36: 88-93.

Moldenke, H. N. 1957. Additional notes on the Eriocaulaceae. XII. Bull. Jard. Bot. 'Etat. Bruxelles 27: 115-141.

Moldenke, H. N. 1969. Additional notes on the Eriocaulaceae. XXII. Phytologia 18: 344-396.

Moldenke, H. N., G. F. Dillman, F. D. Kern \& F. Place. 1939. Field trips of the club. Torreya 39: 143-151.

Mollik, M. A. H., M. S. Hossan, A. K. Paul, M. Taufiq-Ur-Rahman, R. Jahan \& M. Rahmatullah. 2010. A comparative analysis of medicinal plants used by folk medicinal healers in three districts of Bangladesh and inquiry as to mode of selection of medicinal plants. Ethnobot. Res. Appl. 8: 195-218.

Monda, M. J., J. T. Ratti \& T. R. McCabe. 1994. Reproductive ecology of tundra swans on the Arctic National Wildlife Refuge, Alaska. J. Wildl. Manag. 58: 757-773.

Monk, C. D. \& T. W. Brown. 1965. Ecological consideration of cypress heads in northcentral Florida. Am. Midl. Nat. 74: 126-140.

Monsod, Jr., G. G. 1979. Man and the Water Hyacinth. Vantage Press, New York, NY. 48 pp.

Montz, G. N. 1978. The submerged vegetation of Lake Pontchartrain, Louisiana. Castanea 43: 115-128.

Mony, C., T. J. Koschnick, W. T. Haller \& S. Muller. 2007. Competition between two invasive Hydrocharitaceae (Hydrilla verticillata (L.f.) (Royle) and Egeria densa (Planch)) as influenced by sediment fertility and season. Aquat. Bot. 86: 236-242.

Moodie, G. E. E. 1976. Heat production and pollination in Araceae. Can. J. Bot. 54: 545-546.

Moody, K. 1989. Weeds Reported in Rice in South and Southeast Asia. International Rice Research Institute, Los Baños, Laguna, Philippines. 442 pp.

Moon, B.-C., C.-S. Kim, T.-S. Park, J.-R. Jo, I.-Y. Lee \& J.-E. Park. 2000. Germination and dormancy by different seed types of marsh dayflower (Aneilema keisak Hassk.). Korean J. Weed Sci. 20: 191-196.

Moore, E. 1913. The Potamogetons in relation to pond culture. Bull. U.S. Bur. Fish. 33: 251-291.

Moore, D. L. 2000. The aquatic macrophyte community at Put-inBay, Ohio. Great Lakes Res. Rev. 5: 37-42.

Moore, G. 2004. Field trip reports. J. Torrey Bot. Soc. 131: 403-419.

Moore, K. A., R. J. Orth \& J. F. Nowak. 1993. Environmental regulation of seed germination in Zostera marina L. (eelgrass) in Chesapeake Bay: effects of light, oxygen and sediment burial. Aquat. Bot. 45: 79-91.

Moore, T. R., J. L. Bubier, S. E. Frolking, P. M. Lafleur \& N. T. Roulet. 2002. Plant biomass and production and $\mathrm{CO}_{2}$ exchange in an ombrotrophic bog. J. Ecol. 90: 25-36.

Moore, M. T., H. L. Tyler \& M. A. Locke. 2013. Aqueous pesticide mitigation efficiency of Typha latifolia (L.), Leersia oryzoides (L.) Sw., and Sparganium americanum Nutt. Chemosphere 92: 1307-1313.

Moorehouse, A., A. Mankowski, W. E. McClain \& J. E. Ebinger. 2002. Status of the known populations of the Virginia bunchflower (Melanthium virginicum) in Illinois. Castanea 67: 188-192.

Mopper, S., K. C. Wiens \& G. A. Goranova. 2016. Competition, salinity, and clonal growth in native and introduced irises. Am. J. Bot. 103: 1575-1581.
Moran, R. C. 1981. Prairie fens in northeastern Illinois: floristic composition and disturbance. Pp. 164-168 In: R. L. Stuckey \& K. J. Reese (eds.), The Prairie Peninsula--In the "Shadow" of Transeau: Proceedings of the Sixth North American Prairie Conference. Ohio Biological Survey Biological Notes No. 15. Columbus, $\mathrm{OH}$.

Moran, K. L. \& K. A. Bjorndal. 2005. Simulated green turtle grazing affects structure and productivity of seagrass pastures. Mar. Ecol. Prog. Ser. 305: 235-247.

Moran, P. J. \& C. Yang. 2012. Distribution of wild taro (Colocasia esculenta) in subtropical Texas, growth of young colonies, and tolerance to simulated herbivory. Subtrop. Plant Sci. 64: 18-28.

Moran, E. A., R. R. Briese \& J. F. Couch. 1940. Some new cyanogenetic plants. J. Washington Acad. Sci. 30: 237-239.

Mora-Olivo, A., J. G. Martínez-Ávalos \& E. de la Rosa-Manzano. 2018. Heteranthera peduncularis (Pontederiaceae) en Tamaulipas, México. Phytoneuron 2018-7: 1-4.

Moravcová, L., P. Zákravský \& Z. Hroudová. 2001. Germination and seedling establishment in Alisma gramineum, A. plantagoaquatica and $A$. lanceolatum under different environmental conditions. Folia Geobot. 36: 131-146.

Mörch, O. J. N. 1839. Catalogus plantarum horti botanici Hafniensis. Copenhagen Botanical Garden. Hauniæ [Copenhagen], Denmark. 102 pp.

Morgan, G. R. 1980. The ethnobotany of sweet flag among North American Indians. Bot. Mus. Leafl. 28: 235-246.

Morgan, M. D. 1990. Seed germination characteristics of Iris virginica. Am. Midl. Nat. 124: 209-213.

Morgan, M. D. \& K. R. Philipp. 1986. The effect of agricultural and residential development on aquatic macrophytes in the New Jersey Pine Barrens. Biol. Conserv. 35: 143-158.

Morgan, M. T. \& S. C. H. Barrett. 1988. Historical factors and anisoplethic population structure in tristylous Pontederia cordata: a reassessment. Evolution 42: 496-504.

Morgan, M. T. \& S. C. H. Barrett. 1990. Outcrossing rates and correlated mating within a population of Eichhornia paniculata (Pontederiaceae). Heredity 64: 271-280.

Morgan, E. C. \& W. A. Overholt. 2005. New records of invasive exotic plant species in St. Lucie County, Florida. Castanea 70: 59-62.

Morgan, V. H. \& M. Sytsma. 2009. Introduction to Common Native and Potential Invasive Freshwater Plants in Alaska. Center for Lakes and Reservoirs Publications and Presentations. Paper 26. Portland State University, Portland, OR. 195 pp.

Morgan, P. A. \& M. D. O. Adams. 2017. Tidal marshes in the Saco River Estuary, Maine: a study of plant diversity and possible effects of shoreline development. Rhodora 119: 304-331.

Mori, E. S., C. F. Gouvea, S. M. M. Leite, C. L. Marino, D. Martins \& E. D. Velini. 1999. Genetic characterization of Egeria najas presented in the Jupia lake and its tributaries. Planta Daninha 17: $217-225$.

Mori, E. S., D. Martins, E. D. Velini, C. L. Marino, C. F. Gouvêa, S. M. M. Leite, E. Camacho \& R. P. Guries. 2012. Genetic diversity in Egeria densa and E. najas in Jupiá Reservoir, Brazil. Ci. Invest. Agraria 39: 321-330.

Morinaga, T. 1926. The favorable effect of reduced oxygen supply upon the germination of certain seeds. Am. J. Bot. 13: 159-166.

Morita, T., A. Miyamatsu, M. Fujii, H. Kokubu, M. Abe, A. Kurashima \& M. Maegawa. 2011. Germination in Zostera japonica is determined by cold stratification, tidal elevation and sediment type. Aquat. Bot. 95: 234-241.

Morong, T. 1893. The Naiadaceae of North America. Mem. Torrey Bot. Club 3: 1-65. 
Morong, T. 1894. The Smilaceae of North and Central America. Bull. Torrey Bot. Club 21: 419-443.

Morris, M. W. 1988. Noteworthy vascular plants from Grenada County, Mississippi. Sida 13: 177-186.

Morris, E. C. 2003. How does fertility of the substrate affect intraspecific competition? Evidence and synthesis from self-thinning. Ecol. Res. 18: 287-305.

Morris, M. W. 2012. Stenanthium leimanthoides (Melanthiaceae) and Nestronia umbellula (Santalaceae) in Alabama. Castanea 77: $375-380$.

Morris, M. W. 2013. The genus Platanthera (Orchidaceae) in Mississippi. J. Bot. Res. Inst. Texas 7: 323-339.

Morris, D. M. 2014. Aquatic habitat use by North American moose (Alces alces) and associated richness and biomass of submersed and floating-leaved aquatic vegetation in north-central Minnesota. M.S. thesis. Lakehead University, Thunder Bay, ON. 130 pp.

Morris, P. F. \& W. G. Barker. 1977. Oxygen transport rates through mats of Lemna minor and Wolffia sp. and oxygen tension within and below the mat. Can. J. Bot. 55: 1926-1932.

Morris, C. D., J. L. Callahan \& R. H. Lewis. 1990. Distribution and abundance of larval Coquillettidia perturbans in a Florida freshwater marsh. J. Am. Mosq. Control Assoc. 6: 452-460.

Morrone, J. J. 2013. The subtribes and genera of the tribe Listroderini (Coleoptera, Curculionidae, Cyclominae): phylogenetic analysis with systematic and biogeographical accounts. Zookeys 273: $15-71$.

Morton, J. F. 1963. Principal wild food plants of the United States excluding Alaska and Hawaii. Econ. Bot. 17: 319-330.

Morton, J. F. 1975. Cattails (Typha spp.) - weed problem or potential crop? Econ. Bot. 29: 7-29.

Morton, M. L. 1994. Comparison of reproductive timing to snow conditions in wild onions and White-crowned Sparrows at high altitude. Great Basin Nat. 54: 371-375.

Morton, J. K. \& E. H. Hogg. 1989. Biogeography of island floras in the Great Lakes. II. Plant dispersal. Can. J. Bot. 67: 1803-1820.

Morzaria-Luna, H. N. \& J. B. Zedler. 2007. Does seed availability limit plant establishment during salt marsh restoration? Estuaries Coast. 30: 12-25.

Morzaria-Luna, H. N. \& J. B. Zedler. 2014. Competitive interactions between two salt marsh halophytes across stress gradients. Wetlands 34: 31-42.

Moseley, R. K. 1989. Field investigations of Allium validum (tall swamp onion) and Douglasia idahoensis (Idaho Douglasia), region 1 sensitive species, on the Nez Pierce National Forest. Unpublished Report. Idaho Department of Fish and Game, Conservation Data Center, Boise, ID. 18 pp.

Moscone, E. A. \& L. M. Bernardello. 1985. Chromosome Studies on Hydromystria laevigata (Hydrocharitaceae). Ann. Missouri Bot. Gard. 72: 480-484.

Moss, E. H. 1932. The vegetation of Alberta: IV. The poplar association and related vegetation of central Alberta. J. Ecol. 20: $380-415$.

Mossman, R. E. 2009. Seed dispersal and reproduction patterns among Everglades plants. Ph.D. dissertation. Florida International University, Miami, FL. 125 pp.

Motley, T. J. 1994. The ethnobotany of sweet flag, Acorus calamus (Araceae). Econ. Bot. 48: 397-412.

Motzkin, G. 1994. Calcareous fens of western New England and adjacent New York state. Rhodora 96: 44-68.

Moulton, J. K. \& P. H. Adler. 1995. Revision of the Simulium jenningsi species-group (Diptera: Simuliidae). Trans. Am. Entomol. Soc. 121: 1-57.

Mouissie, A. M., W. Lengkeek \& R. Van Diggelen. 2005. Estimating adhesive seed-dispersal distances: field experiments and correlated random walks. Funct. Ecol. 19: 478-486.
Moulton, O. M. \& S. D. Hacker. 2011. Congeneric variation in surfgrasses and ocean conditions influence macroinvertebrate community structure. Mar. Ecol. Prog. Ser. 433: 53-63.

Mowat, G., P. J. Curtis \& D. J. R. Lafferty. 2017. The influence of sulfur and hair growth on stable isotope diet estimates for grizzly bears. PloS One 12: e0172194.

Moyer, R. D. \& E. L. Bridges. 2015. Xyris chapmanii, an overlooked Xyris species of the New Jersey Pine Barrens. Bartonia 67: 58-74.

Moyer, R. D. \& R. F. C. Naczi. 2017. Rhynchospora leptocarpa, an overlooked species of the New Jersey Pine Barrens. Brittonia 69: $127-132$.

Moyle, J. B. 1944. Wild rice in Minnesota. J. Wildl. Manag. 8: 177-184.

Moyle, J. B. 1945. Some chemical factors influencing the distribution of aquatic plants in Minnesota. Am. Midl. Nat. 34: 402-420.

Moyle, J. B. \& N. Hotchkiss. 1945. The aquatic and marsh vegetation of Minnesota and its value to waterfowl. Technical Bulletin No. 3. Minnesota Dept. of Conservation, St. Paul, MN. 122 pp.

Mrachek, R. J. 1966. Macroscopic invertebrates on the higher aquatic plants at Clear Lake, Iowa. Proc. Iowa Acad. Sci. 73: 168-177.

Mtewa, A. G., S. Deyno, K. Ngwira, F. Lampiao, E. L. Peter, L. Y. Ahovegbe, P. E. Ogwang \& D. C. Sesaazi. 2018. Drug-like properties of anticancer molecules elucidated from Eichhornia crassipes. J. Pharmacogn. Phytochem. 7: 2075-2079.

Muehlstein, L. K., D. T. S. F. Porter \& F. T. Short. 1988. Labyrinthula sp., a marine slime mold producing the symptoms of wasting disease in eelgrass, Zostera marina. Mar. Biol. 99: 465-472.

Muehlstein, L. K., D. Porter \& F. T. Short. 1991. Labyrinthula zosterae sp. nov., the causative agent of wasting disease of eelgrass, Zostera marina. Mycologia 83: 180-191.

Mueller, B. 2004. Quality of Halodule wrightii growing near marinas. Bios 75: 53-57.

Mueller, M. H. \& A. G. van der Valk. 2002. The potential role of ducks in wetland seed dispersal. Wetlands 22: 170-178.

Muenchow, G. 1998. Subandrodioecy and male fitness in Sagittaria lancifolia subsp. lancifolia (Alismataceae). Am. J. Bot. 85: 513-513.

Muenchow, G. \& V. A. Delesalle. 1992. Patterns of weevil herbivory on male, monoecious and female inflorescences of Sagittaria latifolia. Am. Midl. Nat. 127: 355-367.

Muenchow, G. \& V. Delesalle. 1994. Pollinator response to male floral display size in two Sagittaria species (Alismataceae). Am. J. Bot. 81: 568-573.

Muenscher, W. C. 1936a. Storage and Germination of Seeds of Aquatic Plants. Agricultural Experiment Station, Cornell University, Ithaca, NY. 17 pp.

Muenscher, W. C. 1936b. The germination of seeds of Potamogeton. Ann. Bot. (Oxford) 50: 805-821.

Muenscher, W. C. 1943. Potamogeton spirillus may grow as an annual. Rhodora 45: 329-330.

Muenscher, W. C. 1948. Potamogeton latifolius in Texas. Madroño 9: 220-223.

Mühlberg, H. 1982. The Complete Guide to Water Plants. EP Publishing Limited, Leipzig, Germany. 392 pp.

Muhonen, M., J. Showman \& R. Couch. 1983. Nutrient absorption by Spirodela polyrrhiza. J. Aquat. Plant Manag. 21: 107-109.

Mújica, E. B., J. J. Mably, S. M. Skarha, L. L. Corey, L. W. Richardson, M. W. Danaher, E. H. González \& L. W. Zettler. 2018. A comparison of ghost orchid (Dendrophylax lindenii) habitats in Florida and Cuba, with particular reference to seedling recruitment and mycorrhizal fungi. Bot. J. Linn. Soc. 186: 572-586.

Mulder, R. 1999. Wolf Lake area. Wolf Lake Report \#2. A preliminary report on the findings of 3 biological surveys at Nisutlin Lake, Wolf River and Morris Lake. Canadian Parks \& Wilderness Society (Yukon Chapter), Whitehorse, Yukon Territory, CA. $103 \mathrm{pp}$. 
Mulder, C. P. H. \& R. W. Ruess. 1998a. Relationships between size, biomass allocation, reproduction, and survival in Triglochin palustris: implications for the effects of goose herbivory. Can. J. Bot. 76: 2164-2176.

Mulder, C. P. H. \& R. W. Ruess. 1998b. Effects of herbivory on arrowgrass: interactions between geese, neighboring plants, and abiotic factors. Ecol. Monogr. 68: 275-293.

Mulder, C. P. H., R. W. Ruess \& J. S. Sedinger. 1996. Effects of environmental manipulations on Triglochin palustris: implications for the role of goose herbivory in controlling its distribution. J. Ecol. 84: 267-278.

Mulhouse, J. M. 2004. Vegetation change in herbaceous Carolina bays of the upper coastal plain: dynamics during drought. M.S. thesis. University of Georgia, Athens, GA. 108 pp.

Müller-Doblies, D. 1969. Über die Blütenstände und Blüten sowie zue embryologie von Sparganium. Bot. Jahrb. Syst. 89: 359-450.

Müller-Doblies, D. 1970. Über die Verwandtschaft von Typha und Sparganium im Infloreszenz- und Blütenbau. Bot. Jahrb. Syst. 89: 451-462.

Müller-Schwarze, D., H. Brashear, R. Kinnel, K. A. Hintz, A. Lioubomirov \& C. Skibo. 2001. Food processing by animals: do beavers leach tree bark to improve palatability? J. Chem. Ecol. 27: 1011-1028.

Mullins, W. H. \& E. G. Bizeau. 1978. Summer foods of sandhill cranes in Idaho. Auk 95: 175-178.

Munden, C. 2001. Native Orchids of Nova Scotia: A Field Guide. University College of Cape Breton Press, Sydney, NS. 96 pp.

Muñoz Escobar, M. M., M. Voyevoda, C. Fühner \& A. Zehnsdorf. 2011. Potential uses of Elodea nuttallii-harvested biomass. Energy Sustain. Soc. 1: 4. doi: 10.1186/2192-0567-1-4.

Munro, J. A. 1936. Food of the common Mallard in the lower Fraser Valley, British Columbia. Condor 38: 109-111.

Munro, M. C., R. E. Newell \& N. M. Hill. 2014. 4-18 Potamogetonaceae, pondweed family. Pp. 1421-1442 In: M. C. Munro, R. E. Newell \& N. M. Hill (eds.), Nova Scotia Plants: Part 4: Monocots. Nova Scotia Museum, Halifax, NS.

Munz, P. A. 1963. California Mountain Wildflowers. University of California Press, Berkeley, CA. 122 pp.

Munz, P. A. \& I. M. Johnston. 1922. Miscellaneous notes on plants of southern California - I. Bull. Torrey Bot. Club 49: 31-44.

Murdy, W. H. 1966. The systematics of Phacelia maculata and $P$. dubia var. georgiana, both endemic to granite outcrop communities. Am. J. Bot. 53: 1028-1036.

Murphy, M. T. 2009. Getting to the root of the matter: variations in vascular root biomass and production in peatlands and responses to global change. Ph.D. dissertation. McGill University, Montreal, CA. 173 pp.

Murphy, P. B. \& R. S. Boyd. 1999. Population status and habitat characterization of the endangered plant, Sarracenia rubra subspecies alabamensis. Castanea 64: 101-113.

Murphy, L. R., S. T. Kinsey \& M. J. Durako. 2003. Physiological effects of short-term salinity changes on Ruppia maritima. Aquat. Bot. 75: 293-309.

Murray, M. 2000. Wetland plant associations of the western hemlock zone in the central coastal and Cascade Mountains. Interim Report. Oregon Natural Heritage Program, Portland, OR. 83 pp.

Murrell, W. 1901. Lachnanthes. Brit. Medical J. 2(2124): 747.

Musselman, L. J. 1972. Root parasitism of Macranthera flammea and Tomanthera auriculata (Scrophulariaceae). J. Elisha Mitchell Sci. Soc. 88: 58-60.

Musselman, L. J., D. A. Knepper, R. D. Bray, C. A. Caplen \& C. Ballou. 1995. A new Isoetes hybrid from Virginia. Castanea 60: $245-254$.
Musselman, L. J., R. D. Bray \& D. A. Knepper. 1996. Isoetes $\times$ bruntonii (Isoetes engelmannii $\times$ I. hyemalis), a new hybrid quillwort from Virginia. Am. Fern J. 86: 8-15.

Musselman, L. J., W. C. Taylor \& R. D. Bray. 2001. Isoetes mattaponica (Isoetaceae), a new diploid quillwort from freshwater tidal marshes of Virginia. Novon 11: 200-204.

Myers, F. J. 1942. The rotatorian fauna of the Pocono Plateau and environs. Proc. Acad. Nat. Sci. Philadelphia 94: 251-285.

Nachtigall, W. \& A. Wisser. 2015. Procedures and processes. Pp. 185-219 In: Bionics by Examples: 250 Scenarios from Classical to Modern Times. Springer Academic Publishing, Dordrecht, Switzerland.

Nachtrieb, J. G., M. J. Grodowitz \& R. M. Smart. 2011. Impact of invertebrates on three aquatic macrophytes: American pondweed, Illinois pondweed, and Mexican water lily. Nordic J. Bot. 11: 179-203.

Nahrsted, A., W. Hösel \& A. Walther. 1979. Characterization of cyanogenic glucosides and $\beta$-glucosidases in Triglochin maritima seedlings. Phytochemistry 18: 1137-1141.

Naidoo, G. 1994. Growth, water and ion relationships in the coastal halophytes Triglochin bulbosa and T. striata. Environ. Exp. Bot. 34: 419-426.

Naidoo, G. \& K. Naicker. 1992. Seed germination in the coastal halophytes Triglochin bulbosa and Triglochin striata. Aquat. Bot. 42: $217-229$.

Nakamura, G. \& J. K. Nelson. 2001. Illustrated Field Guide to Selected Rare Plants of Northern California. Publication 3395. University of California Agriculture and Natural Resources, Oakland, CA. 370 pp.

Nakamura, S., Y. Okazaki, K. Ninomiya, T. Morikawa, H. Matsuda \& M. Yoshikawa. 2008. Medicinal flowers. XXIV. Chemical structures and hepatoprotective effects of constituents from flowers of Hedychium coronarium. Chem. Pharmaceut. Bull. 56: 1704-1709.

Namestnik, S. A., J. R. Thomas \& B. S. Slaughter. 2012. Two recent plant discoveries in Missouri: Cladium mariscus subsp. jamaicense (Cyperaceae) and Utricularia minor (Lentibulariaceae). Phytoneuron 92: 1-6.

NAOCC. 2019. North American Orchid Conservation Center. Go orchids. Available online: https://goorchids.northamericanorchidcenter.org/ [accessed 26 February, 2019].

Nardi, K. de O., A. Oriani \& V. L. Scatena. 2016. Seed micromorphology and its taxonomic significance to Xyris (Xyridaceae, Poales). Brazilian J. Bot. 39: 721-727.

Nash, G. V. 1895. Notes on some Florida plants. Bull. Torrey Bot. Club 22: 141-161.

Nauheimer, L., D. Metzler \& S. S. Renner. 2012. Global history of the ancient monocot family Araceae inferred with models accounting for past continental positions and previous ranges based on fossils. New Phytol. 195: 938-950.

Nault, M. E. \& A. Mikulyuk. 2009. European Frog-bit (Hydrocharis morsus-ranae): a technical review of distribution, ecology, impacts, and management. Bureau of Science Services, PUB-SS-1048 2009. Wisconsin Department of Natural Resources, Madison, WI. 13 pp.

Nava, H. S., M. Á. F. Casado \& F. J. S. Pérez. 2000. Lilaea scilloides (Poir.) Hauman (Lilaeaceae), en Asturias. Ann. Jard. Bot. Madrid 58: 191.

Near, K. A. \& R. O. Belcher. 1974. New localities for Najas minor and N. marina in southeastern Michigan. Michigan Bot. 13: $181-185$.

Nečajeva, J. \& G. Ievinsh. 2007. Interacting influence of cold stratification treatment and osmotic potential on seed germination of Triglochin maritima L. Biology 723: 115-122. 
Neck, R. W. \& H. L. Schramm. 1992. Freshwater molluscs of selected playa lakes of the Southern High Plains of Texas. Southwest. Nat. 37: 205-209.

Nedeau, E. J., R. W. Merritt \& M. G. Kaufman. 2003. The effect of an industrial effluent on an urban stream benthic community: water quality vs. habitat quality. Environ. Pollut. 123: 1-13.

Needham, J. G. 1900. The fruiting of the blue flag (Iris versicolor L.). Am. Nat. 34: 361-386.

Neil, K. 1977. An annotated list of the macrolepidoptera of Sable Island. Proc. Nova Scotia Inst. Sci. 28: 41-46.

Neinhuis, C. \& W. Barthlott. 1997. Characterization and distribution of water-repellent, self-cleaning plant surfaces. Ann. Bot. 79: 667-677.

Nejrup, L. B. \& M. F. Pedersen. 2008. Effects of salinity and water temperature on the ecological performance of Zostera marina. Aquat. Bot. 88: 239-246.

Nekola, J. C. 2004. Vascular plant compositional gradients within and between Iowa fens. J. Veg. Sci. 15: 771-780.

Nekola, J. C. \& T. G. Lammers. 1989. Vascular flora of BraytonHorsley Prairie: a remnant prairie and spring fen complex in eastern Iowa. Castanea 54: 238-254.

Nekrasova, G. F., D. A. Ronzhina, M. G. Maleva \& V. I. P'yankov. 2003. Photosynthetic metabolism and activity of carboxylating enzymes in emergent, floating, and submersed leaves of hydrophytes. Russ. J. Plant Physiol. 50: 57-67.

Nelsen, Jr., J. E. \& R. N. Ginsburg. 1986. Calcium carbonate production by epibionts on Thalassia in Florida Bay. J. Sediment. Petrol. 56: 622-628.

Nelson, J. B. 1986. The Natural Communities of South Carolina. Initial Classification and Description. South Carolina Wildlife \& Marine Resources Department, Charleston, SC. 64 pp.

Nepal, S. K. \& P. Way. 2007. Comparison of vegetation conditions along two backcountry trails in Mount Robson Provincial Park, British Columbia (Canada). J. Environ. Manage. 82: 240-249.

Nesom, G. L. 2009. Assessment of invasiveness and ecological impact in non-native plants of Texas. J. Bot. Res. Inst. Texas 3: 971-991.

Ness, R. W., S. W. Graham \& S. C. H. Barrett. 2011. Reconciling gene and genome duplication events: using multiple nuclear gene families to infer the phylogeny of the aquatic plant family Pontederiaceae. Mol. Biol. Evol. 28: 3009-3018.

Netherland, M. D. 1997. Turion ecology of hydrilla. J. Aquat. Plant Manag. 35: 1-10.

Neuenschwander, P., M. H. Julien, T. D. Center \& M. P. Hill. 2009. Pistia stratiotes L. (Araceae). Pp. 332-352 In: R. Muniappan, G. V. Reddy \& A. Raman (eds.), Biological Control of Tropical Weeds Using Arthropods. Cambridge University Press, NY.

Newberry, G. 1991. Factors affecting the survival of the rare plant, Sagittaria fasciculata EO Beal (Alismataceae). Castanea 56: 59-64.

Newmaster, S. G., A. G. Harris \& L. J. Kershaw. 1997. Wetland Plants of Ontario. Lone Pine Publishing, Redmond, WA. 240 pp.

Newton, R. E. 2008. A floristic inventory of selected Bureau of Land Management wetlands in Wyoming. M.S. thesis. University of Wyoming, Laramie, WY. 93 pp.

Newton, R. J., D. R. Shelton, S. Disharoon \& J. E. Duffey. 1978. Turion formation and germination in Spirodela polyrhiza. Am. J. Bot. 65: 421-428.

Ngai, J. T. \& R. L. Jefferies. 2004. Nutrient limitation of plant growth and forage quality in Arctic coastal marshes. J. Ecol. 92: $1001-1010$.

Ngamau, K. 2001. Development of an in vitro culture procedure using seeds from Zantedeschia aethiopica 'Green Goddess' as explants. Gartenbauwissenschaft 66: 133-139.
Ngamau, K. 2006. Selection for early flowering, temperature and salt tolerance of Zantedeschia aethiopica 'Green Goddess'. Acta Hort. 766: 155-162.

Nguyen, N. H., H. E. Driscoll \& C. D. Specht. 2008. A molecular phylogeny of the wild onions (Allium; Alliaceae) with a focus on the western North American center of diversity. Mol. Phylogenet. Evol. 47: 1157-1172.

Nguyen, X.-V., S. Höfler, Y. Glasenapp, T. Thangaradjou, C. Lucas \& J. Papenbrock. 2015. New insights into DNA barcoding of seagrasses. Syst. Biodivers. 13: 496-508.

Nichols, G. E. 1919. Lophiola aurea in Nova Scotia. Rhodora 21: 68.

Nichols, G. E. 1920. The vegetation of Connecticut. VII. The associations of depositing areas along the seacoast. Bull. Torrey Bot. Club 47: 511-548.

Nichols, G. E. 1933. Notes on Michigan bryophytes. II. Bryologist 36: 69-78.

Nichols, G. E. 1934. The influence of exposure to winter temperatures upon seed germination in various native American plants. Ecology 15: 364-373.

Nichols, S. A. 1975. The impact of overwinter drawdown on the aquatic vegetation of the Chippewa Flowage, Wisconsin. Trans. Wisconsin Acad. Sci. 63: 176-186.

Nichols, S. A. 1984. Macrophyte community dynamics in a dredged Wisconsin lake. J. Am. Water Res. Assoc. 20: 573-576.

Nichols, S. A. 1988. Vegetation of Wisconsin's benchmark lakes. Trans. Wisconsin Acad. Sci. 76: 1-15.

Nichols, S. A. 1990. Interspecific association of some Wisconsin lake plants. Trans. Wisconsin Acad. Sci. 78: 111-128.

Nichols, S. A. 1999. Distribution and habitat descriptions of Wisconsin lake plants. Bulletin 96. Wisconsin Geological \& Natural History Survey, Madison, WI. 268 pp.

Nichols, S. A. \& B. H. Shaw. 1986. Ecological life histories of the three aquatic nuisance plants, Myriophyllum spicatum, Potamogeton crispus and Elodea canadensis. Hydrobiologia 131: 3-21.

Nichols, S. A. \& L. A. J. Buchan. 1997. Use of native macrophytes as indicators of suitable Eurasian watermilfoil habitat in Wisconsin lakes. J. Aquat. Plant Manag. 35: 21-24.

Nichols, S., S. Weber \& B. Shaw. 2000. A proposed aquatic plant community biotic index for Wisconsin lakes. Environ. Manage. 26: 491-502.

Nicolson, D. H. 1984. Suprageneric names attributable to Araceae. Taxon 33: 680-690.

Nicholson, A. \& P. A. Keddy. 1983. The depth profile of a shoreline seed bank in Matchedash Lake, Ontario. Can. J. Bot. 61: 3293-3296.

Nicholson, B. J. \& D. H. Vitt. 1994. Wetland development at Elk Island National Park, Alberta, Canada. J. Paleolimnol. 12: 19-34.

Nico, L. G. \& A. M. Muench. 2004. Nests and nest habitats of the invasive catfish Hoplosternum littorale in lake Tohopekaliga, Florida: a novel association with non-native Hydrilla verticillata. Southeast. Nat. 3: 451-467.

Nie, Z.-L., H. Sun, H. Li \& J. Wen. 2006. Intercontinental biogeography of subfamily Orontioideae (Symplocarpus, Lysichiton, and Orontium) of Araceae in eastern Asia and North America. Mol. Phylogenet. Evol. 40: 155-165.

Nielsen, J. S. \& B. L. Møller. 1999. Biosynthesis of cyanogenic glucosides in Triglochin maritima and the involvement of cytochrome P450 enzymes. Arch. Biochem. Biophys. 368: 121-130.

Nielsen, J. S. \& B. L. Møller. 2000. Cloning and expression of cytochrome P450 enzymes catalyzing the conversion of tyrosine to p-hydroxyphenylacetaldoxime in the biosynthesis of cyanogenic glucosides in Triglochin maritima. Plant Physiol. 122: 1311-1322. 
Nielson, P. 2016. Presence and habitat requirements of secretive marshbirds in the Washington, DC metropolitan area. Ph.D. dissertation. University of Maryland, College Park, MD. $147 \mathrm{pp}$.

Nienaber, M. A. 2000. Scheuchzeriaceae Rudolfi. Pp. 41-42 In: Flora North America Editorial Committee (eds.), Flora of North America North of Mexico, Vol. 22: Magnoliophyta: Alismatidae, Arecidae, Commelinidae (in Part), and Zingiberidae. Oxford University Press, New York, NY.

Nies, G. \& T. B. H. Reusch. 2004. Nine polymorphic microsatellite loci for the fennel pondweed Potamogeton pectinatus L. Mol. Ecol. Notes 4: 563-565.

Niles, G. S. 1902. Origin of plant names. H. The lady's slippers and moccasin flowers. Plant World 5: 201-204.

Niles, G. G. 1904. Bog-trotting for Orchids. G. P. Putnam's Sons, Knickerbocker Press, New York, NY. 310 pp.

Nishihara, G. N. \& J. D. Ackerman. 2006. The effect of hydrodynamics on the mass transfer of dissolved inorganic carbon to the freshwater macrophyte Vallisneria americana. Limnol. Oceanogr. 51: 2734-2745.

Nixon, E. S. \& J. R. Ward. 1981. Distribution of Schoenolirion wrightii (Liliaceae) and Bartonia texana (Gentianaceae). Sida 9: 64-69.

Nixon, E. S. \& J. R. Ward. 1986. Floristic composition and management of East Texas pitcher plant bogs. Pp. 283-287. In: D. L. Kulhavy \& R. H. Conner (eds.), Wilderness and Natural Areas in the Eastern United States: A Management Challenge. Center for Applied Studies, School of Forestry, Stephen F. Austin State University, Nacogdoches, TX.

Njambuya, J., I. Stiers \& L. Triest. 2011. Competition between Lemna minuta and Lemna minor at different nutrient concentrations. Aquat. Bot. 94: 158-164.

Nolfo-Clements, L. E. 2006. Vegetative survey of wetland habitats at Jean Lafitte National Historical Park and Preserve in southeastern Louisiana. Southeast. Nat. 5: 499-514.

Noonpui, S. \& P. Thiravetyan. 2011. Treatment of reactive azo dye from textile wastewater by burhead (Echinodorus cordifolius L.) in constructed wetland: effect of molecular size. J. Environ. Sci. Health 46: 709-714.

Norquist, C. 1990. Threatened status for Sagittaria secundifolia (Kral's water-plantain). Fed. Reg. 55: 13907-13910.

Novelo, A. \& A. Lot. 1994. Pontederiaceae. Pp. 65-71 In: G. Davidse, M. Sousa \& A. Chater (eds.), Flora Mesoamericana. Vol. 6. Alismataceae a Cyperaceae. Missouri Botanical Garden Press, St. Louis, MO.

Noyce, K. V., P. B. Kannowski \& M. R. Riggs. 1997. Black bears as ant-eaters: seasonal associations between bear myrmecophagy and ant ecology in north-central Minnesota. Can. J. Zool. 75: 1671-1686.

Nozoe, T., J. Tazawa, A. Uchino \& S. Miura. 2018. Promotive effect of soil solution on germination of Monochoria vaginalis under paddy conditions. Soil Sci. Plant Nutr. 64: 396-405.

Nugraha, A. T., V. Ramadhan, H. Pandapotan \& F. Romadhonsyah. 2017. A study of proliferative activity of herbs Eriocaulon cinereum $\mathrm{R}$. Br on cervical cancer cells (HeLa) with MTT Assay Method. Int. J. Pharm. Med. Biol. Sci. 6: 73-76.

Nuissier, G., B. Rezzonico \& M. Grignon-Dubois. 2010. Chicoric acid from Syringodium filiforme. Food Chem. 120: 783-788.

NYNHP. 2019. New York Natural Heritage Program. 2019. Online Conservation Guide for Iris prismatica. Available online: https://guides.nynhp.org/slender-blue-flag/ [accessed 30 January, 2019].

Oakes, A. J. 1990. Ornamental Grasses and Grasslike Plants. Van Nostrand Reinhold, New York, NY. 618 pp.
Oberholser, H. C. \& W. L. McAtee. 1920. Waterfowl and their food plants in the sandhill region of Nebraska. Bulletin No. 794. United States Department of Agriculture, Washington, DC. 77 pp.

O'Brien, C. W. 1990. Neobagoidus carlsoni, new genus, new species of aquatic weevil from Florida. Southwest. Entomol. 15: 71-76.

O'Brien, C. W. 1997. A Catalogue of the Coleoptera of America North of Mexico. Agriculture Handbook Number 529-143g. United States Department of Agriculture, Washington, DC. 48 pp.

Ochoa, J. G. \& G. I. Andrade. 2003. The introduced flora to Machu Picchu Sanctuary: an inventory and management priorities for biodiversity conservation. Ecol. Bolivia 38: 141-160.

Oda, Y. 1962. Effect of light quality on flowering of Lemna perpusilla 6746. Plant Cell Physiol. 3: 415-417.

Odum, W. E. \& M. A. Heywood. 1978. Decomposition of intertidal freshwater marsh plants. Pp. 89-97 In: R. E. Good, D. F. Whigham \& R. L. Simpson (eds.), Freshwater Wetlands: Ecological Processes and Management Potential. Academic Press, New York, NY.

Odum, W. E., P. W. Kirk \& J. C. Zieman. 1979. Non-protein nitrogen compounds associated with particles of vascular plant detritus. Oikos 32: 363-367.

Offerijns, F. J. M. 1936. Meiosis in the pollen mother cells of some Cannas. Genetica 18: 1-60.

Ogle, D. W. 1989. Barns Chapel Swamp: an unusual arbor-vitae (Thuja occidentalis L.) site in Washington County, Virginia. Castanea 54: 200-202.

Ogle, B. M., P. H. Hung \& H. T. Tuyet. 2001. Significance of wild vegetables in micronutrient intakes of women in Vietnam: an analysis of food variety. Asia Pac. J. Clin. Nutr. 10: 21-30.

Ohanjanian, P. \& C. Carli. 2010. Northern leopard frog. An assessment of potential reintroduction sites in the Columbia marshes. Report to the Local Conservation Fund. The Columbia Basin Environmental Initiatives Fund and The Columbia Wetlands Stewardship Partners. Nelson, BC. 26 pp.

Ohri, D., R. Fritsch \& P. Hanelt. 1998. Evolution of genome size in Allium (Alliaceae). Plant Syst. Evol. 210: 57-86.

O'Kennon, R. J. \& C. McLemore. 2004. Schoenoplectus hallii (Cyperaceae), a globally threatened species new for Texas. Sida 21: 1201-1204.

Okoye, T. C., P. F. Uzor, C. A. Onyeto \& E. K. Okereke. 2014. Safe African medicinal plants for clinical studies. Pp. 535-555 In: V. Kuete (ed.), Toxicological Survey of African Medicinal Plants. Elsevier, London, United Kingdom.

Oláh, V., A. Hepp \& I. Mészáros. 2016. Assessment of giant duckweed (Spirodela polyrhiza L. Schleiden) turions as model objects in ecotoxicological applications. Bull. Environ. Contam. Toxicol. 96: 596-601.

Oliva, A. P. \& J. Arditti. 1984. Seed germination of North American orchids. II. Native California and related species of Aplectrum, Cypripedium, and Spiranthes. Bot. Gaz. 145: 495-501.

Olney, P. J. S. 1960. Lead poisoning in wildfowl. Wildfowl 11: 123-134.

Olofsdotter, M., D. Navarez \& K. Moody. 1995. Allelopathic potential in rice (Oryza sativa L.) germplasm. Ann. Appl. Biol. 127: 543-560.

Olsen, J. L., J. A. Coyer \& B. Chesney. 2014. Numerous mitigation transplants of the eelgrass Zostera marina in southern California shuffle genetic diversity and may promote hybridization with Zostera pacifica. Biol. Conserv. 176: 133-143. 
Olsen, J. L., P. Rouzé, B. Verhelst, Y.-C. Lin, T. Bayer, J. Collen, E. Dattolo, E. De Paoli, S. Dittami, F. Maumus, G. Michel, A. Kersting, C. Lauritano, R. Lohaus, M. Töpel, T. Tonon, K. Vanneste, M. Amirebrahimi, J. Brakel, C. Boström, M. Chovatia, J. Grimwood, J. W. Jenkins, A. Jueterbock, A. Mraz, W. T. Stam, H. Tice, E. Bornberg-Bauer, P. J. Green, G. A. Pearson, G. Procaccini, C. M. Duarte, J. Schmutz, T. B. H. Reusch \& Y. Van de Peer. 2016. The genome of the seagrass Zostera marina reveals angiosperm adaptation to the sea. Nature 530: 331-335.

Olson, E. R. \& J. M. Doherty. 2014. Macrophyte diversity-abundance relationship with respect to invasive and native dominants. Aquat. Bot. 119: 111-119.

Olson, A., J. Paul \& J. R. Freeland. 2009. Habitat preferences of cattail species and hybrids (Typha spp.) in eastern Canada. Aquat. Bot. 91: 67-70.

Onuf, C. P. 1996. Biomass patterns in seagrass meadows of the Laguna Madre, Texas. Bull. Mar. Sci. 58: 404-420.

Oosting, H. J. \& W. D. Billings. 1943. The red fir forest of the Sierra Nevada: Abietum magnificae. Ecol. Monogr. 13: 259-274.

Ophel, I. L. \& C. D. Fraser. 1970. Calcium and strontium discrimination by aquatic plants. Ecology 51: 324-327.

Oraze, M. J. \& A. A. Grigarick. 1992. Biological control of ducksalad (Heteranthera limosa) by the waterlily aphid (Rhopalosiphum nymphaeae) in rice (Oryza sativa). Weed Sci. 40: 333-336.

Oraze, M. J., A. A. Grigarick, J. H. Lynch \& K. A. Smith. 1988. Spider fauna of flooded rice fields in northern California. $J$. Arachnol. 16: 331-337.

Oraze, M. J., A. A. Grigarick \& K. A. Smith. 1989. Population ecology of Pardosa ramulosa (Araneae, Lycosidae) in flooded rice fields of northern California. J. Arachnol. 17: 163-170.

Oriani, A. \& V. L. Scatena. 2012. Floral anatomy of xyrids (Poales): contributions to their reproductive biology, taxonomy, and phylogeny. Int. J. Plant Sci. 173: 767-779.

Oriani, A. \& V. L. Scatena. 2017. Ovule, fruit, and seed development of Orectanthe sceptrum and its systematic relevance to Xyridaceae (Poales). Int. J. Plant Sci. 178: 104-116.

Orians, G. H. 1973. The red-winged blackbird in tropical marshes. Condor 75: 28-42.

Ornduff, R. 1966. The breeding system of Pontederia cordata L. Bull. Torrey Bot. Club 93: 407-416.

Ornduff, R. 1979. Chromosome numbers and relationships of certain African and American genera of Haemodoraceae. Ann. Missouri Bot. Gard. 66: 577-580.

Oron, G., D. Porath \& L. R. Wildschut. 1986. Wastewater treatment and renovation by different duckweed species. J. Environ. Eng. 112: 247-263.

Orpurt, P. A., S. P. Meyers, L. L. Boral \& J. Sims. 1964. Thalassiomycetes V. A new species of Lindra from turtle grass, Thalassia testudinum König. Bull. Mar. Sci. 14: 405-417.

Ortas, L. \& J. A. Martorell. 2001. Heteranthera rotundifolia Griseb., nueva planta adventicia de los arrozales en España. Anales Jard. Bot. Madrid 59: 161.

Orth, R. J. 1973. Benthic infauna of eelgrass, Zostera marina, beds. Chesapeake Sci. 14: 258-269.

Orth, R. J. 1975. Destruction of eelgrass, Zostera marina, by the cownose ray, Rhinoptera bonasus, in the Chesapeake Bay. Chesapeake Sci. 16: 205-208.

Orth, R. J. \& K. L. Heck, Jr. 1980. Structural components of eelgrass (Zostera marina) meadows in the lower Chesapeake Bayfishes. Estuaries 3: 278-288.

Orth, R. J. \& K. A. Moore. 1986. Seasonal and year-to-year variations in the growth of Zostera marina L. (eelgrass) in the lower Chesapeake Bay. Aquat. Bot. 24: 335-341.
Orth, R. J. \& K. A. Moore. 1988. Distribution of Zostera marina L. and Ruppia maritima L. sensu lato along depth gradients in the lower Chesapeake Bay, USA. Aquat. Bot. 32: 291-305.

Orth, A. I. \& K. D. Waddington. 1997. The movement patterns of carpenter bees Xylocopa micans and bumblebees Bombus pennsylvanicus on Pontederia cordata inflorescences. J. Insect Behav. 10: 79-86.

Orth, R. J., K. A. Moore \& J. F. Nowak. 1990. Monitoring seagrass distribution and abundance patterns: a case study from the Chesapeake Bay. Federal coastal wetland mapping programs. Biol. Rep. 90(18): 111-123.

Orth, R. J., M. C. Harwell, E. M. Bailey, A. Bartholomew, J. T. Jawad, A. V. Lombana, K. A. Moore, J. M. Rhode \& H. E. Woods. 2000. A review of issues in seagrass seed dormancy and germination: implications for conservation and restoration. Mar. Ecol. Prog. Ser. 200: 277-288.

Orth, R. J., J. R. Fishman, M. C. Harwell \& S. R. Marion. 2003. Seed-density effects on germination and initial seedling establishment in eelgrass Zostera marina in the Chesapeake Bay region. Mar. Ecol. Prog. Ser. 250: 71-79.

Orth, R. J., M. C. Harwell \& G. J. Inglis. 2006. Ecology of seagrass seeds and seagrass dispersal strategies. Pp. 111-133 In: A. W. D. Larkum, R. J. Orth \& C. M. Duarte (eds.), Seagrasses: Biology, Ecology and Conservation. Springer-Verlag, Dordrecht, The Netherlands.

Orzell, S. L. \& E. L. Bridges. 1991. Carex exilis Dewey (Cyperaceae) new to Alabama. Phytologia 70: 400-403.

Orzell, S. L. \& E. L. Bridges. 1992. Xyris isoetifolia Kral (Xyridaceae) new to Alabama and its range and habitats in Florida. Phytologia 72: 152-156.

Orzell, S. L. \& E. L. Bridges. 1993. Eriocaulon nigrobracteatum (Eriocaulaceae), a new species from the Florida panhandle, with a characterization of its poor fen habitat. Phytologia 74: 104-124.

Orzell, S. L. \& E. Bridges. 2006a. Floristic composition and species richness of subtropical seasonally wet Muhlenbergia sericea prairies in portions of central and south Florida. Pp. 136-175 In: R. F. Noss (ed.), Land of Fire and Water: The Florida Dry Prairie Ecosystem. Proceedings of the Florida Dry Prairie Conference. E. O. Painter Printing Co., DeLeon Springs, FL.

Orzell, S. L. \& E. Bridges. 2006b. Species composition and environmental characteristics of Florida dry prairies from the Kissimmee River region of south-central Florida. Pp. 100-135 In: R. F. Noss (ed.), Land of Fire and Water: The Florida Dry Prairie Ecosystem. Proceedings of the Florida Dry Prairie Conference. E. O. Painter Printing Co., DeLeon Springs, FL.

Ostrofsky, M. L. \& E. R. Zettler. 1986. Chemical defences in aquatic plants. J. Ecol. 74: 279-287.

Osborne, J. A. \& N. M. Sassic. 1981. The size of grass carp as a factor in the control of Hydrilla. Aquat. Bot. 11: 129-136.

Ostrofsky, M. L. \& C. Miller. 2017. Photosynthetically-mediated calcite and phosphorus precipitation by submersed aquatic vascular plants in Lake Pleasant, Pennsylvania. Aquat. Bot. 143: 36-40.

Othman, A. S. 1997. Molecular systematics of the tropical aquatic plant genus, Cryptocoryne Fischer ex Wydler (Araceae). Ph.D. dissertation. University of St. Andrews, St. Andrews, Scotland. 223 pp.

Ott-Conn, C. N., D. Clifford, T. Branston, R. Klinger \& J. Foley. 2014. Pathogen infection and exposure, and ectoparasites of the federally endangered Amargosa vole (Microtus californicus scirpensis), California, USA. J. Wildl. Dis. 50: 767-776.

Owens, S. J. 1981. Self-incompatibility in the Commelinaceae. Ann. Bot. 47: 567-581. 
Owens, C. S., J. D. Madsen, R. M. Smart \& R. M. Stewart. 2001. Dispersal of native and nonnative aquatic plant species in the San Marcos River, Texas. J. Aquat. Plant Manag. 39: 75-79.

Owens, C. S., A. Shad, J. Tripe, L. Dodd \& L. Glomski. 2010. San Marcos River Survey-2009 Feasibility. U.S. Army Corps of Engineers, Lewisville Aquatic Ecosystem Research Facility, Lewisville, TX. 41 pp.

Owens, B. E., L. Allain, E. C. Van Gorder, J. L. Bossart \& C. E. Carlton. 2018. The bees (Hymenoptera: Apoidea) of Louisiana: an updated, annotated checklist. Proc. Entomol. Soc. Washington 120: 272-308.

Oyewo, E. A. \& R. E. Jacobsen. 2007. Polypedilum (Pentapedilum) epleri, a new species from the eastern USA (Diptera: Chironomidae). Pp. 225-234 In: T. Andersen (ed.), Contributions to the Systematics and Ecology of Aquatic Diptera-A Tribute to Ole A. Sather. The Caddis Press, Columbus, $\mathrm{OH}$.

Özbay, H. \& A. Alim. 2009. Antimicrobial activity of some water plants from the northeastern Anatolian region of Turkey. Molecules 14: 321-328.

Özesmi, U. \& W. J. Mitsch. 1997. A spatial habitat model for the marsh-breeding red-winged blackbird (Agelaius phoeniceus L.) in coastal Lake Erie wetlands. Ecol. Modell. 101: 139-152.

Pace, M. C. \& A. E. Brant. 2015. Missouri: Spiranthes praecox (Orchidaceae) and Carex atlantica subsp. capillacea (Cyperaceae): new to the Flora of Missouri. Castanea 80: 144-146.

Pace, M. C. \& K. M. Cameron. 2016. Reinstatement, redescription, and emending of Spiranthes triloba (Orchidaceae): solving a 118 year old cryptic puzzle. Syst. Bot. 41: 924-939.

Pace, M. C. \& K. M. Cameron. 2017. The systematics of the Spiranthes cernua species complex (Orchidaceae): untangling the Gordian knot. Syst. Bot. 42: 640-669.

Pace, M. C., S. L. Orzell, E. L. Bridges \& K. M. Cameron. 2017. Spiranthes igniorchis (Orchidaceae), a new and rare cryptic species from the south-central Florida subtropical grasslands. Brittonia 69: 323-339.

Packer, J. G. 2002a. Pleea Michaux. Pp. 59-60 In: Flora North America Editorial Committee (eds.), Flora of North America North of Mexico, Vol. 26: Magnoliophyta: Liliidae: Liliales and Orchidales. Oxford University Press, New York, NY.

Packer, J. G. 2002b. Triantha (Nuttall) Baker. Pp. 61-64 In: Flora North America Editorial Committee (eds.), Flora of North America North of Mexico, Vol. 26: Magnoliophyta: Liliidae: Liliales and Orchidales. Oxford University Press, New York, NY.

Packer, J. G. \& G. S. Ringius. 1984. The distribution and status of Acorus (Araceae) in Canada. Can. J. Bot. 62: 2248-2252.

Padgett, D. J. \& G. E. Crow. 1994a. A vegetation and floristic analysis of a created wetland in southeastern New Hampshire. Rhodora 96: 1-29.

Padgett, D. J. \& G. E. Crow. 1994b. Foreign plant stock: concerns for wetland mitigation. Restor. Manag. Notes 12: 168-171.

Padgett, D. J., L. Cook, L. Horky, J. Noris \& K. Vale. 2004. Seed production and germination in long's bittercress (Cardamine longii) of Massachusetts. Northeast. Nat. 11: 49-56.

Pagano, A. M. \& J. E. Titus. 2007. Submersed macrophyte growth at low $\mathrm{pH}$ : carbon source influences response to dissolved inorganic carbon enrichment. Freshw. Biol. 52: 2412-2420.

Pagotto, M. A., R. de M. L. Silveira, C. N. da Cunha \& I. FantinCruz. 2011. Distribution of herbaceous species in the soil seed bank of a flood seasonality area, northern Pantanal, Brazil. Int. Rev. Hydrobiol. 96: 149-163.
Pai, A. \& B. C. McCarthy. 2005. Variation in shoot density and rhizome biomass of Acorus calamus L. with respect to environment. Castanea 70: 263-275.

Pai, A. \& B. C. McCarthy. 2010. Suitability of the medicinal plant, Acorus calamus L., for wetland restoration. Nat. Areas J. 30: 380-386.

Palis, J. G. 1998. Breeding biology of the gopher frog, Rana capito, in western Florida. J. Herpetol. 32: 217-223.

Palma, Á. T., A. Schwarz, L. A. Henríquez, X. Alvarez, J. M. Fariña \& Q. Lu. 2013. Do subtoxic levels of chlorate influence the desiccation tolerance of Egeria densa? Environ. Toxicol. Chem. 32: 417-422.

Palmer, M. L. \& F. J. Mazzotti. 2004. Structure of Everglades alligator holes. Wetlands 24: 115-122.

Pandey, M. \& J. Sharma. 2015. Disjunct populations of a locally common North American orchid exhibit high genetic variation and restricted gene flow. Open J. Genet. 5: 159-175.

Pandi, P. S. \& J. Rajkumar. 2015. Phytochemical screening and bioactive potential of Hydrilla verticillata. J. Chem. Pharmaceut. Res. 7: 1809-1815.

Panetta, F. D. 1988. Studies on the seed biology of arum lily (Zantedeschia aethiopica (L.) Spreng.). Plant Protect. Quart. 3: 169-171.

Panigrahy, S. K., A. Kumar \& R. Bhatt. 2018. Hedychium coronarium rhizomes: promising antidiabetic and natural inhibitor of $\alpha$-amylase and $\alpha$-glucosidase. J. Dietary Suppl. doi: 10.1080/19390211.2018.1483462.

Pankey, R. D., H. N. Draudt \& N. W. Desrosier. 1965. Characterization of the starch of Spirodela polyrrhiza. J. Food Sci. 30: 627-631.

Pansarin, E. R., A. Salatino \& M. L. F. Salatino. 2008. Phylogeny of South American Pogonieae (Orchidaceae, Vanilloideae) based on sequences of nuclear ribosomal (ITS) and chloroplast ( $p s a B, r b c L, r p s 16$, and $t r n L-F$ ) DNA, with emphasis on Cleistes and discussion of biogeographic implications. Org. Divers. Evol. 8: 171-181.

Pant, B. 2013. Medicinal orchids and their uses: tissue culture a potential alternative for conservation. Afr. J. Plant Sci. 7: 448-467.

Paolacci, S., S. Harrison \& M. A. K. Jansen. 2018. The invasive duckweed Lemna minuta Kunth displays a different light utilisation strategy than native Lemna minor Linnaeus. Aquat. Bot. 146: 8-14.

Pardee, K. I., P. Ellis, M. Bouthillier, G. H. N. Towers \& C. J. French. 2004. Plant virus inhibitors from marine algae. Can. J. Bot. 82: 304-309.

Parent, G. H. 1977. L'écologie de Sisyrinchium montanum Greene (Iridaceae) en forêt d'Argonne et en Lorraine. Bull. Soc. Roy. Bot. Belgique 110: 77-84.

Parida, R., S. Mohanty \& S. Nayak. 2013. In vitro propagation of Hedychium coronarium Koen. through axillary bud proliferation. Plant Biosyst. 147: 905-912.

Parker, G. 2003. Status Report on the Eastern Moose (Alces alces americana Clinton) in Mainland Nova Scotia. Nova Scotia Department of Natural Resources, Halifax, NS, Canada. 77 pp.

Parker, V. T. \& M. A. Leck. 1985. Relationships of seed banks to plant distribution patterns in a freshwater tidal wetland. Am. J. Bot. 72: 161-174.

Parker, J. D. \& M. E. Hay. 2005. Biotic resistance to plant invasions? Native herbivores prefer non-native plants. Ecol. Lett. 8: 959-967.

Parker, B. C., N. Schanen \& R. Renner. 1969. Viable soil algae from the herbarium of the Missouri Botanical Garden. Ann. Missouri Bot. Gard. 56: 113-119. 
Parker, J. D., C. C. Caudill \& M. E. Hay. 2007a. Beaver herbivory on aquatic plants. Oecologia 151: 616-625.

Parker, J. D., D. E. Burkepile, D. O. Collins, J. Kubanek \& M. E. Hay. 2007b. Stream mosses as chemically-defended refugia for freshwater macroinvertebrates. Oikos 116: 302-312.

Parkes, K. C., D. P. Kibbe \& E. L. Roth. 1978. First records of the Spotted Rail (Pardirallus maculatus) for the United States, Chile, Bolivia and western Mexico breeding range. Am. Birds 32: 295-299.

Parkinson, H., J. Mangold \& C. McLane. 2016. Biology, ecology and management of curlyleaf pondweed (Potamogeton crispus). EBO223. Montana State University Extension, Bozeman, MT. 9 pp.

Partridge, C., A. Boettcher \& A. G. Jones. 2012. Population structure of the gulf pipefish in and around Mobile Bay and the northern Gulf of Mexico. J. Hered. 103: 821-830.

Parvathaneni, R. K., V. L. DeLeo, J. J. Spiekerman, D. Chakraborty \& K. M. Devos. 2017. Parallel loss of introns in the $A B C B 1$ gene in angiosperms. BMC Evol. Biol. 17: 238.

Paşca, M. B., D. Gîtea, A. Pallag, S. Nemeth \& I. Ileş. 2016. Research regarding the capitalization of Iris pseudacorus L. species. Analele Univ. Oradea Fascic. Protecţ. Med. 27: 135-140.

Patel, S. 2012. Threats, management and envisaged utilizations of aquatic weed Eichhornia crassipes: an overview. Rev. Environ. Sci. Bio/Technol. 11: 249-259.

Paterson, M. 1993. The distribution of microcrustacea in the littoral zone of a freshwater lake. Hydrobiologia 263: 173-183.

Pates, A. L. \& G. C. Madsen. 1955. Occurrence of antimicrobial substances in chlorophyllose plants growing in Florida. II. Bot. Gaz. 116: 250-261.

Patrock, R. J. W. 2007. The use by red imported fire ants, Solenopsis invicta (Hymenoptera: Formicidae), of Potamogeton nodosus (Potamogetonaceae) leaves as platforms into the littoral zone in Texas, USA. Entomol. News 118: 527-529.

Patt, J. M., T. G. Hartman, R. W. Creekmore, J. J. Elliott, C. Schal, J. Lech \& R. T. Rosen. 1992. The floral odour of Peltandra virginica contains novel trimethyl-2, 5-dioxabicyclo [3.2.1] nonanes. Phytochemistry 31: 487-491.

Patt, J. M., J. C. French, C. Schal, J. Lech \& T. G. Hartman. 1995. The pollination biology of Tuckahoe, Peltandra virginica (Araceae). Am. J. Bot. 82: 1230-1240.

Patterson, C. T. 1982. Foods of migrating coots (Fulica americana) and sympatric ducks during fall and spring in northeastern Oklahoma. Ph.D. dissertation. Oklahoma State University, Norman, OK. 31 pp.

Patten, M. V. 2016. Phenotypic plasticity and morphological variation in a native submerged aquatic plant. M.S. thesis. San Francisco State University, San Francisco, CA. 59 pp.

Patton, J. E. \& W. S. Judd. 1986. Vascular flora of Paynes Prairie Basin and Alachua Sink Hammock, Alachua County, Florida. Castanea 51: 88-110.

Patton, J. E. \& W. S. Judd. 1988. A phenological study of 20 vascular plant species occurring on the Paynes Prairie Basin, Alachua County, Florida. Castanea 53: 149-163.

Paulus, S. L. 1982a. Feeding ecology of gadwalls in Louisiana in winter. J. Wildl. Manag. 46: 71-79.

Paulus, S. L. 1982b. Gut morphology of gadwalls in Louisiana in winter. J. Wildl. Manag. 46: 483-489.

Paulus, S. L. 1984. Activity budgets of nonbreeding gadwalls in Louisiana. J. Wildl. Manag. 48: 371-380.

Pavek, D. S. 1993. Maianthemum canadense. In: Fire Effects Information System. U.S. Department of Agriculture, Forest Service, Rocky Mountain Research Station, Fire Sciences
Laboratory (Producer). Available online: https://www.fs. fed.us/database/feis/plants/forb/maican/all.html [accessed 23 January, 2019].

Payette, S. \& A. Delwaide. 2000. Recent permafrost dynamics in a subarctic floodplain associated with changing water levels, Québec, Canada. Arct. Antarct. Alp. Res. 32: 316-323.

Payne, T. 1916. California Wild Flowers, Their Culture and Care: A Treatise Describing Over a Hundred Beautiful Species, with a Few Notes on Their Habits and Characteristics, 3rd ed. Theodore Payne, Los Angeles, CA. 24 pp.

PCA (Parks Canada Agency). 2012. Management plan for Hill's pondweed (Potamogeton hillii) in Canada [Proposed]. Species at Risk Act Management Plan Series. Parks Canada Agency, Ottawa, ON, Canada. v +23 pp.

Pearn, M. 2012. Pollination and comparative reproductive success of lady's slipper orchids Cypripedium candidum, C. parviflorum, and their hybrids in southern Manitoba. M.S. thesis. University of Maitoba, Winnipeg, MB. 193 pp.

Peck, M. E. 1925. A preliminary sketch of the plant regions of Oregon. I. Western Oregon. Am. J. Bot. 12: 33-49.

Pedron, M., C. R. Buzatto, R. B. Singer, J. A. N. Batista \& A. Moser. 2012. Pollination biology of four sympatric species of Habenaria (Orchidaceae: Orchidinae) from southern Brazil. Bot. J. Linn. Soc. 170: 141-156.

Pedron, M., C. R. Buzatto, A. J. Ramalho, B. M. Carvalho, J. A. Radins, R. B. Singer \& J. A. N. Batista. 2014. Molecular phylogenetics and taxonomic revision of Habenaria section Pentadactylae (Orchidaceae, Orchidinae). Bot. J. Linn. Soc. 175: 47-73.

Peet, R. K. 2007. Ecological classification of longleaf pine woodlands. Pp. 51-93 In: S. Jose, E. J. Jokela \& D. L. Miller (eds.), The Longleaf Pine Ecosystem. Springer, New York, NY.

Peet, R. K. \& D. J. Allard. 1993. Longleaf pine vegetation of the southern Atlantic and eastern Gulf Coast regions: a preliminary classification. Pp. 45-81 In: S. M. Hermann (ed.), Proceedings of the Tall Timbers Fire Ecology Conference, Vol. 18: The Longleaf Pine Ecosystem: Ecology, Restoration and Management. Tall Timbers Research Station, Tallahassee, FL.

Peeters-Van der Meijden, K. \& T. Rotteveel. 2006. Lysichiton americanus Hultén \& H. St. John, een imposante indringer. Gorteria 32: 37-44.

Peinado, M., J. L. Aguirre, M. Á. Macías \& J. Delgadillo. 2011. A phytosociological survey of the dune forests of the Pacific Northwest. Plant Biosyst. 145: 105-117.

Pellatt, M. G. \& R. W. Mathewes. 1994. Paleoecology of postglacial tree line fluctuations on the Queen Charlotte Islands, Canada. Ecoscience 1: 71-81.

Pellegrini, M. O. O., C. N. Horn \& R. F. Almeida. 2018. Total evidence phylogeny of Pontederiaceae (Commelinales) sheds light on the necessity of its recircumscription and synopsis of Pontederia L. PhytoKeys 108: 25-83.

Pellerin, S., J. Huot \& S. D. Côté. 2006. Long-term effects of deer browsing and trampling on the vegetation of peatlands. Biol. Conserv. 128: 316-326.

Pellerin, S., L.-A. Lagneau, M. Lavoie \& M. Larocque. 2009. Environmental factors explaining the vegetation patterns in a temperate peatland. Comp. Rend. Biol. 332: 720-731.

Pellicer, J., L. J. Kelly, I. J. Leitch, W. B. Zomlefer \& M. F. Fay. 2014. A universe of dwarfs and giants: genome size and chromosome evolution in the monocot family Melanthiaceae. New Phytol. 201: 1484-1497.

Pellmyr, O. \& J. M. Patt. 1986. Function of olfactory and visual stimuli in pollination of Lysichiton americanum (Araceae) by a staphylinid beetle. Madrono 33: 47-54. 
Pemberton, R. W. 1998. Waterblommetjie, an unusual aquatic food plant, new crop and cultural symbol in the Cape of South Africa. Pp. 223-228 In: H. Walker (ed.), Fish: Food from the Waters. Prospect Books, Devon, England.

Pemberton, R. W. 2000. Waterblommetjie (Aponogeton distachyos, Aponogetonaceae), a recently domesticated aquatic food crop in Cape South Africa with unusual origins. Econ. Bot. 54: 144-149.

Pendergrass, L. 1983. Harper's Beauty (Harperocallis flava) Recovery Plan. U.S. Fish \& Wildlife Service, Atlanta, GA. 32 pp.

Penfound, W. T. 1953. Plant communities of Oklahoma lakes. Ecology 34: 561-583.

Penfound, W. T. 1956. Primary production of vascular aquatic plants. Limnol. Oceanogr. 1: 92-101.

Penfound, W. T. \& M. E. O’Neill. 1934. The vegetation of Cat Island, Mississippi. Ecology 15: 1-16.

Penfound, W. T. \& E. S. Hathaway. 1938. Plant communities in the marshlands of southeastern Louisiana. Ecol. Monogr. 8: 1-56.

Penfound, W. T. \& T. T. Earle. 1948. The biology of the water hyacinth. Ecol. Monogr. 18: 447-472.

Penfound, W. T., T. F. Hall \& D. Hess. 1945. The spring phenology of plants in and around the reservoirs in North Alabama with particular reference to malaria control. Ecology 26: 332-352.

Peng, K., C. Luo, L. Lou, X. Li \& Z. Shen. 2008. Bioaccumulation of heavy metals by the aquatic plants Potamogeton pectinatus L. and Potamogeton malaianus Miq. and their potential use for contamination indicators and in wastewater treatment. Sci. Total Environ. 392: 22-29.

Penhale, P. A. 1977. Macrophyte-epiphyte biomass and productivity in an eelgrass (Zostera marina L.) community. J. Exp. Mar. Biol. Ecol. 26: 211-224.

Penko, J. M. \& D. C. Pratt. 1986. The growth and survival of early instars of Bellura obliqua (Lepidoptera: Noctuidae) on Typha latifolia and Typha angustifolia. Great Lakes Entomol. 19: 35-42.

Penn, G. H. 1950. The genus Cambarellus in Louisiana (Decapoda, Astacidae). Am. Midl. Nat. 44: 421-426.

Pennacchio, M., L. Jefferson \& K. Havens. 2010. Uses and Abuses of Plant-Derived Smoke: Its Ethnobotany as Hallucinogen, Perfume, Incense, and Medicine. Oxford University Press, New York, NY. 264 pp.

Pennington, T. G. \& M. D. Sytsma. 2009. Seasonal changes in carbohydrate and nitrogen concentrations in Oregon and California populations of Brazilian Egeria (Egeria densa). Invasive Plant Sci. Manag. 2: 120-129.

Perdomo, P., P. Nitzsche \& D. Drake. 2004. Landscape plants rated by deer resistance. Bulletin E271. Rutgers Cooperative Research \& Extension, NJAES, Rutgers, The State University of New Jersey, New Brunswick, NJ. 6 pp.

Peredo, E. L., D. H. Les, U. M. King \& L. K. Benoit. 2012. Extreme conservation of the $p s a A / p s a B$ intercistronic spacer reveals a translational motif coincident with the evolution of land plants. J. Mol. Evol. 75: 184-197.

Peredo, E. L., U. M. King \& D. H. Les. 2013. The plastid genome of Najas flexilis: adaptation to submersed environments is accompanied by the complete loss of the NDH complex in an aquatic angiosperm. PLoS One 8: e68591.

Pereyra, M. E. 2011. Effects of snow-related environmental variation on breeding schedules and productivity of a high-altitude population of Dusky Flycatchers (Empidonax oberholseri). Auk 128: 746-758.

Pérez, E. A., J. A. Coetzee, T. Ruiz Téllez \& M. P. Hill. 2011. A first report of water hyacinth (Eichhornia crassipes) soil seed banks in South Africa. S. Afr. J. Bot. 77: 795-800.
Perkin, J. S., Z. R. Shattuck \& T. H. Bonner. 2012. Life history aspects of a relict ironcolor shiner Notropis chalybaeus population in a novel spring environment. Am. Midl. Nat. 167: 111-126.

Perleberg, D. 2006. Aquatic Vegetation of Birch Lake (DOW 11-041200) Cass County, Minnesota. Minnesota Department of Natural Resources, Ecological Resources Division, Brainerd, MN. 20 pp.

Perleberg, D. 2008. Aquatic Vegetation of Long Lake (DOW 11-014200), Cass County, Minnesota, 2007. Minnesota Department of Natural Resources, Ecological Resources Division, Brainerd, MN. 24 pp.

Perleberg, D. \& S. Loso. 2009a. Aquatic Vegetation of Thunder Lake (DOW 11-0062-00) Cass County, Minnesota, 2008. Minnesota Department of Natural Resources, Ecological Resources Division, Brainerd, MN. 21 pp.

Perleberg, D. \& S. Loso. 2009b. Aquatic Vegetation Survey of Trout Lake (DOW \#31-0216-00) Itasca County, Minnesota, 2005. Minnesota Department of Natural Resources, Ecological Resources Division, Brainerd, MN. 18 pp.

Perrette, G. 2010. Comparative dendrochronology study of black spruce (Picea mariana) on lowlands \& uplands in the Hudson Bay lowland. B.S. thesis. Laurentian University, Sudbury, ON. 43 pp.

Perry, F. 1961. Water Gardening, revised ed. Country Life Limited, London, UK. 338 pp.

Perry, T. O. 1968. Dormancy, turion formation, and germination by different clones of Spirodela polyrrhiza. Plant Physiol. 43: 1866-1869.

Perry, M. C. \& F. M. Uhler. 1981. Asiatic clam (Corbicula manilensis) and other foods used by waterfowl in the James River, Virginia. Estuaries 4: 229-233.

Perry, M. C. \& F. M. Uhler. 1988. Food habits and distribution of wintering canvasbacks, Aythya valisineria, on Chesapeake Bay. Estuaries 11: 57-67.

Perry, J. E. \& R. B. Atkinson. 1997. Plant diversity along a salinity gradient of four marshes on the York and Pamunkey Rivers in Virginia. Castanea 62: 112-118.

Perry, J. E. \& C. H. Hershner. 1999. Temporal changes in the vegetation pattern in a tidal freshwater marsh. Wetlands 19: 90-99.

Perry, L. E. \& M. E. Dorken. 2011. The evolution of males: support for predictions from sex allocation theory using mating arrays of Sagittaria latifolia (Alismataceae). Evolution 65: 2782-2791.

Persson, H. 1947. Further notes on Alaskan-Yukon bryophytes. Bryologist 50: 279-310.

Persson, H. \& H. T. Shacklette. 1959. Drepanocladus trichophyllus found in North America. Bryologist 62: 251-254.

Perullo, N., R. O. Determann, J. M. Cruse-Sanders \& G. S. Pullman. 2015. Seed cryopreservation and micropropagation of the critically endangered species swamp pink (Helonias bullata L.). In Vitro Cell. Dev. Biol.-Plant 51: 284-293.

Pervin, F., M. M. Hossain, S. Khatun, S. P. Siddique, K. A. Salam, M. R. Karim \& N. Absar. 2006. Comparative citotoxicity study of six bioactive lectins purified from pondweed (Potamogeton nodosus Poir) rootstock on Brine Shrimp. J. Med. Sci. 6: 999-1002.

Petch, T. 1928. Notes on Cryptocoryne. Ann. Roy. Bot. Gard. Peradeniya 11: 11-26.

Peter, C. I. \& S. D. Johnson. 2005. Doing the twist: a test of Darwin's cross-pollination hypothesis for pollinarium reconfiguration. Biol. Lett. 2: 65-68.

Peters, J. A., T. Kreps \& D. M. Lodge. 2008. Assessing the impacts of rusty crayfish (Orconectes rusticus) on submergent macrophytes in a north-temperate US lake using electric fences. Am. Midl. Nat. 159: 287-297. 
Peters, D., A. Morales, S. Morales \& R. Hernández. 2009. Feeding quality evaluation of Lemna obscura meal as ingredients in the elaboration of food for red tilapia (Orechromis spp.). Revista Ci. Fac. Ci. Veterin. Univ. Zulia 19: 303-310.

Petersen, G., O. Seberg, J. I. Davis \& D. W. Stevenson. 2006. RNA editing and phylogenetic reconstruction in two monocot mitochondrial genes. Taxon 55: 871-886.

Petersen, G., O. Seberg \& J. I. Davis. 2013. Phylogeny of the Liliales (Monocotyledons) with special emphasis on data partition congruence and RNA editing. Cladistics 29: 274-295.

Petersen, G., O. Seberg, F. T. Short \& M. D. Fortes. 2014. Complete genomic congruence but non-monophyly of Cymodocea (Cymodoceaceae), a small group of seagrasses. Taxon 63: 3-8.

Petersen, G., O. Seberg, A. Cuenca, D. W. Stevenson, M. Thadeo, J. I. Davis, S. Graham \& T. G. Ross. 2016. Phylogeny of the Alismatales (Monocotyledons) and the relationship of Acorus (Acorales?). Cladistics 32: 141-159.

Petersen, G., A. Cuenca, A. Zervas, G. T. Ross, S. W. Graham, C. F. Barrett, J. I. Davis \& O. Seberg. 2017. Mitochondrial genome evolution in Alismatales: size reduction and extensive loss of ribosomal protein genes. PLoS One 12: e0177606.

Peterson, L. A. 1977. A Field Guide to Edible Wild Plants of Eastern and Central North America. Houghton Mifflin, Company, Boston, MA. 330 pp.

Peterson, J. E. \& A. H. Baldwin. 2004a. Seedling emergence from seed banks of tidal freshwater wetlands: response to inundation and sedimentation. Aquat. Bot. 78: 243-254.

Peterson, J. E. \& A. H. Baldwin. 2004b. Variation in wetland seed banks across a tidal freshwater landscape. Am. J. Bot. 91: 1251-1259.

Peterson, P. M., R. J. Soreng, D. Styer, D. Neubauer, R. Morgan \& V. Yadon. 2011. Agrostis lacuna-vernalis (Pooideae: Poeae: Agrostidinae), a new species from California. J. Bot. Res. Inst. Texas 5: 421-426.

Pettit, G. R., G. R. Pettit III, R. A. Backhaus \& F. E. Boettner. 1995. Antineoplastic agents, 294. Variations in the formation of pancratistatin and related isocarbostyrils in Hymenocallis littoralis. J. Nat. Prod. 58: 37-43.

Pettitt, J. M. \& A. C. Jermy. 1974. Pollen in hydrophilous angiosperms. Micron 5: 377-405.

Petty, R. O. \& A. M. Petty. 2005. Wild Plants in Flower-Wetlands and Quiet Waters of the Midwest. Quarry Books, Bloomington, IN. 100 pp.

Pezeshki, S. R., P. H. Anderson \& R. D. DeLaune. 2000. Effects of nursery pre-conditioning on Panicum hemitomon and Sagittaria lancifolia used for wetland restoration. Restor. Ecol. 8: $57-64$.

Pfauth, M. \& M. Sytsma. 2004. Coastal lakes aquatic plant survey report. Paper 25. Center for Lakes and Reservoirs, Portland State University, Portland, OR. 41 pp.

Pfauth, M. \& M. Sytsma. 2005. Alaska aquatic plant survey report 2005. Paper 12. Center for Lakes and Reservoirs, Portland State University, Portland, OR. 20 pp.

Pfeifer-Meister, L., B. R. Johnson, B. A. Roy, S. Carreño, J. L. Stewart \& S. D. Bridgham. 2012. Restoring wetland prairies: tradeoffs among native plant cover, community composition, and ecosystem functioning. Ecosphere 3(12): 121. doi: 10.1890/ES12-00261.1.

Philbrick, C. T. 1984. Aspects of floral biology in three species of Potamogeton (pondweeds). Michigan Bot. 23: 35-38.

Philbrick, C. T. 1988. Evolution of underwater outcrossing from aerial pollination systems: a hypothesis. Ann. Missouri Bot. Gard. 75: 836-841.
Philbrick, C. T. \& G. J. Anderson. 1987. Implications of pollen/ ovule ratios and pollen size for the reproductive biology of Potamogeton and autogamy in aquatic angiosperms. Syst. Bot. 12: $98-105$.

Philbrick, C. T. \& D. H. Les. 1996. Evolution of aquatic angiosperm reproductive systems. BioScience 46: 813-826.

Phillips, J. C. 1911. Ten years of observation on the migration of Anatidae at Wenham Lake, Massachusetts. Auk 28: 188-200.

Phillips, R. C. 1960. Observations on the ecology and distribution of the Florida seagrasses. Professional Papers Series No. 2. Florida State Board of Conservation, Marine Laboratory, St. Petersburg, FL. 72 pp.

Phillips, E. C. 2008. Invertebrate colonization of native and invasive aquatic macrophytes in Presque Isle Bay, Lake Erie. J. Freshw. Ecol. 23: 451-457.

Phillips, R. C. \& E. G. Meñez. 1988. Seagrasses. Smithsonian Contributions to the Marine Sciences, No. 34. Smithsonian Institution Press, Washington, DC. 104 pp.

Phillips, R. C. \& S. W. Echeverria. 1990. Zostera asiatica Miki on the Pacific coast of North America. Pac. Sci. 44: 130-134.

Phillips, R. C., C. McMillan \& K. W. Bridges. 1983a. Phenology of eelgrass, Zostera marina L., along latitudinal gradients in North America. Aquat. Bot. 15: 145-156.

Phillips, R. C., W. S. Grant \& C. P. McRoy. 1983b. Reproductive strategies of eelgrass (Zostera marina L.). Aquat. Bot. 16: $1-20$.

Phillips, C. T., M. L. Alexander \& A. M. Gonzales. 2011. Use of macrophytes for egg deposition by the endangered fountain darter. Trans. Am. Fish. Soc. 140: 1392-1397.

Pholhiamhan, R., S. Saensouk \& P. Saensouk. 2017. Ethnobotany of Phu Thai ethnic group in Nakhon Phanom Province, Thailand. Walailak J. Sci. Technol. 15: 679-699.

Pickford, G. D. \& E. H. Reid. 1943. Competition of elk and domestic livestock for summer range forage. J. Wildl. Manag. 7: 328-332.

Picking, D. J. \& P. L. M. Veneman. 2004. Vegetation patterns in a calcareous sloping fen of southwestern Massachusetts, USA. Wetlands 24: 514-528.

Pieper, S. J., A. A. Nicholls, J. R. Freeland \& M. E. Dorken. 2017. Asymmetric hybridization in cattails (Typha spp.) and its implications for the evolutionary maintenance of native Typha latifolia. J. Hered. 108: 479-487.

Pierce, J. R. \& M. E. Jensen. 2002. A classification of aquatic plant communities within the Nothern Rocky Mountains. West. N. Am. Nat. 62: 257-265.

Pierinia, S. A. \& S. M. Thomaz. 2004. Effects of inorganic carbon source on photosynthetic rates of Egeria najas Planchon and Egeria densa Planchon (Hydrocharitaceae). Aquat. Bot. 78: 135-146.

Pierre, J. I. St. \& K. E. Kovalenko. 2014. Effect of habitat complexity attributes on species richness. Ecosphere 5: 1-10.

Pieterse, A. H. 1981. Hydrilla verticillata - a review. Abstr. Trop. Agric. 7: 9-34.

Pieterse, A. H. 2013. Is flowering in Lemnaceae stress-induced? A review. Aquat. Bot. 104: 1-4.

Pieterse, A. H. \& K. J. Murphy (eds.). 1993. Aquatic Weeds: The Ecology and Management of Nuisance Aquatic Vegetation. Oxford University Press, Oxford, United Kingdom. 593 pp.

Pieterse, A. H., P. R. Bhalla \& P. S. Sabharwal. 1970. Chemical induction of turions in Wolffiella floridana (JD Smith) Thompson. Acta Bot. Neerl. 19: 901-905.

Pieterse, A. H., P. R. Bhalla \& P. S. Sabharwal. 1971. Endogenous gibberellins in floating plants and turions of Wolffiella floridana. Physiol. Plant. 24: 512-516. 
Pieterse, A. H., L. de Lange \& L. Verhagen. 1981. A study on certain aspects of seed germination and growth of Pistia stratiotes L. Acta Bot. Neerl. 30: 47-57.

Pike, K. S., P. Starý, T. Miller, G. Graf, D. Allison, L. Boydston \& R. Miller. 2000. Aphid parasitoids (Hymenoptera: Braconidae: Aphidiinae) of northwest USA. Proc. Entomol. Soc. Washington 102: 688-740.

Pilon, J. \& L. Santamaría. 2002. Clonal variation in morphological and physiological responses to irradiance and photoperiod for the aquatic angiosperm Potamogeton pectinatus. J. Ecol. 90: 859-870.

Pilon, J., L. Santamaría, M. Hootsmans \& W. van Vierssen. 2003. Latitudinal variation in life-cycle characteristics of Potamogeton pectinatus L.: vegetative growth and asexual reproduction. Plant Ecol. 165: 247-262.

Pindel, Z. 2001. Influence of stratification time and colour of light on the germination of Calla palustris seeds. Zesz. Nauk. Akad. Roln. Kollataja Krakowie 24: 49-56.

Pine, R. T. \& L. W. J. Anderson. 1991. Plant preferences of triploid grass carp. J. Aquat. Plant Manag. 29: 80-82.

Pineda, P. M., R. J. Rondeau \& A. Ochs. 1999. A Biological Inventory and Conservation Recommendations for the Great Sand Dunes and San Luis Lakes, Colorado. Colorado Natural Heritage Program, Colorado State University, Ft. Collins, CO. 67 pp.

Pinkava, D. J. 1963. Vascular flora of the Miller blue hole and stream, Sandusky County, Ohio. Ohio J. Sci. 63: 113-127.

Pip, E. 1979. Survey of the ecology of submerged aquatic macrophytes in central Canada. Aquat. Bot. 7: 339-357.

Pip, E. 1987. The ecology of Potamogeton species in central North America. Hydrobiologia 153: 203-216.

Pip, E. 1988. Niche congruency of aquatic macrophytes in central North America with respect to 5 water chemistry parameters. Hydrobiologia 162: 173-182.

Pip, E. \& J. M. Stewart. 1976. The dynamics of two aquatic plantsnail associations. Can. J. Zool. 54: 1192-1205.

Pip, E. \& K. Simmons. 1986. Aquatic angiosperms at unusual depths in Shoal Lake, Manitoba-Ontario. Can. Field-Nat. 100: $354-358$.

Pıpalová, I. 2002. Initial impact of low stocking density of grass carp on aquatic macrophytes. Aquat. Bot. 73: 9-18.

Pípalová, I. 2003. Grass carp (Ctenopharyngodon idella) grazing on duckweed (Spirodela polyrhiza). Aquac. Int. 11: 325-336.

Pires, J. C. 2002. Brodiaea Smith. Pp. 321-327 In: Flora North America Editorial Committee (eds.), Flora of North America North of Mexico, Vol. 26: Magnoliophyta: Liliidae: Liliales and Orchidales. Oxford University Press, New York, NY.

Pires, J. C. \& K. J. Sytsma. 2002. A phylogenetic evaluation of a biosystematic framework: Brodiaea and related petaloid monocots (Themidaceae). Am. J. Bot. 89: 1342-1359.

Pires, J. C., I. J. Maureira, T. J. Givnish, K. J. Systma, O. Seberg, G. Peterson, J. I. Davis, D. W. Stevenson, P. J. Rudall, M. F. Fay \& M. W. Chase. 2006. Phylogeny, genome size, and chromosome evolution of Asparagales. Aliso 22: 287-304.

Pischtschan, E. \& R. Claßen-Bockhoff. 2008. Setting-up tension in the style of Marantaceae. Plant Biol. 10: 441-450.

Pitts-Singer, T. L., J. L. Hanula \& J. L. Walker. 2002. Insect pollinators of three rare plants in a Florida longleaf pine forest. Florida Entomol. 85: 308-316.

Platt, S. G., R. M. Elsey, H. Liu, T. R. Rainwater, J. C. Nifong, A. E. Rosenblatt, M. R. Heithaus \& F. J. Mazzotti. 2013. Frugivory and seed dispersal by crocodilians: an overlooked form of saurochory? J. Zool. 291: 87-99.

Plowman, T. 1969. Folk uses of new world aroids. Econ. Bot. 23: 97-122.
Pogan, E. 1963. Taxonomical value of Alisma triviale Pursh and Alisma subcordatum Rafin. Can. J. Bot. 41: 1011-1013.

Pogue, C. D., M. J. Monfils, D. L. Cuthrell, B. W. Heumann \& A. K. Monfils. 2016. Habitat suitability modeling of the federally endangered poweshiek skipperling in Michigan. J. Fish Wildl. Manag. 7: 359-368.

Poiani, K. A. \& W. C. Johnson. 1989. Effect of hydroperiod on seedbank composition in semipermanent prairie wetlands. Can. J. Bot. 67: 856-864.

Poiani, K. A. \& P. M. Dixon. 1995. Seed banks of Carolina bays: potential contributions from surrounding landscape vegetation. Am. Midl. Nat. 134: 140-154.

Poirrier, M. A., K. Burt-Utley, J. F. Utley \& E. A. Spalding. 2010. Submersed aquatic vegetation of the Jean Lafitte National Historical Park and Preserve. Southeast. Nat. 9: 477-486.

Pollock, D. A. 1999. Review of the New World Hemipeplinae (Coleoptera: Mycteridae) with descriptions of ten new species. Insect Syst. Evol. 30: 47-73.

Pollux, B. J. A. 2011. The experimental study of seed dispersal by fish (ichthyochory). Freshw. Biol. 56: 197-212.

Pollux, B. J. A. \& N. J. Ouborg. 2006. Isolation and characterization of microsatellites in Sparganium emersum and cross-species amplification in the related species S. erectum. Mol. Ecol. Notes 6: 530-532.

Pollux, B. J. A., N. J. Ouborg, J. M. Van Groenendael \& M. Klaassen. 2007. Consequences of intraspecific seed-size variation in Sparganium emersum for dispersal by fish. Funct. Ecol. 21: 1084-1091.

Pollux, B. J. A., E. Verbruggen, J. M. Van Groenendael \& N. J. Ouborg. 2009. Intraspecific variation of seed floating ability in Sparganium emersum suggests a bimodal dispersal strategy. Aquat. Bot. 90: 199-203.

Ponzio, K. J., S. J. Miller \& M. A. Lee. 2004. Long-term effects of prescribed fire on Cladium jamaicense crantz and Typha domingensis Pers. densities. Wetl. Ecol. Manag. 12: 123-133.

Poole, J. M., W. R. Carr, D. M. Price \& J. R. Singhurst. 2007. Rare Plants of Texas: A Field Guide. Texas A\&M University Press, College Station, TX. 640 pp.

Popenoe, J. 1986. Burmannia flava Mart. in Florida. Florida Sci. 49: 126.

Popov, S. V., G. Y. Popova, N. M. Paderin, O. A. Koval, R. G. Ovodova \& Y. S. Ovodov. 2007. Preventative antiinflammatory effect of potamogetonan, a pectin from the common pondweed Potamogeton natans L. Phytother. Res. 21: 609-614.

Porath, D., B. Hepher \& A. Koton. 1979. Duckweed as an aquatic crop: evaluation of clones for aquaculture. Aquat. Bot. 7: 273-278.

Porcher, R. D. 1981. The vascular flora of the Francis Beidler Forest in Four Holes Swamp, Berkeley and Dorchester Counties, South Carolina. Castanea 46: 248-280.

Posey, M. H. 1988. Community changes associated with the spread of an introduced seagrass, Zostera japonica. Ecology 69: 974-983.

Posey, M. H., C. Wigand \& J. C. Stevenson. 1993. Effects of an introduced aquatic plant, Hydrilla verticillata on benthic communities in the upper Chesapeake Bay. Estuar. Coast. Shelf Sci. 37: 539-555.

Posluszny, U. 1981. Unicarpellate floral development in Potamogeton zosteriformis. Can. J. Bot. 59: 495-504.

Posluszny, U. 1983. Re-evaluation of certain key relationships in the Alismatidae: floral organogenesis of Scheuchzeria palustris (Scheuchzeriaceae). Am. J. Bot. 70: 925-933.

Posluszny, U. \& R. Sattler. 1974. Floral development of Potamogeton richardsonii. Am. J. Bot. 61: 209-216. 
Posluszny, U. \& R. Sattler. 1976. Floral development of Zannichellia palustris. Can. J. Bot. 54: 651-662.

Posluszny, U. \& A. Charlton. 1993. Evolution of the helobial flower. Aquat. Bot. 44: 303-324.

Posluszny, U., W. A. Charlton \& D. K. Jain. 1986. Morphology and development of the reproductive shoots of Lilaea scilloides (Poir.) Hauman (Alismatidae). Bot. J. Linn. Soc. 92: 323-342.

Posluszny, U., W. A. Charlton \& D. H. Les. 2000. Modularity in Helobial flowers. Pp. 63-74 In: K. L. Wilson \& D. Morrison (eds.), Systematics and Evolution of Monocots. CSIRO Publishing, Collingwood, VIC, Australia.

Poster, L. S., A. F. Rhoads \& T. A. Block. 2013. Vascular flora and community assemblages of Delhaas Woods, a coastal plain forest in Bucks County, Pennsylvania. J. Torrey Bot. Soc. 140: 101-124.

Potgieter, M. 1940. Taro (Colocasia esculenta) as a food. J. Am. Diet. Assoc. 16: 536-540.

Pott, V. J. \& A. Pott. 2000. Plantas Aquáticas do Pantanal. EMBRAPA. Comunicação para Transferência de Tecnologia, Brasília, Brazil. 404 pp.

Potter, A., J. Fleckenstein, S. Richardson \& D. Hays. 1999. Washington State Status Report for the Mardon Skipper. Washington Department of Fish and Wildlife, Olympia, WA. 39 pp.

Potter, K. M., B. S. Crane \& W. W. Hargrove. 2017. A United States national prioritization framework for tree species vulnerability to climate change. New Forests 48: 275-300.

Poulin, M., T. Landry, V. Laberge \& L. Rochefort. 2012. Establishing vascular plants from seeds around pool margins in restored peatlands. Extended abstract No. 264. Proceedings of the 14th International Peat Congress, Stockholm, Sweden. 5 pp.

Power, P. 1996. Direct and indirect effects of floating vegetation mats on Texas wildrice (Zizania texana). Southwest. Nat. 41: 462-464.

Pozo, M. I., C. M. Herrera, W. Van den Ende, K. Verstrepen, B. Lievens \& H. Jacquemyn. 2015. The impact of nectar chemical features on phenotypic variation in two related nectar yeasts. FEMS Microbiol. Ecol. 91: fiv055.

Pradeesh, S., G. N. Archana, M. D. Chinmayee, C. S. Sarika, I. Mini \& T. S. Swapna. 2012. Biochemical and nutritional evaluation of Monochoria vaginalis Presl. Pp. 93-101 In: A. Sabu \& A. Augustine (eds.), Prospects in Bioscience: Addressing the Issues. Springer, New Delhi, India.

Prado, P. \& K. L. Heck, Jr. 2011. Seagrass selection by omnivorous and herbivorous consumers: determining factors. Mar. Ecol. Prog. Ser. 429: 45-55.

Prakash, P. S. \& N. M. Nayar. 2000. Flowering and pollination in taro. J. Root Crops 26: 15-19.

Prameela, R. \& M. Venkaiah. 2016. Recent study on aquatic monocots of Vizianagaram district, Andhra Pradesh, India. J. Med. Plant Stud. 4: 1-4.

Prasad, M. N. V. 2007. Aquatic plants for phytotechnology. Pp. 259274 In: S. N. Singh \& R. D. Tripathi (eds.), Environmental Bioremediation Technologies. Springer, Berlin, Germany.

Prasad, V. 2017. Some tetranychoid mites of Michigan. Great Lakes Entomol. 3: 24-31.

Prausová, R., J. Janová \& L. Šafářová. 2013. Testing achene germination of Potamogeton praelongus Wulfen. Centr. Eur. J. Biol. 8: 78-86.

Prausová, R., P. Sikorová \& L. Šafářová. 2014. Generative reproduction of long stalked pondweed (Potamogeton praelongus Wulfen) in the laboratory. Aquat. Bot. 120: 268-274.

Prausová, R., Z. Kozelková \& L. Safářová. 2015. Protocol for acclimatization of in vitro cultured Potamogeton praelongus-aspect of plantlet size and type of substrate. Acta Soc. Bot. Polon. 84: $35-41$.
Prena, J. 2017. Orchid weevils (Coleoptera: Curculionidae) in Canada. Can. Entomol. 149: 38-47.

Prepas, E. E., J. Babin, T. P. Murphy, P. A. Chambers, G. J. Sandland, A. Ghadouani \& M. Serediak. 2001. Long-term effects of successive $\mathrm{Ca}(\mathrm{OH})_{2}$ and $\mathrm{CaCO}_{3}$ treatments on the water quality of two eutrophic hardwater lakes. Freshw. Biol. 46: 1089-1103.

Prescott-Allen, R. \& C. Prescott-Allen. 1990. How many plants feed the world? Conserv. Biol. 4: 365-374.

Preston, C. D. 1995. Pondweeds of Great Britain and Ireland. B.S.B.I. Handbook No. 8. Botanical Society of the British Isles, London. UK. 352 pp.

Preston, C. D. \& J. M. Croft. 1997. Aquatic Plants in Britain and Ireland. Harley Books, Colchester, Essex, United Kingdom. $365 \mathrm{pp}$.

Prevett, J. P., I. F. Marshall \& V. G. Thomas. 1979. Fall foods of lesser snow geese in the James Bay region. J. Wildl. Manag. 43: 736-742.

Prevett, J. P., I. F. Marshall \& V. G. Thomas. 1985. Spring foods of snow and Canada geese at James Bay. J. Wildl. Manag. 49: $558-563$.

Price, M. 1966. The Iris Book. D. Van Nostrand Co., Inc., Princeton, NJ. 204 pp.

Price, S. D. \& S. C. H. Barrett. 1982. Tristyly in Pontederia cordata (Pontederiaceae). Can. J. Bot. 60: 897-905.

Price, S. D. \& S. C. H. Barrett. 1984. The function and adaptive significance of tristyly in Pontederia cordata L. (Pontederiaceae). Biol. J. Linn. Soc. 21: 315-329.

Prichard, E. C. \& F. T. Thorne. 1961. A new locality for Nemastylis floridana Small. Castanea 26: 97-97.

Prince, L. M. 2010. Phylogenetic relationships and species delimitation in Canna (Cannaceae). Pp. 301-331 In: O. Seberg, G. Petersen, A. S. Barfod \& J. I. Davis (eds.), Diversity, Phylogeny, and Evolution in the Monocotyledons. Aarhus University Press, Aarhus, Denmark.

Prince, L. M. \& W. J. Kress. 2006. Phylogenetic relationships and classification in Marantaceae: insights from plastid DNA sequence data. Taxon 55: 281-296.

Pritchard, A. L. 1935. The higher aquatic plants of Lake Abitibi, Ontario. Univ. Toronto Stud., Biol. Ser. 39: 79-85.

Pritchard, G. 1987. Growth and food choice by two species of limnephilid caddis larvae given natural and artificial foods. Freshw. Biol. 18: 529-535.

Proctor, H. C. 1998. Effect of pollen age on fruit set, fruit weight, and seed set in three orchid species. Can. J. Bot. 76: 420-427.

Proctor, H. C. \& L. D. Harder. 1994. Pollen load, capsule weight, and seed production in three orchid species. Can. J. Bot. 72: 249-255.

Profous, G. V. \& R. E. Loeb. 1984. Vegetation and plant communities of Van Cortlandt Park, Bronx, New York. Bull. Torrey Bot. Club 111: 80-89.

Promdee, K., D. Phihusut, A. Monthienvichienchai, Y. Tongaram \& P. Khongsuk. 2018. Conversion of Hydrilla verticillata to biooil and charcoal using a continuous pyrolysis reactor. Biofuels 2018. doi.org/10.1080/17597269.2018.1448633.

Provancha, J. A. \& C. R. Hall. 1991. Observations of associations between seagrass beds and manatees in east central Florida. Florida Sci. 54: 87-98.

Provost, M. W. 1947. Nesting of birds in the marshes of northwest Iowa. Am. Midl. Nat. 38: 485-503.

Puijalon, S., F. Piola \& G. Bornette. 2008. Abiotic stresses increase plant regeneration ability. Evol. Ecol. 22: 493-506.

Pulgar, Í. \& J. Izco. 2005. Egeria densa Planchon (Hydrocharitaceae) in Pontevedra province (Spain). Acta Bot. Malacitana 30: 173-175. 
Pulich, Jr., W. M. 1982. Culture studies of Halodule wrightii Aschers. Edaphic requirements. Bot. Mar. 25: 477-482.

Pulich, Jr., W. M. 1985. Seasonal growth dynamics of Ruppia maritima L. s.l. and Halodule wrightii Aschers. in southern Texas and evaluation of sediment fertility status. Aquat. Bot. 23: 53-66.

Punsalan, A. P., B. Collins \& L. E. DeWald. 2016. The germination ecology of Helonias bullata L. (Swamp Pink) with respect to dry, saturated, and flooded conditions. Aquat. Bot. 133: 17-23.

Purer, E. A. 1939. Ecological study of vernal pools, San Diego County. Ecology 20: 217-229.

Putman, W. L. 1953. Notes on the bionomics of some Ontario cercopids (Homoptera). Can. Entomol. 85: 244-248.

Pyne, M. 2005. West Gulf Coastal Plain flatwoods pond ecological system. Ecological integrity assessment. NatureServe, Ecology Department (Southeast), Durham, NC. 32 pp.

Qais, N., M. R. Mandal, M. A. Rashid, A. Jabbar, H. Koshino, K. Nagasawa \& T. Nakata. 1998. A furanoid labdane diterpene from Potamogeton nodosus. J. Nat. Prod. 61: 156-157.

Qi, Z., K. M. Cameron, P. Li, Y. Zhao, S. Chen, G. Chen \& C. Fu. 2013. Phylogenetics, character evolution, and distribution patterns of the greenbriers, Smilacaceae (Liliales), a near-cosmopolitan family of monocots. Bot. J. Linn. Soc. 173: 535-548.

Qian, Y., N. Xu, J. Liu \& R. Tian. 2018. Inhibitory effects of Pontederia cordata on the growth of Microcystis aeruginosa. Water Sci. Technol. 1: 99-107.

Qian, Y.-P., X.-T. Li \& R.-N. Tian. 2019. Effects of aqueous extracts from the rhizome of Pontederia cordata on the growth and interspecific competition of two algal species. Ecotoxicol. Environ. Saf. 168: 401-407.

Quade, H. W. 1969. Cladoceran faunas associated with aquatic macrophytes in some lakes in northwestern Minnesota. Ecology 50: $170-179$.

Quattrocchi, U. 2012. CRC World Dictionary of Medicinal and Poisonous Plants: Common Names, Scientific Names, Eponyms, Synonyms, and Etymology. 5 vols. CRC Press, Boca Raton, FL. 3960 pp.

Quayyum, H. A., A. U. Mallik \& P. F. Lee. 1999. Allelopathic potential of aquatic plants associated with wild rice (Zizania palustris): I. Bioassay with plant and lake sediment samples. J. Chem. Ecol. 25: 209-220.

Querry, N. D. \& K. A. Harper. 2017. Structural diversity as a habitat indicator for endangered lakeshore flora using an assemblage of common plant species in Atlantic Canada. Plant Ecol. 218: 1339-1353.

Querry, N. D., X. Bordeleau, K. A. Harper \& S. P. Basquill. 2017. Multiscale habitat characterization of herbaceous Atlantic coastal plain flora on lakeshores in Nova Scotia. Botany 95: 587-598.

Quinlan, E. L., E. J. Phlips, K. A. Donnelly, C. H. Jett, P. Sleszynski \& S. Keller. 2008. Primary producers and nutrient loading in Silver Springs, FL, USA. Aquat. Bot. 88: 247-255.

Racine, C. H., M. T. Jorgenson \& J. C. Walters. 1998. Thermokarst vegetation in lowland birch forests on the Tanana Flats, interior Alaska, USA. Pp. 927-933 In: A. G. Lewkowicz \& M. Allard (eds.), Proceedings of the Seventh International Conference on Permafrost, Université Laval, Québec, Collection Nordicana, Vol. 57. Université Laval, Quebec City, QC, Canada.

Radomski, P. \& D. Perleberg. 2012. Application of a versatile aquatic macrophyte integrity index for Minnesota lakes. Ecol. Indicators 20: 252-268.

Rae, J. G. 1995. Aspects of the population and reproductive ecology of the endangered fragrant prickly-apple cactus [Cereus eriophorus var. fragrans (Small) L. Benson]. Castanea 60: 255-269.
Raina, S. N. 1978. Genetic mechanisms underlying evolution in Crinum. Cytologia 43: 575-580.

Ramachandran, K. 1969. Chromosome numbers in Zingiberaceae. Cytologia 34: 213-221.

Ramachandran, R. \& M. Nosonovsky. 2014. Surface micro/nanotopography, wetting properties and the potential for biomimetic icephobicity of skunk cabbage Symplocarpus foetidus. Soft Matter 10: 7797-7803.

Ramaley, F. 1919. Vegetation of undrained depressions on the Sacramento plains. Bot. Gaz. 68: 380-387.

Ramanaiah, K., A. V. R. Prasad \& K. H. C. Reddy. 2011. Mechanical properties and thermal conductivity of Typha angustifolia natural fiber-reinforced polyester composites. Int. J. Polym. Anal. Charact. 16: 496-503.

Ramirez, N. \& Y. Brito. 1990. Reproductive biology of a tropical palm swamp community in the Venezuelan llanos. Am. J. Bot. 77: $1260-1271$.

Ramirez, N. \& Y. Brito. 1992. Pollination biology in a palm swamp community in the Venezuelan central plains. Bot. J. Linn. Soc. 110: 277-302.

Ramirez, Jr., P. \& K. Dickerson. 1997. Follow-up investigation of selenium and other trace elements in biota from the Riverton reclamation project, Fremont County, Wyoming. U.S. Fish \& Wildlife Publication 213. U.S. Fish \& Wildlife Service, Ecological Services, Wyoming Field Office, Cheyenne, WY. $20 \mathrm{pp}$.

Ramirez, Jr., P. \& K. Dickerson. 1999. Monitoring of selenium concentrations in biota from the Kendrick reclamation project, Natrona County, Wyoming 1992-1996. Contaminant Report No.: R6/714C/99. U.S. Fish \& Wildlife Service, Ecological Services, Wyoming Field Office, Cheyenne, WY. 16 pp.

Ramírez-Babativa, D. F. \& A. J. E. Ramírez. 2018. Comparison of the populational characteristics of Lemna minuta (Araceae: Lemnoideae) in three culture media. Revista Colombiana Biotecnol. 20: 84-96.

Ramírez-García, P., A. Lot, C. M. Duarte, J. Terrados \& N. S. R. Agawin. 1998. Bathymetric distribution, biomass and growth dynamics of intertidal Phyllospadix scouleri and Phyllospadix torreyi in Baja California (Mexico). Mar. Ecol. Prog. Ser. 173: 13-23.

Ramırez-Garcıa, P., J. Terrados, F. Ramos, A. Lot, D. Ocaña \& C. M. Duarte. 2002. Distribution and nutrient limitation of surfgrass, Phyllospadix scouleri and Phyllospadix torreyi, along the Pacific coast of Baja California (Mexico). Aquat. Bot. 74: 121-131.

Ramtin, M., M. R. M. K. Pahlaviani, A. Massiha, K. Issazadeh \& S. Heidari. 2013. Comparative evaluation of the antibacterial activities of essential oils of Iris pseudacorus and Urtica dioica native north of Iran. J. Pure Appl. Microbiol. 7: 1065-1070.

Randall, R. P. 2007. The Introduced Flora of Australia and Its Weed Status. CRC for Australian Weed Management, University of Adelaide, Adelaide, SA, Australia. 524 pp.

Randall, R. P. \& S. G. Lloyd. 2002. Weed warning from down under - the weed potential of selected South African plants in cultivation in California. Pp. 192-195 In: H. Spafford-Jacob, J. Dodd \& J. Moore (eds.), Proceedings of the 13th Australian Weeds Conference, Perth, Western Australia September 8-13th 2002. Plant Protection Society of Western Australia, Perth, WA, Australia.

Ransom, J. K. \& E. A. Oelke. 1983. Cultural control of common waterplantain (Alisma triviale) in wild rice (Zizania palustris). Weed Sci. 31: 562-566.

Rapoport, E. H., E. Raffaele, L. Ghermandi \& L. Margutti. 1995. Edible weeds: a scarcely used resource. Bull. Ecol. Soc. Am. 76: $163-166$. 
Rasmussen, H. N. 1995. Terrestrial Orchids: From Seed to Mycotrophic Plant. Cambridge University Press, Oxford, United Kingdom. 444 pp.

Rasmussen, H. N., K. W. Dixon, J. Jersáková \& T. Těšitelová. 2015. Germination and seedling establishment in orchids: a complex of requirements. Ann. Bot. 116: 391-402.

Rataj, K. 1975. Revizion [sic!] of the genus Echinodorus Rich. Studie Československá Akademie Vĕd. Československá akademie věd, Praha, Czech Republic. 156 pp.

Rataj, K. 2004. A New Revision of the Swordplant Genus Echinodorus Richard, 1848 (Alismataceae). Aquapress, Miradolo Terme (Pavia), Italy. 142 pp.

Raulings, E., K. A. Y. Morris, R. Thompson \& R. Mac Nally. 2011. Do birds of a feather disperse plants together? Freshw. Biol. 56: $1390-1402$.

Raven, P. H. \& J. H. Thomas. 1970. Iris pseudacorus in western North America. Madroño 20: 390-391.

Raven, P. H., D. W. Kyhos \& A. J. Hill. 1965. Chromosome numbers of spermatophytes, mostly Californian. Aliso 6: 105-113.

Raven, J. A., L. L. Handley, J. J. MacFarlane, S. McInroy, L. McKenzie, J. H. Richards \& G. Samuelsson. 1988. The role of $\mathrm{CO}_{2}$ uptake by roots and CAM in acquisition of inorganic $\mathrm{C}$ by plants of the isoetid life-form: a review, with new data on Eriocaulon decangulare L. New Phytol. 108: 125-148.

Ray, A. M. \& R. S. Inouye. 2006. Effects of water-level fluctuations on the arbuscular mycorrhizal colonization of Typha latifolia L. Aquat. Bot. 84: 210-216.

Raynal, D. J. \& J. W. Geis. 1978. Winter studies of littoral vegetation. Technical Report G. State University College of Environmental Science \& Forestry, Institute of Environmental Program Affairs, Syracuse, NY. 21 pp.

Rea, A. M. 1997. At the Desert's Green Edge: An Ethnobotany of the Gila River Pima. University of Arizona Press, Tuscon, AZ. $430 \mathrm{pp}$.

Reaume, T. 2009. 620 Wild Plants of North America: Fully Illustrated. Canadian Plains Research Center, Regina, Saskatchewan, CA. $784 \mathrm{pp}$.

Rebaque, D., R. Martínez-Rubio, S. Fornalé, P. García-Angulo, A. Alonso-Simón, J. M. Álvarez, D. Caparros-Ruiz, J. L. Acebes \& A. Encina. 2017. Characterization of structural cell wall polysaccharides in cattail (Typha latifolia): evaluation as potential biofuel feedstock. Carbohydr. Polym. 175: 679-688.

Redekop, P., D. Hofstra \& A. Hussner. 2016. Elodea canadensis shows a higher dispersal capacity via fragmentation than Egeria densa and Lagarosiphon major. Aquat. Bot. 130: 45-49.

Redmond, K., J. A. Reinartz \& S. Critchley. 1993. Flowering phenology along the UWM Field Station boardwalk in the Cedarburg Bog. Field Sta. Bull. 26(2): 1-23.

Reed, E. L. 1930. Vegetation of the playa lakes in the staked plains of western Texas. Ecology 11: 597-600.

Reed, D. C., S. J. Holbrook, E. Solomon \& M. Anghera. 1998. Studies on germination and root development in the surfgrass Phyllospadix torreyi: implications for habitat restoration. Aquat. Bot. 62: 71-80.

Reed, D. C., S. J. Holbrook, C. A. Blanchette \& S. Worcester. 2009. Patterns and sources of variation in flowering, seed supply and seedling recruitment in surfgrass Phyllospadix torreyi. Mar. Ecol. Prog. Ser. 384: 97-106.

Reena, T., R. Prem, M. S. Deepthi, R. B. Ramachanran \& S. Sujatha. 2013. Comparative effect of natural commodities and commercial medicines against oral thrush causing fungal organism of Candida albicans. Sci. J. Clin. Med. 2: 75-80.
Reese, M. C. \& K. S. Lubinski. 1983. A survey and annotated checklist of late summer aquatic and floodplain vascular flora, middle and lower Pool 26, Mississippi and Illinois rivers. Castanea 48: 305-316.

Reeves, L. M. \& T. Reeves. 1984. Life history and reproduction of Malaxis paludosa in Minnesota. Am. Orchid Soc. Bull. 53: 1280-1291.

Reeves, T. \& L. Reeves. 1985. Rediscovery of Malaxis paludosa (L.) Sw. (Orchidaceae) in Minnesota. Rhodora 87: 133-136.

Refaat, J., M. S. Kamel, M. A. Ramadan \& A. A. Ali. 2012a. Crinum; an endless source of bioactive principles: a review, Part II. Crinum alkaloids: crinine-type alkaloids. Int. J. Pharmaceut. Sci. Res. 3: 3091-3100.

Refaat, J., M. S. Kamel, M. A. Ramadan \& A. A. Ali. 2012b. Crinum; an endless source of bioactive principles: a review. Part III; crinum alkaloids: Belladine-, galanthamine-, lycorenine-, tazettine-type alkaloids and other minor types. Int. J. Pharmaceut. Sci. Res. 3: 3630-3638.

Reid, T. C. 1978. Vegetation and environment patterns of Liard River Hot Springs Provincial Park, British Columbia. M.S. thesis. Simon Fraser University, Burnaby, BC. 206 pp.

Reid, C. S. \& P. L. Faulkner. 2010. Noteworthy collections: Louisiana. Castanea 75: 138-140.

Reid, C. S. \& L. Urbatsch. 2012. Noteworthy plant records from Louisiana. J. Bot. Res. Inst. Texas 6: 273-278.

Reid, C. S., P. L. Faulkner, M. H. MacRoberts, B. R. MacRoberts \& M. Bordelon. 2010. Vascular flora and edaphic characteristics of saline prairies in Louisiana. J. Bot. Res. Inst. Texas 4: 357-379.

Reimer, A. 2001. The role of bog plants in the exchange of carbon dioxide and water between the atmosphere and the Mer Bleue peatland. M.S. thesis. McGill University, Montreal, CA. 83 pp.

Reiskind, J. B., T. V. Madsen, L. C. Van Ginkel \& G. Bowes. 1997. Evidence that inducible $\mathrm{C}_{4}$-type photosynthesis is a chloroplastic $\mathrm{CO}_{2}$-concentrating mechanism in Hydrilla, a submersed monocot. Plant Cell Environ. 20: 211-220.

Rejmánek, M. \& J. M. Randall. 1994. Invasive alien plants in California: 1993 summary and comparison with other areas in North America. Madroño 41: 161-177.

Rejmánková, E. 1976. Germination of seeds of Lemna gibba. Folia Geobot. Phytotax. 11: 261-267.

Remizowa, M. V., D. D. Sokoloff, L. M. Campbell, D. W. Stevenson \& P. J. Rudall. 2011. Harperocallis is congeneric with Isidrogalvia (Tofieldiaceae, Alismatales): evidence from comparative floral morphology. Taxon 60: 1076-1094.

Ren, D. \& S. Zhang. 2008. Separation and identification of the yellow carotenoids in Potamogeton crispus L. Food Chem. 106: 410-414.

Renn, C. E. 1935. A mycetozoan parasite of Zostera marina. Nature 135: 544-545.

Renzi, M., A. Giovani \& S. E. Focardi. 2013. Biofuel production from the Orbetello Lagoon macrophytes: efficiency of lipid extraction using accelerate solvent extraction technique. $J$. Environ. Protect. 4: 1224-1229.

Reusch, T. B. H. 2001. Fitness-consequences of geitonogamous selfing in a clonal marine angiosperm (Zostera marina). J. Evol. Biol. 14: 129-138.

Reveal, J. L. 1990. The neotypification of Lemna minuta Humb., Bonpl. \& Kunth, an earlier name for Lemna minuscula Herter (Lemnaceae). Taxon 39: 328-330.

Reveal, J. L. 2012. An outline of a classification scheme for extant flowering plants. Phytoneuron 2012-37: 1-221.

Reverchon, J. 1886. Botanizing in Texas. II. Bot. Gaz. 11: 211-216. 
Reynolds, C., N. A. F. Miranda \& G. S. Cumming. 2015. The role of waterbirds in the dispersal of aquatic alien and invasive species. Divers. Distrib. 21: 744-754.

Reznicek, A. A. 1994. The disjunct coastal plain flora in the Great Lakes region. Biol. Conserv. 68: 203-215.

Reznicek, A. A. \& R. S. W. Bobbette. 1976. The taxonomy of Potamogeton subsection hybridi in North America. Rhodora 78: $650-673$.

Reznicek, A. A. \& D. F. Murray. 2013. A re-evaluation of Carex specuicola and the Carex parryana complex (Cyperaceae). J. Bot. Res. Inst. Texas 7: 37-51.

Rhoades, R. W. 1962. The aquatic form of Alisma subcordatum Raf. Rhodora 64: 227-229.

Rhoads, A. F. 1984. Rare Pennsylvania plants. Bartonia 50: 61-63.

Rhodes, M. J. 1978. Habitat preferences of breeding waterfowl on the Texas high plains. M.S. thesis. Texas Tech University, Lubbock, TX. 48 pp.

Ribeiro, J. P. N., R. S. Matsumoto, L. K. Takao, A. C. Peret \& M. I. S. Lima. 2011. Spatial distribution of Crinum americanum L. in tropical blind estuary: hydrologic, edaphic and biotic drivers. Environ. Exp. Bot. 71: 287-291.

Rich, P. H., R. G. Wetzel \& N. Thuy. 1971. Distribution, production and role of aquatic macrophytes in a southern Michigan marl lake. Freshw. Biol. 1: 3-21.

Richards, J. H. \& C. T. Ivey. 2004. Morphological plasticity of Sagittaria lancifolia in response to phosphorus. Aquat. Bot. 80: $53-67$.

Richardson, F. D. 1980. Ecology of Ruppia maritima L. in New Hampshire (U.S.A.) tidal marshes. Rhodora 82: 403-439.

Richardson, C. J. 1983. Pocosins: vanishing wastelands or valuable wetlands? Bioscience 33: 626-633.

Richardson, J. S. \& H. F. Clifford. 1983. Life history and microdistribution of Neureclipsis bimaculata (Trichoptera: Polycentropodidae) in a lake outflow stream of Alberta, Canada. Can. J. Zool. 61: 2434-2445.

Richardson, A. \& K. King. 2011. Plants of Deep South Texas: A Field Guide to the Woody and Flowering Species. Texas A\&M University Press, College Station, TX. 448 pp.

Richardson, S. M., J. M. Hanson \& A. Locke. 2002. Effects of impoundment and water-level fluctuations on macrophyte and macroinvertebrate communities of a dammed tidal river. Aquat. Ecol. 36: 493-510.

Riddin, T. \& J. B. Adams. 2009. The seed banks of two temporarily open/closed estuaries in South Africa. Aquat. Bot. 90: 328-332.

Ridley, H. N. 1930. The Dispersal of Plants Throughout the World. L. Reeve \& Co. Ltd., Ashford, Kent, United Kingdom. 744 pp.

Riemer, D. N. 1975. Seed dormancy and longevity in Potamogeton pulcher Tuckerm. Proc. Northeast. Weed Control Conf. 29: 114-117.

Riemer, D. N. \& S. J. Toth. 1969. A survey of the chemical composition of Potamogeton and Myriophyllum in New Jersey. Weed Sci. 17: 219-223.

Riggs, G. B. 1925. Some Sphagnum bogs of the north Pacific coast of America. Ecology 6: 260-278.

Riggs, G. B. 1940. Comparisons of the development of some sphagnum bogs of the Atlantic coast, the interior, and the Pacific coast. Am. J. Bot. 27: 1-14.

Riis, T., T. V. Madsen \& R. S. H. Sennels. 2009. Regeneration, colonisation and growth rates of allofragments in four common stream plants. Aquat. Bot. 90: 209-212.

Riis, T., C. Lambertini, B. Olesen, J. S. Clayton, H. Brix \& B. K. Sorrell. 2010. Invasion strategies in clonal aquatic plants: are phenotypic differences caused by phenotypic plasticity or local adaptation? Ann. Bot. 106: 813-822.
Riis, T., B. Olesen, J. S. Clayton, C. Lambertini, H. Brix \& B. K. Sorrell. 2012. Growth and morphology in relation to temperature and light availability during the establishment of three invasive aquatic plant species. Aquat. Bot. 102: 56-64.

Ring, R. M., E. A. Spencer \& K. S. Walz. 2013. Vulnerability of 70 Plant Species of Greatest Conservation Need to Climate Change in New Jersey. New York Natural Heritage Program, Albany, NY and New Jersey Natural Heritage Program, Department of Environmental Protection, Office of Natural Lands Management, Trenton, NJ. 38 pp.

Ritchie, J. C. 1957. The vegetation of northern Manitoba: II. A prisere on the Hudson Bay lowlands. Ecology 38: 429-435.

Rixon, C. A. M., I. C. Duggan, N. M. N. Bergeron, A. Ricciardi \& H. J. Macisaac. 2005. Invasion risks posed by the aquarium trade and live fish markets on the Laurentian Great Lakes. Biodivers. Conserv. 14: 1365-1381.

Rizwana, M., M. Darshan \& D. Nilesh. 2014. Phytoremediation of textile waste water using potential wetland plant [sic!]: eco sustainable approach. Int. J. Interdiscipl. Multidiscipl. Stud. 1: 130-138.

Rober, A. R., K. H. Wyatt, R. J. Stevenson \& M. R. Turetsky. 2014. Spatial and temporal variability of algal community dynamics and productivity in floodplain wetlands along the Tanana River, Alaska. Freshw. Sci. 33: 765-777.

Roberts, T. H. \& D. H. Arner. 1984. Food habits of beaver in eastcentral Mississippi. J. Wildl. Manag. 48: 1414-1419.

Roberts, M. L. \& R. R. Haynes. 1986. Flavonoid systematics of Potamogeton subsections Perfoliati and Praelongi (Potamogetonaceae). Nordic J. Bot. 6: 291-294.

Roberts, B. A. \& A. Robertson. 1986. Salt marshes of Atlantic Canada: their ecology and distribution. Can. J. Bot. 64: 455-467.

Roberts, D. A., R. Singer \& C. W. Boylen. 1985. The submersed macrophyte communities of Adirondack lakes (New York, U.S.A.) of varying degrees of acidity. Aquat. Bot. 21: 219-235.

Roberts, R. E., M.Y. Hedgepeth \& T. R. Alexander. 2008. Vegetational responses to saltwater intrusion along the Northwest Fork of the Loxahatchee River within Jonathan Dickinson State Park. Florida Sci. 71: 383-397.

Robertson, C. 1896. Flowers and insects. XVI. Bot. Gaz. 21: 266-274.

Robertson, C. 1924. Flowers and insects. XXIII. Bot. Gaz. 78: 68-84.

Robertson, K. R. 1976. The genera of Haemodoraceae in the southeastern United States. J. Arnold Arb. 57: 205-216.

Robertson, K. R. 2002. Haemodoraceae R. Brown. Pp. 47-48 In: Flora North America Editorial Committee (eds.), Flora of North America North of Mexico, Vol. 26: Magnoliophyta: Liliidae: Liliales and Orchidales. Oxford University Press, New York, NY.

Robertson, A. I. \& K. H. Mann. 1982. Population dynamics and life history adaptations of Littorina neglecta Bean in an eelgrass meadow (Zostera marina L.) in Nova Scotia. J. Exp. Mar. Biol. Ecol. 63: 151-171.

Robertson, K., G. A. Levin \& L. R. Phillippe. 1995. Vascular plants and natural areas of Site M, Cass County, Illinois. Technical Report 1995 (17). Illinois Natural History Survey, Center for Biodiversity, Champaign, IL. 74 pp.

Robeson, M. S., K. Khanipov, G. Golovko, S. M. Wisely, M. D. White, M. Bodenchuck, T. J. Smyser, Y. Fofanov, N. Fierer \& A. J. Piaggio. 2018. Assessing the utility of metabarcoding for diet analyses of the omnivorous wild pig (Sus scrofa). Ecol. Evol. 8: 185-196.

Robles, W., J. D. Madsen \& V. L. Maddox. 2008. Reservoir Survey for Invasive and Native Aquatic Plants Species Within the Pat Harrison Waterway District. GeoResources Institute, Mississippi State University, Mississippi State, MS. 28 pp. 
Robinson, F. D. 1956. An ecological survey of the vascular aquatic vegetation of the Cumberland Plateau in Tennessee. M.S. thesis. University of Tennessee, Knoxville, TN. 44 pp.

Robinson, J. V. \& B. L. Frye. 1986. Survivorship, mating and activity pattern of adult Telebasis salva (Hagen) (Zygoptera: Coenagrionidae). Odonatologica 15: 211-217.

Robinson, A. T., J. E. Fulmer, L. D. Avenetti. 2007. Aquatic plant surveys and evaluation of aquatic plant harvesting in Arizona reservoirs. Federal Aid in Sport Fish Restoration Project F-14-R. Arizona Game and Fish Department, Phoenix, AZ. 39 pp.

Robinson, D. J., E. Gandy, C. VanHoek \& R. W. Pemberton. 2011. Naturalization of the nun's hood orchid (Phaius tankervilleae: Orchidaceae) in central Florida. J. Bot. Res. Inst. Texas 5: 337-339.

Robson, D. B., J. H. Wiersema, C. B. Hellquist \& T. Borsch. 2016. Distribution and ecology of a new species of water-lily, Nymphaea loriana (Nymphaeaceae), in western Canada. Can. Field-Nat. 130: 25-31.

Rocchio, J., J. Sovell \& P. Lyon. 2001. Survey of Seeps and Springs Within the Bureau of Land Management's Grand Junction Field Office management Area (Garfield County, CO). Colorado Natural Heritage Program, Colorado State University, Fort Collins, CO. 19 pp.

Rocchio, J., M. March \& D. G. Anderson. 2006. Epipactis gigantea Dougl. ex Hook. (Stream Orchid): A Technical Conservation Assessment. USDA Forest Service, Rocky Mountain Region. Available online: http://www.fs.fed.us/r2/projects/scp/assessments/epipactisgigantea.pdf [accessed 17 February, 2019].

Rochefort, L. \& D. H. Vitt. 1988. Effects of simulated acid rain on Tomenthypnum nitens and Scorpidium scorpioides in a rich fen. Bryologist 91: 121-129.

Rodger, E. A. 1933. Wound healing in submerged plants. Am. Midl. Nat. 14: 704-713.

Rodgers, H. L., F. P. Day \& R. B. Atkinson. 2003. Fine root dynamics in two Atlantic white-cedar wetlands with contrasting hydroperiods. Wetlands 23: 941-949.

Rogers, G. K. 1983. The genera of Alismataceae in the southeastern United States. J. Arnold Arbor. 64: 383-420.

Rogers, G. K. 1984. The Zingiberales (Cannaceae, Marantaceae, and Zingiberaceae) in the southeastern United States. J. Arnold Arbor. 65: 5-55.

Rogers, J. G. 1993. Availability of a draft recovery plan for the Little Aguja pondweed for review and comment. Fed. Reg. 58: 67808.

Rogers, J. P. \& L. J. Korschgen. 1966. Foods of lesser scaups on breeding, migration, and wintering areas. J. Wildl. Manag. 30: 258-264.

Rolim, R. G., P. M. A. de Ferreira, A. A. Schneider \& G. E. Overbeck. 2015. How much do we know about distribution and ecology of naturalized and invasive alien plant species? A case study from subtropical southern Brazil. Biol. Invasions 17: $1497-1518$.

Romanello, G. A., K. L. Chuchra-Zbytniuk, J. L. Vandermer \& B. W. Touchette. 2008. Morphological adjustments promote drought avoidance in the wetland plant Acorus americanus. Aquat. Bot. 89: 390-396.

Romero-González, G. A., G. C. Fernández-Concha, R. L. Dressler, L. K. Magrath \& G. W. Argus. 2002. Orchidaceae Jussieu. Orchid family. Pp. 490-499 In: Flora North America Editorial Committee (eds.), Flora of North America North of Mexico, Vol. 26: Magnoliophyta: Liliidae: Liliales and Orchidales. Oxford University Press, New York, NY.

Ronse, A. 2011. Botanic garden escapes' [sic!] from the living collections at the Botanic Garden. Scripta Bot. Belg. 47: 89-111.
Rooney, R. C., C. Carli \& S. E. Bayley. 2013. River connectivity affects submerged and floating aquatic vegetation in floodplain wetlands. Wetlands 33: 1165-1177.

Rosatti, T. J. 1987. The genera of Pontederiaceae in the southeastern United States. J. Arnold Arb. 68: 35-71.

Rose, C. D., W. C. Sharp, W. J. Kenworthy, J. H. Hunt, W. G. Lyons, E. J. Prager, J. F. Valentine, M. O. Hall, P. E. Whitfield \& J. W. Fourqurean. 1999. Overgrazing of a large seagrass bed by the sea urchin Lytechinus variegatus in Outer Florida Bay. Mar. Ecol. Prog. Ser. 190: 211-222.

Rosen, D. J. 2002. Cryptocoryne beckettii (Araceae), a new aquatic plant in Texas. Sida 19: 399-401.

Rosen, D. J. 2007. The vascular flora of Nash Prairie: a coastal prairie remnant in Brazoria County, Texas. J. Bot. Res. Inst. Texas 1: 679-692.

Rosendahl, C. O. \& F. K. Butters. 1935. The genus Najas in Minnesota. Rhodora 37: 345-348.

Rosenthal, S. K., S. S. Stevens \& D. M. Lodge. 2006. Whole-lake effects of invasive crayfish (Orconectes spp.) and the potential for restoration. Can. J. Fish. Aquat. Sci. 63: 1276-1285.

Rosenthal, M. A., S. R. Rosenthal, G. Johnson, W. C. Taylor \& E. A. Zimmer. 2014. Isoetes viridimontana: a previously unrecognized quillwort from Vermont, USA. Am. Fern J. 104: 7-16.

Rosine, W. N. 1955. The distribution of invertebrates on submerged aquatic plant surfaces in Muskee Lake, Colorado. Ecology 36: 308-314.

Ross, C., M. P. Puglisi \& V. J. Paul. 2008. Antifungal defenses of seagrasses from the Indian River Lagoon, Florida. Aquat. Bot. 88: $134-141$.

Ross, T. G., C. F. Barrett, M. S. Gomez, V. K.-Y. Lam, C. L. Henriquez, D. H. Les, J. I. Davis, A. Cuenca, G. Petersen, O. Seberg, M. Thadeo, T. J. Givnish, J. Conran, D. W. Stevenson \& S. W. Graham. 2016. Plastid phylogenomics and molecular evolution of Alismatales. Cladistics 32: 160-178.

Rossell, I. M. \& D. A. Losure. 2005. The habitat and plant associates of Eriocaulon decangulare L. in three southern Appalachian wetlands. Castanea 70: 129-136.

Rossi, C. C., A. P. Aguilar, M. A. N. Diaz \& A. D. O. B. Ribon. 2011. Aquatic plants as potential sources of antimicrobial compounds active against bovine mastitis pathogens. Afr. J. Biotechnol. 10: 8023-8030.

Rosso, W. A. 1977. Acid lake renovation. Pp. 61-70 In: Seventh Symposium on Coal Mine Drainage Research. National Coal Association, Washington, DC.

Rothe, S. P. 2011. Exotic medicinal plants from West Vidarbha region - V. Int. Multidiscip. Res. J. 2011: 14-16.

Rothlisberger, J. D., W. L. Chadderton, J. McNulty \& D. M. Lodge. 2010. Aquatic invasive species transport via trailered boats: what is being moved, who is moving it, and what can be done. Fisheries 35: 121-132.

Rouger, R. \& A. S. Jump. 2013. Isolation and characterization of 20 microsatellite loci for the saltmarsh plant Triglochin maritima L. Conserv. Genet. Resour. 5: 1157-1158.

Rouger, R. \& A. S. Jump. 2014. A seascape genetic analysis reveals strong biogeographical structuring driven by contrasting processes in the polyploid saltmarsh species Puccinellia maritima and Triglochin maritima. Mol. Ecol. 23: 3158-3170.

Rout, G. K., H.-S. Shin, S. Gouda, S. Sahoo, G. Das, L. F. Fraceto \& J. K. Patra. 2018. Current advances in nanocarriers for biomedical research and their applications. Artif. Cells Nanomed. Biotechnol. doi: 10.1080/21691401.2018.14788431-10.

Rowell, Jr., C. M. 1983. Status Report, Potamogeton clystocarpus Fern. U.S. Fish and Wildlife Service. Albuquerque, NM. 9 pp. 
Roze, E. 1887. Le mode de fecondation du Zannichellia palustris L. J. Bot. (Paris) 1: 296-299.

Rozema, J., W. Arp, J. Van Diggelen, M. Van Esbroek, R. Broekman \& H. Punte. 1986. Occurrence and ecological significance of vesicular arbuscular mycorrhiza in the salt marsh environment. Acta Bot. Neerl. 35: 457-467.

Rozentsvet, O. A., N. M. Dembitsky \& V. S. Zhuicova. 1995a. Lipids from macrophytes of the middle Volga. Phytochemistry 38: 1209-1213.

Rozentsvet, O. A., E. R. Ponomareva, Y. N. Mazepova \& N. V. Koneva. 1995b. Lipids of some aquatic plants of the central Volga region. Chem. Nat. Compd. 31: 169-171.

Rozentsvet, O. A., S. V. Saksonov \& V. M. Dembitsky. 2002. Hydrocarbons, fatty acids, and lipids of freshwater grasses of the Potamogetonaceae family. Biochemistry (Moscow) 67: 351-356.

Rubtsov, N. I. 1975. Sagittaria platyphylla-novyi adventivnyi vid flory Evropeiskoi chasti SSSR. Bot. Zhurn. 60: 387-388.

Ruch, D. G., A. Schoultz \& K. S. Badger. 1998. The flora and vegetation of Ginn Woods, Ball State University, Delaware County, Indiana. Proc. Indiana Acad. Sci. 107: 17-60.

Ruch, D. G., B. G. Torke, B. R. Hess, K. S. Badger \& P. E. Rothrock. 2008. The vascular flora and vegetational communities of the wetland complex on the IMI property in Henry County, near Luray, Indiana. Proc. Indiana Acad. Sci. 117: 142-158.

Ruch, D. G., B. G. Torke, B. R. Hess \& K. S. Badger. 2009. The vascular flora and plant communities of the Bennett wetland complex in Henry County, Indiana. Proc. Indiana Acad. Sci. 118: $39-54$.

Ruchty, A. 2011. Conservation Strategy for Sisyrinchium sarmentosum Suks. ex. Greene. USDA Forest Service Region 6, Oregon and Washington, Pacific Northwest Region, Portland, OR. 68 pp.

Ruckelshaus, M. H. 1995. Estimates of outcrossing rates and of inbreeding depression in a population of the marine angiosperm Zostera marina. Mar. Biol. 123: 583-593.

Ruckelshaus, M. H. 1996. Estimation of genetic neighborhood parameters from pollen and seed dispersal in the marine angiosperm Zostera marina L. Evolution 50: 856-864.

Rudall, P. J., C. A. Furness, M. W. Chase \& M. F. Fay. 1997. Microsporogenesis and pollen sulcus type in Asparagales (Lilianae). Can. J. Bot. 75: 408-430.

Rudgley, R. 1999. The Encyclopaedia of Psychoactive Substances. St. Martin's Press, New York, NY. 302 pp.

Rüegg, S., U. Raeder, A. Melzer, G. Heubl \& C. Bräuchler. 2017. Hybridisation and cryptic invasion in Najas marina L. (Hydrocharitaceae)? Hydrobiologia 784: 381-395.

Ruekaewma, N., S. Piyatiratitivorakul \& S. Powtongsook. 2015. Culture system for Wolffia globosa L. (Lemnaceae) for hygiene human food. Songklanakarin J. Sci. Technol. 37: 575-580.

Ruenglertpanyakul, W., S. Attasat \& P. Wanichpongpan. 2004. Nutrient removal from shrimp farm effluent by aquatic plants. Water Sci. Technol. 50: 321-330.

Ruesink, J. L., J.-S. Hong, L. Wisehart, S. D. Hacker, B. R. Dumbauld, M. Hessing-Lewis \& A. C. Trimble. 2010. Congener comparison of native (Zostera marina) and introduced ( $Z$. japonica) eelgrass at multiple scales within a Pacific Northwest estuary. Biol. Invasions 12: 1773-1789.

Ruijgrok, H. W. L. 1974. Cyanogenese bei Scheuchzeria palustris. Phytochemistry 13: 161-162.

Rundel, P. W. 2011. The diversity and biogeography of the alpine flora of the Sierra Nevada, California. Madroño 58: 153-185.

Runkel, S. T. \& D. M. Roosa. 1999. Wildflowers and Other Plants of Iowa Wetlands. Iowa State University Press, Ames, IA. 372 pp.
Rusoff, L. L., E. W. Blakeney, Jr. \& D. D. Culley, Jr. 1980. Duckweeds (Lemnaceae family): a potential source of protein and amino acids. J. Agric. Food Chem. 28: 848-850.

Ruth, A. D., S. Jose \& D. L. Miller. 2008. Seed bank dynamics of sand pine scrub and longleaf pine flatwoods of the Gulf Coastal Plain (Florida). Ecol. Restor. 26: 19-21.

Ryan, J. B., D. N. Riemer \& S. J. Toth. 1972. Effects of fertilization on aquatic plants, water, and bottom sediments. Weed Sci. 20: 482-486.

Rybicki, N. B. \& V. Carter. 1986. Effect of sediment depth and sediment type on the survival of Vallisneria americana Michx grown from tubers. Aquat. Bot. 24: 233-240.

Rybicki, N. B., D. G. McFarland, H. A. Ruhl, J. T. Reel \& J. W. Barko. 2001. Investigations of the availability and survival of submersed aquatic vegetation propagules in the tidal Potomac River. Estuaries Coast. 24: 407-424.

Rydberg, P. A. 1914. Phytogeographical notes on the Rocky Mountain region. III. Formations in the alpine zone. Bull. Torrey Bot. Club 41: 459-474.

Rydberg, P. A. 1926. Two new species from the mountains of West Virginia. Torreya 26: 29-33.

Ryman, S. \& A. Anderberg. 1999. Five species of introduced duckweeds. Svensk Bot. Tidskr. 93: 129-138.

Ryser, P. \& A. T. Kamminga. 2009. Root survival of six cool-temperate wetland graminoids in autumn and early winter. Plant Ecol. Divers. 2: 27-35.

Ryser, P., H. K. Gill \& C. J. Byrne. 2011. Constraints of root response to waterlogging in Alisma triviale. Plant Soil 343: 247-260.

Ryuk, J. A., Y. S. Kim, H. W. Lee \& B. S. Ko. 2014. Identification of Acorus gramineus, A. calamus, and A. tatarinowii using sequence characterized amplified regions (SCAR) primers for monitoring of Acori graminei rhizoma in Korean markets. Int. J. Clin. Exp. Med. 7: 2488-2496.

Saarela, J. M., P. J. Prentis, H. S. Rai \& S. W. Graham. 2008. Phylogenetic relationships in the monocot order Commelinales, with a focus on Philydraceae. Botany 86: 719-731.

Saarela, J. M., P. C. Sokoloff, L. J. Gillespie, L. L. Consaul \& R. D. Bull. 2013. DNA barcoding the Canadian Arctic flora: core plastid barcodes $(r b c L+$ matK) for 490 vascular plant species. PLoS One 8(10): e77982.

Saarela, J. M., P. C. Sokoloff \& R. D. Bull. 2017. Vascular plant biodiversity of the lower Coppermine River valley and vicinity (Nunavut, Canada): an annotated checklist of an Arctic flora. PeerJ 5: e2835.

Sabbatini, M. R. \& K. J. Murphy. 1996. Submerged plant survival strategies in relation to management and environmental pressures in drainage channel habitats. Hydrobiologia 340: 191-195.

Sable, N., S. Gaikwad, S. Bonde, A. Gade \& M. Rai. 2012. Phytofabrication of silver nanoparticles by using aquatic plant Hydrilla verticillata. Nusantara Biosci. 4: 45-49.

Saeger, A. 1933. Manganese and the growth of Lemnaceae. Am. J. Bot. 20: 234-245.

Saeger, A. 1934. Spirodela oligorrhiza collected in Missouri. Bull. Torrey Bot. Club 61: 233-236.

Saghir, A. R. B., L. K. Mann, M. Ownbey \& R. Y. Berg. 1966. Composition of volatiles in relation to taxonomy of American Alliums. Am. J. Bot. 53: 477-484.

Sah, J. P., M. S. Ross \& S. Stofella. 2010. Developing a data-driven classification of South Florida plant communities. SERC Research Reports 93. Available online: http://digitalcommons. fiu.edu/sercrp/93. [accessed 4 February, 2020].

Saini, N. K., M. Singhal, B. Srivastava \& O. P. Sharma. 2011. Antitubercular plants: a review. Inventi 2011: 1-6. 
Šajna, N., M. Haler, S. Škornik \& M. Kaligarič. 2007. Survival and expansion of Pistia stratiotes L. in a thermal stream in Slovenia. Aquat. Bot. 87: 75-79.

Sakhanokho, H. F. \& K. Rajasekaran. 2010. Pollen biology of ornamental ginger (Hedychium spp. J. Koenig). Sci. Hort. 125: 129-135.

Salazar, G. A., L. I. Cabrera, S. Madrinán \& M. W. Chase. 2009. Phylogenetic relationships of Cranichidinae and Prescottiinae (Orchidaceae, Cranichideae) inferred from plastid and nuclear DNA sequences. Ann. Bot. 104: 403-416.

Sale, P. J. M. \& R. G. Wetzel. 1983. Growth and metabolism of Typha species in relation to cutting treatments. Aquat. Bot. 15: 321-334.

Salisbury, E. 1976. Seed output and the efficacy of dispersal by wind. Proc. Royal Soc. London, Ser. B Biol. Sci. 192: 323-329.

Sampson, A. W. 1914. Natural revegetation of range lands based upon growth requirements and life history of the vegetation. $J$. Agric. Res. 3: 93-148.

Sánchez, J. A., L. Montejo, A. Gamboa, D. Albert-Puentes \& F. Hernández. 2015. Germinación y dormancia de arbustos y trepadoras del bosque siempreverde de la Sierra del Rosario, Cuba. Pastos y Forrajes 38: 11-28.

Sánchez-Galván, G., F. J. Mercado \& E. J. Olguín. 2013. Leaves and roots of Pistia stratiotes as sorbent materials for the removal of crude oil from saline solutions. Water Air Soil Pollut. 224: 1421.

Sandberg, D. C., L. J. Battista \& A. E. Arnold. 2014. Fungal endophytes of aquatic macrophytes: diverse host-generalists characterized by tissue preferences and geographic structure. Microbial Ecol. 67: 735-747.

Sand-Jensen, K. \& D. M. Gordon. 1986. Variable $\mathrm{HCO}_{3}^{-}$affinity of Elodea canadensis Michaux in response to different $\mathrm{HCO}_{3}{ }^{-}$and $\mathrm{CO}_{2}$ concentrations during growth. Oecologia 70: 426-432.

Santamaría, L. \& A. I. Llano García. 2004. Latitudinal variation in tuber production in an aquatic pseudo-annual plant, Potamogeton pectinatus. Aquat. Bot. 79: 51-64.

Santamaría, L., I. Charalambidou, J. Figuerola \& A. J. Green. 2002. Effect of passage through duck gut on germination of fennel pondweed seeds. Arch. Hydrobiol. 156: 11-22.

Santos, I. A. D. 2002. Flower-visiting bees and the breakdown of the tristylous breeding system of Eichhornia azurea (Swartz) Kunth (Pontederiaceae). Biol. J. Linn. Soc. 77: 499-507.

Santos, A. G. 2004. Constructive applications of composite gypsum reinforced with Typha latifolia fibres. Material. Construcc. 54: 73-77.

Santos, M. J., L. W. Anderson \& S. L. Ustin. 2011. Effects of invasive species on plant communities: an example using submersed aquatic plants at the regional scale. Biol. Invasions 13: 443-457.

Sarkar, S., D. Deka \& N. Devi. 2008. Studies on some medicinally important wetland angiosperms used by the Bodo tribe of Kamrup District in Assam, India. Pleione 2: 20-26.

Sarkissian, T. S., S. C. Barrett \& L. D. Harder. 2001. Gender variation in Sagittaria latifolia (Alismataceae): is size all that matters? Ecology 82: 360-373.

Sarma, K., R. Tandon, K. R. Shivanna \& H. Y. M. Ram. 2007. Snail-pollination in Volvulopsis nummularium. Curr. Sci. 93: 826-831.

Sarneel, J. M. 2013. The dispersal capacity of vegetative propagules of riparian fen species. Hydrobiologia 710: 219-225.

Sarneel, J. M. \& M. B. Soons. 2012. Post-dispersal probability of germination and establishment on the shorelines of slow-flowing or stagnant water bodies. J. Veg. Sci. 23: 517-525.
Sass, L. L., M. A. Bozek, J. A. Hauxwell, K. Wagner \& S. Knight. 2010. Response of aquatic macrophytes to human land use perturbations in the watersheds of Wisconsin lakes, USA. Aquat. Bot. 93: 1-8.

Sass, C., W. J. D. Iles, C. F. Barrett, S. Y. Smith \& C. D. Specht. 2016. Revisiting the Zingiberales: using multiplexed exon capture to resolve ancient and recent phylogenetic splits in a charismatic plant lineage. PeerJ 4: e1584.

Sasser, C. E. \& J. G. Gosselink. 1984. Vegetation and primary production in a floating freshwater marsh in Louisiana. Aquat. Bot. 20: 245-255.

Sasser, C. E., J. G. Gosselink, E. M. Swenson \& D. E. Evers. 1995a. Hydrologic, vegetation, and substrate characteristics of floating marshes in sediment-rich wetlands of the Mississippi river delta plain, Louisiana, USA. Wetl. Ecol. Manag. 3: 171-187.

Sasser, C. E., J. M. Visser, D. E. Evers \& J. G. Gosselink. 1995b. The role of environmental variables on interannual variation in species composition and biomass in a subtropical minerotrophic floating marsh. Can. J. Bot. 73: 413-424.

Sasser, C. E., G. O. Holm, E. Evers-Hebert \& G. P. Shaffer. 2018. The nutria in Louisiana: a current and historical perspective. Pp. 39-60 In: J. W. Day \& J. A. Erdman (eds.), Mississippi Delta Restoration. Springer, Cham, Switzerland.

Sastroutomo, S. S. 1980. Environmental control of turion formation in curly pondweed (Potamogeton crispus). Physiol. Plant. 49: 261-264.

Sastroutomo, S. S. 1981a. Germination of turions in Potamogeton berchtoldii. Bot. Gaz. 142: 454-460.

Sastroutomo, S. S. 1981b. Turion formation, dormancy, and germination of curlyleaf pondweed, Potamogeton crispus L. Aquat. Bot. 10: 161-173.

Sastroutomo, S. S., I. Ikusima, M. Numata \& S. Iizumi. 1979. Importance of turions in the propagation of pondweed (Potamogeton crispus L.). Ecol. Rev. 19: 75-88.

Satake, K. \& S. Shimura. 1983. Carbon dioxide assimilation from air and water by duckweed Spirodela polyrrhiza (L.) Schleid. Hydrobiologia 107: 51-55.

Sauleda, R. P. 2014. Vertical stratification of epiphytic orchids in a south Florida swamp forest. New World Orchidaceae Nomencl. Notes 11: 1-8.

Saunders, K. 2005. First record of Nymphoides indica (Menyanthaceae) in Texas. Sida 21: 2441-2443.

Sautour, M., A.-C. Mitaine-Offer \& M.-A. Lacaille-Dubois. 2007. The Dioscorea genus: a review of bioactive steroid saponins. J. Nat. Med. 61: 91-101.

Sawyer, M. L. 1925. Crossing Iris pseudacorus and I. versicolor. Bot. Gaz. 79: 60-72.

Sawyer, N. W., D. S. Mertins \& L. A. Schuster. 2005. Pollination biology of Eriocaulon parkeri in Connecticut. Aquat. Bot. 82: 113-120.

SCEPPC. 2011. South Carolina Exotic Pest Plant Council. Invasive Plant Pest Species of South Carolina. Forestry Leaflet 28, Clemson Cooperative Extension Service, Clemson, SC. 4 pp.

Schaffner, J. H. 1924. Expression of the sexual state in Sagittaria latifolia. Bull. Torrey Bot. Club 51: 103-112.

Schaffner, U., D. Kleijn, V. Brown \& H. Muller-Scharer. 2001. Veratrum album in montane grasslands: a model system for implementing biological control in land management practices of high biodiversity habitats. Biocontrol News Inform. 22: $19 \mathrm{~N}-27 \mathrm{~N}$.

Scharfetter, E., C. Lesemann \& R. Kandeler. 1987. Ethylene as a flower-promoting agent in Lemna. Phyton 27: 31-37.

Schenck, S. M. \& E. W. Gifford. 1952. Karok ethnobotany. Anthropol. Rec. 13: 377-392. 
Schep, L. J., D. M. Schmierer \& J. S. Fountain. 2006. Veratrum poisoning. Toxicol. Rev. 25: 73-78.

Schilling, E. E. \& K. C. Grubbs. 2016. Systematics of the Eupatorium mohrii complex (Asteraceae). Syst. Bot. 41: 787-795.

Schincariol, R. A., M. A. Maun, J. N. Steinbachs, J. A. Wiklund \& A. C. Crowe. 2004. Response of an aquatic ecosystem to human activity: hydro-ecology of a river channel in a dune watershed. J. Freshw. Ecol. 19: 123-139.

Schlesinger, W. H. 1978. On the relative dominance of shrubs in Okefenokee Swamp. Am. Nat. 112: 949-954.

Schlickeisen, E., T. E. Tietjen, T. L. Arsuffi \& A. W. Groeger. 2003. Detritus processing and microbial dynamics of an aquatic macrophyte and terrestrial leaf in a thermally constant, spring-fed stream. Microbial Ecol. 45: 411-418.

Schloesser, D. W. \& B. A. Manny. 1986. Distribution of submersed macrophytes in the St. Clair-Detroit River system, 1978. J. Freshw. Ecol. 3: 537-544.

Schloesser, D. W. \& B. A. Manny. 2007. Restoration of wildcelery, Vallisneria americana Michx., in the lower Detroit River of the Lake Huron-Lake Erie corridor. J. Great Lakes Res. 33: 8-19.

Schloesser, D. W., P. L. Hudson \& S. J. Nichols. 1986. Distribution and habitat of Nitellopsis obtusa (Characeae) in the Laurentian Great Lakes. Hydrobiologia 133: 91-96.

Schlüter, U. \& R. M. M. Crawford. 2001. Long-term anoxia tolerance in leaves of Acorus calamus L. and Iris pseudacorus L. J. Exp. Bot. 52: 2213-2225.

Schmalzer, P. A., T. S. Patrick \& H. R. DeSelm. 1985. Vascular flora of the Obed Wild and Scenic River, Tennessee. Castanea 50: 71-88.

Schmeda-Hirschmann, G. 1994. Plant resources used by the Ayoreo of the Paraguayan Chaco. Econ. Bot. 48: 252-258.

Schmid, W. D. 1965. Distribution of aquatic vegetation as measured by line intercept with SCUBA. Ecology 46: 816-823.

Schmidt, J. O., S. L. Buchmann \& M. Glaum. 1989. The nutritional value of Typha latifolia pollen for bees. J. Apicult. Res. 28: 155-165.

Schmitt, R. \& S. Holbrook. 1984. Ontogeny of prey selection by black surfperch Embiotoca jacksoni (Pisces: Embiotocidae): the roles of fish morphology, foraging behavior, and patch selection. Mar. Ecol. Prog. Ser. 18: 225-239.

Schmitz, U., S. Köhler \& A. Hussner. 2014. First records of American Wolffia columbiana in Europe-Clandestine replacement of native Wolffia arrhiza? BioInvas. Rec. 3: 213-216.

Schneider, R. 1994. The role of hydrologic regime in maintaining rare plant communities of New York's coastal plain pondshores. Biol. Conserv. 68: 253-260.

Scholtens, B. 1996. Moths of the Douglas Lake region (Emmet and Cheboygan Counties), Michigan: V. Crambidae and Pyralidae (Lepidoptera). Great Lakes Entomol. 29: 141-160.

Schöpfel, H. 1975. Keine Probleme bei Cryptocorynen. AT-Ratgeber Reihe 3. Urania-Verlag, Leipzig. 51 pp.

Schowalter, T. D. 2018. Biology and management of the eastern lubber grasshopper (Orthoptera: Acrididae). J. Integr. Pest Manag. 9(10): $1-7$.

Schrader, K. K., A. Andolfi, C. L. Cantrell, A. Cimmino, S. O. Duke, W. Osbrink, D. E. Wedge \& A. Evidente. 2010. A survey of phytotoxic microbial and plant metabolites as potential natural products for pest management. Chem. Biodivers. 7: 2261-2280.

Schreinemakers, W. A. C. 1986. The interaction between Cd-absorption and Cd compartmentation in Wolffiella gladiata. Acta Bot. Neerl. 35: 23-34.

Schroll, E., J. Lambrinos, T. Righetti \& D. Sandrock. 2011. The role of vegetation in regulating stormwater runoff from green roofs in a winter rainfall climate. Ecol. Eng. 37: 595-600.
Schuler, C. A., R. G. Anthony \& H. M. Ohlendorf. 1990. Selenium in wetlands and waterfowl foods at Kesterson Reservoir, California, 1984. Arch. Environ. Contam. Toxicol. 19: 845-853.

Schulgasser, K. \& A. Witztum. 2004. Spiralling upward. J. Theoret. Biol. 230: 275-280.

Schuller, R., R. Showalter, T. Kaye \& B. Lawrence. 2014. North Fork Silver Creek Research Natural Area: Guidebook Supplement 47. Gen. Tech. Rep. PNW-GTR-894. U.S. Department of Agriculture, Forest Service, Pacific Northwest Research Station, Portland, OR. 25 pp.

Schults, D. W., K. W. Malueg \& P. D. Smith. 1976. Limnological comparison of culturally eutrophic Shagawa Lake and adjacent oligotrophic Burntside Lake, Minnesota. Am. Midl. Nat. 96: 160-178.

Schutten, J. \& A. J. Davy. 2000. Predicting the hydraulic forces on submerged macrophytes from current velocity, biomass and morphology. Oecologia 123: 445-452.

Schutten, J., J. Dainty \& A. J. Davy. 2005. Root anchorage and its significance for submerged plants in shallow lakes. J. Ecol. 93: $556-571$.

Schuyler, A. E. \& T. Gordon. 2002. Rare plants in the middle branch of the Forked River watershed, Lacey Township, Ocean County, New Jersey. Bartonia 61: 117-121.

Schuyler, A. E., S. B. Andersen \& V. J. Kolaga. 1993. Plant zonation changes in the tidal portion of the Delaware River. Proc. Acad. Nat. Sci. Philadelphia 144: 263-266.

Schwartz, F. C. 2002. Zigadenus Michaux. Pp. 81-88 In: Flora North America Editorial Committee (eds.), Flora of North America North of Mexico, Vol. 26: Magnoliophyta: Liliidae: Liliales and Orchidales. Oxford University Press, New York, NY.

Schwartz, F. J. \& B. W. Dutcher. 1963. Age, growth, and food of the oyster toadfish near Solomons, Maryland. Trans. Am. Fish. Soc. 92: 170-173.

Schwarzschild, A. C. \& J. C. Zieman. 2008. Effects of physiological integration on the survival and growth of ramets and clonal fragments in the seagrass Syringodium filiforme. Mar. Ecol. Prog. Ser. 372: 97-104.

Scotland, M. B. 1934. The animals of the Lemna association. Ecology 15: 290-294.

Scotland, M. B. 1940. Review and summary of studies of insects associated with Lemna minor. J. New York Entomol. Soc. 48: 319-333.

Scott, R. K. 2009. The vascular flora of Turkey Run State Park, Parke County, Indiana. Proc. Indiana Acad. Sci. 118: 55-75.

Scott, J. K. 2012. Zantedeschia aethiopica (L.) Spreng. - arum lily. Pp. 609-613 In: J. K. Scott, M. Julien, R. McFadyen \& J. Cullen (eds.), Biological Control of Weeds in Australia. CSIRO Publishing, Collingwood, VIC, Australia.

Scott, J. A. 2014. Lepidoptera of North America. 13. Flower Visitation by Colorado Butterflies (40,615 Records) with a Review of the Literature on Pollination of Colorado Plants and Butterfly Attraction (Lepidoptera: Hesperioidea and Papilionoidea). C. P. Gillette Museum of Arthropod Diversity, Colorado State University, Fort Collins, CO. 190 pp.

Scott, S. L. \& J. A. Osborne. 1981. Benthic macroinvertebrates of a hydrilla infested central Florida lake. J. Freshw. Ecol. 1: 41-49.

Scott, J. K. \& S. Neser. 1996. Prospects for the biological control of the environmental weed, Zantedeschia aethiopica (arum lily). Pp. 413-416 In: R. C. H. Shepherd (ed.), Proceedings of the 11th Australian Weeds Conference, Melbourne, Australia, 30 September-3 October 1996. Weed Science Society of Victoria Inc., Latrobe University, Bundoora, Victoria, VIC, Australia.

Scribailo, R. W. \& U. Posluszny. 1983. Morphology and establishment of seedlings of Hydrocharis morsus-ranae. Am. J. Bot. 70(5, part 2): 31 . 
Scribailo, R. W. \& U. Posluszny. 1984. The reproductive biology of Hydrocharis morsus-ranae. I. Floral biology. Can. J. Bot. 62: 2779-2787.

Scribailo, R. W. \& U. Posluszny. 1985. The reproductive biology of Hydrocharis morsus-ranae. II. Seed and seedling morphology. Can. J. Bot. 63: 492-496.

Scribailo, R. W. \& M. S. Alix. 2002. First reports of Ceratophyllum echinatum A. Gray from Indiana with notes on the distribution, ecology and phytosociology of the species. J. Torrey Bot. Soc. 129: $164-171$.

Scribailo, R. W., K. Carey \& U. Posluszny. 1984. Isozyme variation and the reproductive biology of Hydrocharis morsus-ranae L. (Hydrocharitaceae). Bot. J. Linn. Soc. 89: 305-312.

Scriber, J. M., M. D. Deering, L. N. Francke, W. F. Wehling \& R. C. Lederhouse. 1998. Notes on swallowtail population dynamics of three Papilio species in south-central Florida (Lepidoptera: Papilionidae). Holarctic Lepidoptera 5: 53-62.

Scudder, S. H. 1889. Classified list of food plants of American butterflies, drawn from Scudder's "Butterflies of the Eastern United States." Psyche 5: 274-278.

Sculthorpe, C. D. 1967. The Biology of Aquatic Vascular Plants. Edward Arnold (Publishers) Ltd., London, United Kingdom. $610 \mathrm{pp}$.

Seabloom, E. W., A. G. van der Valk \& K. A. Moloney. 1998. The role of water depth and soil temperature in determining initial composition of prairie wetland coenoclines. Plant Ecol. 138: 203-216.

Sealy, J. R. 1954. Review of the genus Hymenocallis. Kew Bull. 9: 201-240.

Seaman, D. E. \& W. A. Porterfield. 1964. Control of aquatic weeds by the snail Marisa cornuarietis. Weeds 12: 87-92.

Seaman, D., M. Morse, M. Miller, W. Harvey, L. Buschmann, C. Wick \& B. Fischer. 1968. Controlling submersed weeds in rice. Calif. Agric. 22: 11.

Sears, C. J. 2008. Morphological discrimination of Platanthera aquilonis, $P$. huronensis, and $P$. dilatata (Orchidaceae) herbarium specimens. Rhodora 110: 389-406.

Seberg, O., G. Petersen, J. I. Davis, J. C. Pires, D. W. Stevenson, M. W. Chase, M. F. Fay, D. S. Devey, T. Jøgensen, K. J. Sytsma \& Y. Pillon. 2012. Phylogeny of the Asparagales based on three plastid and two mitochondrial genes. Am. J. Bot. 99: 875-889.

Sedinger, J. S. \& D. G. Raveling. 1984. Dietary selectivity in relation to availability and quality of food for goslings of cackling geese. Auk 101: 295-306.

Sedki, M., M. B. Mohamed, M. Fawzy, D. A. Abdelrehim \& M. M. S. A. Abdel-Mottaleb. 2015. Phytosynthesis of silver-reduced graphene oxide (Ag-RGO) nanocomposite with an enhanced antibacterial effect using Potamogeton pectinatus extract. RSC Adv. 5: 17358-17365.

See, R. B., D. L. Naftz, D. A. Peterson, J. G. Crock, J. A. Erdman, R. C. Severson, P. Ramirez, Jr. \& J. A. Armstrong. 1992. Detailed study of selenium in soil, representative plants, water, bottom sediment, and biota in the Kendrick reclamation project area, Wyoming, 1988-90. Resources Investigations Report 91-4131. U.S. Geological Survey, Cheyenne, WY. 142 pp.

Seeliger, U., C. Cordazzo \& E. W. Koch. 1984. Germination and algal-free laboratory culture of widgeon grass, Ruppia maritima. Estuaries 7: 176-178.

Seigler, D. S. 1976. Plants of the northeastern United States that produce cyanogenic compounds. Econ. Bot. 30: 395-407.

Sekercioglu, Ç. H., D. G. Wenny \& C. J. Whelan. 2016. Why Birds Matter: Avian Ecological Function and Ecosystem Services. University of Chicago Press, Chigago, IL. 368 pp.
Selbo, S. M. \& A. A. Snow. 2004. The potential for hybridization between Typha angustifolia and Typha latifolia in a constructed wetland. Aquat. Bot. 78: 361-369.

Self, C. A., R. H. Chabreck \& T. Joanen. 1975. Food preferences of deer in Louisiana coastal marshes. Pp. 548-556 In: W. A. Rogers (ed.), Proceedings of the Twenty-eighth Annual Conference, November 17-20, 1974. Southeastern Association of Game and Fish Commissioners, White Sulphur Springs, WV.

Seo, C.-S., M.-Y. Lee, I.-S. Shin, J.-A. Lee, H. Ha \& H.-K. Shin. 2012. Spirodela polyrhiza (L.) Sch. ethanolic extract inhibits LPSinduced inflammation in RAW264. 7 cells. Immunopharmacol. Immunotoxicol. 34: 794-802.

Serie, J. R. \& G. A. Swanson. 1976. Feeding ecology of breeding gadwalls on saline wetlands. J. Wildl. Manag. 40: 69-81.

Serviss, B. E., S. T. McDaniel \& C. T. Bryson. 2000. Occurrence, distribution, and ecology of Alocasia, Caladium, Colocasia, and Xanthosoma (Araceae) in the southeastern United States. Sida 19: 149-174.

Setchell, W. A. 1924. Ruppia and its environmental factors. Proc. Natl. Acad. Sci. U.S.A. 10: 286-288.

Seyer, S. C. 1979. Vegetative ecology of a montane mire, Crater Lake National Park, Oregon. M.S. thesis. Oregon State University, Corvallis, OR. 187 pp.

Seymour, R. S. \& A. J. Blaylock. 1999. Switching off the heater: influence of ambient temperature on thermoregulation by eastern skunk cabbage Symplocarpus foetidus. J. Exp. Bot. 50: 1525-1532.

Sexton, O. J. 1959. Spatial and temporal movements of a population of the painted turtle, Chrysemys picta marginata (Agassiz). Ecol. Monogr. 29: 113-140.

Sgattoni, P., V. Ticchiati, F. Arosio, P. Villani \& C. Mallegni. 1989. Distribution and importance of the main rice weeds in Italy: results from a 1988 technical survey. Pp. 301-311 In: Problems of Weed Control in Fruit, Horticultural Crops and Rice. Proceedings of the 4th EWRS Symposium on Weed Problems in Mediterranean Climates (Vol. 2). Valencia, Spain.

Shabnam, N. \& P. Pardha-Saradhi. 2013. Photosynthetic electron transport system promotes synthesis of Au-nanoparticles. PLoS One 8(8): e71123.

Shabnam, N. \& P. Pardha-Saradhi. 2016. Floating and submerged leaves of Potamogeton nodosus exhibit distinct variation in the antioxidant system as an ecophysiological adaptive strategy. Funct. Plant Biol. 43: 346-355.

Shabnam, N., P. Sharmila, A. Sharma, R. J. Strasser \& P. PardhaSaradhi. 2015. Mitochondrial electron transport protects floating leaves of long leaf pondweed (Potamogeton nodosus Poir) against photoinhibition: comparison with submerged leaves. Photosyn. Res. 125: 305-319.

Shacklette, H. T. 1961. Substrate relationships of some bryophyte communities on Latouche Island, Alaska. Bryologist 64: 1-16.

Shafer, D. J., T. D. Sherman \& S. Wyllie-Echeverria. 2007. Do desiccation tolerances control the vertical distribution of intertidal seagrasses? Aquat. Bot. 87: 161-166.

Shafer, D. J., S. Wyllie-Echeverria \& T. D. Sherman. 2008. The potential role of climate in the distribution and zonation of the introduced seagrass Zostera japonica in North America. Aquat. Bot. 89: 297-302.

Shafer, D. J., J. E. Kaldy, T. D. Sherman \& K. M. Marko. 2011. Effects of salinity on photosynthesis and respiration of the seagrass Zostera japonica: a comparison of two established populations in North America. Aquat. Bot. 95: 214-220.

Shafer, D. J., J. E. Kaldy \& J. L. Gaeckle. 2014. Science and management of the introduced seagrass Zostera japonica in North America. Environ. Manage. 53: 147-162. 
Shaffer, G. P., C. E. Sasser, J. G. Gosselink \& M. Rejmanek. 1992. Vegetation dynamics in the emerging Atchafalaya Delta, Louisiana, USA. J. Ecol. 80: 677-687.

Shaffer-Fehre, M. 1991a. The endotegmen tuberculae: an account of little-known structures from the seed coat of the Hydrocharitoideae (Hydrocharitaceae) and Najas (Najadaceae). Bot. J. Linn. Soc. 107: 169-188.

Shaffer-Fehre, M. 1991b. The position of Najas within the subclass Alismatidae (Monocotyledones) in the light of new evidence from seed coat structures in the Hydrocharitoideae (Hydrocharitales). Bot. J. Linn. Soc. 107: 189-209.

Shanks, A. L., B. A. Grantham \& M. H. Carr. 2003. Propagule dispersal distance and the size and spacing of marine reserves. Ecol. Appl. 13: 159-169.

Shannon, R. D., J. R. White, J. E. Lawson \& B. S. Gilmour. 1996. Methane efflux from emergent vegetation in peatlands. J. Ecol. 84: 239-246.

Shao, H., B. Gontero, S. C. Maberly, H. Sheng, J. Yu, C. Wei, L. Wen \& M. Huang. 2017. Responses of Ottelia alismoides, an aquatic plant with three $\mathrm{CCMs}$, to variable $\mathrm{CO}_{2}$ and light. $J$. Exp. Bot. 68: 3985-3995.

Sharitz, R. R., P. Stankus \& L. Lee. 2010. Vegetation community of the H-02 wetlands: importance to amphibians. Pp. 31-41 In: D. Scott \& T. Tuberville (eds.), FY-2009 Annual Report. Savannah River Ecology Laboratory, Aiken, SC.

Sharma, B. M. 1984. Ecophysiological studies on water lettuce in a polluted lake. J. Aquat. Plant Manag. 22: 17-21.

Sharma, A. K. \& A. K. Bal. 1956. A cytological study of a few genera of Amaryllidaceae with a view to find out the basis of their phylogeny. Cytologia 21: 329-352.

Sharpe, P. J. \& A. H. Baldwin. 2012. Tidal marsh plant community response to sea-level rise: a mesocosm study. Aquat. Bot. 101: 34-40.

Shaw, J. P., S. J. Taylor, M. C. Dobson \& N. H. Martin. 2017. Pollinator isolation in Louisiana iris: legitimacy and pollen transfer. Evol. Ecol. Res. 18: 429-441.

Shay, J. M. 1999. Annotated vascular plant species list for the Delta Marsh, Manitoba and surrounding area. Occasional Publication No. 2. University of Manitoba Field Station (Delta Marsh), Winnipeg, MB, Canada. 52 pp.

Shefferson, R. P. 2006. Survival costs of adult dormancy and the confounding influence of size in lady's slipper orchids, genus Cypripedium. Oikos 115: 253-262.

Shefferson, R. P., M. Weiss, T. I. I. U. Kull \& D. L. Taylor. 2005. High specificity generally characterizes mycorrhizal association in rare lady's slipper orchids, genus Cypripedium. Mol. Ecol. 14: 613-626.

Sheldon, S. P. 1986. Factors influencing the numbers of branches and inflorescences of Potamogeton richardsonii (A. Benn.) Rydb. Aquat. Bot. 24: 27-34.

Sheldon, S. P. 1987. The effects of herbivorous snails on submerged macrophyte communities in Minnesota lakes. Ecology 68: 1920-1931.

Sheldon, R. B. \& C. W. Boylen. 1975. Factors affecting the contribution by epiphytic algae to the primary productivity of an oligotrophic freshwater lake. Appl. Microbiol. 30: 657-667.

Sheldon, R. B. \& C. W. Boylen. 1977. Maximum depth inhabited by aquatic vascular plants. Am. Midl. Nat. 97: 248-254.

Shelingoski, S., R. J. LeBlond, J. M. Stucky \& T. R. Wentworth. 2005. Flora and soils of Wells Savannah, an example of a unique savanna type. Castanea 70: 101-114.

Shelton, A. O. 2008. Skewed sex ratios, pollen limitation, and reproductive failure in the dioecious seagrass Phyllospadix. Ecology 89: 3020-3029.
Shelton, A. O. 2010a. The origin of female-biased sex ratios in intertidal seagrasses (Phyllospadix spp.). Ecology 91: 1380-1390.

Shelton, A. O. 2010b. The ecological and evolutionary drivers of female-biased sex ratios: two-sex models of perennial seagrasses. Am. Nat. 175: 302-315.

Sherff, E. E. 1912. The vegetation of Skokie Marsh, with special reference to subterranean organs and their interrelationships. Bot. Gaz. 53: 415-435.

Sheridan, P. F. \& R. J. Livingston. 1983. Abundance and seasonality of infauna and epifauna inhabiting a Halodule wrightii meadow in Apalachicola Bay, Florida. Estuaries Coast. 6: 407-419.

Sheridan, P. M., S. L. Orzell \& E. L. Bridges. 1997. Powerline easements as refugia for state rare seepage and pineland plant taxa. Pp. 451-460 In: J. R. Williams, J. W. Goodrich-Mahoney, J. R. Wisniewski \& J. Wisniewski (eds.), The Sixth International Symposium on Environmental Concerns in Rights-of-Way Management. Elsevier, Oxford, England.

Sher-Kaul, S., B. Oertli, E. Castella \& J.-B. Lachavanne. 1995. Relationship between biomass and surface area of six submerged aquatic plant species. Aquat. Bot. 51: 147-154.

Sherman, H. L. 1979. Evidence of misapplication of the name Schoenolirion texanum (Scheele) Gray (Liliaceae). Southwest. Nat. 24: 123-126.

Sherman, H. L. 2002. Schoenolirion Torrey ex Durand. Pp. 312-314 In: Flora North America Editorial Committee (eds.), Flora of North America North of Mexico, Vol. 26: Magnoliophyta: Liliidae: Liliales and Orchidales. Oxford University Press, New York, NY.

Sherman, H. L. \& R. W. Becking. 1991. The generic distinctness of Schoenolirion and Hastingsia. Madroño 38: 130-138.

Sherman, D. E., R. W. Kroll \& T. L. Engle. 1996. Flora of a diked and an undiked southwestern Lake Erie wetland. Ohio J. Sci. 96: 4-8.

Sheviak, C. J. 1990. A new Spiranthes (Orchidaceae) from the cienegas of southernmost Arizona. Rhodora 92: 213-231.

Sheviak, C. J. 2001. A role for water droplets in the pollination of Platanthera aquilonis (Orchidaceae). Rhodora 103: 380-386.

Sheviak, C. J. 2002a. Cypripedium Linnaeus. Pp. 499-506 In: Flora North America Editorial Committee (eds.), Flora of North America North of Mexico, Vol. 26: Magnoliophyta: Liliidae: Liliales and Orchidales. Oxford University Press, New York, NY.

Sheviak, C. J. 2002b. Habenaria Willdenow. Pp. 581-582 In: Flora North America Editorial Committee (eds.), Flora of North America North of Mexico, Vol. 26: Magnoliophyta: Liliidae: Liliales and Orchidales. Oxford University Press, New York, NY.

Sheviak, C. J. 2002c. Platanthera Richard. Pp. 551-571 In: Flora North America Editorial Committee (eds.), Flora of North America North of Mexico, Vol. 26: Magnoliophyta: Liliidae: Liliales and Orchidales. Oxford University Press, New York, NY.

Sheviak, C. J. \& P. M. Brown. 2002. Spiranthes Richard. Pp. 530544 In: Flora North America Editorial Committee (eds.), Flora of North America North of Mexico, Vol. 26: Magnoliophyta: Liliidae: Liliales and Orchidales. Oxford University Press, New York, NY.

Sheviak, C. J. \& P. M. Catling. 2002a. Arethusa Linnaeus. Pp. 596597 In: Flora North America Editorial Committee (eds.), Flora of North America North of Mexico, Vol. 26: Magnoliophyta: Liliidae: Liliales and Orchidales. Oxford University Press, New York, NY.

Sheviak, C. J. \& P. M. Catling. 2002b. Amerorchis Hultén. Pp. 550551 In: Flora North America Editorial Committee (eds.), Flora of North America North of Mexico, Vol. 26: Magnoliophyta: Liliidae: Liliales and Orchidales. Oxford University Press, New York, NY. 
Sheviak, C. J. \& P. M. Catling. 2002c. Pogonia Jussieu. Pp. 513-514 In: Flora North America Editorial Committee (eds.), Flora of North America North of Mexico, Vol. 26: Magnoliophyta: Liliidae: Liliales and Orchidales. Oxford University Press, New York, NY.

Sheviak, C. J. \& W. F. Jennings. 2006. A new Platanthera (Orchidaceae) from the intermountain west. Rhodora 108: 19-32.

Shields, E. C. \& K. A. Moore. 2016. Effects of sediment and salinity on the growth and competitive abilities of three submersed macrophytes. Aquat. Bot. 132: 24-29.

Shields, E. C., K. A. Moore \& D. B. Parrish. 2012. Influences of salinity and light availability on abundance and distribution of tidal freshwater and oligohaline submersed aquatic vegetation. Estuaries Coast. 35: 515-526.

Shih, J. G. \& S. A. Finkelstein. 2008. Range dynamics and invasive tendencies in Typha latifolia and Typha angustifolia in eastern North America derived from herbarium and pollen records. Wetlands 28: 1-16.

Shin, H. T., M. H. Yi, J. W. Yoon, J. W. Sun \& G. S. Kim. 2012. Status of alien plant species in the Seongeup folk village in Jeju Island. J. Korean Nat. 5: 299-304.

Shinners, L. H. 1962. Annual sisyrinchiums (Iridaceae) in the United States. Sida 1: 32-42.

Shipley, B. \& M. Parent. 1991. Germination responses of 64 wetland species in relation to seed size, minimum time to reproduction and seedling relative growth rate. Funct. Ecol. 5: 111-118.

Shirey, P. D., B. N. Kunycky, D. T. Chaloner, M. A. Brueseke \& G. A. Lamberti. 2013. Commercial trade of federally listed threatened and endangered plants in the United States. Conserv. Lett. 6: 300-316.

Shoemaker, G. \& S. Wyllie-Echeverria. 2013. Occurrence of rhizomal endophytes in three temperate northeast pacific seagrasses. Aquat. Bot. 111: 71-73.

Short, F. T. 1983. The seagrass, Zostera marina L.: plant morphology and bed structure in relation to sediment ammonium in Izembek Lagoon, Alaska. Aquat. Bot. 16: 149-161.

Short, F. T. 1985. A method for the culture of tropical seagrasses. Aquat. Bot. 22: 187-193.

Short, F. T. \& C. P. McRoy. 1984. Nitrogen uptake by leaves and roots of the seagrass Zostera marina L. Bot. Mar. 27: 547-556.

Short, F. T. \& S. Wyllie-Echeverria. 1996. Natural and human-induced disturbance of seagrasses. Environ. Conserv. 23: 17-27.

Short, F. T., W. C. Dennison \& D. G. Capone. 1990. Phosphoruslimited growth of the tropical seagrass Syringodium filiforme in carbonate sediments. Mar. Ecol. Prog. Ser. 62: 169-174.

Short, F. T., J. Montgomery, C. F. Zimmermann \& C. A. Short. 1993. Production and nutrient dynamics of a Syringodium filiforme Kütz. seagrass bed in Indian River Lagoon, Florida. Estuaries 16: 323-334.

Short, F. T., G. E. Moore \& K. A. Peyton. 2010. Halophila ovalis in the tropical Atlantic Ocean. Aquat. Bot. 93: 141-146.

Shu, J. H. 2000. Hedychium. Pp. 370-377 In: Z. Wu \& P. Raven (eds.), Flora of China. Vol. 24 (Flagellariaceae Through Marantaceae). Science Press, Beijing/Missouri Botanical Garden Press, St. Louis, MO.

Shukla, R., S. Srivastava, P. K. Dwivedi, S. Sarkar, S. Gupta \& A. Mishra. 2012. Evaluation of free radical scavenging activity of the different fractions of Typha latifolia (Typhaceae). J. Harmonized Res. Pharm. 1: 33-43.

Shull, G. H. 1914. The longevity of submerged seeds. Plant World 17: 329-337.

Siegfried, W. R. 1976. Breeding biology and parasitism in the Ruddy Duck. Wilson Bull. 88: 566-574.
Sieren, D. J. \& K. R. Warr. 1992. The flora of limesink depressions in Carolina Beach State Park (North Carolina). Rhodora 94: $156-166$.

Sifton, H. B. 1959. The germination of light-sensitive seeds of Typha latifolia L. Can. J. Bot. 37: 719-739.

Sikes, K., D. Roach, J. Buck, J. Nelson \& S. Erwin. 2010. Classification and mapping of vegetation from three fen sites of the Shasta-Trinity National Forest, California. Unpublished Report. U.S. Forest Service, Pacific Southwest Region, Vallejo, CA. 36 pp.

Sikes, K., D. J. Cooper, S. Weis, T. Keeler-Wolf, M. Barbour, D. Ikeda, D. Stout \& J. Evens. 2013. Fen conservation and vegetation assessment in the National Forests of the Sierra Nevada and adjacent mountains, California. Revised public version 2. Unpublished Document. University of California-Davis, Davis, CA. 20 pp.

Silberhorn, G. M., R. J. Orth \& K. A. Moore. 1983. Anthesis and seed production in Zostera marina L. (eelgrass) from the Chesepeake Bay. Aquat. Bot. 15: 133-144.

Siegal-Willott, J. L., K. Harr, L. C. Hayek, K. C. Scott, T. Gerlach, P. Sirois, M. Reuter, D. W. Crewz \& R. C. Hill. 2010. Proximate nutrient analyses of four species of submerged aquatic vegetation consumed by Florida manatee (Trichechus manatus latirostris) compared to romaine lettuce (Lactuca sativa var. longifolia). J. Zoo Wildl. Med. 41: 594-602.

Siegfried, W. R. 1973. Summer food and feeding of the ruddy duck in Manitoba. Can. J. Zool. 51: 1293-1297.

Sikes, K., D. Roach, J. Buck, J. Nelson \& S. Erwin. 2010. Classification and mapping of vegetation from three fen sites of the ShastaTrinity National Forest, California. Unpublished Report to the United States Forest Service, Region 5. Available online: http:// www.academia.edu/download/41910128/Classification and_Mapping_of_Vegetation20160202-15687-1dz4wxa.pdf [accessed 9 February, 2019].

Silva, J., N. Dantas-Santos, D. L. Gomes, L. S. Costa, S. L. Cordeiro, M. S. S. P. Costa, N. B. Silva, M. L. Freitas, K. C. Scortecci, E. L. Leite \& H. A. O. Rocha. 2012. Biological activities of the sulfated polysaccharide from the vascular plant Halodule wrightii. Rev. Bras. Farmacogn. 22: 94-101.

Silveira, M. J., S. M. Thomaz, R. P. Mormul \& F. P. Camacho. 2009. Effects of desiccation and sediment type on early regeneration of plant fragments of three species of aquatic macrophytes. Int. Rev. Hydrobiol. 94: 169-178.

Silvério, A., S. Nadot, T. T. Souza-Chies \& O. Chauveau. 2012. Floral rewards in the tribe Sisyrinchieae (Iridaceae): oil as an alternative to pollen and nectar? Sex. Plant Reprod. 25: 267-279.

Simberloff, D. \& C. Leppanen. 2019. Plant somatic mutations in nature conferring insect and herbicide resistance. Pest Manag. Sci. 75: 14-17.

Simpson, M. G. 1987. Pollen ultrastructure of the Pontederiaceae. Grana 26: 113-126.

Simpson, M. G. 1990. Phylogeny and classification of the Haemodoraceae. Ann. Missouri Bot. Gard. 77: 722-784.

Simpson, M. G. 1998. Haemodoraceae. Pp. 212-222 In: K. Kubitzki, H. Huber, P. J. Rudall, P. S. Stevens \& T. Stützel (eds.), The Families and Genera of Vascular Plants, Vol. IV. Flowering Plants, Monocotyledons: Alismatanae and Commelinanae (Except Gramineae). Springer-Verlag, Berlin, Germany.

Simpson, R. L., D. F. Whigham \& K. Brannigan. 1979. Mid-summer insect communities of freshwater tidal wetland macrophytes. Bull. New Jersey Acad. Sci. 24: 22-28.

Singer, R. B. \& A. A. Cocucci. 1999. Pollination mechanism in southern Brazilian orchids which are exclusively or mainly pollinated by halictid bees. Plant Syst. Evol. 217: 101-117. 
Singer, R., D. A. Roberts \& C. W. Boylen. 1983. The macrophytic community of an acidic lake in Adirondack (New York, USA): a new depth record for aquatic angiosperms. Aquat. Bot. 16: 49-57.

Singer, R. B., T. B. Breier, A. Flach \& R. Farias-Singer. 2007. The pollination mechanism of Habenaria pleiophylla Hoehne \& Schlechter (Orchidaceae: Orchidinae). Funct. Ecosyst. Communities 1: 10-14.

Singh, Y., A. E. Van Wyk \& H. Baijnath. 1996. Floral biology of Zantedeschia aethiopica (L.) Spreng. (Araceae). S. Afr. J. Bot. 62: 146-150.

Singh, D., R. Gupta \& S. A. Saraf. 2012. Herbs-are they safe enough? An overview. Crit. Rev. Food Sci. Nutr. 52: 876-898.

Singh, M., U. N. Rai, U. Nadeem \& A. A. David. 2014. Role of Potamogeton pectinatus in phytoremediation of metals. Chem. Sci. Rev. Lett. 3: 123-129.

Singhurst, J. R., J. C. Cathy, D. Prochaska, H. Haucke, G. C. Kroh \& W. C. Holmes. 2003. The vascular flora of Gus Engeling Wildlife Management Area, Anderson County, Texas. Southeast. Nat. 2: 347-369.

Singhurst, J. R., E. L. Bridges \& W. C. Holmes. 2007. Two additions to the flora of Oklahoma and notes on Xyris jupicai (Xyridaceae) in Oklahoma. Phytologia 89: 211-218.

Singhurst, J. R., D. J. Rosen \& W. C. Holmes. 2009. Two additions to the vascular flora of Texas. Phytologia 91: 69-72.

Singhurst, J. R., J. N. Mink \& W. C. Holmes. 2010. New and noteworthy plants of Texas. Phytologia 92: 249-255.

Singhurst, J. R., A. E. Rushing, C. K. Hanks \& W. C. Holmes. 2011. Isoetes texana (Isoetaceae): a new species from the Texas Coastal Bend. Phytoneuron 2011-22: 1-6.

Singhurst, J. R., B. A. Sorrie \& W. C. Holmes. 2012. Andropogon glaucopsis (Poaceae) in Texas. Phytoneuron 2012-16: 1-3.

Singhurst, J. R., C. T. Witsell, E. Sundell \& W. C. Holmes. 2014a. Utricularia cornuta (Lentibulariaceae) new to the Arkansas and Oklahoma flora. Phytoneuron 2014-109: 1-5.

Singhurst, J. R., A. K. Buthod \& W. C. Holmes. 2014b. Pluchea foetida (Asteraceae) confirmed in the Oklahoma flora. Phytoneuron 2014-97: 1-4.

Singhurst, J. R., A. Cooper, D. J. Rosen \& W. C. Holmes. 2014c. The vascular flora and plant communities of Candy Abshier Wildlife Managament Area, Chamber County, Texas, USA. J. Bot. Res. Inst. Texas 8: 665-675.

Singleton, J. R. 1951. Production and utilization of waterfowl food plants on the east Texas Gulf coast. J. Wildl. Manag. 15: 46-56.

Sinkiewicz, C. \& E. Jules. 2003. Port orford cedar and the non-native pathogen, Phytophthora lateralis. Fremontia 31: 14-20.

Sipaúba-Tavares, L. H. \& F. M. de Souza Braga. 2008. Constructed wetland[s] in wastewater treatment. Acta Sci. Biol. Sci. 30: 261-265.

Sipple, W. S. \& W. A. Klockner. 1980. A unique wetland in Maryland. Castanea 45: 60-69.

Siripahanakul, T., S. Thongsila, T. Tanuthong \& S. Chockchaisawasdee. 2013. Product development of Wolffiapork ball. Int. Food Res. J. 20: 213-217.

Sivakumar, D., R. Anand, J. Rajaganapathy \& M. Balasubramanian. 2008. Textile industry wastewater color removal using Lemna minuta Lin. J. Chem. Pharmaceut. Sci. 8: 563-570.

Siver, P. A. 1978. Development of diatom communities on Potamogeton robbinsii Oakes. Rhodora 80: 417-430.

Siver, P. A. 1980. Microattachment patterns of diatoms on leaves of Potamogeton robbinsii Oakes. Trans. Am. Microsc. Soc. 99: 217-220.

Siver, P. A., A. M. Coleman, G. A. Benson \& J. T. Simpson. 1986. The effects of winter drawdown on macrophytes in Candlewood Lake, Connecticut. Lake Reserv. Manag. 2: 69-73.
Sjöberg, K. \& K. Danell. 1982. Feeding activity of ducks in relation to diel emergence of chironomids. Can. J. Zool. 60: 1383-1387.

Sjörs, H. 1959. Bogs and fens in the Hudson Bay lowlands. Arctic 12: $2-19$.

Skeate, S. T. 1987. Interactions between birds and fruits in a northern Florida hammock community. Ecology 68: 297-309.

Skillicorn, P., W. Spira \& W. Journey. 1993. Duckweed Aquaculture: A New Aquatic Farming System for Developing Countries. The World Bank, Washington, DC. 77 pp.

Skinner, M. W. 1988. Comparative pollination ecology and floral evolution in Pacific Coast Lilium. Ph.D. dissertation. Harvard University, Cambridge, MA.

Skinner, M. W. 2002. Lilium Linnaeus. Pp. 172-197 In: Flora North America Editorial Committee (eds.), Flora of North America North of Mexico, Vol. 26: Magnoliophyta: Liliidae: Liliales and Orchidales. Oxford University Press, New York, NY.

Skinner, W. R. \& E. S. Telfer. 1974. Spring, summer, and fall foods of deer in New Brunswick. J. Wildl. Manag. 38: 210-214.

Skinner, M. W. \& B. A. Sorrie. 2002. Conservation and ecology of Lilium pyrophilum, a new species of Liliaceae from the Sandhills Region of the Carolinas and Virginia, USA. Novon 12: 94-105.

Skougard, M. G. \& J. D. Brotherson. 1979. Vegetational response to three environmental gradients in the salt playa near Goshen, Utah County, Utah. Great Basin Nat. 39: 44-58.

Skov, C. \& J. Wiley. 2005. Establishment of the Neotropical orchid bee Euglossa viridissima (Hymenoptera: Apidae) in Florida. Florida Entomol. 88: 225-228.

Slaughter, B. S. \& D. L. Cuthrell. 2011. A survey and characterization of Michigan's coastal fen communities. Report No. 201112. Michigan Natural Features Inventory, Lansing, MI. 151 pp.

Slaughter, R. J., D. M. G. Beasley, B. S. Lambie, G. T. Wilkins \& L. J. Schep. 2012. Poisonous plants in New Zealand: a review of those that are most commonly enquired about to the National Poisons Centre. New Zealand Med. J. 125: 87-118.

Sledge, W. A. 1948. The distribution and ecology of Scheuchzeria palustris L. Watsonia 1: 24-35.

Sletten, K. K. \& G. E. Larson. 1984. Possible relationships between surface water chemistry and aquatic plants in the Northern Great Plains. Proc. South Dakota Acad. Sci. 63: 70-76.

Small, J. K. 1931. Celestial lilies. J. New York Bot. Gard. 32: 260-269.

Small, J. A., D. Smiley, Jr., P. W. Zimmerman, E. B. Matzke, J. W. Thomson, Jr., O. P. Medsger, H. C. Bold, E. Ashwell \& J. J. Copeland. 1941. Field trips of the club. Torreya 41: 135-142.

Smith, J. G. 1895. A revision of the North American species of Sagittaria and Lophotocarpus. Missouri Bot. Gard. Ann. Rep. 1895: $1-64$.

Smith, J. G. 1900. Revision of the species of Lophotocarpus of the United States: and description of a new species of Sagittaria. Missouri Bot. Gard. Ann. Rep. 1900: 145-151.

Smith, R. W. 1910. The floral development and embryogeny of Eriocaulon septangulare. Bot. Gaz. 49: 281-289.

Smith, R. H. 1953. A study of waterfowl production on artificial reservoirs in eastern Montana. J. Wildl. Manag. 17: 276-291.

Smith, S. G. 1967. Experimental and natural hybrids in north American Typha (Typhaceae). Am. Midl. Nat. 78: 257-287.

Smith, Jr., R. J. 1983. Weeds of major economic importance in rice and yield losses due to weed competition. Pp. 19-36 In: Weed Control in Rice. International Rice Research Institute, Los Baños, Laguna, Philippines.

Smith, B. 1985. Gullible's travails: tuberculosis and quackery 1890 1930. J. Contemp. Hist. 20: 733-756.

Smith, S. G. 1986. The cattails (Typha): interspecific ecological differences and problems of identification. Lake Reserv. Manag. 2: $357-362$. 
Smith, S. G. 1987. Typha: its taxonomy and the ecological significance of hybrids. Arch. Hydrobiol., Beih. Ergebn. Limnol. 27: 129-138.

Smith, W. R. 1993. Orchids of Minnesota. University of Minnesota Press, Minneapolis, MN. 172 pp.

Smith, L. M. 1996. The Rare and Sensitive Natural Wetland Plant Communities of Interior Louisiana. Louisiana Natural Heritage Program, Louisiana Department of Wildlife and Fisheries, Baton Rouge, LA. 40 pp.

Smith, S. G. 2000. Typhaceae A. L. Jussieu. Pp. 278-285 In: Flora North America Editorial Committee (eds.), Flora of North America North of Mexico, Vol. 22: Magnoliophyta: Alismatidae, Arecidae, Commelinidae (in Part), and Zingiberidae. Oxford University Press, New York, NY.

Smith, C. W. G. 2001. Easy-Care Water Garden Plants. Storey Publishing, North Adams, MA. 32 pp.

Smith, W. R. 2012. Native Orchids of Minnesota. University of Minnesota Press, Minneapolis, MN. 254 pp.

Smith, S. D. P. 2014. The roles of nitrogen and phosphorus in regulating the dominance of floating and submerged aquatic plants in a field mesocosm experiment. Aquat. Bot. 112: 1-9.

Smith, R. 2017. Plant species richness and diversity of northern white-cedar (Thuja occidentalis) swamps in northern New York: effects and interactions of multiple variables. M.S. thesis. State University of New York, Syracuse, NY. 87 pp.

Smith, G. R. \& G. E. Snow. 1976. Pollination ecology of Platanthera (Habenaria) ciliaris and P. blephariglottis (Orchidaceae). Bot. Gaz. 137: 133-140.

Smith, L. M. \& J. A. Kadlec. 1983. Seed banks and their role during drawdown of a North American marsh. J. Appl. Ecol. 20: 673-684.

Smith, L. M. \& J. A. Kadlec. 1985. The effects of disturbance on marsh seed banks. Can. J. Bot. 63: 2133-2137.

Smith, G. L. \& W. S. Flory. 1990. Studies on Hymenocallis henryae (Amaryllidaceae). Brittonia 42: 212-220.

Smith, D. R. \& W. McDearman. 1990. A new Rhadinoceraea (Hymenoptera: Tenthredinidae) feeding on Zigadenus (Liliaceae) from southeastern United States. Entomol. News 101: 13-19.

Smith, D. R. \& E. M. Barrows. 1995. Rhadinoceraea n. sp. (Hymenoptera: Tenthredinidae) from West Virginia, a second species on Zigadenus (Liliaceae). Entomol. News 106: 237-240.

Smith, G. L. \& M. A. Garland. 1996. Taxonomic status of Hymenocallis choctawensis and Hymenocallis puntagordensis (Amaryllidaceae). Sida 17: 305-319.

Smith, S. M. \& S. Newman. 2001. Growth of southern cattail (Typha domingensis Pers.) seedlings in response to fire-related soil transformations in the northern Florida Everglades. Wetlands 21: 363-369.

Smith, G. L. \& W. S. Flory. 2002. Hymenocallis Salisbury. Pp. 283 292 In: Flora North America Editorial Committee (eds.), Flora of North America North of Mexico, Vol. 26: Magnoliophyta: Liliidae: Liliales and Orchidales. Oxford University Press, New York, NY.

Smith, G. L. \& M. A. Garland. 2003. Nomenclature of Hymenocallis taxa (Amaryllidaceae) in southeastern United States. Taxon 52: 805-817.

Smith, T. R. \& J. L. Capinera. 2005. Host preferences and habitat associations of some Florida grasshoppers (Orthoptera: Acrididae). Environ. Entomol. 34: 210-224.

Smith, G. L. \& M. A. Garland. 2009. A new species of Hymenocallis (Amaryllidaceae) from the Apalachicola Forest of the Florida panhandle, USA. Novon 19: 234-239.
Smith, F. H., K. C. Beeson \& W. E. Price. 1956. Chemical composition of herbage browsed by deer in two wildlife management areas. J. Wildl. Manag. 20: 359-367.

Smith, G. L., L. C. Anderson \& W. S. Flory. 2001. A new species of Hymenocallis (Amaryllidaceae) in the lower central Florida panhandle. Novon 11: 233-240.

Smith, S. M., P. V. McCormick, J. A. Leeds \& P. B. Garrett. 2002. Constraints of seed bank species composition and water depth for restoring vegetation in the Florida Everglades, USA. Restor. Ecol. 10: 138-145.

Smith, K. B., C. E. Smith, S. F. Forest \& A. J. Richard. 2007. A Field Guide to the Wetlands of the Boreal Plains Ecozone of Canada. Ducks Unlimited Canada, Western Boreal Office, Edmonton, AB. 98 pp.

Smith, R. J., S. D. Hopper \& M. W. Shane. 2011. Sand-binding roots in Haemodoraceae: global survey and morphology in a phylogenetic context. Plant Soil 348: 453-470.

Smith, S. M., A. R. Thime, B. Zilla \& K. Lee. 2015. Responses of narrowleaf cattail (Typha angustifolia) to combinations of salinity and nutrient additions: implications for coastal marsh restoration. Ecol. Restor. 33: 297-302.

Smith, S. Y., W. J. D. Iles, J. C. Benedict \& C. D. Specht. 2018. Building the monocot tree of death: progress and challenges emerging from the macrofossil-rich Zingiberales. Am. J. Bot. 105: $1389-1400$.

Smits, A. J. M., M. J. H. De Lyon, G. Van der Velde, P. L. M. Steentjes \& J. G. M. Roelofs. 1988. Distribution of three nymphaeid macrophytes (Nymphaea alba L., Nuphar lutea (L.) Sm. and Nymphoides peltata (Gmel.) O. Kuntze) in relation to alkalinity and uptake of inorganic carbon. Aquat. Bot. 32: 45-62.

Smits, A. J. M., R. Van Ruremonde \& G. Van der Velde. 1989. Seed dispersal of three nymphaeid macrophytes. Aquat. Bot. 35: 167-180.

Smock, L. A. \& K. L. Harlowe. 1983. Utlization and processing of freshwater wetland macrophytes by the detritivore Asellus forbesi. Ecology 64: 1556-1565.

Smock, L. A., D. L. Stoneburner \& D. R. Lenat. 1981. Littoral and profundal macroinvertebrate communities of a coastal brownwater lake. Arch. Hydrobiol. 92: 306-320.

Smreciu, A., S. Wood, K. Gould \& B. Wood. 2014. Propagation protocol for ratroot (Acorus americanus). Native Plant J. 15: 219-222.

Smreciu, A., K. Gould \& S. Wood. 2015. Stratification and light promote germination of ratroot (Acorus americanus (Raf.) Raf. [Acoraceae]) seeds harvested in northeastern Alberta. Native Plant J. 16: 19-22.

Sneddon, L. \& E. E. Lamont. 2010. Diversity and classification of tidal wetlands on Long Island, New York. Mem. Torrey Bot. Soc. 26: 14-33.

Snoad, B. 1955. Somatic instability of chromosome number in Hymenocallis calathinum. Heredity 9: 129-134.

Snow, A. A., S. E. Travis, R. Wildová, T. Fér, P. M. Sweeney, J. E. Marburger, S. Windels, B. Kubátová, D. E. Goldberg \& E. Mutegi. 2010. Species-specific SSR alleles for studies of hybrid cattails (Typha latifolia $\times$ T. angustifolia; Typhaceae) in North America. Am. J. Bot. 97: 2061-2067.

Snyder, D. B. 1988. Heteranthera multiflora in New Jersey: a first look. Bartonia 54: 21-23.

Snyder, D. 1996. The genus Rhexia in New Jersey. Bartonia 59: 55-70.

Soda, S., T. Ohchi, J. Piradee, Y. Takai \& M. Ike. 2015. Duckweed biomass as a renewable biorefinery feedstock: ethanol and succinate production from Wolffia globosa. Biomass Bioenergy 81: $364-368$. 
Soerjani, M., A. J. G. H. Kostermans \& G. Tjitrosoepomo (eds.). 1987. Weeds of Rice in Indonesia. Balai Pustaka, Jakarta. 716 pp.

Sohsalam, P., A. J. Englande \& S. Sirianuntapiboon. 2008. Seafood wastewater treatment in constructed wetland: Tropical case. Bioresour. Technol. 99: 1218-1224.

Solomeshch, A. I., M. G. Barbour \& R. F. Holland. 2007. Vernal pools. Pp. 394-424 In: M. Barbour, T. Keeler-Wolf \& A. A. Schoenherr (eds.), Terrestrial Vegetation of California, 3rd ed. University of California Press, Berkeley, CA.

Soltis, D., P. Soltis, P. Endress, M. W. Chase, S. Manchester, W. Judd, L. Majure \& E. Mavrodiev. 2018. Phylogeny and Evolution of the Angiosperms. University of Chicago Press, Chicago, IL. 560 pp.

Sommers, K. P., M. Elswick, G. I. Herrick \& G. A. Fox. 2011. Inferring microhabitat preferences of Lilium catesbaei (Liliaceae). Am. J. Bot. 98: 819-828.

Søndergaard, M., L. S. Johansson, T. L. Lauridsen, T. B. Jørgensen, L. Liboriussen \& E. Jeppesen. 2010. Submerged macrophytes as indicators of the ecological quality of lakes. Freshw. Biol. 55: 893-908.

Song, J. Y., J. Naylor-Adelberg, S. A. White, D. A. Mann \& J. Adelberg. 2014. Establishing clones of Veratrum californicum, a native medicinal species, for micropropagation. In Vitro Cell. Dev. Biol.-Plant 50: 337-344.

Sonnenholzner, J. I., G. Montaño-Moctezuma, R. Searcy-Bernal \& A. Salas-Garza. 2011. Effect of macrophyte diet and initial size on the survival and somatic growth of sub-adult Strongylocentrotus purpuratus: a laboratory experimental approach. J. Appl. Phycol. 23: 505-513.

Soomers, H., D. N. Winkel, Y. U. N. Du \& M. J. Wassen. 2010. The dispersal and deposition of hydrochorous plant seeds in drainage ditches. Freshw. Biol. 55: 2032-2046.

Soons, M. B. 2006. Wind dispersal in freshwater wetlands: knowledge for conservation and restoration. Appl. Veg. Sci. 9: 271-278.

Sopajarn, A. \& C. Sangwichien. 2015. Optimization of enzymatic saccharification of alkali pretreated Typha angustifolia for glucose production. Int. J. Chem. Eng. Applic. 6: 232-236.

Soreng, R. J., W. P. Armstrong, A. Tiehm \& T. K. Todsen. 1984. Noteworthy collections. Madroño 31: 123-127.

Soros-Pottruff, C. L. \& U. Posluszny. 1994. Developmental morphology of reproductive structures of Phyllospadix (Zosteraceae). Int. J. Plant Sci. 155: 405-420.

Soros-Pottruff, C. L. \& U. Posluszny. 1995. Developmental morphology of reproductive structures of Zostera and a reconsideration of Heterozostera (Zosteraceae). Int. J. Plant Sci. 156: 143-158.

Sorrie, B. A. 2000. Rhynchospora leptocarpa (Cyperaceae), an overlooked species of the southeastern United States. Sida 19: 139-147.

Sorrie, B. A. \& P. W. Dunwiddie. 1990. Amphicarpum purshii (Poaceae), a genus and species new to New England. Rhodora 92: 105-107.

Sorrie, B. A. \& S. W. Leonard. 1999. Noteworthy records of Mississippi vascular plants. Sida 18: 889-908.

Sorrie, B. A. \& A. S. Weakley. 2001. Coastal plain vascular plant endemics: phytogeographic patterns. Castanea 66: 50-82.

Sorrie, B. A. \& A. S. Weakley. 2017. Stenanthium leimanthoides and S. densum (Melanthiaceae) revisited, with the description of two new species. J. Bot. Res. Inst. Texas 11: 275-286.

Sorrie, B. A., B. Van Eerden \& M. J. Russo. 1997. Noteworthy plants from Fort Bragg and Camp MacKall, North Carolina. Castanea 62: 239-259.

Sorrie, B. A., J. B. Gray \& P. J. Crutchfield. 2006. The vascular flora of the longleaf pine ecosystem of Fort Bragg and Weymouth Woods, North Carolina. Castanea 71: 129-161.
Sorrie, B. A., B. R. Keener \& A. L. Edwards. 2007. Reinstatement of Sagittaria macrocarpa (Alismataceae). J. Bot. Res. Inst. Texas 1: 345-350.

Sorrie, B. A., P. D. McMillan, B. van Eerden, R. J. LeBlond, P. E. Hyatt \& L. C. Anderson. 2011. Carex austrodeflexa (Cyperaceae) a new species of Carex sect. Acrocystis from the Atlantic coastal plain of the southeastern United States. J. Bot. Res. Inst. Texas 5: 45-51.

Sorrie, B. A., W. M. Knapp, D. Estes \& D. D. Spaulding. 2012. A new Sisyrinchium (Iridaceae) from cedar glades in northern Alabama. J. Bot. Res. Inst. Texas 6: 323-329.

Sosiak, A. 2002. Long-term response of periphyton and macrophytes to reduced municipal nutrient loading to the Bow River (Alberta, Canada). Can. J. Fish. Aquat. Sci. 59: 987-1001.

Sousa, W. T. Z. 2011. Hydrilla verticillata (Hydrocharitaceae), a recent invader threatening Brazil's freshwater environments: a review of the extent of the problem. Hydrobiologia 669: 1-20.

Southwick, C. H. \& F. W. Pine. 1975. Abundance of submerged vascular vegetation in the Rhode River from 1966 to 1973. Chesapeake Sci. 16: 147-151.

Spahr, R., L. Armstrong, D. Atwood \& M. Rath. 1991. Threatened, Endangered, and Sensitive Species of the Intermountain Region. U.S. Department of Agriculture, Forest Service, Intermountain Region, Ogden, UT. 560 pp.

Sparrow, F. K. 1974. Observations on chytridiaceous parasites of phanerogams. XX. Resting spore germination and epibiotic stage of Physoderma butomi Schroeter. Am. J. Bot. 61: 203-208.

Spence, J. F. 1981. The diversity and abundance of the benthic macroinvertebrates in an oligo-mesotrophic central Florida lake. M.S. thesis. University of Central Florida, Orlando, FL. 50 pp.

Spence, J. R. 1996. Demography and monitoring of the autumn buttercup, Ranunculus aestivalis (Benson) Van Buren \& Harper, southcentral Utah. Pp. 19-27 In: J. Maschinski, H. D. Hammond \& L. Holter (tech. eds.), Southwestern Rare and Endangered Plants: Proceeding of the Second Conference; 1995 September 11-14; Flagstaff, AZ. Gen. Tech. Rep. RM-GTR-283. U.S. Department of Agriculture, Forest Service, Rocky Mountain Forest and Range Experiment Station, Fort Collins, CO.

Spence, D. H. N. \& J. Chrystal. 1970. Photosynthesis and zonation of freshwater macrophytes I. Depth distribution and shade tolerance. New Phytol. 69: 205-215.

Spence, D. H. N. \& H. M. Dale. 1978. Variations in the shallow water form of Potamogeton richardsonii induced by some environmental factors. Freshw. Biol. 8: 251-268.

Spencer, D. F. 1986. Early growth of Potamogeton pectinatus L. in response to temperature and irradiance: morphology and pigment composition. Aquat. Bot. 26: 1-8.

Spencer, D. F. 1987. Tuber size and planting depth influence growth of Potamogeton pectinatus L. Am. Midl. Nat. 118: 77-84.

Spencer, D. F. \& L. W. J. Anderson. 1987. Influence of photoperiod on growth, pigment composition and vegetative propagule formation for Potamogeton nodosus Poir. and Potamogeton pectinatus L. Aquat. Bot. 28: 103-112.

Spencer, D. F. \& G. G. Ksander. 1992. Influence of temperature and moisture on vegetative propagule germination of Potamogeton species: implications for aquatic plant management. Aquat. Bot. 43: 351-364.

Spencer, D. F. \& G. G. Ksander. 1995. Influence of propagule size, soil fertility, and photoperiod on growth and propagule production by three species of submersed macrophytes. Wetlands $\mathbf{1 5}$ : 134-140.

Spencer, D. F. \& G. G. Ksander. 1996. Growth and carbon utilization by sprouted propagules of two species of submersed rooted aquatic plants grown in darkness. Hydrobiologia 317: 69-78. 
Spencer, D. F. \& G. G. Ksander. 1997. Influence of anoxia on sprouting of vegetative propagules of three species of aquatic plant propagules. Wetlands 17: 55-64.

Spencer, D. F. \& G. G. Ksander. 1999. Phenolic acids and nutrient content for aquatic macrophytes from Fall River, California. $J$. Freshw. Ecol. 14: 197-209.

Spencer, D. F. \& G. G. Ksander. 2001. Comparison of light compensation points for two submersed macrophytes. J. Freshw. Ecol. 16: 509-515.

Spencer, D. F. \& G. G. Ksander. 2002. Sedimentation disrupts natural regeneration of Zannichellia palustris in Fall River, California. Aquat. Bot. 73: 137-147.

Spencer, D. \& G. Ksander. 2003. Nutrient limitation of Zannichellia palustris and Elodea canadensis growing in sediments from Fall River, California. J. Freshw. Ecol. 18: 207-213.

Spencer, D. F. \& M. Rejmánek. 2010. Competition between two submersed aquatic macrophytes, Potamogeton pectinatus and Potamogeton gramineus, across a light gradient. Aquat. Bot. 92: 239-244.

Spencer, D. \& G. Ksander. 2011. Spatial pattern analysis for underground propagules of Potamogeton gramineus L. in two northern California irrigation canals. J. Freshw. Ecol. 8: 297-303.

Spencer, D. F., L. W. J. Anderson \& G. G. Ksander. 1994. Field and greenhouse investigations on winter bud production by Potamogeton gramineus L. Aquat. Bot. 48: 285-295.

Spencer, D. F., F. J. Ryan \& G. G. Ksander. 1997. Construction costs for some aquatic plants. Aquat. Bot. 56: 203-214.

Spencer, D. F., G. G. Ksander, J. D. Madsen \& C. S. Owens. 2000. Emergence of vegetative propagules of Potamogeton nodosus, Potamogeton pectinatus, Vallisneria americana, and Hydrilla verticillata based on accumulated degree-days. Aquat. Bot. 67 : 237-249.

Spencer, D. F., C. L. Elmore, G. G. Ksander \& J. A. Roncoroni. 2003. Influence of dilute acetic acid treatments on American pondweed winter buds in the Nevada irrigation district, California. J. Aquat. Plant Manag. 41: 65-68.

Sperduto, D. D. 2011. Natural Community Systems of New Hampshire. New Hampshire Natural Heritage Bureau, Concord, NH. 119 pp.

Spindler, M. A. \& K. F. Hall. 1991. Local movements and habitat use of Tundra or Whistling Swans Cygnus columbianus in KobukSelawik Lowlands of northwest Alaska. Wildfowl 42: 17-32.

Spinner, G. P. 1942. A studey of herbaceous plants of value to wildlife in Connecticut. M.S. thesis. University of Michigan, Ann Arbor, MI. 63 pp.

Spinner, G. P. \& J. S. Bishop. 1950. Chemical analysis of some wildlife foods in Connecticut. J. Wildl. Manag. 14: 175-180.

Sprenkle, E. S., L. A. Smock \& J. E. Anderson. 2004. Distribution and growth of submerged aquatic vegetation in the Piedmont section of the James River, Virginia. Southeast. Nat. 3: 517-530.

Squires, J. R. \& S. H. Anderson. 1995. Trumpeter swan (Cygnus buccinator) food habits in the Greater Yellowstone ecosystem. Am. Midl. Nat. 133: 274-282.

Squires, M. M. \& L. F. W. Lesack. 2003. The relation between sediment nutrient content and macrophyte biomass and community structure along a water transparency gradient among lakes of the Mackenzie Delta. Can. J. Fish. Aquat. Sci. 60: 333-343.

Srivastava, D. S. \& R. L. Jefferies. 2002. Intertidal plant communities of an Arctic salt marsh: the influence of isostatic uplift and herbivory. Écoscience 9: 112-118.

Srivastava, D. S., C. A. Staicer \& B. Freedman. 1995. Aquatic vegetation of Nova Scotian lakes differing in acidity and trophic status. Aquat. Bot. 51: 181-196.

Stace, C. A. (ed.). 1999. 1OPB chromosome data 14. IOPB Newslett. 30: $10-15$.
Stafford, N. B. \& S. S. Bell. 2006. Space competition between seagrass and Caulerpa prolifera (Forsskaal) Lamouroux following simulated disturbances in Lassing Park, FL. J. Exp. Mar. Biol. Ecol. 333: 49-57.

Stalter, R. 1973. Factors influencing the distribution of vegetation of the Cooper River estuary. Castanea 38: 18-24.

Stalter, R. 1985. The flora of Hunting Island, Beaufort County, South Carolina. Bartonia 51: 99-104.

Stalter, R. \& S. C. Dial. 1984. Hammock vegetation of Little Talbot Island State Park, Florida. Bull. Torrey Bot. Club 111: 494-497.

Stalter, R. \& J. Baden. 1994. A twenty year comparison of vegetation of three abandoned rice fields, Georgetown County, South Carolina. Castanea 59: 69-77.

Standley, P. C. 1919. A new locality for Senecio crawfordii. Rhodora 21: $117-120$.

Stang, M. 2018. Flowers in lace designs. Datatèxtil 38: 2-11.

Stansbury, J., P. Saunders \& D. Winston. 2012. Promoting healthy thyroid function with iodine, bladderwrack, guggul and iris. $J$. Restor. Med. 1: 83-90.

Staples, T. E., K. C. J. Van Rees \& C. van Kessel. 1999. Nitrogen competition using ${ }^{15} \mathrm{~N}$ between early successional plants and planted white spruce seedlings. Can. J. For. Res. 29: 1282-1289.

Stearns, L. A. \& M. W. Goodwin. 1941. Notes on the winter feeding of the muskrat in Delaware. J. Wildl. Manag. 5: 1-12.

Steele, P. R., K. L. Hertweck, D. Mayfield, M. R. McKain, J. Leebens-Mack \& J. C. Pires. 2012. Quality and quantity of data recovered from massively parallel sequencing: examples in Asparagales and Poaceae. Am. J. Bot. 99: 330-348.

Steenkamp, V. 2003. Traditional herbal remedies used by South African women for gynaecological complaints. J. Ethnopharmacol. 86: 97-108.

Stegmaier, C. E. 1966. A leaf-mining Hippelates in south Florida (Diptera, Chloropidae). Florida Entomol. 49: 19-21.

Stehle, M. E. 1920. A preliminary survey of the protozoa of Mirror Lake, on the Ohio State University campus. Ohio J. Sci. 20: 89-127.

Steinbauer, G. P. \& D. Neil. 1948. Dormancy and germination of seeds of the burreeds. Pap. Michigan Acad. Sci. Arts Lett. 34: 33-37.

Stenlund, D. L. \& I. D. Charvat. 1994. Vesicular arbuscular mycorrhizae in floating wetland mat communities dominated by Typha. Mycorrhiza 4: 131-137.

Sterling, C. 1980. Comparative morphology of the carpel in the Liliaceae: Helonieae. Bot. J. Linn. Soc. 80: 341-356.

Stetson, S. 1913. The flora of Copake Falls, NY. Torreya 13: 121-133. Stevens, O. A. 1957. Weights of seeds and numbers per plant. Weeds 5: $46-55$.

Stevenson, D. W. 1998. Mayacaceae. Pp. 294-296 In: K. Kubitzki (ed.), The Families and Genera of Vascular Plants, Vol. IV, Flowering Plants: Monocotyledons, Alismatanae and Commelinanae (Except Gramineae). Springer-Verlag, Berlin, Germany.

Stevenson, J. C., L. W. Staver \& K. W. Staver. 1993. Water quality associated with survival of submersed aquatic vegetation along an estuarine gradient. Estuaries 16: 346-361.

Stevenson, D. W., J. I. Davis, J. V. Freudenstein, C. R. Hardy, M. P. Simmons \& C. D. Specht. 2000. A phylogenetic analysis of the monocotyledons based on morphological and molecular character sets, with comments on the placement of Acorus and Hydatellaceae. Pp. 17-24 In: K. L. Wilson and D. Morrison (eds.), Systematics and Evolution of Monocots. CSIRO Publishing, Collingwood, VIC, Australia.

Steward, K. K. 1991. Growth of various hydrilla races in waters of differing pH. Florida Sci. 54: 117-125. 
Steward, K. K. 1993. Seed production in monoecious and dioecious populations of Hydrilla. Aquat. Bot. 46: 169-183.

Steward, K. K. \& T. K. Van. 1987. Comparative studies of monoecious and dioecious hydrilla (Hydrilla verticillata) biotypes. Weed Sci. 35: 204-210.

Stewart, R. E. \& J. H. Manning. 1958. Distribution and ecology of Whistling Swans in the Chesapeake Bay region. Auk 75: 203-212.

Stewart, R. E. \& H. A. Kantrud. 1972. Vegetation of prairie potholes, North Dakota, in relation to quality of water and other environmental factors. Geological Survey Professional Paper 585-D. U.S. Government Printing Office, Washington, DC. 36 pp.

Stewart, G. R. \& J. A. Lee. 1974. The role of proline accumulation in halophytes. Planta 120: 279-289.

Stewart, J. G. \& L. Rüdenberg. 1980. Microsporocyte growth and meiosis in Phyllospadix torreyi, a marine monocotyledon. Am. J. Bot. 67: 949-954.

Stewart, Jr., C. N. \& E. T. Nilsen. 1993. Association of edaphic factors and vegetation in several isolated Appalachian peat bogs. Bull. Torrey Bot. Club 120: 128-135.

Stewart, S. L. \& L. W. Zettler. 2002. Symbiotic germination of three semi-aquatic rein orchids (Habenaria repens, $H$. quinquiseta, H. macroceratitis) from Florida. Aquat. Bot. 72: 25-35.

Stewart, S. L. \& L. W. Richardson. 2008. Orchid flora of the Florida Panther National Wildlife Refuge. North Am. Native Orchid J. 14: 70-104.

Stewart, H., S. L. Miao, M. Colbert \& C. E. Carraher. 1997. Seed germination of two cattail (Typha) species as a function of Everglandes nutrient levels. Wetlands 17: 116-122.

Steyermark, J. A. \& J. A. Moore. 1933. Report of a botanical expedition into the mountains of western Texas. Ann. Missouri Bot. Gard. 20: 791-806.

Stieglitz, W. O. 1972. Food habits of the Florida duck. J. Wildl. Manag. 36: 422-428.

Stollberg, B. P. 1949. Competition of American coots and shoalwater ducks for food. J. Wildl. Manag. 13: 423-424.

Stollberg, B. P. 1950. Food habits of shoal-water ducks on Horicon Marsh, Wisconsin. J. Wildl. Manag. 14: 214-217.

Stoltz, L. P. 1968. Iris seed dormancy. Physiol. Plant. 21: 1328-1331.

Stoops, C. A., P. H. Adler \& J. W. McCreadie. 1998. Ecology of aquatic Lepidoptera (Crambidae: Nymphulinae) in South Carolina, USA. Hydrobiologia 379: 33-40.

Storch, T. A., J. D. Winter \& C. Neff. 1986. The employment of macrophyte transplanting techniques to establish Potamogeton amplifolius beds in Chautauqua Lake, New York. Lake Reserv. Manag. 2: 263-266.

Stoudt, J. H. 1944. Food preferences of mallards on the Chippewa National Forest, Minnesota. J. Wildl. Manag. 8: 100-112.

Strayer, D. L., C. Lutz, H. M. Malcom, K. Munger \& W. H. Shaw. 2003. Invertebrate communities associated with a native (Vallisneria americana) and an alien (Trapa natans) macrophyte in a large river. Freshw. Biol. 48: 1938-1949.

Strazisar, T., M. S. Koch, E. Dutra \& C. J. Madden. 2013a. Ruppia maritima L. seed bank viability at the Everglades-Florida Bay ecotone. Aquat. Bot. 111: 26-34.

Strazisar, T., M. S. Koch, C. J. Madden, J. Filina, P. U. Lara \& A. Mattair. 2013b. Salinity effects on Ruppia maritima L. seed germination and seedling survival at the Everglades-Florida Bay ecotone. J. Exp. Mar. Biol. Ecol. 445: 129-139.

Strazisar, T., M. S. Koch \& C. J. Madden. 2015. Seagrass (Ruppia maritima L.) life history transitions in response to salinity dynamics along the Everglades-Florida Bay ecotone. Estuaries Coast. 38: 337-352.

Streng, D. R. \& P. A. Harcombe. 1982. Why don't east Texas savannas grow up to forest? Am. Midl. Nat. 108: 278-294.
Stricker, S. A. 1985. A new species of Tetrastemma (Nemertea, Monostilifera) from San Juan Island, Washington, USA. Can. J. Zool. 63: 682-690.

Strong, W. L. 2000. Vegetation development on reclaimed lands in the Coal Valley Mine of western Alberta, Canada. Can. J. Bot. 78: $110-118$.

Strong, M. T. \& P. M. Sheridan. 1991. Juncus caesariensis Coville (Juncaceae) in Virginia peat bogs. Castanea 56: 65-69.

Strong, M. T. \& C. L. Kelloff. 1994. Intertidal vascular plants of Brent Marsh, Potomac River, Stafford County, Virginia. Castanea 59: 354-366.

Sree, K. S., S. Sudakaran \& K.-J. Appenroth. 2015. How fast can angiosperms grow? Species and clonal diversity of growth rates in the genus Wolffia (Lemnaceae). Acta Physiol. Plant. 37: 204.

Sree, K. S., M. Bog \& K. J. Appenroth. 2016. Taxonomy of duckweeds (Lemnaceae), potential new crop plants. Emir. J. Food Agric. 28: 291-302.

Stone, K. R. 2009. Iris pseudacorus. In: Fire Effects Information System. U.S. Department of Agriculture, Forest Service, Rocky Mountain Research Station, Fire Sciences Laboratory. Available online: https://www.fs.fed.us/database/feis/plants/ forb/iripse/all.html [accessed 31 January, 2019].

Stratman, K., W. A. Overholt, J. P. Cuda, M. D. Netherland \& P. C. Wilson. 2013. The diversity of Chironomidae associated with Hydrilla in Florida, with special reference to Cricotopus lebetis (Diptera: Chironomidae). Florida Entomol. 96: 654-657.

Stuart, W. 2018. Cape Fear native flora focus. Native Plant News 15(4): $1,5$.

Stubbs, C. S., H. A. Jacobson, E. A. Osgood \& F. A. Drummond. 1992. Alternative forage plants for native (wild) bees associated with lowbush blueberry, Vaccinium spp., in Maine. Technical Bulletin 148. Maine Agricultural Experiment Station, Orono, ME. 54 pp.

Stubler, A. D., L. J. Jackson, B. T. Furman \& B. J. Peterson. 2017. Seed production patterns in Zostera marina: effects of patch size and landscape configuration. Estuaries Coast. 40: 564-572.

Stuckey, I. H. 1967. Environmental factors and the growth of native orchids. Am. J. Bot. 54: 232-241.

Stuckey, R. L. 1968. Distributional history of Butomus umbellatus (flowering-rush) in the western Lake Erie and Lake St. Clair region. Michigan Bot. 7: 134-142.

Stuckey, R. L. 1971. Changes of vascular aquatic flowering plants during 70 years in Put-in-Bay Harbor, Lake Erie, Ohio. Ohio J. Sci. 71: 321-342.

Stuckey, R. L. 1979. Distributional history of Potamogeton crispus (curly pondweed) in North America. Bartonia 46: 22-42.

Stuckey, R. L. 1983. Absence of certain aquatic vascular plants from the prairie peninsula. Pp. 97-103 In: R. Brewer (ed.), Proceedings of the Eighth North American Prairie Conference. Western Michigan University, Kalamazoo, MI.

Stuckey, R. L. 1985. Distributional history of Najas marina (spiny naiad) in North America. Bartonia 51: 2-16.

Stuckey, R. L. \& D. H. Les. 1984. Pistia stratiotes (Water Lettuce) recorded from Florida in Bartram's Travels, 1765-74. Aquaphyte 4(2): 1, 6.

Stuckey, R. L. \& D. L. Moore. 1995. Return and increase in abundance of aquatic flowering plants in Put-In-Bay Harbor, Lake Erie, Ohio. Ohio J. Sci. 95: 261-266.

Stuckey, I. H. \& L. L. Gould. 2000. Coastal Plants from Cape Cod to Cape Canaveral. The University of North Carolina Press, Chapel Hill, NC. 305 pp.

Stuckey, R. L., J. R. Wehrmeister \& R. J. Bartolotta. 1978. Submersed aquatic vascular plants in ice-covered ponds of central Ohio. Rhodora 80: 575-580. 
Sturtevant, R., L. Berent, T. Makled, W. Conard, A. Fusaro \& E. Rutherford. 2016. An overview of the management of established nonindigenous species in the Great Lakes. NOAA Technical Memorandum GLERL-168. GLERL Information Services, Ann Arbor, MI. 273 pp.

Stützel, T. 1984. Blüten- und infloreszenmorphologische Untersuchungen zur Systematik der Eriocaulaceen. Diss. Bot. 71: 1-108.

Stützel, T. 1998. Eriocaulaceae. Pp. 197-207 In: K. Kubitzki, H. Huber, P. J. Rudall, P. S. Stevens \& T. Stützel (eds.), The Families and Genera of Vascular Plants, Vol. IV. Flowering Plants, Monocotyledons: Alismatanae and Commelinanae (Except Gramineae). Springer-Verlag, Berlin, Germany.

Stützel, T. \& N. Gansser. 1996. Floral morphology of North American Eriocaulaceae and its taxonomic implications. Feddes Repert. 106: 495-502.

Stutzenbaker, C. D. 1999. Aquatic and Wetland Plants of the Western Gulf Coast. Texas Parks \& Wildlife Press/University of Texas Press, Austin, TX. 465 pp.

Su, K. L. \& E. J. Staba. 1972. Aquatic plants from Minnesota. Part 1 chemical survey. Bulletin 46. Water Resources Research Center, University of Minnesota, Minneapolis, MN. 50 pp.

Su, K. L., E. J. Staba \& Y. Abul-Hajj. 1972. Aquatic plants from Minnesota. Part 3 - antimicrobial effects. Bulletin 48. Water Resources Research Center, University of Minnesota, Minneapolis, MN. 36 pp.

Su, K. L., Y. Abul-Hajj \& E. J. Staba. 1973. Antimicrobial effects of aquatic plants from Minnesota. Lloydia 36: 80-87.

Su, H., Y. Zhao, J. Jiang, Q. Lu, Q. Li, Y. Luo, H. Zhao \& M. Wang. 2014. Use of duckweed (Landoltia punctata) as a fermentation substrate for the production of higher alcohols as biofuels. Energy Fuels 28: 3206-3216.

Subudhi, H. N., S. P. Panda, P. K. Behera \& C. Patnaik. 2015. A check list of weeds in rice fields of coastal Orissa, India. Pp. 1-10 In: H. Wang (ed.), Soil Ecology and Land-Use Management. White Word Publications, New York, NY.

Sugden, L. G. \& E. A. Driver. 1980. Natural foods of mallards in Saskatchewan parklands during late summer and fall. J. Wildl. Manag. 44: 705-709.

Suksathan, P., M. H. Gustafsson \& F. Borchsenius. 2009. Phylogeny and generic delimitation of Asian Marantaceae. Bot. J. Linn. Soc. 159: 381-395.

Sullivan, V. I. 1981. Najas minor (Najadaceae) in Louisiana. Sida 9: 88-90.

Sullivan, M. J. 1977. Structural characteristics of a diatom community epiphytic on Ruppia maritima. Hydrobiologia 53: 81-86.

Sullivan, G. \& J. E. Titus. 1996. Physical site characteristics limit pollination and fruit set in the dioecious hydrophilous species, Vallisneria americana. Oecologia 108: 285-292.

Sulman, J. D., B. T. Drew, C. Drummond, E. Hayasaka \& K. J. Sytsma. 2013. Systematics, biogeography, and character evolution of Sparganium (Typhaceae): diversification of a widespread, aquatic lineage. Am. J. Bot. 100: 2023-2039.

Sultana, N., S. S. Sultana \& S. S. Alam. 2013. Karyotype and RAPD analysis to elucidate taxonomic status in two morphological forms of Egeria densa Planch. and Hydrilla verticillata (L.f.) Royle. Cytologia 78: 277-284.

Sumoski, S. E. \& R. J. Orth. 2012. Biotic dispersal in eelgrass Zostera marina. Mar. Ecol. Prog. Ser. 471: 1-10.

Sun, Y., S. A. White, D. Mann \& J. Adelberg. 2012. Chilling requirements to break dormancy of Veratrum californicum. HortScience 47: 1710-1713.

Sundarasekar, J., G. Sahgal, V. Murugaiyah, L. K. Lay, O. M. Thong \& S. Subramaniam. 2018. Wound healing activity of Hymenocallis littoralis-moving beyond ornamental plant. Pak. J. Pharm. Sci. 31: 2537-2543.
Sundell, E. \& R. D. Thomas. 1988. Four new records of Cyperus (Cyperaceae) in Arkansas. Sida 13: 259-261.

Sundue, M. 2006. Addendum to field trip reports. J. Torrey Bot. Soc. 133: 210-211.

Sundue, M. 2007. Field trip reports. J. Torrey Bot. Soc. 134: 144-152. Surdick, J. A. \& A. M. Jenkins. 2010. Population Surveys of Rare Lauraceae Species to Assess the Effect of Laurel wilt Disease in Florida. Florida Natural Areas Inventory, Tallahassee, FL. $15 \mathrm{pp}$.

Suresh, G., P. P. Reddy, K. S. Babu, T. B. Shaik \& S. V. Kalivendi. 2010. Two new cytotoxic labdane diterpenes from the rhizomes of Hedychium coronarium. Bioorg. Med. Chem. Lett. 20: $7544-7548$.

Surveswaran, S., V. Gowda \& M. Sun. 2018. Using an integrated approach to identify cryptic species, divergence patterns and hybrid species in Asian ladies' tresses orchids (Spiranthes, Orchidaceae). Mol. Phylogenet. Evol. 124: 106-121.

Suter, R. B., P. R. Miller \& G. E. Stratton. 2011. Egg capsule architecture and siting in a leaf-curling sac spider, Clubiona riparia (Araneae: Clubionidae). J. Arachnol. 39: 76-83.

Sutherland, S. 1986. Floral sex ratios, fruit-set, and resource allocation in plants. Ecology 67: 991-1001.

Sutherland, W. J. 1990. Iris pseudacorus L. J. Ecol. 78: 833-848.

Sutter, R. 1984. The status of Helonias bullata L. (Liliaceae) in the southern Appalachians. Castanea 49: 9-16.

Sutter, L. A., J. E. Perry \& R. M. Chambers. 2014. Tidal freshwater marsh plant responses to low level salinity increases. Wetlands 34: 167-175.

Sutton, D. L. 1991. Culture and growth of pickerelweed from seedlings. J. Aquat. Plant Manag. 29: 39-42.

Sutton, D. L., T. K. Van \& K. M. Portier. 1992. Growth of dioecious and monoecious hydrilla from single tubers. J. Aquat. Plant Manag. 30: 15-20.

Svedelius, N. 1932. On the different types of pollination in Vallisneria spiralis L. and Vallisneria americana Michx. Svensk Bot. Tidskr. 26: 1-12.

Swales, D. E. 1979. Nectaries of certain arctic and sub-arctic plants with notes on pollination. Rhodora 81: 363-407.

Swanson, G. A. \& J. C. Bartonek. 1970. Bias associated with food analysis in gizzards of blue-winged teal. J. Wildl. Manag. 34: 739-746.

Swindale, D. N. \& J. T. Curtis. 1957. Phytosociology of the larger submerged plants in Wisconsin lakes. Ecology 38: 397-407.

Swinehart, A. L. 1995. Paleoecology of an alkaline peatland in Elkhart County, Indiana. Proc. Indiana Acad. Sci. 104: 43-46.

Sykes, Jr., P. W., C. B. Kepler, K. L. Litzenberger, H. R. Sansing, E. T. R. Lewis \& J. S. Hatfield. 1999. Density and habitat of breeding swallow-tailed kites in the Lower Suwannee Ecosystem, Florida. J. Field Ornithol. 70: 321-336.

Sytsma, M. D. \& M. Pfauth. 2006. 2005 Diamond Lake submersed aquatic vegetation survey. Center for Lakes and Reservoirs Publications and Presentations Paper 43. Portland State University, Portland, OR. 17 pp.

Szlachetko, D. L. \& M. Kolanowska. 2013. Three new species of Ponthieva (Orchidaceae, Spiranthoideae) from Colombia and Venezuela. Plant Syst. Evol. 299: 1671-1678.

Takahashi, M. \& S. Kawano. 1989. Pollen morphology of the Melanthiaceae and its systematic implications. Ann. Missouri Bot. Gard. 76: 863-876.

Takahashi, C. \& K. Kondo. 2004. A comparison of karyotypes in two artificial reciprocal hybrids between Pogonia minor and Pogonia ophioglossoides (Orchidaceae). Chromosome Sci. 8: 11-16.

Takahashi, K. \& T. Asaeda. 2014. The effect of spring water on the growth of a submerged macrophyte Egeria densa. Landscape Ecol. Eng. 10: 99-107. 
Takahashi, C. T., M. Itsuji, T. Yagame \& K. Kondo. 2014. Newly naturally appeared Pogonia isolated from Pogonia japonica and $P$. minor in Japan analyzed by RAPD (randomly amplified polymorphic DNA). Chromosom. Bot. 9: 77-82.

Takayanagi, S., Y. Takagi, A. Shimizu \& H. Hasegawa. 2012. The shoot is important for high-affinity nitrate uptake in Egeria densa, a submerged vascular plant. J. Plant Res. 125: 669-678.

Takemoto, B. K. \& R. D. Noble. 1986. Differential sensitivity of duckweeds (Lemnaceae) to sulphite. New Phytol. 103: 525-539.

Takeuchi, Y., T. Sassa, S. Kawaguchi, M. Ogasawara, K. Yoneyama \& M. Konnai. 1995. Stimulation of germination of Monochoria vaginalis seeds by seed coat puncture and cotylenins. Weed Res. Japan 40: 221-224.

Takhtajan, A. 1969. Flowering Plants: Origin and Dispersal. Smithsonian Institution Press, Washington, DC. 310 pp.

Takhtajan, A. 1995. New families of the monocotyledons [in Russian]. Bot. Zhur. 79: 65-66.

Takhtajan, A. 2009. Flowering Plants. Springer Science \& Business Media B. V., Berlin, Germany. 871 pp.

Takimoto, A. \& O. Tanaka. 1973. Effects of some SH-inhibitors and EDTA on flowering in Lemna perpusilla 6746. Plant Cell Physiol. 14: 1133-1141.

Takos, M. J. 1947. A semi-quantitative study of muskrat food habits. J. Wildl. Manag. 11: 331-339.

Talavera, S., P. Garcia-Murillo \& J. Herrera. 1993. Chromosome numbers and a new model for karyotype evolution in Ruppia L. (Ruppiaceae). Aquat. Bot. 45: 1-13.

Talbot, S. L., S. Wyllie-Echeverria, D. H. Ward, J. R. Rearick, G. K. Sage, B. Chesney \& R. C. Phillips. 2006. Genetic characterization of Zostera asiatica on the Pacific Coast of North America. Aquat. Bot. 85: 169-176.

Talbot, S. S., S. L. Talbot \& L. R. Walker. 2010. Post-eruption legacy effects and their implications for long-term recovery of the vegetation on Kasatochi Island, Alaska. Arct. Antarct. Alp. Res. 42: 285-296.

Talbot, S. L., G. K. Sage, J. R. Rearick, M. C. Fowler, R. MuñizSalazar, B. Baibak, S. Wyllie-Echeverria, A. Cabello-Pasini \& D. H. Ward. 2016. The structure of genetic diversity in eelgrass (Zostera marina L.) along the north Pacific and Bering Sea coasts of Alaska. PLoS One 11(4): e0152701.

Talukdar, T. \& D. Talukdar. 2015. Heavy metal accumulation as phytoremediation potential of aquatic macrophyte, Monochoria vaginalis (Burm. F.) K. Presl ex Kunth. Int. J. Appl. Sci. Biotechnol. 3: 9-15.

Tamada, K., K. Itoh, Y. Uchida, S. Higuchi, D. Sasayama \& T. Azuma. 2015. Relationship between the temperature and the overwintering of water lettuce (Pistia stratiotes) at Kowataike, a branch of Yodogawa River, Japan. Weed Biol. Manag. 15: 20-26.

Tamura, M. N., S. Fuse, H. Azuma \& M. Hasebe. 2004. Biosystematic studies on the family Tofieldiaceae I. Phylogeny and circumscription of the family inferred from DNA sequences of matK and rbcL. Plant Biol. 6: 562-567.

Tan, K. W. 1969. The systematic status of the genus Bletilla (Orchidaceae). Brittonia 21: 202-214.

Tan, B. H. \& W. S. Judd. 1995. A floristic inventory of O'Leno State Park and Northeast River Rise State Preserve, Alachua and Columbia Counties, Florida. Castanea 60: 141-165.

Tanaka, H. 2004. Reproductive biology of Lysichiton camtschatcense (Araceae) in Japan. Aroideana 27: 167-171.

Tanaka, N. 2019. Taxonomy, evolution and phylogeography of the genus Helonias (Melanthiaceae) revisited. Phytotaxa 390: $1-84$.
Tanaka, N., K. Uehara \& J. Murata. 2004. Correlation between pollen morphology and pollination mechanisms in the Hydrocharitaceae. J. Plant Res. 117: 265-276.

Tanaka, N., J. Kuo, Y. Omori, M. Nakaoka \& K. Aioi. 2003. Phylogenetic relationships in the genera Zostera and Heterozostera (Zosteraceae) based on matK sequence data. $J$. Pl. Res. 116: 273-279.

Tanaka, N., H. Uchiyama, H. Matoba \& T. Koyama. 2009. Karyological analysis of the genus Canna (Cannaceae). Plant Syst. Evol. 280: 45-51.

Tang, L.-L. \& S.-Q. Huang. 2007. Evidence for reductions in floral attractants with increased selfing rates in two heterandrous species. New Phytol. 175: 588-595.

Tang, F., J. A. White \& I. Charvat. 2001. The effect of phosphorus availability on arbuscular mycorrhizal colonization of Typha angustifolia. Mycologia 93: 1042-1047.

Tang, Y., L. Chen, X. Wei, Q. Yao \& T. Li. 2013. Removal of lead ions from aqueous solution by the dried aquatic plant, Lemna perpusilla Torr. J. Hazard. Mater. 244: 603-612.

Tang, J., F. Zhang, W. Cui \& J. Ma. 2014. Genetic structure of duckweed population of Spirodela, Landoltia and Lemna from Lake Tai, China. Planta 239: 1299-1307.

Tang, J., Y. Li, X. Wang \& M. Daroch. 2017. Effective adsorption of aqueous $\mathrm{Pb}^{2+}$ by dried biomass of Landoltia punctata and Spirodela polyrhiza. J. Clean. Prod. 145: 25-34.

Tao, Q., B. Li, Q. Li, X. Han, Y. Jiang, R. Jupa, C. Wang \& T. Li. 2019. Simultaneous remediation of sediments contaminated with sulfamethoxazole and cadmium using magnesium-modified biochar derived from Thalia dealbata. Sci. Total Environ. 659: $1448-1456$.

Tárano, Z., S. Strahl \& J. Ojasti. 1995. Feeding ecology of the purple gallinule Porphyrula martinica in the Central Llanos of Venezuela. Ecotropicos 8: 53-61.

Tarbeeva, D. V., S. A. Fedoreev, M. V. Veselova, A. I. Kalinovskii, P. G. Gorovoi, O. S. Vishchuk, S. P. Ermakova \& P. A. Zadorozhnyi. 2015. Polyphenolic metabolites from Iris pseudacorus roots. Chem. Nat. Compd. 51: 451-455.

Tarver, D. P., J. A. Rodgers, M. J. Mahler \& R. L. Lazor. 1978. Aquatic and Wetland Plants of Florida. Bureau of Aquatic Plant Research and Control, Florida Department of Natural Resources, Tallahassee, FL. 127 pp.

Tatkowska, E. \& J. Buczek. 1983. Effect of ammonium nutrition on the nitrate utilization, nitrate reductase actvity and growth of Spirodela polyrrhiza. Acta Soc. Bot. Polon. 52: 241-252.

Tavares, F., F. R. Lapolli, R. Roubach, M. K. Jungles, D. M. Fracalossi \& A. M. Moraes. 2010. Use of domestic effluent through duckweeds and red tilapia farming in integrated system. Pan-Am. J. Aquat. Sci. 5: 1-10.

Tavechio, W. L. G. \& S. M. Thomaz. 2003. Effects of light on the growth and photosynthesis of Egeria najas Planchon. Brazilian Arch. Biol. Technol. 46: 203-209.

Taylor, W. P. 1912. Field notes on amphibians, reptiles and birds of northern Humboldt County, Nevada. Univ. Calif. Publ. Zool. 7: 319-436.

Taylor, C. A. 1956. Alkaloid yields of Veratrum fimbriatum as influenced by site, season and other factors. Econ. Bot. 10: $166-173$.

Taylor, R. L. 1967. The foliar embryos of Malaxis paludosa. Can. J. Bot. 45: 1553-1556.

Taylor, B. R. \& J. Helwig. 1995. Submergent macrophytes in a cooling pond in Alberta, Canada. Aquat. Bot. 51: 243-257.

Taylor, K. N. \& D. Estes. 2012. The floristic and community ecology of seasonally wet limestone glade seeps of Tennessee and Kentucky. J. Bot. Res. Inst. Texas 6: 711-724. 
Taylor, B. R., J. Ferrier, R. Lauff \& D. J. Garbary. 2008. New distribution records for flowering plants in Antigonish County, Nova Scotia. Proc. Trans. Nova Scotian Inst. Nat. Sci. 44: 109-123.

Taylor, M. L., K. M. Altrichter \& L. B. Aeilts. 2018. Pollen ontogeny in Ruppia (Alismatidae). Int. J. Plant Sci. 179: 217-230.

Teamkao, P. \& P. Thiravetyan. 2010. Phytoremediation of ethylene glycol and its derivatives by the burhead plant (Echinodorus cordifolius (L.)): effect of molecular size. Chemosphere 81: 1069-1074.

Teltscherová, L. \& S. Hejný. 1973. The germination of some Potamogeton species from south-Bohemian fishponds. Folia Geobot. Phytotax. 8: 231-239.

Tennessen, K. J. 1993. New distribution records for Ophiogomphus howei (Odonata: Gomphidae). Great Lakes Entomol. 26: 245-249.

Tepedino, V. J. 1981. Notes on the reproductive biology of Zigadenus paniculatus, a toxic range plant. Great Basin Nat. 41: 427-430.

Tepedino, V. J., A. K. Knapp, G. C. Eickwort \& D. C. Ferguson. 1989. Death camas (Zigadenus nuttallii) in Kansas: pollen collectors and a florivore. J. Kansas Entomol. Soc. 62: 411-412.

Terrados, J. \& S. L. Williams. 1997. Leaf versus root nitrogen uptake by the surfgrass Phyllospadix torreyi. Mar. Ecol. Prog. Ser. 149: 267-277.

Terrell, E. E., W. H. Emery \& H. E. Beaty. 1978. Observations on Zizania texana (Texas wildrice), an endangered species. Bull. Torrey Bot. Club 105: 50-57.

Teryokhin, E. S. 1996. The mechanism of hyphydrophilous pollination in Potamogeton filiformis Pers. (Potamogetonaceae). Repr. Biol. 96: 11.

Teryokhin, E. S., S. I. Chubarov \& V. O. Romanova. 2002. Pollination, mating systems and self-incompatibility in some species of the genus Potamogeton L. Phytomorphology 52: 249-261.

Thacker, R. W., B. A. Hazlett, L. A. Esman, C. P. Stafford \& T. Keller. 1993. Color morphs of the crayfish Orconectes virilis. Am. Midl. Nat. 129: 182-199.

Tharaldson, T. M. 2018. The ability of Phyllospadix spp., a pair of intertidal foundation species, to maintain biodiversity and ameliorate $\mathrm{CO}_{2}$ stress in rocky shore tidepools. M.S. thesis. Humboldt State University, Arcata, CA. 104 pp.

Thiébaut, G., Y. Gross, P. Gierlinski \& A. Boiché. 2010. Accumulation of metals in Elodea canadensis and Elodea nuttallii: implications for plant-macroinvertebrate interactions. Sci. Total Environ. 408: 5499-5505.

Thien, L. B. \& B. G. Marcks. 1972. The floral biology of Arethusa bulbosa, Calopogon tuberosus, and Pogonia ophioglossoides (Orchidaceae). Can. J. Bot. 50: 2319-2325.

Thieret, J. W. 1963. Botanical survey along the Yellowknife Highway, Northwest Territories, Canada. I. Catalogue of the flora. Sida 1: 117-170.

Thieret, J. W. 1964. Botanical survey along the Yellowknife Highway, Northwest Territories, Canada: II. Vegetation. Sida 1: 187-239.

Thieret, J. W. 1969. Sagittaria guayanensis (Alismataceae) in Louisiana: new to the United States. Sida 3: 445.

Thieret, J. W. 1970. Bacopa repens (Scrophulariaceae) in the conterminous United States. Castanea 35: 132-136.

Thieret, J. W. 1971a. Eriocaulon cinereum in Louisiana. Southwest. Nat. 15: 391.

Thieret, J. W. 1971b. Additions to the Louisiana flora. Castanea 36: 219-222.

Thieret, J. W. 1975. The Mayacaceae in the southeastern United States. J. Arnold Arb. 56: 248-255.

Thieret, J. W. 1982. The Sparganiaceae in the southeastern United States. J. Arnold Arb. 63: 341-355.

Thieret, J. W., R. R. Haynes \& D. H. Dike. 1969. Blyxa aubertii (Hydrocharitaceae) in Louisiana: new to North America. Sida 3: 343-344.
Theriot, R. F. 1993. Flood tolerance of plant species in bottomland forests of the southeastern United States. Wetlands Research Program Technical Report WRP-DE-6. U.S. Army Corps of Engineers, Vicksburg, MS. 50 pp.

Thom, R., B. Miller \& M. Kennedy. 1995. Temporal patterns of grazers and vegetation in a temperate seagrass system. Aquat. Bot. 50: 201-205.

Thomas, M. C. 2005. An exotic baridine weevil pest (Coleoptera: Curculionidae) of Amaryllidaceae in Florida. Florida Department of Agriculture and Consumer Services, Division of Plant Industry. Available online: www.doacs.state.fl.us/ pi/enpp/ento/amaryllisweevil.html [accessed 25 November, 2018].

Thomas, J. R. 2017. New additions, vouchers of old additions, and a new combination (Dichanthelium inflatum) for the Missouri flora. Missouriensis 34: 4-19.

Thomas, V. G. \& J. P. Prevett. 1980. The nutritional value of arrowgrasses to geese at James Bay. J. Wildl. Manag. 44: 830-836.

Thomas, A. L. \& D. Schrock. 2004. Performance of 67 native Midwestern U.S. perennials in a low-maintenance landscape. HortTechnology 14: 381-388.

Thomaz, S. M., P. A. Chambers, S. A. Pierini \& G. Pereira. 2007. Effects of phosphorus and nitrogen amendments on the growth of Egeria najas. Aquat. Bot. 86: 191-196.

Thompson, C. H. 1898. A revision of the American Lemnaceae occurring north of Mexico. Rep. Missouri Bot. Gard. 9: 21-42.

Thompson, R. L. 1970. Florida sandhill crane nesting on the Loxahatchee National Wildlife Refuge. Auk 87: 492-502.

Thompson, S. A. 2000a. Acoraceae Martinov. Pp. 124-127 In: Flora North America Editorial Committee (eds.), Flora of North America North of Mexico, Vol. 22: Magnoliophyta: Alismatidae, Arecidae, Commelinidae (in Part), and Zingiberidae. Oxford University Press, New York, NY.

Thompson, S. A. 2000b. Araceae Jussieu. Pp. 128-142 In: Flora North America Editorial Committee (eds.), Flora of North America North of Mexico, Vol. 22: Magnoliophyta: Alismatidae, Arecidae, Commelinidae (in Part), and Zingiberidae. Oxford University Press, New York, NY.

Thompson, R. L. 2001. Botanical survey of Myrtle Island Research Natural Area, Oregon. General Technical Report PNWGTR-507. U.S. Department of Agriculture, Forest Service, Pacific Northwest Research Station, Portland, OR. 27 pp.

Thompson, J. S. 2010. Sarracenia minor var. okefenokeensis (Sarraceniaceae) discovered outside of the Okefenokee Swamp area. J. Bot. Res. Inst. Texas 4: 771-773.

Thompson, R. L. \& L. E. McKinney. 2006. Vascular flora and plant habitats of an abandoned limestone quarry at Center Hill Dam, DeKalb County, Tennessee. Castanea 71: 54-64.

Thompson, R. L., J. R. Abbott \& A. E. Shupe. 2005. Vascular flora from five plant habitats of an abandoned limestone quarry in Clark County, Kentucky. J. Kentucky Acad. Sci. 66: 24-35.

Thompson, K., D. Perleberg \& S. Loso. 2009. Final Report on the Sensitive Lakeshore Surveys for Little Boy Lake (11-0167-00), Wabedo Lake (11-0171-00), and Louise Lake (11-0573-00), Cass County, MN. Division of Ecological Resources, Minnesota Department of Natural Resources, St. Paul, MN. 85 pp.

Thompson, I. D., P. A. Wiebe, E. Mallon, A. R. Rodgers, J. M. Fryxell, J. A. Baker \& D. Reid. 2014. Factors influencing the seasonal diet selection by woodland caribou (Rangifer tarandus tarandus) in boreal forests in Ontario. Can. J. Zool. 93: 87-98.

Thomson, E. R. 2005. Papillate watermeal, Wolffia brasiliensis, in eastern Ontario: an addition to the flora of Canada. Can. FieldNat. 119: 137-138. 
Thorhaug, A., A. D. Richardson \& G. P. Berlyn. 2006. Spectral reflectance of Thalassia testudinum (Hydrocharitaceae) seagrass: low salinity effects. Am. J. Bot. 93: 110-117.

Thormann, M. N. \& S. E. Bayley. 1997. Response of aboveground net primary plant production to nitrogen and phosphorus fertilization in peatlands in southern boreal Alberta, Canada. Wetlands 17: 502-512.

Thorne, R. F. 1982. The desert and other transmontane plant communities of southern California. Aliso 10: 219-257.

Thorne, R. F. \& E. W. Lathrop. 1969. A vernal marsh on the Santa Rosa Plateau of Riverside County, California. Aliso 7: 85-95.

Thorne, R. F. \& E. W. Lathrop. 1970. Pilularia americana on the Santa Rosa Plateau, Riverside County, California. Aliso 7: 149-155.

Thorne, J. H., P. R. Huber \& S. Harrison. 2011. Systematic conservation planning: protecting rarity, representation, and connectivity in regional landscapes. Pp. 309-328 In: S. Harrison \& N. Rajakaruna (eds.), Serpentine: The Evolution and Ecology of a Model System. University of California Press, Berkeley, CA.

Thornhill, A. D. 1996. Species and population-level patterns of genetic variation in Epipactis gigantea (Orchidaceae), with examination of local genetic and clonal structure in riparian and bog populations inferred from allozyme analysis. Ph.D. dissertation. University of California-Irvine, Irvine, CA. 73 pp.

Thornhill, R., A. Krings, D. Lindbo \& J. Stucky. 2014. Guide to the vascular flora of the savannas and flatwoods of Shaken Creek Preserve and vicinity (Pender \& Onslow counties, North Carolina, USA. Biodivers. Data J. 2: e1099.

Thorp, A. G., R. C. Jones \& D. P. Kelso. 1997. A comparison of water-column macroinvertebrate communities in beds of differing submersed aquatic vegetation in the tidal freshwater Potomac River. Estuaries 20: 86-95.

Thorpe, A. S. 2008. Habitat Sampling at Hanson, Long Tom, North Taylor, Speedway, and Turtle Swale. Institute for Applied Ecology, Corvallis, OR. 19 pp.

Thursby, G. B. 1984. Root-exuded oxygen in the aquatic angiosperm Ruppia maritima. Mar. Ecol. Prog. Ser. 16: 303-305.

Thursby, G. B. \& M. M. Harlin. 1984. Interaction of leaves and roots of Ruppia maritima in the uptake of phosphate, ammonia and nitrate. Mar. Biol. 83: 61-67.

Thyagarajan, G. (ed.). 1984. Water Hyacinth. Proceedings of the International Conference on Water Hyacinth. United Nations Environment Programme, Nairobi, Kenya. 1005 pp.

Tian, L.-W., Z. Zhang, H.-L. Long \& Y.-J. Zhang. 2017. Steroidal saponins from the genus Smilax and their biological activities. Nat. Prod. Bioprospect. 7: 283-298.

Tibiriçá, E., A. Almeida, S. Caillleaux, D. Pimenta, M. A. Kaplan, M. A. Lessa \& M. R. Figueiredo. 2007. Pharmacological mechanisms involved in the vasodilator effects of extracts from Echinodorus grandiflorus. J. Ethnopharmacol. 111: 50-55.

Tietje, W. D. \& J. G. Teer. 1996. Winter feeding ecology of northern shovelers on freshwater and saline wetlands in south Texas. $J$. Wildl. Manag. 60: 843-855.

Tiffany, L. H., J. F. Shearer \& G. Knaphus. 1990. Plant parasitic fungi of four tallgrass prairies of northern Iowa: distribution and prevalence. J. Iowa Acad. Sci. 97: 157-166.

Tjia, B. 1985. Hybrid calla lilies: a potential new crop for Florida. Proc. Florida State Hort. Soc. 98: 127-130.

Tiling, K. \& C. E. Proffitt. 2017. Effects of Lyngbya majuscula blooms on the seagrass Halodule wrightii and resident invertebrates. Harmful Algae 62: 104-112.

Tillie, N., M. W. Chase \& T. Hall. 2000. Molecular studies in the genus Iris L.: a preliminary study. Ann. Bot. (Rome) 58: 105-112.
Timbrook, J. 1990. Ethnobotany of Chumash indians, California, based on collections by John P. Harrington. Econ. Bot. 44: 236-253.

Timm, A. L. \& R. B. Pierce. 2015. Vegetative substrates used by larval northern pike in Rainy and Kabetogama Lakes, Minnesota. Ecol. Freshw. Fish 24: 225-233.

Timoney, K. P. 2001. String and net-patterned salt marshes: rare landscape elements of Boreal Canada. Can. Field-Nat. 115: 406-412.

Tiner, R. W. 1987. A Field Guide to Coastal Wetland Plants of the Northeastern United States. The University of Massachusetts Press, Amherst, MA. 286 pp.

Tiner, R. W. 1993. Field Guide to Coastal Wetland Plants of the Southeastern United States. The University of Massachusetts Press, Amherst, MA. 328 pp.

Tippery, N. P. \& D. H. Les. 2020. Tiny plants with enormous potential: phylogeny and evolution of duckweeds. Pp. 19-38 In: X. H. Cao, P. Fourounjian \& W. Wang (eds.), The Duckweed Genomes. Compendium of Plant Genomes. Springer-Verlag, New York, NY.

Tippery, N. P., D. H. Les \& D. J. Crawford. 2015. Evaluation of phylogenetic relationships in Lemnaceae using nuclear ribosomal data. Plant Biol. 17(suppl. 1): 50-58.

Tippery, N. P., G. J. Bugbee \& S. E. Stebbins. 2020. Evidence for a genetically distinct strain of introduced Hydrilla verticillata (Hydrocharitaceae) in North America. J. Aquat. Plant Manag. 58: $1-6$.

Tipping, P. W., L. Bauer, M. R. Martin \& T. D. Center. 2009. Competition between Salvinia minima and Spirodela polyrhiza mediated by nutrient levels and herbivory. Aquat. Bot. 90: 231-234.

Tipping, P. W., M. R. Martin, L. Bauer, R. M. Pierce \& T. D. Center. 2012. Ecology of common salvinia, Salvinia minima Baker, in southern Florida. Aquat. Bot. 102: 23-27.

Titcomb, J. W. 1923. Aquatic plants in pond culture, second ed. Bureau of Fisheries Document No. 948. Appendix II to the Report of the U.S. Commissioner of Fisheries for 1923. Department of Commerce, Government Printing Office, Washington, DC. 24 pp.

Titus, J. E. 1983. Submersed macrophyte vegetation and depth distribution in Chenango Lake, New York. Bull. Torrey Bot. Club 110: $176-183$.

Titus, J. H. 2017. Unpublished Wetland Plot Data Recorded in Southwestern Oregon. Oregon Natural Heritage Program, Corvallis, OR. 6 pp.

Titus, J. E. \& M. S. Adams. 1979. Coexistence and the comparative light relations of the submersed macrophytes Myriophyllum spicatum L. and Vallisneria americana Michx. Oecologia 40: 273-286.

Titus, J. E. \& W. H. Stone. 1982. Photosynthetic response of 2 submersed macrophytes to dissolved inorganic carbon concentration and pH. Limnol. Oceanogr. 27: 151-160.

Titus, J. E. \& M. D. Stephens. 1983. Neighbor influences and seasonal growth patterns for Vallisneria americana in a mesotrophic lake. Oecologia 56: 23-29.

Titus, J. E. \& D. J. Grisé. 2009. The invasive freshwater macrophyte Utricularia inflata (inflated bladderwort) dominates Adirondack Mountain lake sites. J. Torrey Bot. Soc. 136: 479-486.

Tobe, J. D., K. C. Burks, R. W. Cantrell, M. A. Garland, M. E. Sweeley, D. W. Hall, P. Wallace, G. Anglin, G. Nelson, J. R. Cooper, D. Bickner, K. Gilbert, N. Aymond, K. Greenwood \& N. Raymond. 1998. Florida Wetland Plants: An Identification Manual. University of Florida, Institute of Food \& Agricultural Sciences, Gainesville, FL. 598 pp. 
Tobe, H., Y.-L. Huang, T. Kadokawa \& M. N. Tamura. 2018. Floral structure and development in Nartheciaceae (Dioscoreales), with special reference to ovary position and septal nectaries. J. Plant Res. 131: 411-428.

Tobiessen, P. \& P. D. Snow. 1984. Temperature and light effects on the growth of Potamogeton crispus in Collins Lake, New York State. Can. J. Bot. 62: 2822-2826.

Todorova, M., N. Grozeva, M. Gospodinova \& J. Ivanova. 2013. Relationships between soil salinity and vascular plants in inland salt meadow near the town of Radnevo. Sci. Pap. Ser. A Agron. 56: 119-125.

Todt, D. L. 1997. Cross-cultural folk classifications of ethnobotanically important geophytes in southern Oregon and northern California. J. Calif. Gt. Basin Anthropol. 19: 250-259.

Tol, S. J., J. C. Jarvis, P. H. York, A. Grech, B. C. Congdon \& R. G. Coles. 2017. Long distance biotic dispersal of tropical seagrass seeds by marine mega-herbivores. Sci. Rep. 7: 4458.

Tolman, D. A. 2006. Characterization of the ecotone between Jeffrey pine savannas and Darlingtonia fens in southwestern Oregon. Madroño 53: 199-210.

Tolman, D. A. 2007. Soil patterns in three Darlingtonia fens of southwestern Oregon. Nat. Areas J. 27: 374-384.

Tom, B. \& S. K. Karr. 2013. Management considerations for the restoration of bunched arrowhead Sagittaria fasciculata. Nat. Areas J. 33: 105-108.

Tomas, W. M. \& S. M. Salis. 2000. Diet of the marsh deer (Blastocerus dichotomus) in the Pantanal wetland, Brazil. Stud. Neotrop. Fauna Environ. 35: 165-172.

Tomlinson, P. B. 1969. On the morphology and anatomy of turtle grass, Thalassia testudinum (Hydrocharitaceae). III. Floral morphology and anatomy. Bull. Mar. Sci. 19: 286-305.

Tooker, J. F. \& L. M. Hanks. 2000. Flowering plant hosts of adult hymenopteran parasitoids of central Illinois. Ann. Entomol. Soc. Am. 93: 580-588.

Tooker, J. F., P. F. Reagel \& L. M. Hanks. 2002. Nectar sources of day-flying Lepidoptera of central Illinois. Ann. Entomol. Soc. Am. 95: 84-96.

Tooker, J. F., M. Hauser \& L. M. Hanks. 2006. Floral host plants of Syrphidae and Tachinidae (Diptera) of central Illinois. Ann. Entomol. Soc. Am. 99: 96-112.

Topuzovic, M. D., I. D. Radojevic, M. S. Dekic, N. S. Radulovic, S. M. Vasic, L. R. Comic \& B. Z. Licina. 2015. Phytomedical investigation of Najas minor All. in the view of the chemical constituents. Excli J. 14: 496-503.

Torit, J., W. Siangdung \& P. Thiravetyan. 2012. Phosphorus removal from domestic wastewater by Echinodorus cordifolius L. J. Environ. Sci. Health 47: 794-800.

Toriyama, K. (ed.). 2005. Rice Is Life: Scientific Perspectives for the 21st Century. International Rice Research Institute, Manila, Philippines. $133 \mathrm{pp}$.

Tornberg, T., M. Bendix \& H. Brix. 1994. Internal gas transport in Typha latifolia L. and Typha angustifolia L. 2. Convective throughflow pathways and ecological significance. Aquat. Bot. 49: 91-105.

Tomlinson, P. B. \& U. Posluzny. 2001. Generic limits in the seagrass family Zosteraceae. Taxon 50: 429-437.

Toner, M., N. Stow \& C. J. Keddy. 1995. Arrow arum, Peltandra virginica: a nationally rare plant in the Ottawa Valley region of Ontario. Can. Field-Nat. 109: 441-442.

Torquemada, Y. F., M. J. Durako \& J. L. S. Lizaso. 2005. Effects of salinity and possible interactions with temperature and $\mathrm{pH}$ on growth and photosynthesis of Halophila johnsonii Eiseman. Mar. Biol. 148: 251-260.
Toth, L. A. \& J. P. Galloway. 2009. Clonal expansion of cattail (Typha domingensis) in Everglades stormwater treatment areas: implications for alternative management strategies. J. Aquat. Plant Manag. 47: 151-155.

Touchette, B. W. 2007. Seagrass-salinity interactions: physiological mechanisms used by submersed marine angiosperms for a life at sea. J. Exp. Mar. Biol. Ecol. 350: 194-215.

Townsend, J. E. 1953. Beaver ecology in western Montana with special reference to movements. J. Mammal. 34: 459-479.

Tracy, M., J. M. Montante, T. E. Allenson \& R. A. Hough. 2003. Long-term responses of aquatic macrophyte diversity and community structure to variation in nitrogen loading. Aquat. Bot. 77: 43-52.

Transeau, E. N. 1903. On the geographic distribution and ecological relations of the bog plant societies of northern North America. Bot. Gaz. 36: 401-420.

Trapnell, D. W., J. L. Hamrick \& D. E. Giannasi. 2004. Genetic variation and species boundaries in Calopogon (Orchidaceae). Syst. Bot. 29: 308-315.

Traub, H. P. 1957. Hymenocallis littoralis from Florida. Rhodora 59: 99.

Travis, S. E. \& P. Sheridan. 2006. Genetic structure of natural and restored shoalgrass Halodule wrightii populations in the NW Gulf of Mexico. Mar. Ecol. Prog. Ser. 322: 117-127.

Tremblay, R. L., J. D. Ackerman, J. K. Zimmerman \& R. N. Calvo. 2004. Variation in sexual reproduction in orchids and its evolutionary consequences: a spasmodic journey to diversification. Biol. J. Linn. Soc. 84: 1-54.

Trevathan-Tackett, S. M., A. L. Lane, N. Bishop \& C. Ross. 2015. Metabolites derived from the tropical seagrass Thalassia testudinum are bioactive against pathogenic Labyrinthula sp. Aquat. Bot. 122: 1-8.

Triest, L. 1988. A revision of the genus Najas L. (Najadaceae) in the Old World. Mém. Acad. Roy. Sci. Outre-Mer, Cl. Sci. Nat. Méd., Collect. 8vo 22: 1-172.

Triest, L. 1989. Electrophoretic polymorphism and divergence in Najas marina L. (Najadaceae): molecular markers for individuals, hybrids, cytodemes, lower taxa, ecodemes and conservation of genetic diversity. Aquat. Bot. 33: 301-380.

Triest, L. \& L. Vanhecke. 1991. Isozymes in European and Mediterranean Zannichellia (Zannichelliaceae) populations: a situation of predominant inbreeders. Opera Bot. Belgica 4: 133-166.

Triest, L. \& S. Fénart. 2014. Clonal diversity and spatial genetic structure of Potamogeton pectinatus in managed pond and river populations. Hydrobiologia 737: 145-161.

Triest, L. \& T. Sierens. 2014. Seagrass radiation after messinian salinity crisis reflected by strong genetic structuring and out-of-Africa scenario (Ruppiaceae). PLoS One 9(8): e104264.

Triest, L. \& T. Sierens. 2015. Strong bottlenecks, inbreeding and multiple hybridization of threatened European Ruppia maritima populations. Aquat. Bot. 125: 31-43.

Triest, L., Y. Viinikka \& M. Agami. 1989. Isozymes as molecular markers for diploid and tetraploid individuals of Najas marina (Najadaceae). Plant Syst. Evol. 166: 131-139.

Triest, L., V. T. Thi \& T. Sierens. 2007. Chloroplast microsatellite markers reveal Zannichellia haplotypes across Europe using herbarium DNA. Belgian J. Bot. 140: 109-120.

Triest, L., D. L. Thi, T. Sierens \& A. Van Geert. 2010. Genetic differentiation of submerged plant populations and taxa between habitats. Hydrobiologia 656: 15-27.

Trocine, R. P., J. D. Rice \& G. N. Wells. 1981. Inhibition of seagrass photosynthesis by ultraviolet-B radiation. Plant Physiol. 68: 74-81. 
Trocine, R. P., J. D. Rice \& G. N. Wells. 1982. Photosynthetic response of seagrasses to ultraviolet-A radiation and the influence of visible light intensity. Plant Physiol. 69: 341-344.

True-Meadows, S., E. J. Haug \& R. J. Richardson. 2016. Monoecious hydrilla-a review of the literature. J. Aquat. Plant Manag. 54: $1-11$.

Truman, H. V. 1931. Pollen of Sparganium americanum and S. androcladum. Rhodora 33: 141-142.

Tryon, C. A. \& N. W. Easterly. 1975. Plant communities of the Irwin Prairie and adjacent wooded areas. Castanea 40: 201-213.

Tsao, T. H., H. W. Zhong, S. P. Jiao \& Z. Y. Tan. 1986. Changes in endogenous ABA and GA contents during floral induction of Lemna aequinoctialis. Acta Bot. Neerl. 35(4): 443-448.

Tsuchiya, T. 1991. Leaf life span of floating-leaved plants. Vegetatio 97: 149-160.

Tu, H.-Y., A.-L. Zhang, W. Xiao, Y.-R. Lin, J.-H. Shi, Y.-W. Wu, S.-T. Wu, C.-H. Zhong \& S.-X. Mo. 2018. Induction and identification of tetraploid Hedychium coronarium through thin cell layer culture. Plant Cell Tissue Organ Cult. 135: 395-406.

Tucker, G. C. 1989. The genera of Commelinaceae in the southeastern United States. J. Arnold Arbor. 70: 97-130.

Tucker, J. M. \& B. J. McCaskill. 1955. Monochoria vaginalis in California. Madroño 13: 112.

Tucker, J. M. \& B. J. McCaskill. 1967. Heteranthera limosa in California. Madroño 19: 64.

Tucker, G. C., J. E. Ebinger, W. E. McClain, E. L. Smith, P. B. Marcum \& R. Jansen. 2015. Marsh vegetation of the Margaret Guzy pothole wetlands land and water reserve, Shelby County, Illinois. Trans. Illinois State Acad. Sci. 108: 7-12.

Turnage, G. \& C. Shoemaker. 2018. 2017 survey of aquatic plant species in MS waterbodies. GRI Report 5077. Geosystems Research Institute, Mississippi State University, Starkville, MS. 69 pp.

Turnage, L. G., C. Duncan \& J. D. Madsen. 2012. Aquatic invasive plant survey of selected Montana waters for 2012. GRI Report 5055. Geosystems Research Institute, Mississippi State University, Starkville, MS. 84 pp.

Turner, C. E. 1980. Noteworthy collections: Ottelia alismoides (L.) Pers. (Hydrocharitaceae). Madroño 27: 177.

Turner, T. 1983. Facilitation as a successional mechanism in a rocky intertidal community. Am. Nat. 121: 729-738.

Turner, T. 1985. Stability of rocky intertidal surfgrass beds: persistence, preemption, and recovery. Ecology 66: 83-92.

Turner, N. J. 1995. Food Plants of Coastal First Peoples. UBC Press, Vancouver, BC. $164 \mathrm{pp}$.

Turner, R. L. 1996. Use of stems of emergent plants for oviposition by the Florida applesnail, Pomacea paludosa, and the implications for marsh management. Florida Sci. 59: 34-49.

Turner, N. J. 2003. The ethnobotany of edible seaweed (Porphyra abbottae and related species; Rhodophyta: Bangiales) and its use by First Nations on the Pacific Coast of Canada. Can. J. Bot. 81: 283-293.

Turner, T. \& J. Lucas. 1985. Differences and similarities in the community roles of three rocky intertidal surfgrasses. J. Exp. Mar. Biol. Ecol. 89: 175-189.

Turner, W. M. \& D. H. Nelson. 2001. Composition of the diet of the Alabama redbelly turtle (Psuedemys [sic!] alabamensis). J. Alabama Acad. Sci. 72: 97-97.

Turner, M. A., D. B. Huebert, D. L. Findlay, L. L. Hendzel, W. A. Jansen, R. A. Bodaly, L. M. Armstrong \& S. E. M. Kasian. 2005. Divergent impacts of experimental lake-level drawdown on planktonic and benthic plant communities in a boreal forest lake. Can. J. Fish. Aquat. Sci. 62: 991-1003.
Turner, C. E., R. R. Haynes \& C. B. Hellquist. 2012. Alismataceae. Water plantain family. Pp. 1288-1289 In: B. G. Baldwin, D. H. Goldman, D. J. Keil, R. Patterson, T. J. Rosatti \& D. H. Wilken (eds.), The Jepson Manual, 2nd ed. University of California Press, Berkeley, CA.

Turesson, G. 1916. Lysichiton camtschatcense (L) Schott, and its behavior in sphagnum bogs. Am. J. Bot. 3: 189-209.

Tveten, J. \& G. Tveten. 1997. Wildflowers of Houston and Southeast Texas. University of Texas Press, Austin, TX. 319 pp.

Tweedy, F. 1880. Notes on the flora of Plainfield, N. J. Bull. Torrey Bot. Club 7: 26-28.

Twilley, R. R. \& J. W. Barko. 1990. The growth of submersed macrophytes under experimental salinity and light conditions. Estuaries 13: 311-321.

Tyler, C. \& M. Borchert. 2003. Reproduction and growth of the chaparral geophyte, Zigadenus fremontii (Liliaceae), in relation to fire. Plant Ecol. 165: 11-20.

Tyndall, R. W. 2000. Vegetation change in a Carolina bay on the Delmarva Peninsula of Maryland during an eleven-year period (1987-1997). Castanea 65: 155-164.

Tyndall, R. W., K. A. McCarthy, J. C. Ludwig \& A. Rome. 1990. Vegetation of six Carolina bays in Maryland. Castanea 55: $1-21$.

Uchimura, M., E. J. Faye, S. Shimada, T. Inoue \& Y. Nakamura. 2008. A reassessment of Halophila species (Hydrocharitaceae) diversity with special reference to Japanese representatives. Bot. Mar. 51: 258-268.

Uhler, F. M. 1982. Food habits of diving ducks in the Carolinas. Proc. Ann. Conf. Southeast. Assoc. Fish Wildl. Agencies 36: 492-504.

Ulrich, S., M. Hesse, D. Bröderbauer, J. Bogner, M. Weber \& H. Halbritter. 2013. Calla palustris (Araceae): new palynological insights with special regard to its controversial systematic position and to closely related genera. Taxon 62: 701-712.

Umetsu, C. A., H. B. A. Evangelista \& S. M. Thomaz. 2012. The colonization, regeneration, and growth rates of macrophytes from fragments: a comparison between exotic and native submerged aquatic species. Aquat. Ecol. 46: 443-449.

Ungar, I. A. 1964. A phytosociological analysis of the Big Salt Marsh, Stafford County, Kansas. Trans. Kansas Acad. Sci. 67: 50-64.

Ungar, I. A. 1970. Species-soil relationships on sulfate dominated soils of South Dakota. Am. Midl. Nat. 83: 343-357.

Ungar, I. A. 1974. Halophyte communities of Park county, Colorado. Bull. Torrey Bot. Club 101: 145-152.

Ungar, I. A., W. Hogan \& M. McClelland. 1969. Plant communities of saline soils at Lincoln, Nebraska. Am. Midl. Nat. 82: 564-577.

Unruh, S. A., M. R. McKain, Y.-I. Lee, T. Yukawa, M. K. McCormick, R. P. Shefferson, A. Smithson, J. H. Leebens-Mack \& J. C. Pires. 2018. Phylotranscriptomic analysis and genome evolution of the Cypripedioideae (Orchidaceae). Am. J. Bot. 105: 631-640.

Unwin, M. M. 2004. Molecular systematics of the Eriocaulaceae Martinov. Ph.D. dissertation. Miami University, Oxford, $\mathrm{OH}$. $127 \mathrm{pp}$.

Uphof, J. C. T. 1922. Ecological relations of plants in southeastern Missouri. Am. J. Bot. 9: 1-17.

Uphof, J. C. T. 1927. The floral behavior of some Eriocaulaceae. Am. J. Bot. 14: 44-48.

Uphof, J. C. T. 1933. Die Blütenbiologie von Mayaca fluviatilis Aub. Ber. Deutsch. Bot. Ges. 51: 78-85.

Uphof, J. C. T. 1938. Cleistogamic flowers. Bot. Rev. 4: 21-49.

Uphof, J. C. T. 1941. Halophytes. Bot. Rev. 7: 1-58. 
Urban, L., S. G. M. Bridgewater \& D. J. Harris. 2006. The Macal River: a floristic and phytosociological study of a threatened riverine vegetation community in Belize. Edinburgh J. Bot. 63: 95-118.

Urban, R. A., J. E. Titus \& W.-X. Zhu. 2009. Shading by an invasive macrophyte has cascading effects on sediment chemistry. Biol. Invasions 11: 265-273.

Urbanska-Worytkiewicz, K. 1975. Cytological variation within Lemna L. Aquat. Bot. 1: 377-394.

Urbanska-Worytkiewicz, K. 1980. Cytological variation within the family of Lemnaceae. Veröff. Geobot. Inst. E. T. H. Stiftung Rübel Zürich 70: 30-101.

Urbatsch, L. E. 2013. Plants new and noteworthy for Louisiana and Mississippi. Phytoneuron 14: 1-7.

USACE. 2016. U.S. Army Corps of Engineers. National Wetland Plant List, version 3.3. Available online: http://wetland-plants. usace.army.mil/. [accessed 4 February, 2020].

USFWS. 1983. Bunched Arrowhead Recovery Plan. U.S. Fish and Wildlife Service, Atlanta, GA. 37 pp.

USFWS. 1991. Swamp Pink (Helonias bullata) Recovery Plan. U.S. Fish and Wildlife Service, Region V. Newton Corner, MA. 56 pp.

USFWS. 2013. Platanthera integrilabia. Species Assessment and Listing Priority Assignment Form. U.S. Fish and Wildlife Service, Region IV (Southeast Region), Atlanta, GA. 15 pp.

USFWS. 2014. Kral's Water-Plantain (Sagittaria secundifolia) 5-Year Review: Summary and Evaluation. U.S. Fish and Wildlife Service, Alabama Ecological Services Field Office, Daphne, AL. 14 pp.

USFWS. 2019. Swamp Pink (Helonias bullata). 5-Year Review. U.S. Fish \& Wildlife Service. New Jersey Field Office, Pleasantview, NJ. 50 pp.

Ushimaru, A., S. Kikuchi, R. Yonekura, A. Maruyama, N. Yanagisawa, M. Kagami, M. Nakagawa, S. Mahoro, Y. Kohmatsu, A. Hatada, S. Kitamura \& K. Nakata. 2007. The influence of floral symmetry and pollination systems on flower size variation. Nordic J. Bot. 24: 593-598.

Usinger, R. L. 1956. Aquatic Insects of California: With Keys to North American Genera and California Species. University of California Press, Berkeley, CA. 508 pp.

Utech, F. H. 1978. Floral vascular anatomy of Pleea tenuifolia Michx. (Liliaceae-Tofieldieae) and its reassignment to Tofieldia. Ann. Carnegie Mus. Pittsburgh 47: 423-454.

Utech, F. H. 2002a. Liliaceae Jussieu. Lily Family. Pp. 49-347 In: Flora North America Editorial Committee (eds.), Flora of North America North of Mexico, Vol. 26: Magnoliophyta: Liliidae: Liliales and Orchidales. Oxford University Press, New York, NY.

Utech, F. H. 2002b. Helonias Linnaeus. Pp. 69-70 In: Flora North America Editorial Committee (eds.), Flora of North America North of Mexico, Vol. 26: Magnoliophyta: Liliidae: Liliales and Orchidales. Oxford University Press, New York, NY.

Utech, F. H. \& A. Adanson. 2002. Narthecium Hudson. Pp. 66-67 In: Flora North America Editorial Committee (eds.), Flora of North America North of Mexico, Vol. 26: Magnoliophyta: Liliidae: Liliales and Orchidales. Oxford University Press, New York, NY.

Utech, F. H. \& L. C. Anderson. 2002. Harperocallis McDaniel. Pp. 58-59 In: Flora North America Editorial Committee (eds.), Flora of North America North of Mexico, Vol. 26: Magnoliophyta: Liliidae: Liliales and Orchidales. Oxford University Press, New York, NY.

Vaile, M. \& S. Gilbert. 2005. The curious case of Dr Alaboneheterodoxy in 19th century medicine. J. Roy. Soc. Med. 98: 281-286.
Vaithiyanathan, P. \& C. J. Richardson. 1999. Macrophyte species changes in the Everglades: examination along a eutrophication gradient. J. Environ. Qual. 28: 1347-1358.

Valentine, D. H. 1976. Patterns of variation in north temperate taxa with a wide distribution. Taxon 25: 225-231.

Valentine, Jr., J. M. \& R. E. Noble. 1970. A colony of sandhill cranes in Mississippi. J. Wildl. Manag. 34: 761-768.

Vamosi, J. C., S. M. Vamosi \& S. C. H. Barrett. 2006. Sex in advertising: dioecy alters the net benefits of attractiveness in Sagittaria latifolia (Alismataceae). Proc. Royal Soc. London B: Biol. Sci. 273: 2401-2407.

Van, T. K. \& K. K. Steward. 1990. Longevity of monoecious hydrilla propagules. J. Aquat. Plant Manag. 28: 74-76.

Van, T. K., W. T. Haller, G. Bowes \& L. A. Garrard. 1977. Effects of light quality on growth and chlorophyll composition in Hydrilla. J. Aquat. Plant Manag. 15: 29-31.

Van Bruggen, H. W. E. 1973. Revision of the genus Aponogeton (Aponogetonaceae) VI. The species of Africa. Bull. Jard. Bot. Natl. Belg. 43: 193-233.

Van Bruggen, H. W. E. 1985. Monograph of the genus Aponogeton (Aponogetonaceae). Biblioth. Bot. 137: 1-97.

Van Bruggen, H. W. E. 1990. Die Gattung Aponogeton (Aponogetonaceae). Aqua-Planta (Sonderheft) 2: 1-84.

Van den Berg, M. S., H. Coops, J. Simons \& A. de Keizer. 1998. Competition between Chara aspera and Potamogeton pectinatus as a function of temperature and light. Aquat. Bot. 60 : 241-250.

Van den Broek, T., R. van Diggelen \& R. Bobbink. 2005. Variation in seed buoyancy of species in wetland ecosystems with different flooding dynamics. J. Veg. Sci. 16: 579-586.

Van der Bijl, L., K. Sand-Jensen \& A.-L. Hjermind. 1989. Photosynthesis and canopy structure of a submerged plant, Potamogeton pectinatus, in a Danish lowland stream. J. Ecol. 77: 947-962.

Van der Kinderen, G. 1995. A method for the study of field germinated seeds of terrestrial orchids. Lindleyana 10: 68-73.

Van der Pijl, L. \& C. H. Dodson. 1966. Orchid Flowers: Their Pollination and Evolution. University of Miami Press, Coral Gables, FL. 214 pp.

Van der Valk, A. G. 1975. Floristic composition and structure of fen communities in northwest Iowa. Proc. Iowa Acad. Sci. 82: 113-118.

Van der Valk, A. G. \& C. B. Davis. 1978. The role of seed banks in the vegetation dynamics of prairie glacial marshes. Ecology 59: 322-335.

Van der Valk, A. G. \& T. R. Rosburg. 1997. Seed bank composition along a phosphorus gradient in the northern Florida Everglades. Wetlands 17: 228-236.

Van der Valk, A. G., S. D. Swanson \& R. F. Nuss. 1983. The response of plant species to burial in three types of Alaskan wetlands. Can. J. Bot. 61: 1150-1164.

Van der Valk, A. G., L. A. Toth, E. B. Gibney, D. H. Mason \& P. R. Wetzel. 2009. Potential propagule sources for reestablishing vegetation on the floodplain of the Kissimmee River, Florida, USA. Wetlands 29: 976-987.

Van Dijk, G. M. \& W. van Vierssen. 1991. Survival of a Potamogeton pectinatus L. population under various light conditions in a shallow eutrophic lake (Lake Veluwe) in The Netherlands. Aquat. Bot. 39: 121-129.

Van Dijk, J. K. \& B. I. Van Tussenbroek. 2010. Clonal diversity and structure related to habitat of the marine angiosperm Thalassia testudinum along the Atlantic coast of Mexico. Aquat. Bot. 92: 63-69. 
Van Dine, D. L. 1922. Impounding water in a bayou to control breeding of malaria mosquitoes. Bulletin 1098. U.S. Department of Agriculture, Washington, DC. 22 pp.

Van Drunen, W. E. \& M. E. Dorken. 2012. Trade-offs between clonal and sexual reproduction in Sagittaria latifolia (Alismataceae) scale up to affect the fitness of entire clones. New Phytol. 196: 606-616.

Van Kampen, K. R., L. F. James \& A. E. Johnson. 1970. Hemolytic anemia in sheep fed wild onion (Allium validum). J. Am. Veterin. Med. Assoc. 156: 328-332.

Van Montfrans, J., R. J. Orth \& S. A. Vay. 1982. Preliminary studies of grazing by Bittium varium on eelgrass periphyton. Aquat. Bot. 14: 75-89.

Van Montfrans, J., R. L. Wetzel \& R. J. Orth. 1984. Epiphyte-grazer relationships in seagrass meadows: consequences for seagrass growth and production. Estuaries Coast. 7: 289-309.

Van Onsem, S., J. Rops \& L. Triest. 2018. Submerged seed, turion and oospore rain: a trap quantifying propagule deposition under aquatic vegetation. Aquat. Bot. 145: 21-28.

Van Tussenbroek, B. I. 1994. Aspects of the reproductive ecology of Thalassia testudinum in Puerto Morelos Reef Lagoon, Mexico. Bot. Marina 37: 413-420.

Van Tussenbroek, B. I. \& M. Muhlia-Montero. 2013. Can floral consumption by fish shape traits of seagrass flowers? Evol. Ecol. 27: 269-284.

Van Tussenbroek, B. I., N. Villamil, J. Marquezguzman, R. Wong, L. V. Monroy-Velázquez \& V. Solis-Weiss. 2016a. Experimental evidence of pollination in marine flowers by invertebrate fauna. Nat. Commun. 7. doi: 10.1038/ncomms12980.

Van Tussenbroek, B. I., T. Valdivia-Carrillo, I. T. Rodríguez-Virgen, S. N. M. Sanabria-Alcaraz, K. Jiménez-Durán, K. J. Van Dijk \& G. J. Marquez-Guzmán. 2016b. Coping with potential biparental inbreeding: limited pollen and seed dispersal and large genets in the dioecious marine angiosperm Thalassia testudinum. Ecol. Evol. 6: 5542-5556.

Van Valkenburg, J. L. C. H. \& R. Pot. 2008. Landoltia punctata (G. Mey.) DH Les \& DJ Crawford (Smal kroos), nieuw voor Nederland. Gorteria 33: 41-49.

Van Vierssen, W. 1982a. Some notes on the germination of seeds of Najas marina L. Aquat. Bot. 12: 201-203.

Van Vierssen, W. 1982b. The ecology of communities dominated by Zannichellia taxa in western Europe. I. Characterization and autecology of the Zannichellia taxa. Aquat. Bot. 12: 103-155.

Van Vierssen, W., R. J. Van Wijk \& J. R. Van der Zee. 1981. Some additional notes on the cytotaxonomy of Ruppia taxa in Western Europe. Aquat. Bot. 11: 297-301.

Van Vierssen, W., R. J. Van Wijk \& J. R. Van der Zee. 1982. On the pollination mechanism of some eurysaline Potamogetonaceae. Aquat. Bot. 14: 339-347.

Van Wijck, C., C.-J. de Groot \& P. Grillas. 1992. The effect of anaerobic sediment on the growth of Potamogeton pectinatus L.: the role of organic matter, sulphide and ferrous iron. Aquat. Bot. 44: 31-49.

Van Wijk, R. J. 1988. Ecological studies on Potamogeton pectinatus L. I. General characteristics, biomass production and life cycles under field conditions. Aquat. Bot. 31: 211-258.

Van Wijk, R. J. 1989a. Ecological studies on Potamogeton pectinatus L. III. Reproductive strategies and germination ecology. Aquat. Bot. 33: 271-299.

Van Wijk, R. J. 1989b. Ecological studies on Potamogeton pectinatus L. IV. Nutritional ecology, field observations. Aquat. Bot. 35: 301-318.

Van Wijk, R. J. 1989c. Ecological studies on Potamogeton pectinatus L. V. Nutritional ecology, in vitro uptake of nutrients and growth limitation. Aquat. Bot. 35: 319-335.
Van Wijk, R. J., E. M. J. Van Goor \& J. A. C. Verkley. 1988. Ecological studies on Potamogeton pectinatus L. II. Autecological characteristics, with emphasis on salt tolerance, intraspecific variation and isoenzyme patterns. Aquat. Bot. 32: 239-260.

Van Wyk, B.-E. 2011. The potential of South African plants in the development of new food and beverage products. S. Afr. J. Bot. 77: 857-868.

Van Zandt, P. A., P. L. Freeman \& L. J. Davenport. 2013. Sporadic destructive occurrence of convict caterpillars (Xanthopastis timais) on Cahaba lilies (Hymenocallis coronaria). S. Lepid. News 35: 5-14.

Van Zuidam, J. P., E. P. Raaphorst \& E. T. H. M. Peeters. 2012. The role of propagule banks from drainage ditches dominated by free-floating or submerged plants in vegetation restoration. Restor. Ecol. 20: 416-425.

Vanitha, K., P. Subhashini \& T. Thangaradjou. 2016. Karyomorphometric analysis of somatic chromosomes of selected seagrasses of families Hydrocharitaceae and Cymodoceaceae. Aquat. Bot. 133: 45-49.

Vankar, P. S. \& J. Srivastava. 2018. A review - canna the wonder plant. J. Textile Eng. Fashion Technol. 4: 158-162.

Vánky, K. 1994. Ustilaginales of Commelinaceae. Mycoscience 35: 353-360.

Vannatta, J. 2016. The giant liver fluke: a review, intermediate host habitat, and infection in a white-tailed deer population in Minnesota. M.S. thesis. University of Minnesota, St. Paul, MN. 137 pp.

Vansell, G. H. \& W. G. Watkins. 1933. A plant poisonous to adult bees. J. Econ. Entomol. 26: 168-170.

VanTassel, N. M. \& A. M. Janosik. 2019. A compendium of coastal dune lakes in northwest Florida. J. Coast. Conserv. 23: 385-416.

Vári, Á. 2013. Colonisation by fragments in six common aquatic macrophyte species. Fundam. Appl. Limnol. 183: 15-26.

Vasconcelos, T., M. Tavares \& N. Gaspar. 1999. Aquatic plants in the rice fields of the Tagus Valley, Portugal. Pp. 59-65 In: J. Caffrey, P. R. F. Barrett, M. T. Ferreira, I. S. Moreira, K. J. Murphy \& P. M. Wade (eds.), Biology, Ecology and Management of Aquatic Plants. Springer, Dordrecht, The Netherlands.

Vasey, M. C., V. T. Parker, J. C. Callaway, E. R. Herbert \& L. M. Schile. 2012. Tidal wetland vegetation in the San Francisco Bay-Delta estuary. San Francisco Estuary Watershed Sci. 10: $1-16$.

Vasseur, L., L. W. Aarssen \& T. Bennett. 1993. Allozymic variation in local apomictic populations of Lemna minor (Lemnaceae). Am. J. Bot. 80: 974-979.

Velichkova, K., I. Sirakov, E. Valkova, S. Stoyanova \& G. Kostadinova. 2017. Bioaccumulation and protein content of Lemna minuta Kunth and Lemna valdiviana Phil. in Bulagarian water reservoirs. Land Reclam. Earth Observ. Surv. Environ. Eng. 6: 104-107.

Venturelli, M. \& F. Bouman. 1986. Embryology and seed development in Mayaca fluviatilis (Mayacaceae). Acta Bot. Neerl. 35 : 497-516.

Verhoeven, J. T. A. 1979. The ecology of Ruppia-dominated communities in Western Europe. I. Distribution of Ruppia representatives in relation to their autecology. Aquat. Bot. 6: 197-268.

Verkleij, J. A. C., A. H. Pieterse, G. J. T. Horneman \& M. Torenbeek. 1983. A comparative study of the morphology and isoenzyme patterns of Hydrilla verticillata (Lf) Royle. Aquat. Bot. 17: 43-59.

Verma, M. \& Y. K. Bansal. 2010. Butterfly lilly [sic!] (Hedychium coronarium Koenig): an endangered medicinal plant. Plant Arch. 10: 841-843. 
Verma, M. \& Y. K. Bansal. 2012. Induction of somatic embryogenesis in endangered butterfly ginger Hedychium coronarium J. Koenig. Indian J. Exp. Biol. 50: 904-909.

Vermaat, J. E. \& M. J. M. Hootsmans. 1994. Growth of Potamogeton pectinatus L. in a temperature-light gradient. Pp. 40-61 In: W. van Vierssen, M. Hootsmans \& J. Vermaat (eds.), Lake Veluwe, A Macrophyte-Dominated System Under Eutrophication Stress. Springer, Dordrecht, The Netherlands.

Vermaat, J. E., L. Santamaria \& P. J. Roos. 2000. Water flow across and sediment trapping in submerged macrophyte beds of contrasting growth form. Arch. Hydrobiol.148: 549-562.

Vest, J. L. \& M. R. Conover. 2011. Food habits of wintering waterfowl on the Great Salt Lake, Utah. Waterbirds 34: 40-50.

Vickery, R. 1983. Lemna minor and Jenny Greenteeth. Folklore 94: 247-250.

Vidal, J. 1960. Les Plantes utiles du Laos. J. Agric. Trop. 7: 560-587.

Vieira, M. F. \& N. A. de Souza Lima. 1997. Pollination of Echinodorus grandiflorus (Alismataceae). Aquat. Bot. 58: 89-98.

Viereck, L. A., C. T. Dyrness, A. R. Batten \& K. J. Wenzlick. 1992. The Alaska vegetation classification. General Technical Report PNW-GTR-286. U.S. Department of Agriculture, Forest Service, Pacific Northwest Research Station, Portland, OR. 278 pp.

Viereck, L. A., C. T. Dyrness \& M. J. Foote. 1993. An overview of the vegetation and soils of the floodplain ecosystems of the Tanana River, interior Alaska. Can. J. For. Res. 23: 889-898.

Viinikka, Y. 1973. The occurrence of B chromosomes and their effect on meiosis in Najas marina. Hereditas 75: 207-212.

Viinikka, Y. 1976. Najas marina L. (Najadaceae). Karyotypes, cultivation and morphological variation. Ann. Bot. Fenn. 13: $119-131$.

Viinikka, Y. 1977. The role of U-type exchanges in the differentiation of karyotypes in Najas marina. Hereditas 86: 91-101.

Viinikka, Y. \& M. Kotimäki. 1979. The meiotic and postmeiotic consequences of spontaneous chromosome breakage in Najas marina. Hereditas 91: 273-277.

Viinikka, Y., M. Kotimäki \& K. Litmanen. 1978. Spontaneous chromosome breakage in natural populations of Najas marina. Hereditas 88: 279-283.

Viinikka, Y., M. Agami \& L. Triest. 1987. A tetraploid cytotype of Najas marina L. Hereditas 106: 289-291.

Vincent, R. E. 1958. The larger plants of Little Kitoi lake. Am. Midl. Nat. 60: 212-218.

Vincent, W. F. \& C. Bertola. 2012. François Alphonse FOREL. Archiv. Sci. 65: 51-64.

Vinson, M. \& B. Bushman. 2005. An Inventory of Aquatic Invertebrate Assemblages in Wetlands in Utah. National Aquatic Monitoring Center, Utah State University, Logan, UT. 224 pp.

Viosca, Jr., P. 1935. The irises ofsoutheastern Louisiana, a taxonomic and ecological interpretation. Bull. Am. Iris Soc. 57: 3-56.

Visser, J. M. \& C. E. Sasser. 2009. The effect of environmental factors on floating fresh marsh end-of-season biomass. Aquat. Bot. 91: 205-212.

Visser, J. M., C. E. Sasser, R. H. Chabreck \& R. G. Linscombe. 1999. Long-term vegetation change in Louisiana tidal marshes, 1968-1992. Wetlands 19: 168-175.

Vitt, D. H. \& N. G. Slack. 1975. An analysis of the vegetation of Sphagnum-dominated kettle-hole bogs in relation to environmental gradients. Can. J. Bot. 53: 332-359.

Vitt, D. H. \& S. Bayley. 1984. The vegetation and water chemistry of four oligotrophic basin mires in northwestern Ontario. Can. J. Bot. 62: $1485-1500$.

Vitt, D. H. \& W.-L. Chee. 1990. The relationships of vegetation to surface water chemistry and peat chemistry in fens of Alberta, Canada. Vegetatio 89: 87-106.
Vitt, D. H., D. G. Horton, N. G. Slack \& N. Malmer. 1990. Sphagnumdominated peatlands of the hyper-oceanic British Columbia coast: patterns in surface water chemistry and vegetation. Can. J. For. Res. 20: 696-711.

Vogel, R. L. 1977. Aquatic plant communities of East-Central Illinois. M.S. thesis. Eastern Illinois University, Charleston, IL. 28 pp.

Volker, R. \& S. G. Smith. 1965. Changes in the aquatic vascular flora of Lake East Okoboji in historic times. Proc. Iowa Acad. Sci. 72: $65-72$.

Volkova, O. A., M. V. Remizowa, D. D. Sokoloff \& E. E. Severova. 2016. A developmental study of pollen dyads and notes on floral development in Scheuchzeria (Alismatales: Scheuchzeriaceae). Bot. J. Linn. Soc. 182: 791-810.

Von Bank, J. A., J. A. DeBoer, A. F. Casper \& H. M. Hagy. 2018. Ichthyochory in a temperate river system by common carp (Cyprinus carpio). J. Freshw. Ecol. 33: 83-96.

Von Mering, S. \& J. W. Kadereit. 2010. Phylogeny, systematics, and recircumscription of Juncaginaceae - a cosmopolitan wetland family. Pp. 55-79 In: O. Seberg, G. Petersen, A. S. Barfod \& J. I. Davis (eds.), Diversity, Phylogeny, and Evolution in the Monocotyledons. Aarhus University Press, Aarhus, Denmark.

Von Mering, S. \& J. W. Kadereit. 2015. Phylogeny, biogeography and evolution of Triglochin L. (Juncaginaceae)--morphological diversification is linked to habitat shifts rather than to genetic diversification. Mol. Phylogenet. Evol. 83: 200-212.

Vossler, F. G., M. C. Telleria \& M. Cunningham. 2010. Floral resources foraged by Geotrigona argentina (Apidae, Meliponini) in the Argentine Dry Chaco forest. Grana 49: 142-153.

Vuille, F. L. 1987. Reproductive biology of the genus Damasonium (Alismataceae). Plant Syst. Evol. 157: 63-71.

Vymaza, J. 2013. Emergent plants used in free water surface constructed wetlands: a review. Ecol. Eng. 61P: 582-592.

Wada, N. \& S. Uemura. 1994. Seed dispersal and predation by small rodents on the herbaceous understory plant Symplocarpus renifolius. Am. Midl. Nat. 132: 320-327.

Wadkar, S. S., C. C. Shete, F. R. Inamdar, S. S. Wadkar \& R. V. Gurav. 2017. Phytochemical screening and antibacterial activity of Cryptocoryne spiralis var. spiralis and Cryptocoryne retrospiralis (Roxb) Kunth. Med. Aromat. Plants 6: 2167-0412.

Wagner, R. 1982. Raising ornamental palms. Principes 26: 86-101.

Wagner, E. J. \& R. W. Oplinger. 2017. Effect of overwinter hydration, seed storage time, temperature, photoperiod, water depth, and scarification on seed germination of some Schoenoplectus, Polygonum, Eleocharis and Alisma species. Aquat. Bot. 136: 164-174.

Wagstaff, D. J. \& A. A. Case. 1987. Human poisoning by Zigadenus. J. Toxicol. 25: 361-367.

Wake, C. M. F. 2007. Micro-environment conditions, mycorrhizal symbiosis, and seed germination in Cypripedium candidum: strategies for conservation. Lankesteriana 7: 423-426.

Wakeman, R. W. \& D. H. Les. 1994a. Interspecific competition between Potamogeton amplifolius and Myriophyllum spicatum. Lake Reserv. Manag. 9: 125-129.

Wakeman, R. W. \& D. H. Les. 1994b. Optimum growth conditions for Potamogeton amplifolius, Myriophyllum spicatum and Potamogeton richardsonii. Lake Reserv. Manag. 9: 129-133.

Walck, J. L. \& S. N. Hidayati. 2004. Differences in light and temperature responses determine autumn versus spring germination for seeds of Schoenolirion croceum. Can. J. Bot. 82: 1429-1437.

Walker, B. H. \& C. F. Wehrhahn. 1971. Relationships between derived vegetation gradients and measured environmental variables in Saskatchewan wetlands. Ecology 52: 85-95. 
Walker, B. N. \& R. J. Medve. 1976. The effects of acid mine drainage on Sparganium americanum Nutt. Proc. Pennsylvania Acad. Sci. 50: 170-172.

Walker, J. \& R. K. Peet. 1984. Composition and species diversity of pine-wiregrass savannas of the Green Swamp, North Carolina. Vegetatio 55: 163-179.

Walker, D. A. \& K. R. Everett. 1991. Loess ecosystems of northern Alaska: regional gradient and toposequence at Prudhoe Bay. Ecol. Monogr. 61: 437-464.

Walker, J. L. \& A. M. Silletti. 2005. A three-year demographic study of Harper's beauty (Harperocallis flava McDaniel), an endangered Florida endemic. J. Torrey Bot. Soc. 132: 551-560.

Walker, D. A., N. D. Lederer \& M. D. Walker. 1987. Permanent vegetation plots. Site factors, soil physical and chemical properties, and plant species cover. Data Report, Department of Energy R4D Project. Plant Ecology Laboratory, Institute of Arctic and Alpine Research, University of Colorado, Boulder, CO. 89 pp.

Walker, D. A., E. Binnian, B. M. Evans, N. D. Lederer, E. Nordstrand \& P. J. Webber. 1989. Terrain, vegetation and landscape evolution of the R4D research site, Brooks Range Foothills, Alaska. Ecography 12: 238-261.

Walker, M. D., D. A. Walker \& N. A. Auerbach. 1994. Plant communities of a tussock tundra landscape in the Brooks Range Foothills, Alaska. J. Veg. Sci. 5: 843-866.

Walker, D. I., B. Olesen \& R. C. Phillips. 2001. Reproduction and phenology in seagrasses. Pp. 59-78 In: F. T. Short \& R. G. Coles (eds.), Global Seagrass Research Methods. Elsevier Science B.V., Amsterdam, The Netherlands.

Wall, M. A., A. P. Teem \& R. S. Boyd. 2002. Floral manipulation by Lasioglossum zephyrum (Hymenoptera: Halictidae) ensures first access to floral rewards by initiating premature anthesis of Xyris tennesseensis (Xyridaceae) flowers. Florida Entomol. 85: 290-292.

Wallace, G. J. 1942. More Berkshire plants. Rhodora 44: 332-334.

Wallace, L. E. 2002. Examining the effects of fragmentation on genetic variation in Platanthera leucophaea (Orchidaceae): inferences from allozyme and random amplified polymorphic DNA markers. Plant Species Biol. 17: 37-49.

Wallace, L. E. 2003a. Molecular evidence for allopolyploid speciation and recurrent origins in Platanthera huronensis (Orchidaceae). Int. J. Plant Sci. 164: 907-916.

Wallace, L. E. 2003b. The cost of inbreeding in Platanthera leucophaea (Orchidaceae). Am. J. Bot. 90: 235-242.

Wallace, L. E. 2004. A comparison of genetic variation and structure in the allopolyploid Platanthera huronensis and its diploid progenitors, Platanthera aquilonis and Platanthera dilatata (Orchidaceae). Can. J. Bot. 82: 244-252.

Wallace, L. E. 2006. Spatial genetic structure and frequency of interspecific hybridization in Platanthera aquilonis and $P$. dilatata (Orchidaceae) occurring in sympatry. Am. J. Bot. 93: 1001-1009.

Waller, D. M. \& D. A. Steingraeber. 1995. Opportunities and constraints in the placement of flowers and fruits. Pp. 51-73 In: B. L. Gartner (ed.), Plant Stems: Physiology and Functional Morphology. Academic Press, New York, NY.

Waller, D. M. \& W. S. Alverson. 1997. The white-tailed deer: a keystone herbivore. Wildl. Soc. Bull. 25: 217-226.

Wallis, C. S. 2007. Vascular plants of the Oklahoma Ozarks. Oklahoma Nat. Plant Rec. 7: 4-20.

Walsh, G. E. \& T. E. Grow. 1972. Composition of Thalassia testudinum and Ruppia maritima. Quart. J. Florida Acad. Sci. 35: 97-108.

Walsh, R. P. \& H. J. Michaels. 2017. When it pays to cheat: examining how generalized food deception increases male and female fitness in a terrestrial orchid. PLoS One 12(1): e 0171286.
Walsh, R. P., P. M. Arnold \& H. J. Michaels. 2014. Effects of pollination limitation and seed predation on female reproductive success of a deceptive orchid. AoB Plants 6(1): plu031.

Walton, G. B. 1995. Report for Field Season 1994 Status Survey for Caltha natans and Sparganium glomeratum in Minnesota. Natural Heritage Program, Minnesota Department of Natural Resources, Minneapolis, MN. 43 pp.

Wan, T., X.-L. Zhang, J. Gregan, Y. Zhang, P. Guo \& Y.-H. Guo. 2012. A dynamic evolution of chromosome in subgenus Potamogeton revealed by physical mapping of rDNA loci detection. Plant Syst. Evol. 298: 1195-1210.

Wang, W. 1990. Literature review on duckweed toxicity testing. Environ. Res. 52: 7-22.

Wang, B. \& Y.-L. Qiu. 2006. Phylogenetic distribution and evolution of mycorrhizas in land plants. Mycorrhiza 16: 299-363.

Wang, W. H. \& J. Min. 2007. Comparison on salt tolerance of nine submerged macrophytes. J. Agro-Environ. Sci. 26: 1259-1263.

Wang, W. \& J. Messing. 2011. High-throughput sequencing of three Lemnoideae (duckweeds) chloroplast genomes from total DNA. PLoS One 6: e24670.

Wang, W. \& J. Messing. 2015. Status of duckweed genomics and transcriptomics. Plant Biol. 17: 10-15.

Wang, L. \& K. H. Hasenstein. 2016. Seed coat stomata of several Iris species. Flora 224: 24-29.

Wang, G., Y. Yamasue, K. Itoh \& T. Kusanagi. 1998. Outcrossing rates as affected by pollinators and the heterozygote advantage of Monochoria korsakowii. Aquat. Bot. 62: 135-143.

Wang, H., W. Li, Z. Gu \& Y. Chen. 2001. Cytological study on Acorus L. in southwestern China, with some cytogeographical notes on A. calamus. Acta Bot. Sin. 43: 354-358.

Wang, X.-F., Y.-Y. Tan, J.-H. Chen \& Y.-T. Lu. 2006. Pollen tube reallocation in two preanthesis cleistogamous species, Ranalisma rostratum and Sagittaria guyanensis ssp. lappula (Alismataceae). Aquat. Bot. 85: 233-240.

Wang, B., L. Peng, L. Zhu \& P. Ren. 2007. Protective effect of total flavonoids from Spirodela polyrrhiza (L.) Schleid on human umbilical vein endothelial cell damage induced by hydrogen peroxide. Colloids Surf. B Biointerfaces 60: 36-40.

Wang, H., H. Zhu, K. Zhang, L. Zhang \& Z. Wu. 2010. Chemical composition in aqueous extracts of Najas marina and Najas minor and their algae inhibition activity. Sci. Res. 2010: 806-809.

Wang, W., R. A. Kerstetter \& T. P. Michael. 2011a. Evolution of genome size in duckweeds (Lemnaceae). J. Bot. 2011. doi: 10.1155/2011/570319.

Wang, G., L. Chen, Z. Hao, X. Li \& Y. Liu. 2011b. Effects of salinity stress on the photosynthesis of Wolffia arrhiza as probed by the OJIP test. Fresenius Environ. Bull. 20: 432-438.

Wang, X., W. Zhou, J. Lu, H. Wang, C. Xiao, J. Xia \& G. Liu. 2012a. Effects of population size on synchronous display of female and male flowers and reproductive output in two monoecious Sagittaria species. PLoS One 7(10): e48731.

Wang, W., Y. Wu \& J. Messing. 2012b. The mitochondrial genome of an aquatic plant, Spirodela polyrhiza. PLoS One 7(10): e46747.

Wang, W., Y. Wu \& J. Messing. 2014a. RNA-Seq transcriptome analysis of Spirodela dormancy without reproduction. BMC Genomics 15(1): 60.

Wang, H. Q., H. J. Zhu, L. Y. Zhang, W. J. Xue \& B. Yuan. 2014b. Identification of antialgal compounds from the aquatic plant Elodea nuttallii. Allelopathy J. 34: 207-214.

Wang, W., G. Haberer, H. Gundlach, C. Gläßer, T. C. L. M. Nussbaumer, M. C. Luo, A. Lomsadze, M. Borodovsky, R. A. Kerstetter, J. Shanklin, D. W. Byrant, T. C. Mockler, K. J. Appenroth, J. Grimwood, J. Jenkins, J. Chow, C. Choi, 
C. Adam, X.-H. Cao, J. Fuchs, I. Schubert, D. Rokhsar, J. Schmutz, T. P. Michael, K. F. X. Mayer \& J. Messing. 2014c. The Spirodela polyrhiza genome reveals insights into its neotenous reduction fast growth and aquatic lifestyle. Nat. Commun. 5: ncomms4311.

Wang, W., W. Zhang, Y. Wu, P. Maliga \& J. Messing. 2015. RNA editing in chloroplasts of Spirodela polyrhiza, an aquatic monocotelydonous species. PLoS One 10(10): e0140285.

Wang, P., P. Alpert \& F.-H. Yu. 2016. Clonal integration increases relative competitive ability in an invasive aquatic plant. Am. J. Bot. 103: 2079-2086.

Wang, C.-J., J.-Z. Wan, H. Qu \& Z.-X. Zhang. 2017. Climatic niche shift of aquatic plant invaders between native and invasive ranges: a test using 10 species across different biomes on a global scale. Knowl. Manag. Aquat. Ecosyst. 418: 1-27.

Wang, W., A. Dong, C. Li, Y. Zhou \& Y. Wu. 2018a. Genomes and transcriptomes of duckweeds. Front. Chem. 6: 230. doi: 10.3389/fchem.2018.00230.

Wang, R., M. Li, X. Wu, C. Shen, W. Yu, J. Liu, Z. Qi \& P. Li. 2018b. Characterization of polymorphic microsatellite loci for North American common greenbrier, Smilax rotundifolia (Smilacaceae). Appl. Plant Sci. 6: e01163.

Ward, L. F. 1882. Proterogyn in Sparganium eurycarpum. Bot. Gaz. 7: 100 .

Ward, L. F. 1883. Marsh and aquatic plants of the Northern United States, many of which are suitable for carp ponds. Bull. U.S. Fish Commiss. 3: 257-265.

Ward, D. B. 2011. Spirodela oligorrhiza (Lemnaceae) is the correct name for the lesser greater duckweed. J. Bot. Res. Inst. Texas 5: 197-203.

Ward, D. B. 2012. New combinations in the Florida flora III. Phytologia 94: 459-485.

Ward, C. H. \& S. S. Wilks. 1963. Use of algae and other plants in the development of life support systems. Am. Biol. Teach. 25: 512-521.

Ward, D. B. \& A. F. Clewell. 1989. Atlantic white cedar (Chamaecyparis thyoides) in the southern states. Florida Sci. 52: 8-47.

Ware, D. M. E. \& S. Ware. 1992. An Acer barbatum-rich ravine forest community in the Virginia coastal plain. Castanea 57: 110-122.

Waridel, P., J.-L. Wolfender, J.-B. Lachavanne \& K. Hostettmann. 2003. ent-Labdane diterpenes from the aquatic plant Potamogeton pectinatus. Phytochemistry 64: 1309-1317.

Warrington, P. D. 1986. The pH Tolerance of the Aquatic Plants of British Columbia. Part I. Literature Survey of the $\mathrm{pH}$ Limits of Aquatic Plants of the World. Water Management Branch, British Columbia Ministry of Environment, Victoria, BC. $157 \mathrm{pp}$.

Wasowicz, P., E. M. Przedpelska-Wasowicz, L. Guðmundsdóttir \& M. Tamayo. 2014. Vallisneria spiralis and Egeria densa (Hydrocharitaceae) in arctic and subarctic Iceland. New J. Bot. 4: 85-89.

Watson, J. R. 1941. Migrations and food preferences of the lubberly locust. Florida Entomol. 24: 40-42.

Watson, L. E., G. E. Uno, N. A. McCarty \& A. B. Kornkven. 1994. Conservation biology of a rare plant species, Eriocaulon kornickianum (Eriocaulaceae). Am. J. Bot. 81: 980-986.

Watson, L. E., A. B. Kornkven, C. R. Miller, J. R. Allison, N. B. McCarty \& M. M. Unwin. 2002. Morphometric and genetic variation in Eriocaulon koernickianum Van Heurck \& MullerArgoviensis (Eriocaulaceae): a disjunct plant species of the southeastern United States. Castanea 67: 416-426.

Waud, M., P. Busschaert, S. Ruyters, H. Jacquemyn \& B. Lievens. 2014. Impact of primer choice on characterization of orchid mycorrhizal communities using 454 pyrosequencing. Mol. Ecol. Resour. 14: 679-699.
Way, M. O. 1982. The aster leafhopper, Macrosteles fascifrons Stål: conditions affecting abundance, tactics for control and effects on yield of rice in California. Ph.D. dissertation. University of California, Davis, CA.

Waycott, M. \& D. H. Les. 1996. An integrated approach to the evolutionary study of seagrasses. Pp. 71-78 In: R. C. Philipps, D. I. Walker \& H. Kirkman (eds.), Seagrass Biology: Proceedings of an International Workshop, Rottnest Island, Western Australia, 25-29 January, 1996. Faculty of Sciences, University of Western Australia, Nedlands, WA, Australia.

Waycott, M., D. W. Freshwater, R. A. York, A. Calladine \& W. J. Kenworthy. 2002. Evolutionary trends in the seagrass genus Halophila (Thouars): insights from molecular phylogeny. Bull. Mar. Sci. 71: 1299-1308.

Waycott, M., G. Procaccini, D. H. Les \& T. B. H. Reusch. 2006. Seagrass evolution, ecology and conservation: a genetic perspective. Pp. 25-50 In: A. W. D. Larkum, R. J. Orth \& C. M. Duarte (eds.), Seagrasses: Biology, Ecology and Conservation. Springer-Verlag, Dordrecht, The Netherlands.

Weakley, A. S. 1991. Classification of pocosins of the Carolina coastal plain. Wetlands 11: 355-375.

Weakley, A. S. \& M. P. Schafale. 1994. Non-alluvial wetlands of the southern Blue Ridge-diversity in a threatened ecosystem. Water Air Soil Pollut. 77: 359-383.

Weatherbee, P. B. \& G. E. Crow. 1992. Natural plant communities of Berkshire County, Massachusetts. Rhodora 94: 171-209.

Weber, W. A. 1940. Potamogeton hillii in Berkshire County, Massachusetts. Rhodora 42: 95.

Weber, J. \& S. Rooney. 1994. Josselyn Botanical Society's Annual Meeting, Unity College, July 1993. Maine Nat. 2: 50-52.

Weberg, M. A., B. R. Murphy, A. L. Rypel \& J. R. Copeland. 2015. A survey of the New River aquatic plant community in response to recent triploid grass carp introductions into Claytor Lake, Virginia. Southeast. Nat. 14: 308-318.

Webster, C. G. 1964. Fall foods of soras from two habitats in Connecticut. J. Wildl. Manag. 28: 163-165.

Weerasundara, L., C. N. Nupearachchi, P. Kumarathilaka, B. Seshadri, N. Bolan \& M. Vithanage. 2016. Bio-retention systems for storm water treatment and management in urban systems. Pp. 175-200 In: A. A. Ansari, S. S. Gill, R. Gill, G. R. Lanza \& L. Newman (eds.), Phytoremediation. Management of Environmental Contaminants, Volume 4. Springer International Publishing, Basel, Switzerland.

Wees, D. 2004. Stratification and priming may improve seed germination of purple coneflowers, blue-flag iris, and evening primrose. Acta Hort. 629: 391-395.

Wehrmeister, J. R. 1978. An ecological life history of the pondweed Potamogeton crispus L. in North America. CLEAR Technical Report No. 99. The Ohio State University Center for Lake Erie Area Research, Columbus, OH. 157 pp.

Wei, Z.-Z., L.-B. Luo, H.-L. Zhang, M. Xiong, X. Wang \& D. Zhou. 2012. Identification and characterization of 43 novel polymorphic EST-SSR markers for arum lily, Zantedeschia aethiopica (Araceae). Am. J. Bot. 99: e493-e497.

Weiher, E. \& P. A. Keddy. 1995. The assembly of experimental wetland plant communities. Oikos 73: 323-335.

Weiher, E., S. Peot \& K. Voss. 2003. Experimental restoration of lake shoreland in western Wisconsin. Ecol. Restor. 21: 186-191.

Weiher, E. R., C. W. Boylen \& P. A. Bukaveckas. 2011. Alterations in aquatic plant community structure following liming of an acidic Adirondack lake. Can. J. Fish. Aquat. Sci. 51: 20-24.

Wein, K. 1939. Die älteste Einführungs- und Ausbreitungsgeschichte von Acorus calamus. Erster Teil. Hercynia (Special Edition) 1: $367-450$. 
Wein, K. 1940a. Die älteste Einführungs- und Ausbreitungsgeschichte von Acorus calamus. Zweiter Teil. Hercynia (Special Edition) 3: $72-128$.

Wein, K. 1940b. Die älteste Einführungs- und Ausbreitungsgeschichte von Acorus calamus. Dritter Teil. Hercynia (Special Edition) 3: 241-291.

Weinhold, C. E. \& A. G. Van der Valk. 1988. The impact of duration of drainage on the seed banks of northern prairie wetlands. Can. J. Bot. 67: 1878-1884.

Weishampel, P. A. \& B. L. Bedford. 2006. Wetland dicots and monocots differ in colonization by arbuscular mycorrhizal fungi and dark septate endophytes. Mycorrhiza 16: 495-502.

Welch, J. R. 2013. Sprouting Valley: Historical Ethnobotany of the Northern Pomo from Potter Valley, California. Society of Ethnobiology, Department of Geography, University of North Texas, Denton, TX. 207 pp.

Wellborn, G. A. \& J. V. Robinson. 1987. Microhabitat selection as an antipredator strategy in the aquatic insect Pachydiplax longipennis Burmeister (Odonata: Libellulidae). Oecologia 71: 185-189.

Weller, M. W. (ed.). 1988. Waterfowl in Winter: Selected Papers from Symposium and Workshop Held in Galveston, Texas, 7-10 January 1985. University of Minnesota Press, Minneapolis, MN. 624 pp.

Wells, B. W. 1928. Plant communities of the coastal plain of North Carolina and their successional relations. Ecology 9: 230-242.

Wells, B. W. 1942. Ecological problems of the southeastern United States coastal plain. Bot. Rev. 8: 533-561.

Wells, E. D. 1996. Classification of peatland vegetation in Atlantic Canada. J. Veg. Sci. 7: 847-878.

Wells, A. F. 2006. Deep canyon and subalpine riparian and wetland plant associations of the Malheur, Umatilla, and WallowaWhitman National Forests. Gen. Tech. Rep. PNW-GTR-682. U.S. Department of Agriculture, Forest Service, Pacific Northwest Research Station, Portland, OR. 277 pp.

Wells, C. \& M. Alexander. 2014. Bunched Arrowhead (Sagittaria fasciculata) 5-Year Review: Summary and Evaluation. U.S. Fish and Wildlife Service, Southeast Region, Asheville Ecological Services Field Office, Asheville, NC. 22 pp.

Weltzin, J. F., J. Pastor, C. Harth, S. D. Bridgham, K. Updegraff \& C. T. Chapin. 2000. Response of bog and fen plant communities to warming and water-table manipulations. Ecology 81: 3464-3478.

Wen, J. 1999. Evolution of eastern Asian and eastern North American disjunct distributions in flowering plants. Ann. Rev. Ecol. Syst. 30: 421-455.

Wen, J., R. K. Jansen \& K. Kilgore. 1996. Evolution of the eastern Asian and eastern North American disjunct genus Symplocarpus (Araceae): insights from chloroplast DNA restriction site data. Biochem. Syst. Ecol. 24: 735-747.

Wentz, W. A. \& R. L. Stuckey. 1971. The changing distribution of the genus Najas (Najadaceae) in Ohio. Ohio J. Sci. 71: 292-302.

Werblan, D., R. J. Smith, A. G. van der Valk \& C. B. Davis. 1978. Treatment of waste from a confined hog feeding unit by using artificial marshes. Pp. 149-155 In: H. L. McKim (ed.), State of Knowledge in Land Treatment of Wastewater, Vol. 2. U.S. Army Corps of Engineers, Cold Regions Research and Engineering Laboratory, Hanover, NH.

Werckmeister, P. 1969. Red irises and cyanidin. Bull. Am. Iris Soc. 194: 7-13.

Wersal, R. M., B. R. McMillan \& J. D. Madsen. 2005. Food habits of dabbling ducks during fall migration in a prairie pothole system, Heron Lake, Minnesota. Can. Field-Nat. 119: 546-550.

Wersal, R. M., J. D. Madsen \& J. C. Cheshier. 2010. Aquatic plant monitoring in Noxon Rapids Reservoir and Cabinet Gorge Reservoir for 2010. Geosystem Research Institute Report \#5042. Geosystems Research Institute, Mississippi State University, Mississippi State, MS. 18 pp.
Wesselingh, R. A. \& M. L. Arnold. 2000a. Pollinator behaviour and the evolution of Louisiana iris hybrid zones. J. Evol. Biol. 13: 171-180.

Wesselingh, R. A. \& M. L. Arnold. 2000b. Nectar production in Louisiana Iris hybrids. Int. J. Plant Sci. 161: 245-251.

Wesselingh, R. A. \& M. L. Arnold. 2003. A top-down hierarchy in fruit set on inflorescences in Iris fulva (Iridaceae). Plant Biol. 5: 651-660.

West, E. 1941. Notes on Florida fungi. II. Mycologia 33: 38-49.

West, E. 1945. Notes on Florida fungi. III. Mycologia 37: 65-79.

West, D. \& D. F. Whigham. 1975. Seed germination of arrow arum (Peltandra virginica L.). Bartonia 44: 44-49.

Westcott, K., T. H. Whillans \& M. G. Fox. 1997. Viability and abundance of seeds of submerged macrophytes in the sediment of disturbed and reference shoreline marshes in Lake Ontario. Can. J. Bot. 75: 451-456.

Wester, L. 1992. Origin and distribution of adventive alien flowering plants in Hawai 'i. Pp. 99-154 In: C. P. Stone, C. W. Smith \& J. T. Tunison (eds.), Alien Plant Invasions in Native Ecosystems of Hawaii: Management and Research. University of Hawaii Press, Honolulu, HI.

Westervelt, K., E. Largay, R. Coxe, W. McAvoy, S. Perles, G. Podniesinski, L. Sneddon \& K. Walz. 2006. A Guide to the Natural Communities of the Delaware Estuary: Version I. NatureServe, Arlington, VA. 336 pp.

Wetmore, C. M. 2001. Rare Lichens Habitats in Superior National Forest. USDA Forest Service, Duluth, MN. 20 pp.

Wetterer, J. K., S. E. Miller, D. E. Wheeler, C. A. Olson, D. A. Polhemus, M. Pitts, I. W. Ashton, A. G. Himler, M. M. Yospin, K. R. Helms, E. L. Harken, J. Gallaher, C. E. Dunning, M. Nelson, J. Litsinger, A. Southern \& T. L. Burgess. 1999. Ecological dominance by Paratrechina longicornis (Hymenoptera: Formicidae), an invasive tramp ant, in biosphere 2. Florida Entomol. 82: 381-388.

Wetzel, R. G. 1960. Marl encrustation on hydrophytes in several Michigan lakes. Oikos 11: 223-236.

Wetzel, R. G. \& D. L. McGregor. 1968. Axenic culture and nutritional studies of aquatic macrophytes. Am. Midl. Nat. 80: 52-64.

Wetzel, P. R. \& A. G. Van Der Valk. 1998. Effects of nutrient and soil moisture on competition between Carex stricta, Phalaris arundinacea, and Typha latifolia. Plant Ecol. 138: 179-190.

Wetzel, P. R. \& W. M. Kitchens. 2007. Vegetation change from chronic stress events: detection of the effects of tide gate removal and long-term drought on a tidal marsh. J. Veg. Sci. 18: 431-442.

Wetzel, P. R., A. G. van der Valk \& L. A. Toth. 2001. Restoration of wetland vegetation on the Kissimmee River floodplain: potential role of seed banks. Wetlands 21: 189-198.

Wetzel, P. R., W. M. Kitchens, J. M. Brush \& M. L. Dusek. 2004. Use of a reciprocal transplant study to measure the rate of plant community change in a tidal marsh along a salinity gradient. Wetlands 24: 879-890.

Wheeler, A. S. \& C. A. Wilson. 2014. Exploring phylogenetic relationships within a broadly distributed northern hemisphere group of semi-aquatic Iris species (Iridaceae). Syst. Bot. 39: 759-766.

Wheeler, G. A., P. H. Glaser, E. Gorham, C. M. Wetmore, F. D. Bowers \& J. A. Janssens. 1983. Contributions to the flora of the Red Lake Peatland, northern Minnesota, with special attention to Carex. Am. Midl. Nat. 110: 62-96.

Wheeler, E. J., S. Mashayekhi, D. W. McNeal, J. T. Columbus \& J. C. Pires. 2013. Molecular systematics of Allium subgenus Amerallium (Amaryllidaceae) in North America. Am. J. Bot. 100: 701-711.

Wheelwright, N. T., E. E. Dukeshire, J. B. Fontaine, S. H. Gutow, D. A. Moeller, J. G. Schuetz, T. M. Smith, S. L. Rodgers \& A. G. Zink. 2006. Pollinator limitation, autogamy and minimal inbreeding depression in insect-pollinated plants on a boreal island. Am. Midl. Nat. 155: 19-38. 
Wheelwright, N. T., E. Begin, C. Ellwanger, S. H. Taylor \& J. L. Stone. 2016. Minimal loss of genetic diversity and no inbreeding depression in blueflag iris (Iris versicolor) on islands in the Bay of Fundy. Botany 94: 543-554.

Wherry, E. T. 1918. The reactions of the soils supporting the growth of certain native orchids. J. Washington Acad. Sci. 8: 589-598.

Wherry, E. T. 1920. Soil tests of Ericaceae and other reactionsensitive families in northern Vermont and New Hampshire. Rhodora 22: 33-49.

Wherry, E. T. 1921. The soil reactions of Spiranthes cernua and its relatives. Rhodora 23: 127-129.

Wherry, E. T. 1927. Divergent soil reaction preferences of related plants. Ecology 8: 197-206.

Wherry, E. T. 1928. Northward range-extensions of some southern orchids in relation to soil reaction. J. Washington Acad. Sci. 18: $212-216$.

Whetstone, R. D., C. L. Lawler, L. H. Hopkins, A. L. Martin \& C. C. Dickson. 1987. Kral's water-plantain, Sagittaria secundifolia Kral (Alismataceae), new to Georgia. Castanea 52: 313-314.

Whigham, D. F. \& R. L. Simpson. 1978. The relationship between aboveground and belowground biomass of freshwater tidal wetland macrophytes. Aquat. Bot. 5: 355-364.

Whigham, D. F. \& R. L. Simpson. 1982. Germination and dormancy studies of Pontederia cordata L. Bull. Torrey Bot. Club 109: 524-528.

Whigham, D. F. \& C. J. Richardson. 1988. Soil and plant chemistry of an Atlantic white cedar wetland on the inner coastal plain of Maryland. Can. J. Bot. 66: 568-576.

Whigham, D. F., R. L. Simpson \& M. A. Leck. 1979. The distribution of seeds, seedlings, and established plants of arrow arum (Peltandra virginica (L.) Kunth) in a freshwater tidal wetland. Bull. Torrey Bot. Club 106: 193-199.

Whigham, D. F., T. E. Jordan \& J. Miklas. 1989. Biomass and resource allocation of Typha angustifolia L. (Typhaceae): the effect of within and between year variations in salinity. Bull. Torrey Bot. Club 116: 364-370.

White, D. J. 2010. Plants of Lanark County Ontario. Published by the author, Lanark, ON. 100 pp.

White, D. H. \& D. James. 1978. Differential use of fresh water environments by wintering waterfowl of coastal Texas. Wilson Bull. 90: 99-111.

White, D. A. \& M. J. Simmons. 1988. Productivity of the marshes at the mouth of the Pearl River, Louisiana. Castanea 53: 215-224.

White, W. A. \& J. G. Paine. 1992. Wetland plant communities, Galveston Bay system. GBNEP-16. Galveston Bay National Estuary Program, Galveston, TX. 124 pp.

White, D. W. \& E. W. Stiles. 1992. Bird dispersal of fruits of species introduced into eastern North America. Can. J. Bot. 70: 1689-1696.

White, S. L. \& R. R. Wise. 1998. Anatomy and ultrastructure of Wolffia columbiana and Wolffia borealis, two nonvascular aquatic angiosperms. Int. J. Plant Sci. 159: 297-304.

White, S. A. \& M. M. Cousins. 2013. Floating treatment wetland aided remediation of nitrogen and phosphorus from simulated stormwater runoff. Ecol. Eng. 61: 207-215.

White, C. R. \& G. L. Harley. 2016. Historical fire in longleaf pine (Pinus palustris) forests of south Mississippi and its relation to land use and climate. Ecosphere 7: e01458.

White, S. A., M. D. Taylor, S. L. Chandler, T. Whitwell \& S. J. Klaine. 2010. Remediation of nitrogen and phosphorus from nursery runoff during the spring via free water surface constructed wetlands. J. Environ. Hort. 28: 209-217.

White, S. A., M. D. Taylor \& D. Z. Damrel. 2012. Floral colonization of a free-water surface constructed wetland system in Grady County, Georgia. Castanea 77: 159-171.
White, P. J., H. C. Bowen, E. Farley, E. K. Shaw, J. A. Thompson, G. Wright \& M. R. Broadley. 2015. Phylogenetic effects on shoot magnesium concentration. Crop Pasture Sci. 66: 1241-1248.

Whitehead, M. R. \& C. A. Brown. 1940. The seed of the spider lily, Hymenocallis occidentalis. Am. J. Bot. 27: 199-203.

Whitfeld, T. J. S., E. R. Rowe, M. D. Lee \& W. R. Smith. 2015. New occurrences of the elusive Malaxis paludosa (Orchidaceae) in Minnesota. Rhodora 117: 98-105.

Whittaker, R. H. 1960. Vegetation of the Siskiyou mountains, Oregon and California. Ecol. Monogr. 30: 279-338.

Whittall, J. B., C. B. Hellquist, E. L. Schneider \& S. A. Hodges. 2004. Cryptic species in an endangered pondweed community (Potamogeton, Potamogetonaceae) revealed by AFLP markers. Am. J. Bot. 91: 2022-2029.

Whittemore, A. T. 2000. Zingiberaceae Lindley. Ginger family. Pp. 305-309 In: Flora North America Editorial Committee (eds.), Flora of North America North of Mexico, Vol. 22: Magnoliophyta: Alismatidae Arecidae, Commelinidae (in Part), and Zingiberidae. Oxford University Press, New York, NY.

Whyte, R. J. \& B. W. Cain. 1981. Wildlife habitat on grazed or ungrazed small pond shorelines in South Texas. J. Range Manag. 34: 64-68.

Wichman, B., R. K. Peet \& T. R. Wentworth. 2007. Natural Vegetation of the Carolinas: Classification and Description of Montane Non-Alluvial Wetlands of the Southern Appalachian Region. Carolina Vegetation Survey, University of North Carolina, Chapel Hill, NC. 15 pp.

Wicksten, M. K. 1979. Decorating behavior in Loxorhynchus crispatus Stimpson and Loxorhynchus grandis Stimpson (Brachyura, Majidae). Crustaceana (Suppl.) 5: 37-46.

Wieffering, J. H. 1972. Some notes on the diploid chromosome number of the genus Acorus L. (Araceae). Acta Bot. Neerl. 21: $555-559$.

Wiegleb, G. \& H. Brux. 1991. Comparison of life history characters of broad-leaved species of the genus Potamogeton L. I. General characterization of morphology and reproductive strategies. Aquat. Bot. 39: 131-146.

Wiegleb, G. \& Z. Kaplan. 1998. An account of the species of Potamogeton L. (Potamogetonaceae). Folia Geobot. 33: 241-316.

Wiersema, J. H. 2015. Application of the name Lemna punctata G. Mey., the type of Landoltia Les \& DJ Crawford. Plant Biol. 17: 5-9.

Wigand, C. 1997. Facilitation of phosphate assimilation by aquatic mycorrhizae of Vallisneria americana Michx. Hydrobiologia 342: 35-41.

Wiland-Szymańska, J., K. Buczkowska, M. Drapikowska, M. Maślak, A. Bączkiewicz \& A. Czylok. 2016. Genetic structure and barcode identification of an endangered orchid species, Liparis loeselii, in Poland. Syst. Biodivers. 14: 345-354.

Wilcox, D. A. 2012. Response of wetland vegetation to the post-1986 decrease in Lake St. Clair water levels: seed-bank emergence and beginnings of the Phragmites australis invasion. J. Great Lakes Res. 38: 270-277.

Wilcox, D. A. \& J. E. Meeker. 1991. Disturbance effects on aquatic vegetation in regulated and unregulated lakes in northern Minnesota. Can. J. Bot. 69: 1542-1551.

Wilcox, D. A. \& J. E. Meeker. 1992. Implications for faunal habitat related to altered macrophyte structure in regulated lakes innorthern Minnesota. Wetlands 12: 192-203.

Wilder, G. J. 1974. Symmetry and development of Limnobium spongia (Hydrocharitaceae). Am. J. Bot. 61: 624-642.

Wiley, R. H. \& M. S. Wiley. 1980. Territorial behavior of a blackbird: mechanisms of site-dependent dominance. Behaviour 73: 130-154. 
Wiley, M. J., S. M. Pescitelli \& L. D. Wike. 1986. The relationship between feeding preferences and consumption rates in grass carp and grass carp $\times$ bighead carp hybrids. J. Fish Biol. 29: 507-514.

Wilhelm, G. S. \& R. H. Mohlenbrock. 1986. Rediscovery of Potamogeton floridanus Small (Potamogetonaceae). Sida 11: 340-346.

Wilkinson, R. E. 1961. Effects of reduced sunlight on water stargrass (Heteranthera dubia). Weeds 9: 457-462.

Wilkinson, F. \& P. J. Beckett. 2002. Aquatic plant establishment on nickel tailings five years after flooding. Proc. Am. Soc. Min. Reclam. 2002: 178-193.

Willcocks, P. A. 1982. Colonization and distribution of the red algal epiphytes Melobesia mediocris and Smithora naiadum on the seagrass Phyllospadix torreyi. Aquat. Bot. 12: 365-373.

Willette, D. A. \& R. F. Ambrose. 2012. Effects of the invasive seagrass Halophila stipulacea on the native seagrass, Syringodium filiforme, and associated fish and epibiota communities in the Eastern Caribbean. Aquat. Bot. 103: 74-82.

Williams, K. A. 1919. A botanical study of skunk cabbage, Symplocarpus foetidus. Torreya 19: 21-29.

Williams, L. 1981. Foods for early man. Revista Ceiba 24: 4-39.

Williams, S. L. 1987. Competition between the seagrasses Thalassia testudinum and Syringodium filiforme in a Caribbean lagoon. Mar. Ecol. Prog. Ser. 35: 91-98.

Williams, S. L. 1995. Surfgrass (Phyllospadix torreyi) reproduction: reproductive phenology, resource allocation, and male rarity. Ecology 76: 1953-1970.

Williams, S. L. 2007. Introduced species in seagrass ecosystems: status and concerns. J. Exp. Mar. Biol. Ecol. 350: 89-110.

Williams, M. C. \& E. H. Cronin. 1968. Dormancy, longevity, and germination of seed of three larkspurs and western false hellebore. Weed Sci. 16: 381-384.

Williams, M. C. \& E. H. Cronin. 1981. Ten-year control of western false hellebore (Veratrum californicum). Weed Sci. 29: 22-23.

Williams, C. E. \& W. J. Moriarity. 2000. Composition and structure of hemlock-dominated riparian forests of the northern Allegheny Plateau: a baseline assessment. Pp. 216-224 In: K. A. McManus, K. S. Shields \& D. R. Souto (eds.), GTR-NE-267. Proceedings: Symposium on Sustainable Management of Hemlock Ecosystems in Eastern North America. U.S. Department of Agriculture, Forest Service, Northeastern Research Station, Newtown Square, PA.

Williams, S. L. \& E. D. Grosholz. 2002. Preliminary reports from the Caulerpa taxifolia invasion in southern California. Mar. Ecol. Prog. Ser. 233: 307-310.

Williams, D. A., N. E. Harms, L. Dodd, M. J. Grodowitz \& G. O. Dick. 2017. Do the US dioecious and monoecious biotypes of Hydrilla verticillata hybridize? J. Aquat. Plant Manag. 55: 35-38.

Willner, G. R., J. A. Chapman \& D. Pursley. 1979. Reproduction, physiological responses, food habits, and abundance of nutria on Maryland marshes. Wildl. Monogr. 65: 3-43.

Willson, M. F. 1993. Mammals as seed-dispersal mutualists in North America. Oikos 67: 159-176.

Willson, M. F. \& P. E. Hennon. 1997. The natural history of western skunk cabbage (Lysichiton americanum) in southeast Alaska. Can. J. Bot. 75: 1022-1025.

Wilsey, B. J., R. H. Chabreck \& R. G. Linscombe. 1991. Variation in nutria diets in selected freshwater forested wetlands of Louisiana. Wetlands 11: 263-278.

Wilson, L. R. 1935. Lake development and plant succession in Vilas County, Wisconsin. Ecol. Monogr. 5: 207-247.

Wilson, L. R. 1937. A quantitative and ecological study of the larger aquatic plants of Sweeney Lake, Oneida County, Wisconsin. Bull. Torrey Bot. Club 64: 199-208.
Wilson, B. 1998. Epiphytal foraminiferal assemblages on the leaves of the seagrasses Thalasia testudinum and Syringodium filiforme. Caribbean J. Sci. 34: 131-131.

Wilson, C. A. 2009. Phylogenetic relationships among the recognized series in Iris section Limniris. Syst. Bot. 34: 277-284.

Wilson, C. A. 2011. Subgeneric classification in Iris re-examined using chloroplast sequence data. Taxon 60: 27-35.

Wilson, D. C. 2014. Pollination biology of the stream orchid, Epipactis gigantea. Aquilegia 38: 9-11.

Wilson, S. D. \& P. A. Keddy. 1985a. The distribution of Xyris difformis along a gradient of exposure to waves: an experimental study. Can. J. Bot. 63: 1226-1230.

Wilson, S. D. \& P. A. Keddy. 1985b. Plant zonation on a shoreline gradient: physiological response curves of component species. J. Ecol. 73: 851-860.

Wilson, S. D. \& P. A. Keddy. 1988. Species richness, survivorship, and biomass accumulation along an environmental gradient. Oikos 53: 375-380.

Wilson, C. J. \& K. H. Dunton. 2012. Assessment of Seagrass Habitat Quality and Plant Physiological Condition in Texas Coastal Waters. Marine Science Institute, University of Texas at Austin, Port Aransas, TX. 46 pp.

Wilson, S. S. \& K. H. Dunton. 2017. Hypersalinity during regional drought drives mass mortality of the seagrass Syringodium filiforme in a subtropical lagoon. Estuaries Coast. doi: 10.1007/ s12237-017-0319-x.

Wilson, S. D., P. A. Keddy \& D. L. Randall. 1985. The distribution of Xyris difformis along a gradient of exposure to waves: an experimental study. Can. J. Bot. 63: 1226-1230.

Wilson, J. B., W. M. King, M. T. Sykes \& T. R. Partridge. 1996. Vegetation zonation as related to the salt tolerance of species of brackish riverbanks. Can. J. Bot. 74: 1079-1085.

Wilson, D. M., W. Fenical, M. Hay, N. Lindquist \& R. Bolser. 1999. Habenariol, a freshwater feeding deterrent from the aquatic orchid Habenaria repens (Orchidaceae). Phytochemistry 50: 1333-1336.

Wilson, B. L., D. L. Doede \& V. D. Hipkins. 2000. Isozyme variation in Sisyrinchium sarmentosum (Iridaceae). Northwest Sci. 74: 346-354.

Wilson, A. S. G., B. J. van der Kamp \& C. Ritland. 2005. Opportunities for geitonogamy in the clonal herb Maianthemum dilatatum. Can. J. Bot. 83: 1082-1087.

Winge, Ö. 1927. Chromosome behaviour in male and female individuals of Vallisneria spiralis and Najas marina. J. Genet. 18: 99-107.

Winkel, A. \& J. Borum. 2009. Use of sediment $\mathrm{CO}_{2}$ by submersed rooted plants. Ann. Bot. 103: 1015-1023.

Winner, A. L. \& M. G. Simpson. 2007. A new subspecies of Pentagramma triangularis (Pteridaceae). Madroño 54: 345-354.

Winter, K. 1978. Short-term fixation of ${ }^{14}$ carbon by the submerged aquatic angiosperm Potamogeton pectinatus. J. Exp. Bot. 29: 1169-1172.

Wirth, F. F., K. J. Davis \& S. B. Wilson. 2004. Florida nursery sales and economic impacts of 14 potentially invasive landscape plant species. J. Environ. Hort. 22: 12-16.

Wisheu, I. C. 1994. Disjunct Atlantic coastal plain species in Nova Scotia: distribution, habitat and conservation priorities. Biol. Conserv. 68: 217-224.

Wisheu, I. C. \& P. A. Keddy. 1989. The conservation and management of a threatened coastal plain plant community in eastern North America (Nova Scotia, Canada). Biol. Conserv. 48: 229-238.

Witmer, S. W. 1964. Butomus umbellatus L. in Indiana. Castanea 29: $117-119$. 
Witty, M. 2009. Wolffia columbiana can switch between two anatomically and physiologically separate states: buoyant for invasion and starch rich for colonization. Int. J. Bot. 5: 307-313.

Witty, M. 2011. Suppression of the invasive plant watermeal (Wolffia columbiana) by interfering with floatation. Int. J. Plant Pathol. 2: $96-100$.

Witz, M. J. A. \& C. J. Dawes. 1995. Flowering and short shoot age in three Thalassia testudinum meadows off west-central Florida. Bot. Marina 38: 431-436.

Witztum, A. 1977. An ecological niche for Lemna gibba L. that depends on seed formation. Israel J. Bot. 26: 36-38.

Witztum, A. 1986. Seed viability in Lemna gibba L. Israel J. Bot. 35: 279-279.

Witztum, A. \& M. Chaouat. 1991. Contributions to the flora of Israel and Sinai. VI. Najas guadalupensis (Sprengel) Magnus in Israel. Israel J. Bot. 40: 65-66.

Witztum, A. \& R. Wayne. 2014. Fibre cables in the lacunae of Typha leaves contribute to a tensegrity structure. Ann. Bot. 113: 789-797.

Wofford, B. E. 2006. A new species of Stenanthium (Melanthiaceae) from Tennessee, USA. Sida 22: 447-459.

Wohl, D. L. \& J. V. McArthur. 1998. Actinomycete-flora associated with submersed freshwater macrophytes. FEMS Microbiol. Ecol. 26: 135-140.

Wohler, J. R., I. M. Wohler \& R. T. Hartman. 1965. The occurrence of Spirodela oligorrhiza in western Pennsylvania. Castanea 30: 230-231.

Wohler, J. R., D. B. Robertson \& H. R. Laube. 1975. Studies on the decomposition of Potamogeton diversifolius. Bull. Torrey Bot. Club 102: 76-78.

Wolf, E. C. \& D. J. Cooper. 2015. Fens of the Sierra Nevada, California, USA: patterns of distribution and vegetation. Mires Peat 15: 1-22.

Wolfe, L. M. \& S. C. H. Barrett. 1987. Pollinator foraging behavior and pollen collection on the floral morphs of tristylous Pontederia cordata L. Oecologia 74: 347-351.

Wolfe, L. M. \& S. C. H. Barrett. 1988. Temporal changes in the pollinator fauna of tristylous Pontederia cordata, an aquatic plant. Can. J. Zool. 66: 1421-1424.

Wolfe, L. M. \& S. C. H. Barrett. 1989. Patterns of pollen removal and deposition in tristylous Pontederia cordata L. (Pontederiaceae). Biol. J. Linn. Soc. 36: 317-329.

Wolfer, S. R. \& D. Straile. 2004. Spatio-temporal dynamics and plasticity of clonal architecture in Potamogeton perfoliatus. Aquat. Bot. 78: 307-318.

Wolfer, S. R. \& D. Straile. 2012. To share or not to share: clonal integration in a submerged macrophyte in response to light stress. Hydrobiologia 684: 261-269.

Wolters, M., A. Garbutt \& J. P. Bakker. 2005. Plant colonization after managed realignment: the relative importance of diaspore dispersal. J. Appl. Ecol. 42: 770-777.

Won, B. Y., K. K. Yates, S. Fredericq \& T. O. Cho. 2010. Characterization of macroalgal epiphytes on Thalassia testudinum and Syringodium filiforme seagrass in Tampa Bay, Florida. Algae 25: 141-153.

Wong, S. Y., P. C. Boyce, A. S. bin Othman \& L. C. Pin. 2010. Molecular phylogeny of tribe Schismatoglottideae (Araceae) based on two plastid markers and recognition of a new tribe, Philonotieae, from the Neotropics. Taxon 59: 117-124.

Wood, R. D. 1950. Stability and zonation of Characeae. Ecology 31: 642-647.

Wood, Jr., C. E. 1983. The genera of Burmanniaceae in the southeastern United States. J. Arnold Arbor. 64: 293-307.
Wood, T. 1992. Management of a rare lily, Lilium parryi, at Ramsey Canyon Preserve. Pp. 50-52 In: A. M. Barton \& S. A. Sloane (eds.), Chiricahua Mountains Research Symposium. Proceedings. Southwest Parks and Monuments Association, Tucson, AZ.

Wood, J. D. \& M. D. Netherland. 2017. How long do shoot fragments of hydrilla (Hydrilla verticillata) and Eurasian watermilfoil (Myriophyllum spicatum) remain buoyant? J. Aquat. Plant Manag. 55: 76-82.

Wood, J. R., V. H. Resh \& E. M. McEwan. 1982. Egg masses of nearctic sericostomatid caddisfly genera (Trichoptera). Ann. Entomol. Soc. Am. 75: 430-434.

Wood, T. H., W. M. Whitten \& N. H. Williams. 2000. Phylogeny of Hedychium and related genera (Zingiberaceae) based on ITS sequence data. Edinburgh J. Bot. 57: 261-270.

Woodcock, E. F. 1925. Observations on the poisonous plants of Michigan. Am. J. Bot. 12: 116-131.

Woodruffe-Peacock, E. A. 1917. The means of plant dispersal. Selborne Mag. Nat. Notes 28/29: 80-83; 97-101; 114-116.

Woods, M., A. R. Diamond, Jr. \& C. N. Horn. 2006. Noteworthy collections. Alabama. Castanea 71: 251-252.

Woolf, T. E. \& J. D. Madsen. 2003. Seasonal biomass and carbohydrate allocation patterns in southern Minnesota curlyleaf pondweed populations. J. Aquat. Plant Manag. 41: 113-118.

Wooten, J. W. 1970. Experimental investigations of the Sagittaria graminea complex: transplant studies and genecology. J. Ecol. 58: $233-242$.

Wooten, J. W. 1971. The monoecious and dioecious conditions in Sagittaria latifolia L. (Alismataceae). Evolution 25: 549-553.

Wooten, J. W. 1973a. Taxonomy of seven species of Sagittaria from eastern North America. Brittonia 25: 64-74.

Wooten, J. W. 1973b. Edaphic factors in species and ecotype differentiation in Sagittaria. J. Ecol. 61: 151-156.

Wooten, J. W. 1978. Effects of photoperiod, light intensity, and stage of development on flower initiation in Sagittaria graminea Michx. (Alismataceae). Aquat. Bot. 4: 245-255.

Wooten, J. W. 1986. Edaphic factors associated with eleven species of Sagittaria (Alismataceae). Aquat. Bot. 24: 35-41.

Wooten, J. W. \& S. A. Brown. 1983. Observations of inflorescence patterns and flower sex in a population of Sagittaria papillosa Buch. (Alismataceae). Aquat. Bot. 15: 409-418.

Wooten, J. W. \& R. L. Leonard. 1984. Community organization based on medians of various parameters amog marsh and aquatic plants in North Carolina. J. Elisha Mitchell Sci. Soc. 100: 12-22.

Worden, E. C., T. K. Broschat \& C. Yurgalevitch. 2002. Care and maintenance of landscape palms in South Florida. Document ENH 866. University of Florida Extension, Institute of Food and Agricultural Sciences, Gainseville, FL. 8 pp.

Worley, A. C., L. Sawich, H. Ghazvini \& B. A. Ford. 2009. Hybridization and introgression between a rare and a common lady's slipper orchid, Cypripedium candidum and C. parviflorum (Orchidaceae). Botany 87: 1054-1065.

Wright, A. H. \& A. A. Wright. 1932. The habitats and composition of the vegetation of Okefinokee Swamp, Georgia. Ecol. Monogr. 2: 109-232.

Wu, H., X. Zhang, S. Zheng, I. J. Shi \& Y. Bi. 2008. Polyploid induction of coloured Zantedeschia aethiopica. Acta Hort. Sin. 35: 443-446.

Wu, S.-H., T. Y. A. Yang, Y.-C. Teng, C.-Y. Chang, K.-C. Yang \& C.-F. Hsieh. 2010. Insights of the latest naturalized flora of Taiwan: change in the past eight years. Taiwania 55: 139-159.

Wu, X., H. Wu, J. Ye \& B. Zhong. 2015. Study on the release routes of allelochemicals from Pistia stratiotes Linn., and its anti-cyanobacteria mechanisms on Microcystis aeruginosa. Environ. Sci. Pollut. Res. 22: 18994-19001. 
Wu, K., C.-N. N. Chen \& K. Soong. 2016. Long distance dispersal potential of two seagrasses Thalassia hemprichii and Halophila ovalis. PLoS One 11: e0156585.

Wunderlin, T. F. \& R. P. Wunderlin. 1968. A preliminary survey of the algal flora of Horseshoe Lake, Alexander County, Illinois. Am. Midl. Nat. 79: 534-539.

Wunderlin, R. P., B. F. Hansen \& L. C. Anderson. 2002. Plants new to the United States and Florida. Sida 20: 813-817.

Wylie, R. B. 1917. The pollination of Vallisneria spiralis. Bot. Gaz. 63: $135-145$.

Wylie, R. B. 1919. Cleistogamy in Heteranthera dubia. Bull. Lab. Nat. Hist. State Univ. Iowa 7: 48-58.

Wynn, T. D. 2012. Habitat-specific production of a fall line river shoal macroinvertebrate assemblage. Ph.D. dissertation. University of Alabama, Tuscaloosa, AL. 123 pp.

Xiao, C. \& S. S. Desser. 1998. The oligochaetes and their actinosporean parasites in Lake Sasajewun, Algonquin Park, Ontario. J. Parasitol. 84: 1020-1026.

Xiao, C., W.-F. Dou \& G.-H. Liu. 2010. Variation in vegetation and seed banks of freshwater lakes with contrasting intensity of aquaculture along the Yangtze River, China. Aquat. Bot. 92: 195-199.

Xie, W.-Y., Q. Huang, G. Li, C. Rensing \& Y.-G. Zhu. 2013. Cadmium accumulation in the rootless macrophyte Wolffia globosa and its potential for phytoremediation. Int. J. Phytoremed. 15: 385-397.

Xie, D., D. Yu, C. Xia \& W. You. 2014. Stay dormant or escape sprouting? Turion buoyancy and sprouting abilities of the submerged macrophyte Potamogeton crispus L. Hydrobiologia 726: $43-51$.

Xu, N.-N., X. Tong, P.-K. E. Tsang, H. Deng \& X.-Y. Chen. 2011. Effects of water depth on clonal characteristics and biomass allocation of Halophila ovalis (Hydrocharitaceae). J. Plant Ecol. 4: 283-291.

Xu, J., H. Zhao, A.-M. Stomp \& J. J. Cheng. 2012. The production of duckweed as a source of biofuels. Biofuels 3: 589-601.

Xu, Y., S. Ma, M. Huang, M. Peng, M. Bog, K. S. Sree, K.-J. Appenroth \& J. Zhang. 2015. Species distribution, genetic diversity and barcoding in the duckweed family (Lemnaceae). Hydrobiologia 743: 75-87.

Xu, H., C. Yu, X. Xia, M. Li, H. Li, Y. Wang, S. Wang, C. Wang, Y. Ma \& G. Zhou. 2018a. Comparative transcriptome analysis of duckweed (Landoltia punctata) in response to cadmium provides insights into molecular mechanisms underlying hyperaccumulation. Chemosphere 190: 154-165.

Xu, N., F. Hu, J. Wu, W. Zhang, M. Wang, M. Zhu \& J. Ke. 2018 b. Characterization of 19 polymorphic SSR markers in Spirodela polyrhiza (Lemnaceae) and cross-amplification in Lemna perpusilla. Appl. Plant Sci. 6(5): e01153.

Xue, H., Y. Xiao, Y. Jin, X. Li, Y. Fang, H. Zhao, Y. Zhao \& J. Guan. 2012. Genetic diversity and geographic differentiation analysis of duckweed using inter-simple sequence repeat markers. Mol. Biol. Rep. 39: 547-554.

Yacoub, H. 2009. Najas spp. growth in relation to environmental factors in Wadi Allaqi (Nasser Lake, Egypt). Transylv. Rev. Syst. Ecol. Res. 8: 1-40.

Yakandawala, K. \& D. M. G. S. Dissanayake. 2010. Mayaca fluviatilis Aubl.: an ornamental aquatic with invasive potential in Sri Lanka. Hydrobiologia 656: 199-204.

Yan, N. D., G. E. Miller, I. Wile \& G. G. Hitchin. 1985. Richness of aquatic macrophyte floras of soft water lakes of differing $\mathrm{pH}$ and trace metal content in Ontario, Canada. Aquat. Bot. 23: 27-40.

Yan, Y., J. Candreva, H. Shi, E. Ernst, R. Martienssen, J. Schwender \& J. Shanklin. 2013. Survey of the total fatty acid and triacylglycerol composition and content of 30 duckweed species and cloning of a $\Delta 6$-desaturase responsible for the production of $\gamma$-linolenic and stearidonic acids in Lemna gibba. BMC Plant Biol. 13: 201.

Yang, L., Y. Han, D. Wu, W. Yong, M. Liu, S. Wang, W. Liu, M. Lu, Y. Wei \& J. Sun. 2017. Salt and cadmium stress tolerance caused by overexpression of the Glycine $\operatorname{max~} \mathrm{Na}^{+} / \mathrm{H}^{+}$ Antiporter (GmNHXl) gene in duckweed (Lemna turionifera 5511). Aquat. Toxicol. 192: 127-135.

Yannitsaros, A. 1998. Additions to the flora of Kithira (Greece) I. Willdenowia 28: 77-94.

Yanovsky, E. 1936. Food Plants of the North American Indians. U.S. Department of Agriculture, Washington, DC. 84 pp.

Yanuwiadi, B. \& B. Polii. 2013. Phytoremediation of arsenic from geothermal power plant waste water using Monochoria vaginalis, Salvinia molesta and Colocasia esculenta. Int. J. Biosci. 3: 104-111.

Yao, J. 1., R. E. Rowland \& D. Cohen. 1994. Karyotype studies in the genus Zantedeschia (Araceae). S. Afr. J. Bot. 60: 4-7.

Yarrow, M., V. H. Marin, M. Finlayson, A. Tironi, L. E. Delgado \& F. Fischer. 2009. The ecology of Egeria densa Planchon (Liliopsida: Alismatales): a wetland ecosystem engineer? Revista Chilena de Historia Natural 82: 299-313.

Yasukawa, K. 1981. Male quality and female choice of mate in the red-winged blackbird (Agelaius phoeniceus). Ecology 62: 922-929.

Yates, K. K., C. Dufore, N. Smiley, C. Jackson \& R. B. Halley. 2007. Diurnal variation of oxygen and carbonate system parameters in Tampa Bay and Florida Bay. Mar. Chem. 104: 110-124.

Yatskievych, G. \& C. E. Jenkins. 1981. Fall vegetation and zonation of Hooker Cienega, Graham County, Arizona. J. ArizonaNevada Acad. Sci. 16: 7-11.

Yatskievych, G. \& J. A. Raveill. 2001. Notes on the increasing proportion of non-native angiosperms in the Missouri flora, with reports of three new genera for the state. Sida 23: 701-709.

Yazbek, P. B., J. Tezoto, F. Cassas \& E. Rodrigues. 2016. Plants used during maternity, menstrual cycle and other women's health conditions among Brazilian cultures. J. Ethnopharmacol. 179: 310-331.

Yeo, R. R. 1964. Life history of common cattail. Weeds 12: 284-288.

Yeo, R. R. 1966. Yields of propagules of certain aquatic plants I. Weeds 14: 110-113.

Yeo, R. R. 1967. Silver dollar fish for biological control of submersed aquatic weeds. Weeds 15: 27-31.

Yilmaz, D. D. 2007. Effects of salinity on growth and nickel accumulation capacity of Lemna gibba (Lemnaceae). J. Hazard. Mater. 147: 74-77.

Y1lmaz, E., İ. Akyurt \& G. Günal. 2004. Use of duckweed, Lemna minor, as a protein feedstuff in practical diets for common carp, Cyprinus carpio, fry. Turk. J. Fish. Aquat. Sci. 4: 105-109.

Yin, L., C. Wang, Y. Chen, C. Yu, Y. Cheng \& W. Li. 2009. Cold stratification, light and high seed density enhance the germination of Ottelia alismoides. Aquat. Bot. 90: 85-88.

Yin, L., R. Zhang, Z. Xie, C. Wang \& W. Li. 2013. The effect of temperature, substrate, light, oxygen availability and burial depth on Ottelia alismoides seed germination. Aquat. Bot. 111: 50-53.

Yin, L., W. Li, T. V. Madsen, S. C. Maberly \& G. Bowes. 2017. Photosynthetic inorganic carbon acquisition in 30 freshwater macrophytes. Aquat. Bot. 140: 48-54.

Yocom, C. F. \& H. A. Hansen. 1960. Population studies of waterfowl in eastern Washington. J. Wildl. Manag. 24: 237-250.

Yoder, J. A., S. M. Imfeld, D. J. Heydinger, C. E. Hart, M. H. Collier, K. M. Gribbins \& L. W. Zettler. 2010. Comparative water balance profiles of Orchidaceae seeds for epiphytic and terrestrial taxa endemic to North America. Plant Ecol. 211: 7-17. 
York, H. H. 1905. The hibernacula of Ohio water plants. Ohio Nat. 5: 291-293.

York, R. A., M. J. Durako, W. J. Kenworthy \& D. W. Freshwater. 2008. Megagametogenesis in Halophila johnsonii, a threatened seagrass with no known seeds, and the seed-producing Halophila decipiens (Hydrocharitaceae). Aquat. Bot. 88: 277-282.

You, J., X. Z. Sun \& H. Q. Wang. 1985. Taxonomy of Najas: a synthetical analysis with evidences on cytology, isozymes and SEM examination. J. Wuhan Univ. Nat. Sci. 4: 111-118. [in Chinese].

Youngken, H. W. 1919. Notes on the Dasheen and Chayote. Am. J. Bot. 6: 380-386.

Yousefi, Z. \& A. Mohseni-Bandpei. 2010. Nitrogen and phosphorus removal from wastewater by subsurface wetlands planted with Iris pseudacorus. Ecol. Eng. 36: 777-782.

Yu, L.-F. \& D. Yu. 2009. Responses of the threatened aquatic plant Ottelia alismoides to water level fluctuations. Fundam. Appl. Limnol. 174: 295-300.

Yu, S., M.-Y. Cui, B. Liu, X.-Y. Wang \& X.-Y. Chen. 2009. Development and characterization of microsatellite loci in Ruppia maritima L. (Ruppiaceae). Conserv. Genet. Resour. 1: 241-243.

Yu, G., H. Liu, K. Venkateshan, S. Yan, J. Cheng, X. S. Sun \& D. Wang. 2011. Functional, physiochemical, and rheological properties of duckweed (Spirodela polyrhiza) protein. Trans. Am. Soc. Agric. Biol. Eng. 54: 555-561.

Yu, H.-B., Z.-J. Yang, R.-L. Xiao, S.-N. Zhang, F. Liu \& Z.-X. Xiang. 2013. Absorption capacity of nitrogen and phosphorus of aquatic plants and harvest management research. Acta Pratacult. Sinica 22: 294-299.

Yuan, J. \& K. Xu. 2017. Effects of simulated microgravity on the performance of the duckweeds Lemna aequinoctialis and Wolffia globosa. Aquat. Bot. 137: 65-71.

Yuan, J.-X., J. Pan, B.-S. Wang \& D.-M. Zhang. 2011. Genetic differentiation of Wolffia globosa in China. J. Syst. Evol. 49: 509-517.

Zaebst, T. W., W. M. Aust, S. H. Schoenholtz \& C. Fristoe. 1995. Recovery status of a tupelo-cypress wetland seven years after disturbance: silvicultural implications. Pp. 229-235 In: M. B. Edwards (ed.), Proceedings of the Eighth Biennial Southern Silvicultural Research Conference. General Technical Report SRS-1. USDA Forest Service, Southern Research Station, Asheville, NC.

Zákravsky, P. \& Z. Hroudová. 1998. Reproductive ecology of Alisma gramineum Gmel. Pp. 155-158 In: A. Monteiro, T. Vasconcelos \& L. Catarino (eds.), Management and Ecology of Aquatic Plants. Proceedings of the 10th EWRS International Symposium on Aquatic Weeds, Lisbon, Portugal, 21-25 September 1998. European Weed Research Society, Poznañ, Poland.

Zalewska-Gałosz, J. \& M. Ronikier. 2012. Molecular evidence for two rare Potamogeton natans hybrids with reassessment of Potamogeton hybrid diversity in Poland. Aquat. Bot. 103: $15-22$.

Zaman, T. \& T. Asaeda. 2013. Effects of $\mathrm{NH}_{4}-\mathrm{N}$ concentrations and gradient redox level on growth and allied biochemical parameters of Elodea nuttallii (Planch.). Flora, Morphol. Distrib. Funct. Ecol. Plant 208: 211-219.

Zampella, R. A., J. F. Bunnell, K. J. Laidig \& C. L. Dow. 2001. The Mullica River basin. A report to the Pinelands Commission on the status of the landscape and selected aquatic and wetland resources. Pinelands Commission, New Lisbon, NJ. 371 pp.

Zanetti,A. 2014. Taxonomic revision of North American Eusphalerum Kraatz, 1857 (Coleoptera, Staphylinidae, Omaliinae). Insecta Mundi 0379: 1-80.
Zapfe, L. \& J. R. Freeland. 2015. Heterosis in invasive $F_{1}$ cattail hybrids (Typha $\times$ glauca). Aquat. Bot. 125: 44-47.

Zaremba, R. E. \& E. E. Lamont. 1993. The status of the coastal plain pondshore community in New York. Bull. Torrey Bot. Club 120: $180-187$.

Zebryk, T. M. 2004. Inland sandy acid pondshores in the lower Connecticut River Valley, Hampden County, Massachusetts. Rhodora 106: 66-76.

Zedler, J. B., J. C. Callaway, J. S. Desmond, G. Vivian-Smith, G. D. Williams, G. Sullivan, A. E. Brewster \& B. K. Bradshaw. 1999. Californian salt-marsh vegetation: an improved model of spatial pattern. Ecosystems 2: 19-35.

Zedler, J. B., H. Morzaria-Luna \& K. Ward. 2003. The challenge of restoring vegetation on tidal, hypersaline substrates. Plant Soil 253: $259-273$.

Zefferman, E. 2014. Increasing canopy shading reduces growth but not establishment of Elodea nuttallii and Myriophyllum spicatum in stream channels. Hydrobiologia 734: 159-170.

Zelmer, C. D. \& R. S. Currah. 1995. Ceratorhiza pernacatena and Epulorhiza calendulina spp. nov.: mycorrhizal fungi of terrestrial orchids. Can. J. Bot. 73: 1981-1985.

Zelmer, C. D., L. Cuthbertson \& R. S. Currah. 1996. Fungi associated with terrestrial orchid mycorrhizas, seeds and protocorms. Mycoscience 37: 439-448.

Zemskova, E. A. \& L. I. Sveshnikova. 1999. Karyological study of some representatives of the family Amaryllidaceae. Bot. Zhurn. S.S.S.R. 84: 86-98.

Zepeda, C., A. Lot, X. A. Nemiga \& J. Manjarrez. 2014. Seed bank and established vegetation in the last remnants of the Mexican Central Plateau wetlands: the Lerma marshes. Revista Biol. Tropic. 62: 455-472.

Zettler, L. W. \& J. E. Fairey III. 1990. The status of Platanthera integrilabia, an endangered terrestrial orchid. Lindleyana 5: 212-217.

Zettler, L. W. \& T. M. McInnis, Jr. 1992. Propagation of the endangered terrestrial orchid Platanthera integrilabia (Correll) Luer through symbiotic seed germination. Lindleyana 7: 154-161.

Zettler, L. W. \& T. M. McInnis, Jr. 1994. Light enhancement of symbiotic seed germination and development of an endangered terrestrial orchid (Platanthera integrilabia). Plant Sci. 102: 133-138.

Zettler, L. W. \& C. J. Hofer. 1997. Sensitivity of Spiranthes odorata seeds to light during in vitro symbiotic seed germination. Lindleyana 12: 26-29.

Zettler, L. W. \& C. J. Hofer. 1998. Propagation of the little club-spur orchid (Platanthera clavellata) by symbiotic seed germination and its ecological implications. Environ. Exp. Bot. 39: 189-195.

Zettler, L. W. \& K. A. Piskin. 2011. Mycorrhizal fungi from protocorms, seedlings and mature plants of the eastern prairie fringed orchid, Platanthera leucophaea (Nutt.) Lindley: a comprehensive list to augment conservation. Am. Midl. Nat. 166: $29-40$.

Zettler, L. W., F. V. Barrington \& T. M. McInnis. 1995. Developmental morphology of Spiranthes odorata seedlings in symbiotic culture. Lindleyana 10: 211-216.

Zettler, L. W., N. S. Ahuja \& T. M. McInnis, Jr. 1996. Insect pollination of the endangered monkey-face orchid (Platanthera integrilabia) in McMinn County, Tennessee: one last glimpse of a once common spectacle. Castanea 61: 14-24.

Zettler, L. W., J. A. Sunley \& T. W. Delaney. 2000. Symbiotic seed germination of an orchid in decline (Platanthera integra) from the Green Swamp, North Carolina. Castanea 65: 207-212.

Zettler, L. W., S. L. Stewart, M. L. Bowles \& K. A. Jacobs. 2001. Mycorrhizal fungi and cold-assisted symbiotic germination of the federally threatened eastern prairie fringed orchid, Platanthera leucophaea (Nuttall) Lindley. Am. Midl. Nat. 145: 168-176. 
Zettler, L. W., K. A. Piskin, S. L. Stewart, J. J. Hartsock, M. L. Bowles \& T. J. Bell. 2005. Protocorm mycobionts of the federally threatened eastern prairie fringed orchid, Platanthera leucophaea (Nutt.) Lindley, and a technique to prompt leaf elongation in seedlings. Stud. Mycol. 53: 163-171.

Zhang, W. \& J. Gao. 2018. High fruit sets in a rewardless orchid: a case study of obligate agamospermy in Habenaria. Aust. J. Bot. 66: 144-151.

Zhang, Y. W., S. J. Huang, X. N. Zhao, F. Liu \& J. M. Zhao. 2010a. New record of an invasive species, Sagittaria graminea, in Yalu River Estuary wetland. J. Wuhan Bot. Res. 28: 631-633.

Zhang, Y., Y. Hu, B. Yang, F. Ma, P. Lu, L. Li, C. Wan, S. Rayner \& S. Chen. 2010b. Duckweed (Lemna minor) as a model plant system for the study of human microbial pathogenesis. PLoS One 5(10): e13527.

Zhang, Y.-Y., D.-Y. Zhang \& S. C. H. Barrett. 2010c. Genetic uniformity characterizes the invasive spread of water hyacinth (Eichhornia crassipes), a clonal aquatic plant. Mol. Ecol. 19: 1774-1786.

Zhang, T.-T., L.-L. Wang, Z.-X. He \& D. Zhang. 2011. Growth inhibition and biochemical changes of cyanobacteria induced by emergent macrophyte Thalia dealbata roots. Biochem. Syst. Ecol. 39: 88-94.

Zhang, X., M. K. Uroic, W.-Y. Xie, Y.-G. Zhu, B.-D. Chen, S. P. McGrath, J. Feldmann \& F.-J. Zhao. 2012. Phytochelatins play a key role in arsenic accumulation and tolerance in the aquatic macrophyte Wolffia globosa. Environ. Pollut. 165: 18-24.

Zhang, Y., L. Zhang, X. Zhao, S. Huang \& J. Zhao. 2013a. Effects of tidal action on pollination and reproductive allocation in an estuarine emergent wetland plant-Sagittaria graminea (Alismataceae). PLoS One 8(11): e78956.

Zhang, Z., Y. Zhou, X. Song, H. Xu \& D. Cheng. 2013b. Insecticidal activity of the whole grass extract of Typha angustifolia and its active component against Solenopsis invicta. Sociobiology 60: $362-366$.

Zhang, L.-H., Y.-W. Zhang, X.-N. Zhao, S.-J. Huang, J.-M. Zhao \& Y.-F. Yang. 2014a. Effects of different nutrient sources on plasticity of reproductive strategies in a monoecious species, Sagittaria graminea (Alismataceae). J. Syst. Evol. 52: 84-91.

Zhang, Y., L. Yin, H.-S. Jiang, W. Li, B. Gontero \& S. C. Maberly. 2014b. Biochemical and biophysical $\mathrm{CO}_{2}$ concentrating mechanisms in two species of freshwater macrophyte within the genus Ottelia (Hydrocharitaceae). Photosyn. Res. 121: 285-297.

Zhao, Y.-M., W. Wang \& S.-R. Zhang. 2012. Delimitation and phylogeny of Aletris (Nartheciaceae) with implications for perianth evolution. J. Syst. Evol. 50: 135-145.

Zhen, G., T. Kobayashi, X. Lu, G. Kumar \& K. Xu. 2016. Biomethane recovery from Egeria densa in a microbial electrolysis cellassisted anaerobic system: performance and stability assessment. Chemosphere 149: 121-129.

Zhongqiang, L., D. Yu \& T. Manghui. 2005. Seed germination of three species of Vallisneria (Hydrocharitaceae), and the effects of freshwater microalgae. Hydrobiologia 544: 11-18.

Zhou, X., Z. He, F. Ding, L. Li \& P. J. Stoffella. 2018. Biomass decaying and elemental release of aquatic macrophyte detritus in waterways of the Indian River Lagoon basin, South Florida, USA. Sci. Total Environ. 635: 878-891.

Zhu, B. 2014. Investigating snails as potential biological control agents for invasive European frogbit (Hydrocharis morsusranae). J. Aquat. Plant Manag. 52: 102-105.

Zhu, B., D. G. Fitzgerald, C. M. Mayer, L. G. Rudstam \& E. L. Mills. 2006. Alteration of ecosystem function by zebra mussels in Oneida Lake: impacts on submerged macrophytes. Ecosystems 9: $1017-1028$.

Zhu, B., M. S. Ellis, K. L. Fancher \& L. G. Rudstam. 2014. Shading as a control method for invasive European frogbit (Hydrocharis morsus-ranae L.) PLoS One 9(6): e98488.
Zhu, J., X. Xu, Q. Tao, P. Yi, D. Yu \& X. Xu. 2017. High invasion potential of Hydrilla verticillata in the Americas predicted using ecological niche modeling combined with genetic data. Ecol. Evol. 7: 4982-4990.

Zidorn, C. 2016. Secondary metabolites of seagrasses (Alismatales and Potamogetonales; Alismatidae): chemical diversity, bioactivity, and ecological function. Phytochemistry 124: 5-28.

Ziegler, P., K. Adelmann, S. Zimmer, C. Schmidt \& K.-J. Appenroth. 2015. Relative in vitro growth rates of duckweeds (Lemnaceae)-the most rapidly growing higher plants. Plant Biol. 17: 33-41.

Zieman, J. C., R. L. Iverson \& J. C. Ogden. 1984. Herbivory effects on Thalassia testudinum leaf growth and nitrogen content. Mar. Ecol. Prog. Ser. 15: 151-158.

Zika, P. F. 1996. Pilularia americana A. Braun in Klamath County, Oregon. Am. Fern J. 86: 26-26.

Zika, P. F., E. R. Alverson \& L. Wilson. 2000. Noteworthy collections: Oregon; Washington. Madroño 47: 213-216.

Zimba, P. V. \& S. R. Bates. 1996. Mineralogical and microscopic analyses of material deposited on submersed macrophytes in Florida lakes. Hydrobiologia 340: 37-41.

Zimba, P. V., M. S. Hopson \& D. E. Colle. 1993. Elemental composition of five submersed aquatic plants collected from Lake Okeechobee, Florida. J. Aquat. Plant Manag. 31: 137-137.

Zimorski, S. E., T. L. Perkins \& W. Selman. 2013. Chelonian species in the diet of reintroduced whooping cranes (Grus americana) in Louisiana. Wilson J. Ornithol. 125: 420-423.

Zink, R. A. \& N. T. Wheelwright. 1997. Facultative self-pollination in island irises. Am. Midl. Nat. 137: 72-78.

Zomlefer, W. B. 1997. The genera of Nartheciaceae in the southeastern United States. Harvard Pap. Bot. 2: 195-211.

Zomlefer, W. B. \& W. S. Judd. 2002. Resurrection of segregates of the polyphyletic genus Zigadenus s.l. (Liliales: Melanthiaceae) and resulting new combinations. Novon 12: 299-308.

Zomlefer, W. B. \& G. L. Smith. 2002. Documented chromosome numbers 2002: 1. Chromosome number of Stenanthium (Liliales: Melanthiaceae) and its significance in the taxonomy of tribe Melanthieae. Sida 20: 221-226.

Zomlefer, W. B., N. H. Williams, W. M. Whitten \& W. S. Judd. 2001. Generic circumscription and relationships in the tribe Melanthieae (Liliales, Melanthiaceae), with emphasis on Zigadenus: evidence from ITS and $t r n L-F$ sequence data. Am. J. Bot. 88: 1657-1669.

Zomlefer, W. B., W. M. Whitten, N. H. Williams \& W. S. Judd. 2003. An overview of Veratrum s.l. (Liliales: Melanthiaceae) and an infrageneric phylogeny based on ITS sequence data. Syst. Bot. 28: 250-269.

Zomlefer, W. B., W. S. Judd, W. M. Whitten \& N. H. Williams. 2006. A synopsis of Melanthiaceae (Liliales) with focus on character evolution in tribe Melanthieae. Aliso: 22: 566-578.

Zomlefer, W. B., M. McKain \& J. Rentsch. 2014. Documentation of the chromosome number for Zigadenus glaberrimus (Liliales: Melanthiaceae) and its significance in the taxonomy of tribe Melanthieae. Syst. Bot. 39: 411-414.

Zona, S. 1997. The genera of Palmae (Arecaceae) in the southeastern United States. Harvard Pap. Bot. 2: 77-107.

Zona, S. 2000. Arecaceae Schultz Schultzenstein. Palm family. Pp. 95-123 In: Flora North America Editorial Committee (eds.), Flora of North America North of Mexico, Vol. 22: Magnoliophyta: Alismatidae Arecidae, Commelinidae (in Part), and Zingiberidae. Oxford University Press, New York, NY.

Zona, S. 2001. Starchy pollen in commelinoid monocots. Ann. Bot. 87: 109-116.

Zona, S. \& A. Henderson. 1989. A review of animal-mediated seed dispersal of palms. Selbyana 11: 6-21. 
Zona, S., P. Davis, L. A. A. H. Gunathilake, J. Prince \& J. W. Horn. 2012. Seeds of Eriocaulaceae of the United States and Canada. Castanea 77: 37-45.

Zundel, G. L. 1920. Some Ustilagineae of the state of Washington. Mycologia 12: 275-281.

Zupo, V. \& W. G. Nelson. 1999. Factors influencing the association patterns of Hippolyte zostericola and Palaemonetes intermedius (Decapoda: Natantia) with seagrasses of the Indian River Lagoon, Florida. Mar. Biol. 134: 181-190.
Zurita, F., M. A. Belmont, J. De Anda \& J. Cervantes-Martinez. 2008. Stress detection by laser-induced fluorescence in Zantedeschia aethiopica planted in subsurface-flow treatment wetlands. Ecol. Eng. 33: 110-118.

Zurzycki, J. 2015. The energy of chloroplast movements in Lemna trisulca L. Acta Soc. Bot. Poloniae 34: 637-666. 